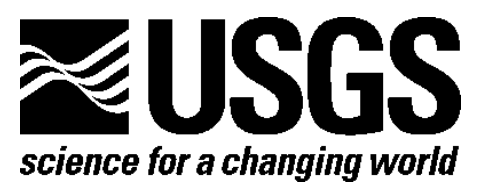

\title{
Assessing Climate-Sensitive Ecosystems in the Southeastern United States
}

By Jennifer Costanza, Scott Beck, Milo Pyne, Adam Terando, Matthew Rubino, Rickie White, and Jaime Collazo

Open-File Report 2016-1073

U.S. Department of the Interior

U.S. Geological Survey 


\title{
U.S. Department of the Interior
}

\section{SALLY JEWELL, Secretary}

\section{U.S. Geological Survey}

\author{
Suzette M. Kimball, Director
}

U.S. Geological Survey, Reston, Virginia: 2016

For more information on the USGS-the Federal source for science about the Earth, its natural and living resources, natural hazards, and the environment-visit http://www.usgs.gov/ or call 1-888-ASK-USGS (1-888-275-8747).

For an overview of USGS information products, including maps, imagery, and publications, visit http://www.usgs.gov/pubprod/.

Any use of trade, firm, or product names is for descriptive purposes only and does not imply endorsement by the U.S. Government.

Although this information product, for the most part, is in the public domain, it also may contain copyrighted materials as noted in the text. Permission to reproduce copyrighted items must be secured from the copyright owner.

Suggested citation:

Costanza, Jennifer, Beck, Scott, Pyne, Milo, Terando, Adam, Rubino, Matthew, White, Rickie, and Collazo, Jaime, 2016, Assessing climate-sensitive ecosystems in the Southeastern United States: U.S. Geological Survey Open-File Report 2016-1073, 278 p., http://dx.doi.org/10.3133/ofr20161073.

ISSN 2331-1258 (online) 


\section{Contents}

Executive Summary

1. Project Report...1.

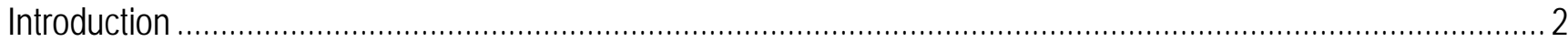

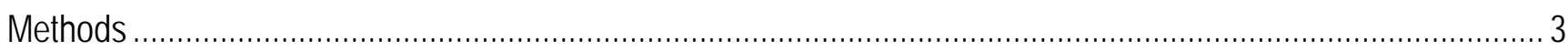

The Southeast—Overview and Climate............................................................................................... 3

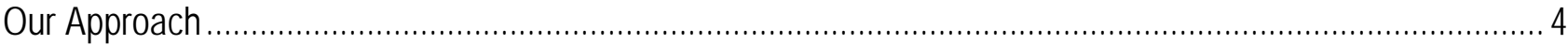

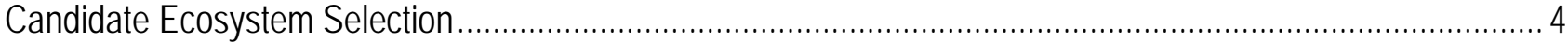

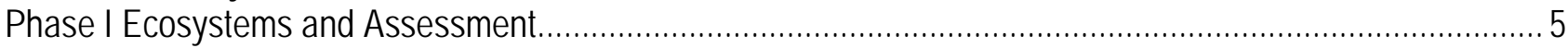

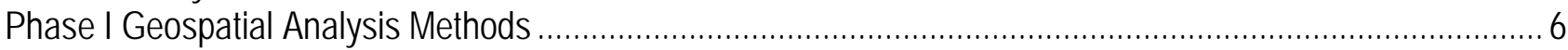

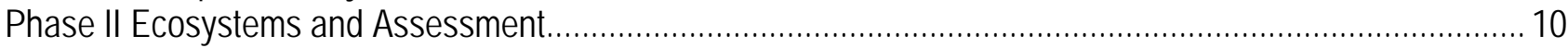

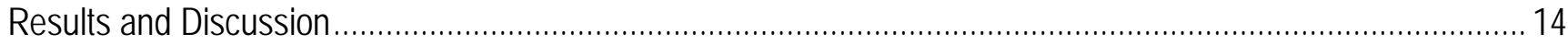

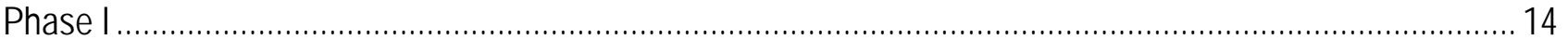

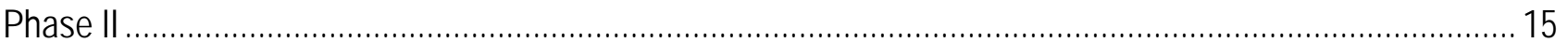

Sources of Uncertainty and Needs for Future Research ……............................................................. 16

Comparing Vulnerability Approaches, and Recommendations for Future Assessments ................................. 16

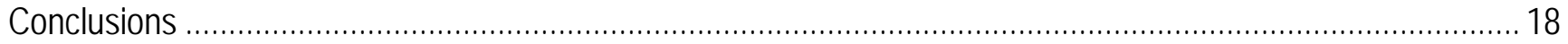

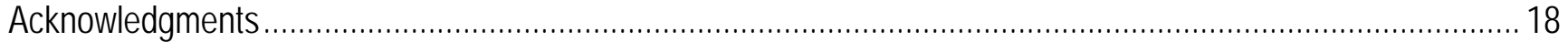

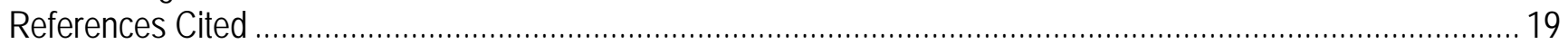

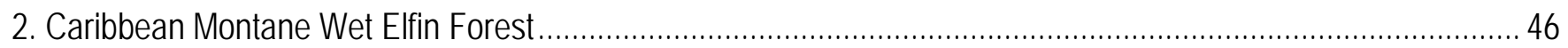

3. Central Atlantic Coastal Plain Wet Longleaf Pine Savanna and Flatwoods .................................................... 55

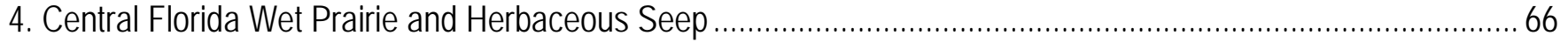

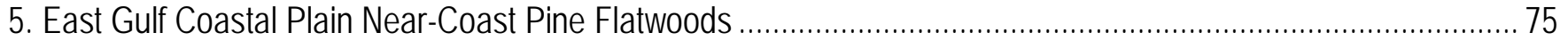

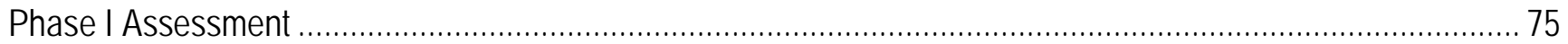

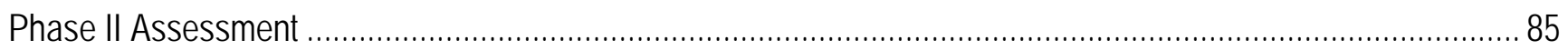

6. East Gulf Coastal Plain Southern Loess Bluff Forest................................................................................. 96

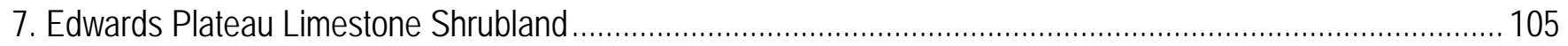

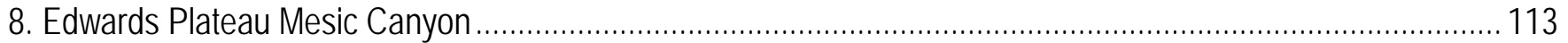

9. Manglar Costero del Caribe (Caribbean Coastal Mangrove) ………........................................................... 121

10. Nashville Basin Limestone Glade and Woodland ....................................................................... 130

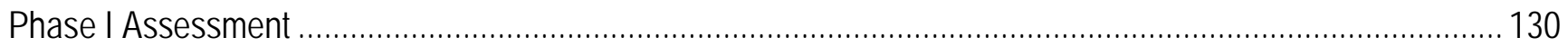

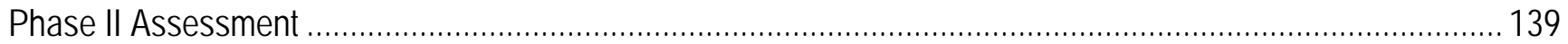

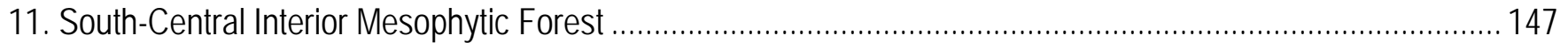

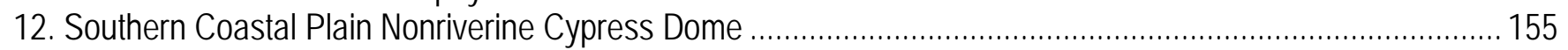

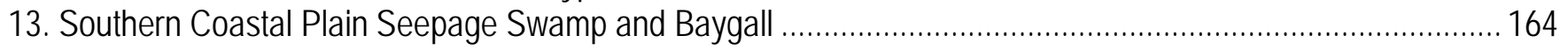

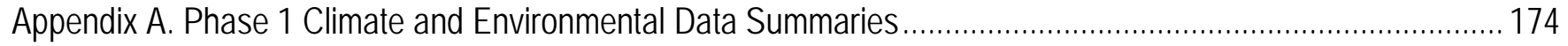

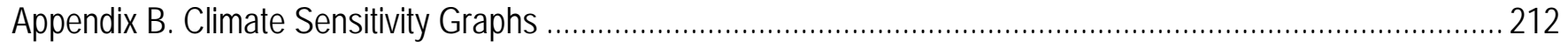

Appendix C. Projected Change in Standard Deviation of Climate Variables.....................................................240

Appendix D. MaxEnt ${ }^{\mathrm{TM}}$-Data Preparation and Processing for the East Gulf Coastal Plain Near-Coast Pine

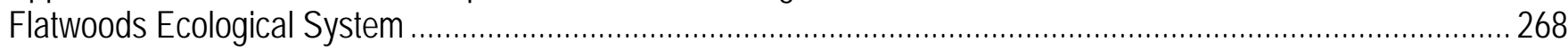

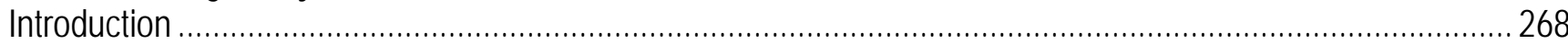

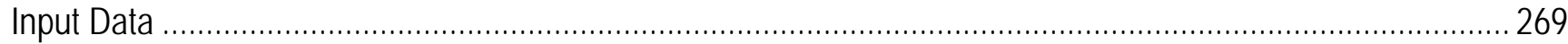

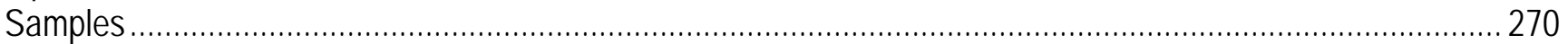

Using "Samples with Data" (SWD) / CSV Files as Inputs ....................................................................... 272 


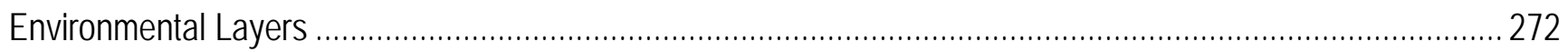

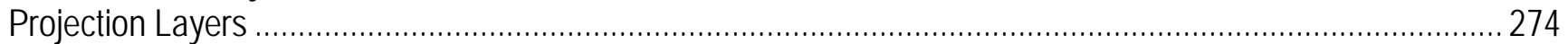

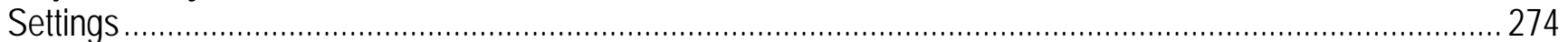

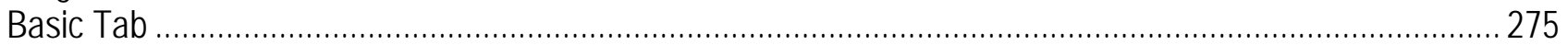

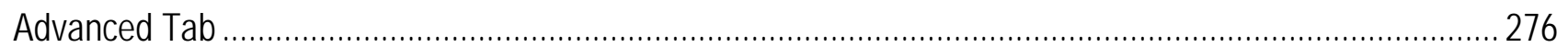

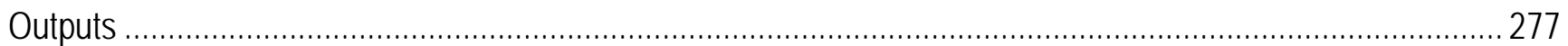

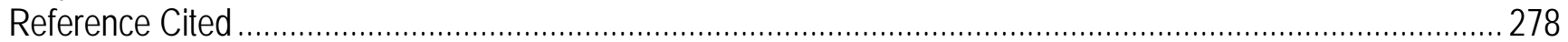




\section{Conversion Factors}

Inch/Pound to International System of Units

\begin{tabular}{|c|c|c|}
\hline Multiply & $\mathrm{By}$ & To obtain \\
\hline \multicolumn{3}{|c|}{ Length } \\
\hline foot (ft) & 0.3048 & eter (m) \\
\hline \multicolumn{3}{|c|}{ Area } \\
\hline Acre & 4,047 & uare meter $\left(\mathrm{m}^{2}\right)$ \\
\hline Acre & 0.4047 & ctare (ha) \\
\hline Acre & $0.4047 \quad$ sc & uare hectometer $\left(\mathrm{hm}^{2}\right)$ \\
\hline Acre & 0.004047 sc & uare kilometer $\left(\mathrm{km}^{2}\right)$ \\
\hline \multicolumn{3}{|c|}{ International System of Units to Inch/Pound } \\
\hline Multiply & $\mathrm{By}$ & To obtain \\
\hline \multicolumn{3}{|c|}{ Length } \\
\hline millimeter (mm) & 0.03937 & inch (in.) \\
\hline meter (m) & 3.281 & foot $(\mathrm{ft})$ \\
\hline kilometer (km) & 0.6214 & mile (mi) \\
\hline kilometer (km) & 0.5400 & mile, nautical (nmi) \\
\hline \multicolumn{3}{|c|}{ Area } \\
\hline square meter $\left(\mathrm{m}^{2}\right)$ & 0.0002471 & acre \\
\hline hectare (ha) & 2.471 & acre \\
\hline square hectometer $\left(\mathrm{hm}^{2}\right)$ & 2.471 & acre \\
\hline square kilometer $\left(\mathrm{km}^{2}\right)$ & 247.1 & acre \\
\hline square meter $\left(\mathrm{m}^{2}\right)$ & 10.76 & square foot $\left(\mathrm{ft}^{2}\right)$ \\
\hline hectare (ha) & 0.003861 & square mile $\left(\mathrm{mi}^{2}\right)$ \\
\hline square kilometer $\left(\mathrm{km}^{2}\right)$ & 0.3861 & square mile $\left(\mathrm{mi}^{2}\right)$ \\
\hline
\end{tabular}

Flow rate

millimeter per year $(\mathrm{mm} / \mathrm{yr}) \quad 0.03937$ inch per year (in/yr)

Temperature in degrees Celsius $\left({ }^{\circ} \mathrm{C}\right)$ may be converted to degrees Fahrenheit $\left({ }^{\circ} \mathrm{F}\right)$ as ${ }^{\circ} \mathrm{F}=\left(1.8 \times{ }^{\circ} \mathrm{C}\right)+32$.

\section{Datums}

Vertical coordinate information is referenced to the North American Vertical Datum of 1988 (NAVD 88).

Horizontal coordinate information is referenced to the North American Datum of 1983 (NAD 83).

Elevation, as used in this report, refers to distance above the vertical datum. 


\title{
Assessing Climate-Sensitive Ecosystems in the Southeastern United States
}

\author{
By Jennifer Costanza, ${ }^{1,6}$ Scott Beck, ${ }^{2}$ Milo Pyne,${ }^{3}$ Adam Terando, ${ }^{4}$ Matthew Rubino, ${ }^{1}$ Rickie White, ${ }^{3}$ \\ and Jaime Collazo 5
}

\section{Executive Summary}

Climate change impacts ecosystems in many ways, from effects on species to phenology to wildfire dynamics. Assessing the potential vulnerability of ecosystems to future changes in climate is an important first step in prioritizing and planning for conservation. Although assessments of climate change vulnerability commonly are done for species, fewer have been done for ecosystems. To aid regional conservation planning efforts, we assessed climate change vulnerability for ecosystems in the Southeastern United States and Caribbean.

First, we solicited input from experts to create a list of candidate ecosystems for assessment. From that list, 12 ecosystems were selected for a vulnerability assessment that was based on a synthesis of available geographic information system (GIS) data and literature related to 3 components of vulnerability - sensitivity, exposure, and adaptive capacity. This literature and data synthesis comprised "Phase I" of the assessment. Sensitivity is the degree to which the species or processes in the ecosystem are affected by climate. Exposure is the likely future change in important climate and sea level variables. Adaptive capacity is the degree to which ecosystems can adjust to changing conditions. Where available, GIS data relevant to each of these components were used. For example, we summarized observed and projected climate, protected areas existing in 2011, projected sea-level rise, and projected urbanization across each ecosystem's distribution. These summaries were supplemented with information in the literature, and a short narrative assessment was compiled for each ecosystem. We also summarized all information into a qualitative vulnerability rating for each ecosystem.

\footnotetext{
${ }^{1}$ North Carolina Cooperative Fish and Wildlife Research Unit, Department of Applied Ecology, North Carolina State University, Raleigh.

${ }^{2}$ North Carolina State University, Department of Forestry and Environmental Resources, Raleigh.

${ }^{3}$ NatureServe, Durham, North Carolina.

${ }^{4}$ U.S. Geological Survey, Southeast Climate Science Center Raleigh, North Carolina.

${ }^{5}$ U.S. Geological Survey, North Carolina Cooperative Fish and Wildlife Research Unit, Department of Applied Ecology, North Carolina State University, Raleigh.

${ }^{6}$ Current: North Carolina State University, Department of Forestry and Environmental Resources, Raleigh.
} 
Next, for 2 of the 12 ecosystems (East Gulf Coastal Plain Near-Coast Pine Flatwoods and Nashville Basin Limestone Glade and Woodland), the NatureServe Habitat Climate Change Vulnerability Index (HCCVI) framework was used as an alternative approach for assessing vulnerability. Use of the HCCVI approach comprised "Phase II" of the assessment. This approach uses summaries of GIS data and models to develop a series of numeric indices for components of vulnerability. We incorporated many of the data sources used in Phase I, but added the results of several other data sources, including climate envelope modeling and vegetation dynamics modeling. The results of Phase II were high and low numeric vulnerability ratings for mid-century and the end of century for each ecosystem. The high and low ratings represented the potential range of vulnerability scores owing to uncertainties in future climate conditions and ecosystem effects.

Of the 12 ecosystems assessed in the first approach, five were rated as having high vulnerability (Caribbean Coastal Mangrove, Caribbean Montane Wet Elfin Forest, East Gulf Coastal Plain Southern Loess Bluff Forest, Edwards Plateau Limestone Shrubland, and Nashville Basin Limestone Glade and Woodland). Six ecosystems had medium vulnerability, and one ecosystem had low vulnerability. For the two ecosystems assessed with both approaches, vulnerability ratings generally agreed. The assessment concluded by comparing the two approaches, identifying critical research needs, and making suggestions for future ecosystem vulnerability assessments in the Southeast and beyond. Research needs include reducing uncertainty in the degree of climate exposure likely in the future, as well as acquiring more information on how climate might affect biotic interactions and hydrologic processes. Ideally, a comprehensive vulnerability assessment would include both the narrative summaries that resulted from the synthesis in Phase I, as well as a numeric index that incorporates uncertainty as in Phase II.

\section{Project Report}

\section{Introduction}

In recent years, average global temperatures have risen, precipitation patterns have changed, and sea level has risen (Intergovernmental Panel on Climate Change, 2007a, 2013). These trends are accelerating and are expected to become more pronounced in the future (Karl and others, 2009). Climate change already has impacted ecosystems, from local declines in populations of some species (Cahill and others, 2013) to changes in animal and plant phenology (Parmesan, 2007) to shifts in geographic range (Chen and others, 2011) to changes in wildfire activity (Westerling and others, 2006). In the future, these impacts are expected to become more pronounced, as suitable habitat shifts (for example, Iverson and others, 2008) and sea level rise continues (National Oceanic and Atmospheric Administration, 2013). Assessing the vulnerability of ecosystems to these types of changes in the future under climate change is a key first step in regional conservation planning and prioritization.

Vulnerability of any system to climate change depends on its inherent sensitivity to changes in climate, its level of exposure to those changes, and its capacity to adapt to those changes (fig. 1.1; Intergovernmental Panel on Climate Change, 2007b; Williams and others, 2008; Dawson and others, 2011). Assessment of climate change vulnerability for species is becoming fairly common, and tools and techniques for species-level assessments are widely established (Williams and others, 2008; Bagne and 
others, 2011; Dubois and others, 2011; Young and others, 2011; Moritz and Agudo, 2013). Nonetheless, much uncertainty remains about how species will respond to a changing climate (Moritz and Agudo, 2013). On the other hand, assessing the vulnerability of ecosystems is less common, and is more complex and challenging than species-level vulnerability assessments. Because ecosystems encompass multiple species and their habitats, along with species interactions and other ecological processes such as fire, much of our knowledge about the vulnerability of ecosystems to climate change is limited. However, some studies have used the vulnerability concept for ecosystems or natural communities (for example, Damschen and others, 2012; Hameed and others, 2013; Brandt and others, 2014), and Glick and others (2011) recommend factors to consider when assessing vulnerability for ecosystems. Additionally, NatureServe has piloted a method for assessing ecosystem vulnerability (Comer and others, 2012).

In this report, we build on these efforts to assess climate change vulnerability for a set of important ecosystems in the Southeastern United States and Caribbean (hereafter referred to as "the Southeast”), while demonstrating a method that can be repeated for other ecosystems in the United States. Important gaps in scientific knowledge are also identified that, if filled, would contribute substantially to our knowledge of future vulnerability, and therefore should be areas of future scientific research.

\section{Methods}

\section{The Southeast-Overview and Climate}

Our assessment focuses on ecosystems that occur in the Southeastern Association of Fish and Wildlife Agencies (SEAFWA) region-15 States in the Southeastern United States, plus Puerto Rico and the U.S. Virgin Islands (USVI) in the Caribbean (fig. 1.2). The study region overlaps with all or most of six U.S. Department of Interior Landscape Conservation Cooperatives (LCCs) — the Appalachian, Caribbean, Gulf Coast Prairie, Gulf Coastal Plains and Ozarks, Peninsular Florida, and South Atlantic (fig. 1.2).

Observed and projected future changes to climate in the Southeastern United States and Caribbean have been synthesized elsewhere (for example, Cambers and others, 2008; Karl and others, 2009; Vose and others, 2012; Wear and Greis, 2012; Conrad and Fuhrmann, 2013; Jacobs and others, 2013; Carter and others, 2014), but the major climatic trends are summarized here. Average annual temperature did not change substantially in the Southeast over the 20th century as a whole, but has risen by about 2 degrees Celsius $\left({ }^{\circ} \mathrm{C}\right.$ ) since 1970, with the highest average increases in summer (Carter and others, 2014). Annual precipitation has increased across the Southeast over the past century, with large increases in fall precipitation everywhere except for Florida (Karl and others, 2009). The proportion of the Southeast experiencing drought has increased since the 1970s (Karl and others, 2009).

Future projections from climate models for the Southeast, including the Caribbean, overall agree that temperature is likely to increase, but they diverge on how precipitation will change. Most climate models project an increase in precipitation for all seasons except for summer (Conrad and Fuhrmann, 2013). Water availability and associated water stress are likely to increase because of increased temperatures and longer periods of time between rainfall events (McNulty, 2012). Hurricanes are likely to increase in intensity, bringing more rainfall per storm event, higher wind speeds, and larger storm surges 
(Intergovernmental Panel on Climate Change, 2007b). Rising sea level is likely to interact with more intense hurricanes to aggravate storm surges, coastal inundation, and shoreline retreat.

Climate change also affects ecosystems in the context of other stressors such as land-use change and forest management (Staudt and others, 2013). These non-climate stressors are particularly important in the Southeast. Habitat conversion to urban and agricultural areas, along with logging and other forestmanagement practices that alter habitat, are nearly ubiquitous across the region. Insect and pathogen outbreaks also are important and have been increasing in the Southeast (Duerr and Mistretta, 2012). Some of these outbreaks may become more active under future scenarios (Duerr and Mistretta, 2012). Finally, in some ecosystems, particularly open pine savannas on the coastal plain, past wildfire suppression is another major factor that has led to a decline in habitat quality (VanLear and others, 2005). In those ecosystems, the influence of climate change on wildfire, as well as the ability to conduct prescribed burning, will be critical to understand (Stanturf and Goodrick, 2013).

\section{Our Approach}

This assessment was conducted in three steps. First, a list was assembled of candidate ecosystems in the Southeast for analysis based on metrics of potential sensitivity to climate change, supplemented with additional ecosystem suggestions from Southeast LCCs. That list is a product of expert knowledge that can be used by other, subsequent assessment efforts by the Southeast Climate Science Center and LCCs. Second, an assessment was conducted of the state of knowledge on climate change vulnerability for a subset of the candidate ecosystems. This assessment is "Phase I" of the analysis. For this analysis phase, the available geographic information system (GIS) datasets were summarized, along with literature and reports. Third, two Phase I ecosystems were selected for "Phase II", or in-depth analysis of climate change vulnerability. For the Phase II analysis, we used the NatureServe new Habitat Climate Change Vulnerability Index tool (HCCVI; Comer and others, 2012), with inputs from niche models and vegetation dynamics simulation models, to more fully assess the potential impacts of climate change.

\section{Candidate Ecosystem Selection}

We first selected a list of potentially vulnerable ecosystems as candidates for analysis. We relied on the NatureServe ecological systems as the units of analysis for this project. These systems were used for two reasons. First, they are mid-scale classifications, meant for use in conservation planning (Comer and others, 2003). Second, these systems also are the units for mapping in Gap Analysis Program (GAP) and Landscape Fire and Resource Management Planning Tools (LANDFIRE) land-cover maps, so regional spatial data are available for their extent. This assessment was limited to terrestrial ecosystems and did not include aquatic or marine ecosystems.

To develop the list of focal ecosystems, we used the databases and descriptions of ecological systems developed by NatureServe (Comer and others, 2003; NatureServe, 2003). We selected 36 ecological systems in the Southeast that met one or more of the following criteria:

1. Likely to be subject to sea level rise or other hydrologic changes-Ecosystems in coastal or coastal plain regions, or wetland ecosystems.

2. Likely to be influenced by temperature and (or) precipitation and orographic effects-Ecosystems that occur at high elevations. 
3. Ecologically insular-Geographically discrete, defined by boundaries with steep environmental gradients, strongly controlled by elevation or geologic factors, subject to stressful edaphic or disturbance regimes, or biogeographically endemic.

4. Threatened-Classified as critically endangered, endangered, or vulnerable, based on an International Union for Conservation of Nature (IUCN) category, a metric for ecological systems that are in development by NatureServe.

These criteria were used because these types of ecosystems may be especially vulnerable to climate change. This could manifest as exhibiting high sensitivity (for example, high-elevation systems), high exposure (for example, coastal systems), low adaptive capacity (for example, insular systems), or a combination of these factors.

After this selection process, we solicited additional ecosystem suggestions from LCC staff and participants by email and conference call. The result was a list of 55 ecosystems (table 1.1). This list includes wetland and non-wetland systems; coastal, and high- and low-elevation systems; and insular and non-insular systems.

\section{Phase I Ecosystems and Assessment}

From the list of 55 candidate ecosystems, two ecosystems were selected for assessment in Phase I because their extents were coincident with the majority of the six LCCs in the Southeast. This selection was made at random for every ecosystem except for three. The selection of the two ecosystems in the Caribbean (Caribbean Coastal Mangrove and Caribbean Montane Wet Elfin Forest) was based on the availability of suitable land-cover data that enabled their locations to be mapped. Similarly, the Edwards Plateau Carbonate Glade and Barrens originally was selected, but was substituted with the Edwards Plateau Limestone Shrubland also because of land-cover data availability. The result was a list of 12 ecosystems (shown in bold in table 1.1). Like the list of candidate ecosystems, the 12 ecosystems selected represent a range of wetland status, elevation, and insularity. Additionally, 5 of the 12 systems were those suggested by LCCs.

For each of these 12 Phase I ecosystems, the three components of climate vulnerability were assessed (fig. 1.1) using information in published literature and reports, along with new GIS analysis. Sensitivity was assessed based on the characteristics of each ecosystem. Exposure was assessed based on the degree and likelihood of change for important climate variables and sea levels in the future. For the assessment of sensitivity and exposure, we focused on climate factors that affect one or more of the following: (1) the distribution of the ecosystem; (2) important ecological processes, including fire and hydrology; (3) the dominant plant species; and (4) plant or animal species that are important for conservation. We considered all climate and climate-related factors, including temperature, precipitation, wind, storms, fire and hydrology.

Adaptive capacity is the degree to which ecosystems can adjust to changing conditions. Not only does adaptive capacity depend on characteristics of the ecosystem, but also can be directly enhanced by management and conservation action (Turner and others, 2003; Heller and Zavaleta, 2009). Glick and others (2011) lists several principles that can be used to guide management-based adaptation efforts, including the reduction of existing stressors, managing for ecosystem function, and improving habitat connectivity. These principles were used to guide the assessment of adaptive capacity, under the 
assumption that ecosystems with few non-climate stressors, that retain their ecological functions, that are highly connected, and that are topographically more complex have high adaptive capacity. We focused on the degree to which each ecosystem had been affected by anthropogenic changes in the past, and projected future threats. This included an assessment of past and future habitat fragmentation, habitat conversion, invasive plants, pests and pathogens, heterogeneity in elevation, and alterations to habitat from changes to hydrology or the fire regime.

Where available, GIS data were used to assess the three components of vulnerability. The GIS analysis was supplemented with information from published literature to create a detailed report of climate-change sensitivity, exposure, and adaptive capacity for each ecosystem.

\section{Phase I Geospatial Analysis Methods}

For GIS analysis, ecosystem extent was defined as the raster pixels on which each was mapped according to data obtained from NatureServe (2013; for the Southeastern United States), the Puerto Rico Gap Analysis Project (PRGAP; Gould and others, 2007), or the U.S. Virgin Islands (USVI) Gap Analysis Project (USVIGAP; Gould and others, 2012). The raster-based land-cover data also were used to digitize polygon shapefiles of each ecosystem's range.

For each ecosystem, climate, sea level rise, land cover, and other environmental GIS data were extracted at locations within the ecosystem extent. The climate data were summarized across the extent of each ecosystem because of the coarse spatial resolution and greater homogeneity of these data compared to the land-cover data. Elevation data were also summarized across each extent in order to examine the variability of habitats in and around the places where each ecosystem was mapped. For all other data, the raster-based land-cover data were used to summarize data. Geospatial data were collected from government agencies and their Web sites, as well as university researchers (see tables 1.2 and 1.3 for a detailed list of sources).

To assess climate change impact, as defined by the combination of sensitivity and exposure, we used metrics related to observed and projected climate, as well as projected sea level rise and coastal vegetation impacts for each ecosystem. In addition, we assessed the area and fragmentation of the ecosystem's extent, the percentage of each ecosystem in existing protected areas, proximity to existing and future urban areas, elevation heterogeneity for each ecosystem, and an index of human modification.

For climate, sea level rise, and future urbanization projections, two time periods, mid-century (2050), and end-of-century (2100) were used for analysis. Two fossil fuel emission scenarios were used for the climate projections, one representing a future where emission rates remain high, and one representing a future where emissions are stabilized and then reduced. Comparisons between ecosystems with differing expected adaptive capacities and exposures to anthropogenic changes were expressed by calculating the percentage area of ecosystems affected by these changes (see tables 1.2 and 1.3 for summaries of metrics used).

Geospatial analysis was completed in ArcGIS ${ }^{\mathrm{TM}} 10.1$ (Environmental Systems Research Institute, 2012). Detailed GIS methods are described in the following section. 


\section{Sensitivity}

To measure sensitivity, GIS data depicting present climatology were combined with syntheses of published literature regarding the influence of climate on the range, dominant species, and important ecological processes of each ecosystem. The climatological data are from WorldClim (http://www.worldclim.org; Hijmans and others, 2005) and represent interpolated raster data based on a 1950-1999 reference period. Across the range of each U.S. and Caribbean ecosystem, monthly minimum and maximum temperatures, and average precipitation values were calculated. Seasonal minimum and maximum temperature, and average precipitation summaries were created by combining monthly values, where winter was December-February, spring was March-May, summer was June-August, and fall was September-November.

\section{Exposure}

Exposure was assessed using data on projected climate, sea level rise, and coastal vegetation impacts. For the Southeastern United States, gridded climate projections for the A1FI (high emissions) and B1 (low emissions) scenarios were obtained from the Southeast Climate Science Center for the range of each ecosystem based on statistically downscaled data with $1 / 8^{\circ}$ spatial resolution (Stoner and others, 2012). For 2040-2060 and 2080-2100, changes in seasonal minimum and maximum temperatures, as well as changes in seasonal average precipitation, were summarized for each ecosystem extent using $\mathrm{R}$ software, version 3.0.1 (R Core Team, 2013). Seasons were the same as those used for observed climate data. For each metric, all climate models available were averaged for each emissions scenario (4 models were available for A1FI, and 15 models were available for B1).

Climate projections for ecosystems in the Caribbean were obtained from statistically downscaled General Circulation Models (GCMs) for Puerto Rico (Hayhoe, 2013; Ryu and Hayhoe, 2013). Those data are not gridded, but are organized by climate monitoring locations in Puerto Rico (fig. 1.3). The statistically downscaled data were summarized for all climate stations within 5 kilometers $(\mathrm{km})$ of each ecosystem's range in Puerto Rico (11 stations for Caribbean Montane Wet Elfin Forest and 33 for Manglar Costero del Caribe, fig. 1.3). No climate data at a suitable spatial resolution were available for the U.S. Virgin Islands. For projected changes in minimum and maximum temperature, projections from phase 3 of the Coupled Model Intercomparison Project (CMIP3) were used because those from CMIP5 were not available. For projected changes in precipitation, available projections from models from CMIP5 were used because of the known issues with precipitation modeling in CMIP3 models (Hayhoe, 2013). For precipitation, results were analyzed solely for the RCP85 emissions scenario, which is a highemissions scenario somewhat analogous to A1FI. CMIP5 model selection was limited to those that are known to better simulate regional annual cycles of precipitation according to information by Hayhoe (2013).

Data from the National Oceanic and Atmospheric Administration (NOAA) Sea Level Rise and Coastal Flooding impacts dataset (National Oceanic and Atmospheric Administration, 2013) were used to assess coastal ecosystem changes resulting from sea level rise. Sea level rise scenarios of 1 and 6 feet (ft) [0.3 and 1.8 meters $(\mathrm{m})$ ] above mean higher high water were selected, which represent the minimum and maximum of the range of sea level rise scenarios being used for U.S. national assessments. For each ecosystem's extent, the percentage system area that was projected to be inundated under the two sea level 
rise scenarios was summarized. Full coverage of these data was not available for all coastal and Caribbean systems, so calculations were only done for portions of the Central Atlantic Coastal Plain Wet Longleaf Pine Forest, Central Florida Wet Prairie and Herbaceous Seep, East Gulf Coastal Plain Near Coast Pine Flatwoods, Southern Coastal Plain Nonriverine Cypress Dome, and Southern Coastal Plain Seepage Swamp and Baygall ecosystems (see Appendix A for portions of each ecosystem's coastal extent that was covered by the NOAA data). The sea level rise scenario results were also summarized separately for the Puerto Rico and USVI portions of the Caribbean Mangrove Forest and Shrubland.

Coastal vegetation impacts were analyzed using data from the Sea Level Affecting Marshes Model (SLAMM) dataset for the Southeastern United States under the A1FI and B1 scenarios (Rubino, 2012). Full coverage of these data is not available for all coastal and Caribbean systems, so calculations were only done for the Central Atlantic Coastal Plain Wet Longleaf Pine Forest, and portions of the Southern Coastal Plain Seepage Swamp and Baygall, Southern Coastal Plain Nonriverine Cypress Dome, and East Gulf Coastal Plain Near Coast Pine Flatwoods ecosystems (see Appendix A for portions of each ecosystem covered by the data). Summaries were calculated of the percentage of each ecosystem's extent that was projected to change to a different vegetation type in SLAMM projections by 2050 and 2100, compared with the baseline year of 2010.

\section{Adaptive Capacity}

Adaptive capacity metrics are important non-climate variables that could influence an ecosystem's vulnerability to climate change. To assess adaptive capacity, data were summarized on the fragmentation, area under conservation protection, existing and future urbanization, and variation in elevation for each ecosystem. For other non-climate stressors such as changes in the fire regime and hydrology, published literature was used to complement the GIS analysis.

The mean, range, and standard deviation of patch sizes in the land-cover map were summarized to estimate fragmentation for each ecosystem. Calculations were made of the percentage area of each ecosystem in the Southeastern United States that is protected for conservation from the U.S. Geological Survey (USGS) Gap Analysis Program Protected Areas Data (U.S. Geological Survey, 2011). For Caribbean ecosystems, the same calculations were made using stewardship data collected from PRGAP (Gould and others, 2007) and USVIGAP (Gould and others, 2012). Easements and privately owned land not permanently marked for conservation were excluded from all protected areas. The average degree of human modification was summarized across the extent of all southeastern ecosystems, excluding those in the Caribbean. Data from Theobald and others (2012) were used to quantify the degree of human modification, which incorporates the effects of roads, housing density, and traffic.

For ecosystems in the Southeastern U.S., distance to existing urban areas was summarized using the National Land Cover Database (NLCD; Fry and others, 2011). The four NLCD classes representing all densities of developed cover (classes 21, 22, 23, 24) were extracted and reclassified to a single urban class. This urban class was used to determine the minimum, maximum, average, and standard deviation of distances from ecosystem pixels to urban pixels.

Projected future urbanization was summarized for most southeastern ecosystems based on SLEUTH urban growth data (Terando and others, 2014; http://www.basic.ncsu.edu/dsl/urb.html). Those 
projections extend just north of Kentucky and Virginia, to just west of the Mississippi River, and south to the Gulf Coast and Florida. Thus, projections were not available for the ecosystems in the Edwards Plateau, Caribbean, or the northern portion of the South-Central Interior Mesophytic Forest ecosystem (see Appendix A for portion of each ecosystem's coastal extent that was covered by the SLEUTH data). For the systems that were covered by the data, we calculated the percentage of each ecosystem's extent that had at least a 90 percent modeled probability of being converted to development by 2050 and 2100.

Projected urbanization for the two ecosystems in the Edwards Plateau was based on percentage of impervious surface projections from the U.S. Environmental Protection Agency (USEPA) Integrated Climate and Land Use Scenarios (ICLUS) project (U.S. Environmental Protection Agency, 2010). The percentage of impervious surface is an indicator of urbanization, and has been used as a proxy for urban land cover (Arnold and Gibbons, 1996; Wickham and others, 2013). The ICLUS data have a spatial resolution of $1 \mathrm{~km}$, and the ecosystem data have a 30-m resolution. Thus, the raster data were resampled for each ecosystem's extent to $1 \mathrm{~km}$. For each ecosystem's extent, the average impervious surface was then projected in 2050 and 2100, and compared those values to the average in 2010.

Land-cover data from PRGAP (Gould and others, 2007) and USVIGAP (Gould and others, 2012) were used to define the extent of urban areas in Puerto Rico and the USVI, respectively. The minimum, maximum, average, and standard deviation of urban distances to ecosystem pixels was calculated using the same methods as in the continental United States Projected urbanization data were not available in the Caribbean.

Finally, ecosystems that occur in areas with a range of abiotic conditions may have greater capacity to adapt to a changing climate than those that exist in only limited conditions. As a measure of the heterogeneity of conditions for each ecosystem and its surrounding landscape, metrics were calculated based on variation in elevation data. For ecosystems in the Southeastern United States, excluding the Caribbean, the National Elevation Dataset (http://viewer.nationalmap.gov/viewer/; Gesch and others, 2009) was used. The digital elevation dataset that was developed by PRGAP (Gould and others, 2007) was used for Caribbean ecosystems. In all cases, summaries were calculated of the range, average, and standard deviation of elevation values across each ecosystem's range.

\section{Vulnerability Rating}

For Phase I, a qualitative vulnerability rating was assigned to each ecosystem based on its climate change impact (a combination of sensitivity and exposure) and its adaptive capacity. These ratings are not meant to be absolute scores, but are relative ratings when compared to the other systems in this assessment. We recognize that either an absolute rating or a rating relative to all ecosystems nationally would be valuable. However, it was not feasible for the Phase I portion of this assessment because the approach is qualitative and has not been completed for most other ecosystems in the United States. Phase II assigns a quantitative score and is intended to be an absolute vulnerability rating.

To assign a vulnerability rating to each ecosystem, a "low," “medium," or "high" value was assigned to the categories of sensitivity, exposure, and adaptive capacity based on the primary factors identified from the GIS analysis and literature review. For sensitivity and exposure, low had a value of 1 , medium had a value of 2 , and high had a value of 3 . For adaptive capacity, low $=3$, medium $=2$, and high 
$=1$. The overall vulnerability rating was an average of the values for impact and adaptive capacity, where the impact was weighted 50 percent and the adaptive capacity was weighted 50 percent. However, if the climate change impact was low for a given ecosystem, its vulnerability rating also was low, regardless of the adaptive capacity rating.

\section{Phase II Ecosystems and Assessment}

For this additional phase of the assessment, two ecosystems were selected that were included in the Phase I assessment. Those ecosystems were (1) Nashville Basin Limestone Glade and Woodland, and (2) East Gulf Coastal Plain Near-Coast Pine Flatwoods. These were chosen because they represent two different types of ecosystems that share characteristics with many other systems in the Southeast —one system is an edaphically constrained, small-patch ecosystem that will not be affected by sea level rise by the end of the century (the Glade and Woodland system), and the other is a matrix ecosystem that is likely to be affected by sea level rise (the Near-Coast Pine Flatwoods system).

The NatureServe Habitat Climate Change Vulnerability Index (HCCVI) framework (Comer and others, 2012) was used for the Phase II analysis. That framework distinguishes between factors that contribute to an ecosystem's climate-change sensitivity, including the direct effects of climate, and those that influence its climate-change resilience, which is comprised of the indirect effects of climate and an ecosystem's adaptive capacity (fig. 1.4). We followed the HCCVI methods suggested by Comer and colleagues in their pilot study, but modified them where appropriate for each ecosystem's geography and characteristics. Interested readers should refer to Comer and others (2012) for more details on the HCCVI framework.

When applicable, sensitivity and resilience indices for mid-century and late century were included, as well as a minimum and maximum value for each time period. Doing so allowed for the incorporation of changes in vulnerability over time, as well as differences among emissions scenarios and uncertainty in input data.

\section{Sensitivity-Direct Effects}

Climate Stress Index. - We generally followed methods described by Comer and others (2012) to calculate this metric. Observed data represented the period 1980-1999, and were from the Maurer and others (2002) gridded observed meteorological dataset (table 1.4). Projections came from statistically downscaled data (Stoner and others, 2012). Projected climate model output was used for the period 20402060 to represent mid-century, and 2080-2100 to represent the end of the century. Both observed and projected data had $1 / 8^{\circ}$ spatial resolutions. For each future time period, observed and projected climate data were compared for three average monthly variables-maximum temperature, minimum temperature, and precipitation. This resulted in a total of 36 variables for comparison. At each pixel location, the proportion of variables was calculated for which the projected mean value exceeded 2 standard deviations above or below the recent observed mean. The climate stress index was defined as 1 minus that proportion. Smaller values of this index indicated that a greater number of climate variables for a given time period and scenario exceeded observed variability, and resulted in a higher sensitivity value. The proportion at mid-century and end of century was calculated under three emissions scenarios: B1, A2, and 
A1FI. The minimum and maximum index value was calculated at each time period, regardless of the emissions scenario to which it corresponded.

Envelope Shift Index.- - The envelope shift index indicates the degree to which the distribution of each ecosystem would need to shift in order to keep up with the climate envelope over time. This metric was calculated for the East Gulf Coastal Plain range of the Near-Coast Pine Flatwoods ecosystem only. For that ecosystem, there were few pixels present along the Atlantic Coast, well outside the range of most of the ecosystem. Including those disjunct pixels would misrepresent the dominant climate envelope of this system. This metric was not calculated for the Nashville Basin Limestone Glade and Woodland system because that system's extent is driven more by soils and hydrology than by temperature and precipitation. Therefore, even if the temperature and precipitation envelope shifted, the distribution of the ecosystem likely would not change in response to that shift.

To assess the distribution of future climate envelopes for the ecosystem, the maximum entropy modeling algorithm software (MaxEnt ${ }^{\mathrm{TM}}$; Phillips and others, 2006) was used (see data preparation and processing details in Appendix D). The same monthly observed and projected data used to calculate the climate stress index were used to project climate envelopes for two time periods (mid-century and latecentury) under three emissions scenarios (B1, A2, and A1FI). A total of 36 observed variables (three climate variables for each of 12 months) were used to generate a maximum entropy distribution for the mapped extent. After some testing, it was determined that collapsing the 36 variables into a total of 12 seasonal variables (3 variables $\times 4$ seasons) was desirable to reduce model overfitting and to increase model interpretability. Therefore, these seasonal variables were used as inputs to MaxEnt ${ }^{\mathrm{TM}}$.

Data representing the distribution of the ecosystem were generated from the USGS Gap Analysis Program land cover. In order to match the approximate size of the climate data tiles $\left(1 / 8^{\circ} \times 1 / 8^{\circ}\right)$, it was necessary to reproject the distribution data to a geographic coordinate system and aggregate $30-\mathrm{m}$ cells by summing. Based on the range of the ecosystem, it is reasonable to assume that any area outside the geographic extent depicted by GAP land cover is a known absence for this ecosystem. Therefore, 1,000 random points were generated throughout the study area and provided those as direct input to MaxEnt ${ }^{\mathrm{TM}}$ as absence or "background" locations. The mapped accuracy as reported by LANDFIRE was used as the probability of presence, or "prevalence" in MaxEnt ${ }^{\mathrm{TM}}$. Overall accuracy reported by LANDFIRE was 0.699 (user’s accuracy $=0.685$, producer's accuracy $=0.625$; LANDFIRE, 2014). The “default prevalence” parameter in MaxEnt ${ }^{\mathrm{TM}}$, therefore, was set to 0.7 for all model runs.

The climate envelope for the ecosystem was then projected to the entire Southeastern United States extending from west of the Mississippi River, north to northern Kentucky and Virginia, east to the Outer Banks of North Carolina, and south to central Florida. The climate stress index was calculated as a scaled version of the average logistic output value for all climate data points within the mapped ecosystem range. This logistic output value can be thought of as the projected relative occurrence rate (ROR) for the ecosystem (Merow and others, 2013). For each time period and emissions scenario, the ROR was averaged for all points within the ecosystem extent. The same procedure was applied for the observed data. We assumed that the average ROR for the observed climate would be the maximum ROR 
possible at any future time period. Therefore, the average ROR was scaled for each of the projected climates by the average ROR value for the observed climate.

Dynamic Process Forecast.-State-and-transition simulation models (STSMs) were used to characterize the conditions of each ecosystem and model future dynamics. The STSMs used were based on those developed by the LANDFIRE project (Grace and Wilder, 2009; Pyne and Fitch, 2009; Rollins, 2009). These models describe the vegetation states of each ecosystem, and include transitions between states owing to disturbances such as wildfires. The LANDFIRE models indicate dynamics that would have occurred prior to European settlement, according to expert knowledge. We adjusted the wildfire probabilities to represent fire suppression, and where possible, these probabilities were adjusted further to incorporate changes owing to climate change. The dynamics were then simulated through the end of the 21st century, and computed the percentage of the vegetation that is departed from expected pre-European settlement conditions, also referred to as "ecological departure”. Higher ecological departure indicated high sensitivity. However, for all other calculated sensitivity metrics, low values represented high sensitivity. Therefore, in order to be compatible with those metrics, a calculated value of 1 minus ecological departure was used as the sensitivity metric in this case.

Sea Level Rise.-As in Phase I, the Sea Level Rise and Coastal Flooding impacts dataset from NOAA was used to calculate the percentage of the East Gulf Coastal Plain Near-Coast Pine Flatwoods ecosystem that would be inundated under 1- and 6-ft (0.3- and 1.8-m) sea level rise scenarios.

\section{Resilience_-Indirect Effects}

Landscape Condition.-NatureServe Landscape Condition data (Comer and others, 2012) were used to estimate landscape condition. This layer was overlaid on the extent of each ecosystem and the weighted average of landscape condition values was calculated.

Proportion Non-urban-Historical, Current, Future.-In addition to landscape condition data, past (circa 1960), present (circa 2010), and future (circa 2050 and 2010) housing density data from the USEPA ICLUS study (Bierwagen and others, 2010) were used to determine the total percentage of each ecosystem's extent that had not been converted to any level of urban development. These data provide a consistent picture of past, present, and future land use that was informative for describing ecosystem resilience. The SLEUTH data from Phase I were not used because those data do not include historical time periods. All pixels in the ICLUS data with housing densities of 40 acres per unit or greater were used, which correspond to exurban, suburban, or urban areas (U.S. Environmental Protection Agency, 2009). Calculations were then performed of the proportion of each ecosystem that was not mapped as one of these classes in 1960, 2010, 2050, and 2100. For 2010, 2050, and 2100, estimates were included from data under B1 and A2 emissions scenarios.

Invasive Species Threat, Current.-For the assessed ecosystems, sufficient spatial data on the range and abundance of important invasive species were not available. Therefore, to summarize the effects of invasive species, information was gathered in the literature about the important invasive plant and animal species for each ecosystem. Consideration was given to the abundance of these species, as well as their realized and potential effects on the biodiversity or ecological processes in each ecosystem. Because this metric was based on largely qualitative information, there is some degree of uncertainty 
surrounding its value in each ecosystem. To document our uncertainty about this metric, a range of values for resilience was assigned.

Invasive Species Threat, 1960.- - This metric was included in the pilot version of the HCCVI tool (Comer and others, 2012), but there was little information available to assess historical invasive species threats for ecosystems in the Southeast. Therefore, it was omitted from the analysis.

Dynamic Process Alteration.-Because ecosystems that are degraded in terms of their ecological processes are less able to respond to climate change, it is important to incorporate a metric describing the ecological dynamics within each ecosystem. Data developed by LANDFIRE describe the vegetation in terms of its fire regime. LANDFIRE S-class data (LANDFIRE, 2013) were used to determine the composition of state classes within mapped pixels of each ecosystem according to The National Map (Sugarbaker and Carswell, 2011), compared to supposed pre-European settlement conditions. The ecological departure value was calculated as described in the "Sensitivity-Direct Effects” report section. The metric for resilience in this case was 1 minus ecological departure.

\section{Resilience-Adaptive Capacity}

Diversity within Functional Groups. - The number and types of functional groups that occur within a given ecosystem are recognized to be important for ecosystem function (Díaz and Cabido, 2001). In particular, functional groups that relate to disturbance response are essential for maintaining ecological resilience in the face of change (Lavorel and others, 1997; Folke and others, 2004). As such, one to two functional groups per ecosystem were identified that would be critical for responding to the characteristic disturbance of that ecosystem. The diversity of species within those functional groups was assessed based on information in literature, and estimated numeric values for this metric. To document uncertainty, a range of values for resilience was assigned.

Keystone Species Vulnerability.-One keystone species was identified for each ecological system, which was defined as a species that has a large impact on the system, compared with its low abundance. Once the species was identified, a literature search was conducted for existing vulnerability assessments. Any existing assessments were supplemented with other literature and information about how the important threats for each species are likely to change over time, and thus change vulnerability through the end of the century. To document our uncertainty about this metric, a range of values were assigned for resilience for each time period.

Bioclimatic Variability. - Similar to methods in Comer and others (2012), each ecosystem's extent was overlaid on the isobioclimate data (Sayre and others, 2009) to calculate the number of unique isobioclimate regions the ecosystem covered. This number was scaled by the maximum number of isobioclimates, which equaled 25 for all ecosystems in the Southeast. As stated by Comer and others (2012), ideally, this would be scaled based on all ecosystems in the United States. In that study, the authors examined all ecosystems in the Southwest, and the maximum number of isobioclimates covered by a single ecosystem was 20 .

Elevation Range.-Elevation data were classified for the Southeast into bands of $100 \mathrm{~m}$ each. All ecosystems in the Southeast were overlaid onto the elevation bands to calculate the number covered by each ecosystem. For each Phase II ecosystem, the constructed resilience metric was the ratio of the 
number of elevation bands covered to the maximum number covered by a southeastern ecosystem (equal to 27 bands). As stated by Comer and others (2012), ideally, this would be scaled based on all ecosystems in the U.S. Although the number of elevation bands covered for all U.S. ecosystems was not calculated, in the Desert Southwest, the maximum elevation covered by a single ecosystem was $1829 \mathrm{~m}$, or $19100-\mathrm{m}$ elevation bands.

\section{Results and Discussion}

\section{Phase I}

The summaries of projected changes for precipitation and temperature in Southeast showed large differences between emissions scenarios, and among climate models within the same scenario (figs. 1.51.10). However, although individual General Circulation Models (GCMs) vary in their quantitative projections, they overwhelmingly suggest the same qualitative change in the Southeastern United States and Caribbean - that projected mean temperatures will increase across the region under every emissions scenario for the middle and end of the century (figs. 1.5, 1.6, 1.8, and 1.9). There are a few exceptions for the Southeastern United States for some seasons at mid-century under the B1 emissions scenario. In contrast, precipitation projections were highly uncertain both qualitatively and quantitatively. In the Southeastern United States and Puerto Rico, for every time period and emissions scenario, at least one GCM projected an increase in precipitation, but at least one other projected a decrease (figs. 1.7 and 1.10).

Of the 12 ecosystems assessed, 5 were rated as having high vulnerability to climate change, 6 had medium vulnerability, and 1 had low vulnerability (table 1.5). The two Caribbean systems, along with the East Gulf Coastal Plain Southern Loess Bluff Forest, had the highest ratings for sensitivity to climate change. These three systems are all fairly range-restricted. The Caribbean Coastal Mangrove system is especially sensitive to sea level rise and storm events. The other two systems, the Caribbean Montane Wet Elfin Forest and the East Gulf Coastal Plain Southern Loess Bluff Forest, are sensitive to changes in temperature because they provide refugia for disjunct species. Many of the other assessed ecosystems are sensitive to changes in disturbances such as fire and hurricanes, or hydrology.

The two Caribbean ecosystems also had the highest ratings for climate change exposure (table 1.5). The Caribbean Coastal Mangrove ecosystem is expected to have high exposure to sea level rise, while the Caribbean Montane Wet Elfin Forest is expected to experience increased temperatures, to which it is highly sensitive. Most other ecosystems had moderate ratings for climate change exposure. Many are expected to have a change in fire regimes, hurricanes, hydrology, and sea level rise. For many ecosystems, the future level of exposure to climate change is an area with much uncertainty. As a result, exposure to changes in drought, fires, and other precipitation-dependent factors are highly uncertain for all ecosystems we assessed.

Four ecosystems were rated as having low adaptive capacity, which adds to their climate change vulnerability (table 1.5). Two of them-the Central Atlantic Coastal Plain Wet Longleaf Pine Savanna and Flatwoods, and the Edwards Plateau Limestone Shrubland-are susceptible to changes in the structure and species composition of the habitat because of fire suppression. The other two low-rating systems - the Nashville Basin Limestone Glade and Woodland and the Caribbean Montane Wet Elfin 
Forest ecosystems - are range-restricted. These ecosystems and their species will have low capacity to migrate in response to changes in climate. Most other ecosystems were rated as having a moderate level of adaptive capacity. These ecosystems had one or more factors that decrease adaptive capacity, such as small patch sizes, threats from development, invasive species or diseases, fire suppression, and hydrology. However, these threats usually were balanced with factors that increase adaptive capacity, such as a high level of protection for conservation.

Overall, five ecosystems in our assessment were rated as having high vulnerability to climate change. Two of them - the Caribbean Coastal Mangrove and Caribbean Montane Wet Elfin Forest ecosystems - had high levels of sensitivity and exposure, with low or moderate adaptive capacities. The Nashville Basin Limestone Glade and Woodland and the Edwards Plateau Limestone Shrubland ecosystems had moderate ratings for sensitivity and exposure, but low adaptive capacities. One ecosystem, the East Gulf Coastal Plain Near-Coast Pine Flatwoods, had high sensitivity to climate change, along with moderate expected exposure and adaptive capacity.

The only ecosystem rated as having low vulnerability to climate change was the Central Atlantic Coastal Plain Wet Longleaf Pine Savanna and Flatwoods ecosystem. The analysis and literature synthesis suggested that the ecosystem processes and major species are minimally sensitive to changes in climate. Although this ecosystem may be exposed to changes in fires, hurricanes, and sea level rise, the assessment also suggested that these changes may be minimal. However, there is a great deal of uncertainty associated with these changes. Finally, the adaptive capacity of this ecosystem is moderate, but the minimum impact from climate change keeps the system's overall vulnerability low.

\section{Phase II}

The HCCVI framework was used to calculate vulnerability scores for the East Gulf Coastal Plan Near-Coast Pine Flatwoods ecosystem and the Nashville Basin Limestone Glade and Woodland ecosystem. Results show that, for each ecosystem, scores varied by time period and with assumptions of minimum and maximum future impacts (table 1.6; fig. 1.11).

In general, for both mid- and late-century time periods, the Nashville Basin Limestone Glade and Woodland ecosystem had slightly higher vulnerability than the Near-Coast Pine Flatwoods ecosystem (table 1.6, fig. 1.11). These sensitivity scores differed more from one another than their resilience scores, which were most similar at mid-century. Likewise, the systems had similarities and differences for individual metrics calculated in the HCCVI. The systems had similar values for the climate stress index, indicating small to moderate changes in climate for the ecosystem ranges over the 21st century. The dynamic process forecast values for both systems indicate high future ecological departure because of altered fire regimes. In the past (around 1960), urbanization levels were relatively low for both ecosystems. Present and future urbanization levels are higher, particularly for the Limestone Glade and Woodland ecosystem. Similarly, landscape condition is better for the Near-Coast Pine Flatwoods ecosystem than for the Limestone Glade and Woodland ecosystem. Both ecosystems have relatively low elevation and bioclimatic variability and high diversity within important functional groups.

Both systems scored lowest in metrics related to adaptive capacity, compared with direct effects and indirect effects. Low scores were influenced by the narrow range of bioclimatic and elevation bands 
in which each system is distributed. Additionally, the Nashville Basin Limestone Glade and Woodland ecosystem had relatively low scores for metrics related to the direct effects of climate change, indicating high sensitivity, especially for the end of the century. The dynamic process forecast for that ecosystem indicates that the vegetation dynamics of that system could be altered substantially throughout the century. For the East Gulf Coastal Plain Near-Coast Pine Flatwoods ecosystem, the dynamic process forecast also indicated a high level of alteration. However, for that ecosystem, the envelope shift index for that ecosystem shows the largest decrease by the end of the century.

\section{Sources of Uncertainty and Needs for Future Research}

While compiling these vulnerability assessments, several sources of uncertainty were identified as well as other areas that warrant further research. Research needs for specific ecosystems are detailed in each system's assessment. This section focuses on needs and uncertainty that apply to many ecosystems.

The metrics and data related to the exposure portion of vulnerability contained a high degree of uncertainty. For example, available climate data for Puerto Rico suggest potentially large future changes in temperature and precipitation with high uncertainty (figs. 1.8, 1.9, and 1.10), which contributed to high exposure ratings for the Caribbean ecosystems we assessed. Because the climate of the Caribbean is difficult to simulate with GCMs, further work on climate projections in the region is needed (Hayhoe, 2013; Ryu and Hayhoe, 2013). Even for ecosystems in the Southeastern United States, differences in climate projections, especially for precipitation, make it difficult to make even qualitative assessments of the direction of change in some processes such as drought and fire regimes. Further studies that incorporate a range of projected climates in a sensitivity analysis may shed light on the likely range of effects on these processes. Additionally, for many ecosystems, there is a critical need for further research on how climate change will affect hydrology (Seager and others, 2009). Whereas in some isolated cases such as the East Gulf Coastal Plain Near-Coast Pine Flatwoods, there was existing information on the effect of climate on hydrology (Lu and others, 2009), for most ecosystems such information was lacking.

Another major area for additional research is on the future of biotic interactions including trophic relationships and dispersal under climate change. These are often difficult to predict (Blois and others, 2013) and, as a result, there are little data on species interactions that can inform ecosystem vulnerability assessment. In limited places within our Phase I analysis, we were able to incorporate species interactions. For example, in the Central Atlantic Coastal Plain Wet Longleaf Pine Savanna and Flatwoods and East Gulf Coastal Plain Near-Coast Pine Flatwoods systems, the effects of cogongrass were considered. This is an invasive species that can increase fire intensity and lead to increased pine mortality following wildfires. Within the HCCVI framework, the dynamic process forecast, invasive species threat, and keystone species vulnerability metrics are all places where information on species interactions could be incorporated. Again, with few exceptions, information on species interactions was not incorporated in the HCCVI assessment.

\section{Comparing Vulnerability Approaches, and Recommendations for Future Assessments}

The literature and GIS data synthesis used for Phase I and the HCCVI framework used in Phase II have important similarities and differences. The overall results from each method are similar-the Nashville Basin Limestone Glade and Woodland ecosystem has relatively high vulnerability, whereas the 
East Gulf Coastal Plain Near-Coast Pine Flatwoods ecosystem has moderate vulnerable. Both methods are flexible enough to include various data sources and types, from GIS data to literature synthesis to expert opinion. Indeed, there were some overlaps in the data sources used in the two methods; the same climate, sea level rise, and elevation data were used for both parts of this assessment. One important difference in data inputs between the two approaches was the use of MaxEnt ${ }^{\mathrm{TM}}$ and state-and-transition simulation models to develop scores in the HCCVI framework for Phase II. Allowing models to inform vulnerability is appealing because insights can be gained from model results that may not be obvious otherwise, such as the potential future effects of fire suppression. However, the flexibility of data sources in the Phase I approach would allow incorporation of these models there as well.

Both of these approaches treat the three components of vulnerability as relatively separate from one another, and do not incorporate the effects of climate change on adaptive measures. Including interactions among the vulnerability components, and especially the effects of climate change on adaptive capacity, is especially critical in ecosystems where prescribed burning and invasive species control are important management strategies. For example, an ecosystem that is likely to be exposed to climate that will decrease wildfire frequency may have a buildup of fuels, making it more difficult to conduct prescribed burning for management. Additionally, changes in climate may make suitable weather conditions for burning occur less frequently on average in the future, which could constrain the ability to manage with prescribed fire. Although these effects were mentioned in some Phase I ecosystem assessments (for example, for the East Gulf Coastal Plain Near-Coast Pine Flatwoods ecosystem), finding better ways to explicitly incorporate interactions among components of vulnerability and the effects of climate on adaptive capacity is an important future need for vulnerability assessments, and especially in the HCCVI approach.

One major difference between the two methods is the numeric score for vulnerability calculated with HCCVI, versus the qualitative rating based on our own judgment, informed by literature and analysis in Phase I. There are definite advantages to calculating numeric scores. Although in Phase I, only one category of vulnerability was assigned per ecosystem, in the HCCVI method, a range of numeric vulnerability scores were calculated to capture uncertainty in data, and scores varied by time period. These numeric values for each component of vulnerability facilitate comparison among a large pool of ecosystems through graphical representations and other visualizations (for example, fig. 1.11). This approach would work well for situations in which many ecosystems need to be assessed in a short period of time. On the other hand, the data and literature synthesis that was conducted for Phase I can provide a more nuanced assessment of vulnerability that was not able to be captured with the HCCVI alone. This approach is suitable when for example: there are few ecosystems to assess, a detailed written report is desired, or there is ample time to synthesize a wide body of existing literature. However, because the synthesis approach for vulnerability has not been conducted for many ecosystems, and because it does not include quantitative scoring of each ecosystem's vulnerability, it was only possible to calculate a vulnerability rating in comparison to the other ecosystems being assessed. Additionally, the vulnerability rating assigned was subjective, based on the authors' assessment of the evidence. As such, this rating likely would be different if the assessment were repeated. This is a drawback of the Phase I approach. In this way, the vulnerability rating resulting from Phase I may be less useful than the report and synthesis of data and literature. Ideally, when conducting vulnerability assessments, both the synthesis and HCCVI 
approaches would be combined to provide a more comprehensive assessment sensitivity, exposure, and adaptive capacity.

\section{Conclusions}

The Southeast contains various diverse, important ecosystems, from montane woodlands to grasslands to coastal systems. Likewise, the types and magnitudes of likely climate change effects on these ecosystems vary greatly. Five of the ecosystems we assessed were rated as having high vulnerability compared to others in the region. The characteristics of these ecosystems vary, but all are somewhat range-restricted and occur in ecologically or geographically unique habitats. All but one, the East Gulf Coastal Plain Southern Loess Bluff Forest, were labeled as "insular" in our initial ecosystem selection process. The insular nature of those ecosystems will make adaptation to even moderate climate change difficult. For those ecosystems, reducing the effects of non-climate stressors, maintaining remaining examples, and ensuring connectivity with similar ecosystems will be important.

The ecosystems that were given a vulnerability rating of "medium" have moderate-to-high values in at least one of the three components of vulnerability. Therefore, reducing exposure or increasing adaptive capacity will still be important for those ecosystems, even though they were not rated highly vulnerable. The one ecosystem that was given a rating of "low" vulnerability, the Central Atlantic Coastal Plain Wet Longleaf Pine Savanna and Flatwoods, had a fairly low sensitivity to climate change based on existing knowledge, but had reduced adaptive capacity. Monitoring could be important for that ecosystem.

Critical research needs exist to inform assessments of climate change vulnerability for each ecosystem in this study. Overall, there was a high degree of uncertainty related to climate change exposure and sensitivity for most ecosystems in our assessment. Many ecosystems we assessed are sensitive to changes in hydrology, and additional information on how each ecosystem's hydrology might be affected by climate change is needed. Information regarding climate change effects on biotic interactions for all ecosystems is another place where information is lacking and is essential for future research. Updating the vulnerability assessments in this report will be crucial when new information becomes available.

The methods used in this study represent two methods for assessing vulnerability to ecosystem climate change. One provided a synthesis of available data and literature related to each component of vulnerability, and the other calculated a series of numeric metrics summarizing components of vulnerability. Each approach has merit, depending on the purpose of the assessment. To maximize the value of future vulnerability assessments in the Southeast and beyond, it is recommended that a comprehensive assessment include both approaches.

\section{Acknowledgments}

Bill Wolfe and Jennifer Cartwright (U.S. Geological Survey) assisted with ecosystem selection and especially the concept of "insular" ecosystems. Bill Gould (U.S. Department of Agriculture Forest Service), Jane Fitzgerald (American Bird Conservancy), Rua Mordecai (U.S. Fish and Wildlife Service), Bruce Moring (U.S. Geological Survey), and John Tirpak 
(U.S. Fish and Wildlife Service) assisted with ecosystem selection. Bill Gould and staff at the U.S. Department of Agriculture Forest Service International Institute of Tropical Forestry graciously shared Puerto Rico and U.S. Virgin Islands data. Doug Marcy (National Oceanic and Atmospheric Administration) assisted with sea level rise data. Dave Theobald (Conservation Science Partners) provided access to historical Integrated Climate and Land Use Scenario and Human Modification data. Helpful feedback on Phase I ecosystem assessments was provided by Lee Elliott (University of Missouri), Rua Mordecai (U.S. Fish and Wildlife Service), Brent Murry (U.S. Fish and Wildlife Service), Judy Teague (NatureServe), John Tirpak (U.S. Fish and Wildlife Service), and Jeffrey Walck (Middle Tennessee State University). Patrick Comer (NatureServe) provided guidance on Habitat Climate Change Vulnerability Index methods and data sources. Carl Nordman (NatureServe) provided helpful ideas on invasive species for the East Gulf Coastal Plain Near-Coast Pine Flatwoods Ecosystem. This research was supported by the U.S. Department of the Interior Southeast Climate Science Center. The project described in this publication was supported by Cooperative Agreement No. 200 from the U.S. Geological Survey. This manuscript is submitted for publication with the understanding that the U.S. Government is authorized to reproduce and distribute reprints for Governmental purposes.

\section{References Cited}

Arnold, C.L., and Gibbons, C.J., 1996, Impervious surface coverage-The emergence of a key environmental indicator: Journal of the American Planning Association, v. 62, p. 243-258.

Bagne, K.E., Friggens, M.M., and Finch, D.M., 2011, A system for assessing vulnerability of species (SAVS) to climate change: U.S. Forest Service, Rocky Mountain Research Station, Fort Collins, Colorado, General Technical Report RMRS-GTR-257, 28 p.

Bierwagen, B.G., Theobald, D.M., Pyke, C.R., Choate, A., Groth, P., Thomas, J.V., and Morefield, P., 2010, National housing and impervious surface scenarios for integrated climate impact assessments: Proceedings of the National Academy of Sciences of the United States of America, v. 107, p. 20,88720,892.

Blois, J.L., Zarnetske, P.L., Fitzpatrick, M.C., and Finnegan S., 2013, Climate change and the past, present, and future of biotic interactions: Science, v. 341, p. 499-504.

Brandt, L., He, H., Iverson, L., Thompson, F.R., Butler, P., Handler, S., Janowiak, M., Shannon, D.P., Swanston, C., Albrecht, M., Blume-Weaver, R., Deizman, P., DePuy, J., Dijak, W.D., Dinkel, G., Fei, S., Jones-Farrand, D.T., Leahy, M., Matthews, S., Nelson, P., Oberle, B., Perez, J., Peters, M., Prasad, A., Schneiderman, J.E., Shuey, J., Smith, A.B., Studyvin, C., Tirpak, J.M., Walk, J.W., Wang, W.J., Watts, L., Weigel, D., and Westin S., 2014, Central hardwoods ecosystem vulnerability assessment and synthesis-A report from the Central Hardwoods Climate Change Response Framework Project: U.S. Forest Service, Northern Research Station, Newton Square,Pennsylvania, General Technical Report NRS 124, 254 p.

Cahill, A.E., Aiello-Lammens, M.E., Fisher-Reid, M.C., Hua, X., Karanewsky, C.J., Ryu, H.Y., Sbeglia, G.C., Spagnolo, F., Waldron, J.B., Warsi, O., and Wiens, J.J., 2013, How does climate change cause extinction?: Proceedings of the Royal Society B, v. 280, 9 p. 
Cambers, G., Claro, R., Juman, R., and Scott, S., 2008, Climate change impacts on coastal and marine biodiversity in the insular Caribbean-Report of Working Group II, Climate change and biodiversity in the insular Caribbean: Trinidad, West Indies, Caribbean Natural Resources Institute, 87 p.

Carter, L.M., Jones, J.W., Berry, L., Burkett, V., Murley, J.F., Obeysekera, J., Schramm, P.J., and Wear, D., 2014, Southeast and the Caribbean, chap. 17 of Melillo, J.M., Richmond, T.C., and Yohe, G.W., eds., Climate change impacts in the United States-The third national climate assessment: U.S. Global Change Research Program, p. 386-417, accessed June 2014, at http://nca2014.globalchange.gov/report/regions/southeast.

Chen, I.-C., Hill, J.K., Ohlemüller, R., Roy, D.B., and Thomas, C.D., 2011, Rapid range shifts of species associated with high levels of climate warming: Science, v. 333, p. 1,024-1,026.

Comer, P., Faber-Langendoen, D., Evans, R., Gawler, S., Josse, C., Kittel, G., Menard, S., Pyne, M., Reid, M., Schultz, K., Snow, K., and Teague, J., 2003, Ecological systems of the United States-A working classification of U.S. terrestrial systems: Arlington, Virginia, NatureServe, 82 p.

Comer, P.J., Young, B., Schulz, K., Kittel, G., Unnasch, B., Braun, D., Hammerson, G., Smart, L., Hamilton, H., Auer, S., Smyth, R., and Hak, J., 2012, Ecological systems of the United States-A working classification of U.S. terrestrial systems: Arlington, Virginia, NatureServe, 82 p.

Conrad, C.E., and Fuhrmann, C.M., 2013, Climate of the Southeast USA-Past, present, and future, in Ingram, K.T., Dow, K., Carter, L., and Anderson, J., eds., Climate of the southeast United StatesVariability, change, impacts, and vulnerability: Washington, D.C., Island Press, p. 8-42.

Damschen, E.I., Harrison, S., Ackerly, D.D., Fernandez-Going, B.M., and Anacker, B.L., 2012, Endemic plant communities on special soils-Early victims or hardy survivors of climate change?: Journal of Ecology, v. 100, p. 1,122-1,130.

Dawson, T.P., Jackson, S.T., House, J.I., Prentice, I.C., and Mace, G.M., 2011, Beyond predictionsBiodiversity conservation in a changing climate: Science, v. 332, p. 53-58.

Díaz, S., and Cabido, M., 2001, Vive la difference-Plant functional diversity matters to ecosystem processes: Trends in Ecology \& Evolution, v. 16, p. 646-655.

Dubois, N., Caldas, A., Boshoven, J., and Delach A., 2011, Integrating climate change vulnerability assessments into adaptation planning-A case study using the NatureServe Climate Change Vulnerability Index to inform conservation planning for species in Florida: Washington, D.C, Defenders of Wildlife report, 246 p.

Duerr, D.A., and Mistretta P.A., 2012, Invasive pests-Insects and diseases, in Wear, D.N., and Greis, J.G., eds., The Southern Forest Futures Project-Technical report: U.S. Forest Service, Southern Reserach Station, Asheville, North Carolina, General Technical Report SRS-GTR-178, p. 457-508.

Environmental Systems Research Institute, 2012, ArcGIS Desktop: Release 10.1. Environmental Systems Research Institute, Redlands, California. 
Folke, C., Carpenter, S., Walker, B., Scheffer, M., Elmqvist, T., Gunderson, L., and Holling C.S., 2004, Regime shifts, resilience, and biodiversity in ecosystem management: Annual Review of Ecology, Evolution, and Systematics, v. 35, p. 557-581.

Fry, J.A., Xian, G., Jin, S., Dewitz, J.A., Homer, C.G., Yang, L., Barnes, C., Herold, N., and Wickham, J.D., 2011, Completion of the 2006 National Land Cover Database for the conterminous United States: Photogrammetric Engineering and Remote Sensing, v. 77, p. 858-864.

Gesch, D., Evans, G., Mauck, J., Hutchinson, J., and Carswell W.J., 2009, The National Map: elevation: U.S. Geological Survey Fact Sheet 2009-3053, 4 p.

Glick, P., Stein, B.A., and Edelson N.A., 2011, Scanning the conservation horizon-A guide to climate change vulnerability assessment: Washington, D.C., National Wildlife Federation, 168 p.

Gould, W.A., Alarcón, C., Fevold, B., Jiménez, M.E., Martinuzzi, S., Potts, G., Solórzano, M., and Ventosa, E., 2007, Puerto Rico Gap Analysis Project-Final report. U.S. Department of Agriculture Forest Service, Moscow, Idaho, and Rio Piedras, Puerto Rico, 159 p.

Gould, W.A., Potts, G., Quiñones, M., and Solórzano, M., 2012, Virgin Islands GAP Land Cover: U.S. Department of Agriculture Forest Service, International Institute of Tropical Forestry, Río Piedras, Puerto Rico.

Grace, S., and Wilder T., 2009, LANDFIRE biophysical setting model for East Gulf Coastal Plain NearCoast Pine Flatwoods-LANDFIRE biophysical setting descriptions, Map zone 55: LANDFIRE program model, p. 113-117, accessed May 2012, at

http://www.landfire.gov/national_veg_models_op2.php.

Hameed, S.O., Holzer, K.A., Doerr, A.N., Baty, J.H., and Schwartz, M.W., 2013, The value of a multifaceted climate change vulnerability assessment to managing protected lands-Lessons from a case study in Point Reyes National Seashore: Journal of Environmental Management, v. 121, p. 37-47.

Hayhoe, K., 2013, Quantifying key drivers of climate variability and change for Puerto Rico and the Caribbean: Final Report to the Southeast Climate Science Center, Raleigh, North Carolina, 241 p.

Heller, N.E., and Zavaleta, E.S., 2009, Biodiversity management in the face of climate change-A review of 22 years of recommendations: Biological Conservation, v. 142, p. 14-32.

Hijmans, R.J., Cameron, S.E., Parra, J.L., Jones, P.G., and Jarvis, A., 2005, Very high resolution interpolated climate surfaces for global land areas: International Journal of Climatology, v. 25, p. 19651978.

Intergovernmental Panel on Climate Change, 2007a, Climate change 2007-The physical science basisContribution of Working Group I to the Fourth Assessment Report of the Intergovernmental Panel on Climate Change: Cambridge and New York, Cambridge University Press, 996 p.

Intergovernmental Panel on Climate Change, 2007b, Climate change 2007-Impacts, adaptation, and vulnerability-Contribution of Working Group II to the Fourth Assessment Report of the 
Intergovernmental Panel on Climate Change: Cambridge and New York, Cambridge University Press, $976 \mathrm{p}$.

Intergovernmental Panel on Climate Change, 2013, Climate change 2013—The physical science basisContribution of Working Group I to the Fifth Assessment Report of the Intergovernmental Panel on Climate Change: Cambridge and New York, Cambridge University Press, 976 p.

Iverson, L.R., Prasad, A.M., Matthews, S.N., and Peters M., 2008, Estimating potential habitat for 134 eastern US tree species under six climate scenarios: Forest Ecology and Management, v. 254, p. 390406.

Jacobs, K.R., Carrubba, L., and Díaz, E.L., eds., 2013, Puerto Rico Climate Change Council vulnerability assessment, Working Group 2 report-Ecology and biodiversity: San Juan, Puerto Rico, Puerto Rico Department of Natural and Environmental Resources, National Oceanic and Atmospheric Administration Office of Ocean and Coastal Resource Management [Also available at http://prccc.org/download/PR\%20State\%20of\%20the\%20Climate-WG2.pdf.]

Karl, T.R., Melillo, J.M., and Peterson, T.C., eds., 2009, Global climate change impacts in the United States: New York, Cambridge University Press, 188 p.

LANDFIRE, 2013, LANDFIRE 2010 (version 1.2.0) Succession Class (S-Class) Layer: U.S. Geological Survey LANDFIRE Data Distribution Site, accessed March 2014, at http://landfire.cr.usgs.gov/viewer.

LANDFIRE, 2014, National product assessment—Eastern milestone super zone analysis and report: LANDFIRE program report, accessed May 2014, at http://www.landfire.gov/dp_quality_assessment.php.

Lavorel, S., McIntyre, S., Landsberg, J., and Forbes, T.D.A., 1997, Plant functional classifications—From general groups to specific groups based on response to disturbance: Trends in Ecology \& Evolution, v. 12, no. 12, p. 474-478.

Lu, J., Sun, G., McNulty, S.G., and Comerford N.B., 2009, Sensitivity of pine flatwoods hydrology to climate change and forest management in Florida, USA: Wetlands, v. 29, p. 826-836.

Maurer, E.P., Wood, A.W., Adam, J.C., Lettenmaier, D.P., and Nijssen B., 2002, A long-term hydrologically-based data set of land surface fluxes and states for the conterminous United States: Journal of Climate, v. 15, p. 3,237-3,251.

McNulty, 2012, Southeast, in Vose, J.M., Peterson, D.L, and Patel-Weynand, T., eds., Effects of climatic variability and change on forest ecosystems-A comprehensive science synthesis for the U.S. forest sector: U.S. Forest Service, Pacific Northwest Research Station, Portland, Oregon, General Technical Report PNW-GTR-870, 265 p.

Merow, C., Smith, M.J., and Silander, J.A., 2013, A practical guide to MaxEnt for modeling species’ distributions-What it does, and why inputs and settings matter: Ecography, v. 36, p. 1,058-1,069. 
Moritz, C., and Agudo, R., 2013, The future of species under climate change-Resilience or decline?: Science, v. 341, p. 504-508.

National Oceanic and Atmospheric Administration, 2013, Digital coast sea level rise and coastal flooding impacts data: National Oceanic and Atmospheric Administration Coastal Services Center, Charleston, South Carolina, accessed May 2014, at https://coast.noaa.gov/slr/.

NatureServe, 2003, Ecological systems of Latin America and the Caribbean database, Version 1.01: Arlington, Virginia, NatureServe database.

NatureServe, 2013, U.S. ecological systems national map data: Arlington, Virginia, NatureServe database, accessed January 2013, at http://www.natureserve.org/getData/USecologyData.jsp.

Parmesan, C., 2007, Influences of species, latitudes and methodologies on estimates of phenological response to global warming: Global Change Biology, v. 13, p. 1,860-1,872.

Phillips, S.J., Anderson, R.P., and Schapire, R.E., 2006, Maximum entropy modeling of species geographic distributions: Ecological Modelling, v. 190, p. 231-259.

Puerto Rico Gap Analysis Project, 2006, PRGAP Land cover: U.S. Department of Agriculture Forest Service, Rio Piedras, Puerto Rico.

Pyne, M., and Fitch, K., 2009, LANDFIRE biophysical setting model for Nashville Basin Limestone Glade and Woodland-LANDFIRE biophysical setting descriptions, Map zone 48: LANDFIRE program model, p. 91-155, accessed May 2012, at http://www.landfire.gov/national_veg_models_op2.php.

R Core Team, 2013, R-A language and environment for statistical computing: Vienna, Austria, R Foundation for Statistical Computing.

Rollins, M.G., 2009, LANDFIRE—A nationally consistent vegetation, wildland fire, and fuel assessment: International Journal of Wildland Fire, v. 18, p. 235-249.

Rubino, M.J., 2012, Sea level rise modeling for the SAMBI Designing Sustainable Landscapes Project: Raleigh, North Carolina State University Web site, accessed June 2013, at http://basic.ncsu.edu/dsl/slr.html.

Ryu, J.-H., and Hayhoe, K., 2013, Understanding the sources of Caribbean precipitation biases in CMIP3 and CMIP5 simulations: Climate Dynamics, v. 42, p. 3,233-3,252.

Sayre, R., Comer, P., Warner, H., and Cress J., 2009, A new map of standardized terrestrial ecosystems of the conterminous United States: U.S. Geological Survey Professional Paper 1768, 17 p.

Seager, R., Tzanova, A., and Nakamura J., 2009, Drought in the Southeastern United States-Causes, variability over the last millennium, and the potential for future hydroclimate change: Journal of Climate, v. 22, p. 5,021-5,045. 
Stanturf, J.A., and Goodrick, S.L., 2013, Fire, in Wear, D.N., and Greis, J.G., eds., The Southern Forest Futures Project-Technical report: U.S. Forest Service, Southern Research Station, Asheville, North Carolina, General Technical Report SRS-GTR-178, 542 p.

Staudt, A., Leidner, A.K., Howard, J., Brauman, K.A., Dukes, J.S., Hansen, L.J., Paukert, C., Sabo, J., and Solórzano, L.A., 2013, The added complications of climate change-Understanding and managing biodiversity and ecosystems: Frontiers in Ecology and the Environment, v. 11, p. 494-501.

Stoner, A.M.K., Hayhoe, K., Yang, X., and Wuebbles, D.J., 2012, An asynchronous regional regression model for statistical downscaling of daily climate variables: International Journal of Climatology, v. 33, p. 2,473-2,494.

Sugarbaker, L.J., and Carswell, W.J., 2011, The National Map: U.S. Geological Survey Fact Sheet 20113042, 4 p.

Terando, A., Costanza, J.K., Belyea, C., Dunn, R.R., McKerrow, A.J., and Collazo, J.A., 2014, The southern megalopolis-Using the past to predict the future of urban sprawl in the Southeast US: PloS ONE, v. 9, no. 7, 8 p.

Theobald, D.M., Reed, S.E., Fields, K., and Soulé, M., 2012, Connecting natural landscapes using a landscape permeability model to prioritize conservation activities in the United States: Conservation Letters, v. 5, p. 123-133.

Turner, B.L., Kasperson, R.E., Matson, P.A, McCarthy, J.J., Corell, R.W., Christensen, L., Eckley, N., Kasperson, J.X., Luers, A., Martello, M.L., Polsky, C., Pulsipher, A., and Schiller, A., 2003, A framework for vulnerability analysis in sustainability science: Proceedings of the National Academy of Sciences of the United States of America, v. 100, p. 8,074-8,079.

U.S. Environmental Protection Agency, 2009, Land-use scenarios-Scenarios consistent with climate change storylines: U.S. Environmental Protection Agency, Global Change Research Program, National Center for Environmental Assessment, EPA/600/R-08/076F, accessed December 2013, at http://www.epa.gov/ncea.

U.S. Environmental Protection Agency, 2010, Integrated climate and land-use scenarios (ICLUS) tools and datasets (version 1.3 and 1.3.1): U.S. Environmental Protection Agency, EPA/600/R-09/143F.

U.S. Geological Survey, 2011, Protected areas database-US (PAD-US), version 1.2:

U.S. Geological Survey National Gap Analysis Program database, accessed July 2013, at http://gapanalysis.usgs.gov/padus/.

VanLear, D.H., Carroll, W.D., Kapeluck, P.R., and Johnson, R., 2005, History and restoration of the longleaf pine-grassland ecosystem-Implications for species at risk: Forest Ecology and Management, v. 211, p. 150-165.

Vose, J.M., Peterson, D.L., and Patel-Weynand, T., eds., 2012, Effects of climatic variability and change on forest ecosystems-A comprehensive science synthesis for the U.S. forest sector:U.S. Forest 
Service, Pacific Northwest Research Station, Portland, Oregon, General Technical Report PNW-GTR870, 265 p.

Wear, D.N., and Greis, J.G., 2012, The Southern Forest Futures Project-Summary report: U.S. Forest Service, Southern Research Station, Asheville, North Carolina, General Technical Report SRS-168, $54 \mathrm{p}$.

Westerling, A.L., Hidalgo, H.G., Cayan, D.R., and Swetnam, T.W., 2006, Warming and earlier spring increase western U.S. forest wildfire activity: Science, v. 313, p. 940-943.

Wickham, J.D., Stehman, S.V., Gass, L., Dewitz, J., Fry, J.A., and Wade, T.G., 2013, Accuracy assessment of NLCD 2006 land cover and impervious surface: Remote Sensing of Environment, v. 130, p. 294-304.

Williams, S.E., Shoo, L.P., Isaac, J.L., Hoffmann, A.A., and Langham, G., 2008, Towards an integrated framework for assessing the vulnerability of species to climate change: PLoS Biology, v. 6, p. 2,6212,626 .

Young, B., Byers, E., Gravuer, K., Hall, K., Hammerson, G., and Redder, A., 2011, Guidelines for using the NatureServe Climate Change Vulnerability Index, Release 2.1: Arlington, Virginia, NatureServe, $54 \mathrm{p}$. 


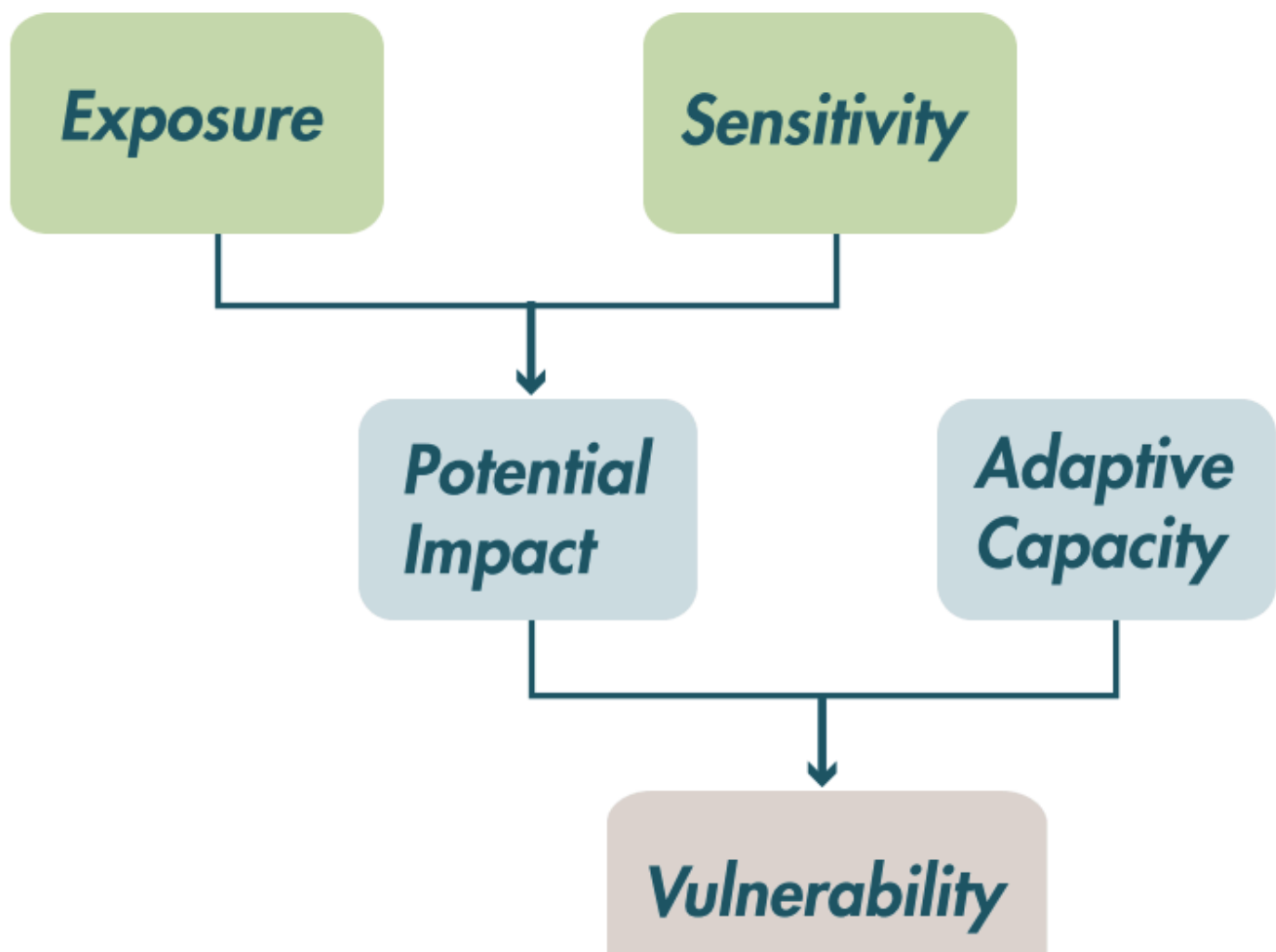

Figure 1.1. Components of climate change vulnerability (from Glick and others, 2011). 


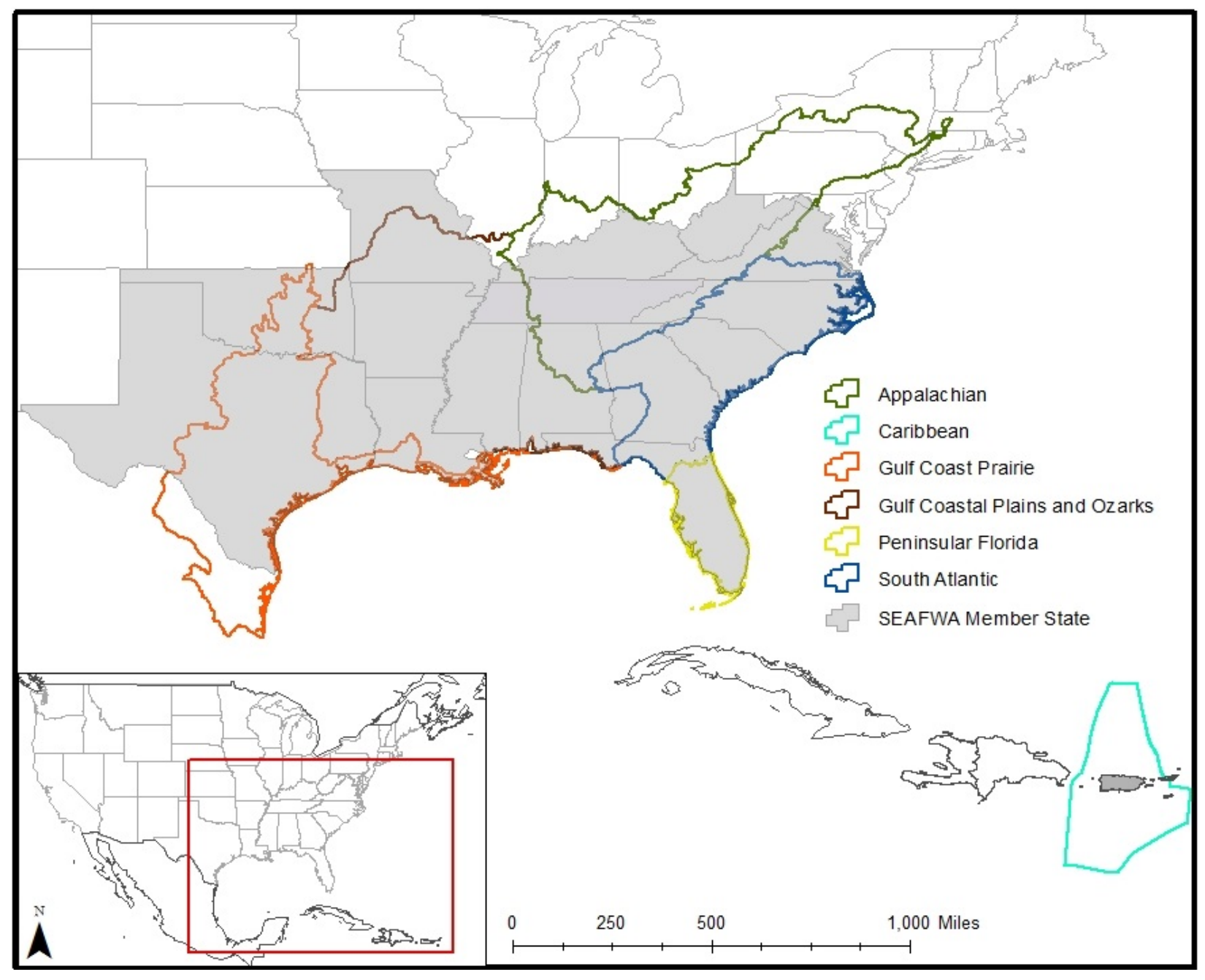

Figure 1.2. The Southeastern Association of Fish and Wildlife Agencies (SEAFWA) region, along with the six U.S. Department of Interior Landscape Conservation Cooperatives in the Southeast and Caribbean. 


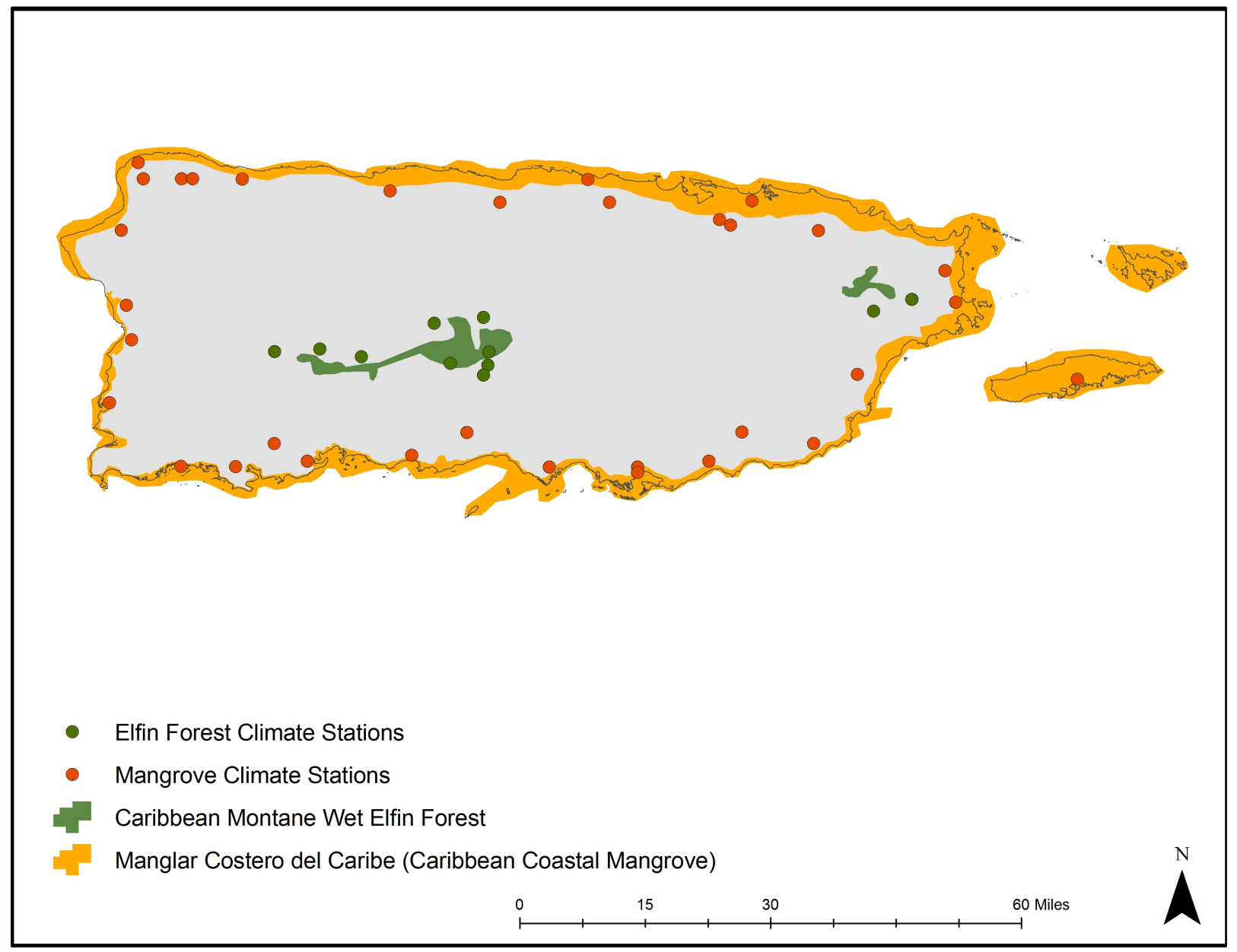

Figure 1.3. Climate stations used for summarizing projected change in climate variables for the two ecosystems in the Caribbean. Stations within 3.1 miles (5 kilometers) of each ecosystem's range were used in the analysis. 


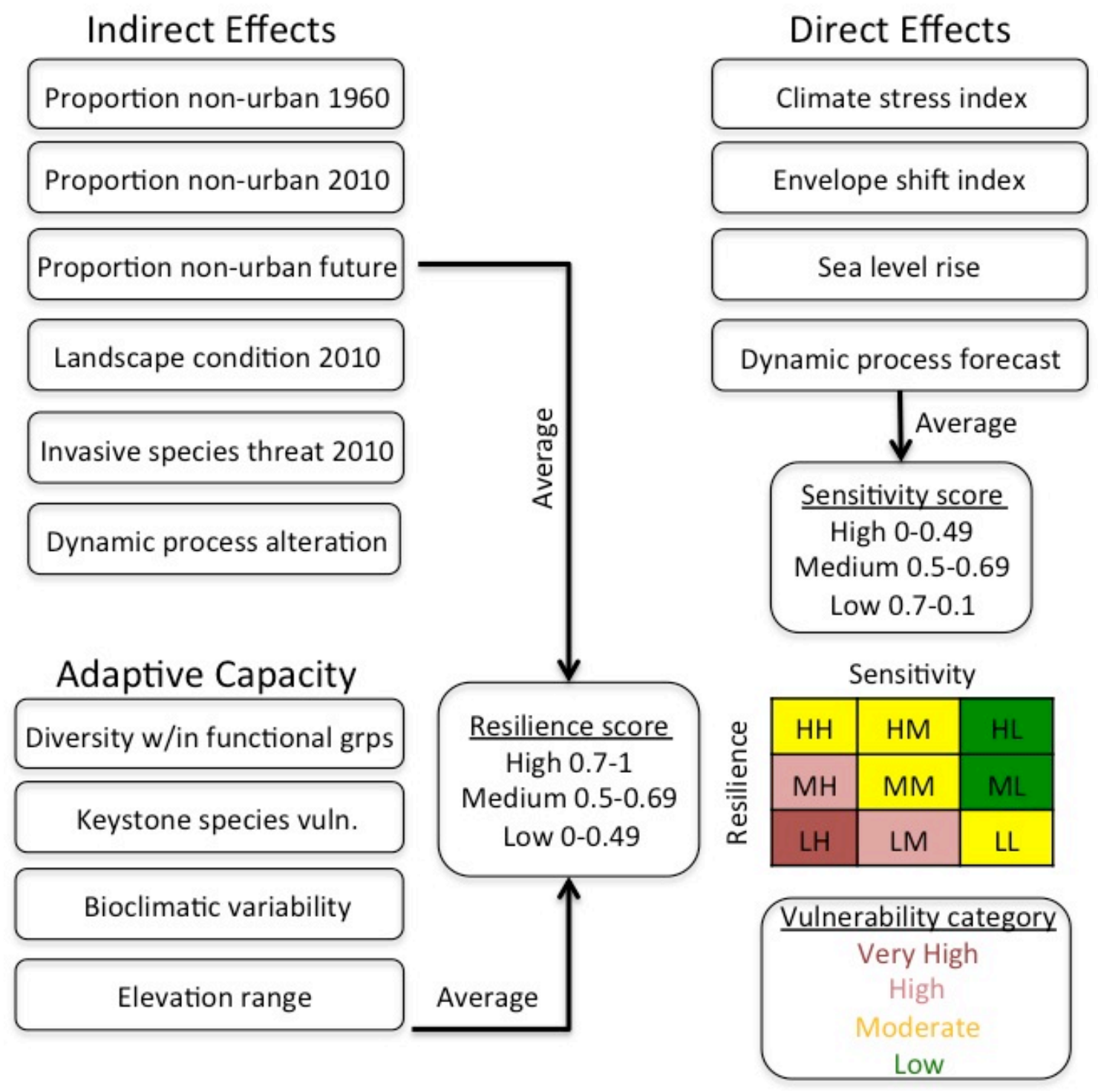

Figure 1.4. Flow chart for the NatureServe Habitat Climate Change Vulnerability Index ( $\mathrm{HCCVI}$ ) framework, modified from Comer and others (2012) to represent methods in the current study. 


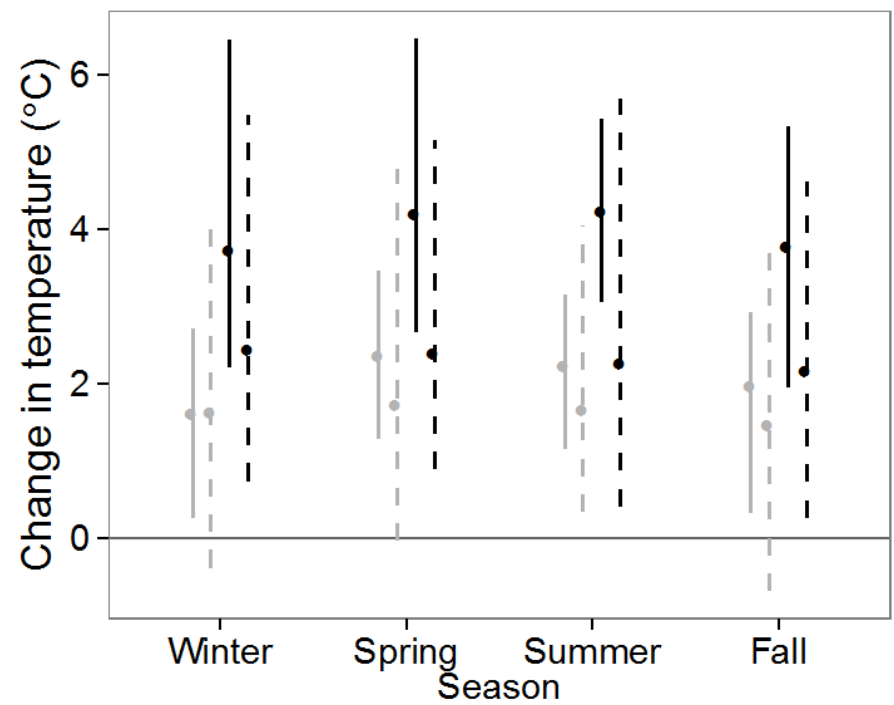

Scenario, time period

- A1FI, mid-century

- B1, mid-century

$\rightarrow \mathrm{A} 1 \mathrm{Fl}$, end of century

- - B1, end of century

Figure 1.5. Projected change in seasonal maximum temperatures (in degrees Celsius $\left[{ }^{\circ} \mathrm{C}\right]$ ) across the Southeastern United States for the middle (2040-2060) and the end of the 21st century (2080-2100), compared with the recent time period (1981-2000), for two emissions scenarios. Solid dots and error bars represent, respectively, the means and ranges of projections across climate models under each scenario.

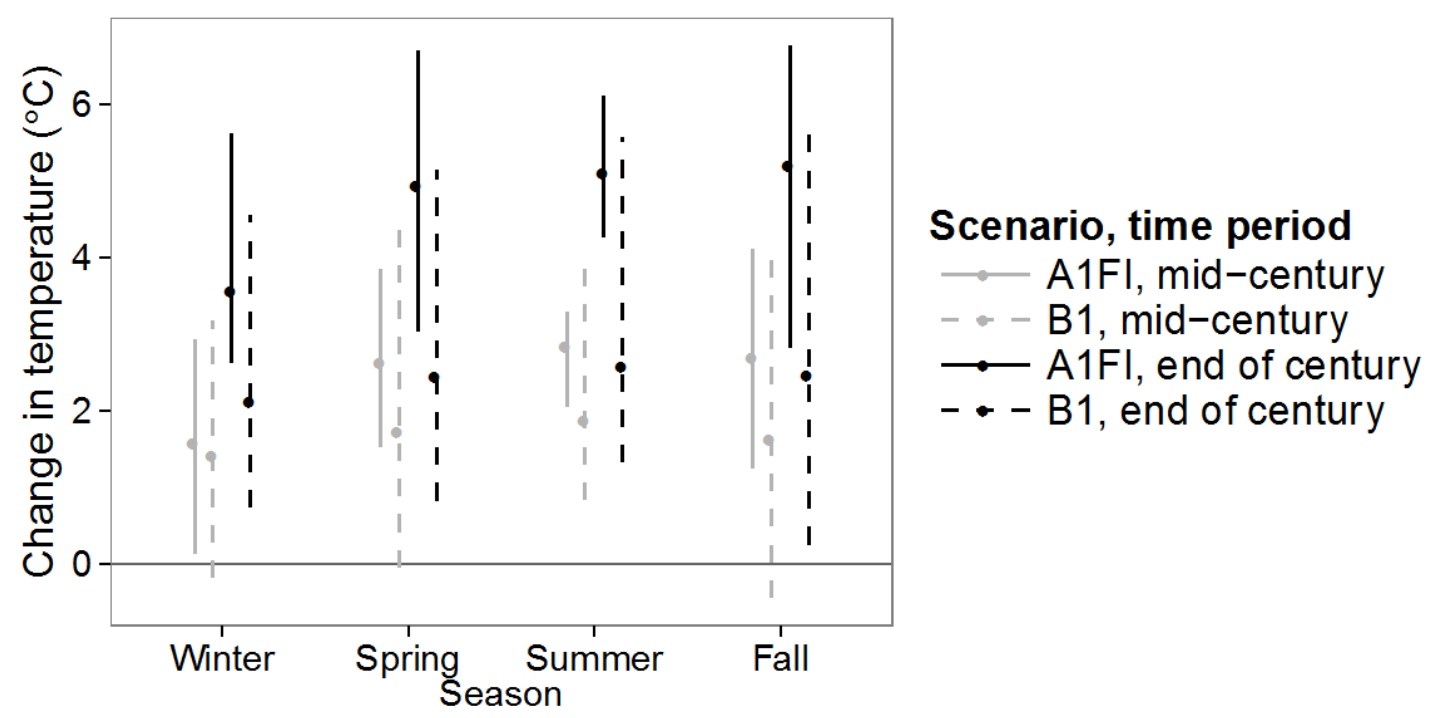

Figure 1.6. Projected change in seasonal minimum temperatures (in degrees Celsius $\left[{ }^{\circ} \mathrm{C}\right]$ ) across the Southeastern United States for the middle (2040-2060) and the end of the 21st century (2080-2100), compared with the recent time period (1981-2000), for two emissions scenarios. Solid dots and error bars represent, respectively, the means and ranges of projections across climate models under each scenario. 


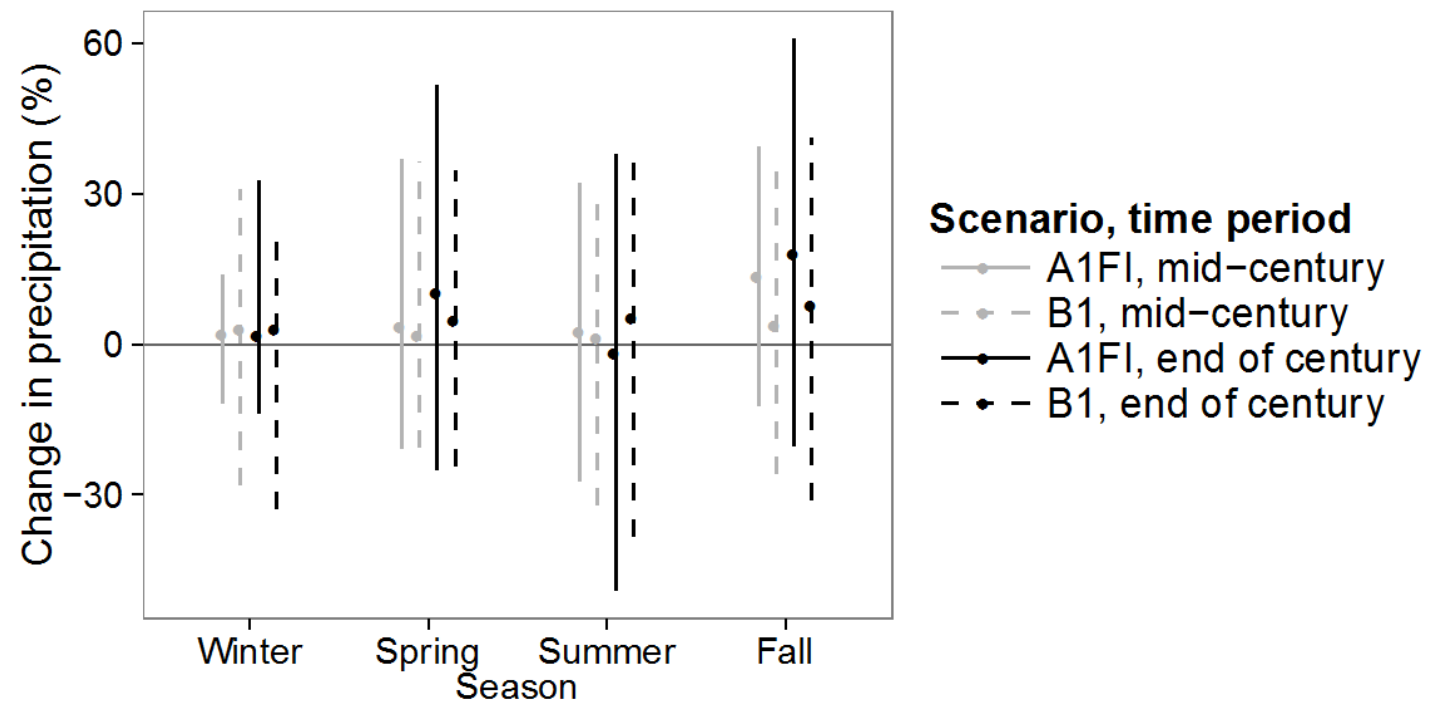

Figure 1.7. Projected percentage (\%) change in seasonal average precipitation across the Southeastern United States for the middle (2040-2060) and the end of the 21st century (2080-2100), compared with the recent time period (1981-2000), for two emissions scenarios. Solid dots and error bars represent, respectively, the means and ranges of projections across climate models under each scenario.

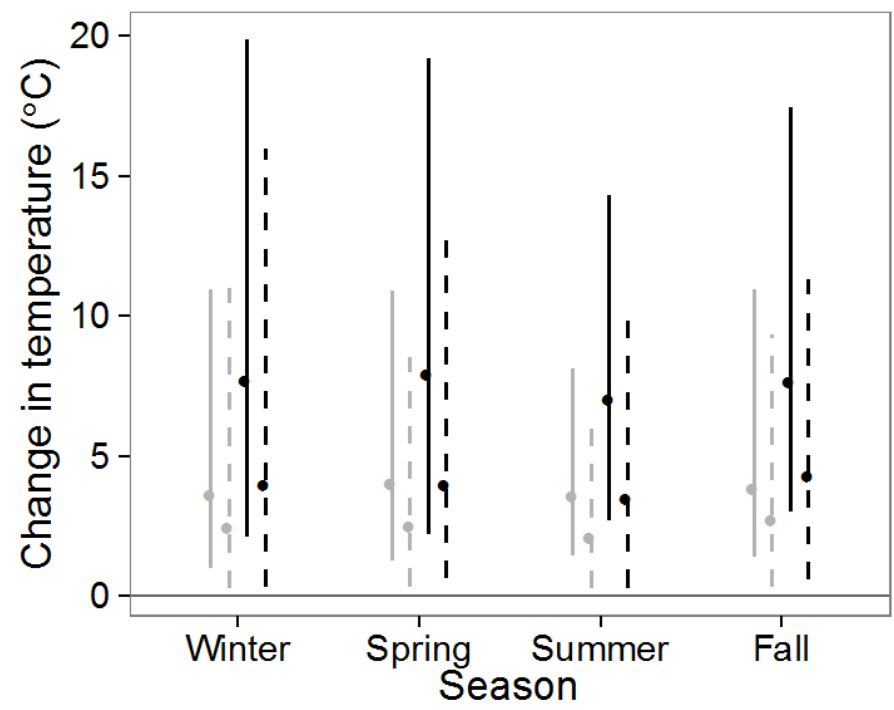

Scenario, time period $\rightarrow \mathrm{A} 1 \mathrm{FI}$, mid-century

- B1, mid-century $\rightarrow \mathrm{A} 1 \mathrm{Fl}$, end of century - - B1, end of century

Figure 1.8. Projected change in seasonal maximum temperatures (in degrees Celsius $\left[{ }^{\circ} \mathrm{C}\right]$ ) for all climate stations in Puerto Rico climate stations for the middle (2040-2060) and the end of the 21st century (2080 2100), compared with the recent time period (1981-2000), for two emissions scenarios. Solid dots and error bars represent, respectively, the means and ranges of projections across climate models under each scenario. 


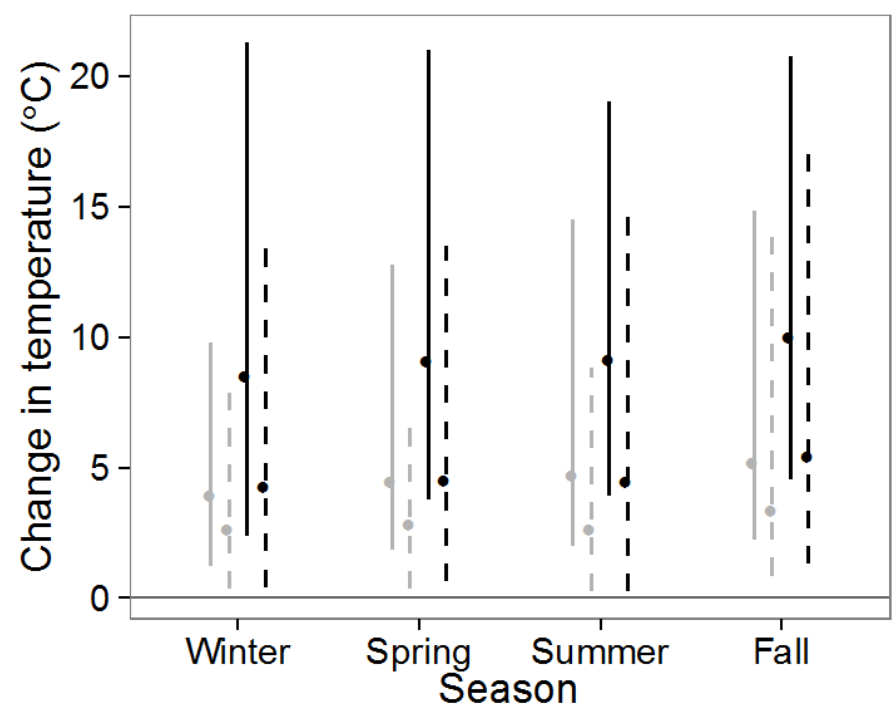

\section{Scenario, time period} A1FI, mid-century

- B1, mid-century

$\rightarrow \mathrm{A} 1 \mathrm{FI}$, end of century

- - B1, end of century

Figure 1.9. Projected change in seasonal minimum temperatures (in degrees Celsius [ $\left.{ }^{\circ} \mathrm{C}\right]$ ) for all climate stations in Puerto Rico climate stations for the middle (2040-2060) and the end of the 21st century (20802100), compared with the recent time period (1981-2000), for two emissions scenarios. Solid dots and error bars represent, respectively, the means and ranges of projections across climate models under each scenario.

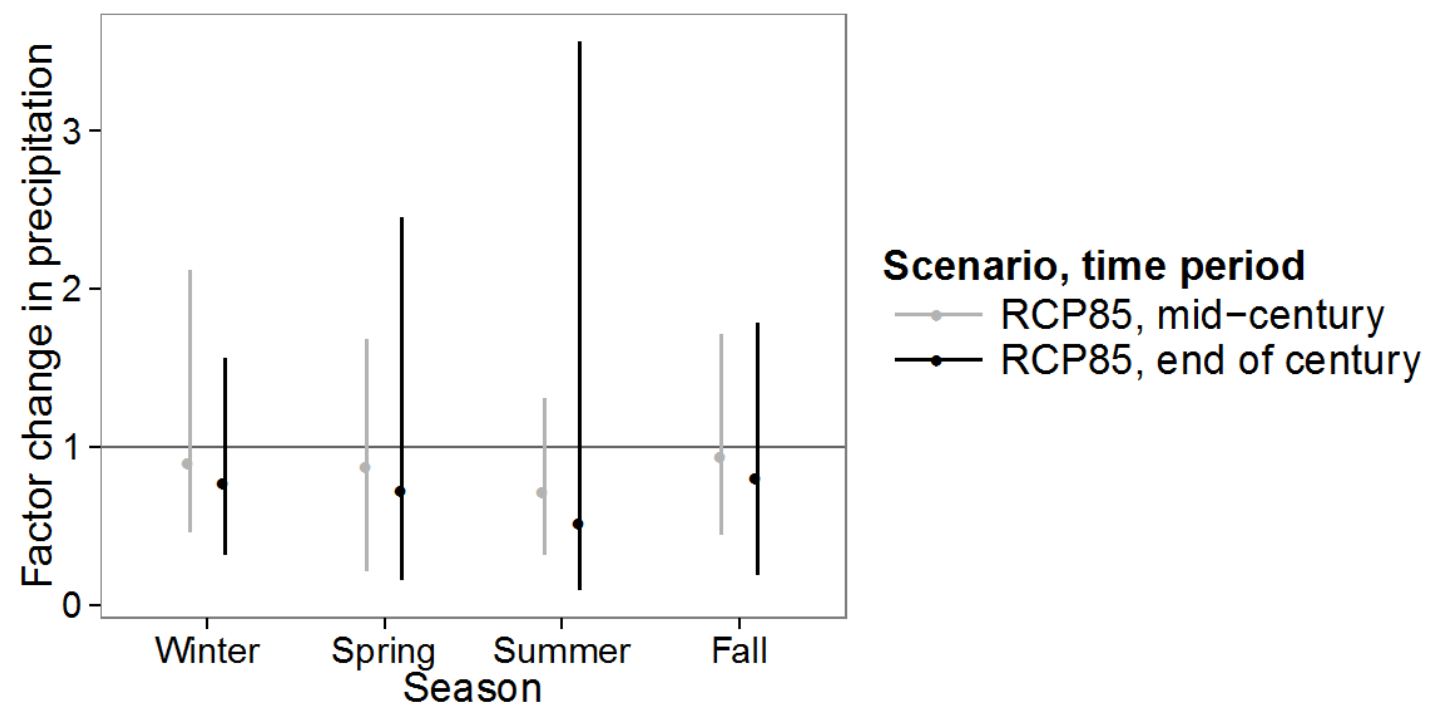

Figure 1.10. The projected factor changes in seasonal average precipitation across the Southeastern United States for the middle (2040-2060) and the end of the 21st century (2080-2100), compared with the recent time period (1981-2000), for two emissions scenarios. Solid dots and error bars represent, respectively, the means and ranges of projections across climate models under each scenario. Values of less than 1 represent a decrease in precipitation, whereas values of greater than 1 represent an increase in precipitation. 


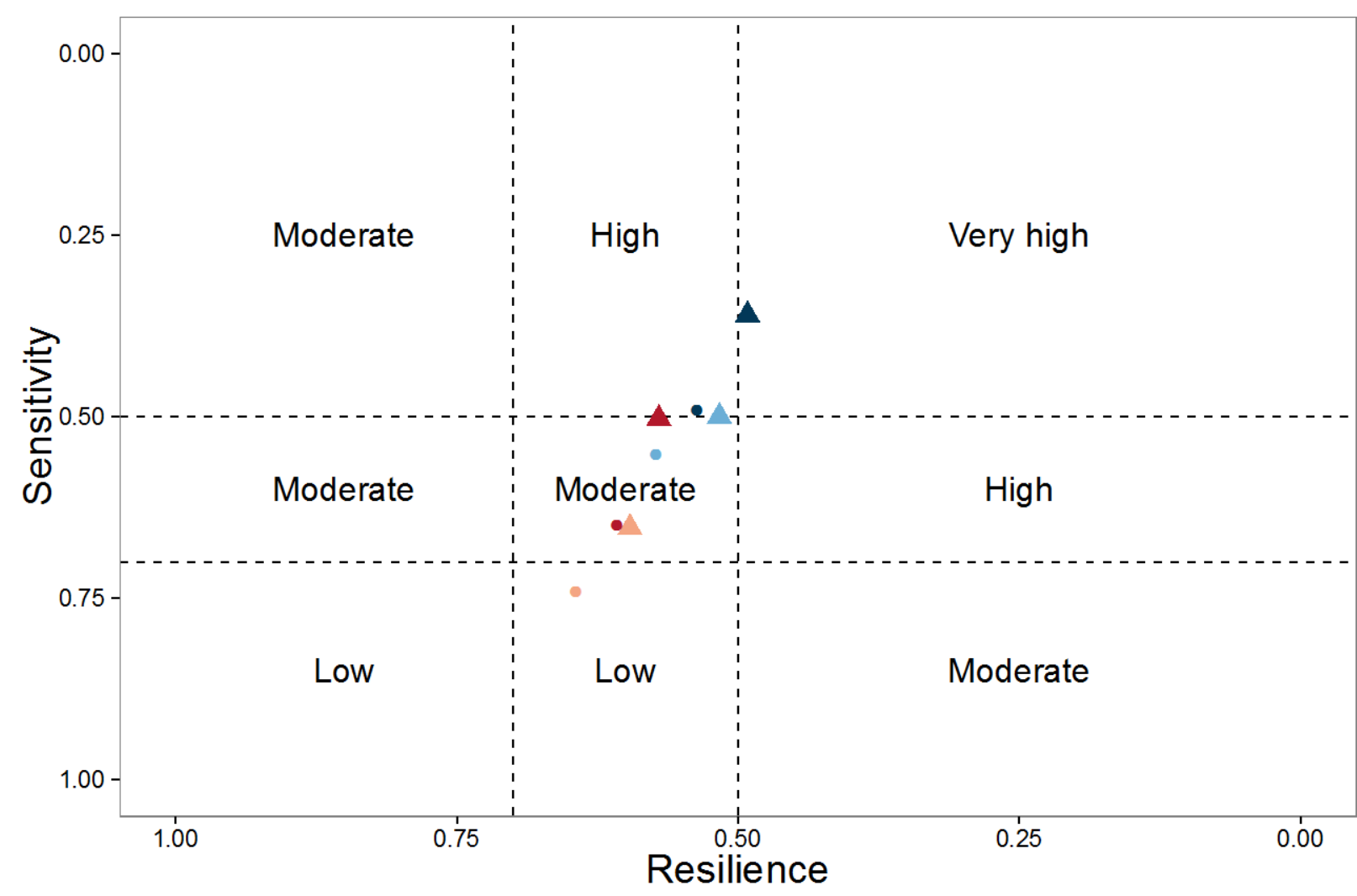

System and time period

- Pine Flatwoods mid-century min

$\Delta$ Pine Flatwoods mid-century max

- Pine Flatwoods late-century min

A Pine Flatwoods late-century max

- Nashville Basin mid-century min

$\Delta$ Nashville Basin mid-century max

- Nashville Basin late-century min

A Nashville Basin late-century max

Figure 1.11. Results from the NatureServe Habitat Climate Change Vulnerability Index ( $\mathrm{HCCVI})$ analysis for the East Gulf Coastal Plain Near-Coast Pine Flatwoods and Nashville Basin Limestone Glade and Woodland ecosystems. Labels on the figure indicate the climate change vulnerability rating, according to Comer and others (2012). Metrics for direct climate effects make up the sensitivity score. Metrics for indirect effects and adaptive capacity combine to make up the resilience score. Resilience values closer to 0 indicate lower resilience to climate change, and sensitivity values closer to 0 indicate higher sensitivity to climate change. min, minimum; max, maximum 
Table 1.1. All ecological systems that were candidates for analysis, based on selection criteria or suggested by Landscape Conservation Cooperative (LCC) participants.

[Systems in bold were selected for Phase I assessment. The selection criteria are shown in the table, with the exception of International Union for Conservation of Nature (IUCN) status, which is provisional. An asterisk (*) indicates the two systems that were included in Phase II assessment]

\begin{tabular}{|c|c|c|c|c|c|}
\hline Ecological system name & Coastal status & Wetland & $\begin{array}{c}\text { High } \\
\text { elevation }\end{array}$ & Insular & $\begin{array}{c}\text { Suggestion } \\
\text { from LCC }\end{array}$ \\
\hline Atlantic Coastal Plain Clay-Based Carolina Bay Wetland & Coastal plain & Yes & No & Yes & No \\
\hline Atlantic Coastal Plain Fall-line Sandhills Longleaf Pine Woodland & Coastal plain & No & No & No & No \\
\hline Atlantic Coastal Plain Peatland Pocosin and Canebrake & Coastal plain & Yes & No & Yes & No \\
\hline Atlantic Coastal Plain Sandhill Seep & Coastal plain & Yes & No & Yes & No \\
\hline Atlantic Coastal Plain Upland Longleaf Pine Woodland & Coastal plain & No & No & No & No \\
\hline Caribbean Coastal Dry Evergreen Forest & Coastal & No & No & No & Yes \\
\hline Caribbean Coastal Thornscrub & Coastal & No & No & No & Yes \\
\hline Caribbean Floodplain Forest & Coastal & Yes & No & No & Yes \\
\hline Caribbean Montane Wet Elfin Forest & No & No & Yes & Yes & Yes \\
\hline Caribbean Riparian Forest and Shrubland & No & Yes & No & No & Yes \\
\hline Central and Southern Appalachian Spruce-Fir Forest & No & No & Yes & No & No \\
\hline Central Atlantic Coastal Plain Maritime Forest & Coastal & Yes & No & No & No \\
\hline Central Atlantic Coastal Plain Wet Longleaf Pine Savanna and Flatwoods & Coastal plain & Yes & No & No & No \\
\hline Central Florida Wet Prairie and Herbaceous Seep & Coastal plain & Yes & No & Yes & No \\
\hline Central Interior Highlands and Appalachian Sinkhole and Depression Pond & No & Yes & No & Yes & No \\
\hline Central Interior Highlands Calcareous Glade and Barrens & No & No & No & Yes & Yes \\
\hline Central Interior Highlands Dry Acidic Glade and Barrens & No & No & No & Yes & Yes \\
\hline Cumberland Acidic Cliff and Rockhouse & No & No & Yes & Yes & No \\
\hline Cumberland Seepage Forest & No & Yes & No & Yes & No \\
\hline East Gulf Coastal Plain Depression Pondshore & Coastal plain & Yes & No & Yes & No \\
\hline
\end{tabular}




\begin{tabular}{|c|c|c|c|c|c|}
\hline Ecological system name & Coastal status & Wetland & $\begin{array}{c}\text { High } \\
\text { elevation }\end{array}$ & Insular & $\begin{array}{l}\text { Suggestion } \\
\text { from LCC }\end{array}$ \\
\hline East Gulf Coastal Plain Interior Shortleaf Pine-Oak Forest & Coastal plain & No & No & No & No \\
\hline East Gulf Coastal Plain Jackson Plain Prairie and Barrens & Coastal plain & No & No & Yes & Yes \\
\hline * East Gulf Coastal Plain Near-Coast Pine Flatwoods & Coastal plain & Yes & No & No & No \\
\hline East Gulf Coastal Plain Southern Loess Bluff Forest & Coastal plain & No & No & No & No \\
\hline East-Central Texas Plains Xeric Sandyland & No & No & No & No & Yes \\
\hline Eastern Highland Rim Prairie and Barrens & No & Yes & No & No & No \\
\hline Edwards Plateau Limestone Shrubland ${ }^{1}$ & No & No & No & Yes & Yes \\
\hline Edwards Plateau Cliff & No & Yes & No & Yes & Yes \\
\hline Edwards Plateau Dry-Mesic Slope Forest and Woodland & No & Yes & No & No & Yes \\
\hline Edwards Plateau Floodplain & No & Yes & No & No & Yes \\
\hline Edwards Plateau Limestone Savanna and Woodland & No & No & Yes & No & Yes \\
\hline Edwards Plateau Limestone Shrubland & No & No & No & No & Yes \\
\hline Edwards Plateau Mesic Canyon & No & No & No & Yes & Yes \\
\hline Edwards Plateau Riparian & No & Yes & No & No & Yes \\
\hline Edwards Plateau Upland Depression & No & Yes & No & Yes & Yes \\
\hline Manglar Costero del Caribe (Caribbean Coastal Mangrove) & Coastal & Yes & No & Yes & Yes \\
\hline Manglar Estuarino del Caribe (Caribbean Estuarine Mangrove) & Coastal & Yes & No & Yes & Yes \\
\hline * Nashville Basin Limestone Glade and Woodland & No & No & No & Yes & No \\
\hline Ozark-Ouachita Mesic Hardwood Forest & No & No & No & Yes & No \\
\hline South-Central Interior Mesophytic Forest ${ }^{2}$ & No & No & No & No & No \\
\hline Southeastern Interior Longleaf Pine Woodland & No & No & No & No & No \\
\hline Southern and Central Appalachian Cove Forest & No & No & Yes & No & No \\
\hline Southern Appalachian Grass and Shrub Bald & No & No & Yes & Yes & No \\
\hline Southern Appalachian Northern Hardwood Forest & No & No & Yes & No & No \\
\hline Southern Coastal Plain Nonriverine Cypress Dome & Coastal plain & Yes & No & Yes & No \\
\hline
\end{tabular}




\begin{tabular}{|c|c|c|c|c|c|}
\hline Ecological system name & Coastal status & Wetland & $\begin{array}{l}\text { High } \\
\text { elevation }\end{array}$ & Insular & $\begin{array}{l}\text { Suggestion } \\
\text { from LCC }\end{array}$ \\
\hline Southern Coastal Plain Seepage Swamp and Baygall & Coastal plain & Yes & No & Yes & No \\
\hline Southern Piedmont Granite Flatrock and Outcrop & No & Yes & No & Yes & No \\
\hline West Gulf Coastal Plain Catahoula Barrens & Coastal plain & No & No & No & Yes \\
\hline West Gulf Coastal Plain Herbaceous Seep and Bog & Coastal plain & Yes & No & Yes & Yes \\
\hline West Gulf Coastal Plain Mesic Hardwood Forest & Coastal plain & No & No & No & No \\
\hline West Gulf Coastal Plain Nepheline Syenite Glade & Coastal plain & No & No & Yes & Yes \\
\hline West Gulf Coastal Plain Seepage Swamp and Baygall & Coastal plain & Yes & No & No & Yes \\
\hline West Gulf Coastal Plain Southern Calcareous Prairie & Coastal plain & Yes & No & Yes & No \\
\hline West Gulf Coastal Plain Stream Terrace Sandyland Longleaf Pine Woodland & Coastal plain & No & No & No & Yes \\
\hline West Gulf Coastal Plain Weches Glade & Coastal plain & No & No & Yes & Yes \\
\hline
\end{tabular}

${ }^{1}$ Edwards Plateau Carbonate Glade and Barrens was originally selected, but this ecosystem is not included in the land-cover map, and thus geographic information system analysis would not be possible for the ecosystem. The Edwards Plateau Limestone Shrubland was substituted because of its proximity and similarity.

${ }^{2}$ South-Central Interior Mesophytic Forest is considered "vulnerable” according to IUCN provisional threat status. 
Table 1.2. Geographic information system data sources and derived metrics for Phase I vulnerability assessment of non-Caribbean ecosystems.

[Pixel values from these datasets were extracted and summarized for the areas in each ecosystem's range or extent, as mapped in land-cover data. See table 1.3 for data sources for Caribbean ecosystems. USEPA, U.S. Environmental Protection Agency]

\begin{tabular}{|c|c|c|c|}
\hline $\begin{array}{l}\text { Vulnerability } \\
\text { component }\end{array}$ & Data type & Metrics & Dataset \\
\hline Sensitivity & Recent climate & $\begin{array}{l}\text { Seasonal maximum temperature in ecosystem } \\
\text { range-average, standard deviation, and range } \\
\text { summarized for 1950-1999 }\end{array}$ & $\begin{array}{l}\text { WorldClim Gridded Observed Meteorological Data } \\
\text { (Hijmans and others, 2005; } \\
\text { http://www.worldclim.org) }\end{array}$ \\
\hline Sensitivity & Recent climate & $\begin{array}{l}\text { Seasonal minimum temperature in ecosystem range- } \\
\text { average, standard deviation, and range summarized } \\
\text { for 1950-1999 }\end{array}$ & $\begin{array}{l}\text { WorldClim Gridded Observed Meteorological Data } \\
\text { (Hijmans and others, 2005; } \\
\text { http://www.worldclim.org) }\end{array}$ \\
\hline Sensitivity & Recent climate & $\begin{array}{l}\text { Seasonal total precipitation in ecosystem range- } \\
\text { average, standard deviation, and range summarized } \\
\text { for 1950-1999 }\end{array}$ & $\begin{array}{l}\text { WorldClim Gridded Observed Meteorological Data } \\
\text { (Hijmans and others, 2005; } \\
\text { http://www.worldclim.org) }\end{array}$ \\
\hline Exposure & $\begin{array}{l}\text { Downscaled climate } \\
\text { projections }\end{array}$ & $\begin{array}{l}\text { Seasonal max temperature in ecosystem range-_- } \\
\text { average, standard deviation, and range for 2040- } \\
\text { 2060, 2080-2100 }\end{array}$ & $\begin{array}{l}\text { Statistically downscaled climate projections (Stoner and } \\
\text { others, 2012; http://cida.usgs.gov/climate/gdp/) }\end{array}$ \\
\hline Exposure & $\begin{array}{l}\text { Downscaled climate } \\
\text { projections }\end{array}$ & $\begin{array}{l}\text { Seasonal min temperature in ecosystem range-_- } \\
\text { average, standard deviation, and range for 2040- } \\
\text { 2060, 2080-2100 }\end{array}$ & $\begin{array}{l}\text { Statistically downscaled climate projections (Stoner and } \\
\text { others, 2012; http://cida.usgs.gov/climate/gdp/) }\end{array}$ \\
\hline Exposure & $\begin{array}{l}\text { Downscaled climate } \\
\text { projections }\end{array}$ & $\begin{array}{l}\text { Seasonal total precipitation in ecosystem range-_- } \\
\text { average, standard deviation, and range for 2040- } \\
\text { 2060, 2080-2100 }\end{array}$ & $\begin{array}{l}\text { Statistically downscaled climate projections (Stoner and } \\
\text { others, 2012; http://cida.usgs.gov/climate/gdp/) }\end{array}$ \\
\hline Exposure & Sea level rise & $\begin{array}{l}\text { Percentage of ecosystem extent projected to be } \\
\text { inundated in scenarios of } 1 \text { foot and } 6 \text { feet above } \\
\text { mean higher high water }\end{array}$ & $\begin{array}{l}\text { Sea Level Rise and Coastal Flooding Impacts dataset } \\
\text { (National Oceanic and Atmospheric Administration, } \\
\text { 2013; https://coast.noaa.gov/slr) }\end{array}$ \\
\hline Exposure & $\begin{array}{l}\text { Sea level rise- } \\
\text { vegetation impacts }\end{array}$ & $\begin{array}{l}\text { Percentage of ecosystem extent expected to change } \\
\text { vegetation type by 2050, } 2100\end{array}$ & $\begin{array}{l}\text { SLAMM output } \\
\text { (http://www.basic.ncsu.edu/dsl/slr.html) }\end{array}$ \\
\hline $\begin{array}{l}\text { Adaptive } \\
\text { capacity }\end{array}$ & Ecosystem extent & Total area of extent & $\begin{array}{l}\text { Land cover from The National Map (Sugarbaker and } \\
\text { Carswell, 2011; } \\
\text { http://nationalmap.gov/landcover.html) }\end{array}$ \\
\hline
\end{tabular}




\begin{tabular}{|c|c|c|c|}
\hline $\begin{array}{l}\text { Vulnerability } \\
\text { component }\end{array}$ & Data type & Metrics & Dataset \\
\hline $\begin{array}{l}\text { Adaptive } \\
\text { capacity }\end{array}$ & Connectivity & Mean patch size for each ecosystem's extent & $\begin{array}{l}\text { Land cover from The National Map (Sugarbaker and } \\
\text { Carswell, 2011; } \\
\text { http://nationalmap.gov/landcover.html) }\end{array}$ \\
\hline $\begin{array}{l}\text { Adaptive } \\
\text { capacity }\end{array}$ & Protected areas & Percentage of ecosystem extent within protected areas & $\begin{array}{l}\text { Protected areas database (U.S. Geological Survey, } \\
\text { 2011; http://gapanalysis.usgs.gov/padus/) }\end{array}$ \\
\hline $\begin{array}{l}\text { Adaptive } \\
\text { capacity }\end{array}$ & Existing urban areas & Proximity of ecosystem extent to existing urban areas & $\begin{array}{l}\text { National Land Cover Data } 2006 \text { (Fry and others, 2011; } \\
\text { http://www.mrlc.gov) }\end{array}$ \\
\hline $\begin{array}{l}\text { Adaptive } \\
\text { capacity }\end{array}$ & $\begin{array}{l}\text { Projected urban } \\
\text { growth }\end{array}$ & $\begin{array}{l}\text { Area of ecosystem extent with at least a } 90 \text { percent } \\
\text { modeled probability of conversion to urban, } 2050 \\
\text { and } 2100\end{array}$ & $\begin{array}{l}\text { SLEUTH urban growth projections (Terando and } \\
\text { others, 2014; http://www.basic.ncsu.edu/dsl/urb.html) }\end{array}$ \\
\hline $\begin{array}{l}\text { Adaptive } \\
\text { capacity }\end{array}$ & $\begin{array}{l}\text { Projected urban } \\
\text { growth (Edwards } \\
\text { Plateau ecosystems) }\end{array}$ & $\begin{array}{l}\text { Average impervious surface value in ecosystem } \\
\text { extent in 2050, } 2100\end{array}$ & $\begin{array}{l}\text { USEPA Integrated Climate and Land Use Scenarios } \\
\text { (ICLUS) project v. 1.3.1 (Environmental Protection } \\
\text { Agency, 2010; } \\
\text { http://cfpub.epa.gov/ncea/global/recordisplay.cfm?dei } \\
\text { d=257305) }\end{array}$ \\
\hline $\begin{array}{l}\text { Adaptive } \\
\text { capacity }\end{array}$ & Heterogeneity & $\begin{array}{l}\text { Range and standard deviation of elevation values in } \\
\text { ecosystem range }\end{array}$ & $\begin{array}{l}\text { National elevation dataset (Gesch and others, 2009; } \\
\text { http://nationalmap.gov/elevation.html) }\end{array}$ \\
\hline $\begin{array}{l}\text { Adaptive } \\
\text { capacity }\end{array}$ & Human modification & $\begin{array}{l}\text { Mean and range of human modification values for } \\
\text { ecosystem extent }\end{array}$ & $\begin{array}{l}\text { Landscape Permeability Index (Theobald and others, } \\
\text { 2012) }\end{array}$ \\
\hline
\end{tabular}


Table 1.3. Geographic information system data sources and derived metrics for Phase I vulnerability assessment of ecosystems in the Caribbean.

[Pixel values from these datasets were extracted and summarized for the areas in each ecosystem's range or extent, as mapped in land-cover data. See table 1.2 for data sources for non-Caribbean ecosystems]

\begin{tabular}{|c|c|c|c|}
\hline $\begin{array}{l}\text { Vulnerability } \\
\text { component }\end{array}$ & Data type & Metrics & Dataset \\
\hline Sensitivity & Recent climate & $\begin{array}{l}\text { Seasonal maximum temperature in ecosystem } \\
\text { range-average, standard deviation, and range } \\
\text { summarized for 1950-1999 }\end{array}$ & $\begin{array}{l}\text { WorldClim Gridded Observed Meteorological } \\
\text { Data (Hijmans and others, 2005; } \\
\text { http://www.worldclim.org) }\end{array}$ \\
\hline Sensitivity & Recent climate & $\begin{array}{l}\text { Seasonal minimum temperature in ecosystem } \\
\text { range-average, standard deviation, and range } \\
\text { summarized for 1950-1999 }\end{array}$ & $\begin{array}{l}\text { WorldClim Gridded Observed Meteorological } \\
\text { Data (Hijmans and others, 2005; } \\
\text { http://www.worldclim.org) }\end{array}$ \\
\hline Sensitivity & Recent climate & $\begin{array}{l}\text { Seasonal average precipitation in ecosystem } \\
\text { range-average, standard deviation, and range } \\
\text { summarized for 1950-1999 }\end{array}$ & $\begin{array}{l}\text { WorldClim Gridded Observed Meteorological } \\
\text { Data (Hijmans and others, 2005; } \\
\text { http://www.worldclim.org) }\end{array}$ \\
\hline Exposure & Downscaled climate projections & $\begin{array}{l}\text { Seasonal maximum temperature in ecosystem } \\
\text { range-average, standard deviation, and range } \\
\text { for 2040-2060, 2080-2100 }\end{array}$ & $\begin{array}{l}\text { Statistically downscaled climate projections } \\
\text { (Hayhoe, 2013; Ryu and Hayhoe, 2013) }\end{array}$ \\
\hline Exposure & Downscaled climate projections & $\begin{array}{l}\text { Seasonal minimum temperature in ecosystem } \\
\text { range-average, standard deviation, and range } \\
\text { for 2040-2060, 2080-2100 }\end{array}$ & $\begin{array}{l}\text { Statistically downscaled climate projections } \\
\text { (Hayhoe, 2013; Ryu and Hayhoe, 2013) }\end{array}$ \\
\hline Exposure & Downscaled climate projections & $\begin{array}{l}\text { Seasonal total precipitation in ecosystem range- } \\
\text { average, standard deviation, and range for } \\
\text { 2040-2060, 2080-2100 }\end{array}$ & $\begin{array}{l}\text { Statistically downscaled climate projections } \\
\text { (Hayhoe, 2013; Ryu and Hayhoe, 2013) }\end{array}$ \\
\hline Exposure & Sea level rise & $\begin{array}{l}\text { Percentage of ecosystem extent projected to be } \\
\text { inundated in scenarios of } 1 \text { foot and } 6 \text { feet } \\
\text { above mean higher high water }\end{array}$ & $\begin{array}{l}\text { Sea Level Rise and Coastal Flooding impacts } \\
\text { dataset (National Oceanic and Atmospheric } \\
\text { Administration, 2013; } \\
\text { https://coast.noaa.gov/slr) }\end{array}$ \\
\hline $\begin{array}{l}\text { Adaptive } \\
\text { capacity }\end{array}$ & Ecosystem extent & Total area of extent & $\begin{array}{l}\text { Puerto Rico Gap Analysis Project (PRGAP) } \\
\text { land cover (Puerto Rico Gap Analysis } \\
\text { Project, 2006); U.S. Virgin Islands Gap } \\
\text { Analysis Project (USVIGAP) land cover } \\
\text { (Gould and others, 2012) }\end{array}$ \\
\hline
\end{tabular}




\begin{tabular}{|c|c|c|c|}
\hline $\begin{array}{l}\text { Vulnerability } \\
\text { component }\end{array}$ & Data type & Metrics & Dataset \\
\hline $\begin{array}{l}\text { Adaptive } \\
\text { capacity }\end{array}$ & Connectivity & Mean patch size for ecosystem's extent & $\begin{array}{l}\text { PRGAP land cover (Puerto Rico Gap } \\
\text { Analysis Project, 2006); USVIGAP land } \\
\text { cover (Gould and others, 2012) }\end{array}$ \\
\hline $\begin{array}{l}\text { Adaptive } \\
\text { capacity }\end{array}$ & Protected areas & $\begin{array}{l}\text { Area/proportion of ecosystem extent within } \\
\text { protected areas }\end{array}$ & $\begin{array}{l}\text { PRGAP stewardship (Gould and others, 2007; } \\
\text { http://gapanalysis.usgs.gov/padus/); } \\
\text { USVIGAP stewardship (Gould and others, } \\
\text { 2012) }\end{array}$ \\
\hline $\begin{array}{l}\text { Adaptive } \\
\text { capacity }\end{array}$ & Existing urban & $\begin{array}{l}\text { Proximity of ecosystem extent to existing urban } \\
\text { areas (urban land cover) }\end{array}$ & $\begin{array}{l}\text { PRGAP land cover (Puerto Rico Gap } \\
\text { Analysis Project, 2006); USVIGAP land } \\
\text { cover (Gould and others, 2012) }\end{array}$ \\
\hline $\begin{array}{l}\text { Adaptive } \\
\text { capacity }\end{array}$ & Heterogeneity & $\begin{array}{l}\text { Range and standard deviation of elevation values } \\
\text { in ecosystem range }\end{array}$ & $\begin{array}{l}\text { PRGAP Digital Elevation Model (Gould and } \\
\text { others, 2007) }\end{array}$ \\
\hline
\end{tabular}


Table 1.4. Geographic information system data sources for Phase II vulnerability assessment using the Habitat Climate Change Vulnerability Index (HCCVI).

[USEPA, U.S. Environmental Protection Agency; NA, Not applicable]

\begin{tabular}{|c|c|c|c|c|}
\hline HCCVI category & HCCVI component & Metric & $\begin{array}{l}\text { Source of minimum } \\
\text { and maximum }\end{array}$ & Dataset \\
\hline Direct effects & $\begin{array}{l}\text { Climate stress } \\
\text { index 2050, } 2100\end{array}$ & $\begin{array}{l}\text { Average proportion of pixels in ecosystem } \\
\text { range that exceed } \pm 2 \text { standard deviations } \\
\text { from the recent mean of monthly } \\
\text { minimum temperature, maximum } \\
\text { temperature. and precipitation variables }\end{array}$ & $\begin{array}{l}\text { Emissions } \\
\text { scenarios B1, } \\
\text { A2, A1FI }\end{array}$ & $\begin{array}{l}\text { Climate observations (Maurer and others, } \\
\text { 2002; http://www.engr.scu.edu/ emaurer/ } \\
\text { data.shtml) and statistically downscaled } \\
\text { climate projections (Stoner and others, } \\
\text { 2012; http://cida.usgs.gov/climate/gdp/) }\end{array}$ \\
\hline Direct effects & $\begin{array}{l}\text { Envelope shift } \\
\quad \text { index 2050, } 2100\end{array}$ & $\begin{array}{l}\text { Proportion of pixels in ecosystem range } \\
\text { that overlap between recent and future } \\
\text { modeled climate envelope, } 2050 \text { and } \\
2100\end{array}$ & $\begin{array}{l}\text { Emissions } \\
\text { scenarios B1, } \\
\text { A2, A1FI }\end{array}$ & $\begin{array}{l}\text { Climate observations (Maurer and others, } \\
\text { 2002; http://www.engr.scu.edu/ emaurer/ } \\
\text { data.shtml) and statistically downscaled } \\
\text { climate projections (Stoner and others, } \\
\text { 2012; http://cida.usgs.gov/climate/gdp/) }\end{array}$ \\
\hline Direct effects & $\begin{array}{l}\text { Dynamic process } \\
\text { forecast 2050, } \\
2100\end{array}$ & $\begin{array}{l}\text { Percent departure from pre-European } \\
\text { settlement conditions in } 2050 \text { and } 2100 \\
\text { for ecosystem extent }\end{array}$ & $\begin{array}{l}\text { Emissions } \\
\text { scenarios B1 and } \\
\text { A1FI for Near- } \\
\text { Coast Pine } \\
\text { Flatwoods only }\end{array}$ & $\begin{array}{l}\text { LANDFIRE Vegetation Dynamics } \\
\text { Development Tool (VDDT) models (Grace } \\
\text { and Wilder, 2009; Pyne and Fitch, 2009; } \\
\text { http://www.landfire.gov/national_veg__ } \\
\text { models_op2.php), modified for future } \\
\text { dynamics }\end{array}$ \\
\hline Direct effects & $\begin{array}{l}\text { Sea level rise - } \\
\text { inundation }\end{array}$ & $\begin{array}{l}\text { Proportion of ecosystem extent projected } \\
\text { to be inundated }\end{array}$ & $\begin{array}{l}\text { 1-foot and } 6 \text { feet } \\
\text { rise above mean } \\
\text { higher high } \\
\text { water }\end{array}$ & $\begin{array}{l}\text { Sea Level Rise and coastal Flooding Impacts } \\
\text { dataset (National Oceanic and } \\
\text { Atmospheric Administration, 2013; } \\
\text { https://coast.noaa.gov/slr) }\end{array}$ \\
\hline Indirect effects & $\begin{array}{l}\text { Landscape } \\
\text { condition } 2010\end{array}$ & $\begin{array}{l}\text { Average landscape condition value for } \\
\text { ecosystem extent }\end{array}$ & NA & $\begin{array}{l}\text { NatureServe Landscape Condition data } \\
\text { (Comer and others, 2012; } \\
\text { http://www.natureserve.org/conservation- } \\
\text { tools/data-maps-tools/modeling-landscape- } \\
\text { condition-0) }\end{array}$ \\
\hline Indirect effects & $\begin{array}{l}\text { Proportion non- } \\
\text { urban } 1960\end{array}$ & $\begin{array}{l}\text { Proportion of ecosystem extent that occurs } \\
\text { in urban, suburban, or exurban lands } \\
\text { (about 1960) }\end{array}$ & NA & $\begin{array}{l}\text { USEPA Integrated Climate and Land Use } \\
\text { Scenarios (ICLUS) Housing Density } \\
\text { (Bierwagen and others, 2010) }\end{array}$ \\
\hline
\end{tabular}




\begin{tabular}{|c|c|c|c|c|}
\hline HCCVI category & HCCVI component & Metric & $\begin{array}{l}\text { Source of minimum } \\
\text { and maximum }\end{array}$ & Dataset \\
\hline Indirect effects & $\begin{array}{l}\text { Proportion non- } \\
\text { urban } 2010\end{array}$ & $\begin{array}{l}\text { Proportion of ecosystem extent that occurs } \\
\text { in urban, suburban, or exurban lands } \\
\text { (about 2010) }\end{array}$ & $\begin{array}{l}\text { Emissions } \\
\text { scenarios B1 and } \\
\text { A2 }\end{array}$ & $\begin{array}{l}\text { USEPA ICLUS Housing Density Projections } \\
\text { (Bierwagen and others, 2010; } \\
\text { http://cfpub.epa.gov/ncea/global/recordispl } \\
\text { ay.cfm?deid=205305) }\end{array}$ \\
\hline Indirect effects & $\begin{array}{l}\text { Proportion non- } \\
\text { urban 2050, } \\
2100\end{array}$ & $\begin{array}{l}\text { Proportion of ecosystem extent projected } \\
\text { to occur in urban, suburban, or exurban } \\
\text { lands }\end{array}$ & $\begin{array}{l}\text { Emissions } \\
\text { scenarios B1 and } \\
\text { A2 }\end{array}$ & $\begin{array}{l}\text { USEPA ICLUS Housing Density Projections } \\
\text { (Bierwagen and others, 2010; } \\
\text { http://cfpub.epa.gov/ncea/global/recordispl } \\
\text { ay.cfm?deid=205305) }\end{array}$ \\
\hline Indirect effects & $\begin{array}{l}\text { Invasive species } \\
\text { threat } 1960\end{array}$ & Did not calculate & NA & NA \\
\hline Indirect effects & $\begin{array}{l}\text { Invasive species } \\
\text { threat } 2010\end{array}$ & Estimated from literature synthesis & $\begin{array}{l}\text { Estimation } \\
\text { uncertainty }\end{array}$ & Scientific literature \\
\hline Indirect effects & $\begin{array}{l}\text { Dynamic process } \\
\text { alteration }\end{array}$ & $\begin{array}{l}\text { Percent departure from pre-European } \\
\text { settlement conditions }\end{array}$ & NA & $\begin{array}{l}\text { LANDFIRE Succession Class data } \\
\text { (LANDFIRE, 2013; } \\
\text { http://landfire.cr.usgs.gov/viewer) }\end{array}$ \\
\hline Adaptive capacity & $\begin{array}{l}\text { Diversity within } \\
\text { functional } \\
\text { groups }\end{array}$ & Estimated from literature synthesis & $\begin{array}{l}\text { Estimation } \\
\text { uncertainty }\end{array}$ & Scientific literature \\
\hline Adaptive capacity & $\begin{array}{l}\text { Keystone species } \\
\text { vulnerability }\end{array}$ & Estimated from literature synthesis & $\begin{array}{l}\text { Estimation } \\
\text { uncertainty }\end{array}$ & Scientific literature \\
\hline Adaptive capacity & $\begin{array}{l}\text { Bioclimatic } \\
\text { variability }\end{array}$ & $\begin{array}{l}\text { Number of isobioclimates in which each } \\
\text { ecosystem occurs }\end{array}$ & NA & $\begin{array}{l}\text { Isobioclimates (Sayre and others, 2009; } \\
\text { http://rmgsc.cr.usgs.gov/outgoing/ecosyste } \\
\text { ms/USdata/) }\end{array}$ \\
\hline Adaptive capacity & Elevation range & $\begin{array}{l}\text { Number of } 100 \text {-meter elevation bands } \\
\text { covered by ecosystem extent, relative to } \\
\text { the maximum covered by a single } \\
\text { ecosystem in the Southeast }\end{array}$ & NA & $\begin{array}{l}\text { National elevation dataset (Gesch and others, } \\
\text { 2009; } \\
\text { http://nationalmap.gov/elevation.html) }\end{array}$ \\
\hline
\end{tabular}


Table 1.5. Vulnerability rating for the 12 ecosystems assessed in Phase I.

[These ratings are qualitative based on synthesis of literature and new analysis. See text for details on the factors that contribute to vulnerability of each system]

\begin{tabular}{ll}
\hline \multicolumn{1}{c}{ Vulnerability rating } & \multicolumn{1}{c}{ Ecosystem } \\
\hline High & Manglar Costero del Caribe (Caribbean Coastal Mangrove) \\
High & Caribbean Montane Wet Elfin Forest \\
High & East Gulf Coastal Plain Southern Loess Bluff Forest \\
High & Edwards Plateau Limestone Shrubland \\
High & Nashville Basin Limestone Glade and Woodland \\
Medium & Central Florida Wet Prairie and Herbaceous Seep \\
Medium & East Gulf Coastal Plain Near-Coast Pine Flatwoods \\
Medium & Edwards Plateau Mesic Canyon \\
Medium & South-Central Interior Mesophytic Forest \\
Medium & Southern Coastal Plain Nonriverine Cypress Dome \\
Medium & Southern Coastal Plain Seepage Swamp and Baygall \\
Low & Central Atlantic Coastal Plain Wet Longleaf Pine Savanna and Flatwoods \\
\hline
\end{tabular}


Table 1.6. Phase II vulnerability assessment results from the NatureServe Habitat Climate Change Vulnerability Index (HCCVI) framework.

[See text and figure 1.4 for details on the calculations. Abbreviations: avg., average; min, minimum; max, maximum; NA, Not applicable; prop., proportion; vuln., vulnerability]

\begin{tabular}{|c|c|c|c|c|c|c|c|c|c|}
\hline \multirow[b]{2}{*}{ System } & \multirow[b]{2}{*}{ Time period, $\min / \max$} & \multicolumn{6}{|c|}{ Direct effects } & & \\
\hline & & $\begin{array}{l}\text { Climate } \\
\text { stress } \\
\text { index }\end{array}$ & $\begin{array}{l}\text { Envelope } \\
\text { shift index }\end{array}$ & $\begin{array}{l}\text { Dynamic } \\
\text { process } \\
\text { forecast }\end{array}$ & $\begin{array}{l}\text { Sea level } \\
\text { rise }\end{array}$ & \multicolumn{2}{|c|}{ Sensitivity score } & & \\
\hline \multirow{4}{*}{$\begin{array}{l}\text { East Gulf Coastal Plain } \\
\text { Near-Coast Pine } \\
\text { Flatwoods }\end{array}$} & Mid-century min & 0.85 & 0.81 & 0.31 & 0.99 & 0.74 & Low & & \\
\hline & Mid-century max & 0.75 & 0.63 & 0.31 & 0.92 & 0.65 & Medium & & \\
\hline & Late-century min & 0.75 & 0.54 & 0.31 & 0.99 & 0.65 & Medium & & \\
\hline & Late-century max & 0.55 & 0.25 & 0.29 & 0.92 & 0.50 & Medium & & \\
\hline \multirow{4}{*}{$\begin{array}{l}\text { Nashville Basin } \\
\text { Limestone Glade and } \\
\text { Woodland }\end{array}$} & Mid-century min & 0.88 & NA & 0.22 & NA & 0.55 & Medium & & \\
\hline & Mid-century max & 0.78 & NA & 0.22 & NA & 0.50 & High & & \\
\hline & Late-century min & 0.77 & NA & 0.21 & NA & 0.49 & High & & \\
\hline & Late-century max & 0.51 & NA & 0.21 & NA & 0.36 & High & & \\
\hline \multirow[b]{2}{*}{ System } & & \multicolumn{8}{|c|}{ Indirect effects } \\
\hline & Time period, $\min / \max$ & $\begin{array}{l}\text { Prop. non- } \\
\text { urban } 1960\end{array}$ & $\begin{array}{l}\text { Prop. non- } \\
\text { urban } 2010\end{array}$ & $\begin{array}{l}\text { Prop. non- } \\
\text { urban } \\
\text { projected }\end{array}$ & $\begin{array}{c}\text { Landscape } \\
\text { condition } 2010\end{array}$ & & $\begin{array}{l}\text { Invasive } \\
\text { pecies threat } \\
2010\end{array}$ & $\begin{array}{l}\text { Dynamic } \\
\text { process } \\
\text { alteration }\end{array}$ & Avg. \\
\hline \multirow{4}{*}{$\begin{array}{l}\text { East Gulf Coastal } \\
\text { Plain Near-Coast } \\
\text { Pine Flatwoods }\end{array}$} & Mid-century min & 0.98 & 0.84 & 0.84 & 0.59 & & 0.80 & 0.68 & 0.79 \\
\hline & Mid-century max & 0.98 & 0.84 & 0.82 & 0.59 & & 0.70 & 0.68 & 0.77 \\
\hline & Late-century min & 0.98 & 0.84 & 0.84 & 0.59 & & 0.80 & 0.68 & 0.79 \\
\hline & Late-century max & 0.98 & 0.84 & 0.81 & 0.59 & & 0.70 & 0.68 & 0.77 \\
\hline \multirow{4}{*}{$\begin{array}{l}\text { Nashville Basin } \\
\text { Limestone Glade } \\
\text { and Woodland }\end{array}$} & Mid-century min & 0.96 & 0.69 & 0.64 & 0.70 & & 0.70 & 0.49 & 0.70 \\
\hline & Mid-century max & 0.96 & 0.68 & 0.63 & 0.70 & & 0.50 & 0.49 & 0.66 \\
\hline & Late-century min & 0.96 & 0.69 & 0.64 & 0.70 & & 0.70 & 0.49 & 0.70 \\
\hline & Late-century max & 0.96 & 0.68 & 0.63 & 0.70 & & 0.50 & 0.49 & 0.66 \\
\hline
\end{tabular}


Table 1.6. Phase II vulnerability assessment results from the NatureServe Habitat Climate Change Vulnerability Index (HCCVI) framework.—Continued

[See text and figure 1.4 for details on the calculations. Abbreviations: avg., average; min, minimum; max, maximum; NA, Not applicable; prop., proportion; vuln., vulnerability]

\begin{tabular}{|c|c|c|c|c|c|c|c|c|c|}
\hline \multirow[b]{2}{*}{ System } & \multirow[b]{2}{*}{ Time period, $\min / \max$} & \multicolumn{5}{|c|}{ Adaptive Capacity } & \multirow{2}{*}{\multicolumn{2}{|c|}{ Resilience score }} & \multirow[b]{2}{*}{$\begin{array}{l}\text { Vulnerability } \\
\text { category }\end{array}$} \\
\hline & & $\begin{array}{l}\text { Diversity } \\
\text { within } \\
\text { functional } \\
\text { groups }\end{array}$ & $\begin{array}{l}\text { Keystone } \\
\text { species } \\
\text { vuln. }\end{array}$ & $\begin{array}{l}\text { Bioclimatic } \\
\text { variability }\end{array}$ & $\begin{array}{l}\text { Elevation } \\
\text { range }\end{array}$ & Avg. & & & \\
\hline \multirow{4}{*}{$\begin{array}{l}\text { East Gulf Coastal } \\
\text { Plain Near-Coast } \\
\text { Pine Flatwoods }\end{array}$} & Mid-century min & 0.90 & 0.69 & 0.32 & 0.07 & 0.50 & 0.64 & Medium & Low \\
\hline & Mid-century max & 0.80 & 0.50 & 0.32 & 0.07 & 0.42 & 0.60 & Medium & Moderate \\
\hline & Late-century min & 0.90 & 0.40 & 0.32 & 0.07 & 0.42 & 0.61 & Medium & Moderate \\
\hline & Late-century max & 0.80 & 0.30 & 0.32 & 0.07 & 0.37 & 0.57 & Medium & Moderate \\
\hline \multirow{4}{*}{$\begin{array}{l}\text { Nashville Basin } \\
\text { Limestone Glade } \\
\text { and Woodland }\end{array}$} & Mid-century min & 0.90 & 0.69 & 0.08 & 0.11 & 0.45 & 0.57 & Medium & Moderate \\
\hline & Mid-century max & 0.80 & 0.50 & 0.08 & 0.11 & 0.37 & 0.52 & Medium & High \\
\hline & Late-century min & 0.90 & 0.40 & 0.08 & 0.11 & 0.37 & 0.53 & Medium & High \\
\hline & Late-century max & 0.80 & 0.30 & 0.08 & 0.11 & 0.32 & 0.49 & Low & Very High \\
\hline
\end{tabular}




\section{Caribbean Montane Wet Elfin Forest}

Ecological System Overview.-The Caribbean Montane Wet Elfin Forest ecological system occurs at high elevations on ridges and peaks that are exposed to wind in Cuba, the Dominican Republic, Jamaica, the Lesser Antilles, and Puerto Rico (NatureServe, 2003). For this project, our analysis covers only the Puerto Rico portion of its range (fig. 2.1). Climate conditions in this ecological system are harsh, often with heavy rain, strong winds, and almost constant cloud cover. Soils are saturated and nutrient-poor. As a result, the trees in this forest system are dwarfed (6-12 m high), with gnarled trunks and compact canopies, and often are covered with epiphytes (NatureServe, 2003). The canopy is closed, and the understory often is very dense. Species richness is lower than in forests at lower elevations, but the dominant tree species in this ecological system also are found in lower-elevation forest types, including swamp cyrilla (Cyrilla racemiflora), Sierran palm (Prestoea acuminata var. montana), laurel magnolia (Magnolia splendens), sabinon (Croton poecilanthus), and palo colorado (Ternstroemia luquillensis). This ecological system also provides habitat for the Elfin-woods Warbler (Setophaga angelae) in Puerto Rico. Hurricanes are the major disturbance agent in this ecological system, and the system is slow to recover following disturbances (Byer and Weaver, 1977; Weaver and others, 1986; Boucher, 1990). Several environmental constraints contribute to the slow rate of succession, including saturated soils that impede root growth; low transpiration owing to high atmospheric moisture, which may lead to nutrient deficiencies; and low light conditions (Byer and Weaver, 1977; Weaver and others, 1986).

For a more complete description of this ecological system, see NatureServe (2003), and for a description of ecological succession and major plant species, see Byer and Weaver (1977) and Weaver and others (1986). 


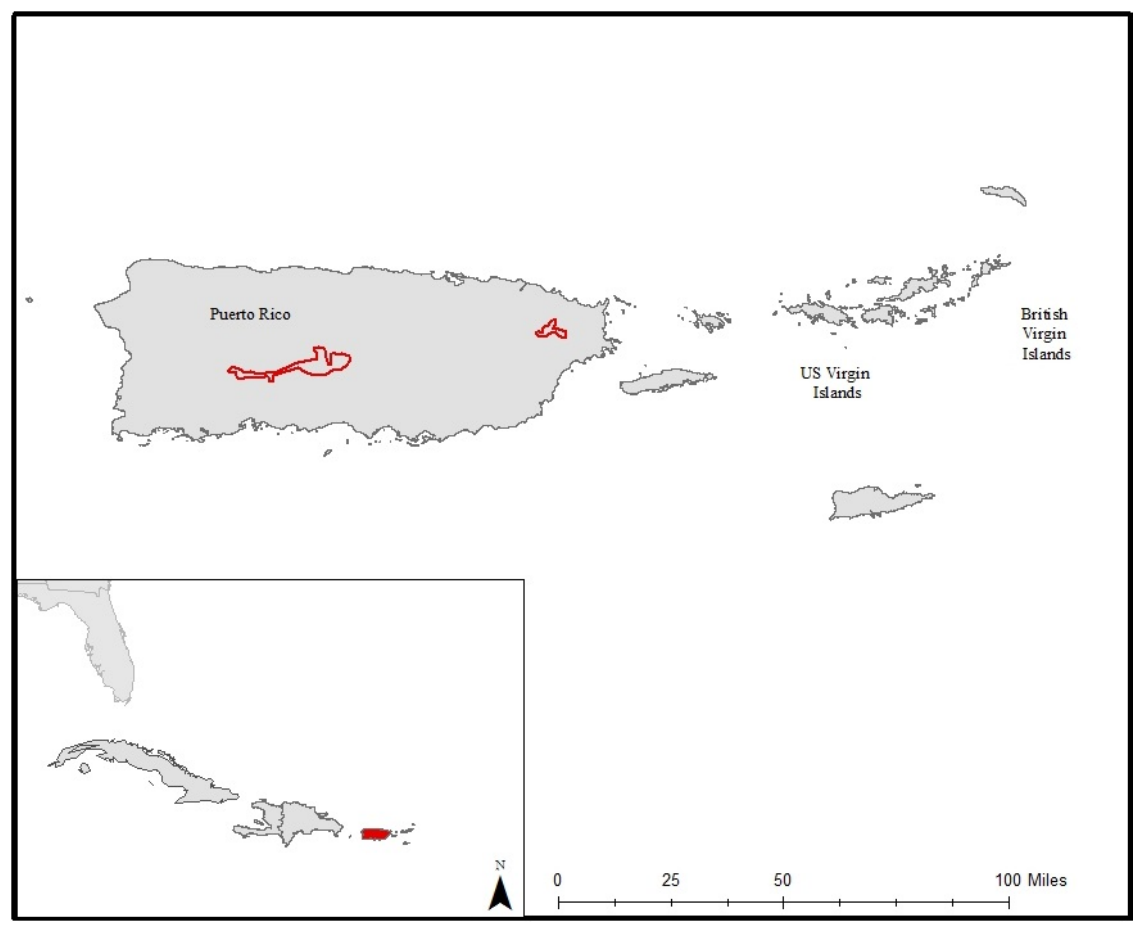

Figure 2.1. Range of the Caribbean Montane Wet Elfin Forest ecological system in Puerto Rico. The system covers 9.6 percent of this range, according to data from the Puerto Rico Gap Analysis Project (Gould and others, 2007). The system occurs elsewhere in the Caribbean, but for this project, our analysis covers only the Puerto Rico portion of its range.

Vulnerability Status.- - Relative to other ecological systems in the Southeast, the vulnerability of this ecological system is rated as High because of its sensitivity to temperature, precipitation, and other climate variables, along with its likely high exposure to changes in those factors. The location of this system at high elevations severely compromises its ability to adapt to projected changes in climate.

Sensitivity.- This ecological system is present in climate conditions that are extreme for the Caribbean islands: almost constant cloud cover and high precipitation, with periodic hurricanes causing localized to widespread disturbance. The structure and composition of the vegetation in this ecological system also are strongly dependent on precipitation and orographic effects. Climate data for the island of Puerto Rico will not capture this microclimate. Nevertheless, we summarized observed temperature and precipitation data from Puerto Rico. Average summer maximum temperature for Puerto Rico is $32{ }^{\circ} \mathrm{C}$ (Appendix B) and average winter minimum temperature is $20^{\circ} \mathrm{C}$ (Appendix B). Precipitation is slightly higher in the summer and fall than in the spring and winter (Appendix B).

Several studies of succession following hurricanes or other disturbances have been conducted in elfin forests and similar forest types in Puerto Rico (for example, Weaver 1990; Comita and others, 2009). Those studies indicate that, although forest structure and biomass recover quickly, succession is slow following disturbance, and the species that colonize during early succession are different from those in a late-succession elfin forest. In particular, hurricanes 
and other disturbances alter understory conditions, leading to colonization by species that are shade-intolerant (Comita and others, 2009). Over time, according to simulation models, both frequency and intensity of hurricanes can alter community composition in tropical montane forests (Uriarte and others, 2009). Hurricanes also influence precipitation and cloud cover. For example, Scatena and Larsen (1991) found that following Hurricane Hugo, rainfall significantly decreased, and the height of the cloud layer rose by $400 \mathrm{~m}$. Additionally, evidence has shown that hurricanes have affected some wildlife populations in the long term. Arendt and others (2013) found that populations of Elfin-woods Warbler had declined, and attributed those declines in part to increases in hurricane activity prior to the declines.

Exposure.-Analysis of projected change in climate for this ecological system shows increases in maximum and minimum temperatures for all models and scenarios, with more change projected under the A1FI scenario, especially toward the end of the century, than under the B1 scenario (figs. 2.2 and 2.3). Under the A1FI scenario, the mean projected change in maximum temperature for every season is more than $6{ }^{\circ} \mathrm{C}$ by the end of this century. Much more change is projected for minimum temperature, with a mean change of more than $12^{\circ} \mathrm{C}$ projected under the A1FI scenario for every season by the end of the century. Under the B1 scenario, a smaller amount of change is projected for both maximum and minimum temperatures by the end of the century. Mean seasonal changes under that scenario for maximum and minimum temperatures, respectively, are projected to be approximately $3^{\circ} \mathrm{C}$ and approximately $6^{\circ} \mathrm{C}$.

On average, climate projections show decreases in precipitation for this ecological system in every climate model, emissions scenario, time period, and season (fig. 2.4). For each season, a slightly smaller decrease is projected by the middle of the century, with a greater decrease projected by the end of the century. However, in each case, the range of projections crosses 1 , indicating much uncertainty in the model projections. Projections for summer show the most uncertainty, with models projecting that the factor change in precipitation compared with recent levels will be between 0.05 and 5.32. The range of projections is narrowest for fall.

Projected changes in the standard deviation, or variability, of temperature and precipitation also show a high degree of uncertainty among climate models. Both the means and ranges of projected change in standard deviation for maximum and minimum temperatures vary considerably (Appendix C). On average across all climate models, for each season under the A1FI scenario, variability in maximum temperature is projected to increase, whereas for most seasons under the B1 scenario, variability is projected to decrease. Variability in minimum temperatures is projected to increase for all seasons, time periods, and emissions scenarios. Projected change in variability of precipitation has a large range of uncertainty in all cases, with the most uncertainty among climate models in winter and spring. For each of these climate variables, the ranges of projections cross 1 , indicating uncertainty among climate models in the direction of change in variability.

Our climate data analysis agrees with the results of other studies that have shown that the Caribbean is projected to warm faster than other places (Jacobs and others, 2013a). Other studies have shown that observed air temperatures as well as sea surface temperatures in the Caribbean have increased (Jacobs and others, 2013a). Our summaries of projected change in precipitation 
for Puerto Rico also agree with studies that have projected a decrease in precipitation, along with much uncertainty (Jacobs and others, 2013a).

Changes in local and regional temperature, precipitation, hurricane frequency, and cloud cover under climate change would affect the Caribbean Montane Wet Elfin Forest ecological system. The future of drought in the Caribbean is unclear, but increased temperature and decreased precipitation are likely to lead to increased drought. If that is the case, species composition of the Caribbean Montane Wet Elfin Forest is likely to change, and shade-intolerant species could become more abundant (Jacobs and others, 2013b).

Hurricane frequency and intensity are likely to increase in the future in the Atlantic and Caribbean (Webster and others, 2005). Additionally, although sea level rise will not directly affect this ecological system, it likely will lead to more intense storms in Puerto Rico, including hurricanes (Jacobs and others, 2013b). Increased frequency of hurricanes would lead to more early-succession forests and a greater proportion of shade-intolerant species in this ecological system, along with reduced biomass and height of trees (Lugo, 2000). The Elfin-woods Warbler, whose observed population declines are thought to be related to increased hurricane activity (Arendt and others, 2013), would likely decline in the future as well.

The effects of climate change on cloud cover in montane tropical forests is uncertain, but some have suggested that low level clouds in tropical areas are likely to be reduced because of increased temperature and more frequent hurricanes (Foster, 2007). A reduction in cloud cover would also affect the species composition in this ecological system. Species that are susceptible to desiccation, including epiphytes, may be particularly affected (Nadkarni and Solano, 2002).

Because this ecological system occurs at the tops of mountains, it is likely to be among the most affected when climate warms because the species cannot shift their ranges to track climate. Additionally, Bruijnzeel and others (2011) discuss the fact that because cloud forests are present in climate conditions that are extreme compared with the surrounding landscape, any warming or drying in climate could result in a substantial decrease in their distribution. Additionally, substantial changes in species composition, loss of biodiversity, and possibly forest die-off are possible (Nadkarni and Solano, 2002; Foster, 2007). 


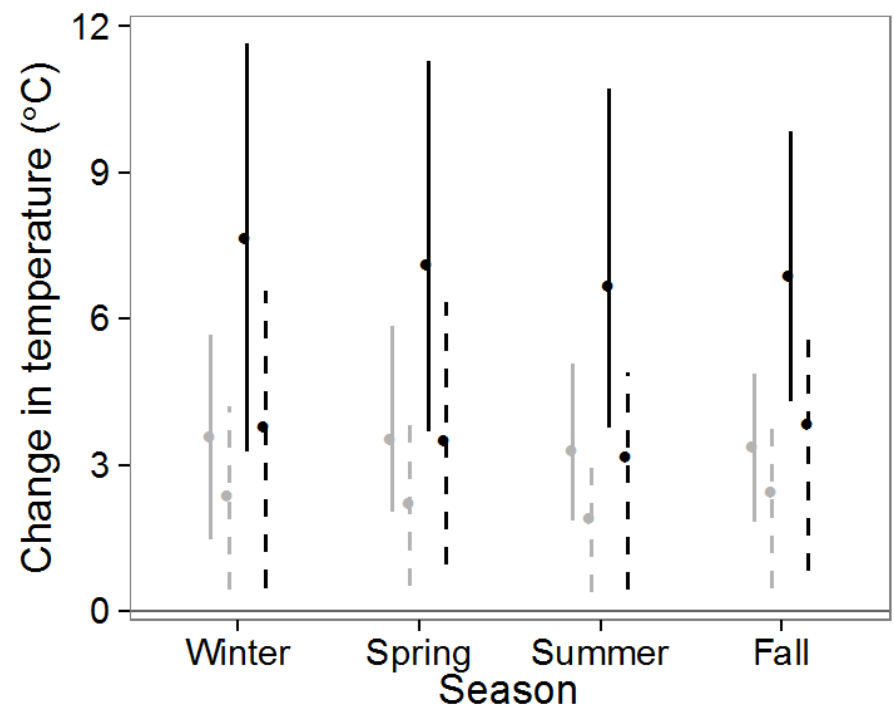

Scenario, time period

- A1FI, mid-century

- B1, mid-century

$\because \mathrm{A} 1 \mathrm{FI}$, end of century

- - B1, end of century

Figure 2.2. Projected change in seasonal maximum temperatures (in degrees Celsius $\left[{ }^{\circ} \mathrm{C}\right]$ ) for the middle (2040-2060) and the end of the 21st century (2080-2100), compared with the recent time period (19812000), for two emissions scenarios for the Caribbean Montane Wet Elfin Forest ecological system. Solid dots and error bars represent, respectively, the means and ranges of projections across climate models under each scenario.

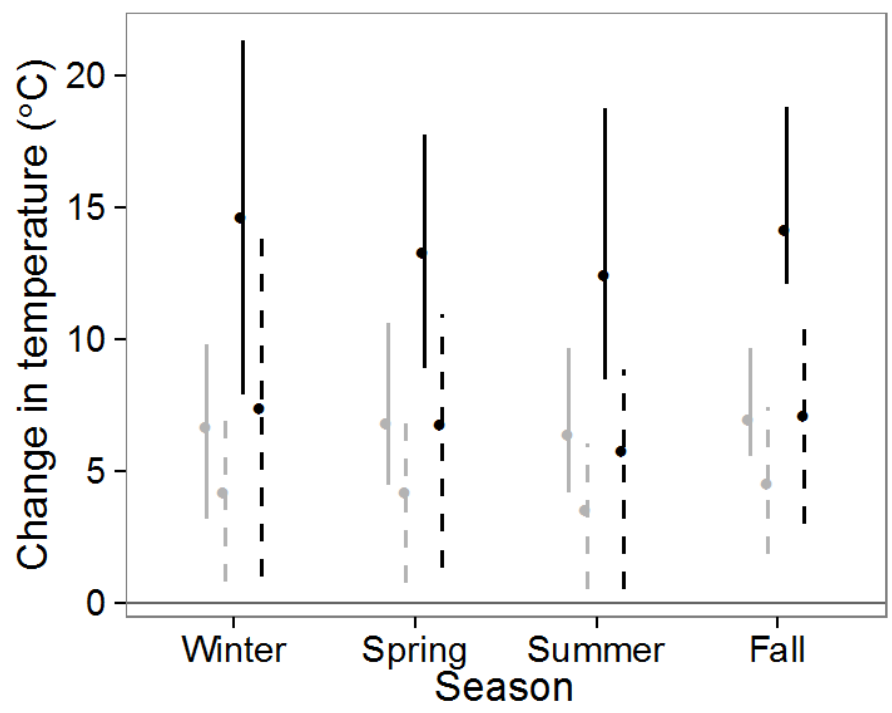

Scenario, time period

$\because \mathrm{A} 1 \mathrm{FI}$, mid-century

- B1, mid-century

$\rightarrow \mathrm{A} 1 \mathrm{FI}$, end of century

- B1, end of century

Figure 2.3. Projected change in seasonal minimum temperatures (in degrees Celsius $\left[{ }^{\circ} \mathrm{C}\right]$ ) for the middle (2040-2060) and the end of the 21st century (2080-2100), compared with the recent time period (19812000), for two emissions scenarios for the Caribbean Montane Wet Elfin Forest ecological system. Solid dots and error bars represent, respectively, the means and ranges of projections across climate models under each scenario. 


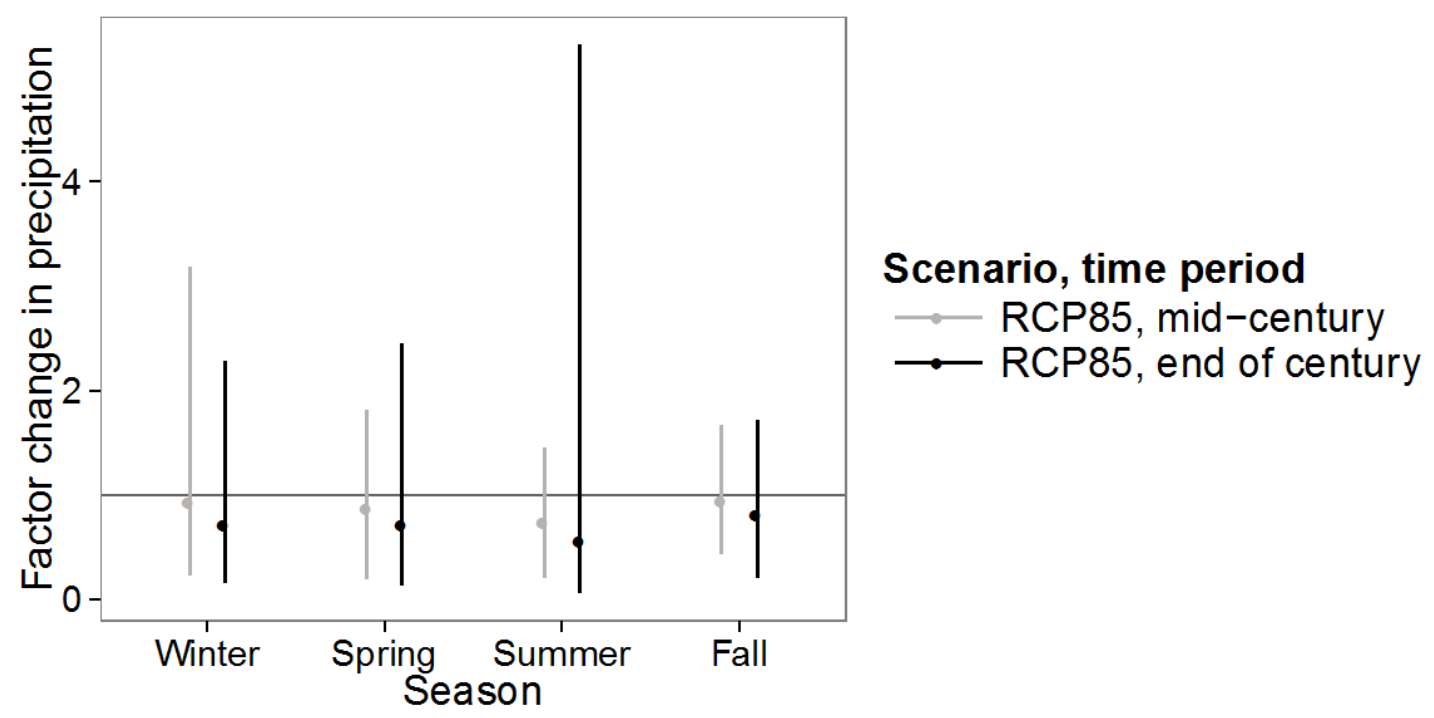

Figure 2.4. Projected factor changes in seasonal average precipitation for the middle (2040-2060) and the end of the 21st century (2080-2100), compared with the recent time period (1981-2000), for a highemissions scenario for the Caribbean Montane Wet Elfin Forest ecological system in Puerto Rico. Solid dots and error bars represent, respectively, the means and ranges of projections across climate models under the scenario. Values of less than 1 indicate a decrease in precipitation, whereas values of greater than 1 indicate an increase in precipitation.

Adaptive Capacity. - The location of this ecological system at high elevations means that any change in climate variables limits the ability of species to adapt to those changes. Many dominant species are endemic to mountain forests in the Caribbean (Weaver, 2008). Although many species that occur in this ecological system also occur in adjacent palo colorado forest and other montane forest ecosystems (NatureServe, 2003), many characteristics of the elfin forest ecological system make it unique in the Caribbean, thus limiting migration options for some species in the system.

Although much of the Caribbean islands have been cleared for agriculture or urban development, there has been relatively little clearing on steep slopes and upper peaks where this ecological system and other similar systems occur (Martinuzzi and others, 2007). Therefore, this habitat is relatively intact across the Caribbean. Indeed, our spatial analysis shows that a moderate proportion of this system occurs in protected areas (14 percent; Appendix A), and its average distance from development is relatively small (940 m; Appendix A). The system also has relatively a large average patch size (47,733 square meters [ $\left.\mathrm{m}^{2}\right]$, or 4.77 hectares [ha]; Appendix A).

Although the mountains may have been less disturbed by human land use, land use in low-lying areas adjacent to the mountains may affect the landscape processes in this ecological system. In Puerto Rico, for example, low-lying areas that have been fragmented by urban and agricultural land use separate the two major mountain regions that contain the elfin forest ecological system. This land use provides a barrier to movement of the Elfin-woods Warbler, and 
has led to population declines (Delannoy-Juliá, 2009). There also is evidence that land use and vegetation in low-lying areas influence the climate, and particularly the cloud cover, in montane forests. For example, in the Luquillo National Forest in Puerto Rico, urbanization in surrounding low-lying areas has modified the height of cloud cover, as well as other aspects of climate (Jacobs and others, 2013b). Therefore, if increased conversion of forest to urban land use occurs in the Caribbean, the climate could be further altered.

Summary.-This ecological system is present in climate conditions that are extreme compared with the rest of the Caribbean. A cool, wet, climate with consistent cloud cover and frequent hurricanes is characteristic. In the future in the Caribbean, temperature is expected to increase. There is some uncertainty about whether precipitation will increase or decrease, but on average, climate models project decreased precipitation. Because temperatures are expected to increase and precipitation may decrease, droughts may increase and cloud cover may decrease. Hurricanes also are likely to become more frequent. All these changes in climate may have substantial effects on this ecological system. Many of the species present in this ecological system are endemic to Caribbean montane forests, and, therefore, will have few adaptation options if climate conditions exceed their tolerances. Although much of this ecological system has not been cleared or developed, land use on low-lying areas influences the climate of these forests and the population dynamics of species within them. More research is needed regarding

projected changes in climate, the potential effects of that climate change on clouds in the montane forests, and the interacting effects of temperature, precipitation, hurricanes, sea level rise, and land use on cloud cover.

\section{References Cited}

Arendt, W.J., Qian, S.S., and Mineard, K.A., 2013, Population decline of the Elfin-woods Warbler Setophaga angelae in eastern Puerto Rico: Bird Conservation International, v. 23, p. 136-146.

Boucher, D.H., 1990, Growing back after hurricanes: BioScience, v. 40, p. 163-166.

Bruijnzeel, L.A., Mulligan, M., and Scatena, F.N., 2011, Hydrometeorology of tropical montane cloud forests-Emerging patterns: Hydrological Processes, v. 25, p. 465-498.

Byer, M.D., and Weaver, P.L., 1977, Early secondary succession in an elfin woodland in the Luquillo Mountains of Puerto Rico: Biotropica, v. 9, p. 35-47.

Comita, L.S., Uriarte, M., Thompson, J., Jonckheere, I., Canham, C.D., and Zimmerman, J.K., 2009, Abiotic and biotic drivers of seedling survival in a hurricane-impacted tropical forest: Journal of Ecology, v. 97, p. 1,346-1,359.

Delannoy-Juliá, C.A., 2009, Elfin-woods Warbler (Dendroica angelae)—Neotropical birds online (Schulenberg, T.S., ed.): Ithaca, New York, Cornell University Lab of Ornithology Web site, accessed April 2014, at http://neotropical.birds.cornell.edu/portal/species/distribution?p_p_spp=569996. 
Foster, P., 2007, The potential negative impacts of global climate change on tropical montane cloud forests: Earth Science Reviews, v. 55, p. 73-106.

Gould, W.A., Alarcón, C., Fevold, B., Jiménez, M.E., Martinuzzi, S., Potts, G., Solórzano, M., and Ventosa, E., 2007, Puerto Rico Gap Analysis Project-Final report: U.S. Department of Agriculture Forest Service, Moscow, Idaho, and Rio Piedras, Puerto Rico, 159 p.

Jacobs, K.R., Carrubba, L., and Díaz, E.L., eds., 2013b, Puerto Rico Climate Change Council vulnerability assessment, Working Group 2 report—Ecology and biodiversity: San Juan, Puerto Rico Coastal Zone Management Program, Departament of Natural and Environmental Resources, National Oceanic and Atmospheric Administration Office of Ocean and Coastal Resource Management, 153 p. [Also available at http://prccc.org/download/PR\%20State\%20of\%20the\%20Climate-WG2.pdf.]

Jacobs, K.R., Terando, A., and Diaz, E.L., eds., 2013a, Puerto Rico Climate Change Council vulnerability assessment, Working Group 1 report—Geophysical and chemical scientific knowledge-Observed trends and future projections: San Juan, Puerto Rico Coastal Zone Management Program, Departament of Natural and Environmental Resources, National Oceanic and Atmospheric Administration Office of Ocean and Coastal Resource Management, 63 p. [Also available at http://pr-ccc.org/download/PR\%20State\%20of\%20the\%20ClimateWG1.pdf.]

Lugo, A.E., 2000, Effects and outcomes of Caribbean hurricanes in a climate change scenario: Science of the Total Environment, v. 262, p. 243-251.

Martinuzzi, S., Gould, W.A., and Ramos González, O.M., 2007, Land development, land use, and urban sprawl in Puerto Rico integrating remote sensing and population census data: Landscape and Urban Planning, v. 79, nos. 3-4, p. 288-297.

Nadkarni, N.M., and Solano, R., 2002, Potential effects of climate change on canopy communities in a tropical cloud forest—An experimental approach: Oecologia, v. 131, p. 580 586.

NatureServe, 2003, Ecological systems of Latin America and the Caribbean database, Version 1.01: Arlington, Virginia, NatureServe database.

Scatena, A.F.N., and Larsen, M.C., 1991, Physical aspects of Hurricane Hugo: Biotropica, v. 23, p. 317-323.

Uriarte, M., Canham, C.D., Thompson, J., Zimmerman, J.K., Murphy, L., Sabat, A.M., Fetcher, N., and Haines, B.L., 2009, Natural disturbance and human land use as determinants of tropical forest dynamics—Results from a forest simulator, Ecological Monographs, v. 79, p. 423-443.

Weaver, P.L., 1990, Succession in the elfin woodland of the Luquillo Mountains of Puerto Rico: Biotropica, v. 22, p. 83-89.

Weaver, P.L., 2008, Dwarf forest recovery after disturbances in the Luquillo Mountains of Puerto Rico: Caribbean Journal of Science, v. 44, p. 150-163. 
Weaver, P.L., Medina, E., Pool, D., Dugger, K., Gonzales-Liboy, J., and Cuevas, E., 1986, Ecological observations in the dwarf cloud forest of the Luquillo Mountains in Puerto Rico: Biotropica, v. 18, p. 79-85.

Webster, P.J., Holland, G.J., Curry, J.A., and Chang, H.-R., 2005, Changes in tropical cyclone number, duration, and intensity in a warming environment: Science, v. 309, p. 1,844-1,846. 


\section{Central Atlantic Coastal Plain Wet Longleaf Pine Savanna and Flatwoods}

Ecological System Overview.- The Central Atlantic Coastal Plain Wet Longleaf Pine Savanna and Flatwoods system occurs on the coastal plain, from North Carolina to northern South Carolina (fig. 3.1), and historically occurred in southern Virginia (Frost and Musselman, 1987; NatureServe, 2013a). The system was once the matrix vegetation in the eastern part of its range (NatureServe, 2013a). Because soils are particularly wet in this ecological system, the canopy often is open. Longleaf pine (Pinus palustris), and to a lesser extent pond pine (Pinus serotina), are dominant canopy species. In some communities, the understory is made up of low shrubs and herbaceous species, including pineland threeawn, which is a species of wiregrass (Aristida stricta). Fires are naturally frequent, and would have occurred in this system every 1-5 years prior to European settlement (Wilson and Mangus, 2006). When frequently burned, savanna communities in this ecological system can contain among the highest levels of plant species richness in the Western Hemisphere at small spatial scales (Peet and Allard, 1993). Many threatened or endangered plant and animal species occur in this system, including roughleaf yellow loosestrife (Lysimachia asperulifolia), Cooley’s meadowrue (Thalictrum cooleyi), and the Red-cockaded Woodpecker (Picoides borealis). In areas that are fire-suppressed or that have been logged in the past, hardwood tree species and loblolly pine (Pinus taeda) often encroach and replace longleaf or pond pine. See NatureServe (2013a) and Schafale (2012; "wet pine flatwoods") for complete descriptions of this ecological system. 


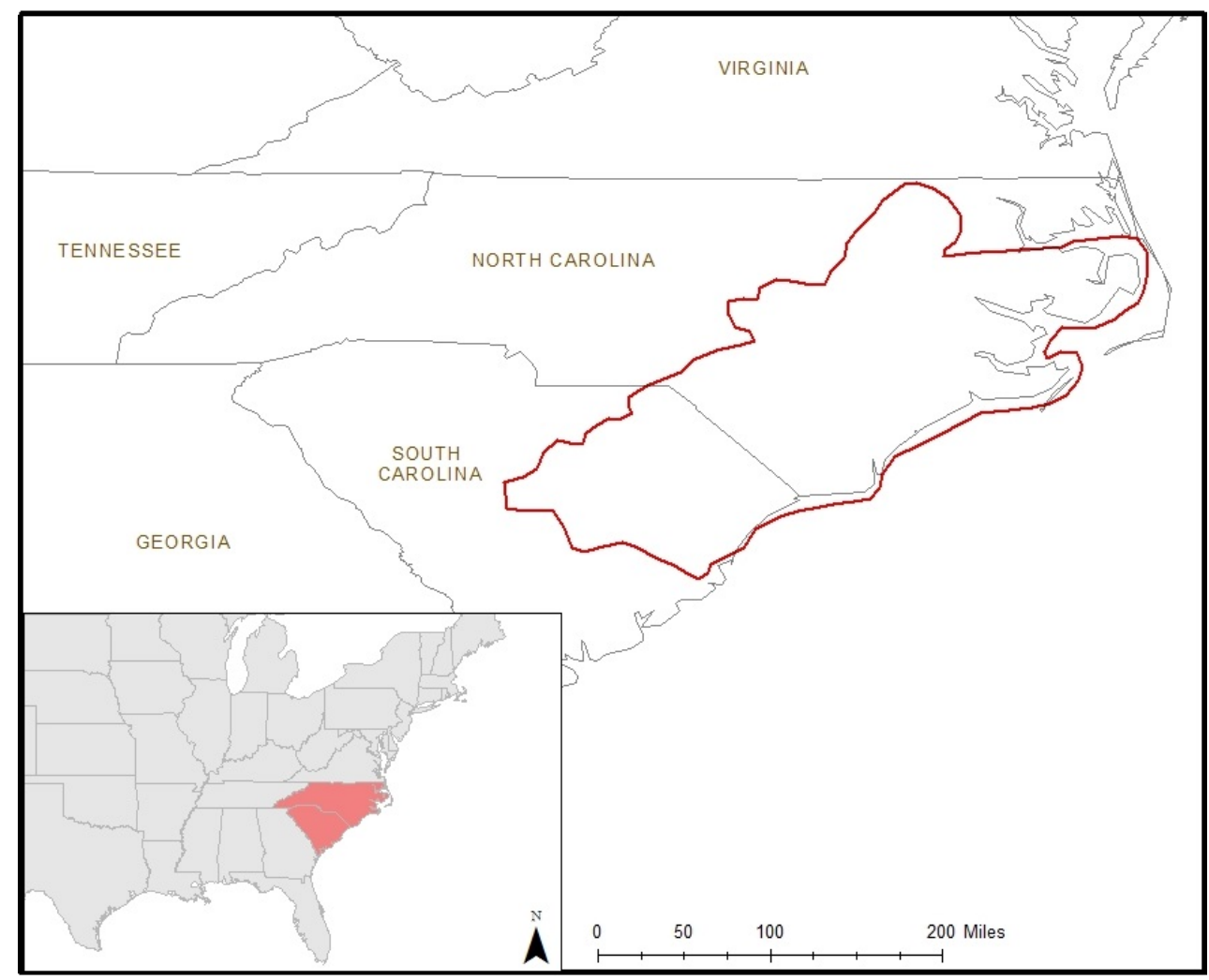

Figure 3.1. Range of the Central Atlantic Coastal Plain Wet Longleaf Pine Savanna and Flatwoods ecological system. The system covers 1.8 percent of this range, according to data from NatureServe (2013b).

Vulnerability Status.- - Relative to other ecological systems in the Southeast, the vulnerability of this ecological system is rated as Low. The vegetation structure is sensitive to fire regimes, hurricanes, and sea level rise, yet the major species in this community are not particularly sensitive to climate. The likely exposure to changes in fire regimes and hurricanes is relatively low. However, a substantial portion of the system could be affected by sea level rise. The system has a low amount of adaptive capacity because it is fire suppressed, has a small average patch size, and has a high degree of human modification. However, because the likely climate change impact is relatively low, a low amount of adaptation may be necessary.

Sensitivity.- Our analysis shows that this system occurs in areas where temperature ranges from an average maximum of $31^{\circ} \mathrm{C}$ in the summer (Appendix $\mathrm{B}$ ) to an average winter minimum of $1{ }^{\circ} \mathrm{C}$ (Appendix B). Average precipitation generally is slightly higher in summer than in other seasons, and precipitation is more variable in summer and fall (Appendix B). In southeastern Virginia, at the northern limit of the range of longleaf pine, growth of longleaf trees is limited by winter temperatures and precipitation (Bhuta and others, 2009). Furthermore, longleaf pines are more drought-tolerant than other southern pine species, including loblolly pine (Samuelson and others, 2012). Pond pine grows in areas with warmer temperatures and a greater range of annual precipitation than this ecological system (Burns and Honkala, 1990) and, therefore, 
small-to-moderate changes in temperature or precipitation under future climate change should not affect that species.

The rich diversity of herbaceous species in this ecological system depends on frequent natural disturbances. Frequent fires in this system maintain the open vegetation structure of communities in this system, prevent the growth of hardwood trees and loblolly pine that compete with longleaf pine, and promote the rich diversity of herbaceous species in the understory (Peet and Allard, 1993; Beckage and others, 2009; Glitzenstein and others, 2012). Periodic hurricanes also decrease the density of trees and shrubs and maintain the open, savanna structure of the vegetation. An altered disturbance regime owing to future climate would impact the ecological system by affecting understory plant diversity as well as the regeneration of longleaf pines.

Exposure.-Our analysis of projected change in climate for the Central Atlantic Coastal Plain Wet Longleaf Savanna and Flatwoods ecological system shows increases in maximum and minimum temperatures for most models, seasons, and scenarios, except for some seasons at midcentury (figs. 3.2 and 3.3). Overall, slightly larger increases are projected for mean minimum temperatures than for mean maximum temperatures. Increases in both mean winter minimum and maximum temperatures are projected to be smaller than for other seasons. Average projections for winter minimum temperatures, which limit the northern growth of longleaf pine trees, show an increase overall. However, at least one General Circulation Model (GCM) under both emissions scenarios projects a decrease at mid-century. Warming temperatures, especially in winter, would increase habitat suitability toward the northern part of the range of longleaf pine.

Projected percentage changes in precipitation for this ecological system show variation among climate models for each season, emissions scenario, and time period, with the least variation among climate models for winter projections

(fig. 3.4). The means of the projections for most emissions scenarios and time periods are positive in most cases, indicating that as a whole, climate models are projecting a general increase in precipitation by the end of the century. However, in all cases, the range of projections crosses 0 , indicating a large amount of variation among climate models in the projected magnitude and direction of change in precipitation. The largest ranges in projected precipitation are for the summer and fall at the end of the century. If precipitation increases, habitat suitability for longleaf pine likely would increase, especially toward the northern portion of the range of this ecological system.

Projected changes in the standard deviation, or variability, of temperature and precipitation for this ecological system differ greatly among climate models. Both the means and ranges of projected change in standard deviation for maximum and minimum temperatures vary considerably (Appendix C). The mean change in the standard deviation of precipitation is greater than 1 in all cases, indicating that although projections vary among models, on average, they predict an increase in variability for precipitation in the future under both emissions scenarios (Appendix C).

According to the U.S. Forest Service Climate Change Tree Atlas, the abundance of longleaf pine will stay constant over the range of this ecological system under all climate scenarios and models considered (Prasad and others, 2007). The modeled abundance of pond pine 
is projected to decrease in coastal North and South Carolina under low- and high-emissions scenarios, and is projected to be low across the Southeast in the future (Prasad and others, 2007). Therefore, pond pine may become even less common in this ecological system in the future.

If temperatures warm and precipitation becomes more variable overall, drought may become more frequent. Other research also has suggested that there is likely to be an increase in the frequency of drought in the in the Southeast in the future (Seager and others, 2009), although the future of drought is somewhat uncertain. Drier conditions also may lead to less soil saturation in this ecological system. If drought increases or soil saturation decreases, longleaf pine likely will thrive more than other species because it is less sensitive to water stress (Samuelson and others, 2012).

Increased temperatures and variability in precipitation, even with a slight increase in precipitation overall, could lead to more wildfires in this ecological system. In the literature, there is some uncertainty about how the area burned by wildfires will change in the area where this system occurs. Some studies have suggested that the wildfire season will become longer, leading to more wildfires in the Southeast (Stanturf and Goodrick, 2013). Alternatively, because of increased precipitation, the area burned may not change in the future under any emissions scenario (Costanza and others, 2015). More wildfire would result in a more open canopy and understory, but a greater number of fires in long-unburned sites or after periods of drought could lead to increased mortality of longleaf pines in this ecological system (Varner and Kush, 2004). Fewer fires in this ecological system would lead to more hardwood and loblolly pine trees in the overstory, a closed canopy, more shrubs and hardwoods in the midstory and understory, and lower herbaceous species richness in the understory.

Because this system occurs along the outer fringes of the Atlantic Coast, it likely will be exposed to sea level rise. According to National Oceanic and Atmospheric Administration (NOAA) Sea Level Trends data, stations within the range of this ecological system have had a moderate amount of annual sea level rise from 1947 to 2006 (National Oceanic and Atmospheric Administration, 2013). The mean annual sea level rise ranged from 2.07 millimeters per year (mm/yr) in Wilmington, North Carolina, to 4.59 mm/yr in Duck, North Carolina (National Oceanic and Atmospheric Administration, 2013). Other evidence has suggested that there has been an acceleration in sea level rise along the Atlantic Coast north of Cape Hatteras, North Carolina, since the middle of the 20th century (Sallenger and others, 2012).

We analyzed the projected inundation owing to sea level rise under a 1- and 6-ft (0.3- and 1.8-m) rise in sea level, according to NOAA data. Those data covered 72 percent of the coastal extent of this ecological system. Within the portion covered by the sea-level-rise data, rising sea level is projected to inundate 4 and 14 percent of this ecological system under a 1and 6-ft rise, respectively (Appendix A). The effects of sea level rise include not only direct loss and fragmentation of habitat through inundation, but also an increase in the severity of other disturbances. For example, storm surges associated with hurricanes cause damage to trees and other vegetation (Stanturf and others, 2007). Thus, the effects of storm surge may become more severe in the future as sea level rises and hurricane intensity and frequency increase, as projected (Webster and others, 2005; Intergovernmental Panel on Climate Change, 2007; Lin and others, 2012). We analyzed data from the Sea Level Affecting Marshes Model (SLAMM) for the entire 
coastal extent of this system. The SLAMM data incorporate some changes in hydrology that accompany inundation from rising sea level. Our analysis shows that more than 15 percent of the system's range is projected to change to another vegetation type by 2050, and more than 24 percent is likely to change by 2100 , with slightly more change projected under the A1FI scenario than the B1 scenario (Appendix A).

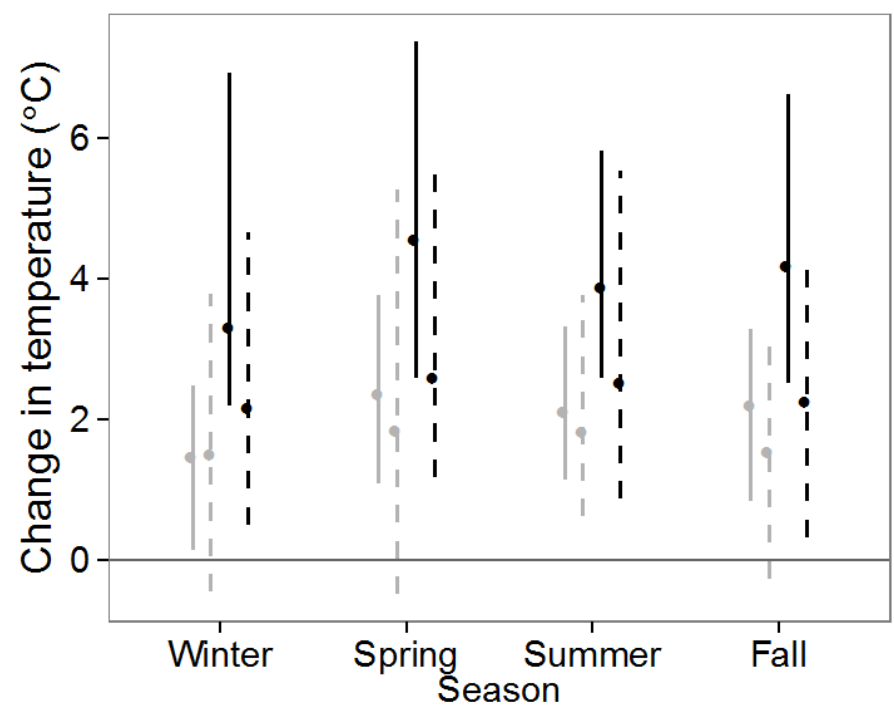

Scenario, time period

- A1FI, mid-century

- B1, mid-century

$\rightarrow \mathrm{A} 1 \mathrm{FI}$, end of century

- - B1, end of century

Figure 3.2. Projected change in seasonal maximum temperatures (in degrees Celsius $\left[{ }^{\circ} \mathrm{C}\right]$ ) for the middle (2040-2060) and the end of the 21st century (2080-2100), compared with the recent time period (19812000), for two emissions scenarios for the Central Atlantic Coastal Plain Wet Longleaf Savanna and Flatwoods ecological system. Solid dots and error bars represent, respectively, the means and ranges of projections across climate models under each scenario. 


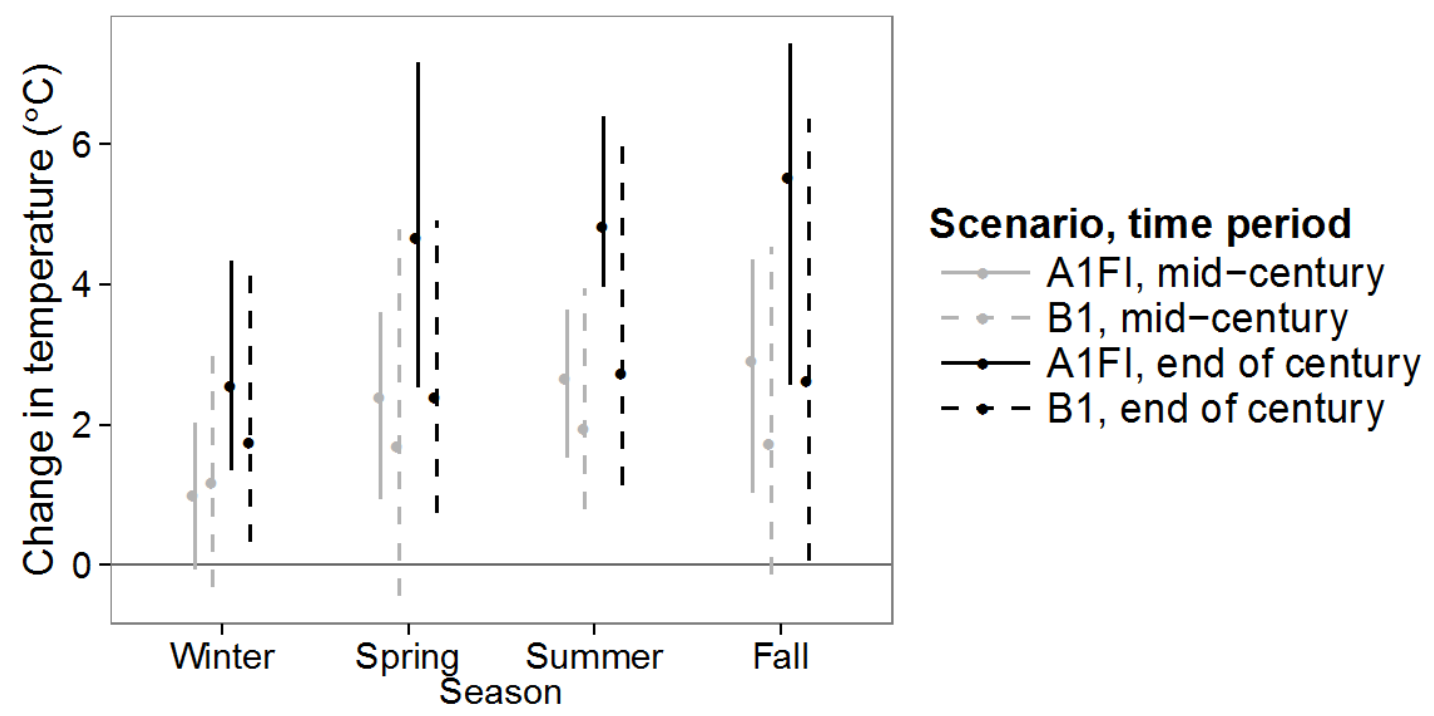

Figure 3.3. Projected change in seasonal minimum temperatures (in degrees Celsius $\left[{ }^{\circ} \mathrm{C}\right]$ ) for the middle (2040-2060) and the end of the 21st century (2080-2100), compared with the recent time period (19812000), for two emissions scenarios for the Central Atlantic Coastal Plain Wet Longleaf Savanna and Flatwoods ecological system. Solid dots and error bars represent, respectively, the means and ranges of projections across climate models under each scenario.

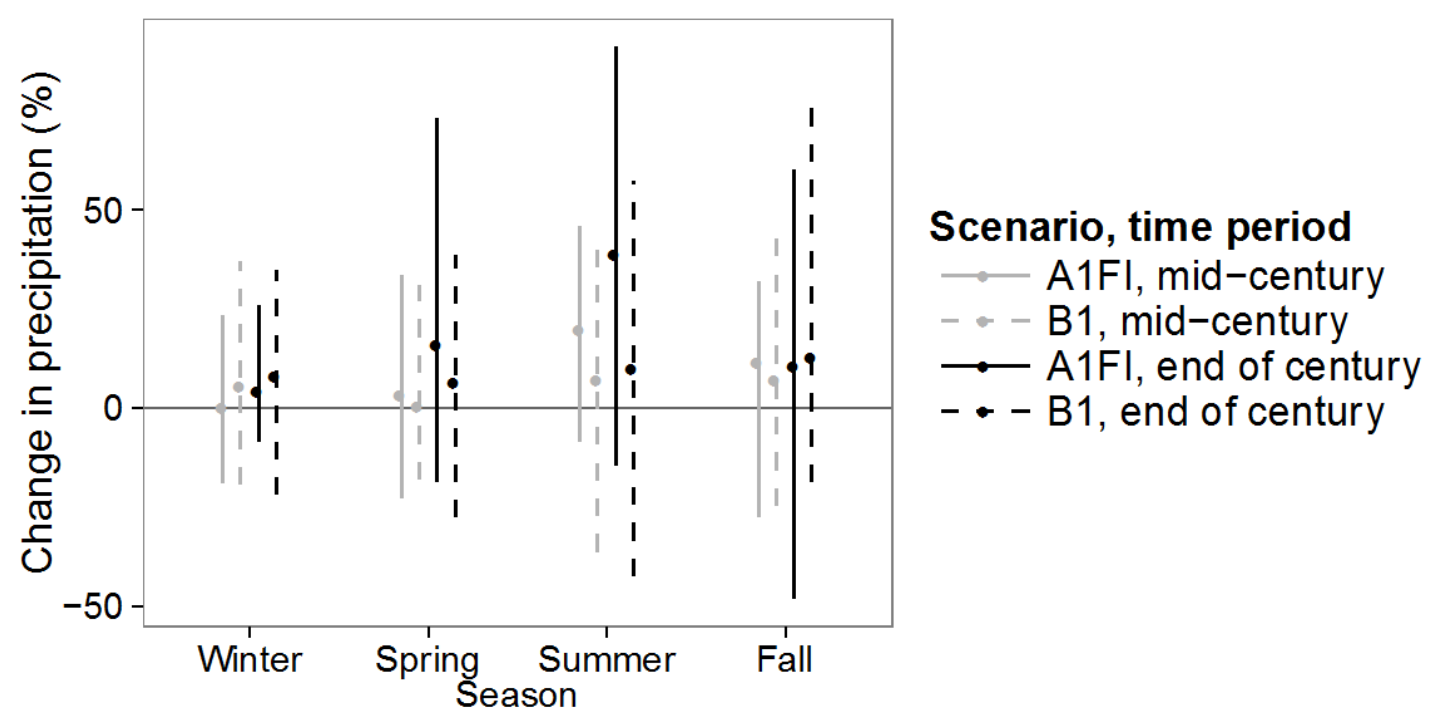

Figure 3.4. Projected percentage (\%) change in seasonal average precipitation for the middle (2040-2060) and the end of the 21st century (2080-2100), compared with the recent time period (1981-2000), for two emissions scenarios for the Central Atlantic Coastal Plain Wet Longleaf Savanna and Flatwoods ecological system. Solid dots and error bars represent, respectively, the means and ranges of projections across climate models under each scenario. 
Adaptive Capacity.-Longleaf pine savannas have been severely fragmented and reduced to less than 5 percent of their former range (Frost, 1993; VanLear and others, 2005). Much of the longleaf pine in the Southeast was exploited for lumber and turpentine during the 1800s and earlier, after which it failed to regenerate (Frost, 2006). Fire suppression beginning in the 20th Century further threatened longleaf generation, and has led to a decline in understory species richness in this ecological system (VanLear and others, 2005; Frost, 2006).

Prescribed fire is a major management and restoration tool in pine communities in the Southeastern United States. In the most fire-suppressed regions, restoration to a more open structure often is difficult with fires alone, and may involve mechanical treatment in combination with several prescribed burns (Outcalt and Brockway, 2010). Prescribed burning in pine communities that are in need of fire often is difficult, and management agencies often are constrained by lack of resources, fuel build-up owing to dense vegetation in the understory and midstory, and inappropriate weather conditions (Costanza and Moody, 2011; Costanza and others, 2013). If climate change leads to hotter, drier conditions, although the potential for wildfires may increase, the number of days per year with suitable conditions for prescribed burning could decrease, further constraining prescribed fire in this system. The potential effects of climate change on suitable burning conditions is an area of considerable uncertainty, and further research on this topic is necessary.

Another threat to this ecosystem is the non-native species cogongrass (Imperata cylindrica), an invasive species in pine savannas and flatwoods in the Southeastern United States. Although it is more common and has been present longer in Florida and along the Gulf Coast, cogongrass is present in a few locations in South Carolina, and has been found on the coastal plain of North Carolina (North Carolina Cooperative Extension, 2012). Invasion by cogongrass has been shown to decrease herbaceous species richness (Brewer, 2008), and increase fuel loads, which could promote hotter, more intense fires (Platt and Gottschalk, 2001). Additionally, fire can facilitate spread of cogongrass (Yager and others, 2010). Therefore, more frequent fires under climate change could lead to further spread of cogongrass, and additional losses to biodiversity in this pine flatwoods system.

Conservation and management of this ecological system is constrained because little of this ecological system (6 percent) is present in protected areas (fig. 3.7), and its average patch size is small $\left(2,846 \mathrm{~m}^{2}\right.$, or 0.28 ha; Appendix A). The system has the highest average degree of human modification of all systems included in this assessment (81 percent; Appendix A), the average distance from this ecological system and existing development is low (425 m; Appendix A), placing constraints on management, and especially prescribed burning. These data, combined with the non-climate related adaptive factors described earlier in this section, limit the adaptive capacity of this ecological system. However, a fairly small amount of the system is likely to be converted to development in the future. Conversion of nearly 1 percent is projected by 2050, and 2 percent is projected by 2100 (fig. 3.5).

This system often occurs in areas adjacent to the Southern Atlantic Coastal Plain Upland Longleaf Pine Woodland system and north of the Southern Atlantic Coastal Plain Wet Pine Savanna and Flatwoods system. These systems share many species in common, so the capacity of 
these species to adapt and move in response to changing climate would be enhanced by increasing connectivity among the systems.

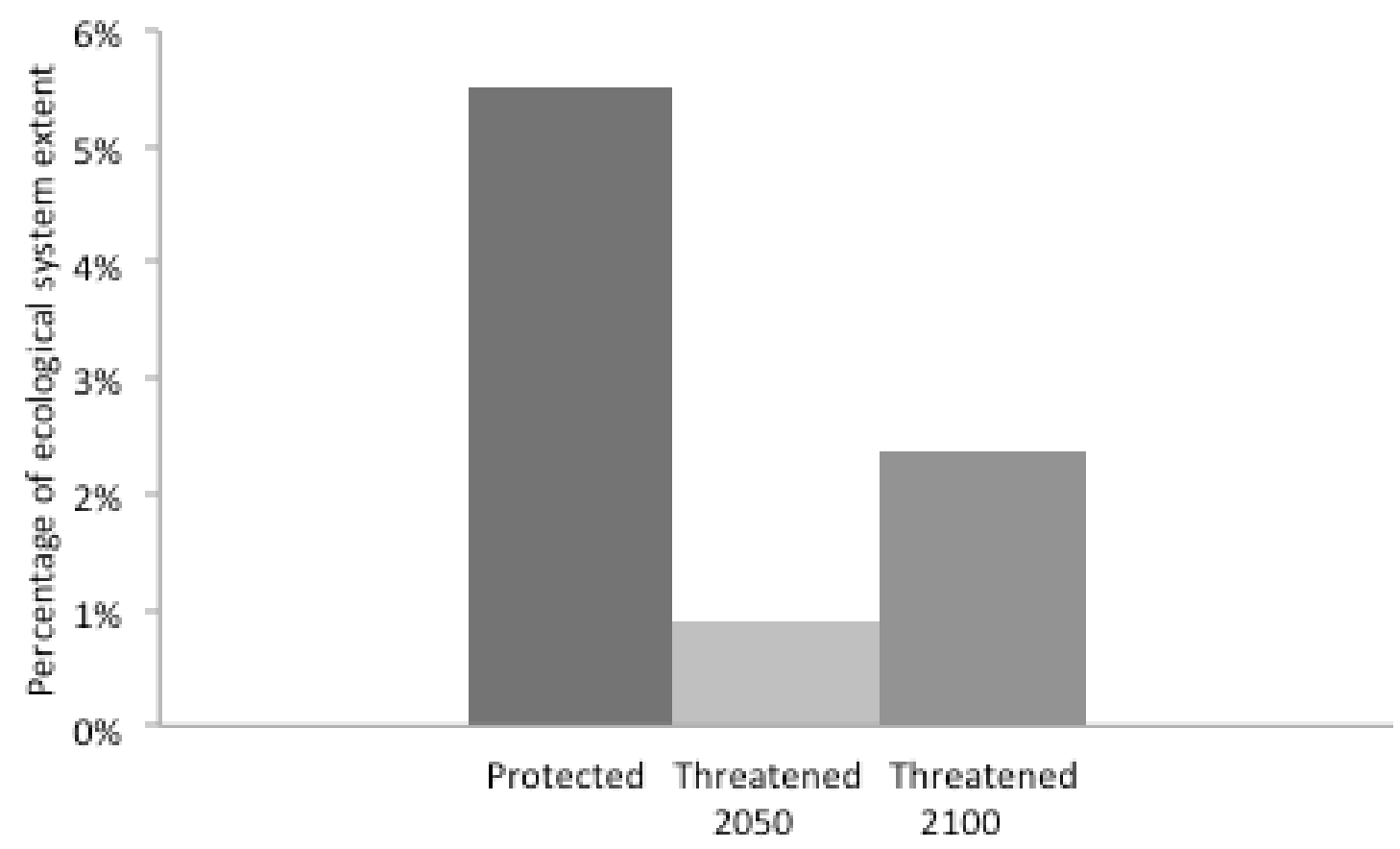

Figure 3.5. Percentage of the extent of the Central Atlantic Coastal Plain Wet Longleaf Pine Savanna and Flatwoods ecological system that is protected for conservation, and the percentage threatened by future development in 2050 and 2100.

Summary.-Under a changing climate in the Central Atlantic Coastal Plain Wet Longleaf Pine Savanna and Flatwoods ecological system, longleaf pine trees may thrive under climate change, and may even expand their range northward, whereas pond pine may become less important in this system. As a whole, this system is sensitive to disturbance frequency. In particular, frequent fires promote the open habitat structure on which many plant and wildlife species depend, and promote a rich diversity of herbaceous plant species in the understory. There is some uncertainty about the likely effects of climate change on fires in this ecological system. A hotter, drier climate may lead to an increase in wildfires, and also likely would restrict the number of days that managers can implement prescribed burns. Hurricanes are another major disturbance in this system, and are likely to become more frequent during climate change. Additionally, a substantial portion of this ecological system may be directly or indirectly affected by sea level rise by the end of the 21st century. This ecological system and similar longleaf pine systems in the Southeast have been severely fragmented, reducing the capacity of these systems and the species associated with them to adapt to the effects of sea level rise by migrating inland. Future research needs include investigations of the potential effects of climate change on hurricanes and fire in this ecosystem, including the effects of climate on suitable conditions for prescribed burning. 


\section{References Cited}

Beckage, B., Platt, W.J., and Gross, L.J., 2009, Vegetation, fire, and feedbacks-A disturbancemediated model of savannas: The American Naturalist, v. 174, p. 805-818.

Bhuta, A.A.R., Kennedy, L.M., and Pederson, N., 2009, Climate-radial growth relationships of northern latitudinal range margin longleaf pine (Pinus palustris P. Mill.) in the Atlantic Coastal Plain of southeastern Virginia: Tree-Ring Research 65, p. 105-115.

Brewer, S., 2008, Declines in plant species richness and endemic plant species in longleaf pine savannas invaded by Imperata cylindrica: Biological Invasions, v. 10, p. 1,257-1,264.

Burns, R.M., and Honkala, B.H., tech. coords., 1990, Silvics of North America-Volume 1, Conifers: U.S. Forest Service, Agriculture Handbook 654, 877 p.

Costanza, J.K., and Moody, A., 2011, Deciding where to burn—Stakeholder priorities for prescribed burning of a fire-dependent ecosystem: Ecology And Society, v. 16, no. 1, p. 14.

Costanza, J., Weiss, J., and Moody, A., 2013, Examining the knowing-doing gap in the conservation of a fire-dependent ecosystem: Biological Conservation, v. 158, p. 107-115.

Costanza, J.K., Terando, A.J., McKerrow, A.J., and Collazo, J.A., 2015, Modeling climate change, urbanization, and fire effects on Pinus palustris ecosystems of the Southeastern U.S.: Journal of Environmental Management, v. 151, p. 186-199.

Frost, C.C., 1993, Four centuries of changing landscape patterns in the longleaf pine ecosystem, in Hermann, S., ed., Proceedings of the Tall Timbers Fire Ecology Conference, No. 18, The longleaf pine ecosystem-Ecology, restoration and management, Tall Timbers Research Station, Tallahassee, Florida, p. 17-43.

Frost, C.C., 2006, History and future of the longleaf pine ecosystem, in Jose, S., Jokela, E., and Miller, D., eds., Longleaf pine ecosystems: Ecology, Management, and Restoration: New York, Springer, p. 9-48.

Frost, C.C., and Musselman, L.J., 1987, History and vegetation of the Blackwater Ecologic Preserve: Castanea, v. 52 p. 16-46.

Glitzenstein, J.S., Streng, D.R., Masters, R.E., Robertson, K.M., and Hermann, S.M., 2012, Firefrequency effects on vegetation in north Florida pinelands-Another look at the long-term Stoddard Fire Research Plots at Tall Timbers Research Station: Forest Ecology and Management, v. 264, p. 197-209.

Intergovernmental Panel on Climate Change, 2007, Climate change 2007-The physical science basis-Contribution of Working Group I to the Fourth Assessment Report of the Intergovernmental Panel on Climate Change: Cambridge and New York, Cambridge University Press, $996 \mathrm{p}$. 
Lin, N., Emanuel, K., Oppenheimer, M., and Vanmarcke, E., 2012, Physically based assessment of hurricane surge threat under climate change: Nature Climate Change, v. 2, p. 462-467.

National Oceanic and Atmospheric Administration, 2013, Sea levels online-Sea level variations of the United States derived from National Water Level Observation Network stations: National Oceanic and Atmospheric Administration Ocean Service, Center for Operational Oceanographic Products and Services (CO-OPS), accessed October 2013, at http://tidesandcurrents.noaa.gov/sltrends.

NatureServe, 2013a, NatureServe explorer-An online encyclopedia of life, Version 7.1: Arlington, Virginia, NatureServe Web application, accessed May 2013, at http://www.natureserve.org/explorer.

NatureServe, 2013b, U.S. ecological systems National Map data: Arlington, Virginia, NatureServe database, accessed January 2013, at http://www.natureserve.org/getData/USecologyData.jsp.

North Carolina Cooperative Extension, 2012, One of world's worst weeds recently found in Pender County: Raleigh, North Carolina State University, North Carolina Cooperative Extension Service Web site, accessed August 2013, at http://pender.ces.ncsu.edu/2012/06/oneof-worlds-worst-weeds-recently-found-in-pender-county.

Outcalt, K.W., and Brockway, D.G., 2010, Structure and composition changes following restoration treatments of longleaf pine forests on the Gulf Coastal Plain of Alabama: Forest Ecology and Management, v. 259, p. 1,615-1,623.

Peet, R.K., and Allard, D.J., 1993, Longleaf pine vegetation of the southern Atlantic an eastern Gulf Coast regions-A preliminary classification, in Hermann, S.M., ed., Proceedings of the Tall Timbers Fire Ecology Conference, No. 18, The longleaf pine ecosystem-Ecology, restoration and management, Tall Timbers Research Station, Tallahassee, Florida, p. 45-81.

Platt, W.J., and Gottschalk, R.M., 2001, Effects of exotic grasses on potential fine fuel loads in the groundcover of south Florida slash pine savannas: International Journal of Wildland Fire, v. 10, p. 155-159.

Prasad, A.M., Iverson, L.R., Matthews, S., and Peters, M., 2007, A climate change atlas for 134 forest tree species of the Eastern United States: U.S. Forest Service database, Northern Research Station, Delaware, Ohio, accessed May 2013, at http://www.nrs.fs.fed.us/atlas/tree.

Sallenger, A.H., Doran, K.S., and Howd, P.A., 2012, Hotspot of accelerated sea-level rise on the Atlantic coast of North America: Nature Climate Change, v. 2, p. 884-888.

Samuelson, L.J., Stokes, T.A., and Johnsen, K.H., 2012, Ecophysiological comparison of 50year-old longleaf pine, slash pine and loblolly pine: Forest Ecology and Management, v. 274, p. 108-115.

Schafale, M.P., 2012, Guide to the natural communities of North Carolina—Fourth Approximation: Raleigh, North Carolina Department of Environment and Natural Resources, 
North Carolina Natural Heritage Program, 217 p., accessed August 2013, at http://portal.ncdenr.org/c/document_library/get_file?uuid=cbaac345-aca2-4312-acca1004f2ba59a9\&groupId=61587.

Seager, R., Tzanova, A., and Nakamura, J., 2009, Drought in the Southeastern United StatesCauses, variability over the last millennium, and the potential for future hydroclimate change: Journal of Climate, v. 22, p. 5,021-5,045.

Stanturf, J.A., and Goodrick, S.L., 2013, Fire, in Wear, D.N., and Greis, J.G., eds., The southern forest futures project-Technical report: U.S. Forest Service, Southern Research Station, Asheville, North Carolina, General Technical Report SRS-GTR-178, 542 p.

Stanturf, J.A., Goodrick, S.L., and Outcalt, K.W., 2007, Disturbance and coastal forests-A strategic approach to forest management in hurricane impact zones: Forest Ecology and Management, v. 250, p. 119-135.

VanLear, D.H., Carroll, W.D., Kapeluck, P.R., and Johnson, R., 2005, History and restoration of the longleaf pine-grassland ecosystem-Implications for species at risk: Forest Ecology and Management, v. 211, p. 150-165.

Varner, J.M., and Kush, J.S., 2004, Remnant old-growth longleaf pine (Pinus palustris Mill.) savannas and forests of the southeastern USA—Status and threats: Natural Areas Journal, v. 24, p. 141-149.

Webster, P.J., Holland, G.J., Curry, J.A., and Chang, H.-R., 2005, Changes in tropical cyclone number, duration, and intensity in a warming environment: Science, v. 309, p. 1,844-1,846.

Wilson, B., and Mangus, J., 2006, LANDFIRE biophysical setting model for Central Atlantic Coastal Plain Wet Longleaf Pine Savanna and Flatwoods-LANDFIRE biophysical setting descriptions, Map zone 58: LANDFIRE) program model, p. 48-53, accessed August 2013, at http://www.landfire.gov/national_veg_models_op2.php.

Yager, L.Y., Miller, D.L., and Jones, J., 2010, Susceptibility of longleaf pine forest associations in south Mississippi to invasion by cogongrass [Imperata cylindrica (L.) Beauv.]: Natural Areas Journal, v. 30, p. 226-232. 


\section{Central Florida Wet Prairie and Herbaceous Seep}

Ecological System Overview.-The Central Florida Wet Prairie and Herbaceous Seep system occurs in central Florida, particularly around the Lake Wales Ridge, and includes seepage wetlands and nearly treeless plains (fig. 4.1; NatureServe, 2013a). In this system, herbaceous species are dominant, but often some small shrubs are found in the understory. This system differs from other prairie and wetland ecological systems nearby because it contains subtropical plant species that do not occur farther north. Specifically, cutthroat grass (Panicum abscissum) is a subtropical grass species endemic to central Florida that is dominant in some sites. Much plant and animal diversity is present in this system, owing to small-scale differences in soil moisture, hydrology, elevation and slope (U.S. Fish and Wildlife Service, 1999; Florida Natural Areas Inventory, 2010). The prairies and seeps in this ecological system occur on soils that are poorly drained with some groundwater seepage. These communities also rely on fires that occur as frequently as annually to promote reproduction of many herbaceous species and to prevent growth of tree species (U.S. Fish and Wildlife Service, 1999; Florida Natural Areas Inventory, 2010).

Research on the ecology of this ecological system is limited. See NatureServe (2013a), the Florida Natural Areas Inventory (2010; Wet Prairie), and Carr and others (2010; Central Florida Flatwoods/Prairies) for complete descriptions of this ecological system. 


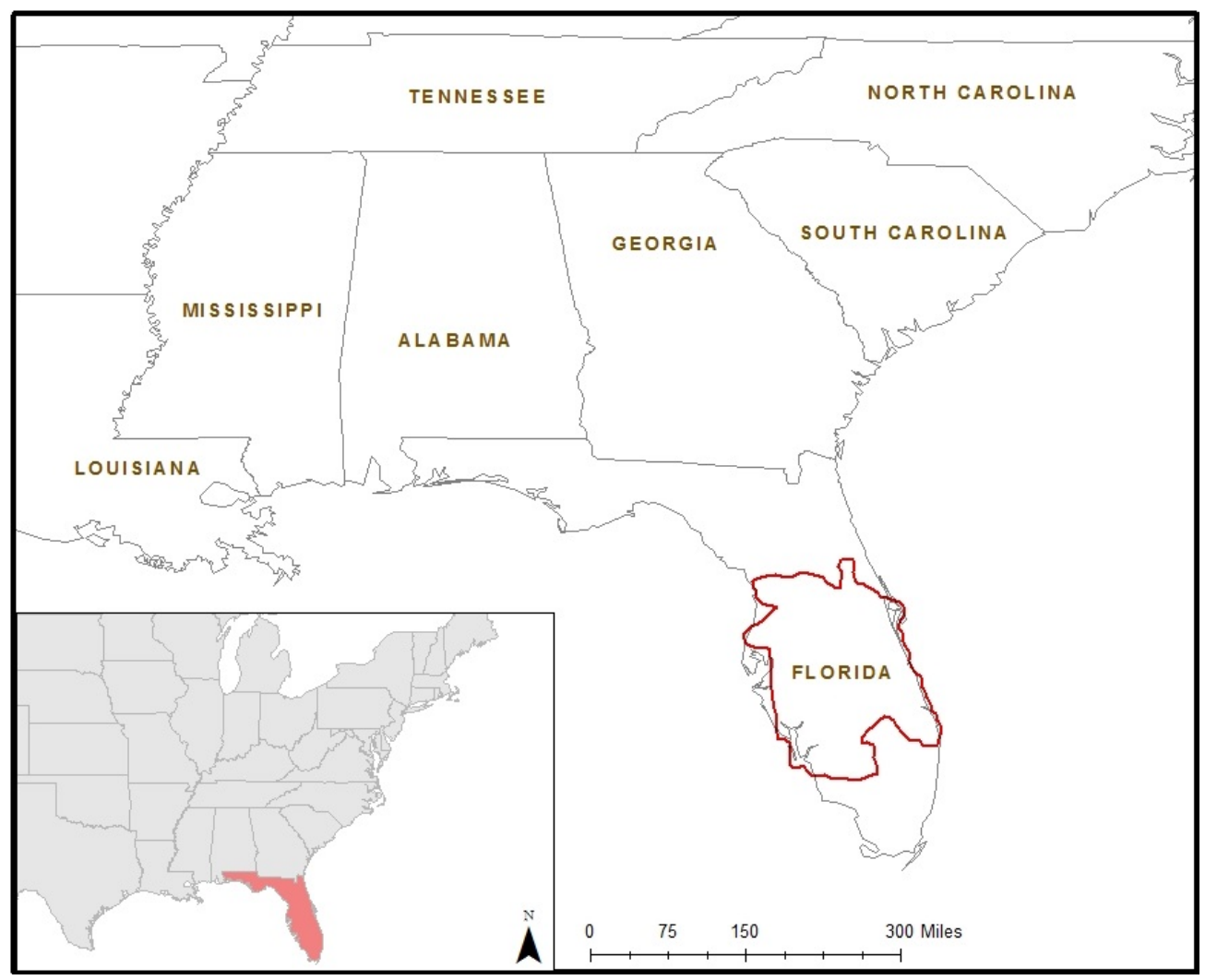

Figure 4.1. Range (outlined in top map) of the Central Florida Wet Prairie and Herbaceous Seep ecological system. The system covers 0.34 percent of this range, according to data from NatureServe (2013b).

Vulnerability Status. - Relative to other ecological systems in the Southeast, the vulnerability of this ecological system is rated as Medium because of its moderate sensitivity to precipitation, fire frequency, and storm events, along with its likely moderate exposure to changes in those factors along with sea level rise. Although this ecological system has been severely fragmented and patch sizes are small, a large portion of it is protected and a relatively small portion is projected to be developed, so the system likely has a moderate ability to adapt to future climate change.

Sensitivity.-Our analysis shows that this system occurs in areas where temperature ranges from an average maximum of $34^{\circ} \mathrm{C}$ in the summer (Appendix B) to an average winter minimum of $2{ }^{\circ} \mathrm{C}$ (Appendix B). Precipitation generally is less during the winter than in other seasons (Appendix B).

Many species that occur in this ecological system do not occur in other systems to the north. For example, cutthroat grass is restricted to a small region in central Florida, and is not present in the prairies and grasslands that occur to the north (U.S. Fish and Wildlife Service, 1999). Part of the reason for the restricted distribution of this and other species could be related to climate, but the full reason for the restriction is unknown (U.S. Fish and Wildlife Service, 1999).

This ecological system depends on frequent fire and occurs on continuously wet soils. Fires promote annual or biennial flowering in many of the grasses and other herbaceous species 
in this system, prevent dominance by shrub species, and prevent establishment of trees (U.S. Fish and Wildlife Service, 1999). Cutthroat grass, Beyrich threeawn, which is a species of wiregrass (Aristida beyrichiana), and other herbaceous species grow quickly following fire, providing highly flammable material to carry subsequent fires soon after they are burned (Lemon, 1949; Abrahamson, 1984). Without frequent fires, this system becomes invaded by shrub species such as fetterbush (Lyonia lucida), evergreen bayberry (Morella caroliniensis) and inkberry (Ilex glabra), as well as tree species such as loblolly bay (Gordonia lasianthus) and other bays. This change in species composition and vegetation structure can lead to fewer, more intense fires.

In addition to fire frequency, the season of fire influences regrowth and community succession in this system. Frequent fires in the early growing season are essential for stimulating flowering and reproduction of many herbaceous species, including cutthroat grass. Fires occurring later in the growing season or during the winter favor vegetative growth of many tree species. If growing-season fires become less frequent, the rich grass layer of the prairies and seeps in this system could be threatened.

Little hydrologic and soil research has been done on this ecosystem. However, evidence from other prairies and seeps in the Southeast suggests that the hydrology of these communities is influenced by soil characteristics, vegetation, and topography of local and surrounding areas (Bridges and Orzell, 1989). Vegetation and hydrology influence each other in this system. Increased woody vegetation, especially increased hardwood density, decreases the amount of flow to seeps and prairies in this ecological system (U.S. Fish and Wildlife Service, 1999). Likewise, drier soils lead to increased establishment of trees and shrubs.

Exposure.-Analysis of projected change in climate for the Central Florida Wet Prairie and Herbaceous Seep ecological system shows increases in maximum and minimum temperatures for most models and most scenarios (figs. 4.2 and 4.3). The projected change in maximum temperature is greater for spring and summer than for winter and fall, with a mean change of more than $5{ }^{\circ} \mathrm{C}$ projected under the A1FI scenario by the end of this century in those seasons. The projected changes in minimum temperature are similar for all seasons, with slightly less change projected under the A1FI scenario for winter.

Projected percentage changes in precipitation for this ecological system show variation among climate models for each season, emissions scenario, and time period, with the most variation among climate models in fall (fig. 4.4). The means across models for each emissions scenario and time period are all negative in spring and summer, positive in all cases for the fall, and both positive and negative for the winter. However, in all cases, the range of projections crosses 0 , indicating much uncertainty among climate models in both the magnitude and direction of change in precipitation. The greatest changes in precipitation are projected under the A1FI model for fall, when as much as a 118-percent increase in precipitation is projected by midcentury, and a 142-percent increase is projected by the end of the century.

Projected changes in the standard deviation, or variability, of temperature and precipitation for this ecological system show a high degree of uncertainty among climate models. Both the means and ranges of change in standard deviation for maximum and minimum temperatures vary considerably (Appendix C). The mean change in the standard deviation of 
precipitation is greater than 1 in nearly all cases. Therefore, although projections vary among models, on average, they predict an increase in variability for precipitation in the future (Appendix C).

A change in the amount or variability of precipitation would change the fire regime in this ecological system. In previous studies, wildfire frequency in southern Florida has been linked to the El Niño-Southern Oscillation (ENSO). Wildfires were found to occur more frequently in La Niña years when precipitation is decreased (Beckage and others, 2003). Some evidence suggests fewer La Niña events with future climate change, which would lead to fewer fires in this ecological system (Timmermann and others, 1999; Beckage and others, 2006). However, the link between ENSO and climate change is uncertain (Cobb and others, 2013). A decrease in the number of fires in this ecological systems would lead to encroachment by shrubs like fetterbush, as well as tree species, including bay species.

A decrease, or even a small increase, in precipitation, when coupled with projected increases in temperature, could lead to more frequent droughts in this ecological system. According to the previous studies, drought conditions are expected to become more common in the Southeast under climate change, although there is some disagreement among climate models (Seager and others, 2009). Changes in soil hydrologic conditions within wet prairies and seeps would alter community composition by changing soil moisture or by interacting with the fire regime. Drier soils in this ecological system could lead to future establishment of shrubs and tree species where grasslands are present.

The location of this ecological system in peninsular Florida means that it is likely to be exposed to sea level rise. According to the National Oceanic and Atmospheric Administration (NOAA) Sea Level Trends data, stations within the range of this ecological system have had a relatively small amount of annual sea level rise from 1947 to 2006 (National Oceanic and Atmospheric Administration, 2013). The mean annual sea level rise ranged from $2.02 \mathrm{~mm} / \mathrm{yr}$ in Naples, Florida, to $2.43 \mathrm{~mm} / \mathrm{yr}$ in Clearwater Beach, Florida (National Oceanic and Atmospheric Administration, 2013).

We analyzed the projected inundation of the Central Florida Wet Prairie and Herbaceous Seep ecological system owing to sea level rise under an additional 1- and 6-ft (0.3- and 1.8-m) rise in sea level, according to NOAA data. Those data covered 98 percent of the coastal extent of this system. Within the area covered by the data, rising sea level is projected to directly affect 0.07 percent and 0.8 percent of the extent of this ecological system under 1- and 6-ft rises, respectively (Appendix A) —relatively small amounts. The effects of sea level rise include not only direct loss and fragmentation of habitat through inundation, but also increased salinity in the water table from inundation of adjacent or downstream sites. Rising sea level also will increase the severity of other disturbances. For example, the risk of storm surges associated with hurricanes is expected to increase with sea level rise (Webster and others, 2005; Intergovernmental Panel on Climate Change, 2007; Lin and others, 2012), causing damage to trees and other vegetation (Stanturf and others, 2007). 


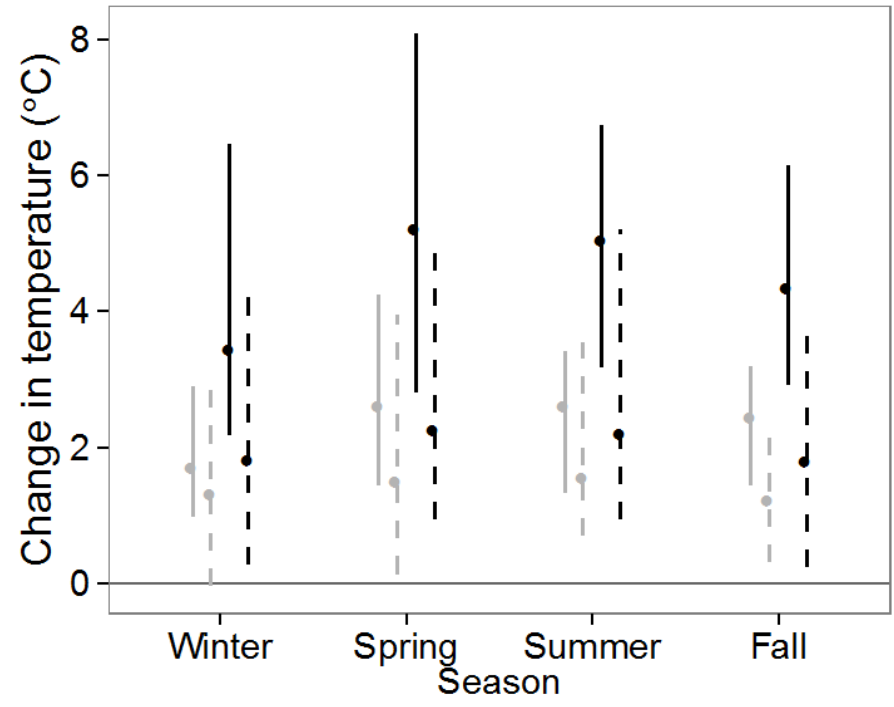

Scenario, time period

$\longrightarrow \mathrm{A} 1 \mathrm{FI}$, mid-century

- - B1, mid-century

$\rightarrow \mathrm{A} 1 \mathrm{Fl}$, end of century

- - B1, end of century

Figure 4.2. Projected change in seasonal maximum temperatures (in degrees Celsius $\left[{ }^{\circ} \mathrm{C}\right]$ ) for the middle (2040-2060) and the end of the 21st century (2080-2100), compared with the recent time period (19812000), for two emissions scenarios for the Central Florida Wet Prairie and Herbaceous Seep ecological system. Solid dots and error bars represent, respectively, the means and ranges of projections across climate models under each scenario.

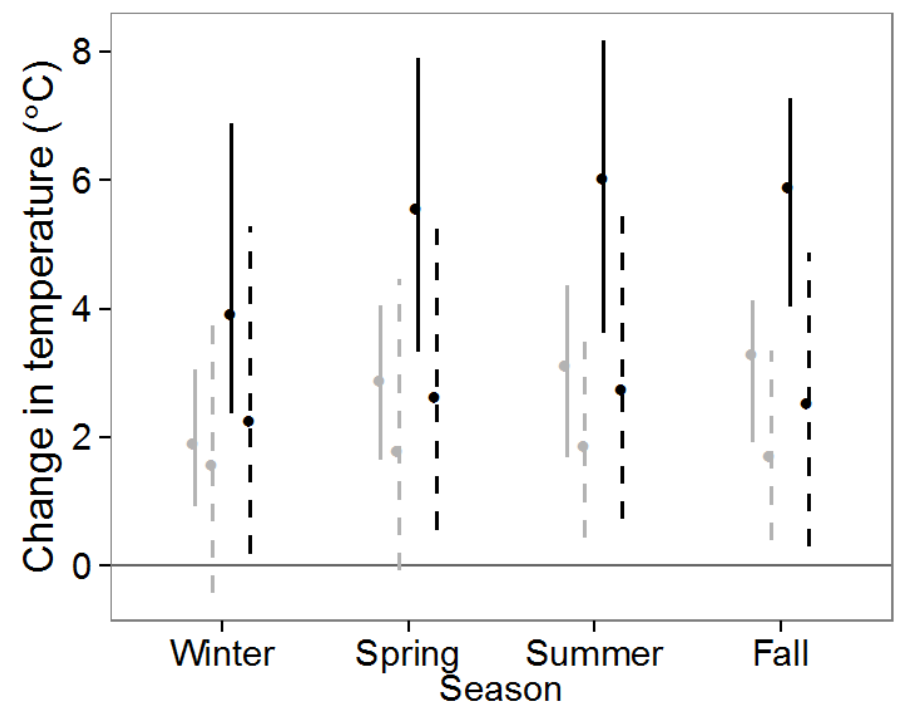

Scenario, time period

$\because \mathrm{A} 1 \mathrm{FI}$, mid-century

- B1, mid-century

$\rightarrow \mathrm{A} 1 \mathrm{FI}$, end of century

- - B1, end of century

Figure 4.3. Projected change in seasonal minimum temperatures (in degrees Celsius $\left[{ }^{\circ} \mathrm{C}\right]$ ) for the middle (2040-2060) and the end of the 21st century (2080-2100), compared with the recent time period (19812000), for two emissions scenarios for the Central Florida Wet Prairie and Herbaceous Seep ecological system. Solid dots and error bars represent, respectively, the means and ranges of projections across climate models under each scenario. 


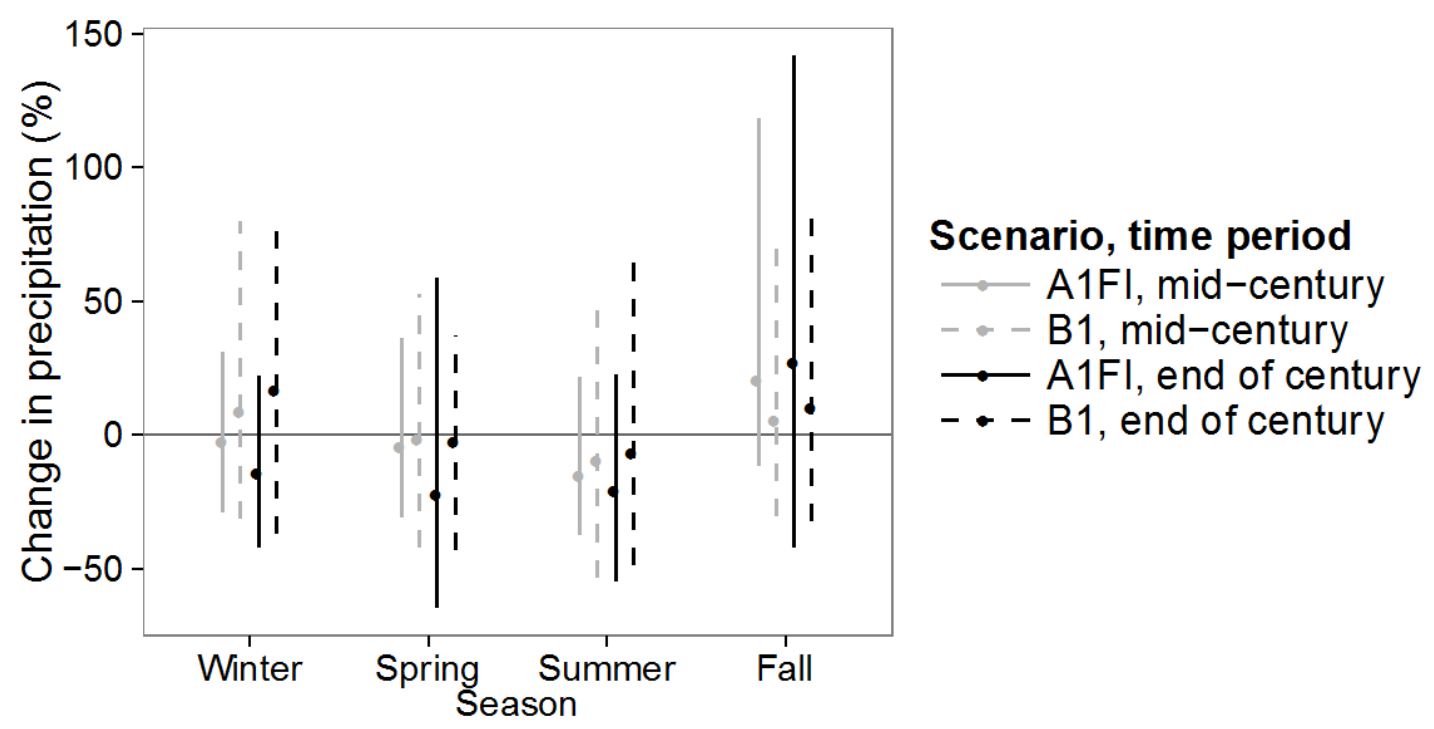

Figure 4.4. Projected percentage (\%) change in seasonal average precipitation for the middle (2040-2060) and the end of the 21st century (2080-2100), compared with the recent time period (1981-2000), for two emissions scenarios for the Central Florida Wet Prairie and Herbaceous Seep ecological system. Solid dots and error bars represent, respectively, the means and ranges of projections across climate models under each scenario.

Adaptive Capacity.-This ecological system was once much more widespread than it is today. The system and its dominant plants are threatened by fire exclusion, hydrologic alteration, land conversion, and grazing (Yahr and others, 2000; Florida Natural Areas Inventory, 2010). Additionally, because it is hydrologically connected to surrounding upland sites, this ecological system is affected by alterations to surrounding habitat. As a result, cutthroat grass seeps and prairies, which are part of this ecological system, are recognized by the U.S. Fish and Wildlife Service as an important focus of conservation in South Florida (U.S. Fish and Wildlife Service, 1999). Additionally, several species in the system are listed by NatureServe as globally imperiled or vulnerable, including cutthroat grass, Florida hartwrightia (Hartwrightia floridana), and Round-tailed Muskrat (Neofiber alleni) (NatureServe, 2013a).

Our analysis shows that a relatively high 39 percent of the extent of the system is protected for conservation (fig. 4.5), and this system has a fairly large average distance from development of 1,707 m (Appendix A). Because of this, the projected rapid development in peninsular Florida is not expected to result in substantial urbanization of this system in the future. Only 0.8 percent of its extent is likely to be urbanized by 2050, and 7 percent by 2100 (fig. 4.5; areas identified as “Threatened”). However, because the system's extent is greatly reduced compared to its historical range, any future urbanization (even a relatively small amount) could affect ecological processes. Indeed, the system has a moderate degree of human modification, compared with other systems in the Southeast (64 percent modified on average; Appendix A), and the mean patch size is smaller than all other ecological systems we analyzed (2023 $\mathrm{m}^{2}$ or 0.20 ha; Appendix A). As a result, many species present in this ecological system may not be able to migrate to escape the effects of sea level rise and changes in fire or hydrologic regimes that could 
result from climate change. Therefore, the capacity of species in this ecological system to adapt to climate change is likely somewhat compromised, and conservation and management options may be constrained.

Several ecological systems that are closely related to this system are present to the north, including the East Gulf Coastal Plain Savanna and Wet Prairie system. Some species are shared in common with this ecological system, and it occurs on sites similar to those of the Central Florida Wet Prairie and Herbaceous Seep system. However, many species, especially perennial grasses, are not shared between these systems. With changes in climate, species from the central Florida system may be able to survive in the East Gulf Coastal Plain system, but research on the factors that restrict the range of species in the central Florida system is limited. Future research could address whether plant species from this ecological system can survive in conditions where those adjacent savanna and prairie systems occur, in order to inform whether facilitating connectivity or assisted migration would be fruitful.

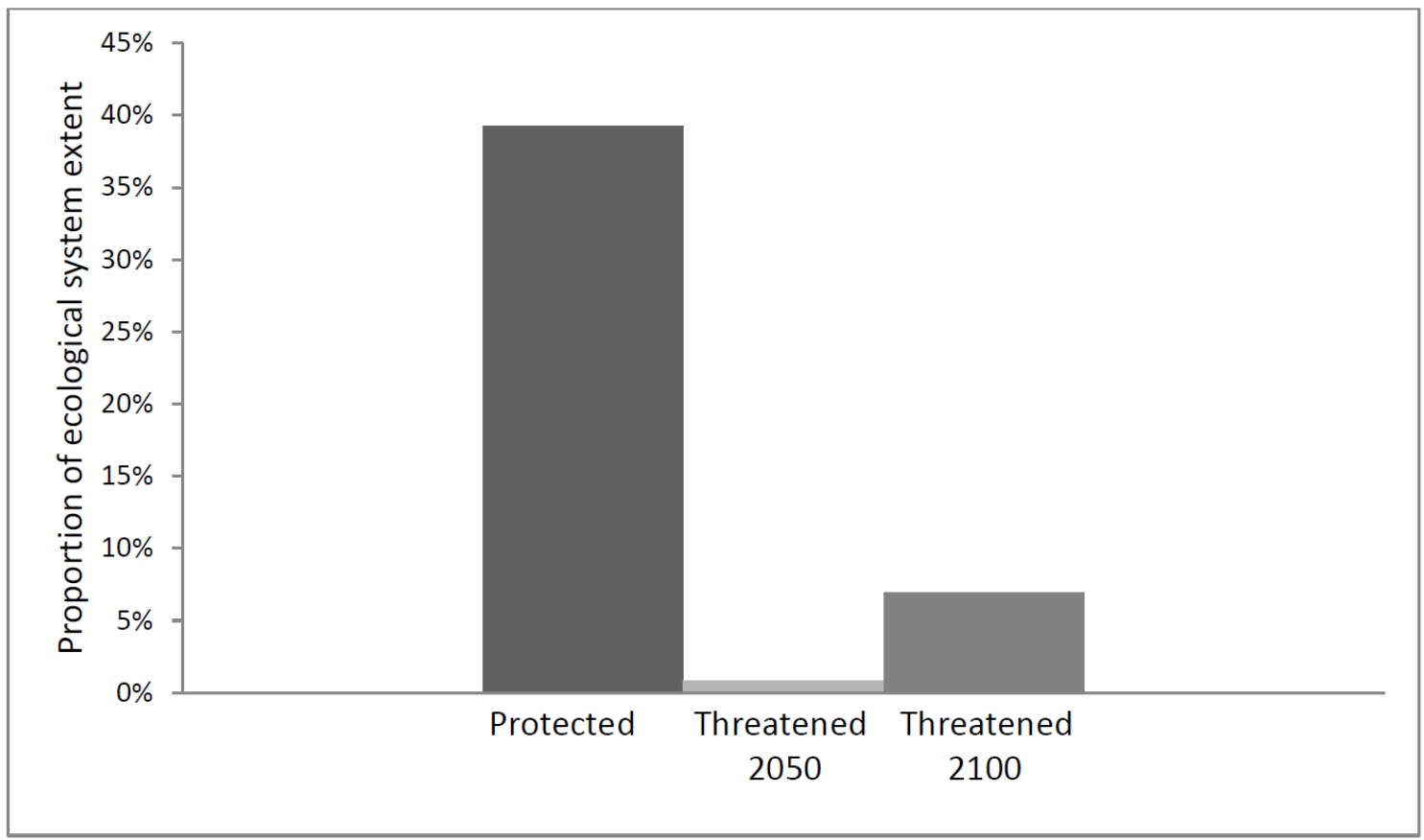

Figure 4.5. Percentage of the extent of the Central Florida Wet Prairie and Herbaceous Seep ecological system that is protected for conservation, and the percentage threatened by future development in 2050 and 2100. 
Summary.-The Central Florida Wet Prairie and Herbaceous Seep ecological system is present on poorly-drained sites with some groundwater seepage and where fire occurs frequently. The system differs from other prairies to the north because it contains subtropical herbaceous species such as cutthroat grass. Frequent fires occur during the early growing season, promoting the growth of perennial grasses and discouraging competitive exclusion by shrubs and trees. Climate models project an increase in maximum and minimum temperatures, on average, for all seasons through the end of the 21st century. Projected changes in precipitation vary across climate models, scenarios, and seasons. Projected changes in climate are likely to lead to decreased wildfire frequency in the future, which would cause tree and shrub species to replace herbaceous species in this ecological system. The impacts of climate change on hydrology are less certain than these other changes. Sea level rise is only projected to affect a minimal portion of this system. Non-climate stressors that have already affected this system include altered hydrology, reduced connectivity, and a high degree of land conversion. A relatively small proportion of this system is projected to be developed in the future. Finally, more research is necessary to understand the precise climate, hydrologic, and soil conditions in this ecological system that lead to dominance by subtropical species such as cutthroat grass, and the impacts of climate change on these conditions. With that information, scientists will be able to better predict how species characteristic of this ecological system will respond to climate change.

\section{References Cited}

Abrahamson, W.G., 1984, Species responses to fire on the Florida Lake Wales Ridge: American Journal of Botany, v. 71, p. 35-43.

Beckage, B., Gross, L.J., Platt, W.J., Louis, J., and William, J., 2006, Modelling responses of pine savannas to climate change and large-scale disturbance: Applied Vegetation Science, v. 9, p. 75-82.

Beckage, B., Platt, W.J., Slocum, M.G., and Panko, B., 2003, Influence of the El Niño Southern Oscillation on fire regimes in the Florida Everglades: Ecology, v. 84, p. 3,124-3,130.

Bridges, E.L., and Orzell, S.L., 1989, Longleaf pine communities of the West Gulf Coastal Plain: Natural Areas Journal, v. 9, p. 246-263.

Carr, S.C., Robertson, K.M., and Peet, R.K., 2010, A vegetation classification of fire-dependent pinelands of Florida: Castanea, v. 75, p. 153-189.

Cobb, K.M., Westphal, N., Sayani, H.R., Watson, J.T., Di Lorenzo, E., Cheng, H., Edwards, R.L., and Charles, C.D., 2013, Highly variable El Niño-Southern Oscillation throughout the Holocene: Science, v. 339, p. 67-70.

Florida Natural Areas Inventory, 2010, Guide to the natural communities of Florida—2010 edition: Tallahassee, Florida Natural Areas Inventory, accessed May 2013, at http://www.fnai.org/naturalcommguide.cfm.

Intergovernmental Panel on Climate Change, 2007, Climate change 2007-The physical science basis-Contribution of Working Group I to the Fourth Assessment Report of the 
Intergovernmental Panel on Climate Change: Cambridge and New York, Cambridge University Press, 996 p.

Lemon, P.C., 1949, Successional responses of herbs in the longleaf-slash pine forest after fire: Ecology, v. 30, p. 135-145.

Lin, N., Emanuel, K., Oppenheimer, M., and Vanmarcke, E., 2012, Physically based assessment of hurricane surge threat under climate change: Nature Climate Change, v. 2, p. 462-467.

National Oceanic and Atmospheric Administration, 2013, Sea levels online-Sea level variations of the United States derived from National Water Level Observation Network stations: National Oceanic and Atmospheric Administration Ocean Service, Center for Operational Oceanographic Products and Services (CO-OPS), Silver Spring, Maryland, accessed October 2013, at http://tidesandcurrents.noaa.gov/sltrends.

NatureServe, 2013a, NatureServe explorer-An online encyclopedia of life, Version 7.1: Arlington, Virginia, NatureServe Web application, accessed May 2013, at http://www.natureserve.org/explorer.

NatureServe, 2013b, U.S. ecological systems National Map data: Arlington, Virginia, NatureServe database, accessed January 2013, at http://www.natureserve.org/getData/USecologyData.jsp.

Seager, R., Tzanova, A., and Nakamura, J., 2009, Drought in the Southeastern United StatesCauses, variability over the last millennium, and the potential for future hydroclimate change: Journal of Climate, v. 22, p. 5,021-5,045.

Stanturf, J.A., Goodrick, S.L., and Outcalt, K.W., 2007, Disturbance and coastal forests-A strategic approach to forest management in hurricane impact zones: Forest Ecology and Management, v. 250, p. 119-135.

Timmermann, A., Oberhuber, J., Bacher, A., Esch, M., Latif, M., and Roeckner, E., 1999, Increased El Niño frequency in a climate model forced by future greenhouse warming: Nature, v. 398, p. 694-697.

U.S. Fish and Wildlife Service, 1999, South Florida multi-species recovery plan-Cutthroat grass communities: U.S. Fish and Wildlife Service, Southeast Region, Atlanta, Georgia, accessed Septemgber 2013, at http://www.fws.gov/verobeach/ListedSpeciesMSRP.html.

Webster, P.J., Holland, G.J., Curry, J.A., and Chang, H.-R., 2005, Changes in tropical cyclone number, duration, and intensity in a warming environment: Science, v. 309, p. 1,844-1,846.

Yahr, R., Menges, E.S., and Berry, D., 2000, Effects of drainage, fire exclusion, and time-sincefire on endemic cutthroat grass communities in central Florida: Natural Areas Journal, v. 20, p. 3-11. 


\section{East Gulf Coastal Plain Near-Coast Pine Flatwoods}

\section{Phase I Assessment}

Ecological System Overview.-The East Gulf Coastal Plain Near-Coast Pine Flatwoods ecological system is the matrix vegetation on upland and wetland areas along the northern Gulf Coast east of the Mississippi River and the Atlantic Coast in Georgia (fig. 5.1; NatureServe, 2013a). The canopy is dominated by longleaf pine (Pinus palustris) and, to a lesser extent, by slash pine (Pinus elliottii). The system is present in soils with a range of moisture conditions, but often occurs on mesic sites where the soil is saturated or inundated with water after heavy rains (Florida Natural Areas Inventory, 2010). Fires are naturally frequent, occurring every 1-3 years, even on wet sites where the water table is high (Grace and Wilder, 2009; Florida Natural Areas Inventory, 2010). On more fire-prone sites, longleaf pine is more common, whereas slash pine, which is less fire-tolerant than longleaf pine, occurs on wetter sites or sites that have not burned as often (Monk, 1968). The understory ranges from grass-dominated flora on frequently burned sites, to a dense shrubby thicket on fire-suppressed sites (Christensen, 2000; Peet, 2006).

Frequently burned sites have a rich diversity of herbaceous species, and several threatened or endangered herbaceous species are present in this system, including Florida skullcap (Scutellaria floridana) and gentian pinkroot (Spigelia gentianoides). Many endangered wildlife species occur here as well, including the Reticulated Flatwoods Salamander (Ambystoma bishopi) and the Redcockaded Woodpecker (Picoides borealis).

See NatureServe (2013a) and the Florida Natural Areas Inventory (2010) for a complete description of this ecological system. 


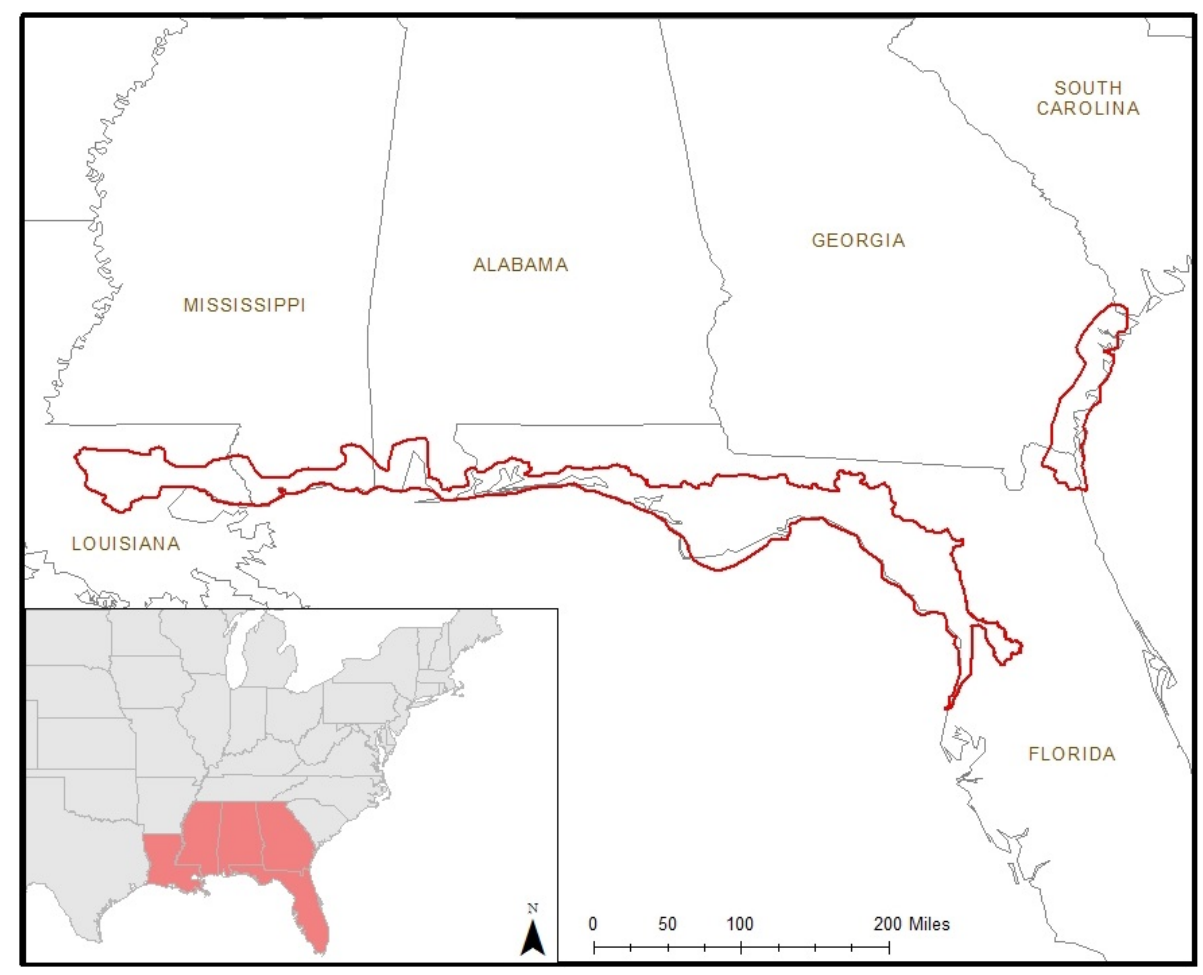

Figure 5.1. Range of the East Gulf Coastal Plain Near-Coast Pine Flatwoods ecological system. The system covers 14 percent of this range, according to data from to NatureServe (2013b). Most of the distribution occurs along the Gulf Coast, with only a few scattered pixels mapped along the Atlantic Coast portion of this range.

Vulnerability Status. - Relative to other ecological systems in the Southeast, the vulnerability of this ecological system is rated as Medium. The vegetation structure is sensitive to fire regimes, hurricanes, hydrology, and sea level rise. The likely exposure to changes in fire regimes and hurricanes is low; however, changes in hydrology could lead to more intense fires, and sea level rise could inundate some of this system. The system has substantial adaptive capacity because of the relatively high proportion of the system that is under protection and the fact that nearby systems contain similar species.

Sensitivity.-Our analysis shows that this system occurs in areas where temperature ranges from an average maximum of $33^{\circ} \mathrm{C}$ in the summer (Appendix $\mathrm{B}$ ) to an average winter minimum of $6{ }^{\circ} \mathrm{C}$ (Appendix B). Precipitation is fairly high in all seasons, but average summer precipitation generally is slightly higher than in other seasons (Appendix B). According to the Silvics of North America, longleaf and slash pine, the most important tree species in this pine flatwoods system, grow in warmer climates than this system and in areas with a wide range of annual precipitation (Burns and Honkala, 1990). Therefore, small-to-moderate changes in temperature or precipitation should not affect these species in the range of this ecological system.

Although many of the dominant species in this ecological system are not especially sensitive to temperature and precipitation within the range of the system, the rich diversity of herbaceous species depends on frequent disturbances. Frequent fires and periodic hurricanes in 
this system keep the understory and midstory open, and promote the growth of longleaf and slash pine trees (Platt, 1999). Specifically, fires during the growing season are most beneficial for reducing shrubby and hardwood vegetation and promoting herbaceous groundcover (Florida Natural Areas Inventory, 2010). Where disturbance frequency is reduced, shrubs and hardwood trees in the understory and midstory become denser, and herbaceous diversity decreases (Florida Natural Areas Inventory, 2010). Hurricanes kill overstory trees, and mortality generally is higher for older trees (Platt and others, 2000). Additionally, fire and hurricanes likely interact to influence this ecological system. In slash pine stands in southern Florida, Platt and others (2002) found that slash pine mortality from hurricanes is higher on long-unburned sites than on those where fire has been common. There is some evidence that longleaf pine trees are more resistant to wind damage from hurricanes than loblolly pines (Johnsen and others, 2009).

Additionally, many rare species in this system depend on the mesic, periodically saturated conditions, including several rare salamander species. These species could be affected by changes in climate and hydrology occurring under climate change. Lu and others (2009) modeled the effects of increased temperature and increased precipitation at a site that contained a mixture of pine flatwoods and cypress swamps. Under both scenarios, the authors found that increased temperature caused a lower water table during dry periods, but did not change hydrology during wet periods.

Exposure.-Analysis of projected change in climate for the East Gulf Coastal Plain Near-Coast Pine Flatwoods ecological system shows increases in maximum and minimum temperatures for most models, seasons, and scenarios (figs. 5.2 and 5.3). Increases are projected to be slightly larger for minimum temperatures than for maximum temperatures overall. Under the B1 scenario, projected changes in minimum and maximum temperature for all seasons are relatively similar for both mid- and late-century. Under the A1FI scenario, a slightly smaller increase is projected for winter than for other seasons.

Projected percentage changes in precipitation for this ecological system show variation among climate models for each season, emissions scenario, and time period, with the most variation among climate models for summer and fall projections, and least variation for winter (fig. 5.4). The means of projections for most emissions scenarios and time periods are close to 0 except for fall, indicating that as a whole, climate models are projecting a general increase in fall precipitation through the 21st century. In fact, some climate models project as much as an 87 - or 106-percent increase in fall precipitation under the B1 and A1FI scenarios, respectively, by the end of the century. However, in all seasons, including fall, the range of projected change crosses 0 , indicating much uncertainty among climate models in the magnitude and direction of change in precipitation. Other studies have shown that more rainfall and more precipitation variability are likely in the future, owing to increased hurricane frequency and intensity (Webster and others, 2005; Intergovernmental Panel on Climate Change, 2007).

Projected changes in the standard deviation, or variability, of temperature and precipitation for this ecological system show a high degree of uncertainty among climate models. Both the means and ranges of projected change in standard deviation for maximum and minimum temperatures vary considerably (Appendix C). The mean change in the standard deviation of 
precipitation is greater than 1 in all cases, indicating that although projections vary among models, on average, they predict an increase in variability for precipitation in the future under both emissions scenarios (Appendix C).

An increase in temperature, along with a decrease or even a slight increase in precipitation and more precipitation variability, could lead to more frequent dry periods. Some research in similar ecological systems has shown that increased temperature or decreased precipitation would lower the water table during dry periods (Lu and others, 2009). However, if precipitation increased substantially, as some climate models project under some scenarios, the hydrologic effects may be minimal.

If temperature increases, and variability in precipitation increases, as projected, wildfires in this ecological system could become more common or more intense. A lower water table during dry periods could lead to more ground fires and more severe effects on vegetation. At the same time, there is some debate about how the annual area burned by wildfires will change near this ecological system. In the inner coastal plain of Georgia and Alabama, annual area burned may not change substantially in the future under any emissions scenario (Costanza and others, 2015). However, in south and central Florida, wildfires occur more frequently in La Niña years when precipitation is decreased in Florida (Beckage and others, 2003; Slocum and others, 2010). Some evidence shows decreases in La Niña events with future climate change, which would lead to fewer fires in this ecological system (Timmermann and others, 1999; Beckage and others, 2006). However, the link between El Niño-Southern Oscillation (ENSO) and climate change is uncertain (Cobb and others, 2013).

There are several possible effects of these projected changes on the species in this system. According to climate envelope modeling done for the U.S. Forest Service Climate Change Tree Atlas, the abundance of longleaf and slash pine will not change substantially over the range of this ecological system under all climate scenarios and models considered (Prasad and others, 2007). A lower water table during dry periods could cause increased vulnerability for species that are sensitive to dry conditions, including the rare salamander species that are found in this ecological system (Means, 2006). More intense fires could lead to greater mortality of longleaf pines and other vegetation in this system. However, if fewer fires occur, increased dominance by slash pine compared to longleaf pine, less herbaceous ground cover, lower herbaceous richness, and a denser midstory would result. More hurricanes may lead to increased mortality of overstory trees, especially in areas that have not burned recently.

Because this system occurs along the outer fringes of the Gulf and Atlantic Coasts, it likely will be exposed to sea level rise. According to the National Oceanic and Atmospheric Administration (NOAA) Sea Level Trends data, stations within the range of this ecological system have had a moderate amount of annual sea level rise from 1947 to 2006 (National Oceanic and Atmospheric Administration, 2013). The mean annual sea level rise ranged from $0.75 \mathrm{~mm} / \mathrm{yr}$ in Panama City, Florida, to 2.98 mm/yr in Dauphin Island, Alabama (National Oceanic and Atmospheric Administration, 2013).

We analyzed the projected inundation owing to sea level rise under a 1- and 6-ft (0.3- and 1.8-m) rise in sea level, according to NOAA data. Those data covered 
85 percent of the coastal extent of this ecological system, on the Gulf Coast in Mississippi, Alabama, and Florida. Within the area covered by the data, rising sea level is projected to inundate 0.7 and 7.9 percent of this ecological system under 1- and 6-ft rises, respectively (Appendix A). The effects of sea level rise include not only direct loss and fragmentation of habitat through inundation, but also an increase in the severity of other disturbances. For example, storm surges associated with hurricanes cause damage to trees and other vegetation (Stanturf and others, 2007). Thus, the effects of storm surge may become more severe in the future as sea level rises and hurricane intensity and frequency increase, as projected (Webster and others, 2005; Intergovernmental Panel on Climate Change, 2007). We also analyzed data from the Sea Level Affecting Marshes Model (SLAMM) for this system. The SLAMM data incorporate some changes in hydrology that accompany inundation from rising sea level. The SLAMM data only covered 44 percent of the coastal extent of this system, along the Georgia coast and a portion of the Florida Gulf Coast. For the extent of the SLAMM data, our analysis shows that about 2 and 3 percent of this system's range is projected to change vegetation types by 2050 and 2100, respectively. Slightly more change is projected under the A1FI scenario than the B1 scenario at mid-century, and more change is projected under the B1 scenario than the A1FI scenario at the end of the century (Appendix A).

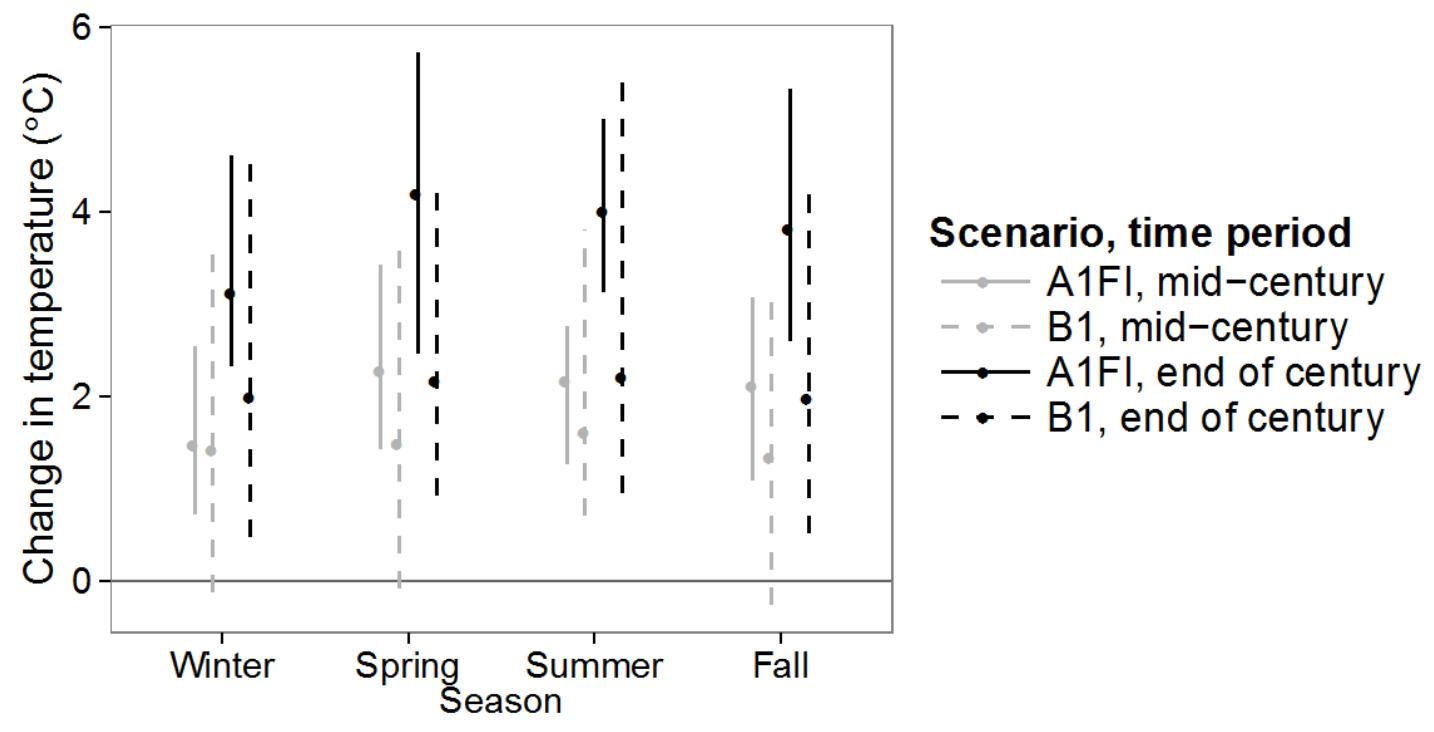

Figure 5.2. Projected change in seasonal maximum temperatures (in degrees Celsius $\left[{ }^{\circ} \mathrm{C}\right]$ ) for the middle (2040-2060) and the end of the 21st century (2080-2100), compared with the recent time period (19812000), for two emissions scenarios for the East Gulf Coastal Plain Near-Coast Pine Flatwoods ecological system. Solid dots and error bars represent, respectively, the means and ranges of projections across climate models under each scenario. 


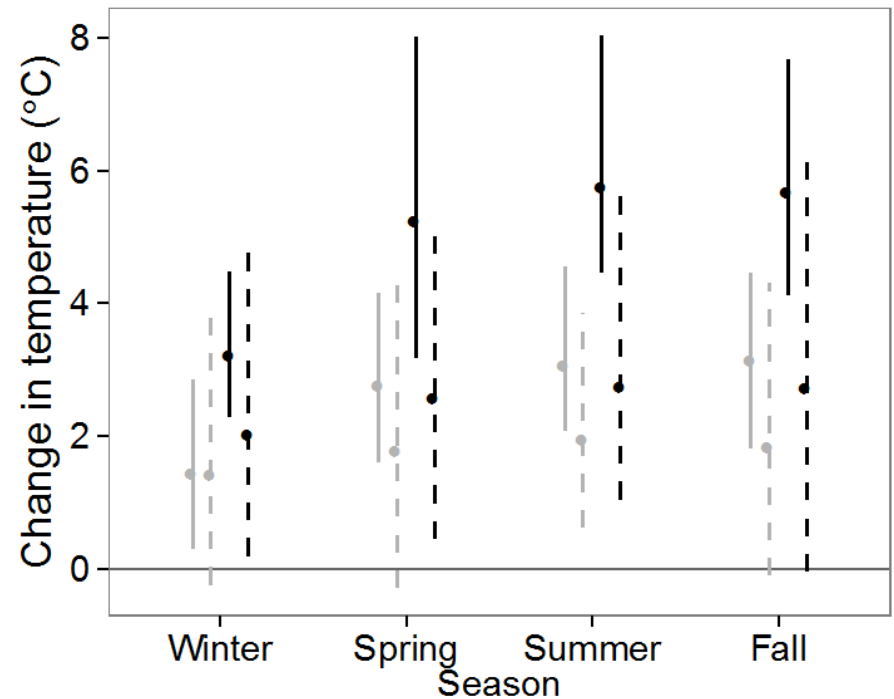

Scenario, time period

$\ldots \mathrm{A} 1 \mathrm{FI}$, mid-century

- - B1, mid-century

$\rightarrow \mathrm{A} 1 \mathrm{Fl}$, end of century

- - B1, end of century

Figure 5.3. Projected change in seasonal minimum temperatures (in degrees Celsius $\left[{ }^{\circ} \mathrm{C}\right]$ ) for the middle (2040-2060) and the end of the 21st century (2080-2100), compared with the recent time period (19812000), for two emissions scenarios for the East Gulf Coastal Plain Near-Coast Pine Flatwoods ecological system. Solid dots and error bars represent, respectively, the means and ranges of projections across climate models under each scenario.

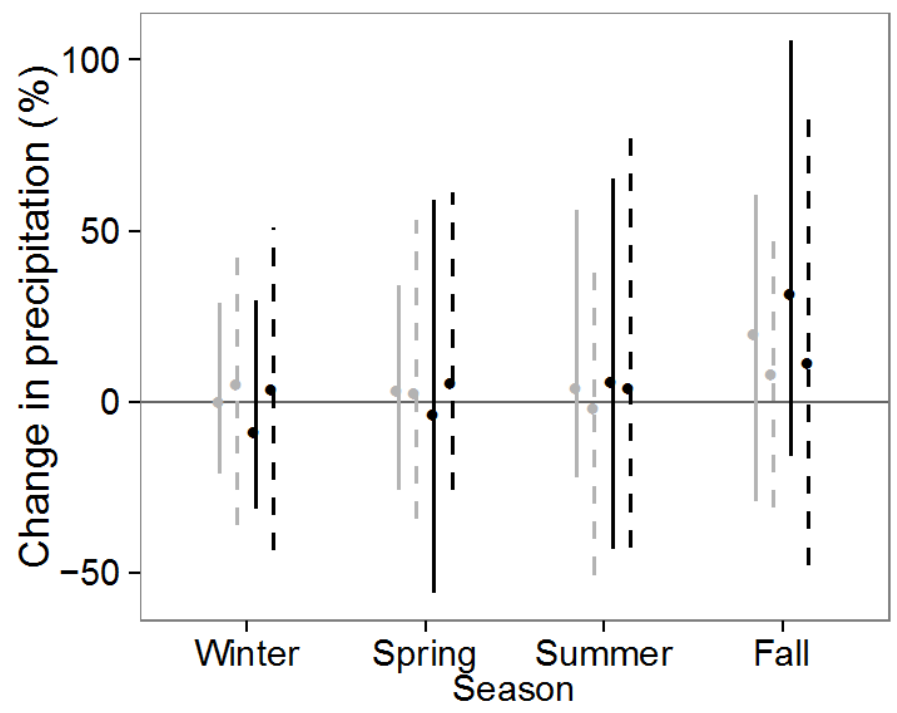

Scenario, time period

$\because \mathrm{A} 1 \mathrm{FI}$, mid-century

- B1, mid-century

$\rightarrow \mathrm{A} 1 \mathrm{FI}$, end of century

- - B1, end of century

Figure 5.4. Projected percentage (\%) change in seasonal average precipitation for the middle (2040-2060) and the end of the 21st century (2080-2100), compared with the recent time period (1981-2000), for two emissions scenarios for the East Gulf Coastal Plain Near-Coast Pine Flatwoods ecological system. Solid dots and error bars represent, respectively, the means and ranges of projections across climate models under each scenario. 
Adaptive Capacity.-Fire suppression starting in the 1930s led to proliferation of shrubs and hardwood species and a decline in understory herbaceous species as well as other plant and animal species that inhabit this system (Florida Natural Areas Inventory, 2010). As a result, prescribed fire is a major tool used for management and restoration in pine communities in the Southeastern United States. In the most fire-suppressed regions, restoration to a more open structure often is difficult with fires alone, and may involve mechanical treatment in combination with several prescribed burns (Outcalt and Brockway, 2010). Prescribed burning in pine communities that are in need of fire often is difficult, and management agencies often are constrained by lack of resources, fuel build-up owing to dense vegetation in the understory and midstory, and inappropriate weather conditions (Costanza and Moody, 2011; Costanza and others, 2013). If climate change leads to hotter and (or) drier conditions, although the potential for wildfires may increase, the number of days per year with suitable conditions for prescribed burning could decrease, further constraining prescribed fire in this system. However, this is an area of considerable uncertainty, and more research could be done to determine the relationship between climate change and suitable burning conditions. Furthermore, several cities are located along the Gulf Coast where this system occurs, increasing risk from prescribed burning in the wildland-urban interface (WUI).

Indeed, according to our analysis, this system has a relatively small average patch size (8,971 $\mathrm{m}^{2}$, or 0.90 ha; Appendix A), and occurs fairly close to development (429 m from developed areas, on average; Appendix A), constraining management and increasing risk from prescribed burning in the WUI. The pixels mapped as this ecological system have a moderate amount of human modification (57 percent; Appendix A). According to SLEUTH urbanization modeling, about 6 percent of the system is projected to be converted to development by 2050, and 12 percent by 2100 (fig. 5.5). On the other hand, more than 50 percent of the area of this system is protected for conservation, which is the largest percentage of all systems included in this assessment, and which will help facilitate future management (fig. 5.5). Nonetheless, as population increases and the urban areas become larger in the future, the area of WUI likely will expand, further constraining prescribed burning, even in protected areas. Additionally, because of its hydrology, this ecological system is particularly sensitive to changes in hydrology owing to urbanization, tree removal, or other land management activities in adjacent upland sites (Lu and others, 2009).

The non-native species cogongrass (Imperata cylindrica) is an invasive species in pine savannas and flatwoods in the Southeastern United States. Invasion by cogongrass has been shown to decrease herbaceous species richness (Brewer, 2008), and increase fuel loads, which could promote hotter, more intense fires (Platt and Gottschalk, 2001). Additionally, fire can facilitate spread of cogongrass (Yager and others, 2010). Therefore, more frequent fires under climate change could lead to further spread of cogongrass, and further losses to biodiversity in this pine flatwoods system.

This system occurs in a matrix of other pine savanna and flatwoods systems in the Southeast. Other similar systems include Southern Atlantic Coastal Plain Wet Pine Savanna and Flatwoods, Central Florida Pine Flatwoods, and East Gulf Coastal Plain Interior Upland Longleaf Pine Woodland. Many of the species that occur in this system, such as the Red-cockaded Woodpecker and Reticulated Flatwoods Salamander, also occur in other similar systems, so their 
capacity to adapt and move in response to changing climate may be higher than in more isolated systems.

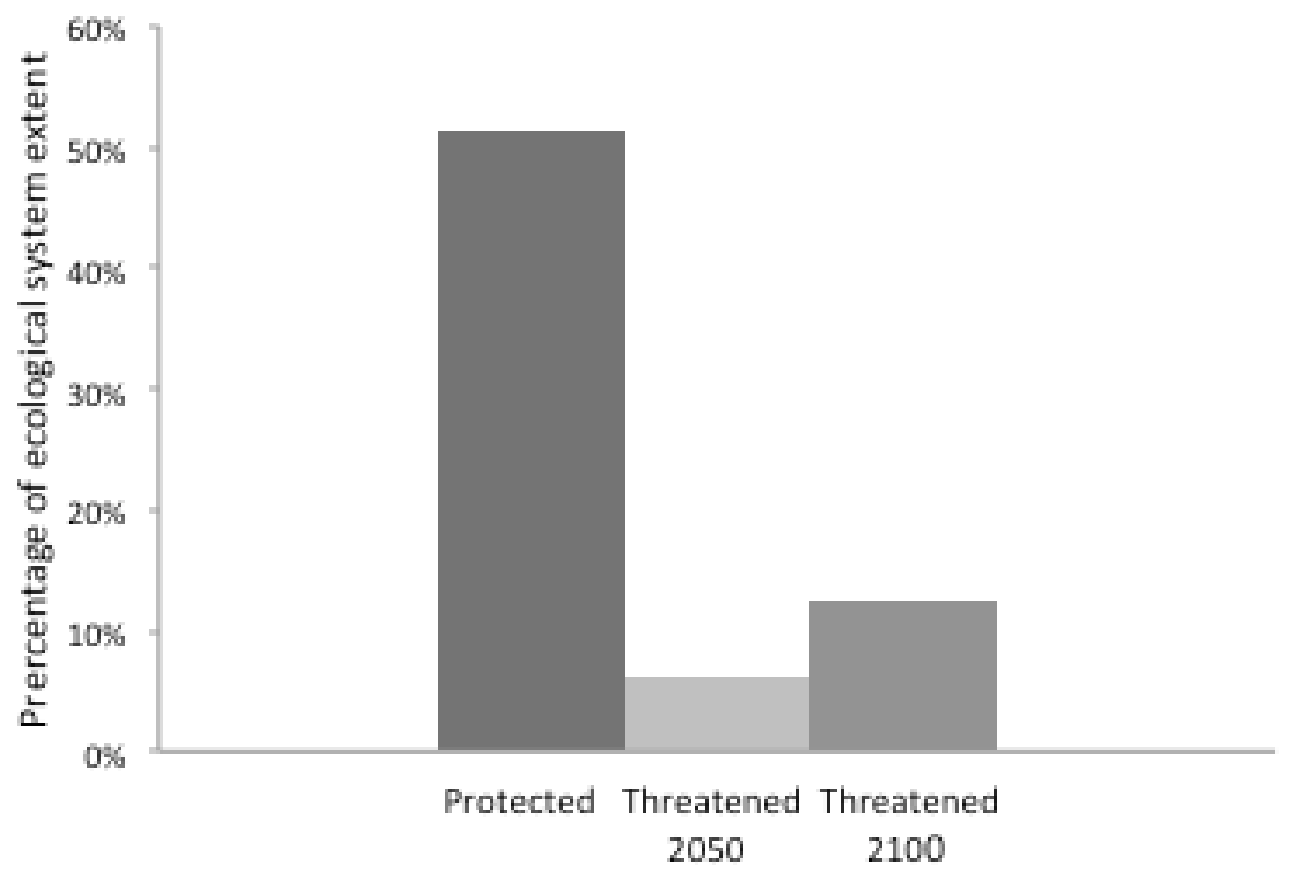

Figure 5.5. Percentage of the extent of the East Gulf Coastal Plain Near-Coast Pine Flatwoods ecological system that is protected for conservation, and the percentage threatened by future development in 2050 and 2100.

Summary.-The East Gulf Coastal Plain Near-Coast Pine Flatwoods ecological system is sensitive to disturbance frequency. Frequent fires promote the open habitat structure on which many plant and wildlife species depend, and lead to a rich diversity of herbaceous plant species in the understory. There is some uncertainty about the likely effect of climate change on wildfires in this system. A hotter, drier climate may lead to an increase in wildfires and a lower water table during dry periods. However, if precipitation increases, wildfires could become even less frequent than they are at present. Hurricanes are another major disturbance in this system, and are likely to become more frequent during climate change. Sea level rise is a large threat from climate change. Almost 8 percent of the extent of this system could be inundated, and 2-3 percent could change to another vegetation type. Many of the species that occur in this system also occur in other similar systems, so their capacity to adapt and move in response to changing climate and sea level rise may be greater than in more isolated systems. Areas of future research include more work to determine how fire regimes, including prescribed burning, in this system may be affected by climate change and urban growth. 


\section{References Cited}

Beckage, B., Gross, L.J., Platt, W.J., Louis, J., and William, J., 2006, Modelling responses of pine savannas to climate change and large-scale disturbance, Applied Vegetation Science: v. 9, p. 75-82.

Beckage, B., Platt, W.J., Slocum, M.G., and Panko, B., 2003, Influence of the El Niño Southern Oscillation on fire regimes in the Florida Everglades: Ecology, v. 84, p. 3,124-3,130.

Brewer, S., 2008, Declines in plant species richness and endemic plant species in longleaf pine savannas invaded by Imperata cylindrica: Biological Invasions, v. 10, p. 1,257-1,264.

Burns, R.M., and Honkala, B.H., tech. coords., 1990, Silvics of North America-Volume 1, Conifers: U.S. Forest Service, Agriculture Handbook 654, 877 p.

Christensen, N.L., 2000, Vegetation of the southeastern coastal plain, in Barbour, M.G., and Billings, W.D., eds., North American terrestrial vegetation (2d ed.): Cambridge, United Kingdom, Cambridge University Press, p. 397-448

Cobb, K.M., Westphal, N., Sayani, H.R., Watson, J.T., Di Lorenzo, E., Cheng, H., Edwards, R.L., and Charles, C.D., 2013, Highly variable El Niño-Southern Oscillation throughout the Holocene: Science, v. 339, p. 67-70.

Costanza, J.K., and Moody, A., 2011, Deciding where to burn—Stakeholder priorities for prescribed burning of a fire-dependent ecosystem: Ecology And Society, v. 16, no. 1, p. 14.

Costanza, J., Weiss, J., and Moody, A., 2013, Examining the knowing-doing gap in the conservation of a fire-dependent ecosystem: Biological Conservation, v. 158, p. 107-115.

Costanza, J.K., Terando, A.J., McKerrow, A.J., and Collazo, J.A., 2015, Modeling climate change, urbanization, and fire effects on Pinus palustris ecosystems of the Southeastern U.S.: Journal of Environmental Management v. 151, p. 186-199.

Florida Natural Areas Inventory, 2010, Guide to the natural communities of Florida—2010 edition: Tallahassee, Florida Natural Areas Inventory, accessed May 2013, at http://www.fnai.org/naturalcommguide.cfm.

Grace, S., and Wilder, T., 2009, LANDFIRE biophysical setting model for East Gulf Coastal Plain Near-Coast Pine Flatwoods_LANDFIRE biophysical setting descriptions, Map zone 55: LANDFIRE program model, p. 113-117, accessed May 2012, at http://www.landfire.gov/national_veg_models_op2.php.

Intergovernmental Panel on Climate Change, 2007, Climate change 2007-The Physical science basis-Contribution of Working Group I to the Fourth Assessment Report of the Intergovernmental Panel on Climate Change: Cambridge and New York, Cambridge University Press, 996 p. 
Johnsen, K.H., Butnor, J.R., Kush, J.S., Schmidtling, R.C., and Nelson, C.D., 2009, Hurricane Katrina winds damaged longleaf pine less than loblolly pine: Southern Journal of Applied Forestry, v. 33, p. 178-181.

Lu, J., Sun, G., McNulty, S.G., and Comerford, N.B., 2009, Sensitivity of pine flatwoods hydrology to climate change and forest management in Florida, USA: Wetlands, v. 29, p. 826836.

Means, D.B., 2006, Vertebrate faunal diversity of longleaf pine ecosystems, in Jose, S., Jokela, E., and Miller, E., eds., The longleaf pine ecosystem: New York, NY, Springer, p. 157-213.

Monk, C.D., 1968, Successional and environmental relationships of the forest vegetation of north central Florida: American Midland Naturalist, v. 79, p. 441-457.

National Oceanic and Atmospheric Administration, 2013, Sea levels online-Sea level variations of the United States derived from National Water Level Observation Network stations: National Oceanic and Atmospheric Administration Ocean Service, Center for Operational Oceanographic Products and Services (CO-OPS), Silver Spring, Maryland, accessed October 2013, at http://tidesandcurrents.noaa.gov/sltrends.

NatureServe, 2013a, NatureServe explorer-An online encyclopedia of life, Version 7.1: Arlington, Virginia, NatureServe, accessed May 2013, at http://www.natureserve.org/explorer.

NatureServe, 2013b, U.S. ecological systems National Map data: Arlington, Virginia, NatureServe database, accessed January 2013, at http://www.natureserve.org/getData/USecologyData.jsp.

Outcalt, K.W., and Brockway, D.G., 2010, Structure and composition changes following restoration treatments of longleaf pine forests on the Gulf Coastal Plain of Alabama: Forest Ecology and Management, v, 259, p. 1,615-1,623.

Peet, R.K., 2006, Ecological classification of longleaf pine woodlands, in Jose, S., Jokela, E., and Miller, D., eds., Longleaf pine ecosystems-Ecology, management, and restoration: New York, Springer, p. 51-94.

Platt, W.J., 1999, Southeastern pine savannas, in Anderson, R.C., Fralish, J.S., and Baskin, J., eds., The savanna, barren, and rock outcrop communities of North America: Cambridge, United Kingdom, Cambridge University Press.

Platt, W.J., Beckage, B., Doren, R.F., and Slater, H.H., 2002, Interactions of large-scale disturbances-Prior fire regimes and hurricane mortality of savanna pines: Ecology, v. 83 , p. $1,566-1,572$.

Platt, W.J., Doren, R.F., and Armentano, T.V., 2000, Effects of Hurricane Andrew on stands of slash pine (Pinus elliottii var. densa) in the Everglades region of south Florida (USA): Plant Ecology, v. 146, p. 43-60. 
Platt, W.J., and Gottschalk, R.M., 2001, Effects of exotic grasses on potential fine fuel loads in the groundcover of south Florida slash pine savannas: International Journal of Wildland Fire v. 10, p. 155-159.

Prasad, A.M., Iverson, L.R., Matthews, S., and Peters, M., 2007, A climate change atlas for 134 forest tree species of the Eastern United States: U.S. Forest Service database, Northern Research Station, Delaware, Ohio, accessed May 2013, at http://www.nrs.fs.fed.us/atlas/tree.

Slocum, M.G., Platt, W.J., Beckage, B., Orzell, S.L., and Taylor, W., 2010, Accurate quantification of seasonal rainfall and associated climate-wildfire relationships: Journal of Applied Meteorology and Climatology, v. 49, p. 2,559-2,573.

Stanturf, J.A., Goodrick, S.L., and Outcalt, K.W., 2007, Disturbance and coastal forests-A strategic approach to forest management in hurricane impact zones: Forest Ecology and Management, v. 250, p. 119-135.

Timmermann, A., Oberhuber, J., Bacher, A., Esch, M., Latif, M., and Roeckner, E., 1999, Increased El Niño frequency in a climate model forced by future greenhouse warming: Nature, v. 398, p. 694-697.

Webster, P.J., Holland, G.J., Curry, J.A., and Chang, H.-R., 2005, Changes in tropical cyclone number, duration, and intensity in a warming environment: Science, v. 309, p. 1,844-1,846.

Yager, L.Y., Miller, D.L., and Jones J., 2010, Susceptibility of longleaf pine forest associations in south Mississippi to invasion by cogongrass [Imperata cylindrica (L.) Beauv.]: Natural Areas Journal, v. 30, p. 226-232.

\section{Phase II Assessment}

Overall Vulnerability Rating.—Low to Medium (mid-century), Medium (late-century)

For the East Gulf Coastal Plain Near-Coast Pine Flatwoods ecological system, sensitivity to climate change is low to moderate at mid-century, and moderate by the end of the century. The climate stress index and envelope shift index both have low-to-moderate values for the middle of the century, but contribute to the system's higher sensitivity by the end of the century. The dynamic process forecast for the ecological system suggests that there will be a moderate-to-high degree of ecological departure through the rest of the century. Rising sea levels are likely to directly inundate only a relatively small portion of this ecosystem by the end of the century.

Resilience for this ecological system is moderate for both mid-century and late-century time periods. The indirect effects of climate change on average contribute to high values of resilience for this ecological system. The proportion of the system that was non-urban in the past, or is projected to be non-urban in the future, is high. The invasive-species threat is low. The dynamic process alteration is relatively high, suggesting that the ecological departure of this ecological system, owing to changes in fire regimes, is relatively low. On average, metrics related to adaptive capacity contributed to a moderate value of resilience. Diversity within functional groups is high, and keystone vulnerability is moderate. However, because this ecological system 
is present only on the coastal plain in relatively flat areas, the bioclimatic variability and elevation range for the system are low.

Sensitivity Rating. - 0.74-0.65, Low to Medium (mid-century); 0.65-0.5, Medium (late-century)

Climate Stress Index.—0.75-0.85 (mid-century), 0.55-0.75 (late-century)

For a given time period and emissions scenario, climate stress was defined as 1 minus the proportion of the 36 climate variables that were projected to exceed 2 standard deviations above or below the recent mean. Maps of the number of variables within the range of this ecological system exceeding 2 standard deviations for each scenario and time period were considered (fig. 5.6). For a given emissions scenario, a greater number of variables on average generally exceeded 2 standard deviations later in the century, as compared with midcentury. For both time periods, but especially for the end of the century, more variables exceeded 2 standard deviations for the A2 and A1FI scenarios than for the B1 scenario. Additionally, for the end of the century under the A2 and A1FI scenarios, the portion of the system's range along the Atlantic Coast is projected to have more variables that exceed 2 standard deviations, compared with the Gulf Coast portion.

Envelope Shift Index.-0.63-0.81 (mid-century), 0.25-0.54 (late-century)

We used MaxEnt ${ }^{\mathrm{TM}}$ to model the climate envelope for this ecological system, then projected this envelope under future climates (see Appendix D for detailed methods). The variable with the highest contribution to the model was average minimum winter temperature. This result agrees with past studies that have shown that winter minimum temperature is important for determining the northern range of pine-dominated vegetation in the coastal plain of the Southeast (Delcourt and Delcourt, 2000). Other important variables included average minimum spring and fall temperature, average maximum winter temperature, and average fall precipitation.

The average logistic output score for the area within the range of this ecological system under the observed climate was 0.72 . This logistic score also is known as the relative occurrence rate (ROR) of the ecological system, and is used as the value for the envelope shift index. Higher values of ROR indicate higher potential climate suitability. We treated this value as the maximum value that would be achieved under any future climate, and scaled all average ROR values accordingly. Therefore, this observed value became 1 . When projected across the Southeast, the highest ROR under observed climate matched well with the range of this ecological system (figs. 5.7 and 5.8). For projected climates during both mid- and late-century, the most suitable modeled climate space for this ecological system shifted farther north of the range of the system (figs. 5.7 and 5.8). However, even at the end of the century, the Southern Appalachian Mountains in western North Carolina and Virginia had low values of ROR. Within the range of the ecological system, ROR values on average were lowest at the end of the century, followed by the middle of the century (figs. 5.7 and 5.8).

Dynamic Process Forecast.—0.31 (mid-century), 0.29-0.31 (late-century) 
We used a modified version of the LANDFIRE state-and-transition simulation model (STSM) for this ecological system to simulate future vegetation dynamics and to determine ecological departure (see Grace and Wilder, 2009, for a complete description of the original LANDFIRE model). The STSM consisted of five state classes representing early-, mid-, or latesuccession, and the open or closed canopy structure. Transitions among the state classes represented succession, wildfire, insects and disease, and wind/weather/stress. The mapped conditions for this ecological system indicate that, compared with estimated pre-European settlement conditions, the mid- and late-succession, closed canopy states are overrepresented, and the late-succession, open canopy state is underrepresented in the landscape (table 5.1).

We ran the STSM into the future with fire probabilities that were adjusted for fire suppression and climate change. We developed a multiplier value that we used to adjust the wildfire probabilities to account for fire suppression in the STSM. Previous work in the Southeast indicated that wildfire probabilities have been reduced by a factor of 0.072 from estimated preEuropean settlement on private lands (Costanza and others, 2015). However, 51 percent of this particular ecological system occurs on public conservation lands. We assumed that those lands will have minimal fire suppression; therefore, we calculated a weighted average of 0.072 and 1 to arrive at 0.27 as the final value for the fire-suppression multiplier. We also used previous work that related temperature and precipitation to past wildfire probabilities and developed probabilistic projections of those probabilities under climate-change emissions scenarios A1FI and B1 (Costanza and others, 2015). We ran the simulation 50 times for each scenario to determine the future distribution of state classes in this ecological system.

Values of ecological departure were calculated based on the mean composition across the simulations of each state class under each of these scenarios for 2050 and 2100. Models indicate little difference in ecological departure between emissions scenarios and time periods. For all scenarios and time periods, the values indicate that a relatively high level of departure is expected. The dynamic process forecast values were 1 minus ecological departure for each scenario and time period, and correspond to a relatively high sensitivity of the state class composition of this ecological system to changes in fire regimes and climate.

Sea Level Rise. - $0.92-0.99$ (both time periods)

Less than 1 percent of this ecological system is projected to be inundated under 1- and 6$\mathrm{ft}(0.3$ - and $1.8-\mathrm{m})$ rises in sea level above mean higher high water. Therefore, this system has a low sensitivity under this metric.

Resilience Rating.-0.64-0.6, Medium (mid-century); 0.61-0.57, Medium (late-century).

Landscape Condition. - $\mathbf{0 . 7 0}$ (both time periods)

This ecological system had a high value for landscape condition, indicating it has fairly high resilience according to this metric.

Proportion Non-Urban, Historical.— 0.98 (both time periods) 
A relatively high proportion of this ecological system was free of urban, suburban, and exurban development in 1960.

Proportion Non-Urban, Current.— $\mathbf{0 . 8 4}$ (both time periods)

A high proportion of this ecological system was free of urban, suburban, and exurban development in 2010.

Proportion Non-Urban, Future. - 0.82-0.84 (mid-century), 0.81-0.84 (late-century)

A high proportion of this ecological system was still projected to be free of urban, suburban, and exurban development in 2050 and 2100. The urbanization data we used projected changes in the intensity of development within already-urbanized places near this system, rather than an expansion of the footprint of urbanization.

Invasive species threat, Current-0.7-0.8 (both time periods)

Several invasive plant and animal species have the potential to affect the native species and ecological processes in this ecological system. One of the most important invasive plants in this system is cogongrass (Imperata cylindrica), which is present throughout the range of this ecological system. Cogongrass can form dense mats and exclude native species. The species also can alter fire regimes in this system by causing hotter, more frequent fires, which can cause higher mortality of pines and other characteristic species. Several other important plant species are invasive in this system (table 5.2; Florida Natural Areas Inventory, 2010), all of which have the potential to displace native species (Florida Exotic Pest Plant Council, 2013). In addition to plants, there are a few animal species that are particularly damaging in this system. Feral pigs (Sus scrofa) can be damaging to longleaf pine seedlings (Noss, 2013), and also can damage native ground cover. Two other invasive animal species that invade this system are red imported fire ants (Solenopsis invicta) and tawny crazy ants (Nylanderia fulva), which can displace native communities of ants and other arthropods (LeBrun and others, 2013). Because of the effects on this ecological system by some species including cogongrass, along with the potential for several other species to invade and do damage, we assigned values between 0.7 and 0.8 to this system.

Dynamic Process Alteration.- $\mathbf{0 . 6 8}$ (both time periods)

We calculated the initial ecological departure based on the composition for this ecological system as the basis for this metric. As stated in the section, "Dynamic Process Forecast," the mapped conditions included an overrepresentation of closed-canopy states, whereas the late-succession open-canopy state class was underrepresented (table 5.1). As a result, the initial departure of this system was 0.32, which is a fairly low departure value, and indicates that the composition of state classes in the ecological system is relatively similar to estimated preEuropean settlement conditions. The resulting metric for dynamic process alteration was $1-0.32=$ 0.68 . 
Diversity within Functional Groups.-minimum, 0.8; maximum, 0.9 (both time periods)

We identified two functional groups that are important to this ecological system: species that require mesic conditions (and, specifically, soil saturation during wet periods), and species that are tolerant of high fire frequency. The seasonal saturation and fire frequency are two characteristics of this system. Although pine flatwoods systems are not as species rich as some pine-dominated systems in the Southeast such as wet savannas, they contain a high diversity of plant species, especially in the understory (Peet and Allard, 1993; Carr and others, 2010). All these species tolerate frequent fire, and some require fire to reproduce (Florida Natural Areas Inventory, 2010). Additionally, mesic conditions are required by several plant and animal species, including many amphibians such as Flatwoods Salamanders (Ambystoma bishopi and Ambystoma cingulatum), and Gopher Frogs (Lithobates capito and Lithobates sevosus). Therefore, the diversity of each of the functional groups is relatively high in this system.

Keystone Species Vulnerability.—0.5-0.69 (mid-century); 0.3-0.4 (late-century)

The keystone species we used for this ecological system was the Gopher Tortoise (Gopherus polyphemus; Noss, 2013). A vulnerability assessment for the Gopher Tortoise at Fort Stewart, Georgia, determined that the species was moderately vulnerable by 2050 because of its sensitivity to hydrology and its historical thermal niche, as well as projected anthropogenic barriers to movement (Sperry and Hayden, 2011). Therefore, we assigned the range of values in the "moderate" range of this metric. Because temperature increases and land conversion to urbanization are projected to be greater by the end of the century, we assumed greater vulnerability for this species by the end of the century, and assigned slightly lower values.

Bioclimatic Variability. - 0.32 (both time periods)

This ecological system is present in eight bioclimates, indicating a fairly restricted range for this system, and a low value for this resilience metric. The maximum number of bioclimates for any southeastern system is 25 .

Elevation Range.- $\mathbf{0 . 0 7}$ (both time periods)

This system is present in three 100-m elevation bands, which, like the bioclimatic variability index, indicates a restricted range for this system and a low resilience value. The maximum number of elevation bands for any southeastern system is 27. 


\section{References Cited}

Carr, S.C., Robertson, K.M., and Peet, R.K., 2010, A vegetation classification of fire-dependent pinelands of Florida: Castanea, v. 75, p. 153-189.

Costanza, J.K., Terando, A.J., McKerrow, A.J., and Collazo, J.A., 2015, Modeling climate change, urbanization, and fire effects on Pinus palustris ecosystems of the southeastern U.S.: Journal of Environmental Management, v. 151, p. 186-199.

Delcourt, H.R., and Delcourt, P.A., 2000, Eastern deciduous forests, in Barbour, M.G., and Billings, W.D., eds., North American terrestrial vegetation (2d ed.): Cambridge, United Kingdom, Cambridge University Press, p. 357-395.

Florida Exotic Pest Plant Council, 2013, List of invasive plant species: Florida Exotic Pest Plant Council Web site, accessed June 2014, at http://www.fleppc.org/list/list.htm.

Florida Natural Areas Inventory, 2010, Guide to the natural communities of Florida (2010 ed.): Tallahassee, Florida Natural Areas Inventory, accessed May 2013, at http://www.fnai.org/naturalcommguide.cfm.

Grace, S., and Wilder, T., 2009, LANDFIRE Biophysical Setting Model for East Gulf Coastal Plain Near-Coast Pine Flatwoods-LANDFIRE biophysical setting descriptions, Map zone 55LANDFIRE program model, p. 113-117, accessed May 2012, at http://www.landfire.gov/national_veg_models_op2.php.

LeBrun, E.G., Abbott, J., and Gilbert, L.E., 2013, Imported crazy ant displaces imported fire ant, reduces and homogenizes grassland ant and arthropod assemblages: Biological Invasions, v. 15, p. 2,429-2,442.

Noss, R.F., 2013, Forgotten grasslands of the South—Natural history and conservation: Washington, D.C., Island Press, 317 p.

Peet, R.K., and Allard, D.J., 1993, Longleaf pine vegetation of the southern Atlantic an eastern Gulf Coast regions-A preliminary classification, in Hermann, S.M., ed., Proceedings of the Tall Timbers Fire Ecology Conference, No. 18, The longleaf pine ecosystem-Ecology, restoration and management, Tall Timbers Research Station, Tallahassee, Florida, p. 45-81.

Sperry, J., and Hayden, T., 2011, Use of a climate change vulnerability index for assessing species at risk on military lands: U.S. Army Corps of Engineers Engineer Research and Development Center, Construction Engineering Research Laboratory, Champaign, Illinois, ERDC/CERL TR-11-29, 51 p. 

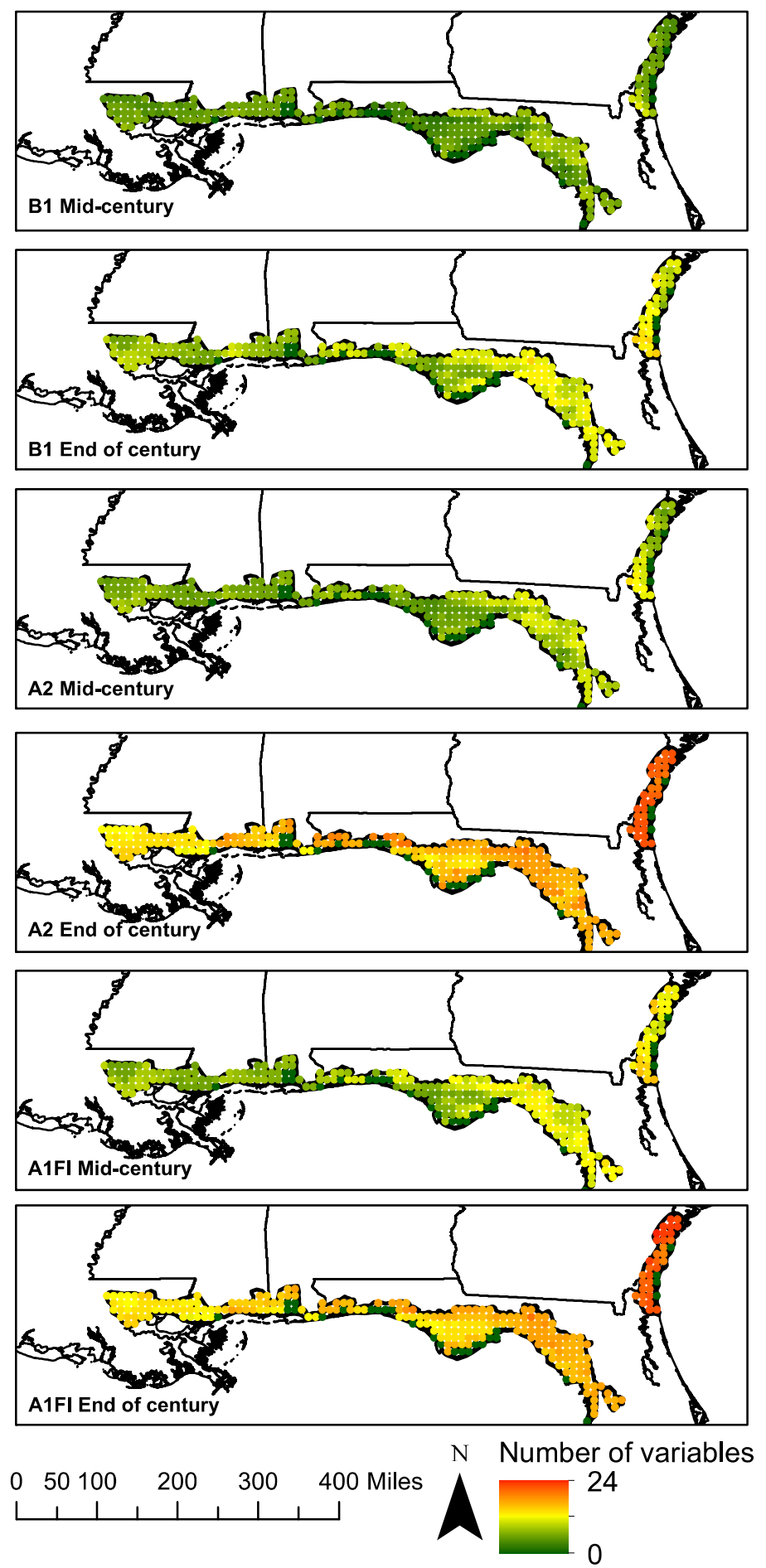

Figure 5.6. Count of the monthly climate variables projected to exceed 2 standard deviations above or below the recent mean across the range of the East Gulf Coastal Plain Near-Coast Pine Flatwoods ecological system. Values for this system ranged from 0 to 24 variables exceeding recent variability, out of a possible 36 variables. This count was used to calculate the climate stress index. 

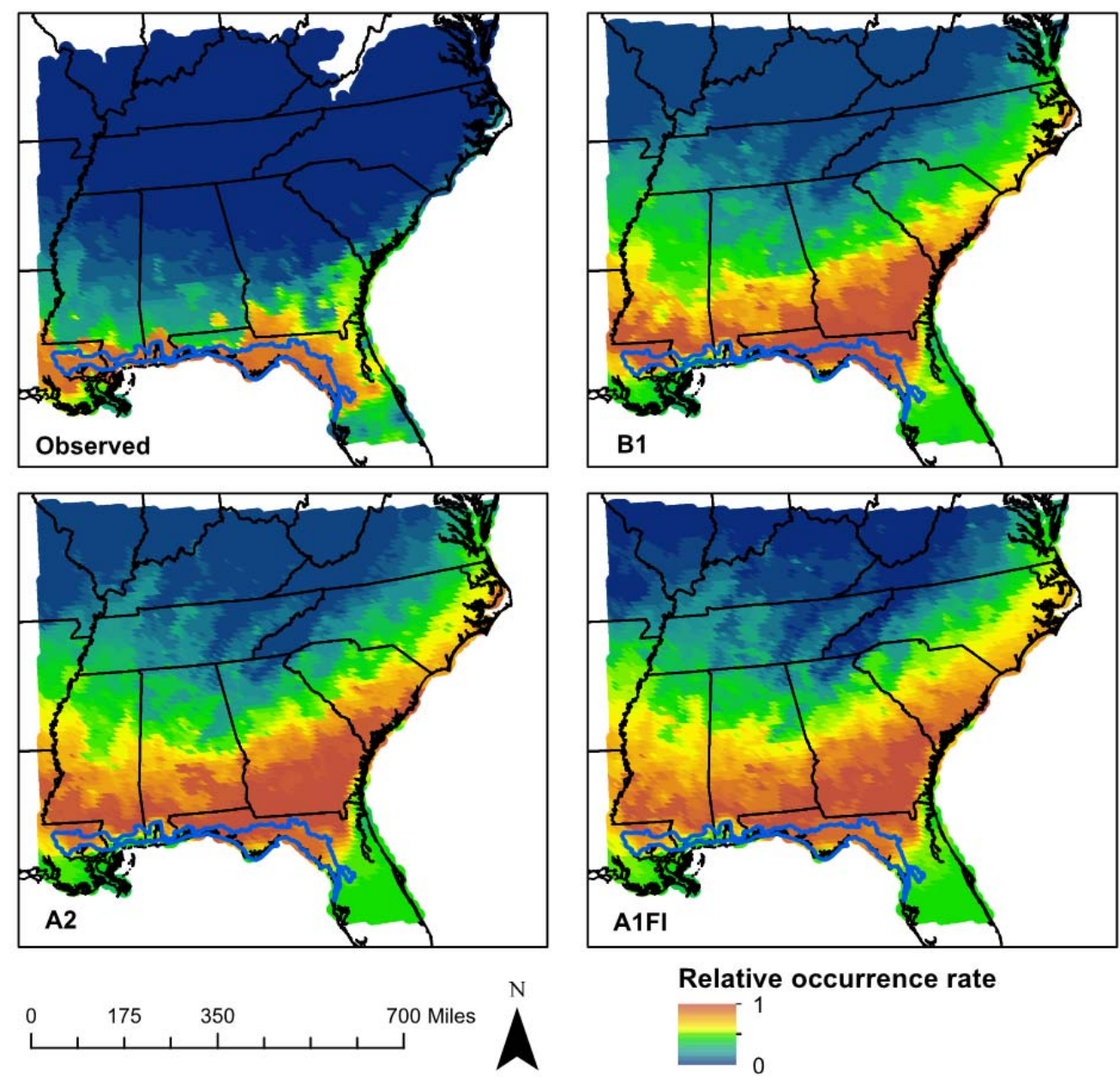

Relative occurrence rate

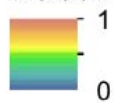

Figure 5.7. Climate envelope model results for the East Gulf Coastal Plain Near-Coast Pine Flatwoods ecological system projected onto observed climate and three emissions scenarios at mid-century. Thick closed lines indicate the range of the system. 

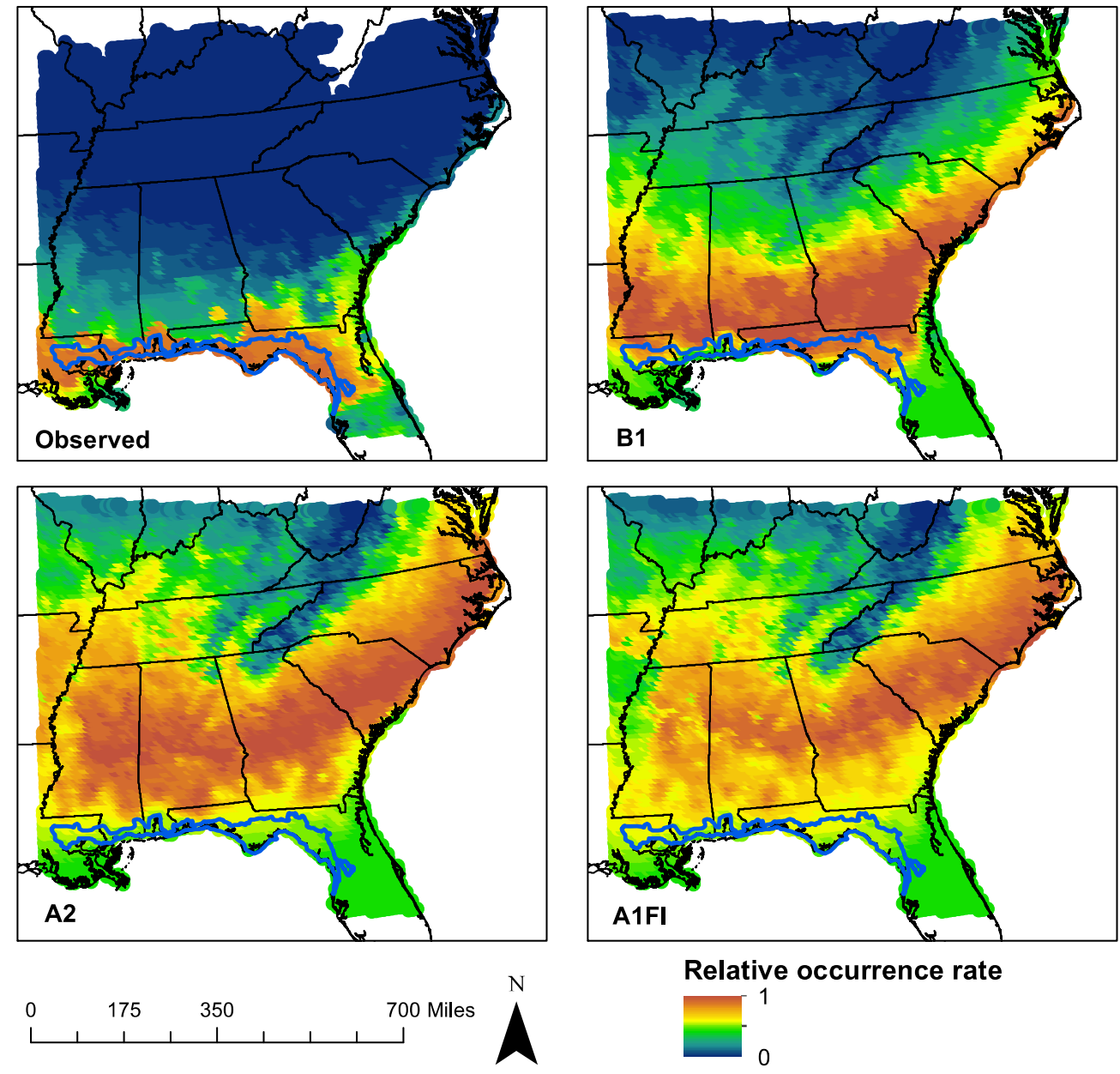

Relative occurrence rate

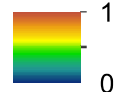

Figure 5.8. Climate envelope model results for the East Gulf Coastal Plain Near-Coast Pine Flatwoods ecological system projected onto observed climate and three emissions scenarios at the end of the century. Thick closed lines indicate the range of the system. 
Table 5.1. Landscape composition and ecological departure values for the East Gulf Coastal Plain Near-Coast Pine Flatwoods ecological system. A value of "NA" indicates the metric is not applicable.

\begin{tabular}{|c|c|c|c|c|c|c|c|}
\hline Time period, metric, and scenario & $\begin{array}{c}\text { Early- } \\
\text { succession }\end{array}$ & $\begin{array}{l}\text { Mid- } \\
\text { succession, } \\
\text { closed }\end{array}$ & $\begin{array}{l}\text { Mid- } \\
\text { succession, } \\
\text { open }\end{array}$ & $\begin{array}{l}\text { Late- } \\
\text { succession, } \\
\text { open }\end{array}$ & $\begin{array}{l}\text { Late- } \\
\text { succession, } \\
\text { closed }\end{array}$ & $\begin{array}{c}\text { Total } \\
\text { departure }\end{array}$ & Metric \\
\hline Pre-settlement composition & 0.15 & 0.05 & 0.35 & 0.35 & 0.1 & NA & NA \\
\hline Composition & 0.11 & 0.26 & 0.34 & 0.08 & 0.21 & NA & NA \\
\hline Initial - departure & 0.11 & 0.05 & 0.34 & 0.08 & 0.1 & 0.32 & ${ }^{1} 0.68$ \\
\hline Mid-century departure - B1 & 0.06 & 0.05 & 0.05 & 0.05 & 0.1 & 0.69 & ${ }^{2} 0.31$ \\
\hline Late-century composition - B1 & 0.06 & 0.22 & 0.05 & 0.05 & 0.63 & NA & NA \\
\hline Late-century departure - B1 & 0.06 & 0.05 & 0.05 & 0.05 & 0.1 & 0.69 & ${ }^{2} 0.31$ \\
\hline Mid-century composition - A1FI & 0.06 & 0.29 & 0.05 & 0.05 & 0.55 & NA & NA \\
\hline Mid-century departure - A1FI & 0.06 & 0.05 & 0.05 & 0.05 & 0.1 & 0.69 & ${ }^{2} 0.31$ \\
\hline Late-century departure - A1FI & 0.06 & 0.05 & 0.04 & 0.04 & 0.1 & 0.71 & ${ }^{2} 0.29$ \\
\hline
\end{tabular}

${ }^{1}$ This value was used as the dynamic process alteration metric.

${ }^{2}$ These values were used as the dynamic process forecast metric. 
Table 5.2 Invasive species found in the East Gulf Coastal Plain Near-Coast Pine Flatwoods ecological system.

\begin{tabular}{ll}
\hline \multicolumn{1}{c}{ Common name } & \multicolumn{1}{c}{ Scientific name } \\
\hline Rose myrtle, Downy myrtle & Rhodomyrtus tomentosa \\
Cogongrass & Imperata cylindrica \\
Old World climbing fern & Lygodium microphyllum \\
Camphor tree & Cinnamomum camphora \\
Rose Natal grass & Melinis repens \\
Feral pig & Sus scrofa \\
Red imported fire ant & Solenopsis invicta \\
Tawny crazy ant & Nylanderia fulva \\
\hline
\end{tabular}




\section{East Gulf Coastal Plain Southern Loess Bluff Forest}

Ecological System Overview.- The East Gulf Coastal Plain Southern Loess Bluff Forest ecological system occurs on bluffs and adjacent plains in the Mississippi River Alluvial Plain, to the east of the Mississippi River in Mississippi and Louisiana (fig. 6.1). This ecological system is mapped almost entirely within the U.S. Environmental Protection Agency Loess Bluff Hills Ecoregion (U.S. Environmental Protection Agency, 2013), with a small portion in the Mississippi Valley Loess Plains (NatureServe, 2013a). The fertile loess deposits in this system are thickest near the Mississippi River (30-60 m thick), becoming thinner to the east (Davenport, 2009). This system differs from the Northern Loess Bluff Forest because of the occurrence of southern magnolia (Magnolia grandiflora). Fertile soils and the cool, moist microclimate resulting from the topography of this region make it a refugium for many plant and animal species present farther north (Delcourt and Delcourt, 1975; NatureServe, 2013b). More than 50 tree species are found on the loess bluffs, and species richness often is higher in this ecological system than in surrounding areas with non-loess soils (Delcourt and Delcourt, 1974; NatureServe, 2013b). Tree species are predominantly deciduous, and include southern magnolia, American beech (Fagus grandifolia), sweetgum (Liquidambar styraciflua), and several oak species (Quercus sp.). The flora is rich in shrub and herbaceous species, particularly ferns, and canebrakes were common historically (Delcourt and Delcourt, 1974; Louisiana Department of Wildlife and Fisheries, 2005). These forests are subject to hurricanes and landslides (Quigley and Platt, 1996).

The ecology of this system has not been studied extensively. For a more complete description of this ecological system, see NatureServe (2013b), Davenport (2009), Delcourt and Delcourt (1975), and Louisiana Department of Wildlife and Fisheries (2005; p. 198-202, “Southern Mesophytic Forest”). 


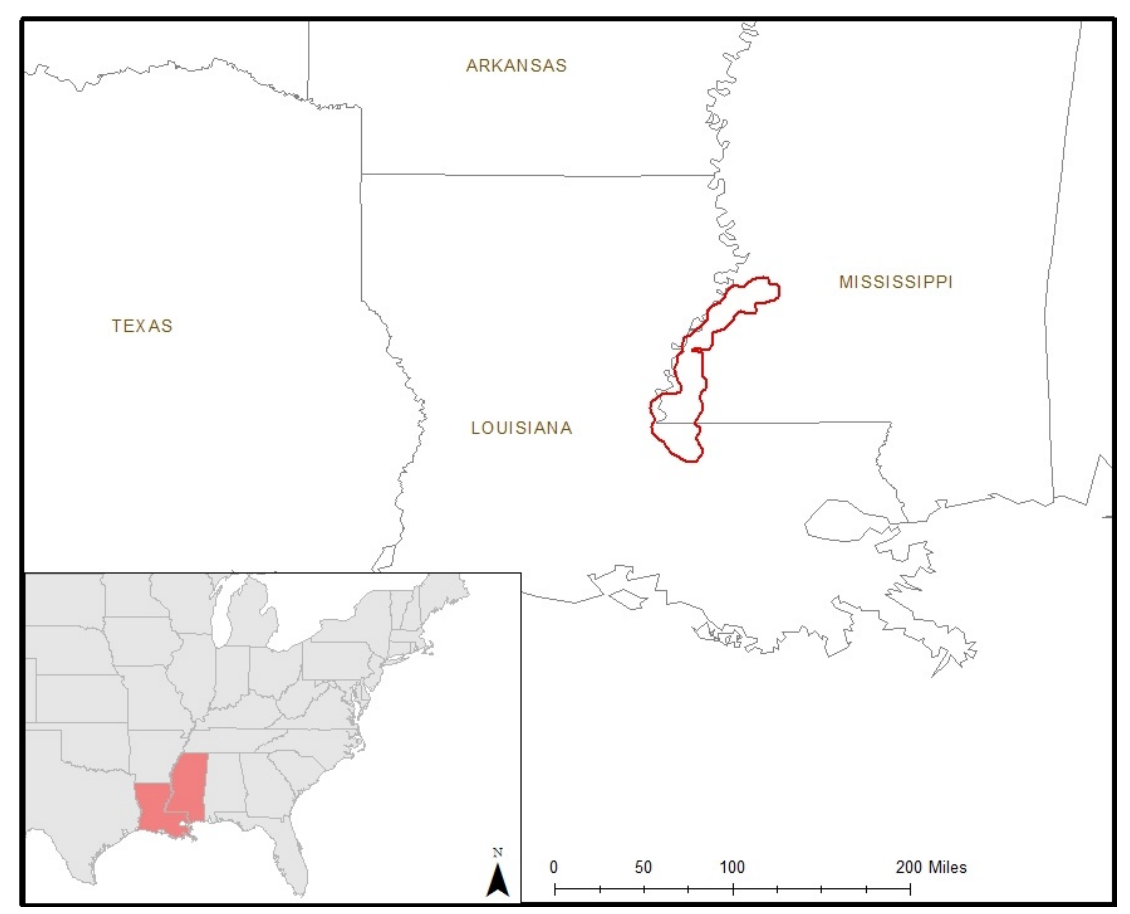

Figure 6.1. Range (outlined in top map) of the East Gulf Coastal Plain Southern Loess Bluff Forest ecological system. The system covers 45.0 percent of this range, according to data from NatureServe (2013a).

Vulnerability Status.- - Relative to other ecological systems in the Southeast, the vulnerability of this ecological system is rated as High. This system is sensitive to climate, and cool microclimate conditions along with hurricanes are important for maintaining species diversity. The likely exposure to changes in climate is moderate, with warmer and drier conditions likely, as well as increased hurricane activity. The system has a moderate level of adaptive capacity. The system has a high average patch size and low level of projected future conversion to development. However, because many species are at the southern terminus of their ranges, any increase in temperature will necessitate northern migration of species, which will be challenging for many species in the fragmented regional landscape.

Sensitivity.-Our analysis shows that this system is present in areas where temperature ranges from an average maximum of $33^{\circ} \mathrm{C}$ in the summer (Appendix $\mathrm{B}$ ) to an average winter minimum of $4{ }^{\circ} \mathrm{C}$ (Appendix B). Average summer precipitation generally is slightly higher than in other seasons, and precipitation is more variable in the summer and fall than in other seasons (Appendix B). However, microclimate conditions likely are important for this system. The topography of the bluffs and ravines in this region creates a cooler, moister microclimate than surrounding areas, and helps support deciduous vegetation that is more common to the north or in bottomland habitats (NatureServe, 2013b). The tree canopy likely promotes this cool, moist microclimate. In a warmer and drier climate, this ecological system could persist for some time, but might fail to regenerate following a large disturbance that clears the canopy and changes the microclimate. 
Delcourt and Delcourt (2000, and references therein) summarized the changes in climate and resulting distribution of Eastern deciduous forest since the last glacial maximum. These forests extend south to the point where the minimum winter temperature averages greater than about $-15^{\circ} \mathrm{C}$, or, in other words, where extreme winter chilling does not tend to occur (Delcourt and Delcourt, 2000). Where seasonal differences in climate become less pronounced, this forest type gives way to more pine-dominated forests.

Fires are not common in this ecological system, but hurricanes are a disturbance agent that promotes diversity. Hurricanes create canopy gaps that foster recruitment of shade-intolerant species, including eastern hophornbeam (Ostrya virginiana) (Kwit and Platt, 2003). Gaps also encourage the growth of other tree species, as well as shrub and herbaceous species, resulting in greater spatial heterogeneity in species composition and a higher diversity of tree ages than nonhurricane disturbed mesophytic forests (Quigley and Platt, 1996).

Exposure.-Analysis of projected change in climate for this ecological system shows increases in maximum and minimum temperatures for most models, scenarios, and time periods, with the exception of some models under the B1 scenario at mid-century (figs. 6.2 and 6.3). There is not much difference across seasons in the amount of change projected, with the exception of winter minimum temperatures, which are expected to change by a smaller amount than in other seasons. The largest increases in mean maximum temperature are projected under the A1FI scenario, and range from $3.2^{\circ} \mathrm{C}$ to $3.6^{\circ} \mathrm{C}$ by the end of this century. Winter minimum temperatures, which may help determine the distribution of this system, have lower projected increases on average by the end of the century compared with other seasons, under both emissions scenarios. The highest increases in minimum temperature are projected for the summer. These increases in temperature may mean that the cool microclimate in this ecological system is disrupted. Because many plant and animal species are at the southern terminus of their ranges in this ecological system, any increase in temperature could have severe impacts on the species composition of this ecological system.

Projected changes in precipitation for this ecological system show variation among climate models for each season, emissions scenario, and time period (fig. 6.4). The means across climate models are positive for spring and fall, but vary for winter and summer. The largest projected increases are 127 and 109 percent, for the end of the century in the fall, under the A1FI and B1 scenarios, respectively. Global climate models project a decrease in precipitation of as much as 69 percent for the summer by the end of the century under the A1FI scenario. However, in all cases for all seasons, scenarios, and time periods, the range of projections crosses 0 , indicating much uncertainty among climate models.

Projected changes in the standard deviation, or variability, of temperature and precipitation show a high degree of uncertainty among climate models. Both the means and ranges of change in standard deviation for maximum and minimum temperatures vary considerably (Appendix C). The mean change in the standard deviation of precipitation is positive in all cases except for the A1FI emissions scenario in the spring, indicating that although model projections are variable, on average, they show an increase in variability for precipitation in the future for most seasons (Appendix C). 
Southern magnolia, a characteristic species in this ecological system, is locally important in and around this ecological system. A hotspot of importance, consisting of the top 10 percent of importance values for the species, occurs in the Southern loess bluff region. According to the U.S. Forest Service Climate Change Tree Atlas, under low climate-emissions scenarios in the future, the local hotspot of importance will remain (Prasad and others, 2007). However, under high-emissions scenarios, the local hotspot will disappear. The differences in these two sets of projections is likely because the most important variable predicting southern magnolia abundance in the Tree Atlas models is mean summer precipitation, which is projected to decrease under some scenarios and increase under others. Further work to determine how precipitation may change locally, and how it may affect southern magnolia, will be important.

Additionally, according to the Tree Atlas, American beech has low abundance in the loess bluffs region, and is projected to remain in low abundance under all emissions scenarios modeled (Prasad and others, 2007). Sweetgum has high abundance and importance in this region, and a new hotspot of local importance is projected to occur in and near the Southern loess bluff region under the high-emissions scenarios (Prasad and others, 2007).

Hurricane frequency and intensity is likely to increase in the future (Webster and others, 2005; Intergovernmental Panel on Climate Change, 2007). This should have positive effects on species richness and vegetation structural diversity in this system, as long as hurricanes do not become too frequent or intense for many species to recover between events. Determining the effects of future hurricane disturbances on this system is an important area of future research.

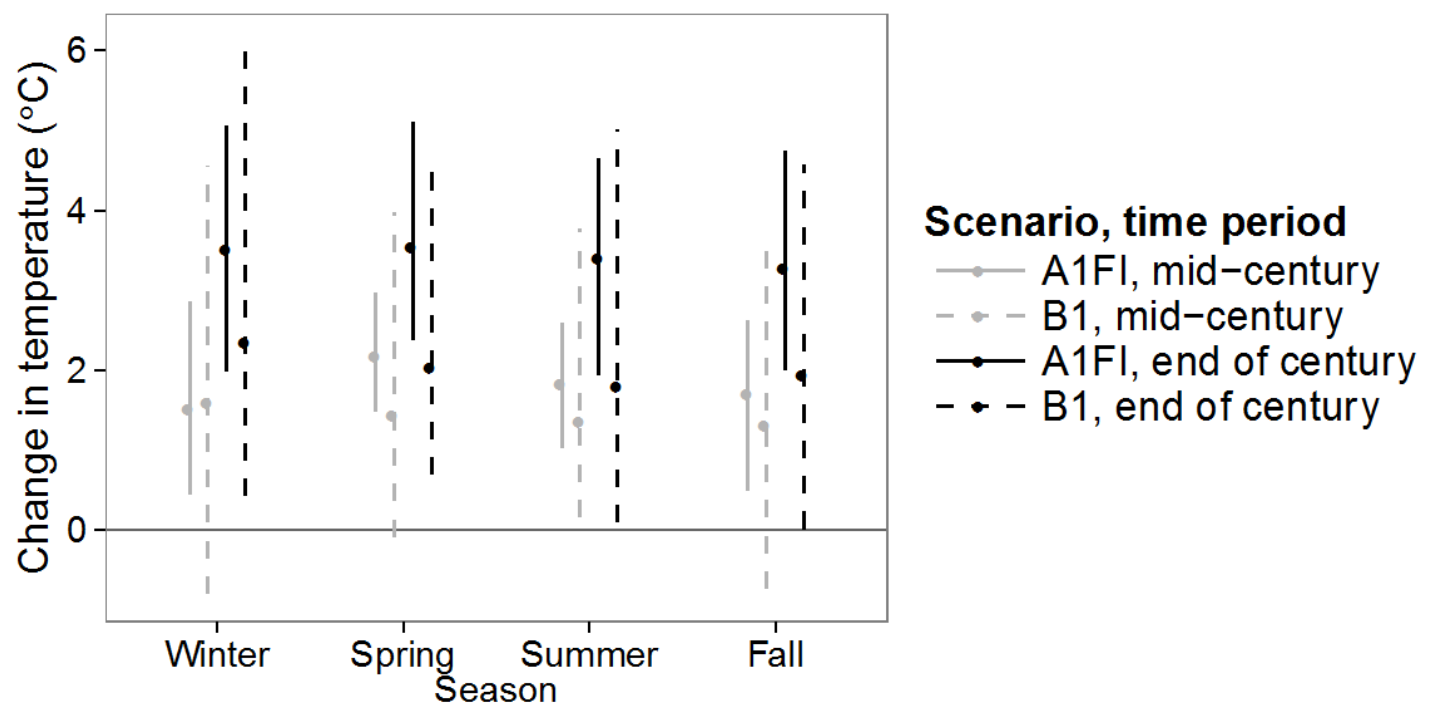

Figure 6.2. Projected change in seasonal maximum temperatures (in degrees Celsius $\left[{ }^{\circ} \mathrm{C}\right]$ ) for the middle (2040-2060) and the end of the 21st century (2080-2100), compared with the recent time period (19812000), for two emissions represent the East Gulf Coastal Plain Southern Loess Bluff Forest ecological system. Solid dots and error bars represent, respectively, the means and ranges of projections across climate models under each scenario. 


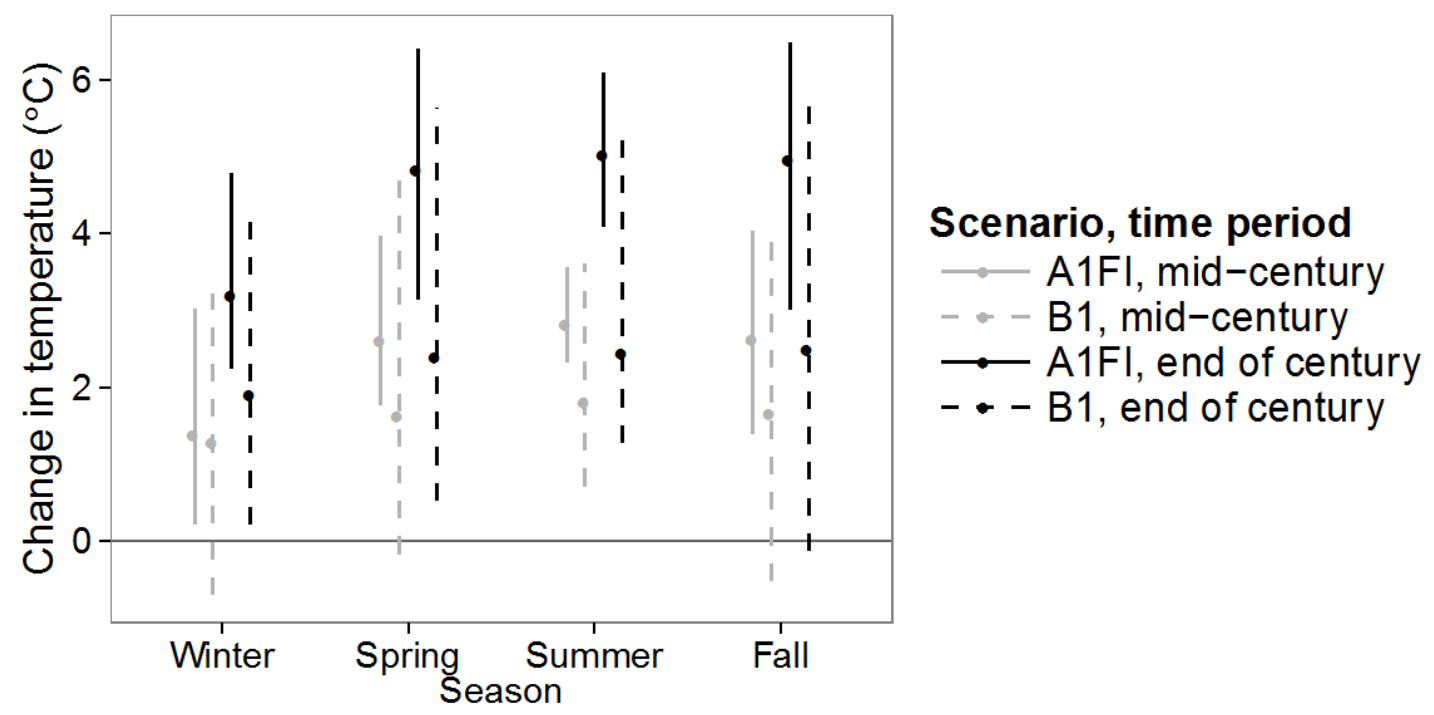

Figure 6.3. Projected change in seasonal minimum temperatures (in degrees Celsius $\left[{ }^{\circ} \mathrm{C}\right]$ ) for the middle (2040-2060) and the end of the 21st century (2080-2100), compared with the recent time period (19812000), for two emissions scenarios for the East Gulf Coastal Plain Southern Loess Bluff Forest ecological system. Solid dots and error bars represent, respectively, the means and ranges of projections across climate models under each scenario.

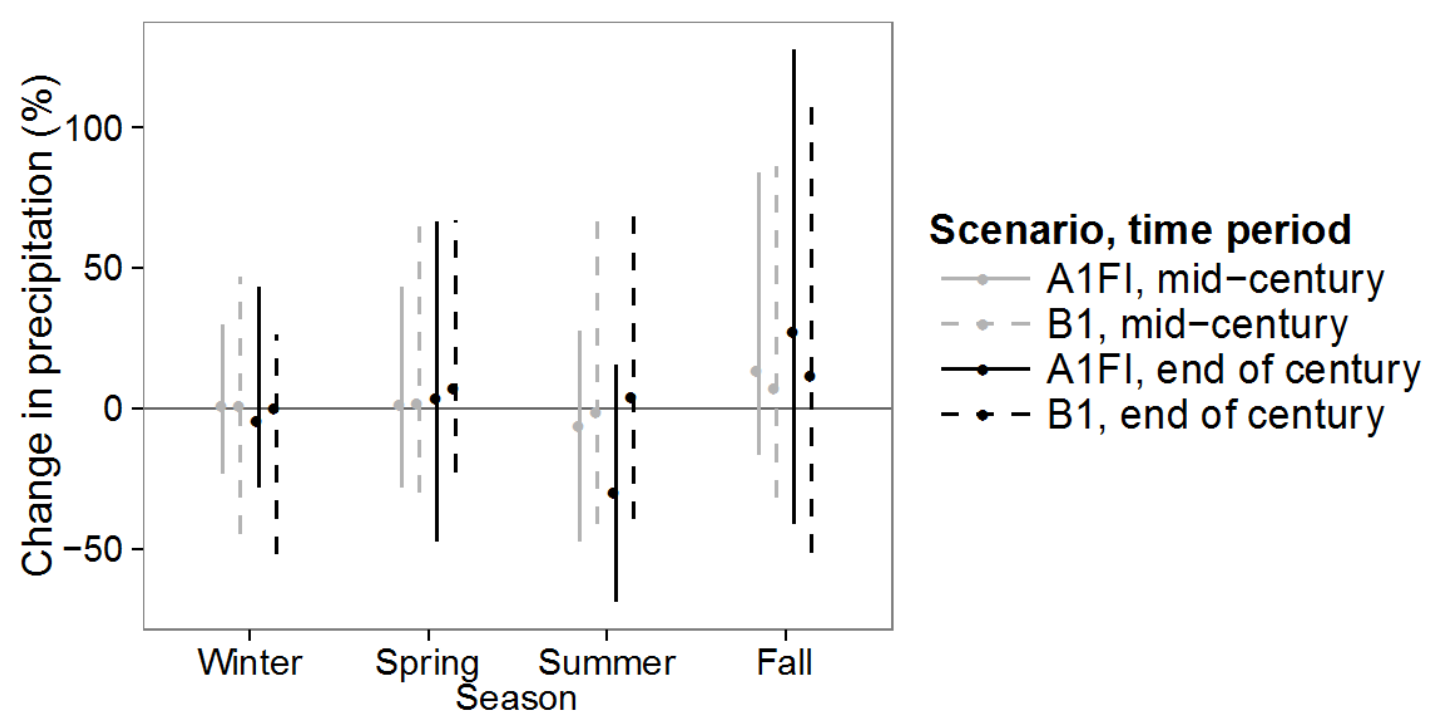

Figure 6.4. Projected percentage change in seasonal average precipitation for the middle (2040-2060) and the end of the 21st century (2080-2100), compared with the recent time period (1981-2000), for two emissions scenarios for the East Gulf Coastal Plain Southern Loess Bluff Forest ecological system. Solid dots and error bars represent, respectively, the means and ranges of projections across climate models under each scenario. 
Adaptive Capacity.-This ecological system is fairly restricted in its range, occurring in a total area of only 1,975 square kilometers $\left(\mathrm{km}^{2}\right)$. The system has been cleared extensively in the past for timber harvest, agriculture, and development, even in steep areas (Louisiana Department of Wildlife and Fisheries, 2005; Mississippi Department of Wildlife, Fisheries and Parks, 2005). Only about 3 percent of this extent is protected for conservation (fig. 6.5). However, the existing extent of this system has a fairly high average patch size (197,090 m², or 19.7 ha; Appendix A), and a low average level of human modification (44 percent; Appendix A) compared to other ecological systems in the Southeast. This suggests that existing patches of this system are relatively intact and have relatively few threats from humans. Despite past clearing of this system, only an additional 0.8 percent is expected to be converted to development by 2050, and 2.4 percent is expected to be converted by 2100 (fig. 6.5). The low rate of projected development may be owing to the local variation in topography for this system. Even with low rates of development expected, any clearing on steep slopes could cause erosion and, thus, have major impacts in this ecological system.

High diversity of trees and understory species may mean that the overall vegetation structure of this ecological system is more resilient to future changes than the vegetation structure of other systems. In other portions of the mixed forest in the Eastern United States, fire suppression and reductions in canopy gap size during the 20th century have led to reductions in canopy diversity and understory tree diversity (for example, Rentch and others, 2003). No documented evidence in the literature for these changes in this particular ecological system could be found, but they are likely, and would reduce the adaptive capacity of this system to climate change. Additionally, several invasive species are present in this ecological system that could cause changes in structure and ecological processes. For example, sacred bamboo (Nandina domestica) may alter the fire regime in this ecological system (Stone, 2009). Another major invasive species in this system is Japanese honeysuckle (Lonicera japonica), which is a major pest in many areas of Louisiana (Louisiana Department of Wildlife and Fisheries, 2005).

This system is restricted to loess bluffs and surrounding plains in a small region east of the Mississippi River in Louisiana and Mississippi, and is different from other adjacent systems. The East Gulf Coastal Plain Northern Loess Bluff Forest ecological system occurs to the north, and is similar to this ecological system, although it differs slightly in species composition (NatureServe, 2013b). Many plant and animal species in the Southern Loess Bluff Forest likely would be able to survive in that northern bluff region. However, any northern migration owing to increased temperature would be difficult in the region because of regional fragmentation of natural areas resulting from conversion to agriculture. Thus, the connectivity between this system and many surrounding systems likely is low for most species. In particular, one species that is not shared by the Northern Loess Bluff Forest system is the southern magnolia, and its local abundance is projected to decline with climate change under some emissions scenarios (see section, "Exposure"). Therefore, more information on how to facilitate adaptation of that and other species to climate change would be critical. 


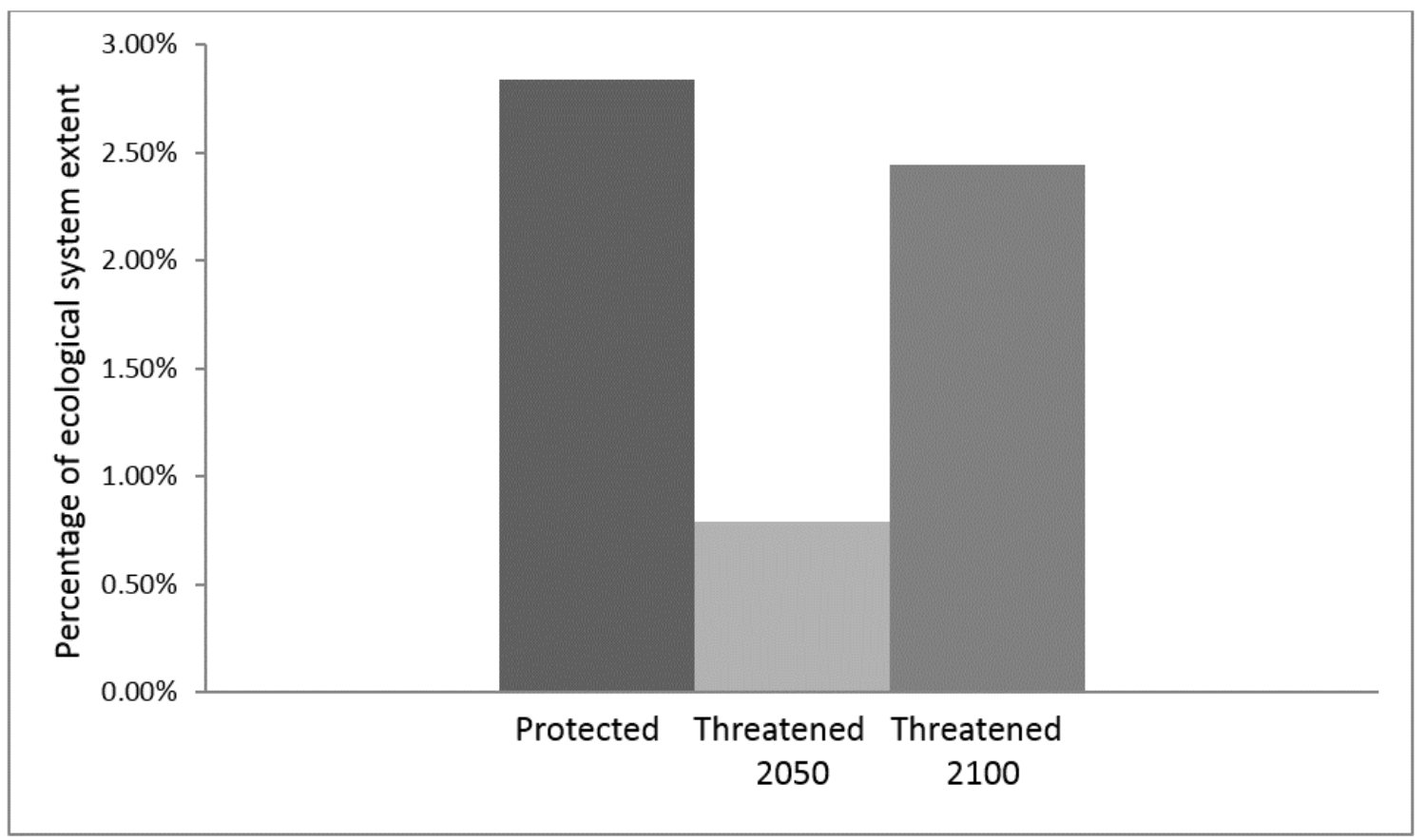

Figure 6.5. Percentage of extent of the East Gulf Coastal Plain Southern Loess Bluff Forest ecological system that is protected for conservation, and the percentage threatened by future development in 2050 and 2100 .

Summary.-This ecological system is restricted to loess bluffs and surrounding plains east of the Mississippi River in Louisiana and Mississippi. Cool microclimate conditions are important for maintaining refugia for many species, and temperatures are projected to increase under climate change. Hurricanes also are important for maintaining the high species richness and structural diversity in this system. Hurricane frequency and intensity are expected to increase under climate change, which may be good for this ecological system, unless they are too frequent or intense for species to recover between events. This system is restricted in its range, but does have a fairly large average patch size, and faces little threat from future development. However, logging, road building, and conversion to agriculture have been threats in the past and could be ongoing threats in the future. To maximize adaptive capacity, this ecological system could benefit from maintenance and restoration of connectivity with the East Gulf Coastal Plain Northern Loess Bluff Forest system. Further research into the ecology of this system is important, including the ecology of disturbances and the potential effects of future changes in hurricane dynamics on species in this system. Additionally, more information about how local changes in climate may affect southern magnolia and other species with disjunct occurrences in this system is important for informing adaptation strategies for this ecological system. 


\section{References Cited}

Davenport, B., 2009, LANDFIRE biophysical setting model for East Gulf Coastal Plain Southern Loess Bluff Forest—LANDFIRE biophysical setting descriptions, Map zone 99: LANDFIRE program model, p. 7-12, accessed September 2013, at http://www.landfire.gov/national_veg_models_op2.php.

Delcourt, H.R., and Delcourt, P.A., 1974, Primeval magnolia-holly-beech climax in Louisiana: Ecology, v. 55, p. 638-644.

Delcourt, H.R., and Delcourt, P.A., 1975, The Blufflands-Pleistocene pathway into the Tunica Hills: American Midland Naturalist, v. 94, p. 385-400.

Delcourt, H.R., and Delcourt, P.A., 2000, Eastern deciduous forests, in Barbour, M.G., and Billings, W.D., eds., North American terrestrial vegetation (2d ed.): Cambridge, United Kingdom, Cambridge University Press, p. 357-395.

Intergovernmental Panel on Climate Change, 2007, Climate change 2007-Impacts, adaptation, and vulnerability Climate change 2007-Contribution of Working Group II to the Fourth Assessment Report of the Intergovernmental Panel on Climate Change: Cambridge and New York, Cambridge University Press, 976 p.

Kwit, C., and Platt, W.J., 2003, Disturbance history influences regeneration of non-pioneer understory trees: Ecology, v. 84, p. 2,575-2,581.

Louisiana Department of Wildlife and Fisheries, 2005, Louisiana comprehensive wildlife conservation strategy: Baton Rouge, Louisiana, 451 p., accessed September 2013, at http://www.wlf.louisiana.gov/wildlife/wildlife-action-plan-details.

Mississippi Department of Wildlife, Fisheries and Parks, 2005, Mississippi’s comprehensive wildlife conservation strategy_2005-2015: Jackson, Mississippi Department of Wildlife, Fisheries and Parks, 418 p., accessed September 2013, at http://www.mdwfp.com/media/63792/cwcs.pdf.

NatureServe, 2013b, NatureServe explorer-An online encyclopedia of life, Version 7.1: Arlington, Virginia, NatureServe Web application, accessed May 2013, at http://www.natureserve.org/explorer.

NatureServe, 2013a, U.S. ecological systems National Map data: Arlington, Virginia, NatureServe database, accessed January 2013, at http://www.natureserve.org/getData/USecologyData.jsp.

Prasad, A.M., Iverson., L.R., Matthews, S., and Peters, M., 2007, A climate change atlas for 134 forest tree species of the Eastern United States: U.S. Forest Service database, Northern Research Station, Delaware, Ohio, accessed May 2013, at http://www.nrs.fs.fed.us/atlas/tree.

Quigley, M.F., and Platt, W.J., 1996, Structure and pattern in temperate seasonal forests: Vegetatio, v. 123, p. 117-138. 
Rentch, J.S., Fajvan, M.A., and Hicks, R.R., 2003, Oak establishment and canopy accession strategies in five old-growth stands in the central hardwood forest region: Forest Ecology and Management, v. 184, p. 285-297.

Stone, K.R., 2009, Fire Effects Information System (FEIS): U.S. Forest Service database, Rocky Mountain Research Station, Fire Sciences Laboratory, Missoula, Montana, accessed June 2014, at http://www.fs.fed.us/database/feis/plants/shrub/nandom/all.html.

U.S. Environmental Protection Agency, 2013, Level III and IV ecoregions of the continental United States:U.S. Environmental Protection Agency, Western Ecology Division, Corvallis, Oregon, accessed August 2013, at http://www.epa.gov/wed/pages/ecoregions/level_iii_iv.htm.

Webster, P.J., Holland, G.J., Curry, J.A., and Chang, H.-R., 2005, Changes in tropical cyclone number, duration, and intensity in a warming environment: Science, v. 309, p. 1,844-1,846. 


\section{Edwards Plateau Limestone Shrubland}

Ecological System Overview.-The Edwards Plateau Limestone Shrubland ecological system consists of short-to-tall shrublands (0.5-3 m in height) occurring on shallow soils over limestone bedrock, or in the xeric, western part of the Edwards Plateau (fig. 7.1; White and others, 2008). The system occurs in small-to-large patches across the plateaus and small hills and bluffs in the region (White and others, 2008; NatureServe, 2013a). Woody species in this system include white shin oak (or white shin oak, Quercus sinuata var. breviloba), plateau oak (Quercus fusiformis), and Ashe juniper (Juniperus ashei). In the western portion of the range, papershell pinyon (Pinus remota), Mohr's oak (Quercus mohriana), and sandpaper oak (Quercus vaseyana) also are important species. All these woody species may occur as emergent trees, but they usually contribute to a diverse shrub layer in this ecological system (Elliott, 2011). This system develops over long time scales and may persist for long periods without disturbance on shallow soils (NatureServe, 2013a). The diverse shrub layer in this ecological system provides habitat for the Federally endangered Black-capped Vireo (Vireo atricapilla).

The ecology of this system has not been studied extensively. For a more complete description, see NatureServe (2013a) and Elliott (2011).

The spatial analysis for this system was done using the system distribution from The National Map (NatureServe, 2013b). An updated and more detailed mapping of this system has been done by the Texas Parks and Wildlife Department Ecological Systems Classification Project (Texas Parks and Wildlife Department, 2014). That project mapped about 10 times as much of this system compared with National Map data (Lee Elliott, University of Missouri, pers. commun., May 12, 2014), but incorporating those newer data was not practical in the present study. However, using this updated map likely would change our analysis results. If redone with the newer data, the analysis related to adaptive capacity such as patch size, distance to urban areas, and future urbanization for this system likely would show the most change. The recent and projected climate analysis is likely to be affected only minimally because of the relatively coarse spatial resolution of the climate data. 


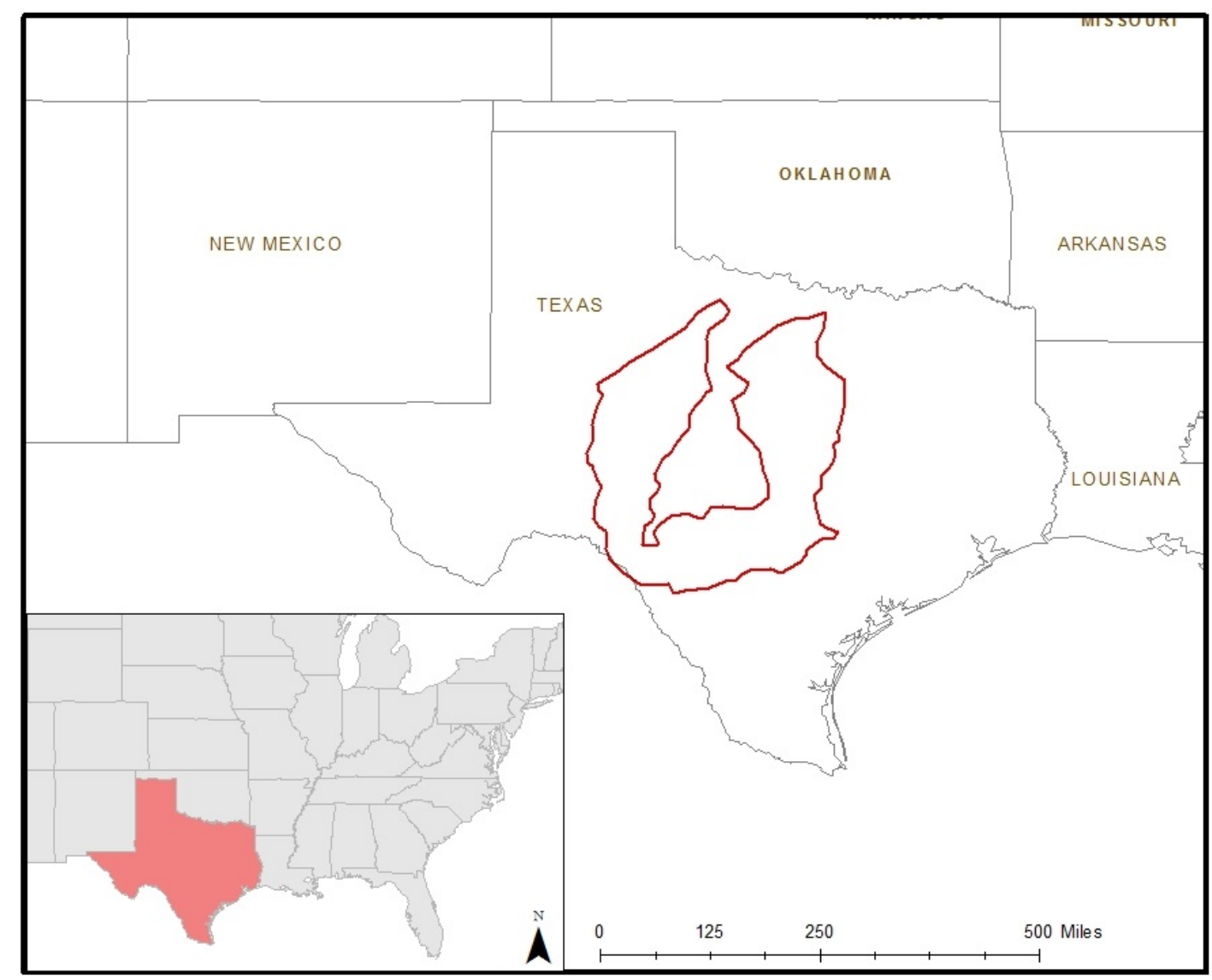

Figure 7.1. Range of the Edwards Plateau Limestone Shrubland ecological system. The system covers 1.4 percent of this range, according data from to NatureServe (2013b).

Vulnerability Status.- - Relative to other ecological systems in the Southeast, the vulnerability of this ecological system is rated as High. Many of the major species in this diverse shrubland community have narrow distributions and are at their northern ranges, and thus would be sensitive to changes in climate. The likely exposure to changes in climate is moderate, with warmer and drier conditions likely. The system has a low level of adaptive capacity because it has been severely fragmented and is at risk of future invasion by Ashe juniper.

Sensitivity.-Our analysis shows that this system occurs in areas where temperature ranges from an average maximum of $34^{\circ} \mathrm{C}$ in the fall (Appendix B) to an average minimum in the spring of $4{ }^{\circ} \mathrm{C}$ (Appendix B). Precipitation generally is fairly even across seasons, with winter precipitation lower than precipitation in all other seasons (Appendix B). Severe storms with hail, strong winds, and (or) tornadoes are fairly common in central Texas (Nielsen-Gammon, 2011).

The dominant woody species in this ecological system (including white shin oak, plateau oak, Ashe juniper, Mohr's oak, and cedar elm (Ulmus crassifolia)) are endemic to the region in and around central Texas and the Edwards Plateau (Flora of North America Editorial Committee, 1993). Therefore, if climate change results in substantially different conditions in the region, these species may be sensitive. Since the early 1900s, Ashe juniper has become more dominant in Edwards Plateau communities, likely because of a combination of many factors, including fire 
suppression, drought, overgrazing, and soil erosion (Smeins and Fuhlendorf, 1997). There is some evidence that Ashe juniper may thrive more than other species under drought conditions or decreased precipitation because the species is better able to withstand low soil water potentials than other species (Elkington and others, 2012). However, in the eastern portion of this system's range, less available water may actually slow succession toward Ashe juniper woodlands and make the system more stable (NatureServe, 2013a).

There is some uncertainty about the historical role of fire in this system. On thin-soiled sites, especially in more xeric portions of its range, this system will persist without fire. However, across much of their range in the Edwards Plateau, shrublands, without fire, will become denser and increasingly dominated by Ashe juniper (Amos and Gehlbach, 1988; White and others, 2008). Periodic low-intensity fires occur every

20-50 years, whereas replacement fires occur every 100 years following dry periods, after which shrubs regenerate (White and others, 2008). Fires following dry periods reduce vegetation density and maintain diverse, shrubland communities and prevent Ashe juniper dominance (White and others, 2008).

Exposure.-Analysis of projected change in climate for the Edwards Plateau Limestone Shrubland ecological system shows increases in maximum and minimum temperatures for most models, scenarios, and time periods (figs. 7.2 and 7.3). However, some models under the B1 scenario project a decrease in temperature between now and mid-century. Overall, projected changes in minimum temperature are greater than for maximum temperature. The mean projected changes in maximum temperature are greatest in summer and spring, with a change of at least 4 ${ }^{\circ} \mathrm{C}$ projected under the A1FI scenario by the end of this century during those seasons. The mean projected changes in minimum temperature for the same scenario and time period are at least 5 ${ }^{\circ} \mathrm{C}$ in spring, summer, and fall, whereas a mean change of $3.9^{\circ} \mathrm{C}$ is projected for winter. Our results agree with Nielsen-Gammon (2011), who found that temperatures across Texas have been warming and are expected to increase over the 21st century.

Projected percentage changes in precipitation for this ecological system show variation among climate models for each season, emissions scenario, and time period (fig. 7.4). In all cases, the range of projections crosses 0 , indicating much uncertainty among climate models, with at least one global climate model projecting a decrease and one projecting an increase for each scenario and time period. The means vary from positive to negative across emissions scenarios and time periods, with the exception of fall, when the mean projected change is positive in all cases. The greatest projected changes in either direction are for summer, when some models project increases of as much as 211 and 169 percent under the B1 scenario in the middle and end of the century, respectively, and one model projects a 73-percent decrease under the A1FI scenario at the end of the century. Other studies have found that fall and winter precipitation has increased since the mid- $20^{\text {th }}$ century across Texas, but is projected to decline in the first one-half of the 21st century, with substantial disagreement among climate models in their projections (Nielsen-Gammon, 2011).

A decrease or even a slight increase in precipitation, when coupled with the projected increases in temperature, could mean increased drought frequency and severity and more water 
stress (Nielsen-Gammon, 2011). More drought may lead to a greater number of replacement fires, especially in the western portion of this system's range, where aridity is higher. Following replacement fires, all shrub species must regenerate, and Ashe juniper dominance would be slowed. Conversely, increased drought could also lead to greater dominance by Ashe juniper because it is better able than other species to withstand low soil water potentials, especially in the eastern portion of this system's range.

Projected changes in the standard deviation, or variability, of temperature and precipitation for this ecological system show a high degree of uncertainty among climate models. Both the means and ranges of change in standard deviation for maximum and minimum temperatures vary considerably (Appendix C). The mean change in the standard deviation of precipitation is greater than 1 in nearly all cases, indicating an increase in variability. Summer is the season with the widest range of projections, with some climate models projecting a decrease in variability in summer precipitation to another model (the B1 scenario for end of century) projecting an as much as five-fold increase. In other words, although model projections are variable, as a whole, they predict an increase in variability for precipitation in the future (Appendix C).

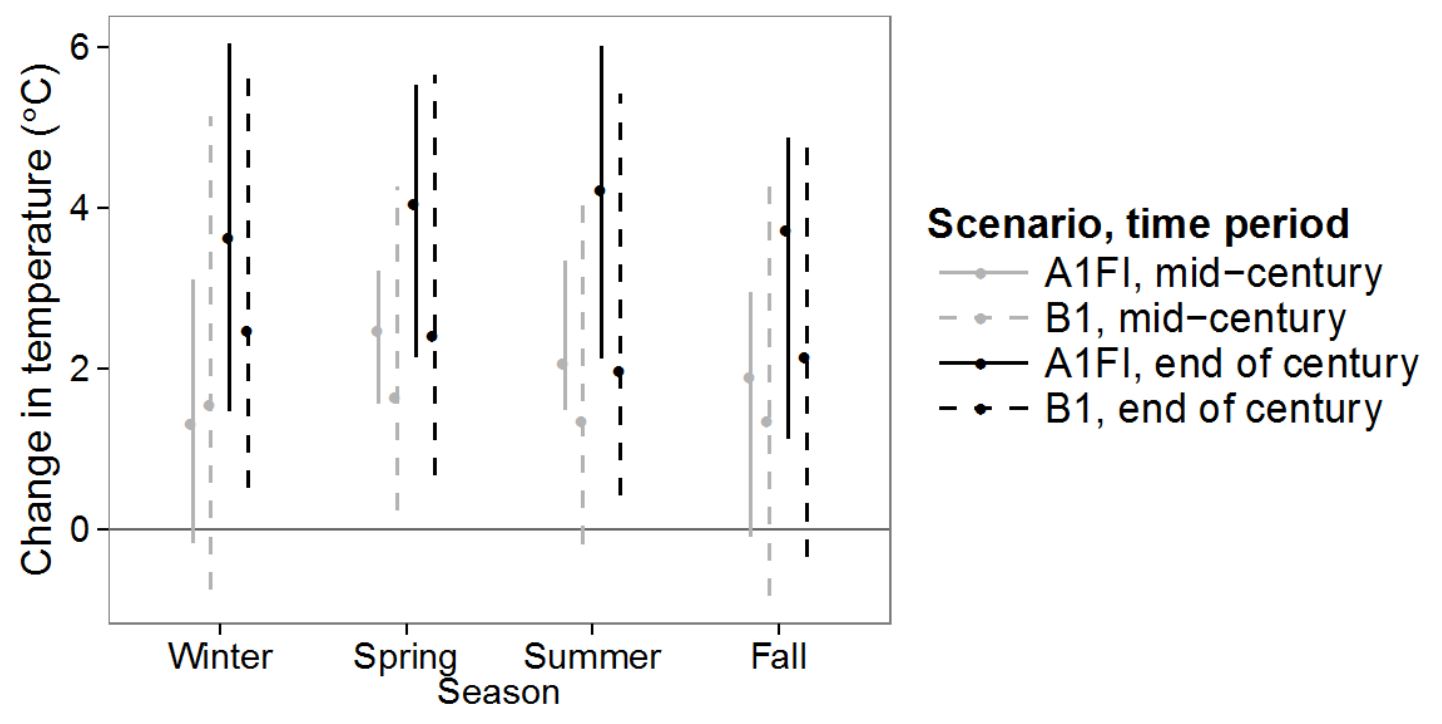

Figure 7.2. Projected change in seasonal maximum temperatures (in degrees Celsius $\left[{ }^{\circ} \mathrm{C}\right]$ ) for the middle (2040-2060) and the end of the 21st century (2080-2100), compared with the recent time period (19812000), for two emissions scenarios for the Edwards Plateau Limestone Shrubland ecological system. Solid dots and error bars represent, respectively, the means and ranges of projections across climate models under each scenario. 


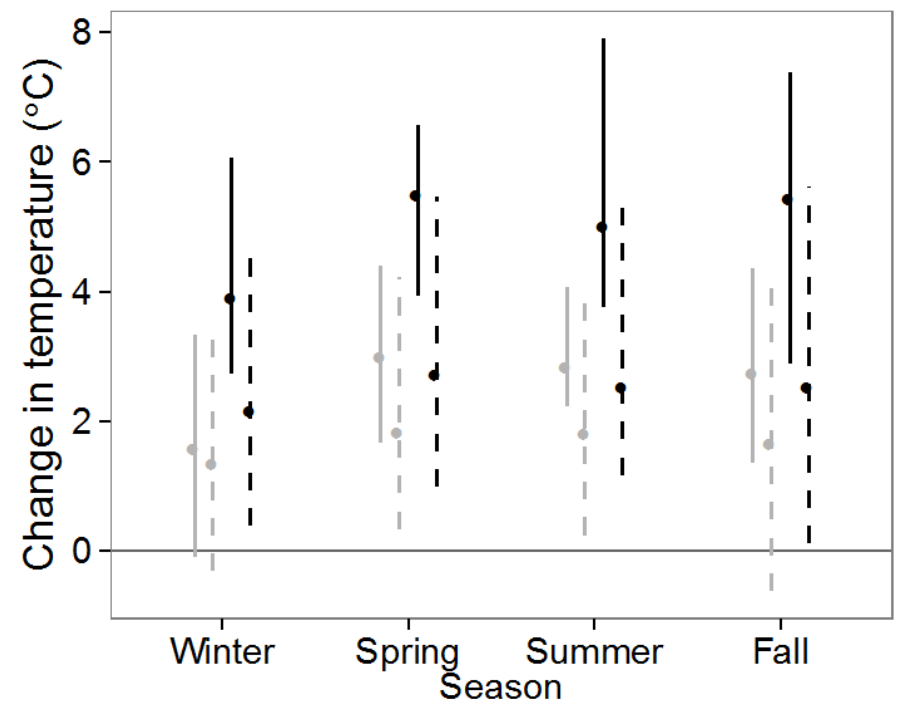

Scenario, time period

$\ldots \mathrm{A} 1 \mathrm{FI}$, mid-century

- - B1, mid-century

$\rightarrow \mathrm{A} 1 \mathrm{Fl}$, end of century

- - B1, end of century

Figure 7.3. Projected change in seasonal minimum temperature (in degrees Celsius $\left[{ }^{\circ} \mathrm{C}\right]$ ) for the middle (2040-2060) and the end of the 21st century (2080-2100), compared with the recent time period (19812000), for two emissions scenarios for the Edwards Plateau Limestone Shrubland ecological system. Solid dots and error bars represent, respectively, the means and ranges of projections across climate models under each scenario.

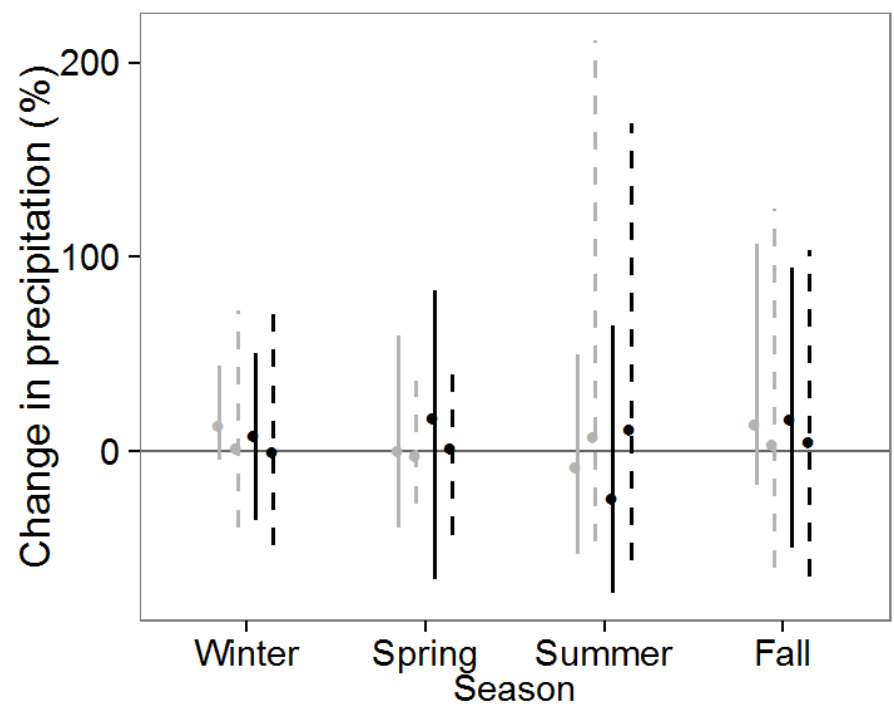

Scenario, time period

$\because \mathrm{A} 1 \mathrm{FI}$, mid-century

- B1, mid-century $\mathrm{A} 1 \mathrm{FI}$, end of century

- - B1, end of century

Figure 7.4. Projected percentage (\%) change in seasonal average precipitation for the middle (2040-2060) and the end of the 21st century (2080-2100), compared with the recent time period (1981-2000), for two emissions scenarios for the Edwards Plateau Limestone Shrubland ecological system. Solid dots and error bars represent, respectively, the means and ranges of projections across climate models under each scenario. 
Adaptive Capacity.-This ecological system occurs on various landforms in the Edwards Plateau, from plateaus to steeper slopes. In fact, it is distributed across a large range of elevations, according to our analysis (102-848 m; Appendix A). However, urbanization and overgrazing have altered and fragmented the habitat (Riskind and Diamond, 1988; Fuhlendorf and others, 1997; VanAuken, 2000). As a result, the existing patches are relatively small on average (0.74 ha, or 7,401 m²; Appendix A). Additionally, according to our analysis, only 1.2 percent of the extent is protected for conservation (Appendix A). Thus, this ecological system and the species that depend on it have declined (Pope and others, 2013).

Despite being converted by urban development in the past, the extent of this system is relatively far from developed areas on average compared with other systems in this assessment (16,637 m, or $16.6 \mathrm{~km}$; Appendix A). The average percentage of human modification for this ecological system is 52 percent, which is lower than for most other systems we studied in the Southeast (Appendix A). Pixels mapped as this system have a low average percentage of imperviousness ( 0.5 percent), but that number is projected to increase 69 percent to 0.9 -percent impervious by 2050 and 122 percent to 1.1-percent impervious by 2100 (Appendix A). Indeed, others have suggested that impacts from urbanization on ecosystems in the Edwards Plateau are likely to worsen in the future (Packard and others, 2011).

Existing research has documented a shift in the Edwards Plateau from diverse, shrublands and grasslands with low shrub cover to shrublands and woodlands with a high density of shrub and tree cover, many of which are dominated by Ashe juniper. Fire suppression and grazing have led to a conversion of diverse shrublands to woodlands, whereas grasslands are being replaced by Ashe juniper-dominated shrublands (Riskind and Diamond, 1988; Fuhlendorf and others, 1997; VanAuken, 2000). Application of prescribed fire is an important management strategy for maintaining open, diverse conditions. However, forcing complete coverage of prescribed fire across a burned site can be detrimental to shrubland diversity, and care should be taken with burning to promote a variety of fire intensities and burn conditions (Texas Parks and Wildlife Department, 2012).

The narrow regional distributions of the dominant species in this ecological system likely would make large-scale migration in response to climate change difficult. However, some migration locally and regionally among ecological systems may be possible. This system has dominant species in common with several other adjacent ecological systems, including the Edwards Plateau Limestone Savanna and Woodland ecological system, and shares some dominant species with the Edwards Plateau Mesic Canyon and the Edwards Plateau Dry-Mesic Slope Forest and Woodland systems (White and others, 2008). These systems may provide critical habitat for some species that usually rely on limestone shrubland, including the Blackcapped Vireo, in places where shrubland habitat has become less diverse (Pope and others, 2013).

Summary.-The rich diversity of woody species in the Edwards Plateau Limestone Shrubland provide important habitat for many species. The distributions of these characteristic species are restricted to the unique soils and topography of the Edwards Plateau and surrounding region. Therefore, species in this system are likely to be sensitive to changes in climate, and may be limited in their ability to adapt by migrating. Increases in minimum and maximum temperature 
are projected for this ecological system through the 21st century. Projected changes in precipitation vary across climate models, scenarios and seasons. A decrease, or even a slight increase, in precipitation could lead to more drought events under climate change, which may favor invasion by Ashe juniper, but also could lead to more replacement fires, which prevent Ashe juniper dominance. Additionally, the proliferation of Ashe juniper-dominated woodlands in areas that formerly were shrublands places further constraints on the ability of many species in this ecological system to adapt to climate change. Further research is suggested regarding the future of climate in the Edwards Plateau region, especially with respect to drought and wildfires, and on how to maximize connectivity for species of concern.

\section{References Cited}

Amos, B.B., and Gehlbach, F.R., eds., 1988, Edwards Plateau vegetation: Waco, Texas, Baylor University Press, 144 p.

Elkington, R.J., Rebel, K.T., Heilman, J.L., Litvak, M.E., Dekker, S.C., and Moore, G.W., 2012, Species-specific water use by woody plants on the Edwards Plateau, Texas: Ecohydrology, v. 7, p. 278-290.

Elliott, L., 2011, Draft description of systems, mapping subsystems, and vegetation types for Phase IV, in Diamond, D.D., and Elliott, L., eds., Texas ecological systems classification project: Missouri Resource Assessment Partnership, 65 p., accessed April 2014, at http://www.cerc.usgs.gov/morap/Assets/UploadedFiles/Projects/Texas_Ecological_Systems_Cl assification/Phase_4_Systems_Descriptions.pdf.

Flora of North America Editorial Committee, 1993, Flora of North America—North of Mexico: New York and Oxford, Oxford University Press, 16+ volumes.

Fuhlendorf, S.D., Smeins, F.E., Taylor, C.A., and Taylor, A., 1997, Browsing and tree size influences on Ashe juniper understory: Journal of Range Management, v. 50, p. 507-512.

NatureServe, 2013a, NatureServe explorer-An online encyclopedia of life, Version 7.1: Arlington, Virginia, NatureServe Web application, accessed May 2013, at http://www.natureserve.org/explorer.

NatureServe, 2013b, U.S. ecological systems National Map data.: Arlington, Virginia, NatureServe database, accessed January 2013, at http://www.natureserve.org/getData/USecologyData.jsp.

Nielsen-Gammon, J.W., 2011, The changing climate of Texas, in Schmandt, J., North, G.R., and Clarkson, J., eds., The impact of global warming on Texas (2d ed.): Austin, University of Texas Press, p. 39-68.

Packard, J.M., Gordon, W., and Clarkson, J., 2011, Biodiversity, in Schmandt, J., North, G.R., and Clarkson, J., eds., The impact of global warming on Texas (2d ed.): Austin, University of Texas Press, p. 124-156. 
Pope, T.L., Morrison, M.L., and Wilkins, R.N., 2013, Woodlands as quality breeding habitat for black-capped vireos: The Journal of Wildlife Management, v. 77, p. 994-1,001.

Riskind, D.H., and Diamond, D.D., 1988, An introduction to environments and vegetation, in Amos, B.B., and Gehlbach, F.R., eds., Edwards Plateau vegetation: Waco, Texas, Baylor University Press, p. 1-15.

Smeins, F.E., and Fuhlendorf, S.D., 1997, Biology and ecology of Ashe juniper, chap. 3 of 1997 Juniper Symposium Proceedings: College Station, Texas A\&M University, accessed April 2014, at http://texnat.tamu.edu/library/symposia/juniper-ecology-and-management.

Texas Parks and Wildlife Department, 2012, Texas conservation action plan—Edwards Plateau: Austin, Texas Parks and Wildlife Department, 35 p., accessed September 2013, at http://www.tpwd.state.tx.us/landwater/land/tcap/documents/edpt_tcap_2012.pdf.

Texas Parks and Wildlife Department, 2014, Texas ecological systems classification project: Texas Parks and Wildlife Department, accessed April 2014, at https://tpwd.texas.gov/gis/data/downloads\#EMS-T.

VanAuken, O.W., 2000, Shrub invasions of North American semiarid grasslands: Annual Review of Ecology and Systematics, v. 31, p. 197-215.

White, J., Elliott, L., and Reemts, C., 2008, LANDFIRE biophysical setting model for Edwards Plateau Limestone Shrubland-LANDFIRE biophysical setting descriptions, Map zone 35:

LANDFIRE program model, p. 81-84, accessed September 2013, at http://www.landfire.gov/national_veg_models_op2.php. 


\section{Edwards Plateau Mesic Canyon}

Ecological System Overview.-The Edwards Plateau Mesic Canyon ecological system represents a group of forested communities that occur primarily in canyons of the Balcones Canyonlands area of the Edwards Plateau ecoregion (fig. 8.1; Riskind and Diamond, 1988; NatureServe, 2013a), but also occupies similar geographical settings in other portions of the ecoregion. The system is present on slopes with high moisture availability and where there is some protection from the sun (NatureServe, 2013a). The system often occurs in bands of vegetation with widths of 9-30 m (Diamond, 1997) and that often are interspersed with savannas or shrubby openings (Texas Parks and Wildlife Department, 2013). Many of the tree species that dominate the communities in this system are fairly restricted in their ranges. They include cedar elm (Ulmus crassifolia), Lacey’s oak (Quercus laceyi), Buckley’s oak (Quercus buckleyi), Arizona walnut (Juglans major), and chinkapin oak (Quercus muehlenbergii), and sometimes Ashe juniper (Juniperus ashei) (Riskind and Diamond, 1988; NatureServe, 2013a). Fire and hurricanes do not play a substantial role in this system, but grazing by native and non-native ungulates may influence tree regeneration and species composition (Reemts and White, 2008).

The ecology of this system has not been studied extensively. For a more complete description of this ecological system, see NatureServe (2013a) or Elliott (2011).

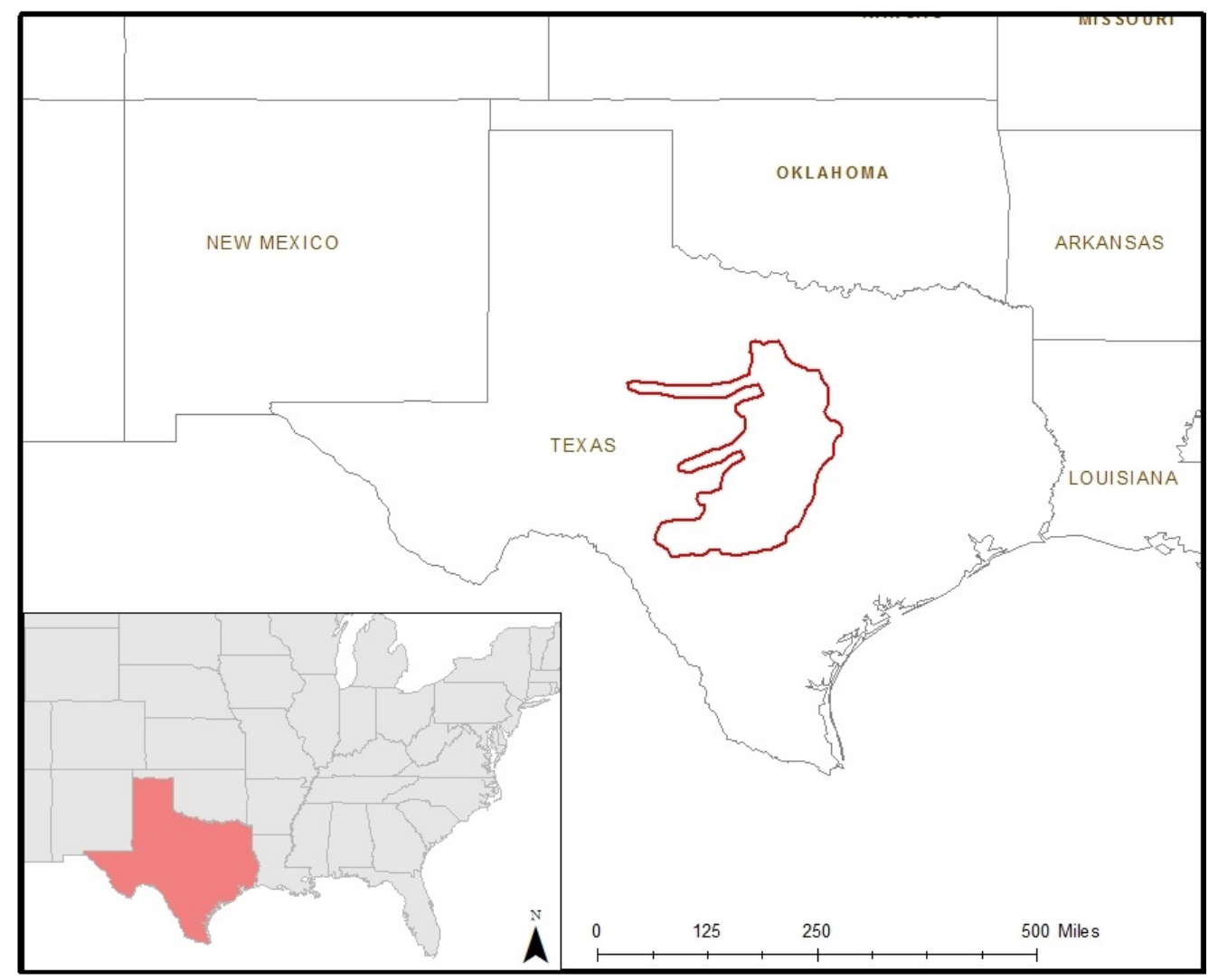

Figure 8.1. Range (outlined in top map) of the Edwards Plateau Mesic Canyon ecological system. The system covers 1.5 percent of this range, according to data from NatureServe (2013b). 
Vulnerability Status.-Relative to other ecological systems in the Southeast, the vulnerability of this ecological system is rated as Medium. Many of the major species in this community have narrow distributions and are at their range limits, and thus would be sensitive to changes in climate. The likely exposure to changes in climate is moderate, with warmer and drier conditions likely. The system has a moderate level of adaptive capacity. A large percentage of the system is protected, yet a large increase in imperviousness in the extent is projected in the future. Ashe juniper should thrive under drier future conditions, yet many other species in the system that are near their southern range limits, or are near temperature and moisture extremes in the Edwards Plateau, will need assistance adapting to change.

Sensitivity.-Our analysis shows that this system occurs in areas where temperature ranges from an average maximum of $33^{\circ} \mathrm{C}$ in the summer (Appendix B) to an average winter minimum of $10^{\circ} \mathrm{C}$ (Appendix B). Precipitation generally is highest in the summer compared with other seasons, followed by fall (Appendix B).

Some tree species in this ecological system, including Lacey’s oak, chinkapin oak, and cedar elm, are near their southern range limits or are near temperature and moisture extremes in the Edwards Plateau. For example, most of the range of cedar elm has a generally moister and cooler climate than in the Edwards Plateau region (Burns and Honkala, 1990). Therefore, these species are likely to be sensitive to changes in climate in this region.

Although fire in the Edwards Plateau historically was fairly frequent, this ecological system occurs in topographically sheltered sites (Amos and Gehlbach, 1988) with little fine fuel accumulation. Species dominant in this system, and especially Ashe juniper, are sensitive to fire. In areas with more frequent, low-intensity fires, this system transitions to grassland or shrubland, and regeneration of Ashe juniper can be slow after fire (Fuhlendorf and others, 1996; Reemts and Hansen, 2008).

Exposure.-Analysis of projected change in climate for the Edwards Plateau Mesic Canyon ecological system shows increases in maximum and minimum temperatures for most models, scenarios, and time periods (figs. 8.2 and 8.3). Overall, projected changes in minimum temperature are greater than for maximum temperature. The mean projected changes in maximum temperature are greatest in spring and summer, with a change of $4{ }^{\circ} \mathrm{C}$ projected under the A1FI scenario by the end of this century for those seasons, and less change projected during the fall and winter. On the other hand, mean projected increases in minimum temperature are greatest in spring and fall, when climate models project more than $5{ }^{\circ} \mathrm{C}$ increases by the end of the century under the A1FI emissions scenario.

Projected percentage changes in precipitation for this ecological system show variation among climate models for each season, emissions scenario, and time period (fig. 8.4). In all cases, the range of projections crosses 0 , indicating much uncertainty among climate models, with at least one model projecting a decrease and one projecting an increase under all scenarios and time periods. The mean projected changes in precipitation vary from positive to negative across emissions scenarios and time periods, with the exception of fall, when the mean projected change is positive in all cases. For summer under the B1 emissions scenario, the range of projected change is large, with some global climate models projecting increases by as much as 270 percent 
and 238 percent by the middle and end of the century, respectively, whereas other models project moderate declines in precipitation for the same periods. Nielsen-Gammon (2011) found that fall and winter precipitation has increased since the mid-20th century across Texas, but is projected to decline in the first half of the 21st century. That study also showed disagreement among climate models (Nielsen-Gammon, 2011). A decrease in precipitation, or even a slight increase, when coupled with the projected increases in temperature, could mean increased drought frequency and severity and more water stress (Nielsen-Gammon, 2011).

More drought may negatively impact some species like cedar elm that are at the southern end of their ranges. According to the U.S. Forest Service Climate Change Tree Atlas, cedar elm has very low abundance and importance in the Edwards Plateau region, and that is likely to remain the same under low- and high-emissions scenarios (Prasad and others, 2007). However, this result should be interpreted with caution because U.S. Forest Service Forest Inventory and Analysis data generally are sparse on the Edwards Plateau. The other major tree species present in this ecological system either were not modeled for the Edwards Plateau region, or were not included in the atlas.

Projected changes in the standard deviation, or variability, of temperature and precipitation for this ecological system show a high degree of uncertainty among climate models. Both the means and ranges of change in standard deviation for maximum and minimum temperatures vary considerably (Appendix C). The mean change in the standard deviation of precipitation is greater than 1 in nearly all cases, indicating an increase in variability. Some climate models project variability in summer precipitation to increase by as much as four-fold by the end of the century under the B1 scenario. Therefore, although model projections are variable, as a whole, they predict an increase in variability for precipitation in the future (Appendix C).

Little information is available about potential changes in disturbances and drought in the Edwards Plateau region (Texas Parks and Wildlife Department, 2012). Given the projected increase in temperature and decrease in precipitation, it is likely that the area burned by wildfires in Texas will increase in the future (Nielsen-Gammon, 2011). If wildfires increase, Ashe juniper could become less abundant in this system. 


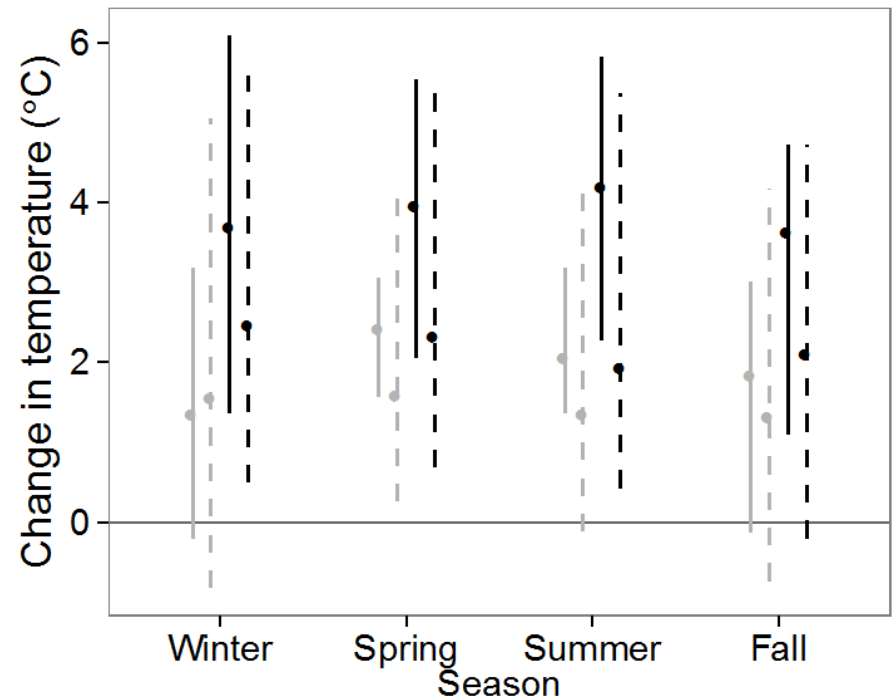

Scenario, time period

$\ldots \mathrm{A} 1 \mathrm{FI}$, mid-century

- - B1, mid-century

$\rightarrow \mathrm{A} 1 \mathrm{Fl}$, end of century

- - B1, end of century

Figure 8.2. Projected change in seasonal maximum temperatures (in degrees Celsius $\left[{ }^{\circ} \mathrm{C}\right]$ ) for the middle (2040-2060) and the end of the 21st century (2080-2100), compared with the recent time period (19812000), for two emissions scenarios for the Edwards Plateau Mesic Canyon ecological system. Solid dots and error bars represent, respectively, the means and ranges of predictions across climate models under each scenario.

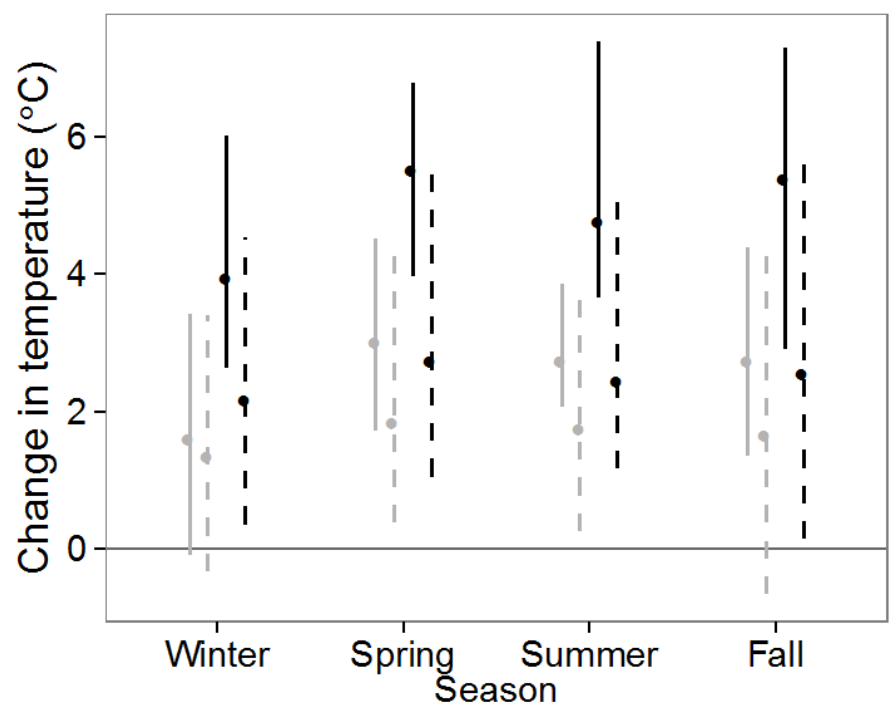

Scenario, time period

$\ldots$ A1FI, mid-century

- B1, mid-century

$\rightarrow \mathrm{A} 1 \mathrm{FI}$, end of century

- - B1, end of century

Figure 8.3. Projected change in seasonal minimum temperature (in degrees Celsius $\left[{ }^{\circ} \mathrm{C}\right]$ ) for the middle (2040-2060) and the end of the 21st century (2080-2100), compared with the recent time period (19812000), for two emissions scenarios for the Edwards Plateau Mesic Canyon ecological system. Solid dots and error bars represent, respectively, the means and ranges of predictions across climate models under each scenario. 


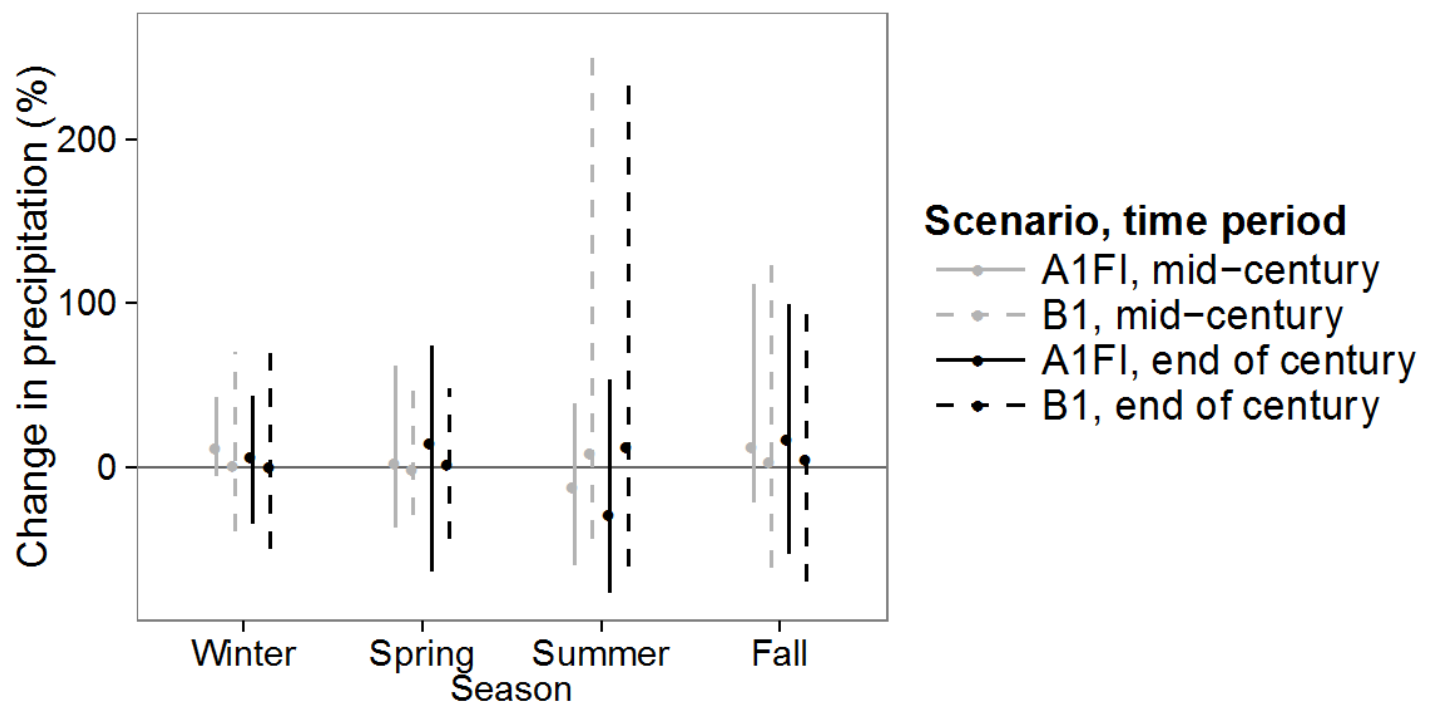

Figure 8.4. Projected percentage (\%) change in seasonal average precipitation for the middle (2040-2060) and the end of the 21st century (2080-2100), compared with the recent time period (1981-2000), for two emissions scenarios for the Edwards Plateau Mesic Canyon ecological system. Solid dots and error bars represent, respectively, the means and ranges of predictions across climate models under each scenario.

Adaptive Capacity.-This mesic canyon system is relatively rare, occurring within fairly narrow topographic and moisture conditions in fire-sheltered scarps. The mean patch size in this system is relatively small, at 0.36 ha (3,575 $\mathrm{m}^{2}$; Appendix A). As a result, habitat connectivity within the system likely is low. However, a relatively large 39 percent of this system is protected (Appendix A), making management of this system for climate change more feasible than many other systems in the Southeast. Probably because much of the system is protected, this system has less evidence of direct human influence than other systems in the Southeast. The distance from patches of this system to urban areas is fairly large $(1,707 \mathrm{~m}$, or $1.7 \mathrm{~km}$; Appendix A), the mean percentage of impervious surface for the system's extent is relatively low (1.5percent impervious on average; fig. 8.4), and the pixels mapped as this ecological system have a lower degree of human modification on average (52 percent, Appendix A). However, the mean percentage of impervious surface for the system's extent is projected to increase 86 percent to 2.7-percent impervious by 2050, and 135 percent to 3.4-percent impervious by 2100 compared to the 2010 value (Appendix A). This analysis agrees with Packard and others (2011), who found that impacts from urbanization on ecosystems in the Edwards Plateau are likely to worsen in the future.

Ashe juniper may be better able than other species in the region to adapt to climate change. Forests containing Ashe juniper have invaded former grassland and shrubland areas in the Edwards Plateau region because of fire suppression and the introduction of domestic grazing animals (Riskind and Diamond, 1988; Fuhlendorf and others, 1997). As a result, the species is present at a greater density across a larger area in the Edwards Plateau than it would have been historically (Amos and Gehlbach, 1988). Additionally, the species is able to withstand low soil 
water potentials (Elkington and others, 2012). Thus, this species may thrive under drought conditions or decreased precipitation, as long as fires do not become more common.

Aside from Ashe juniper, many of the tree species in this ecological system may have low adaptive capacity. The biogeographic distributions of many of these species are relatively narrow. For example, the range of Lacey's oak is restricted to the Edwards Plateau and northeastern Mexico (Flora of North America Editorial Committee, 1993). Buckley's oak is restricted to limestone ridges, slopes, and creek bottoms in Texas and Oklahoma (Flora of North America Editorial Committee, 1993). As climate conditions shift, the narrow distribution of species in this system likely will present challenges for adaptation and migration of these species, and the others associated with them in this ecological system. Additionally, the oaks in this system are susceptible to oak wilt, a disease caused by the fungus Ceratocystis fagacearum. Management and prevention of the disease will be important for maximizing the resilience of these species, and thus their capacity to adapt to climate change.

Although many of the species in this ecological system are range-restricted, they are not endemic to this ecological system. There are several similar systems nearby that contain some of the same species. For example, the Edwards Plateau Dry-Mesic Slope Forest and Woodland system occurs on adjacent sites that are more mesic than those in this system. That system covers five times the extent of the mesic canyon system, and contains many of the same tree and shrub species. Ashe juniper occurs in other adjacent systems where fire has been limited, including some portions of the Edwards Plateau Limestone Savanna and Woodland system, which is a matrix system across the Edwards Plateau. Ensuring connectivity among these systems would help many species in the Edwards Plateau Mesic Canyon system adapt to climate change. The potential future ranges of the species in this ecological system, as well as their ability to migrate in response to climate change, merits further attention from researchers.

Summary.-This ecological system is restricted in its extent, occurring across a small area of the Edwards Plateau on fire-sheltered mesic scarps. The system contains many species that are restricted in their range, and several dominant species are at their range limits, or are restricted to the cool and moist sites present in the geophysical setting occupied by this system. Therefore, these species are likely to be sensitive to warmer temperatures. Climate models project an increase in maximum and minimum temperatures, on average, for all seasons through the end of the 21st century. Projected changes in precipitation vary across climate models, scenarios, and seasons. A decrease or even a slight increase in precipitation could lead to more drought events under climate change, which could lead to more stress for the species in this system, such as cedar elm, that are already at the southern limits of their range. More information is needed regarding projected changes in climate in this region, particularly with respect to changes in disturbance regimes, including wildfires, hurricanes, droughts, and other extreme weather events. Additionally, further research regarding how the distribution of suitable conditions for major species in this system may change in response to climate would be useful. 


\section{References Cited}

Amos, B.B., and Gehlbach, F.R., eds., 1988, Edwards Plateau vegetation: Waco, Texas, Baylor University Press, 44 p.

Burns, R.M., and Honkala, B.H., tech. coords., 1990, Silvics of North America-Volume 2, Hardwoods: U.S. Forest Service, Agriculture Handbook 654, 877 p., accessed June 2013, at http://www.na.fs.fed.us/spfo/pubs/silvics_manual/table_of_contents.htm.

Diamond, D.D., 1997, An Old-Growth Definition for Western Juniper Woodlands; Texas Ashe Juniper Dominated or Codominated Communities: U.S. Forest Service, Southern Research Station, Asheville, North Carolina, General Technical Report SRS-15, 10 p.

Elkington, R.J., Rebel, K.T., Heilman, J.L., Litvak, M.E., Dekker, S.C., and Moore, G.W., 2012, Species-specific water use by woody plants on the Edwards Plateau, Texas: Ecohydrology, v. 7, p. 278-290.

Elliott, L., 2011, Draft description of systems, mapping subsystems, and vegetation types for Phase IV, in Diamond, D.D., and Elliott, L., eds., Texas Ecological Systems Project: Missouri Resource Assessment Partnership, 65 p., accessed April 2014, at http://www.cerc.usgs.gov/morap/Assets/UploadedFiles/Projects/Texas_Ecological_Systems_Cl assification/Phase_4_Systems_Descriptions.pdf.

Flora of North America Editorial Committee, 1993, Flora of North America—North of Mexico: New York and Oxford, Oxford University Press, 16+ volumes.

Fuhlendorf, S.D., Smeins, F.E., and Grant, W.E., 1996, Simulation of a fire-sensitive ecological threshold-A case study of Ashe juniper on the Edwards Plateau of Texas, USA: Ecological Modelling, v. 90, p. 245-255.

Fuhlendorf, S.D., Smeins, F.E., Taylor, C.A., and Taylor, A., 1997, Browsing and tree size influences on Ashe juniper understory: Journal of Range Management, v. 50, p. 507-512.

NatureServe, 2013a, NatureServe explorer-An online encyclopedia of life, Version 7.1: Arlington, Virginia, NatureServe Web application, accessed May 2013, at http://www.natureserve.org/explorer.

NatureServe, 2013b, U.S. ecological systems National Map data: Arlington, Virginia, NatureServe database, accessed January 2013, at http://www.natureserve.org/getData/USecologyData.jsp.

Nielsen-Gammon, J.W, 2011, The changing climate of Texas, in Schmandt, J., North, G.R., and Clarkson, J., eds., The impact of global warming on Texas (2d ed.): Austin, University of Texas Press.

Packard, J.M., Gordon, W., and Clarkson, J., 2011, Biodiversity, in Schmandt, J., North, G.R., and Clarkson, J., eds., The impact of global warming on Texas (2d ed.): Austin, University of Texas Press, p. 124-156. 
Prasad, A.M., Iverson, L.R., Matthews, S., and Peters, M., 2007, A climate change atlas for 134 forest tree species of the Eastern United States: U.S. Forest Service database, Northern Research Station, Delaware, Ohio, accessed May 2013, at http://www.nrs.fs.fed.us/atlas/tree.

Reemts, C.M., and Hansen, L.L., 2008, Slow recolonization of burned oak-juniper woodlands by Ashe juniper (Juniperus ashei)—Ten years of succession after crown fire: Forest Ecology and Management, v. 255, p. 1,057-1,066.

Reemts, C., and White, J., 2008, LANDFIRE Biophysical Setting Model for Edwards Plateau Mesic Canyon-LANDFIRE biophysical setting descriptions, Map zone 35: LANDFIRE program model, p. 134-137, accessed September 2013, at http://www.landfire.gov/national_veg_models_op2.php.

Riskind, D.H., and Diamond, D.D., 1988, An introduction to environments and vegetation, in Amos, B.B., and Gehlbach, F.R., eds., Edwards Plateau vegetation: Waco, Texas, Baylor University Press, p. 1-15.

Texas Parks and Wildlife Department, 2012, Texas conservation action plan-Edwards Plateau: Austin, Texas Parks and Wildlife Department, 35 p., accessed September 2013, at http://www.tpwd.state.tx.us/landwater/land/tcap/documents/edpt_tcap_2012.pdf.

Texas Parks and Wildlife Department, 2013, Rare plant communities of Texas_Edwards Plateau lacey oak-ashe juniper woodland: Austin, Texas Parks and Wildlife Department, accessed September 2013, at https://tpwd.texas.gov/huntwild/wild/wildlife_diversity/nongame/communities/edwardsplateau/lacey-oak.phtml. 


\section{Manglar Costero del Caribe (Caribbean Coastal Mangrove)}

Ecological System Overview.-The Caribbean Coastal Mangrove ecological system is distributed along coastal fringes in the Greater Antilles, including Puerto Rico and the U.S. Virgin Islands (fig. 9.1; NatureServe, 2003). Species richness in the system is low, and the system is dominated by red mangrove (Rhizophora mangle), which grows on aerial roots above the water. This coastal mangrove system is habitat for the imperiled Yellow-shouldered Blackbird (Agelaius xanthomus), and the vulnerable White-crowned Pigeon (Patagioenas leucocephala). Mangroves in general are widely known to provide many ecosystem services, including coastal flooding protection, nutrient cycling, and fish nurseries (Walters and others, 2008; Polidoro and others, 2010). In particular, in extreme storm events, red mangrove acts as a physical barrier to storm surges and flooding because of its aerial root system (Dahdouh-Guebas and others, 2005). Therefore, loss of mangroves has major economic and ecological consequences (Polidoro and others, 2010). The coastal mangrove system is distinguished from the Caribbean Estuarine Mangrove ecological system because that other system is dominated by white mangrove (Laguncularia racemosa) and black mangrove (Avicennia germinans) species, and is less subject to tidal flooding than the coastal mangrove system. Succession in mangrove systems begins with red mangrove invading small islands and coastlines, followed by black mangrove in more saline inland areas, and emergence of salt flats in the most saline areas (Cintrón and others, 1978). For a more complete description of this ecological system, see Cintrón and others (1978).

Because the existing land-cover data and some of the scientific literature do not distinguish between coastal and estuarine mangroves, much of our assessment did not distinguish between the two types. We note in the text whether we are referring to "mangroves" (both types), or "coastal mangroves" (this ecological system only). 


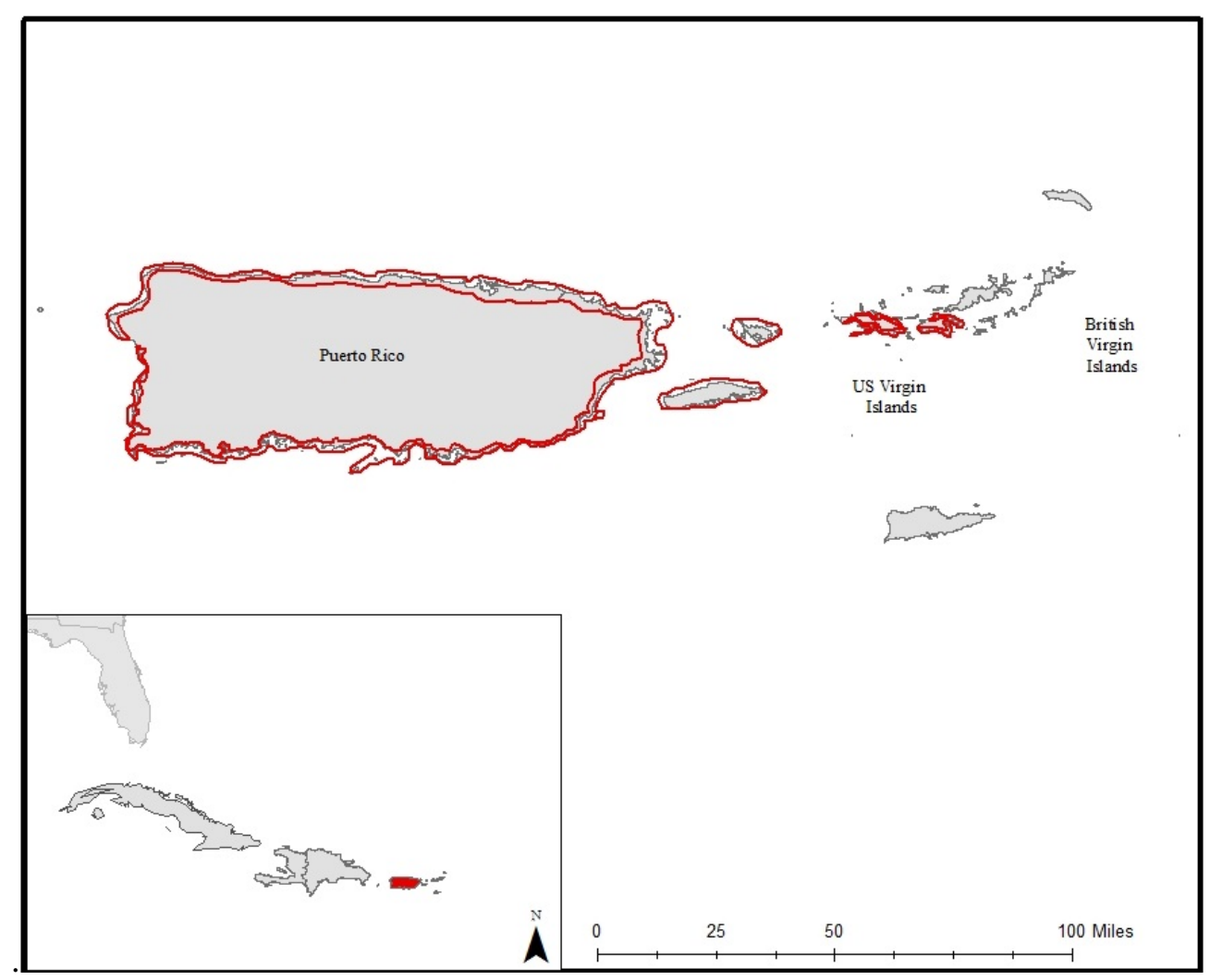

Figure 9.1. Range of mangroves in Puerto Rico and the U.S. Virgin Islands. Mangroves cover 4.4 percent of this range, according to data from Puerto Rico and U.S. Virgin Islands Gap Analysis Projects (Gould and others, 2007, 2012).

Vulnerability Status.-Relative to other ecological systems in the Southeast, the vulnerability of this ecological system is rated as High because of its sensitivity to sea level rise, precipitation, and storm events, along with its likely high exposure to changes in those factors. Overall, the system has some ability to adapt to those changes where topographic relief is minimal and urbanization levels are low. However, in many places the landscape is highly developed and topography is not conducive to migration, presenting challenges for adaptation.

Sensitivity.-In Puerto Rico and the U.S. Virgin Islands, where mangroves occur, the average summer maximum temperatures are $26^{\circ} \mathrm{C}$ and average winter minimum temperatures are $14{ }^{\circ} \mathrm{C}$ (Appendix B). Precipitation is slightly higher in the summer and fall across the extent of mangroves (Appendix B). The distribution of all mangroves is dependent on seawater temperature, and the red mangrove tree occurs in areas where the average winter seawater isotherm is greater than $20^{\circ} \mathrm{C}$ (Hill, 2001).

This ecological system is sensitive to sea level, precipitation, drought, and storm events. The red mangrove trees that make up this system are particularly sensitive to soil salinity, which is linked to sea level and climate. During droughts, the soil becomes more saline, and coastal mangroves can decrease in area, whereas wet periods cause this system to expand (Cintrón and others, 1978). However, mangrove species, including red mangrove, have adaptations such as 
aerial roots that allow them to live in muddy, saline conditions, which may allow them to stay in place for a limited amount of time as salinity levels change (McLeod and Salm, 2006).

Hurricanes or other extreme storm events can cause mass mortality in mangrove systems because of increased inundation and erosion of the substrate (Piou and others, 2006).

Exposure.-According to the Millennium Ecosystem Assessment (2005), climate change is likely to contribute to the loss of mangrove forests worldwide. In particular, future changes in sea level, precipitation, drought, and storm events could affect the distribution of this ecological system.

Analysis of projected change in climate for the portion of this ecological system in Puerto Rico shows increases in maximum and minimum temperatures for all seasons, models, and scenarios, with more change projected under the A1FI scenario, especially toward the end of the century, than in the B1 scenario (figs. 9.2 and 9.3). Under the A1FI scenario, the mean projected change in maximum temperature for every season is greater than $7^{\circ} \mathrm{C}$ by the end of this century, with as much as a $16{ }^{\circ} \mathrm{C}$ increase projected by some models for spring and winter. Much more change is projected for minimum temperature, with a mean increase of between $8{ }^{\circ} \mathrm{C}$ and $9{ }^{\circ} \mathrm{C}$ projected under the A1FI scenario for every season by the end of the century. Some models project as much as a $19{ }^{\circ} \mathrm{C}$ increase in the fall and summer by the end of the century. Under the B1 emissions scenario, a smaller amount of change is projected for both maximum and minimum temperatures. Mean changes under that scenario for maximum and minimum temperatures, respectively, are projected to be between $2{ }^{\circ} \mathrm{C}$ and $5{ }^{\circ} \mathrm{C}$ for every season. Increases in temperature likely would have minimal effect on the mangrove species in this ecological system because the ranges of those species include warmer areas closer to the equator.

Mean precipitation projections across climate models for this ecological system show increases for some seasons and time periods, and decreases in other cases (fig. 9.4). On average, increases are projected for winter and fall, and a decrease is projected for summer. In spring, an increase is projected by mid-century, with a decrease by the end of the century. However, in each case, the range of projections crosses 1 and spans a large range, indicating much uncertainty in the model projections not only about the amount of change but also the direction of change in precipitation.

Projected changes in the standard deviation, or variability, of temperature and precipitation also show a high degree of uncertainty among climate models (Appendix C). On average, changes in standard deviation for maximum and minimum temperature are almost all positive, meaning that an increase in variability is expected. On average, projected change in variability of precipitation is positive in all cases except for summer, meaning that climate models on average project an increase in variability of precipitation in the winter, spring, and fall. Summer variability in precipitation is expected to decrease on average. However, for each of these climate variables, the ranges of projections cross 1, indicating uncertainty among climate models in the direction of change in variability.

Our results agree with other studies that have projected a decrease in precipitation along with some uncertainty in these projections (Jacobs and others, 2013a). Decreased rainfall would 
lead to reduced mangrove area, but if rainfall increases, it could mean areas with suitable precipitation for coastal mangroves would become more common. Likewise, the future of drought in the Caribbean is unclear, but decreased precipitation and increased temperature are likely to lead to more frequent drought. If that is the case, soil salinity in this coastal mangrove system could increase, leading to a reduction in area of this system.

We analyzed the projected inundation of mangroves in Puerto Rico and the U.S. Virgin Islands owing to sea level rise under a 1- and 6-ft (0.3- and 1.8-m) rise in sea level, using National Oceanic and Atmospheric Administration data. Rising sea level is projected to inundate a substantial portion of mangroves, especially in Puerto Rico, with more than 90 percent of mangroves expected to be inundated under a 6-ft (1.8-m) rise in sea level there (Appendix A). The percentages affected in Puerto Rico under either a 1- or 6-ft (0.3- or 1.8-m) rise in sea level are larger than for any other ecological system included in this analysis. The effects of sea level rise on this ecological system are likely to vary depending on the location. Oceanward areas may become flooded, and thus less suitable for mangroves, whereas inland areas may be more tidally flooded, and therefore potentially more suitable for coastal mangroves (Cambers and others, 2008). This change, along with potential changes in precipitation amount and variability in the future, means that local changes could include loss or gain in area of coastal mangrove (Ellison and Farnsworth, 1996; Cambers and others, 2008; Jacobs and others, 2013b). The net result of sea level rise may be an inland migration of this ecological system (Jacobs and others, 2013b). However, migration only could occur in places that are not heavily fragmented by urbanization and other land-use change, and would be subject to topographical, edaphic, and other environmental constraints. Furthermore, the rate at which sea level rise occurs would affect the ability of this system to adapt to that change (see section "Adaptive Capacity” for more discussion of the rate of change). Therefore, at any given local area, there may be an increase or a decrease in red mangrove extent.

Hurricane frequency and intensity are likely to increase in the future in the Atlantic and Caribbean (Webster and others, 2005). Additionally, sea level rise also likely will lead to more intense storms, including hurricanes (Jacobs and others, 2013a). An increase in storms, especially combined with sea level rise, could result in reduced area of this ecological system if the change happens faster than red mangrove is able to migrate inland (Jacobs and others, 2013b). Therefore, research on the pace at which red mangrove trees can migrate, relative to the expected rate of sea level rise, is an important area of future research.

Sea surface and air temperatures are projected to warm in the future in the Caribbean (Jacobs and others, 2013a). However, these projected increases in sea surface temperature are not likely to affect mangrove species (Jacobs and others, 2013b). 


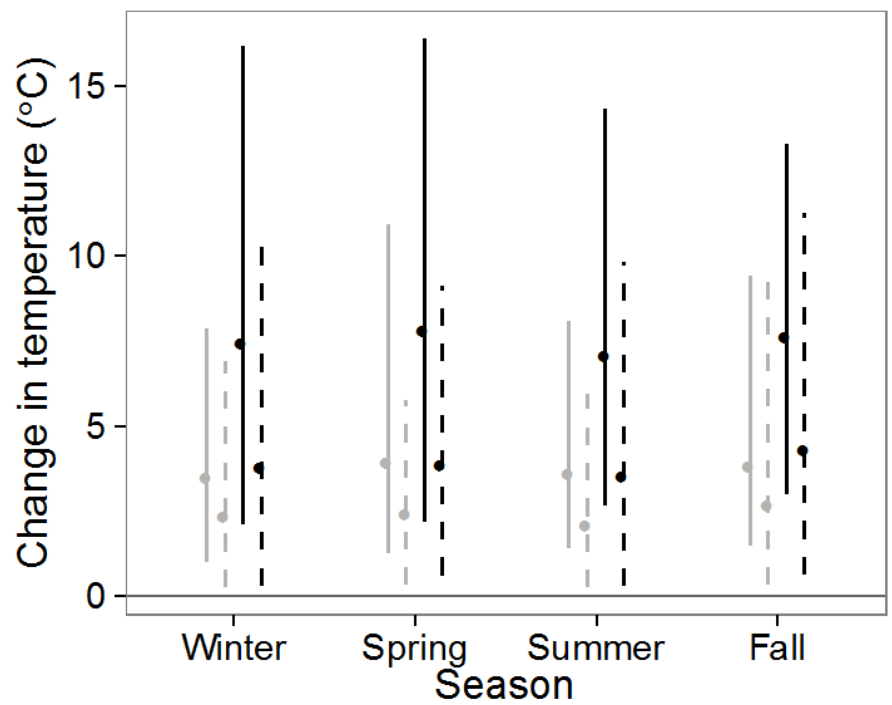

Scenario, time period A1FI, mid-century

- B1, mid-century

$\rightarrow \mathrm{A} 1 \mathrm{Fl}$, end of century

- - B1, end of century

Figure 9.2. Projected change in seasonal maximum temperatures (in degrees Celsius $\left[{ }^{\circ} \mathrm{C}\right]$ ) for the middle (2040-2060) and the end of the 21st century (2080-2100), compared with the recent time period (19812000), for two emissions scenarios for the Caribbean Coastal Mangrove ecological system in Puerto Rico. Solid dots and error bars represent, respectively, the means and ranges of projections across climate models under each scenario.

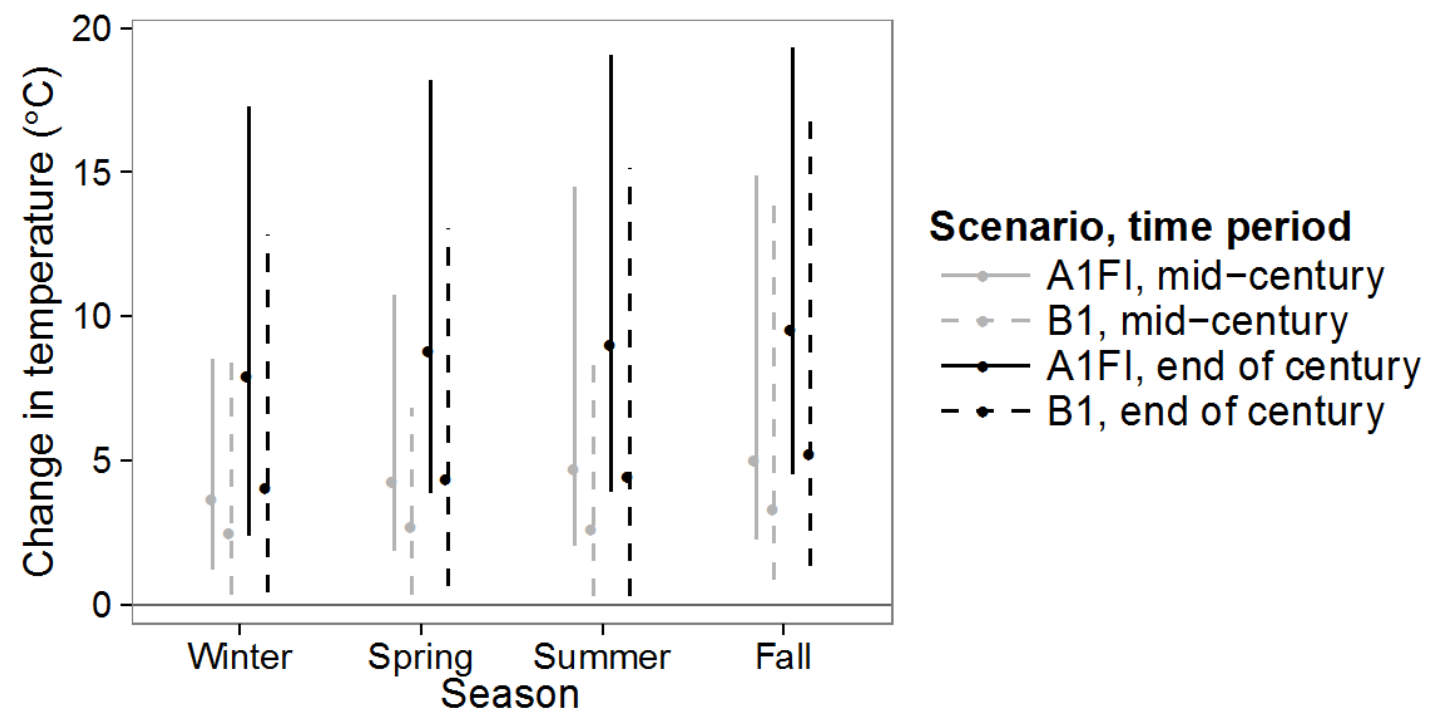

Figure 9.3. Projected change in seasonal minimum temperature (in degrees Celsius $\left[{ }^{\circ} \mathrm{C}\right]$ ) for the middle (2040-2060) and the end of the 21st century (2080-2100), compared with the recent time period (19812000), for two emissions scenarios for the Caribbean Coastal Mangrove ecological system in Puerto Rico. Solid dots and error bars represent, respectively, the means and ranges of projections across climate models under each scenario. 


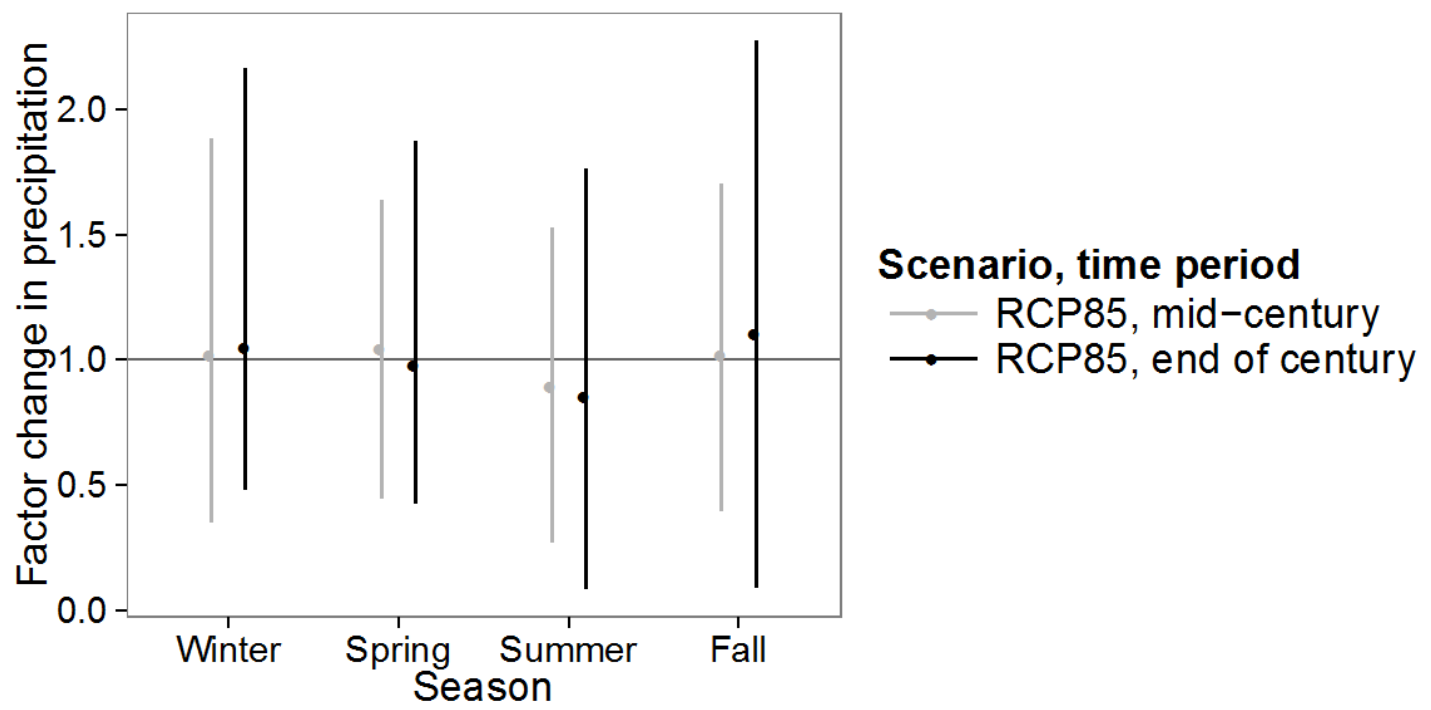

Figure 9.4. Projected factor change in seasonal average precipitation for the middle (2040-2060) and the end of the 21st century (2080-2100), compared with the recent time period (1981-2000), for a highemissions scenario for the Caribbean Coastal Mangrove ecological system in Puerto Rico. Solid dots and error bars represent, respectively, the means and ranges of projections across climate models under the scenario. Values of less than 1 indicate a decrease in precipitation, whereas values of greater than 1 indicate an increase in precipitation.

Adaptive Capacity.- In the past, a large area of mangroves across the Caribbean was cleared for agriculture. In Puerto Rico, for example, 45 percent of mangroves were cleared between 1800 and 1940 (Martinuzzi and others, 2009). As a result of this land clearing, many of the species that depend on mangroves for habitat were affected. For example, populations of the White-crowned Pigeon, which breeds in coastal mangroves, declined in part because of habitat destruction (Wiley, 1979). However, owing in part to habitat management efforts, populations of this species had increased by the early 21st century (McNair, 2008).

Since 1972 all mangroves in Puerto Rico have been legally protected, whether or not they are in an area that is formally managed for conservation stewardship. Additionally, 33 percent of mangroves in Puerto Rico are on lands managed for conservation. Martinuzzi and others (2009) analyzed changes in Puerto Rico mangrove extent and found that since legal protection of all mangroves was introduced, the area of mangroves on the island has increased, even as human population has increased. Their results are promising for conservation of this ecological system in Puerto Rico, although across much of the Caribbean, to date, there has been a net loss of mangroves (Bacon, 2000).

In the U.S. Virgin Islands, there is no similar protection for all mangroves. However, 39 percent of mangroves are on conservation lands. We suggest that formal protection of all mangroves be a priority in the U.S. Virgin Islands and across the Caribbean. 
Despite being relatively well protected, mangroves in Puerto Rico and the U.S. Virgin Islands are fragmented and near urban areas. Our analysis shows that the average distance from mangroves to developed areas is $966 \mathrm{~m}$ in Puerto Rico, and $167 \mathrm{~m}$ in the U.S. Virgin Islands. Based on land-cover data, the average patch size for mangroves in Puerto Rico is 22,130 $\mathrm{m}^{2}$ (2.2 ha), and 2,114 $\mathrm{m}^{2}$ (0.21 ha) in the U.S. Virgin Islands. Martinuzzi and others (2009) also showed that mangroves in Puerto Rico are highly fragmented and that many patches are near urban areas. Therefore, if inland areas become more suitable for mangroves as the result of changes in climate and sea level rise, this system will only be able to migrate inland in areas where fragmentation and urbanization levels are low.

The capacity of this ecological system to adapt to rising sea level will depend on the degree and pace of sea level rise, as well as condition of the landscape into which the system needs to migrate. If sea level rise occurs quickly and inundates a large area, the red mangroves and other species in this system will need to migrate quickly. Little research has been done on the pace at which mangrove trees could migrate, and this is a suggested area for future research. Additionally, the land cover and land use surrounding mangroves are among the important environmental and landscape factors that contribute to the ability of mangroves to adapt to sea level rise globally (McLeod and Salm, 2006). Mangroves that have the highest adaptive capacity are those with room to move landward - those surrounded by low-lying areas that are not developed and contain either other mangrove forests or salt flats (McLeod and Salm, 2006). Therefore, the existing fragmentation of this ecological system and its proximity to urban areas could make migration difficult under sea level rise. If coastal mangroves cannot adapt by migrating landward, populations of species that depend on the ecological system, such as the White-crowned Pigeon and Yellow-shouldered Blackbird, may face additional threats. Therefore, attention to the landscape surrounding coastal mangroves is important to ensure that habitats are connected and that there is room for the ecological system to migrate as sea level rises.

Summary.-The Caribbean Coastal Mangrove ecological system is present on coastal fringes throughout the Caribbean. It is sensitive to soil salinity, which is related to sea level, precipitation, and drought. Its extent and distribution likely will be affected most by sea level rise, along with changes in precipitation and storm events. As sea level rises, the oceanward range boundary of this system may retract, and its inland range may expand, at least in some local areas. Adaptation may be possible if the migration of the red mangrove is able to keep up with sea level rise. Adaptation to these changes will be easiest in areas with little urban or agricultural development, and where habitat fragmentation is low and the topographic relief is minimal so the system has room to migrate. Legal protection of all mangroves has been shown to contribute to their recovery in Puerto Rico. Further research could focus on the interacting effects of sea level rise, precipitation changes, and changes in runoff on this ecological system. In particular, an important area of future research is how fast the red mangrove is able to migrate inland, compared to the rate of sea level rise. 


\section{References Cited}

Bacon, P., 2000, Redefining tropical coastal wetlands: InterCoast, Fall 2000, no. 37, p. 12-13.

Cambers, G., Claro, R., Juman, R., and Scott, S., 2008, Climate change impacts on coastal and marine biodiversity in the insular Caribbean-Report of Working Group II, Climate change and biodiversity in the insular Caribbean: Trinidad, West Indies, Caribbean Natural Resources Institute, $87 \mathrm{p}$.

Cintrón, G., Lugo, A.E., Pool, D.J., and Morris, G., 1978, Mangroves of arid environments in Puerto Rico and adjacent islands: Biotropica, v. 10, p. 110-121.

Dahdouh-Guebas, F., Jayatissa, L.P., Di Nitto, D., Bosire, J.O., Lo Seen, D., and Koedam, N., 2005, How effective were mangroves as a defence against the recent tsunami?: Current Biology, v. 15, p. R443-R447.

Ellison, A.M., and Farnsworth, E.J., 1996, Anthropogenic disturbance of Caribbean mangrove ecosystems_-Past impacts, present trends, and future predictions: Biotropica, v. 28, p. 549565.

Gould, W.A., Alarcón, C., Fevold, B., Jiménez, M.E., Martinuzzi, S., Potts, G., Solórzano, M., and Ventosa, E., 2007, Puerto Rico Gap Analysis Project-Final report: U.S. Geological Survey and the USDA Forest Service International Institute of Tropical Forestry, Moscow, Idaho, and Rio Piedras, Puerto Rico, 159 p.

Gould, W.A., Potts, G., Quiñones, M., and Solórzano, M., 2012, Virgin Islands GAP Land Cover: U.S. Forest Service, International Institute of Tropical Forestry, Río Piedras, Puerto Rico.

Hill, K., 2001, Rhizophora mangle (red mangrove): Fort Pierce, Florida, Smithsonian Marine Station at Fort Pierce Web site, accessed June 2014, at http://www.sms.si.edu/irLspec/Rhizop_mangle.htm.

Jacobs, K.R., Carrubba, L., and Díaz, E.L., eds., 2013b, Puerto Rico Climate Change Council vulnerability assessment, Working Group 2 report—Ecology and biodiversity: San Juan, Puerto Rico Coastal Zone Management Program, Departament of Natural and Environmental Resources, National Oceanic and Atmospheric Administration Office of Ocean and Coastal Resource Management, 153 p. [Also available at http://prccc.org/download/PR\%20State\%20of\%20the\%20Climate-WG2.pdf.]

Jacobs, K.R., Terando, A., and Diaz, E.L., eds., 2013a, Puerto Rico Climate Change Council vulnerability assessment, Working Group 1 report-Geophysical and chemical scientific knowledge-Observed trends and future projections: San Juan, Puerto Rico Coastal Zone Management Program, Departament of Natural and Environmental Resources, National Oceanic and Atmospheric Administration Office of Ocean and Coastal Resource Management, 63 p. [ Also available at http://pr-ccc.org/download/PR\%20State\%20of\%20the\%20ClimateWG1.pdf.] 
Martinuzzi, S., Gould, W.A., Lugo, A.E., and Medina, E., 2009, Conversion and recovery of Puerto Rican mangroves_-200 years of change: Forest Ecology and Management, v. 257, p. 75-84.

McLeod, E., and Salm, R.V., 2006, Managing mangroves for resilience to climate change: Gland, Switzerland, International Union for Conservation of Nature, 64 p.

McNair, D., 2008, Conservation implications of the current breeding distribution and abundance of the White-crowned Pigeon Patagioenas leucocephala at St. Croix, U.S. Virgin Islands: Caribbean Journal of Science, v. 44, p. 311-320.

Millennium Ecosystem Assessment, 2005, Ecosystems and human well-being-Biodiversity synthesis: Washington, D.C., World Resources Institute, 86 p., accessed August 2013, at http://www.unep.org/maweb/documents/document.354.aspx.pdf.

NatureServe, 2003, Ecological systems of Latin America and the Caribbean database, Version 1.01: Arlington, Virginia, NatureServe database.

Piou, C., Feller, I.C., Berger, U., and Chi, F., 2006, Zonation patterns of Belizean offshore mangrove Forests 41 years after a catastrophic hurricane: Biotropica, v. 38, p. 365-374.

Polidoro, B.A., Carpenter, K.E., Collins, L., Duke, N.C., Ellison, A.M., Ellison, J.C. Farnsworth, E.J., Fernando, E.S., Kathiresan, K., Koedam, N.E., Livingstone, S.R., Miyagi, T., Moore, G.E., Ngoc Nam, V., Ong, J.E., Primavera, J.H., Salmo, S.G., Sanciangco, J.C., Sukardjo, S., Wang, Y., and Yong, J.W.H., 2010, The loss of species-Mangrove extinction risk and geographic areas of global concern: PloS ONE, v. 5, no. 4, 10 p.

Walters, B.B., Rönnbäck, P., Kovacs, J.M., Crona, B., Hussain, S.A., Badola, R., Primavera, J.H., Barbier, E., and Dahdouh-Guebas F., 2008, Ethnobiology, socio-economics and management of mangrove forests-A review: Aquatic Botany, v. 89, p. 220-236.

Webster, P.J., Holland, G.J., Curry, J.A., and Chang, H.-R., 2005, Changes in tropical cyclone number, duration, and intensity in a warming environment: Science, v. 309, p. 1,844-1,846.

Wiley, J., 1979, The White-crowned Pigeon in Puerto Rico-Status, distribution, and movements: The Journal of Wildlife Management, v. 43, p. 402-413. 


\section{Nashville Basin Limestone Glade and Woodland}

\section{Phase I Assessment}

Ecological System Overview.-The Nashville Basin Limestone Glade and Woodland is an ecological system restricted to areas of thin soils over limestone. It is mapped in the Central Basin of Tennessee (NatureServe, 2013a; fig. 10.1), but also occurs in Kentucky, Virginia, Alabama, and Georgia (Baskin and Baskin, 1999; NatureServe, 2013b). The system includes a combination of rock outcrops, annual and perennial grasslands, seasonally wet herbaceous washes and seeps, shrublands, and woodlands dominated by eastern redcedar (Juniperus virginiana) oak species such as chinkapin oak (Quercus muehlenbergii), white ash (Fraxinus americana), and shagbark hickory (Carya ovata) (Adams and others, 2012; NatureServe, 2013b). The rock outcrops and areas dominated by herbaceous plants usually are referred to as "glades." Although the factors maintaining this ecological system have been debated, a combination of unique hydrologic conditions, soil moisture, and soil depth (along with disturbance, specifically fire and grazing) likely control its plant communities and vegetation structure (Baskin and Baskin, 2004). The system contains numerous endemic herbaceous plants (Noss, 2013).

See NatureServe (2013b) for a complete description of this ecological system. 


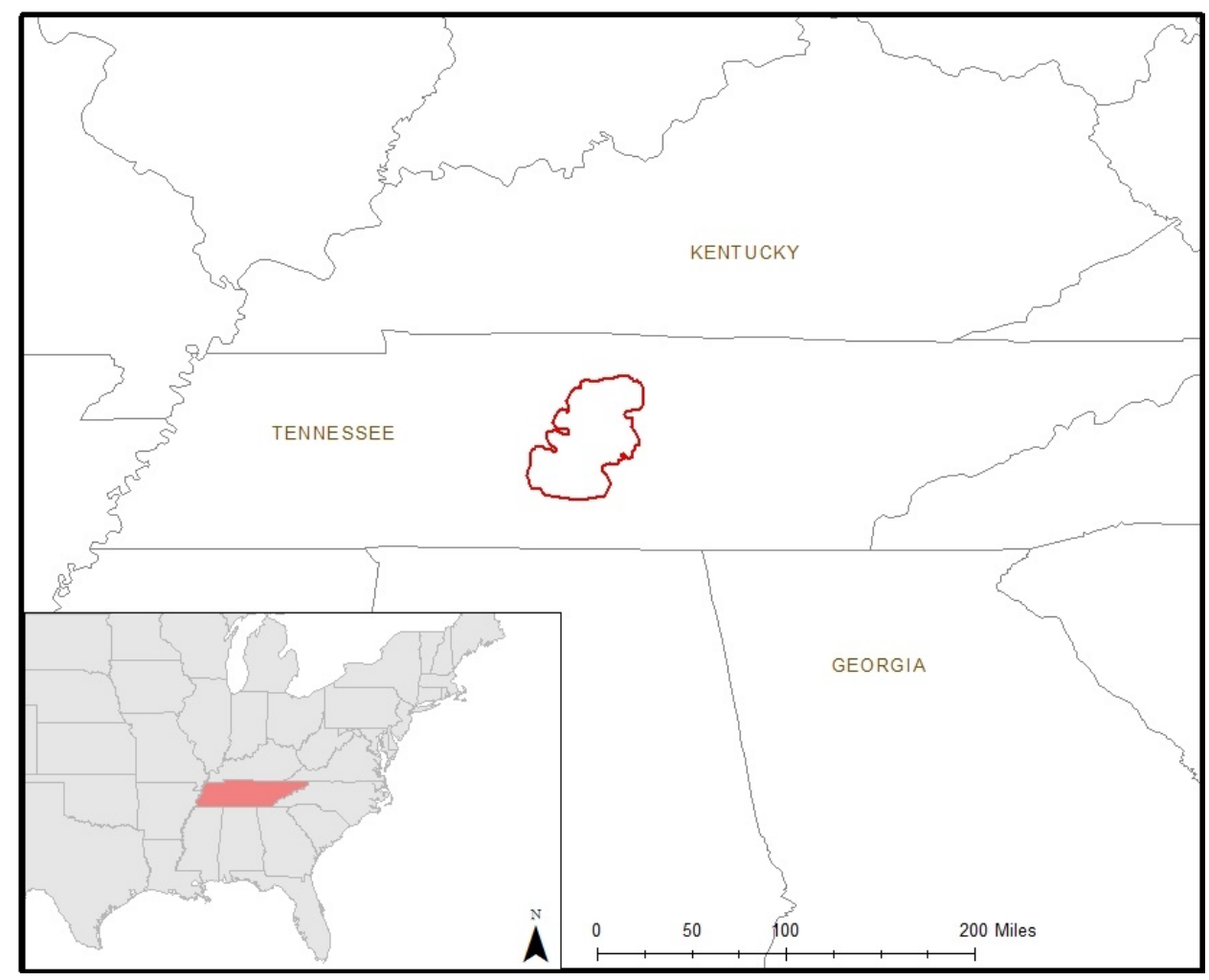

Figure 10.1. Range of the Nashville Basin Limestone Glade and Woodland ecological system. The system covers 11.83 percent of this range, according to data from NatureServe (2013a).

Vulnerability Status.- - Relative to other ecological systems in the Southeast, the vulnerability of this ecological system is rated as High. Sensitivity to climate is moderate, because species in this system thrive under drought conditions in the summer and fall. The likely exposure to changes in climate also is moderate. Warmer conditions are likely, but precipitation changes are uncertain. Drier conditions along with an increase in drought could occur with a decrease or even a slight increase in precipitation, but some climate models predict a substantial increase in precipitation. The system has a low level of adaptive capacity because of its restricted range and the high rate of future projected conversion to urban land use.

Sensitivity.-Washville Basin Limestone Glades and Woodlands, and especially the glade portions of the system, occur on thin, rocky limestone soils that often dry out in the summer and fall, but are saturated in the winter and spring (Quarterman, 1950a; Baskin and Baskin, 1999). Succession from open glades with herbaceous species to redcedar forest or woodlands to oak-hickory forest occurs without disturbance. Drought, removal of redcedar through management, and fire all likely slow woody plant invasion into glades (Baskin and Baskin, 2004; Noss, 2013).

Droughts occur every 10-20 years, most often in the late summer and fall (Quarterman, 1950b; Pyne and Fitch, 2009). These seasonal extremes in soil moisture and longer-term drought cycles lead to more adaptations for survival, and this could be the reason for the many rare plant species, especially grasses and forbs, in this ecological system (Noss, 2013). The plants that occur 
in this system generally are adapted to tolerate abiotic stress and usually are poor competitors with species from more mesic areas. Many plant species, both native and non-native to this ecological system, have their centers of distribution in drier regions to the west (Bridges and Orzell, 1986; Noss, 2013).

Our analysis shows that this ecological system occurs in an area with moderate seasonal changes in temperature, where summer maximum temperatures average $31^{\circ} \mathrm{C}$ (Appendix B), and winter minimum temperatures average $-2{ }^{\circ} \mathrm{C}$ (Appendix B). Precipitation is higher in the winter and spring, averaging 118 and 128 millimeters ( $\mathrm{mm}$ ), respectively, whereas in summer and fall, the averages are 103 and $97 \mathrm{~mm}$, respectively (Appendix B). This precipitation pattern likely contributes to the seasonal extremes in soil moisture seen in this ecological system.

Eastern redcedar, one of the major and characteristic tree species in the woodlands of this ecological system, can grow under various climatic conditions. Summer precipitation may be more important in limiting the species than annual precipitation (Burns and Honkala, 1990). The species is sensitive to fire because of its thin bark, shallow root system, and highly flammable foliage (Prasad and others, 2007). Lack of disturbances such as grazing and fire may lead to this tree forming a dense understory in woodlands, and proliferating in cracks and soil pockets in glade areas, eventually crowding out herbaceous plants.

Other species present in the woodlands within this ecological system include shagbark hickory, chinquapin oak, and white ash. These species are fairly wide-ranging and occur across a wide range of temperatures and precipitation levels. These species generally are shade-intolerant, and are present in the hardwood forest that succeeds redcedar forest or woodlands in this system.

Exposure.-Analysis of projected change in climate for the Nashville Basin Limestone Glade and Woodland ecological system shows increases in maximum and minimum temperatures for most models and most scenarios (figs. 10.2 and 10.3). The mean projected change in minimum temperature is greatest for the fall, with greater than a $5{ }^{\circ} \mathrm{C}$ increase projected under the A1FI scenario by the end of the century. The mean projected change in maximum temperature is greatest in spring, with a projected increase of more than $4{ }^{\circ} \mathrm{C}$ under the A1FI scenario for both of these metrics by the end of this century. However, projections range from an increase of more than $7^{\circ} \mathrm{C}$ to a slight decrease in temperature for some seasons and some scenarios.

Projected percentage changes in precipitation for this ecological system show variation among climate models for each season, emissions scenario, and time period (fig. 10.4). The mean values for each emissions scenario and time period are nearly all positive, with the exception of the end of the century under the A1FI scenario. Mean projections range from an 11-percent increase to a 3-percent decrease in precipitation. However, in all cases, the range of projections crosses zero. That pattern indicates much uncertainty among climate models, and under most scenarios and time periods, at least one model projects a substantial decrease in precipitation. The largest increases are projected under some models for the fall, with as much as a 106-percent increase in precipitation projected under the A1FI scenario by the end of the century. The largest decrease in precipitation, as much as 63 percent, is projected for the summer under the A1FI scenario by the end of the century. 
Projected changes in the standard deviation, or variability, of temperature and precipitation for this ecological system show a high degree of uncertainty among climate models. Both the means and ranges of change in standard deviation for maximum and minimum temperatures vary considerably (Appendix C). The mean change in the standard deviation of precipitation is greater than 1 in nearly all cases, except for the summer under the A1FI scenario. This indicates that, although model projections are variable, as a whole, they predict an increase in variability for precipitation in the future (Appendix C).

A decrease or even slight increase in precipitation, when coupled with the projected increases in temperature, could mean more drought events for this ecological system. In the Southeast as a whole, drought conditions are expected to become more common under climate change because of increased evapotranspiration (Seager and others, 2009). If that is the case, especially for summer and fall in this ecological system, woody invasion from woodlands into grasslands or glades would be slowed. Additionally, competition from species from adjacent mesic forests and woodlands should remain low. However, because climate models do not agree on projected precipitation, projections of drought frequency and severity remain uncertain.

An increase in temperature and decrease in precipitation also could lead to more frequent wildfires in and near this ecological system. Although to our knowledge, no detailed projections of wildfire occurrence have been done for the Central Basin of Tennessee, there is some uncertainty about how fire regimes in the Southeast may change in the future under climate change. An increase in wildfire frequency would negatively affect eastern redcedar, which is sensitive to fire, and could promote the growth of oak and hickory. An increase in fire would lead to more open glades.

According to the U.S. Forest Service Climate Change Tree Atlas, under all climate models and emissions scenarios included except for a single GCM under low-emissions scenario, the modeled importance value and abundance of eastern redcedar in central Tennessee will decrease (Prasad and others, 2007). The most important variable predicting projected future importance for the species in the Tree Atlas was mean summer temperature, which is projected to increase in the future. These results agree with similar models run for eastern redcedar in the Tennessee Wildlife Resources Agency (2009) climate change report. The importance values of other species in this ecological system are projected to decline with climate change as well. Chinkapin oak, shagbark hickory, and white ash are all projected to lose importance in middle Tennessee under both low- and high-emissions scenarios (Prasad and others, 2007; Tennessee Wildlife Resources Agency, 2009). Therefore, climate conditions likely will become less suitable for the species in middle Tennessee in the future. 


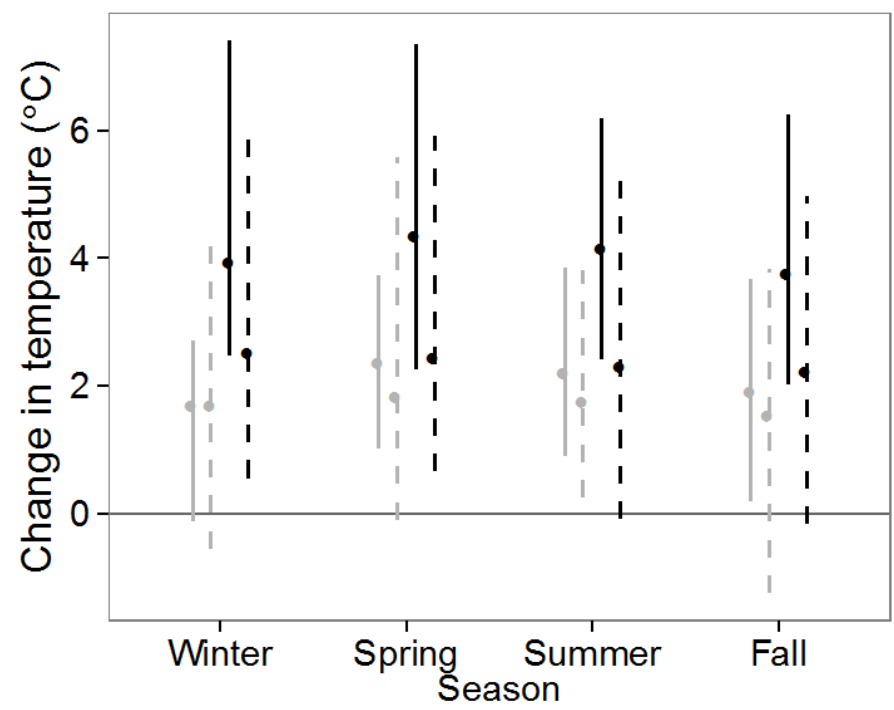

\section{Scenario, time period}

A1FI, mid-century

- - B1, mid-century

$\rightarrow \mathrm{A} 1 \mathrm{Fl}$, end of century

- - B1, end of century

Figure 10.2. Projected change in seasonal maximum temperatures (in degrees Celsius $\left[{ }^{\circ} \mathrm{C}\right]$ ) for the middle (2040-2060) and the end of the 21st century (2080-2100), compared with the recent time period (19812000), for two emissions scenarios for the Nashville Basin Limestone Glade and Woodland ecological system. Solid dots and error bars, respectively, represent the means and ranges of projections across climate models under each scenario.

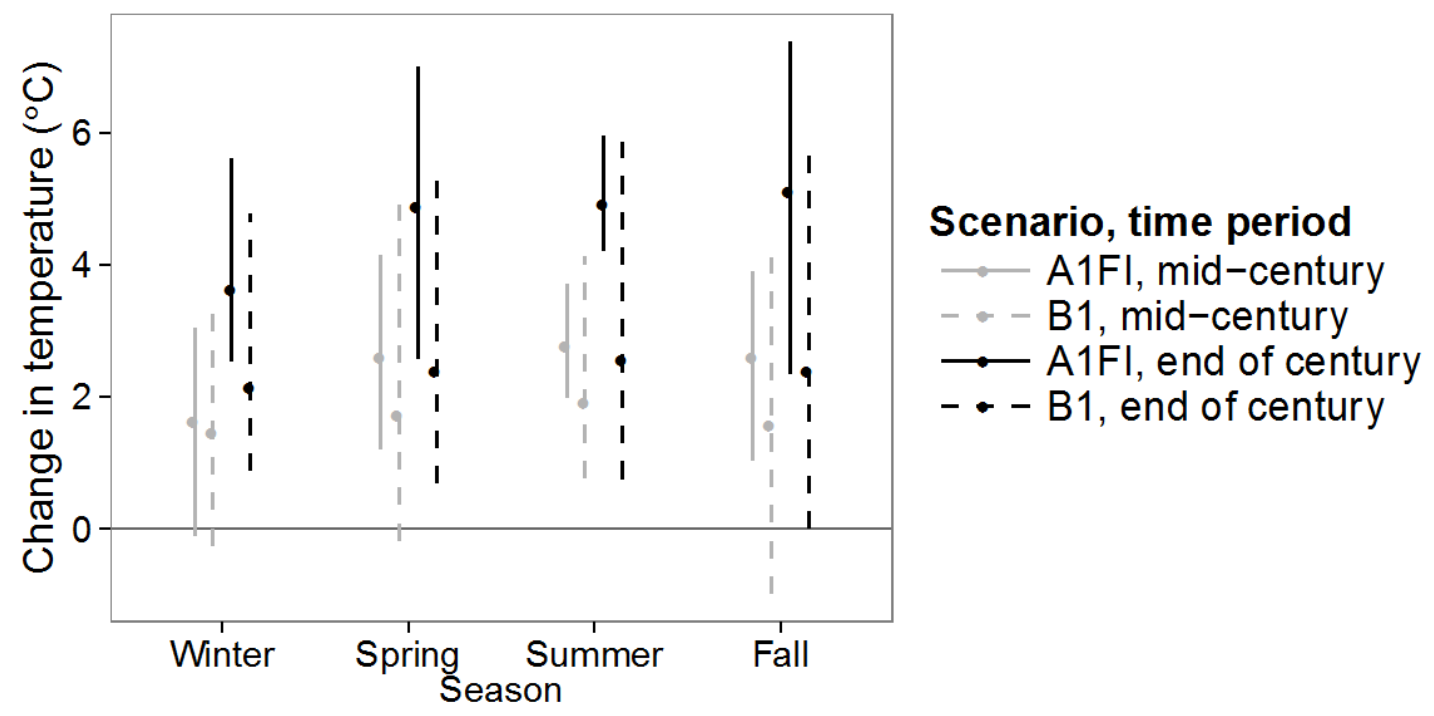

Figure 10.3. Projected change in seasonal minimum temperatures (in degrees Celsius [ $\left.{ }^{\circ} \mathrm{C}\right]$ ) for the middle (2040-2060) and the end of the 21st century (2080-2100), compared with the recent time period (19812000), for two emissions scenarios for the Nashville Basin Limestone Glade and Woodland ecological system. Solid dots and error bars represent, respectively, the means and ranges of projections across climate models under each scenario. 


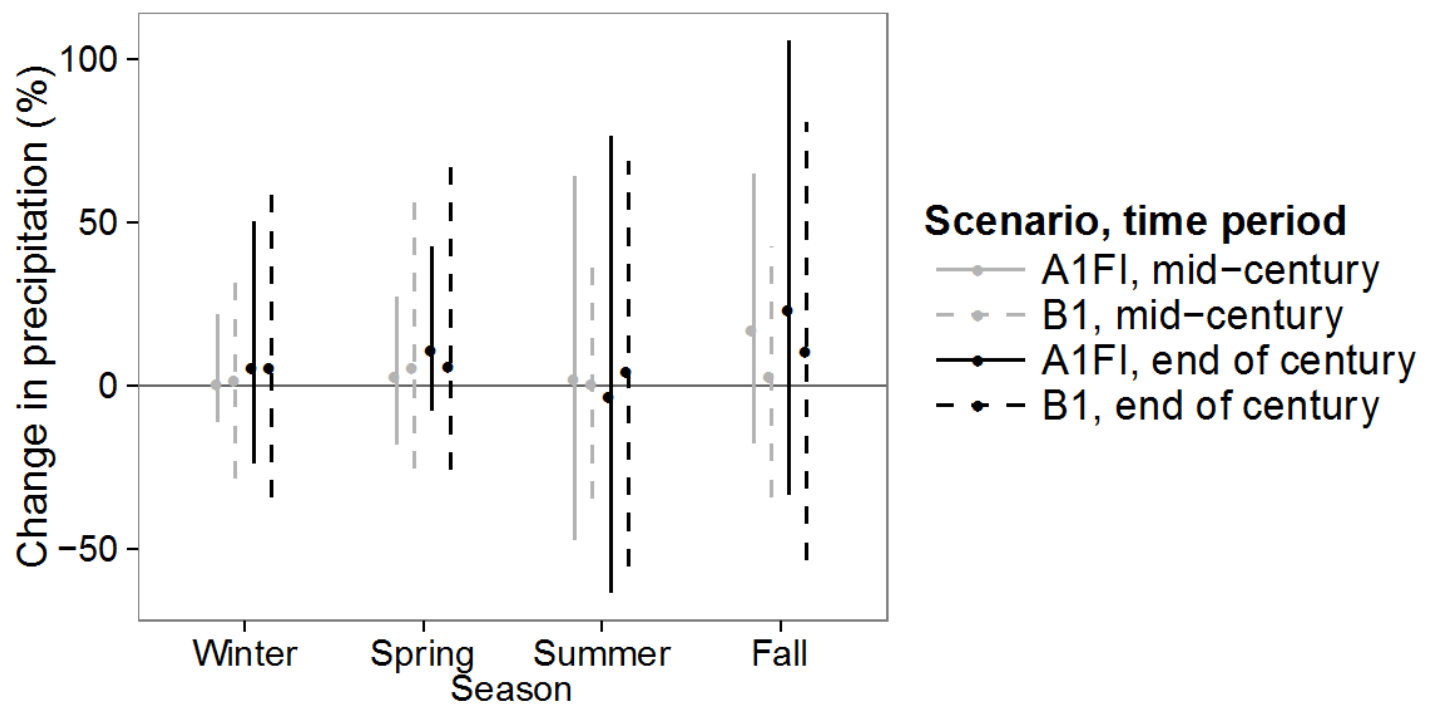

Figure 10.4. Projected percentage (\%) change in seasonal average precipitation for the middle (20402060) and the end of the 21st century (2080-2100), compared with the recent time period (1981-2000), for two emissions scenarios for the Nashville Basin Limestone Glade and Woodland ecological system. Solid dots and error bars represent, respectively, the means and ranges of projections across climate models under each scenario.

Adaptive Capacity. - The Nashville Basin Limestone Glade and Woodland ecological system is limited in its distribution, and is mapped on only 63,858 ha in the Central Basin of Tennessee, over a narrow range of elevations (116-417 m; Appendix A). The system does have a fairly large average patch size of 3.0 ha (29,800 m²; Appendix A) compared with other ecological systems in the Southeast. However, its small geographic distribution and restriction to unique edaphic conditions make the adaptive capacity of this system inherently low.

Aside from climate change, threats include conversion to urban land uses, invasion by native and non-native woody plants, and fire suppression. In 1993, the overall loss of limestone cedar glades in Tennessee was estimated at 50 percent, and the loss of intact limestone cedar glades was estimated at 90 percent, making them an endangered ecosystem (Noss and others, 1995). Additional losses have occurred since that time, and are likely to continue in the future because only 5 percent of the ecosystem's extent is protected for conservation (fig. 10.5).

Lack of fire or grazing has led to woody encroachment on deeper soils in limestone cracks and in forests surrounding glades. Fires are estimated to have occurred as frequently as every 3-7 years in woodlands and in the grasslands surrounding pure glades, which also are part of this ecological system (Pyne and Fitch, 2009; Sutter and others, 2011), but many areas have been without fire for much longer than that. Sutter and others (2011) found an increase in woody cover of both eastern redcedar and the non-native species Chinese privet (Ligustrum sinense), as well as decreases in density of characteristic herbaceous glade species after 13-15 years without fire or woody plant management. Additionally, mesophication, or a replacement of some shadeintolerant species, such as oaks, with more shade-tolerant, mesophytic species such as maple 
species may be occurring in this system (Adams and others, 2012). Mesophication often is caused by lack of fire (Nowacki and Abrams, 2008), but the causes in this system are not fully known.

The concentration of this ecological system in and around the rapidly growing NashvilleMurfreesboro area of Tennessee means that future loss of these communities is likely. The population of the metropolitan area is projected to nearly double by 2030, which likely will lead to conversion of this habitat and further constraints on prescribed burning (Niemiller and others, 2011). Existing patches are relatively near existing urban areas (mean distance, $342 \mathrm{~m}$; Appendix A) and have a high degree of human modification on average (81 percent; Appendix A). Our analysis shows that by 2050, 17 percent of the area of this ecological system is projected to be urbanized, and that number may rise to 39 percent by 2100 (fig. 10.5). These are the highest percentages of projected urbanization of all of the systems included in this assessment.

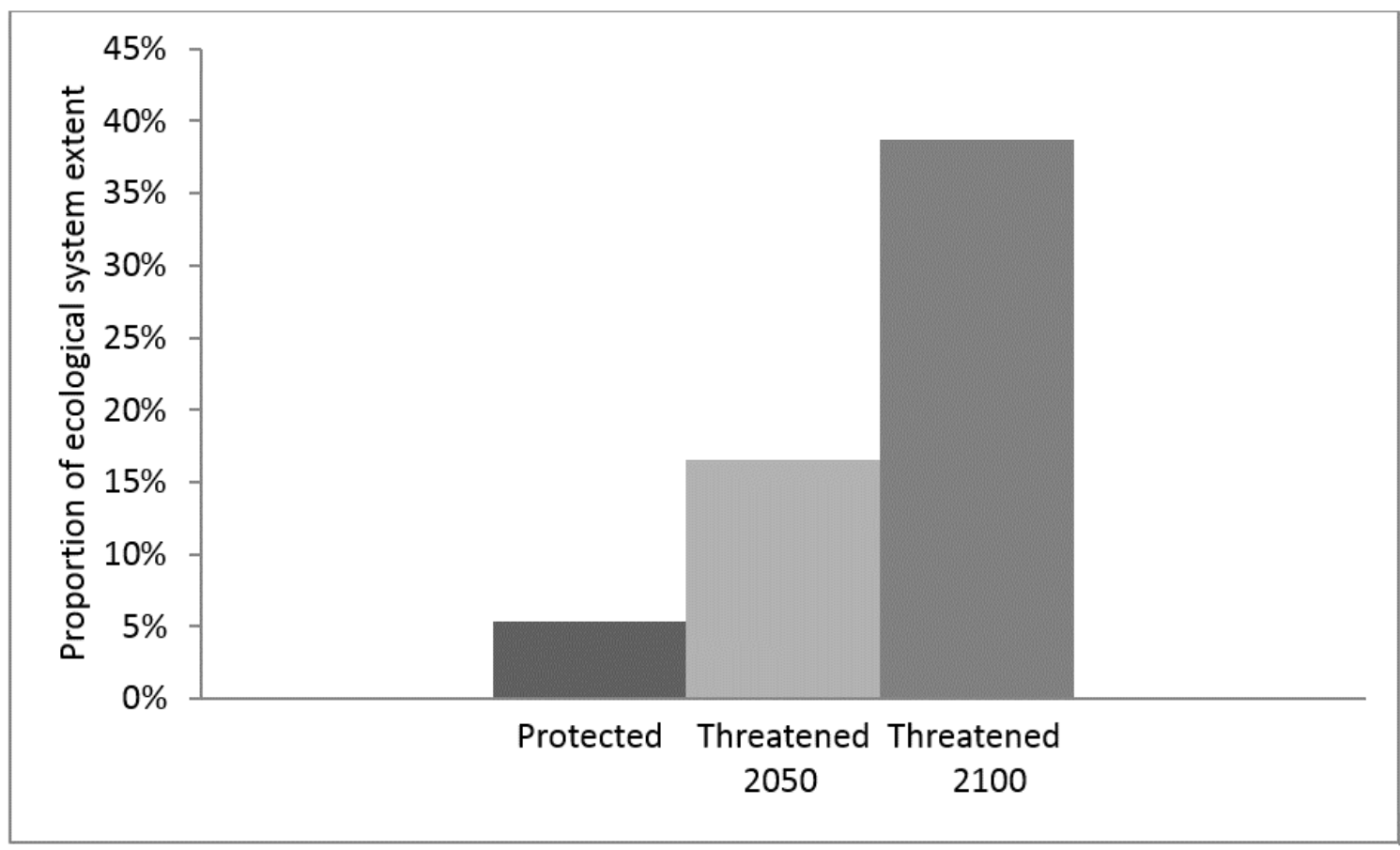

Figure 10.5. Percentage of the extent of the Nashville Basin Limestone Glade and Woodland ecological system that is protected for conservation, and the percentage threatened by future development in 2050 and 2100.

Summary.-The Nashville Basin Limestone Glade and Woodland system is restricted to a small geographic range and a narrow set of edaphic conditions in middle Tennessee. The species in this system thrive under low soil moisture and drought conditions. Projected changes in climate suggest that both minimum and maximum temperatures will increase, but there is much uncertainty about how seasonal precipitation will change. A decrease or even a slight increase in precipitation, when coupled with increasing temperatures, could result in more drought for this ecological system, but a large increase in precipitation could lead to fewer droughts. More drought would slow invasion of woody species into glades and slow competition from herbaceous species from adjacent mesic areas. Because of its limited distribution, as well as its proximity to 
urban areas, the adaptive capacity of this system is fairly low. Future research could address whether facilitating connectivity or assisted migration of plant species from this ecological system to those other glade and barrens systems would be fruitful. Research also could examine the specific factors that contribute to seasonal changes in soil moisture, as well as the drought cycle in this ecological system, and how those factors might change in response to climate change.

\section{References Cited}

Adams, D.A., Walck, J.L., Howard, R.S., and Milberg, P., 2012, Forest composition and structure on glade-forming limestones in middle Tennessee: Castanea, v. 77, p. 335-347.

Baskin, J., and Baskin, C., 1999, Cedar glades of the Southeastern United States, in Anderson, R.C., Fralish, J.S., and Baskin, J.M., eds., Savannas, barrens, and rock outcrop plant communities of North America: Cambridge, United Kingdom, Cambridge University Press, p. 206-219.

Baskin, J., and Baskin, C., 2004, History of the use of "cedar glades” and other descriptive terms for vegetation on rocky limestone soils in the Central Basin of Tennessee: The Botanical Review, v. 70, p. 403-424.

Bridges, E.L., and Orzell, S.L., 1986, Distribution patterns of the non-endemic flora of middle Tennessee limestone glades: Association of Southeastern Biologists Bulletin, v. 33, p. 155166.

Burns, R.M., and Honkala, B.H., tech. coords., 1990, Silvics of North America-Volume 1, Conifers: U.S. Forest Service, Agriculture Handbook 654, 877 p.

NatureServe, 2013a, U.S. ecological systems National Map data: Arlington, Virginia, NatureServe database, accessed January 2013, at http://www.natureserve.org/getData/USecologyData.jsp.

NatureServe, 2013b, NatureServe explorer-An online encyclopedia of life, Version 7.1: Arlington, Virginia, NatureServe Web application, accessed May 2013, at http://www.natureserve.org/explorer.

Niemiller, M., Reynolds, R., Glorioso, B., Spiess, J., and Miller, B., 2011, Herpetofauna of the cedar glades and associated habitats of the inner Central Basin of middle Tennessee: Herpetological Conservation Biology, v. 6, p. 135-149.

Noss, R.F., 2013, Forgotten grasslands of the South—Natural history and conservation. Washington, D.C., Island Press, 317 p.

Noss, R., LaRoe, E., and Scott, J., 1995, Endangered ecosystems of the United States-A preliminary assessment of loss and degradation: Washington, D.C., U.S. Department of the Interior, National Biological Service, Biological Report 28, 60 p. 
Nowacki, G.J., and Abrams, M.D., 2008, The demise of fire and “mesophication” of forests in the Eastern United States: BioScience, v. 58, p. 123.

Prasad, A.M., Iverson, L.R., Matthews, S., and Peters, M., 2007, A climate change atlas for 134 forest tree species of the Eastern United States: U.S. Forest Service database, Northern Research Station, Delaware, Ohio, accessed May 2013, at http://www.nrs.fs.fed.us/atlas/tree.

Pyne, M., and Fitch, K., 2009, LANDFIRE biophysical setting model for Nashville Basin Limestone Glade and Woodland—LANDFIRE biophysical setting descriptions, Map zone 48: LANDFIRE program model, p. 91-155, accessed May 2012, at http://www.landfire.gov/national_veg_models_op2.php.

Quarterman, E., 1950a, Ecology of cedar glades-I, Distribution of glade flora in Tennessee: Bulletin of the Torrey Botanical Club, v. 77, p. 1-9.

Quarterman, E., 1950b, Major plant communities of Tennessee cedar glades: Ecology, v. 31, p. 234-254.

Seager, R., Tzanova, A., and Nakamura, J., 2009, Drought in the Southeastern United StatesCauses, variability over the last millennium, and the potential for future hydroclimate change: Journal of Climate, v. 22, p. 5,021-5045.

Sutter, R.D., Govus, T.E., Smyth, R.L., Nordman, C., Pyne, M.,and Hogan, T., 2011, Monitoring change in a central U.S. calcareous glade-Resampling transects established in 1993: Natural Areas Journal, v. 31, p. 163-172.

Tennessee Wildlife Resources Agency, 2009, Climate change and potential impacts to wildlife in Tennessee-An update to Tennesseee's state wildlife action plan: Nashville, Tennessee Wildlife Resources Agency, 106 p. 


\section{Phase II Assessment}

Overall Vulnerability Rating.--Medium to High (mid-century), High to Very High (latecentury)

For the Nashville Basin Limestone Glade and Woodland ecological system, sensitivity to climate change is moderate to high at mid-century, and high by the end of the century. The climate stress index is low for the middle of the century, but becomes moderate by the end of the century. The dynamic process forecast for the ecological system suggests that there will be a high degree of ecological departure in fire regime through the rest of the century.

Resilience for this ecological system is moderate at mid-century, and moderate to low by the end of the century. The indirect effects of climate change on average contribute to moderateto-high values of resilience for this ecological system. The proportion of the system that was nonurban in the past is high, but only a moderate proportion is projected to be non-urban in the future. The invasive species threat is low to moderate. The dynamic process alteration is relatively low, suggesting that the ecological departure of this ecological system owing to changes in fire regimes is fairly high. On average, metrics related to adaptive capacity contributed to a moderate value of resilience at mid-century, and a moderate to low resilience by the end of the century. Diversity within functional groups is high, but keystone vulnerability is moderate to low by the end of the century. Additionally, because this ecological system has a restricted range, bioclimatic variability and elevation range indices are low.

Sensitivity Rating. - 0.55-0.5, Medium to High (mid-century), 0.49-0.36, High (late-century)

Climate Stress Index.-0.78-0.88 (mid-century), 0.51-0.77 (late-century)

For a given time period and emissions scenario, climate stress was defined as 1 minus the proportion of the 36 climate variables that were projected to exceed

2 standard deviations above or below the recent mean. The number of variables within the range of this ecological system exceeding 2 standard deviations for each scenario and time period that were considered are shown in figure 10.6. For a given emissions scenario, a greater number of variables on average generally exceeded

2 standard deviations later in the century, as compared with mid-century. For a given time period, more variables exceeded 2 standard deviations for the A2 and A1FI scenarios than for the B1 scenario. Additionally, for a given time period and scenario, locations in the north and east portions of the range tended to have more variables exceeding 2 standard deviations, compared with locations in the south and west portions.

\section{Envelope Shift Index.-Not Applicable}

This metric was not calculated for this ecological system. Preliminary testing of climate envelope models with MaxEnt ${ }^{\mathrm{TM}}$ indicated that the favorable climate conditions would shift substantially to the north under all scenarios for all time periods, with no overlap of the range of the system. These models misrepresented the future vulnerability of this ecological system. The system is greatly restricted in its range to areas in and around limestone outcrops with specific 
hydrologic conditions. Therefore, the climate envelope is not as relevant to this ecological system as it is to wider-ranging systems.

Dynamic Process Forecast.—0.22 (mid-century), 0.21-0.22 (late-century)

We used a modified version of the LANDFIRE state-and-transition simulation model (STSM) for this ecological system to simulate future vegetation dynamics and to determine ecological departure (see Pyne and Fitch, 2009, for a complete description of the original LANDFIRE model). The STSM consisted of five state classes representing early-, mid-, or latesuccession, and the open or closed canopy structure. Transitions among the state classes represented succession, wildfire, insects and disease, and wind/weather/stress. The mapped conditions for this ecological system indicate that, compared with estimated pre-European settlement conditions, the early-succession state class is underrepresented and the late-succession closed canopy state is overrepresented in the landscape (table 10.1).

We ran the STSM into the future with fire probabilities that were adjusted for fire suppression. We developed a multiplier value, which we used to adjust the wildfire probabilities to account for fire suppression in the STSM. Previous work in the Southeast indicated that wildfire probabilities have been reduced by a factor of 0.072 from estimated pre-European settlement on private lands (Costanza and others, 2015). Therefore, we multiplied all wildfire probabilities in the model by 0.072 . We ran the simulation 50 times to determine the future distribution of state classes in this ecological system.

Values of ecological departure were calculated based on the mean composition of each state class at 2050 and 2100. Models indicate little difference in ecological departure between future time periods. For both time periods, the values indicate that a relatively high level of departure is expected. The dynamic process forecast values were 1 minus ecological departure for each scenario and time period, and correspond to a relatively high sensitivity of the state class composition of this ecological system to changes in fire regimes.

\section{Sea Level Rise.-Not Applicable}

Because it is an inland system, this metric was not calculated for this ecological system.

Resilience Rating. - 0.57-0.52, Medium (mid-century), 0.53-0.49, Medium to Low (latecentury)

Landscape Condition. $-\mathbf{0 . 5 9}$ (both time periods)

This ecological system had a moderate value for landscape condition, indicating it has moderate resilience according to this metric.

Proportion Non-Urban, Historical.—0.96 (both time periods)

A relatively high proportion of the range of this ecological system was free of urban, suburban, and exurban development in 1960. 
Proportion Non-Urban, Current. - $\mathbf{0 . 6 8 8 8 - 0 . 6 9}$ (both time periods)

A moderate proportion of the range of this ecological system was free of urban, suburban, and exurban development in 2010.

Proportion Non-Urban, Future.-0.63-0.64 (both time periods)

A moderate proportion of this ecological system was still projected to be free of urban, suburban, and exurban development in 2050 and 2100. The urbanization data we used projected changes in the intensity of development within already-urbanized places, rather than an expansion of the footprint of urbanization. Therefore, there was only a small amount of change between mid-century, and end-of-century proportions.

Invasive Species Threat, Current. $-0.5-0.7$ (both time periods)

Because of the high degree of endemism and low competitive ability of several plants found in this ecological system, the system has high sensitivity to invasive species that can outcompete native species. Nine invasive plant species have been found in this system, or have been found in areas near where the system occurs (table 10.2; Nordman, 2004; Norton, 2010). Of the nine species, six of them are of them are ranked as either an Alert, Severe Threat, or Significant Threat species in Tennessee (Tennessee Exotic Pest Plant Council, 2009). When they are present in this ecological system, most of these species occur at fairly low frequencies, perhaps because they do not thrive under seasonal drought conditions (Norton, 2010), but a few have the potential to be a major threat. For example, Chinese privet has the potential to threaten the woodlands in this system (Norton, 2010). Because of the low occurrence of exotic species, but high potential for damage, we assigned values between 0.5 and 0.7 to this system.

Dynamic Process Alteration. - 0.49 (both time periods)

We used the ecological departure for this ecological system as the basis for this metric. As stated in the section, "Dynamic Process Forecast," the mapped conditions included an overrepresentation of closed-canopy states, whereas the late-succession open-canopy state class was underrepresented compared to estimated pre-settlement conditions (table 10.1). As a result, the departure of this system was 0.49 , which is a moderately low departure value, and indicates that the mapped composition of state classes in the ecological system is somewhat similar to estimated pre-European settlement conditions. The resulting metric for dynamic process alteration was $1-0.49=0.51$.

Diversity within Functional Groups. - 0.8-0.9 (both time periods)

We identified species that are tolerant of seasonal drought cycles as the functional group of interest, because seasonal droughts are characteristic of this ecological system. This system is high in richness of species that tolerate drought. In fact, many plant species, both native and nonnative to this ecological system, have their centers of distribution in drier regions to the west (Bridges and Orzell, 1986; Noss, 2013). 
Keystone Species Vulnerability.—0.5-0.69 (mid-century); 0.3-0.4 (late-century)

The keystone species we identified for this ecological system was the Allegheny Woodrat (Neotoma magister), a pack rat that lives near rock outcrops. The woodrat builds middens, and fills them with seeds, acorns, and other plant material, along with trash. A vulnerability assessment of the species for the year 2050 was conducted in Pennsylvania, and it was rated moderately vulnerable because it is a habitat specialist and has limited dispersal (Furedi and others, 2011). It also may be threatened by decreasing supplies of acorns from oak trees (Monty and Feldhamer, 2002).

Bioclimatic Variability. $-\mathbf{0 . 0 8}$ (both time periods)

This ecological system is present in 2 bioclimates, indicating a restricted range for this system, and a low value for this resilience metric. The maximum number for any southeastern system is 25 .

Elevation Range. - $\mathbf{0 . 1 1}$ (both time periods)

This system is present in two 100-m elevation bands, which, like the bioclimatic variability index, indicates a restricted range for this system and a low resilience value. The maximum number of elevation bands for any southeastern system is 27 .

\section{References Cited}

Bridges, E.L., and Orzell, S.L., 1986, Distribution patterns of the non-endemic flora of middle Tennessee limestone glades: Association of Southeastern Biologists Bulletin, v. 33, p. 155-166.

Costanza, J.K., Terando, A., Mckerrow, A.J., and Collazo, J.A., 2015, Modeling climate change, urbanization, and fire effects on Pinus palustris ecosystems of the southeastern U.S.: Journal of Environmental Management v. 151 p. 186-199

Furedi, M., Leppo, B., Kowalski, M., Davis, T., and Eichelberger, B., 2011, Identifying species in Pennsylvania potentially vulnerable to climate change: Pittsburgh, Pennsylvania Natural Heritage Program, 229 p.

Monty, A.-M., and Feldhamer, G.A., 2002, Conservation assessment for the Eastern Woodrat (Neotoma floridana) and the Allegheny Woodrat (Neotoma magister):

U.S. Forest Service, Eastern Region, 36 p.

Nordman, C., 2004, Vascular plant community classification for Stones River National Battlefield, Durham, North Carolina: Prepared by NatureServe for the National Park Service Southeast Regional Office, 63 p. plus appendixes.

Norton, K., 2010, A floristic ecology study of seasonally wet limestone cedar glades of Tennessee and Kentucky: Clarksville, Tennessee, Austin Peay State University, 326 p. 
Noss, R.F., 2013, Forgotten grasslands of the South-Natural history and conservation: Washington, D.C., Island Press, 317 p.

Pyne, M., and Fitch, K., 2009, LANDFIRE biophysical setting model for Nashville Basin Limestone Glade and Woodland_LANDFIRE biophysical setting descriptions, Map zone 48: LANDFIRE program model, p. 91-155, accessed May 2012, at http://www.landfire.gov/national_veg_models_op2.php.

Tennessee Exotic Pest Plant Council, 2009, Invasive exotic pest plants in Tennessee (2d ed.): Tennessee Exotic Pest Plant Council Web site, accessed May 2014, at http://www.tneppc.org/invasive_plants. 

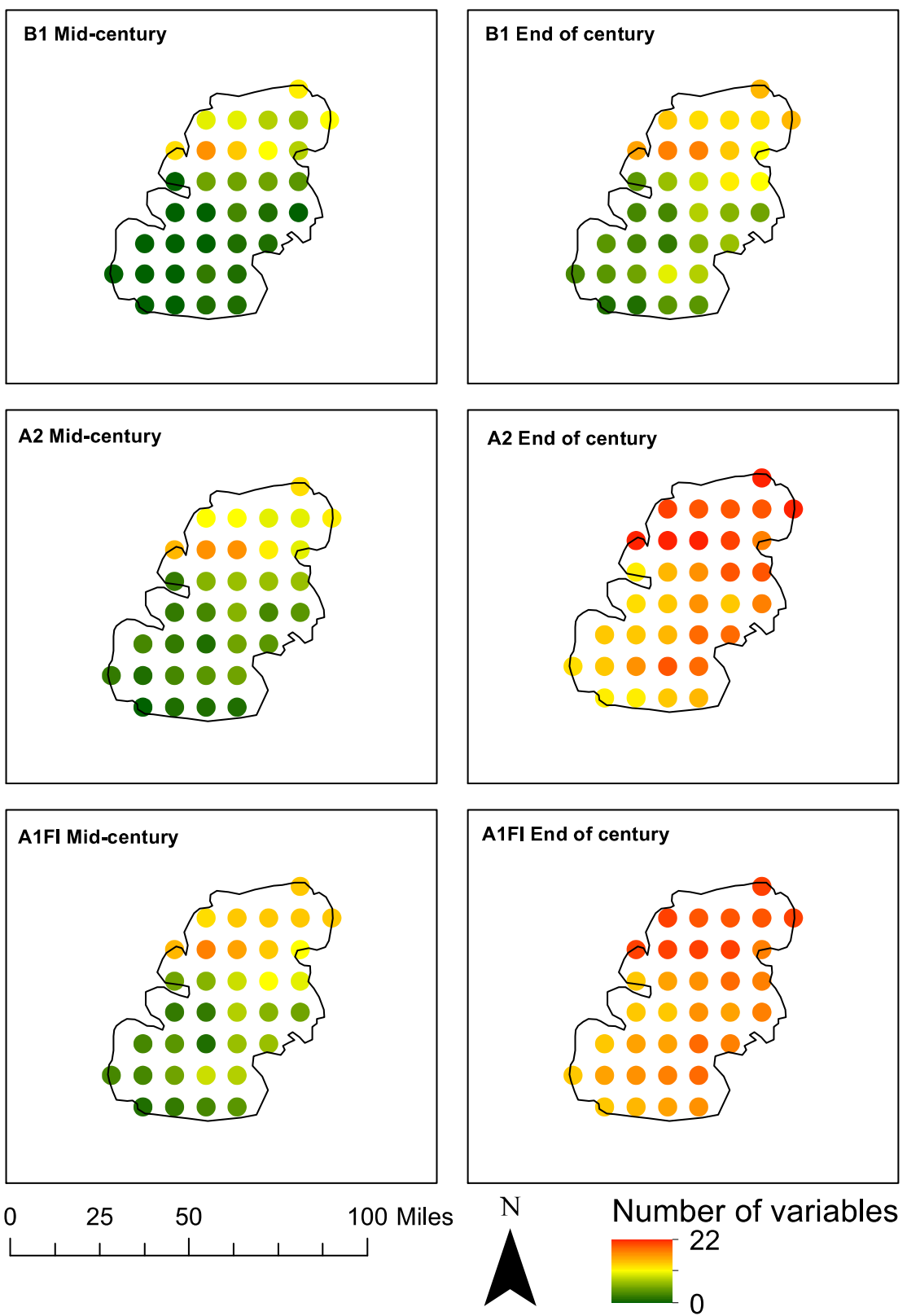

Figure 10.6. Count of the monthly climate variables projected to exceed 2 standard deviations above or below the recent mean across the range of the Nashville Basin Limestone Glade and Woodland ecological system. Black outline indicates the range of the system in middle Tennessee. Values for this system ranged from 0 to 22 variables exceeding recent variability, out of a possible 36 variables. This count was used to calculate the climate stress index. 
Table 10.1. Landscape composition and ecological departure values for the Nashville Basin Limestone Glade and Woodland ecological system. A value of "NA" indicates the metric is not applicable.

\begin{tabular}{|c|c|c|c|c|c|c|c|}
\hline Time period and metric & $\begin{array}{c}\text { Early- } \\
\text { succession }\end{array}$ & $\begin{array}{l}\text { Mid- } \\
\text { succession, } \\
\text { closed }\end{array}$ & $\begin{array}{l}\text { Mid- } \\
\text { succession, } \\
\text { open }\end{array}$ & $\begin{array}{l}\text { Late- } \\
\text { succession, } \\
\text { open }\end{array}$ & $\begin{array}{l}\text { Late- } \\
\text { succession, } \\
\text { closed }\end{array}$ & $\begin{array}{c}\text { Total } \\
\text { departure }\end{array}$ & Metric \\
\hline Pre-settlement composition & 0.43 & 0.03 & 0.22 & 0.31 & 0.01 & NA & NA \\
\hline Composition & 0.01 & 0.12 & 0.17 & 0.27 & 0.43 & NA & NA \\
\hline Initial - departure & 0.01 & 0.03 & 0.17 & 0.27 & 0.01 & 0.51 & ${ }^{1} 0.49$ \\
\hline Mid-century composition & 0.03 & 0.1 & 0.02 & 0.13 & 0.72 & NA & NA \\
\hline Mid-century departure & 0.03 & 0.03 & 0.02 & 0.13 & 0.01 & 0.78 & ${ }^{2} 0.22$ \\
\hline Late-century composition & 0.03 & 0.07 & 0.01 & 0.13 & 0.76 & NA & NA \\
\hline Late-century departure & 0.03 & 0.03 & 0.01 & 0.13 & 0.01 & 0.79 & ${ }^{2} 0.21$ \\
\hline
\end{tabular}

${ }^{1}$ This value was used as the dynamic process alteration metric.

${ }^{2}$ These values were used as the dynamic process forecast metric. 
Table 10.2. Invasive species found in the Nashville Basin Limestone Glade and Woodland ecological system.

[Rankings in Tennessee come from the Tennessee Exotic Pest Plant Council (2009)]

\begin{tabular}{lll}
\hline \multicolumn{1}{c}{ Common name } & \multicolumn{1}{c}{ Scientific name } & \multicolumn{1}{c}{ Ranking in Tennessee } \\
\hline Tree of heaven & Ailanthus altissima & Severe Threat \\
Mimosa, silktree & Albizia julibrissin & Not ranked \\
Hare's ear & Bupleurum rotundifolium & Lesser Threat \\
Nodding thistle & Carduus nutans & Significant Threat \\
Queen Anne's-lace & Daucus carota & Alert \\
Common teasel & Dipsacus sylvestris & Not ranked \\
Chinese lespedeza & Lespedeza cuneata & Severe Threat \\
Ox-eyed daisy & Leucanthemum vulgare & Alert \\
Chinese privet & Ligustrum sinense & Severe Threat \\
\hline
\end{tabular}




\section{South-Central Interior Mesophytic Forest}

Ecological System Overview.- The South-Central Interior Mesophytic Forest ecological system occurs on rich soils in coves and lower mountain slopes from western Pennsylvania to Illinois, Kentucky, and Tennessee, through the Cumberland and Allegheny Plateaus, as well as in the Ridge and Valley and Low Plateau regions (fig. 11.1; NatureServe, 2013a). The ecological system corresponds to the classic Mixed Mesophytic Forest of Braun (1955), as well as the non-coastal plain portion of the Western Mesophytic Forest, and Beech-Maple Forest region (NatureServe, 2013a). The system contains a high diversity of tree species in the canopy, including sugar maple (Acer saccharum), American beech (Fagus grandifolia), tulip poplar (Liriodendron tulipifera), American basswood (Tilia americana), northern red oak (Quercus rubra), and in some cases eastern hemlock (Tsuga canadensis), as well as a species-rich herbaceous layer (Archibold, 1995; NatureServe, 2013a). Disturbances in these forests are predominantly local-scale windthrows that create treefall gaps, with occasional larger windstorms (Runkle, 1985). Tree gaps maintain canopy and understory diversity at a relatively fine scale (Delcourt and Delcourt, 2000).

Fires are not a common natural disturbance in these forests, and fires historically occurred every 50-200 years or longer (Sole and others, 2009). See NatureServe (2013a) for a complete description of this ecological system.

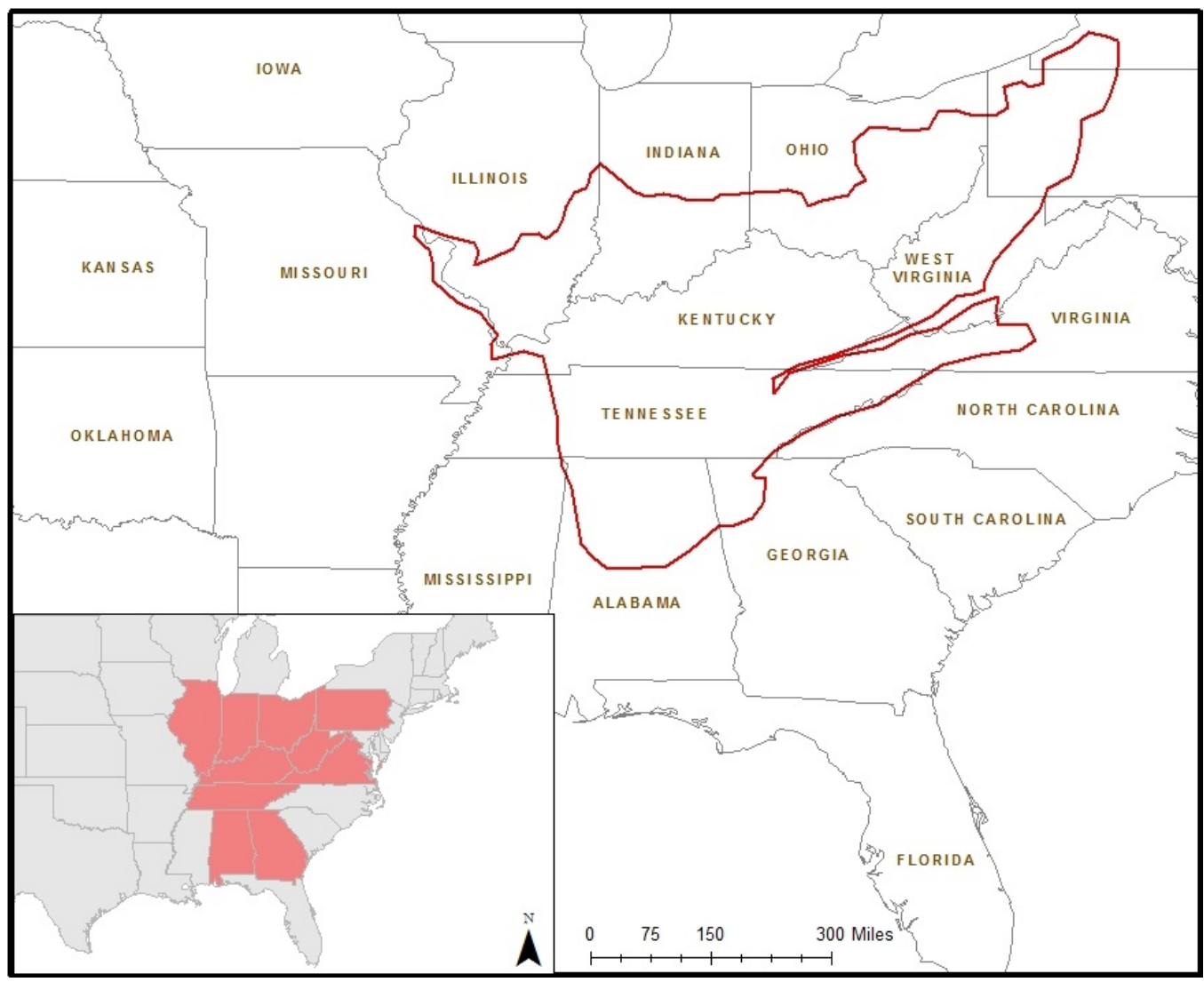

Figure 11.1. Range (outlined in top map) of the South-Central Interior Mesophytic Forest ecological system. The system covers 13.7 percent of this range, according to data from NatureServe (2013b). 
Vulnerability Status.-Relative to other ecological systems in the Southeast, the vulnerability of this ecological system was rated as Medium. This system is sensitive to winter minimum temperatures, which restrict the southern range. The likely exposure to changes in climate is moderate, with warmer and drier conditions likely, and suitable conditions likely to decline, especially in the southern portion of the system's range. The system has a moderate level of adaptive capacity because it is threatened by deer overbrowsing and hemlock wooly adelgid (Adelges tsugae), and a relatively small proportion is protected.

Sensitivity.-Delcourt and Delcourt (2000, and references therein) summarized the changes in climate and resulting distribution of eastern deciduous forest since the last glacial maximum. These forests extend south to the point where the average minimum winter temperatures begin to exceed approximately $-15^{\circ} \mathrm{C}$ (Delcourt and Delcourt, 2000). Our analysis shows that the range of this ecological system occurs where winter minimum temperatures average $-11^{\circ} \mathrm{C}$ or above (Appendix B) and summer maximum temperatures average $33^{\circ} \mathrm{C}$ or below (Appendix B). This ecological system is present in areas that have a wide range of annual precipitation (Appendix B).

Extensive work has been done on the past climate influences on tree species in this ecological system. Tree species composition in this ecological system is the result of species-specific responses to past climate variability (Delcourt and Delcourt, 2000). Among the variables that tree species in this system have responded to in the past are mean annual temperatures, length of the growing season, and the degree of seasonal contrast (Delcourt and Delcourt, 2000). To the south, where the seasonal change in climate becomes less extreme, the forests in similar habitats (for example, lower north-facing slopes and mesic ravines) are characterized by the presence of both broad-leaved (for example, southern magnolia, Magnolia grandiflora) and needle-leaved (for example, loblolly pine, Pinus taeda) evergreen trees, rather than being entirely deciduous in composition. Therefore, any decrease in seasonal climate extremes could shift the southern range of this system to the north.

Some tree species in this ecosystem are restricted to cooler climatic conditions. American beech may be particularly sensitive to summer maximum temperatures (Burns and Honkala, 1990). Sugar maple is restricted to areas with cool, moist climates (Burns and Honkala, 1990).

Exposure.-Analysis of projected change in climate for this ecological system shows increases in maximum and minimum temperatures for most models and most scenarios, with little difference among seasons in the amount of projected change under a given scenario for a particular time period (figs. 11.2 and 11.3). For example, the mean projected change in maximum temperature for all seasons under the A1FI scenario is more than $4^{\circ} \mathrm{C}$ by the end of this century. The southern range of this system is particularly sensitive to winter minimum temperature, which is projected to increase by $1.7^{\circ} \mathrm{C}$ and $1.9^{\circ} \mathrm{C}$ on average under the $\mathrm{B} 1$ and A1FI scenarios, respectively, by the middle of this century, and by $2.4^{\circ} \mathrm{C}$ and $4.0^{\circ} \mathrm{C}$ under the two scenarios by the end of the century. This increase in winter minimum temperatures could lead to a decline in the South-Central Interior Mesophytic Forest in the southern portion of its range. 
The mean projected percentage changes in precipitation for this ecological system across climate models are positive, and are most positive for the spring. However, there is a substantial amount of variation among climate models for each season, emissions scenario, and time period (fig. 11.4). In all cases, the range of projections crosses zero, indicating much uncertainty among climate models. The largest increases are projected under some models for the fall, with as much as an 87-percent increase in precipitation projected under the A1FI scenario by the end of the century. The largest decrease in precipitation, as much as 54 percent, is projected for the summer under the A1FI scenario by the end of the century.

Projected changes in the standard deviation, or variability, of temperature and precipitation show a high degree of uncertainty among climate models. Both the means and ranges of change in standard deviation for maximum and minimum temperatures vary considerably (Appendix C). The mean change in the standard deviation of precipitation is positive in all cases, indicating that although model projections are variable, on average, they predict an increase in variability for precipitation in the future (Appendix C).

According to the U.S. Forest Service Climate Change Tree Atlas, in the region where the SouthCentral Interior Mesophytic Forest occurs, suitable habitat for sugar maple, American beech, red oak, and tulip poplar is projected to decline under all climate models, regardless of emissions scenario (Prasad and others, 2007). Mean summer temperatures and precipitation are among the most important climate predictors in the Tree Atlas models for these species; however, other variables such as soil type, elevation, and slope are more important than climate in predicting the habitats of these species in the Tree Atlas models (Prasad and others, 2007). Similar declines in suitable habitat were indicated for these species by the Tennessee Wildlife Resources Agency (2009) and Dale and others (2009). The area of suitable climate conditions for eastern hemlock also is projected to decline slightly under the highemissions scenario for the area mapped as mesophytic forest (Prasad and others, 2007). Mean July temperature is the most important variable predicting future distribution for this species in the Climate Atlas models (Prasad and others, 2007). Under the high-emissions scenario, the Tree Atlas projects that oak-hickory forest will become more dominant in areas where mixed mesophytic forests occur, whereas suitable areas for maple-beech-birch forest will occur farther north (Prasad and others, 2007). Under the low-emissions scenario, little change in the general distributions of these forest types is projected where mesophytic forests occur. 


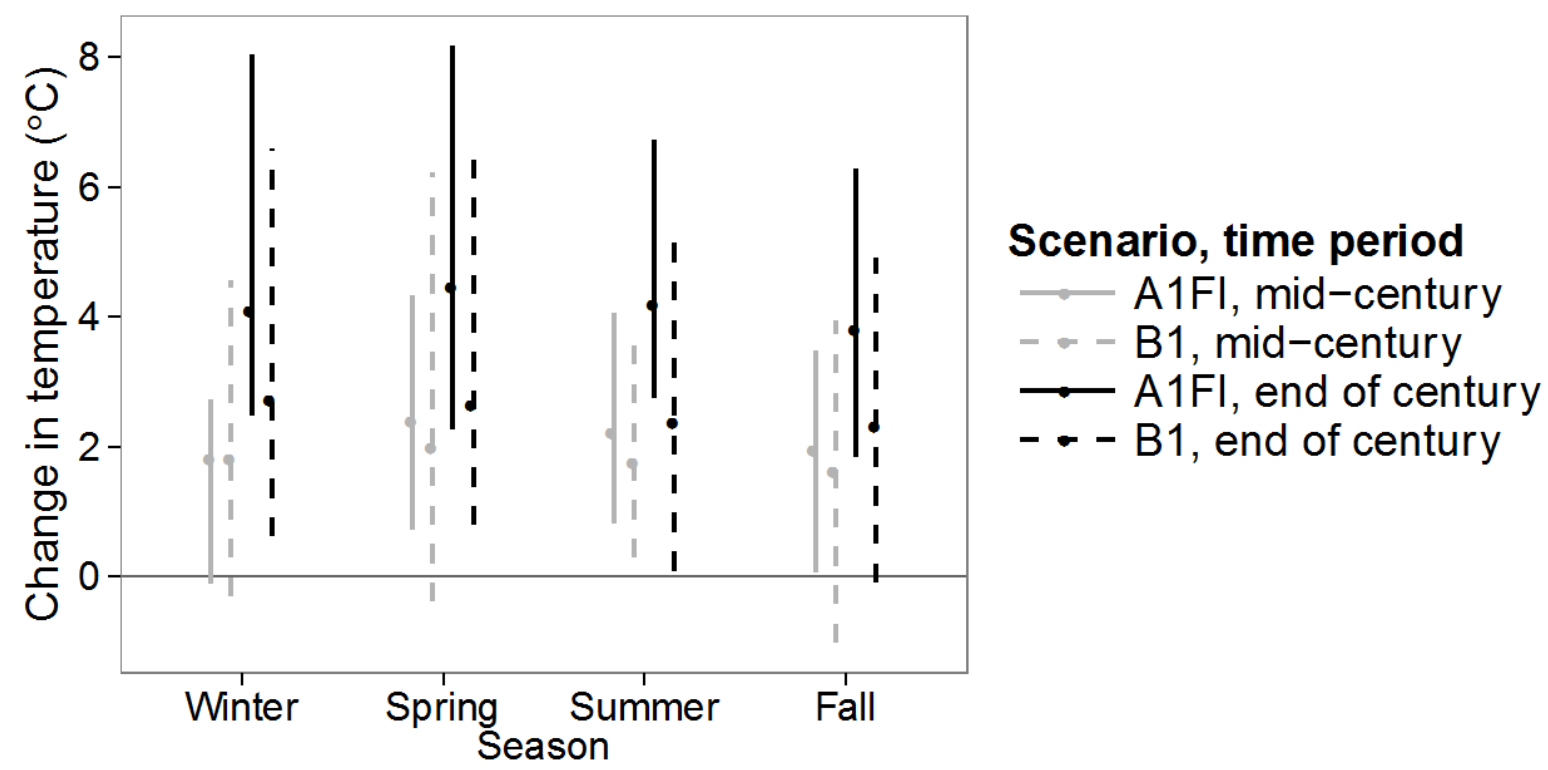

Figure 11.2. Projected change in seasonal maximum temperatures (in degrees Celsius $\left[{ }^{\circ} \mathrm{C}\right]$ ) for the middle $(2040$ 2060) and the end of the 21st century (2080-2100), compared with the recent time period (1981-2000), for two emissions scenarios for the South-Central Interior Mesophytic Forest ecological system. Solid dots and error bars represent, respectively, the means and ranges of projections across climate models under each scenario.

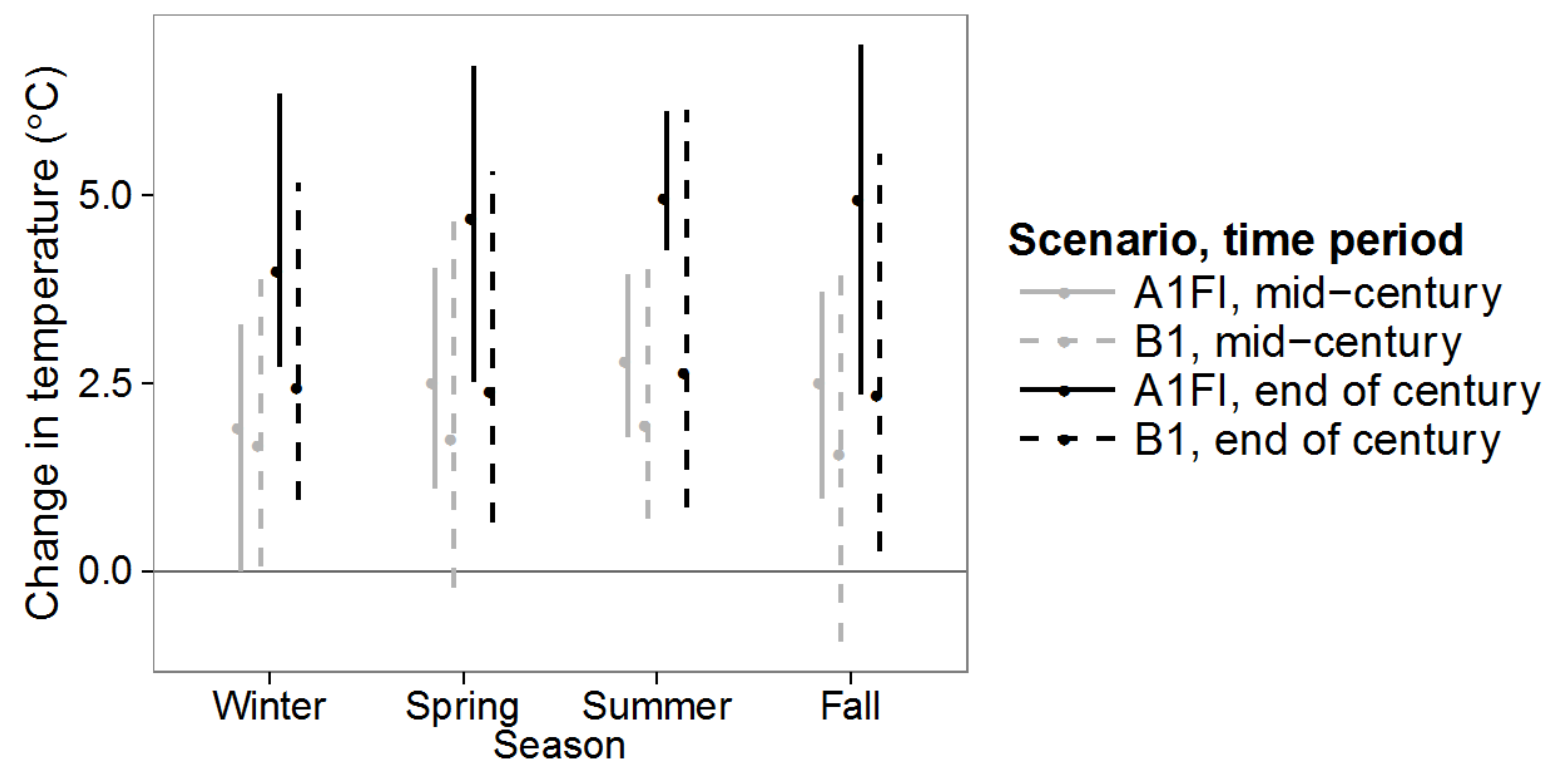

Figure 11.3. Projected change in seasonal minimum temperature (in degrees Celsius $\left[{ }^{\circ} \mathrm{C}\right]$ ) for the middle (20402060) and the end of the 21st century (2080-2100), compared with the recent time period (1981-2000), for two emissions scenarios for the South-Central Interior Mesophytic Forest ecological system. Solid dots and error bars represent, respectively, the means and ranges of projections across climate models under each scenario. 


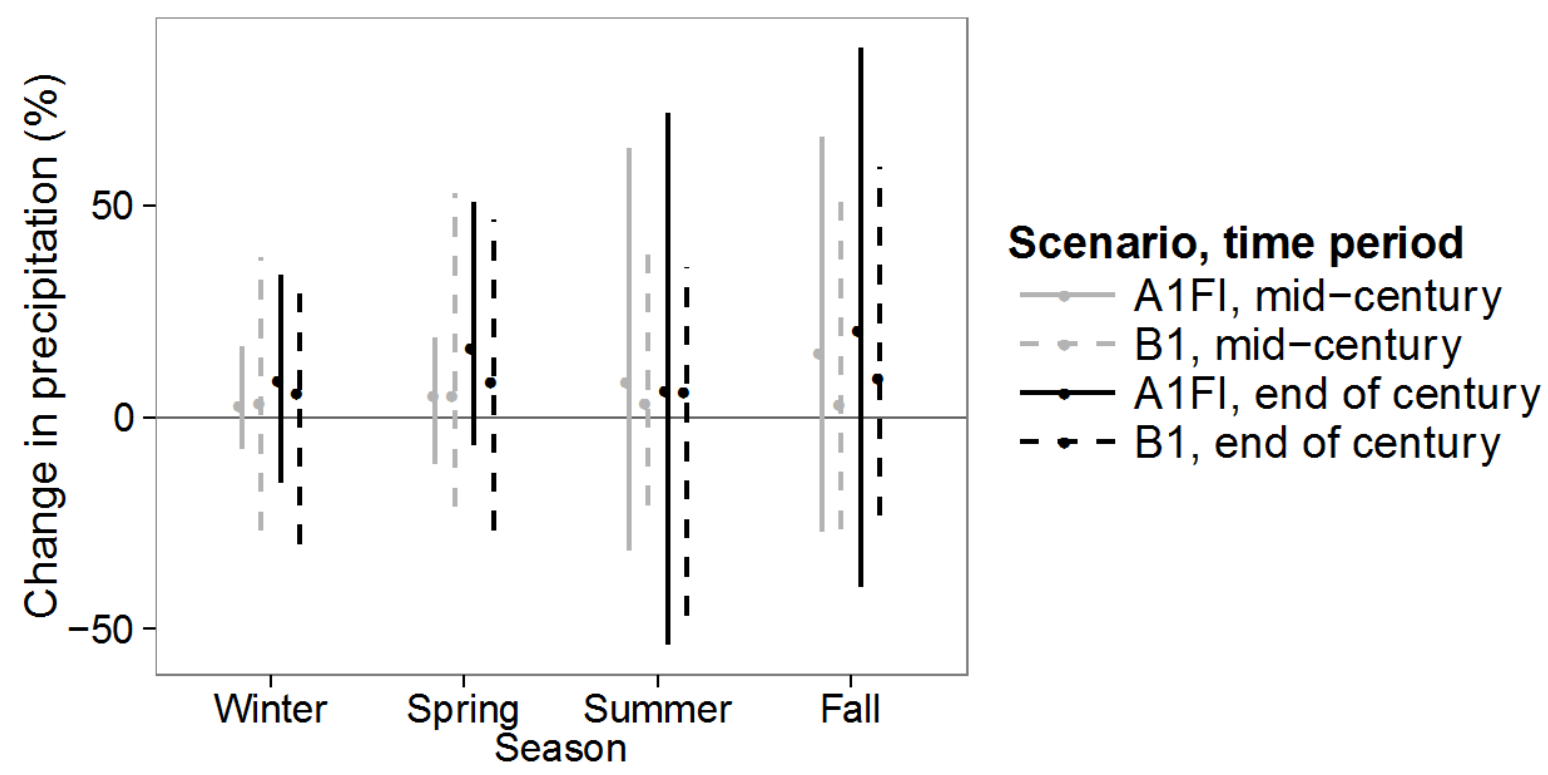

Figure 11.4. Projected percentage (\%) change in seasonal average precipitation for the middle (2040-2060) and the end of the 21st century (2080-2100), compared with the recent time period (1981-2000), for two emissions scenarios for the South-Central Interior Mesophytic Forest ecological system. Solid dots and error bars represent, respectively, the means and ranges of projections across climate models under each scenario.

Adaptive Capacity.-Several aspects of the South-Central Interior Mesophytic Forest ecological system may make it better able to adapt to future changes than other systems in the Southeast. Its high diversity of trees and herbaceous species may make this system resilient under future change. Additionally, this system is distributed across a fairly large area in the central United States, and is present at a large range of elevations (28-2,004 m; Appendix A). The area of this ecological system within protected areas is relatively large, compared with other systems in the Southeast $\left(6,000 \mathrm{~km}^{2}\right.$, or 600,000 ha; Appendix A), but that area represents only 9 percent of the area of the system (fig. 11.5). Patches are fairly large, on average $\left(9,020 \mathrm{~m}^{2}\right)$, compared to other ecological systems in the Southeast (Appendix A). On average, compared with other systems we analyzed in the Southeast, this system is located a moderate distance from development on average (791 m; Appendix A). Additionally, within our analysis area, only 0.3 percent of the system's extent is projected to be urbanized by 2050 (fig. 11.5). However, by 2100, a moderately high 10 percent is projected to be urbanized (fig. 11.5).

This system may be more common than it was historically. Fire suppression and reductions in canopy gap size across several deciduous forest ecosystems in the Eastern United States during the 20th century have led to reductions in canopy diversity and understory tree diversity (Rentch and others, 2003). The result has been a shift from less shade-tolerant oak-hickory forests to more shade-tolerant and more fire-intolerant species such as sugar maple and American beech throughout much of the Eastern United States (Dyer, 2001; Hutchinson and others, 2008).

Despite the characteristics that may make this system better able to adapt to climate change, a few factors may reduce its adaptive capacity. The existing extent of the system is highly modified by humans compared with the rest of the Southeast (71 percent modified on average; Appendix A). Additionally, 
overbrowsing by deer in mixed mesophytic forests has reduced species diversity. Deer select for more palatable tree species, including American beech (Nuttle and others, 2013), and can reduce the diversity of spring wildflowers (Webster and others, 2005). Additionally, as a result of the invasion of the hemlock woolly, hemlock may be lost completely across its range (Dale and others, 2009), or at the very least, its capacity to adapt to climate range may be severely limited. The threats to some tree species, combined with evidence showing less suitable climate conditions for American beech and sugar maple in the range of mixed mesophytic forests (see Exposure section above; Prasad and others, 2007), indicate that substantial shifts in species composition may be seen in the future.

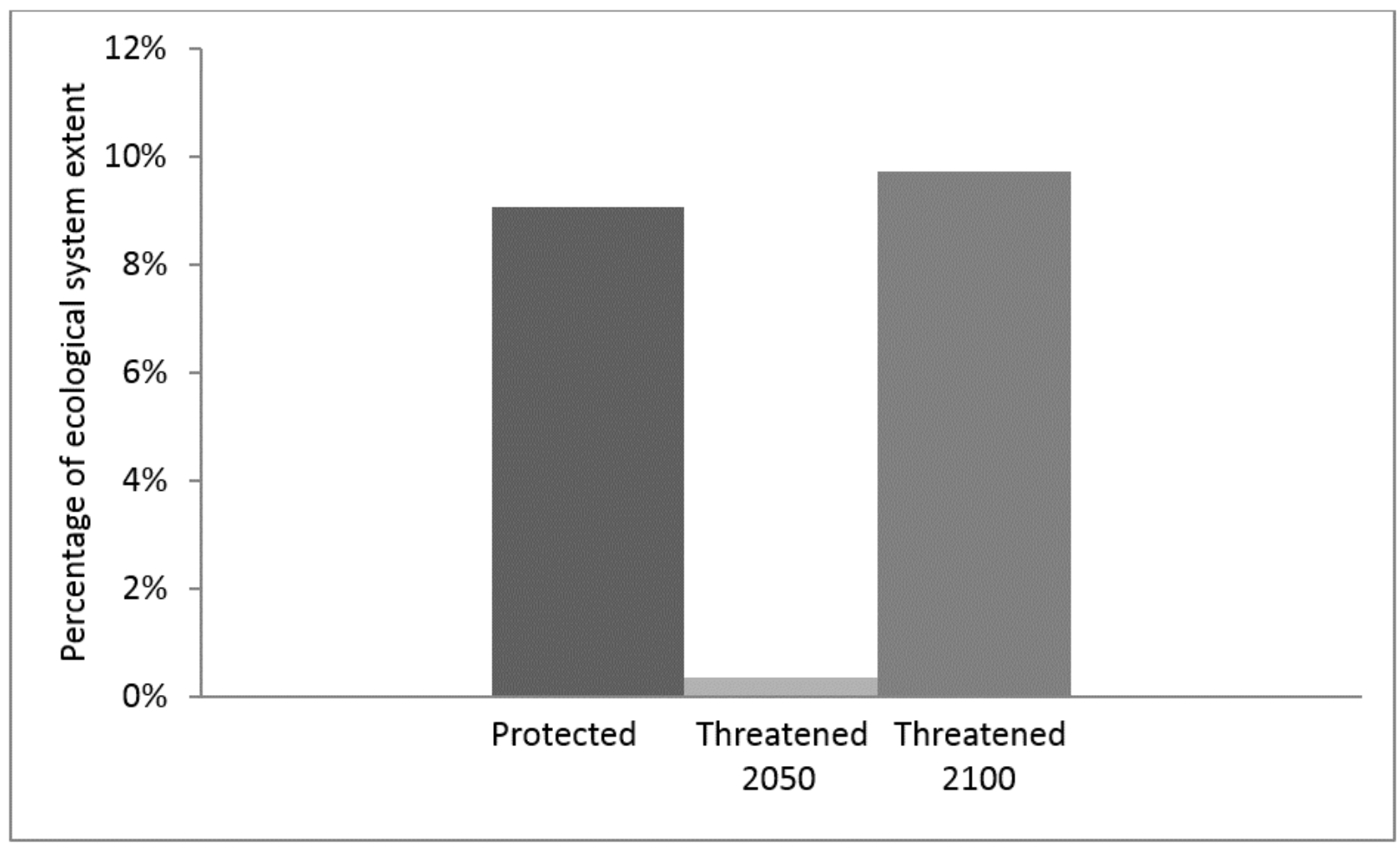

Figure 11.5. Percentage of the extent of the South-Central Interior Mesophytic Forest that is protected for conservation, and the percentage threatened by future development in 2050 and 2100 . Urbanization projections from the SLEUTH model were only available for 19 percent of the ecological system's range, so the numbers reported here are the percentages of that fraction.

Summary.-The South-Central Interior Mesophytic Forest ecological system has a high diversity of tree and understory species that is maintained by local-scale disturbances such as treefall gaps. The southern extent of the system as a whole may be defined by seasonal extremes, and, in particular, winter minimum temperatures. Winter minimum temperatures are projected to increase under climate change; therefore, the southern portion of this system's range could shift to the north.

Additionally, the dominant tree species in this system are sensitive to climate, and exposure to climate change is likely to be high for several of these species. Some aspects of the system suggest potential for relatively high adaptive capacity. The system has a wide distribution, is present in various conditions and at various elevations, and has high tree and understory species diversity. Other factors, such as deer browsing, substantially change species composition and reduce diversity, thus reducing this system's adaptive capacity. Those changes, combined with the projection of less suitable habitat for beech and 
maple because of climate change, suggest the potential for a shift in tree species composition and decrease in tree species richness in the future.

\section{References Cited}

Archibold, O.W., 1995, Ecology of world vegetation: London, Chapman \& Hall, 510 p.

Braun, E., 1955, The phytogeography of unglaciated Eastern United States and its interpretation: Botanical Review, v. 21, p. 297-375.

Burns, R.M., and Honkala, B.H., tech. coords., 1990, Silvics of North America-Volume 1, Conifers: U.S. Forest Service, Agriculture Handbook 654, 877 p.

Dale, V.H., Lannom, K.O., Tharp, M.L., Hodges, D.G., and Fogel, J., 2009, Effects of climate change, land-use change, and invasive species on the ecology of the Cumberland forests: Canadian Journal of Forest Research, v. 39, p. 467-480.

Delcourt, H.R., and Delcourt, P.A., 2000, Eastern deciduous forests, in Barbour, M.G., and Billings, W.D., eds., North American terrestrial vegetation (2d ed.): Cambridge, United Kingdom, Cambridge University Press, p. 357-395.

Dyer, J.M., 2001, Using witness trees to assess forest change in southeastern Ohio: Canadian Journal of Forest Research, v. 31, p. 1,708-1,718.

Hutchinson, T.F., Long, R.P., Ford, R.D., and Sutherland, E.K., 2008, Fire history and the establishment of oaks and maples in second-growth forests: Canadian Journal of Forest Research, v. 38, p. 1,1841,198 .

NatureServe, 2013a, NatureServe explorer-An online encyclopedia of life, Version 7.1: Arlington, Virginia, Nature Serve Web application, accessed May 2013, at http://www.natureserve.org/explorer.

NatureServe, 2013b, U.S. ecological systems National Map data: Arlington, Virginia, NatureServe database, accessed January 2013, at http://www.natureserve.org/getData/USecologyData.jsp.

Nuttle, T., Royo, A., Adams, M.B., and Carson, W.P., 2013, Historic disturbance regimes promote tree diversity only under low browsing regimes in Eastern deciduous forest: Ecological Monographs, v. 83, p. 3-17.

Prasad, A.M., Iverson., L.R., Matthews, S., and Peters, M., 2007, A climate change atlas for 134 forest tree species of the Eastern United States: U.S. Forest Service database, Northern Research Station, Delaware, Ohio, accessed May 2013, at http://www.nrs.fs.fed.us/atlas/tree.

Rentch, J.S., Fajvan, M.A., and Hicks, R.R., 2003, Oak establishment and canopy accession strategies in five old-growth stands in the central hardwood forest region: Forest Ecology and Management, v. 184, p. 285-297. 
Runkle, J.R., 1985, Disturbance Regimes in Temperate Forests, in Pickett, S.T.A., and White, P.S., eds., The ecology of natural disturbance and patch dynamics: San Diego, California, Academic Press, p. 1733.

Sole, J., Olson, R., and Bullington, C., 2009, LANDFIRE biophysical setting model for South-Central Interior Mesophytic Forest—LANDFIRE biophysical setting descriptions, Map zone 48: LANDFIRE program model, p. 42-48, accessed August 2013, at http://www.landfire.gov/national_veg_models_op2.php.

Tennessee Wildlife Resources Agency, 2009, Climate change and potential impacts to wildlife in Tennessee-An update to Tennesseee's State wildlife action plan: Nashville, Tennessee Wildlife Resources Agency, 106 p.

Webster, C.R., Jenkins, M.A., and Rock, J.H., 2005, Long-term response of spring flora to chronic herbivory and deer exclusion in Great Smoky Mountains National Park, USA: Biological Conservation, v. 125, p. 297-307. 


\section{Southern Coastal Plain Nonriverine Cypress Dome}

Ecological System Overview.-The Southern Coastal Plain Nonriverine Cypress Dome ecosystem includes small, forested wetlands dominated by pond cypress (Taxodium ascendens) and sometimes swamp tupelo (Nyssa biflora). These domes occur as unique communities within upland firemaintained habitat such as wet pine flatwoods (Huck, 1987). The system is present in central Florida and on the coastal plain from South Carolina to Alabama (fig. 12.1). Cypress domes have a characteristic dome-shaped appearance, and trees in the center of domes are taller and older than those on the sides (Monk and Brown, 1965; NatureServe, 2013a). The system is underlain by a clay pan that keeps water depths at 1-4 ft (0.3-1.2 m) toward the center, with shallower water toward the edges (Monk and Brown, 1965). Some pans are caused by water dissolving the underlying limestone bedrock (Florida Natural Areas Inventory, 2010). However, cypress domes generally are isolated from rivers and other sources of nutrients, making their soils nutrient-poor compared with floodplain swamps (Christensen, 2000). Monk (1968) called cypress domes a successional community maintained by hydrology and low-intensity fires. In areas that are almost permanently inundated, cypress may form stable populations, whereas on drier sites, bay forests tend to replace cypress (Christensen, 2000). Many at-risk species are present in this ecological system, including 19 plants and animals that are Federally listed as threatened or endangered. The Reticulated Flatwoods Salamander (Ambystoma bishopi) and Frosted Flatwoods Salamander (Ambystoma cingulatum) are examples of such species.

See NatureServe (2013a) and the Florida Natural Areas Inventory (2010, Cypress Domes) for a complete description of this ecological system. 


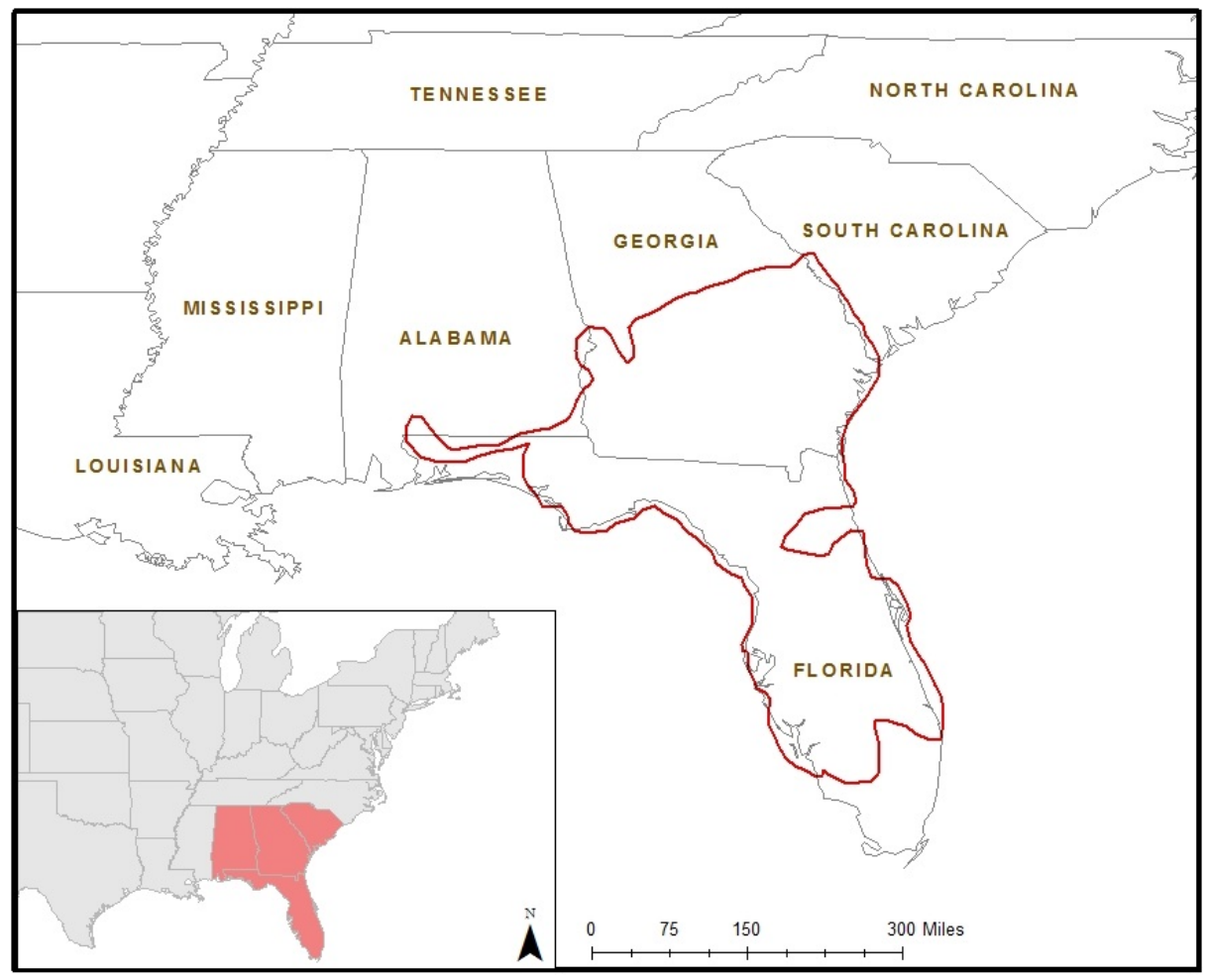

Figure 12.1. Range of the Southern Coastal Plain Nonriverine Cypress Dome ecological system. The system covers 2.33 percent of this range, according to data from NatureServe (2013b).

Vulnerability Status.- - Relative to other ecological systems in the Southeast, the vulnerability of this ecological system was rated as Medium. The system is sensitive to sea level rise, precipitation, and storm events, and likely will be exposed to at least moderate changes in those factors. Although it is somewhat fragmented and threatened by logging and land conversion in the regional landscape, its relatively high proportion of land protected for conservation gives it a moderate ability to adapt to climate and other threats.

Sensitivity.-Our analysis shows that this system occurs in areas where temperature ranges from a summer maximum of $34^{\circ} \mathrm{C}$ (Appendix B) to a winter minimum of $1{ }^{\circ} \mathrm{C}$ (Appendix B). Average summer precipitation generally is higher than during other seasons (Appendix $B$ ).

Hydrologic conditions contribute to the maintenance of Southern Coastal Plain Nonriverine Cypress Domes. This ecological system is present in depressions where soils are almost constantly inundated. The plants in this ecosystem, including pond cypress, generally are shade-intolerant and poor competitors in other ecological systems with less frequent inundation or more nutrients. However, although adult pond cypress, as well as swamp tupelo, thrive in inundated areas, their seeds cannot germinate in flooded soils (Burns and Honkala, 1990; Keeland and others, 1997; Casey and Ewel, 2006). Therefore, this system depends on periods of drought for stand establishment (Christensen, 2000).

Fire also is important for maintaining this community, and especially cypress trees, which are more fire-tolerant than other species in nearby upland communities (Ewel and Mitsch, 1978). Fire frequency generally is as short as every $3-5$ years on the periphery of domes, and can be as long as $100-$ 
150 years toward the center (Florida Natural Areas Inventory, 2010). Less frequent fires can cause cypress trees to become less dominant, while other hardwood or bay species become more dominant. A high-intensity fire during a drought or in a fire-suppressed cypress dome can cause cypress tree mortality. Protection from fire may lead to accumulation of organic matter and lowering of water levels, making conditions more favorable for fire-intolerant species (Casey and Ewel, 2006).

Exposure.-Our analysis of projected change in climate for the Southern Coastal Plain Nonriverine Cypress Dome ecological system shows increases in maximum and minimum temperatures for most models and most scenarios (figs. 12.2 and 12.3). The projected change in maximum temperature is slightly greater for spring than for other seasons, under all scenarios and time periods. A mean change of $4.5^{\circ} \mathrm{C}$ for spring is projected under the A1FI scenario by the end of this century. The projected changes in minimum temperature are similar for all seasons, with slightly less change projected under the A1FI scenario for winter during both the mid- and late-21st century.

Projected percentage changes in precipitation for this ecological system show variation among climate models for each season, emissions scenario, and time period, with the most variation in summer and fall, and less variation among climate models in the winter (fig. 12.4). The means for each emissions scenario and time period are positive in all cases for the fall, but vary between positive and negative for other seasons. However, in all cases, the range of projections crosses 0 , indicating much uncertainty among climate models in the magnitude and direction of change in precipitation. The greatest increases are projected for the summer and fall, with increases of as much as 72 and 82 percent projected under the A1FI scenario by the end of the century for those seasons, respectively. The largest decreases in precipitation are projected for the spring and summer. A decrease in precipitation of as much as 54 percent is projected for the spring under the A1FI scenario by the end of the century, and a decrease of as much as 51 percent is projected for the fall under the B1 scenario at mid-century.

Projected changes in the standard deviation, or variability, of temperature and precipitation for this ecological system show a high degree of uncertainty among climate models. Both the means and ranges of projected change in standard deviation for maximum and minimum temperatures vary considerably (Appendix C). The mean change in the standard deviation of precipitation is greater than 1 in all cases, indicating that although projections vary among models, on average, they predict an increase in variability for precipitation in the future under both emissions scenarios (Appendix C).

According to climate envelope modeling done for the U.S. Forest Service Climate Change Tree Atlas, conditions on the coastal plain will become more suitable for pond cypress in the future (Prasad and others, 2007). This species is expected to increase in importance in the central and northern portions of this ecological system's distribution under all emissions scenarios modeled (Prasad and others, 2007). Annual precipitation and the mean difference between July and January temperature are the two most important variables predicting the distribution of the species (Prasad and others, 2007). The distribution of suitable conditions for swamp tupelo will be broadly similar to its distribution in the early 21st century (Prasad and others, 2007). Mean summer precipitation is the most important climate variable predicting the distribution of swamp tupelo in those models, but soil erodibility was the most important variable overall (Prasad and others, 2007).

A change in the amount or variability of precipitation would change the fire regime in this ecological system, which could affect the dominance of cypress. Uncertainty in the direction and 
magnitude of projected changes in precipitation makes predicting changes in the fire regime challenging. There also are some differing results in previous studies regarding how the area burned by wildfires may change in the area where this system occurs. In the inner coastal plain of Georgia and Alabama, the area burned may not change in the future under any emissions scenario (Costanza and others, 2015). In southern Florida, wildfire frequency is related to the El Niño-Southern Oscillation (ENSO), and wildfires occur more frequently there in La Niña years when precipitation is decreased (Beckage and others, 2006). Some evidence is available for decreases in La Niña events with future climate change (Timmermann and others, 1999; Beckage and others, 2006); however, the link between ENSO and climate change is uncertain (Cobb and others, 2013).

Changes in soil hydrologic conditions within cypress domes or in the adjacent pine flatwoods landscape would alter the plant species composition of these communities. On the one hand, drought conditions are expected to become more common in the Southeast under climate change, although there is some disagreement among climate models (Seager and others, 2009). If cypress domes become drier, shade-tolerant species such as redbay (Persea borbonia), sweetbay (Magnolia virginiana), and loblolly bay (Gordonia lasianthus) may replace pond cypress and swamp tupelo to produce a bay forest. On the other hand, large storms such as hurricanes also are expected to increase in intensity, bringing more rainfall (Intergovernmental Panel on Climate Change, 2007a). If these storms change landscape hydrology such that cypress domes become connected to rivers and acquire nutrient subsidies more often, cypress and tupelo may be replaced by broadleaved deciduous species such as red maple (Acer rubrum), oak species (Quercus sp.), and Carolina ash (Fraxinus caroliniana) (Christensen, 2000).

The location of this ecological system along the coast means that it is likely to be exposed to sea level rise. According to the National Oceanic and Atmospheric Administration (NOAA) Sea Level Trends data, stations within the range of this ecological system have had a relatively small amount of annual sea level rise from 1947 to 2006 (National Oceanic and Atmospheric Administration, 2013). The mean annual sea level rise ranged from $0.75 \mathrm{~mm} / \mathrm{yr}$ in Panama City, Florida, to $2.98 \mathrm{~mm} / \mathrm{yr}$ in Fort Pulaski, Georgia (National Oceanic and Atmospheric Administration, 2013).

We analyzed the projected inundation owing to sea level rise under a 1- and 6-ft (0.3- and 1.8-m) rise in sea level, according to NOAA data. Those data cover 99 percent of the coastal extent of this ecological system. Within the area covered by the data, rising sea level is projected to inundate 1.3 and 5.7 percent of this ecological system under a 1- and 6-ft rise, respectively (Appendix A). The effects of sea level rise include not only direct loss and fragmentation of habitat through inundation, but also an increase in the severity of other disturbances. For example, storm surges associated with hurricanes cause damage to trees and other vegetation (Stanturf and others, 2007). Thus, the effects of storm surge may become more severe in the future as sea level rises and hurricane intensity and frequency increase, as projected (Webster and others, 2005; Intergovernmental Panel on Climate Change, 2007b; Lin and others, 2012). We analyzed data for the portion of this system's range along the Georgia coast and a portion of the Florida Panhandle from the Sea Level Affecting Marshes Model (SLAMM), which incorporates some changes in hydrology that accompany inundation from rising sea level. Our analysis shows that for both the A1FI and B1 scenarios, approximately 2 percent of the system's range is projected to change to another vegetation type by 2050, and nearly 4 percent is likely to change by 2100 (Appendix A). 


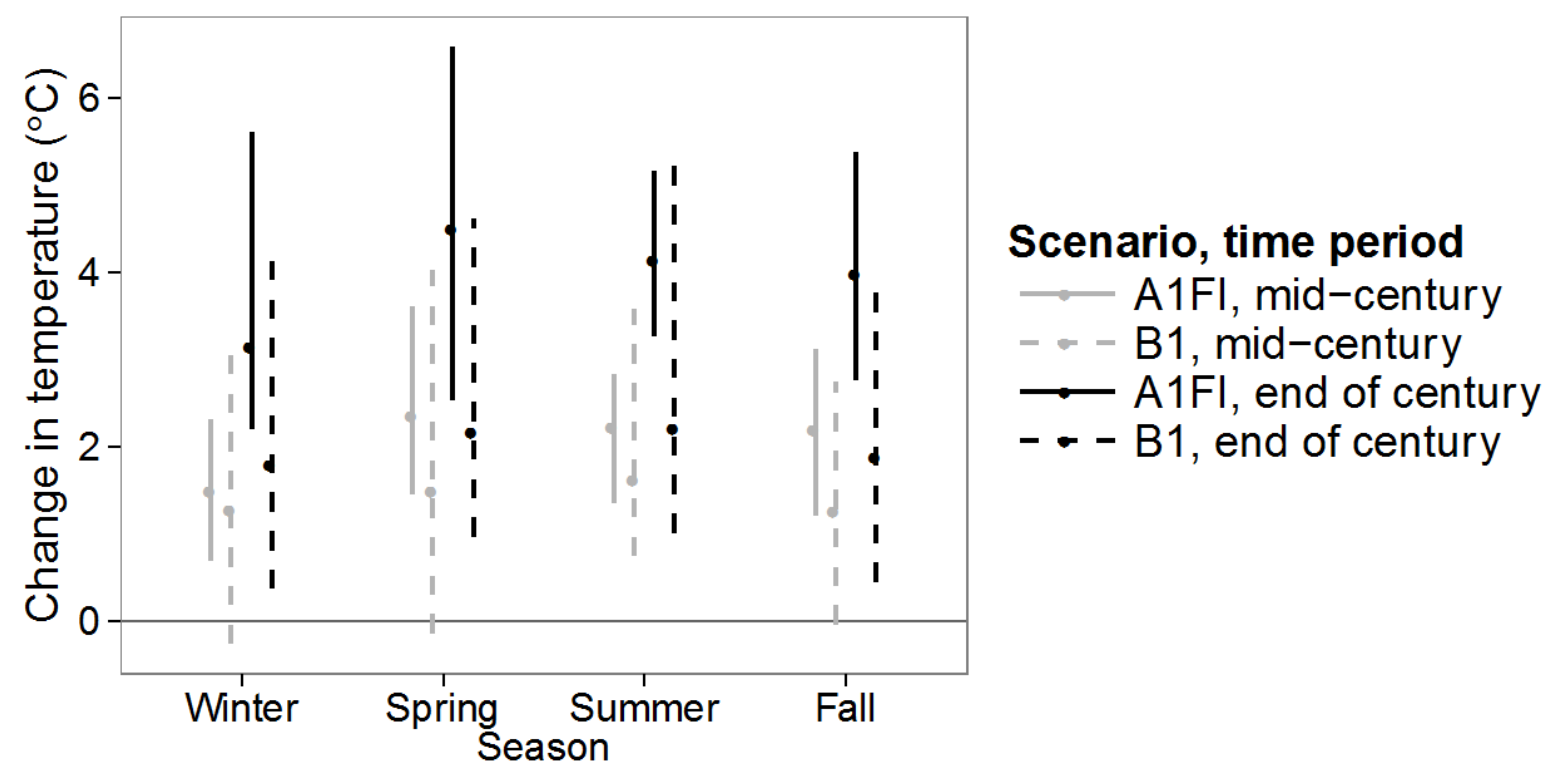

Figure 12.2. Projected change in seasonal maximum temperature (in degrees Celsius [ $\left.{ }^{\circ} \mathrm{C}\right]$ ) for the middle (20402060) and the end of the 21st century (2080-2100), compared with the recent time period (1981-2000), for two emissions scenarios for the Southern Coastal Plain Nonriverine Cypress Dome ecological system. Solid dots and error bars represent, respectively, the means and ranges of projections across climate models under each scenario.

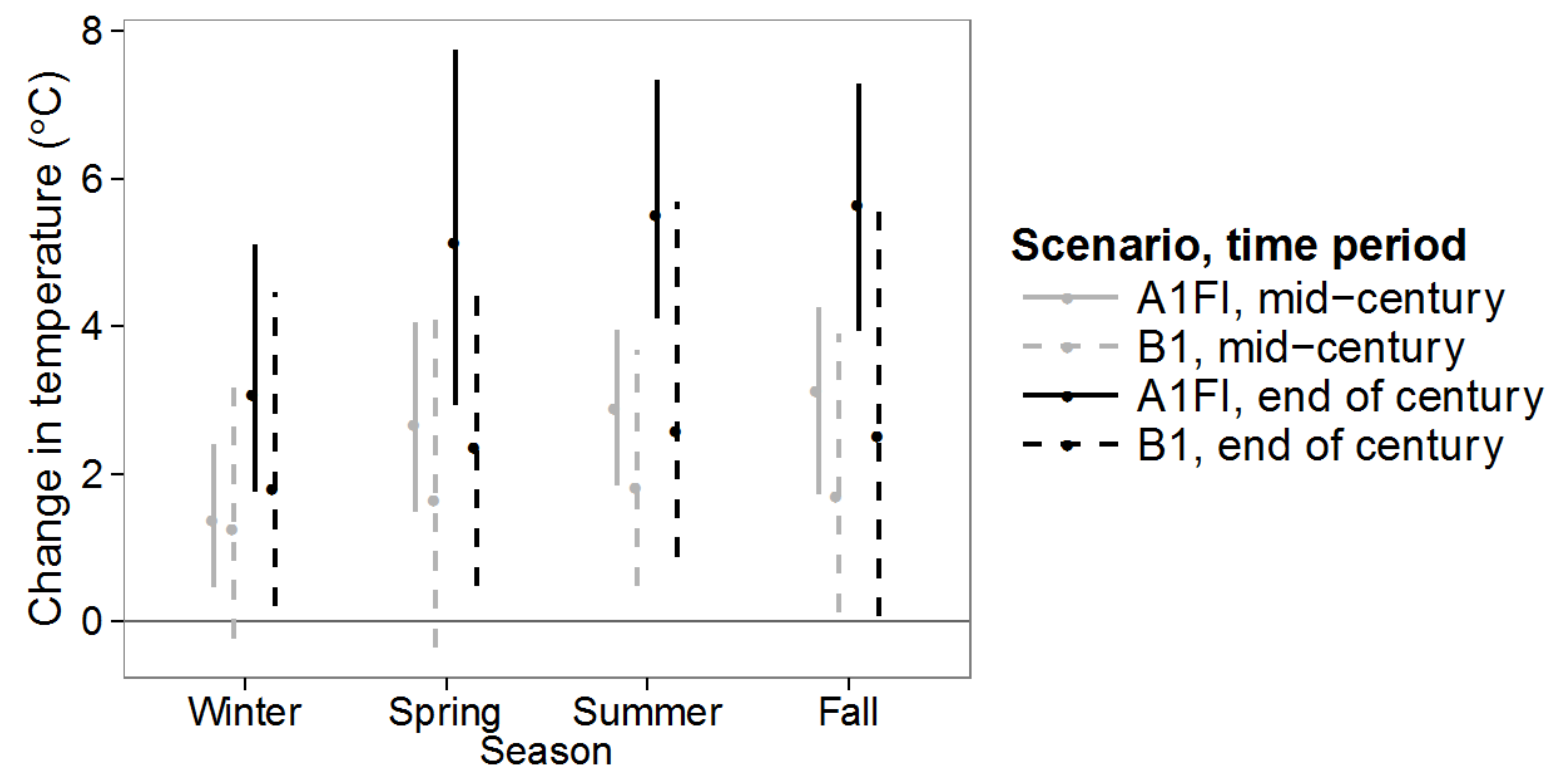

Figure 12.3. Projected change in seasonal minimum temperatures (in degrees Celsius $\left[{ }^{\circ} \mathrm{C}\right]$ ) for the middle $(2040$ 2060) and the end of the 21st century (2080-2100), compared with the recent time period (1981-2000), for two emissions scenarios for the Southern Coastal Plain Nonriverine Cypress Dome ecological system. Solid dots and error bars represent, respectively, the means and ranges of projections across climate models under each scenario. 


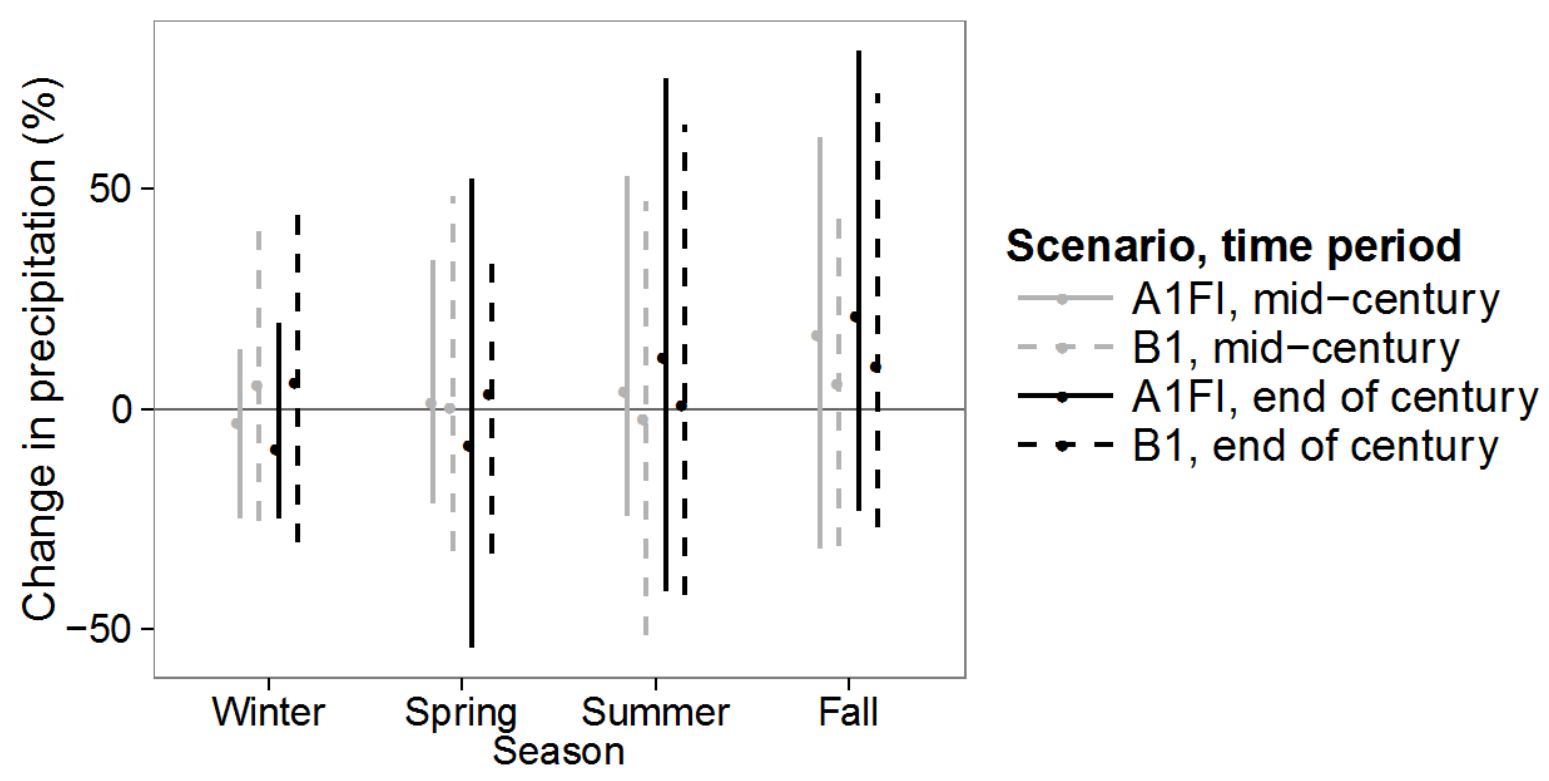

Figure 12.4. Projected percentage (\%) change in seasonal average precipitation for the middle (2040-2060) and the end of the 21st century (2080-2100), compared with the recent time period (1981-2000), for two emissions scenarios for the Southern Coastal Plain Nonriverine Cypress Dome ecological system. Solid dots and error bars represent, respectively, the means and ranges of projections across climate models under each scenario.

Adaptive Capacity.-Cypress domes are isolated communities defined by hydrology, with species composition and community structure that differs from surrounding upland matrix. The system is present in a relatively low range of elevations, from -7 to $80 \mathrm{~m}$ (Appendix A). According to our analysis of land-cover data, patches of this ecological system are relatively small on average $\left(5,747 \mathrm{~m}^{2}\right.$, or $0.57 \mathrm{ha}$; Appendix A). Thus, habitat connectivity for many species may be low within this ecological system. In the event of altered hydrologic conditions owing to climate change or other anthropogenic factors, immediately adjacent upland areas likely will not be suitable for the species in this community. For example, pond cypress trees almost always grow in low elevations, and little is known about whether the species can survive in higher elevations (Burns and Honkala, 1990).

Non-climate threats to the ecological system include logging, nutrient enrichment, conversion to agriculture, agricultural runoff, conversion to urban areas, and encroachment of pine flatwoods vegetation from surrounding areas (Christensen, 2000; Florida Natural Areas Inventory, 2010). Many cypress domes already had been logged or converted to agricultural or urban areas by the middle and end of the 20th century (Monk and Brown, 1965; Christensen, 2000). Our analysis shows that almost one-third of the extent of this system has been protected for conservation (fig. 12.5). Partly as a result of this high level of protection, less than 1 percent of this ecological system's extent may be urbanized by 2050, and 2 percent by 2100 (fig. 12.5).

Although little of this ecological system may be urbanized, the system may be subject to other threats. After logging, cypress often is not replanted and rarely regenerates naturally, and often bay species invade (Florida Natural Areas Inventory, 2010). Additionally, the average distance from this ecological system to existing development is only $586 \mathrm{~m}$, and habitat in this ecological system has a 
relatively high degree of human modification, compared with other systems in the Southeast (71 percent; Appendix A). Therefore, even if the system is not directly converted to urban land uses, the system is vulnerable to the landscape effects of urban growth and development, including changes in hydrology. These threats of conversion and altered hydrology are threats to other important species found in the ecological system, such as flatwoods salamander species, which breed in cypress domes (NatureServe, 2013a). Future research could focus on whether and how these species will be able to adapt to likely changes in hydrology owing to urban growth in the landscape.

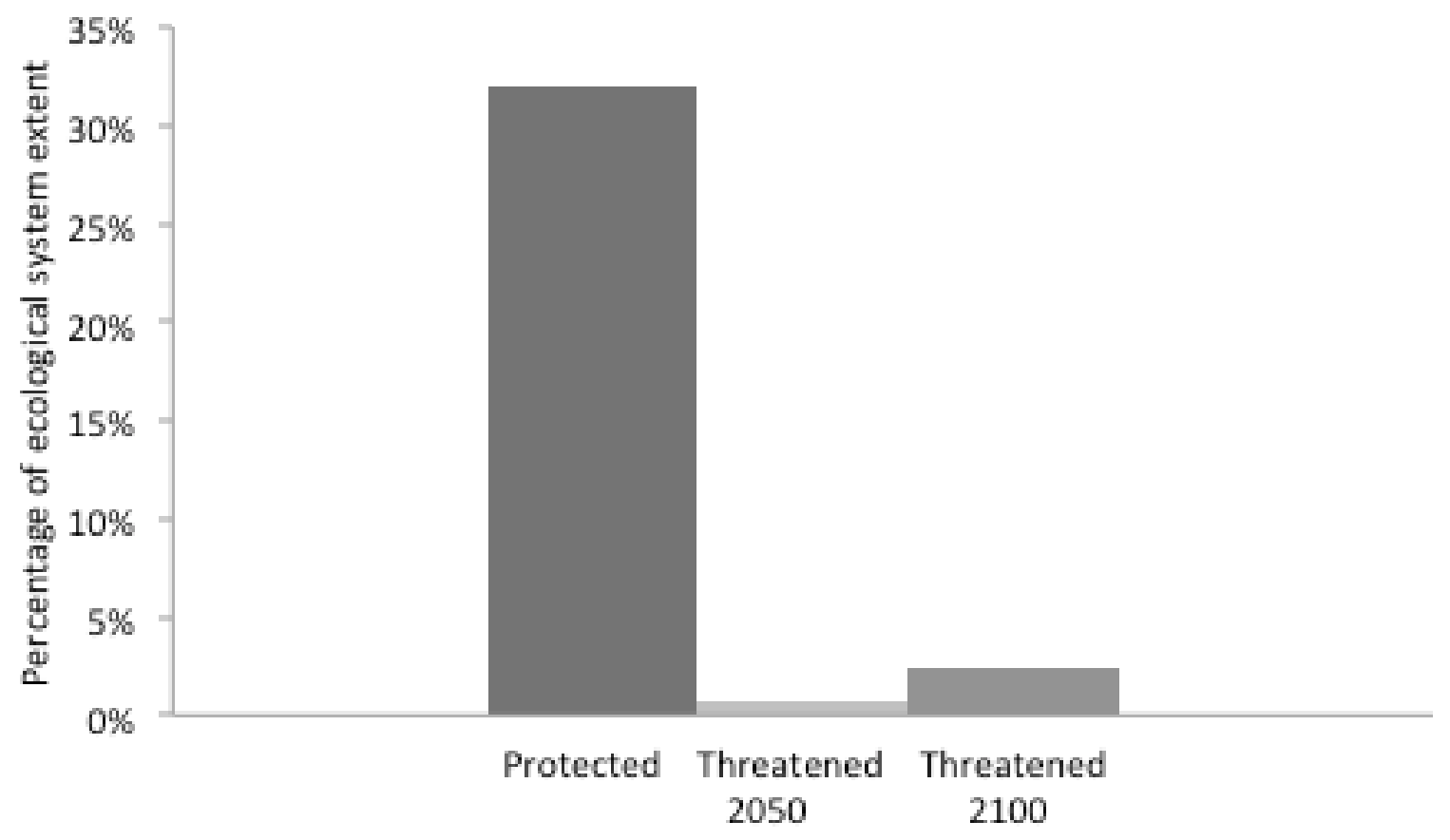

Figure 12.5. Percentage of the extent of the Southern Coastal Plain Nonriverine Cypress Dome ecological system that is protected for conservation, and the percentage threatened by future development in 2050 and 2100 .

Summary.-The Southern Coastal Plain Nonriverine Cypress Dome ecological system is present in areas with hydrology that is isolated from the surrounding landscape, and where soils are constantly inundated. Almost constant inundation will prevent invasion from hardwoods and other species from adjacent habitats. Periodic dry periods will allow cypress trees to establish. The system, and the cypress trees that dominate it, are maintained by fire, and without fire will succeed to bay forest. Climate models project an increase in maximum and minimum temperatures, on average, for all seasons through the end of the 21st century. Projected changes in precipitation vary across climate models, scenarios, and seasons. These changes in climate could lead to a decrease in wildfires, although projected effects of climate on wildfires have a high degree of uncertainty for this ecological system. This ecological system also will be exposed to sea level rise because of its distribution along the coast. Non-climate stressors include a high degree of habitat fragmentation, partially as a result of the unique conditions in which this system occurs naturally. Given that almost one-third of the system is protected, management of existing areas may be easier for this system than for other systems in the Southeast. More research on the potential impacts of climate change on the hydrology of cypress domes and the species that inhabit them would be valuable. 


\section{References Cited}

Beckage, B., Gross, L.J., Platt, W.J., Louis, J., and William, J., 2006, Modelling responses of pine savannas to climate change and large-scale disturbance: Applied Vegetation Science, v. 9, p. 75-82.

Burns, R.M., and Honkala, B.H., tech. coords., 1990, Silvics of North America-Volume 1, Conifers: U.S. Forest Service, Agriculture Handbook 654, 877 p.

Casey, W.P., and Ewel, K.C., 2006, Patterns of succession in forested depressional wetlands in north Florida, USA: Wetlands, v. 26, p. 147-160.

Christensen, N.L., 2000, Vegetation of the southeastern coastal plain, in Barbour, M.G., and Billings, W.D., eds., North American terrestrial vegetation (2d ed.): Cambridge, United Kingdom, Cambridge University Press, p. 397-448.

Cobb, K.M., Westphal, N., Sayani, H.R., Watson, J.T., Di Lorenzo, E., Cheng, H., Edwards, R.L., and Charles, C.D., 2013, Highly variable El Niño-Southern Oscillation throughout the Holocene: Science, v. 339, p. 67-70.

Costanza, J.K., Terando, A.J., McKerrow, A.J., and Collazo, J.A., 2015, Modeling climate change, urbanization, and fire effects on Pinus palustris ecosystems of the Southeastern U.S.: Journal of Environmental Management v. 151, p. 186-199.

Ewel, K.C., and Mitsch, W.J., 1978, The effects of fire on species composition in cypress dome ecosystems: Florida Scientist, v. 41, p. 25-31.

Florida Natural Areas Inventory, 2010, Guide to the natural communities of Florida—2010 edition:

Tallahassee, Florida Natural Areas Inventory, accessed May 2013, at http://www.fnai.org/naturalcommguide.cfm.

Huck, R.B., 1987, Plant communities along an edaphic continuum in a central Florida watershed: Florida Scientist, v. 50, p. 111-128.

Intergovernmental Panel on Climate Change, 2007a, Climate change 2007-Impacts, adaptation, and vulnerability-Contribution of Working Group II to the Fourth Assessment Report of the Intergovernmental Panel on Climate Change: Cambridge and New York, Cambridge University Press, $976 \mathrm{p}$.

Intergovernmental Panel on Climate Change, 2007b, Climate change 2007-The physical science basisContribution of Working Group I to the Fourth Assessment Report of the Intergovernmental Panel on Climate Change: Cambridge and New York, Cambridge University Press, 996 p.

Keeland, B.D., Conner, W.H., and Sharitz R.R., 1997, A comparison of wetland tree growth response to hydrologic regime in Louisiana and South Carolina: Forest Ecology and Management, v. 90, p. 237250.

Lin, N., Emanuel, K., Oppenheimer, M., and Vanmarcke, E., 2012, Physically based assessment of hurricane surge threat under climate change: Nature Climate Change, v. 2, p. 462-467. 
Monk, C.D., 1968, Successional and environmental relationships of the forest vegetation of north central Florida: American Midland Naturalist, v. 79, p. 441-457.

Monk, C.D., and Brown, T.W., 1965, Ecological consideration of cypress heads in northcentral Florida: American Midland Naturalist, v. 74, p. 126-140.

National Oceanic and Atmospheric Administration, 2013, Sea levels online-Sea level variations of the United States derived from National Water Level Observation Network stations: National Oceanic and Atmospheric Administration Ocean Service, Center for Operational Oceanographic Products and Services (CO-OPS), Silver Spring, Maryland, accessed October 2013, at http://tidesandcurrents.noaa.gov/sltrends.

NatureServe, 2013a, NatureServe explorer-An online encyclopedia of life, Version 7.1: Arlington, Virginia, NatureServe Web application, accessed May 2013, at http://www.natureserve.org/explorer.

NatureServe, 2013b, U.S. ecological systems National Map data: Arlington, Virginia, NatureServe database, accessed January 2013, at http://www.natureserve.org/getData/USecologyData.jsp.

Prasad, A.M., Iverson, L.R., Matthews, S., and Peters, M., 2007, A climate change atlas for 134 forest tree species of the Eastern United States: U.S. Forest Service database, Northern Research Station, Delaware, Ohio, accessed May 2013, at http://www.nrs.fs.fed.us/atlas/tree.

Seager, R., Tzanova, A., and Nakamura, J., 2009, Drought in the Southeastern United States-Causes, variability over the last millennium, and the potential for future hydroclimate change: Journal of Climate, v. 22, p. 5,021-5,045.

Stanturf, J.A., Goodrick, S.L., and Outcalt, K.W., 2007, Disturbance and coastal forests-A strategic approach to forest management in hurricane impact zones: Forest Ecology and Management, v. 250, p. 119-135.

Timmermann, A., Oberhuber, J., Bacher, A., Esch, M., Latif, M., and Roeckner, E., 1999, Increased El Nino frequency in a climate model forced by future greenhouse warming: Nature, v. 398, p. 694-697.

Webster, P.J., Holland, G.J., Curry, J.A., and Chang, H.-R., 2005, Changes in tropical cyclone number, duration, and intensity in a warming environment: Science, v. 309, p. 1,844-1,846. 


\section{Southern Coastal Plain Seepage Swamp and Baygall}

Ecological System Overview.-The Southern Coastal Plain Seepage Swamp and Baygall ecological system is a forested wetland system that is mapped by NatureServe (2013a) in Florida and the coastal plain of Georgia (fig. 13.1), and, although it is not mapped there, the system also occurs west along the Gulf Coast to Mississippi (NatureServe, 2013b). Also called "bayheads”, these wetlands are distinct from other wetlands in the same geographic area because they are dominated by broad-leaved evergreen species, including characteristic “bay” species—sweetbay (Magnolia virginiana), redbay (Persea palustris), and loblolly bay (Gordonia lasianthus). Deciduous species also occur in the system, including swamp tupelo (Nyssa biflora), along with sweetgum (Liquidambar styraciflua) and tulip poplar (Liriodendron tulipifera) (Monk, 1966; Florida Natural Areas Inventory, 2010; NatureServe, 2013b). These trees often occur in a tall, dense thicket, with very few herbaceous species present except along edges that have had fires (Christensen, 2000). The system is present in shallow depressions, at the base of uplands, on the edges of floodplains and in drainages, where seepage flow is concentrated (NatureServe, 2013b). Soils generally are acidic with a medium-to-deep layer of peat and are moist or inundated (Monk, 1968; Casey and Ewel, 2006). Fires do not occur in the system, except during major droughts. The at-risk species that occur in this ecological system are not endemic to the system, but include the endangered Florida Panther (Puma concolor coryi) and Eastern Cougar (Puma concolor couguar), as well as the threatened Frosted Flatwoods Salamander (Ambystoma cingulatum) and Eastern Indigo Snake (Drymarchon couperi, NatureServe, 2013b).

See NatureServe (2013b) and the Florida Natural Areas Inventory (2010) for a complete description of this ecological system. 


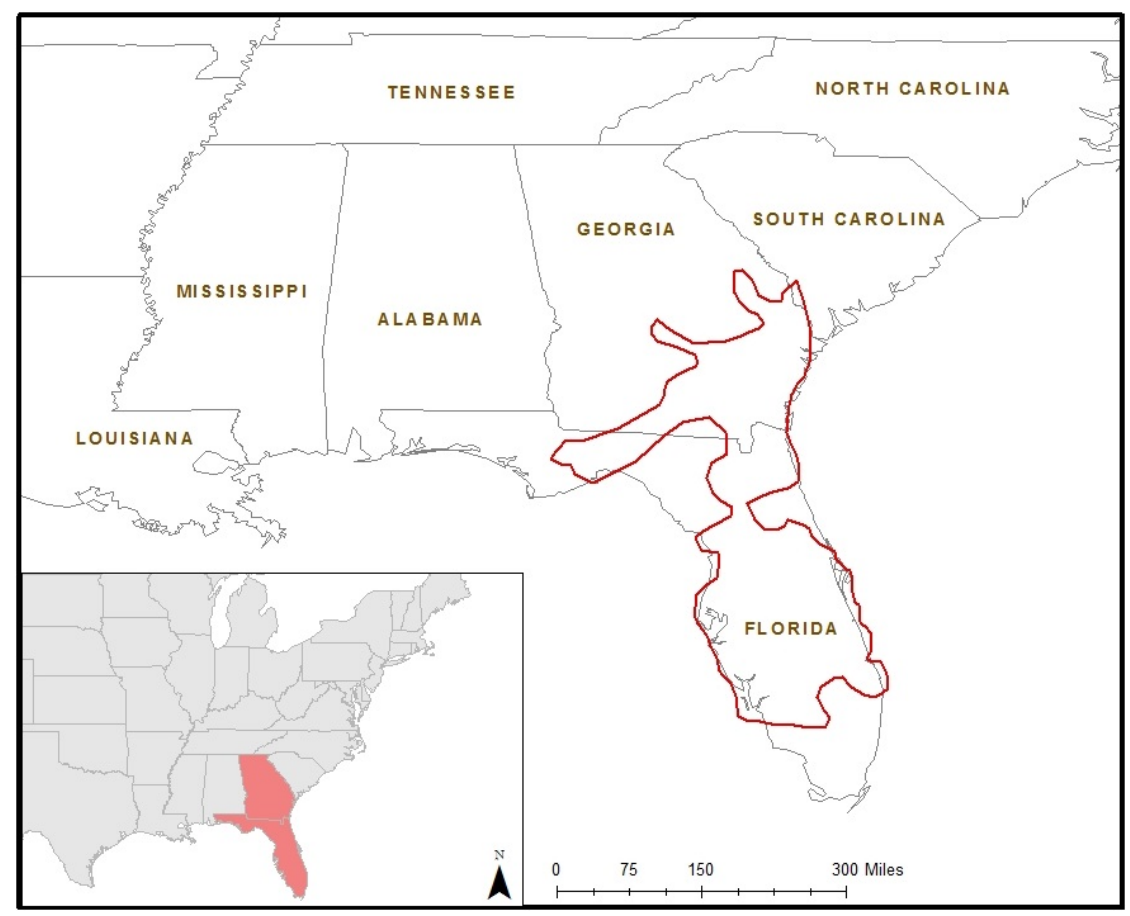

Figure 13.1. Range (outlined in top map) of the Southern Coastal Plain Seepage Swamp and Baygall ecological system. The system covers 0.6 percent of this range, according to data from NatureServe (2013a).

Vulnerability Status. - Relative to other ecological systems in the Southeast, the vulnerability of this ecological system is rated as Medium. This system is sensitive to hydrology, which maintains the major species and overall vegetation structure. The likely exposure to changes in climate is moderate, with some changes in hydrology and disturbance regimes, as well as some inundation owing to sea level rise. The system has a moderate level of adaptive capacity. It invades elsewhere after fire suppression and logging, and future urban growth is projected only to affect a relatively small portion of the extent. However, it is range restricted and has been affected by past urbanization.

Sensitivity.-Our analysis shows that the range of the Southern Coastal Plain Seepage Swamp and Baygall ecological system occurs where the average winter minimum temperatures are $7^{\circ} \mathrm{C}$ or above (Appendix B) and summer maximum temperatures are $33^{\circ} \mathrm{C}$ or below (Appendix B). Summer precipitation generally is very high, and is higher than during other seasons on average (Appendix B). The three bay species that dominate this ecological system occur across much of the southeast coastal plain, and thus are not limited by climate conditions within the range of the system (Burns and Honkala, 1990).

Appropriate hydrologic conditions are essential for the persistence of the Southern Coastal Plain Seepage Swamp and Baygall system. This system occurs on deep peat soils that are moist or inundated, but rarely flooded (Florida Natural Areas Inventory, 2010).

Fires do not occur in this system except during extreme droughts, which happen every 65 years on average (Jurney and others, 2004; Davenport, 2009). As a result, the dominant plant species of the system are fire-intolerant. For example, fires cause substantial damage to redbay, and may prevent reproduction in the species (Burns and Honkala, 1990). After severe fire, baygalls succeed to shrub bogs, 
marsh, or cypress/tupelo swamp (Casey and Ewel, 2006; Florida Natural Areas Inventory, 2010). Hurricanes are the most dominant form of wind damage in this system, and are a more common disturbance than fires (Davenport, 2009). Hurricanes remove the dense canopy trees in this system and result in an open structure.

Exposure.-Analysis of projected change in climate for this ecological system shows increases in maximum and minimum temperatures for most models and most scenarios, with more change projected under the A1FI scenario, especially toward the end of the century, than in the B1 scenario (figs. 13.2 and 13.3). Under the A1FI scenario, the mean projected change in maximum temperature for every season except winter is more than $4{ }^{\circ} \mathrm{C}$ by the end of this century. Slightly more change is projected for minimum temperature, with a mean change of more than $5{ }^{\circ} \mathrm{C}$ projected under the A1FI scenario for every season except winter by the end of the century.

Projected changes in precipitation for this ecological system show a large amount of variation among climate models for each season, emissions scenario, and time period

(fig. 13.4). The projected changes are most positive in the fall, with as much as a 104-percent increase in precipitation projected by one global climate model under the A1FI scenario at the end of the century. However, other seasons show variability among climate models. Additionally, the range of projected change in precipitation in all cases crosses 0 , indicating much uncertainty among climate models for all periods.

Projected changes in the standard deviation, or variability, of temperature and precipitation show a high degree of uncertainty among climate models. Both the means and ranges of change in standard deviation for maximum and minimum temperatures vary considerably (Appendix C). For each season, the mean projected change varies with time period and emissions scenario. In all cases, the ranges of projections cross 0 , indicating uncertainty among climate models in the direction of change in precipitation. The ranges of projections are narrowest for winter, and widest for summer, indicating more uncertainty for summer. The mean change in the standard deviation of precipitation is greater than 1 in all cases, indicating that although model projections are variable, on average, they predict an increase in variability for precipitation in the future (Appendix C).

An increase in variability in precipitation could mean more large storm events or droughts in this ecological system. Large storms, including hurricanes, also are expected to increase in intensity, bringing more rainfall (Intergovernmental Panel on Climate Change, 2007a). If more frequent hurricanes occur in the future, the system may be more dominated by early-succession vegetation and not the characteristic older, dense canopy of trees and shrubs. More research is suggested regarding the potential future changes in droughts and storms, how those changes are likely to interact with fire, and the ways in which this ecological system may be affected by those changes.

Climate envelope modeling by the U.S. Forest Service Climate Change Tree Atlas for sweetbay, redbay, and loblolly bay suggests little change in the abundance of these species in the area where the Southern Coastal Plain Seepage Swamp and Baygall ecological system occurs (Prasad and others, 2007). However, future changes to the moisture regime that change fire frequency or hydrology may affect the maintenance of this ecological system. More frequent fires or less hydrologic inundation may not allow this system to persist. 
Changes in soil moisture conditions in baygalls or in the surrounding landscape would alter the plant species composition of this system. Some studies have suggested that drought conditions are expected to become more common in the Southeast under climate change, although there is some disagreement among climate models (Seager and others, 2009). More droughts could lead to more frequent fires, which would lead to the replacement of bay species in some areas by pond cypress (Taxodium ascendens). However, there is some uncertainty about how climate change will affect the area burned by wildfires in the Southeast in general. In the inner coastal plain of Georgia and Alabama, the area burned may not change in the future under any emissions scenario (Costanza and others, 2015). In southern Florida, wildfire frequency has been shown to be connected with the El Niño-Southern Oscillation (ENSO). Wildfires occur more frequently in La Niña years when precipitation is decreased (Beckage and others, 2006). Some evidence is available for decreases in La Niña events with future climate change (Timmermann and others, 1999; Beckage and others, 2006); however, the link between ENSO and climate change is uncertain (Cobb and others, 2013).

The location of this ecological system along the coast means that it is likely to be exposed to sea level rise. According to the National Oceanic and Atmospheric Administration (NOAA) Sea Level Trends data, stations within the range of this ecological system have had a relatively small amount of annual sea level rise from 1947 to 2006 (National Oceanic and Atmospheric Administration, 2013). The mean annual sea level rise ranged from $0.75 \mathrm{~mm} / \mathrm{yr}$ in Panama City, Florida, to $2.98 \mathrm{~mm} / \mathrm{yr}$ in Fort Pulaski, Georgia (National Oceanic and Atmospheric Administration, 2013).

We analyzed the projected inundation owing to sea level rise under a 1- and 6-ft (0.3- and 1.8-m) rise in sea level, according to NOAA data. Those data cover 98 percent of the coastal extent of this ecological system. Within the area covered by the data, rising sea level is projected to inundate 1 and 5 percent of this ecological system under scenarios that assume a 1- and 6-ft global rise in global sea level, respectively (Appendix A). The effects of sea level rise include not only direct loss and fragmentation of habitat through inundation, but also an increase in the severity of other disturbances. For example, storm surges associated with hurricanes cause damage to trees and other vegetation (Stanturf and others, 2007). Thus, the effects of storm surge may become more severe in the future as sea level rises and hurricane intensity and frequency increase, as projected (Webster and others, 2005; Intergovernmental Panel on Climate Change, 2007b). We analyzed data for the portion of this system's range along the Georgia coast and a portion of the Florida Panhandle from the Sea Level Affecting Marshes Model (SLAMM), which incorporates some changes in hydrology that accompany inundation from rising sea level. The SLAMM data covered 21 percent of this ecological system's extent. Within that area, our analysis shows that for both the A1FI and B1 scenarios, about 2 percent of the system's range is projected to change to different vegetation type by 2050, and nearly 4 percent is likely to change by 2100 (Appendix A). 


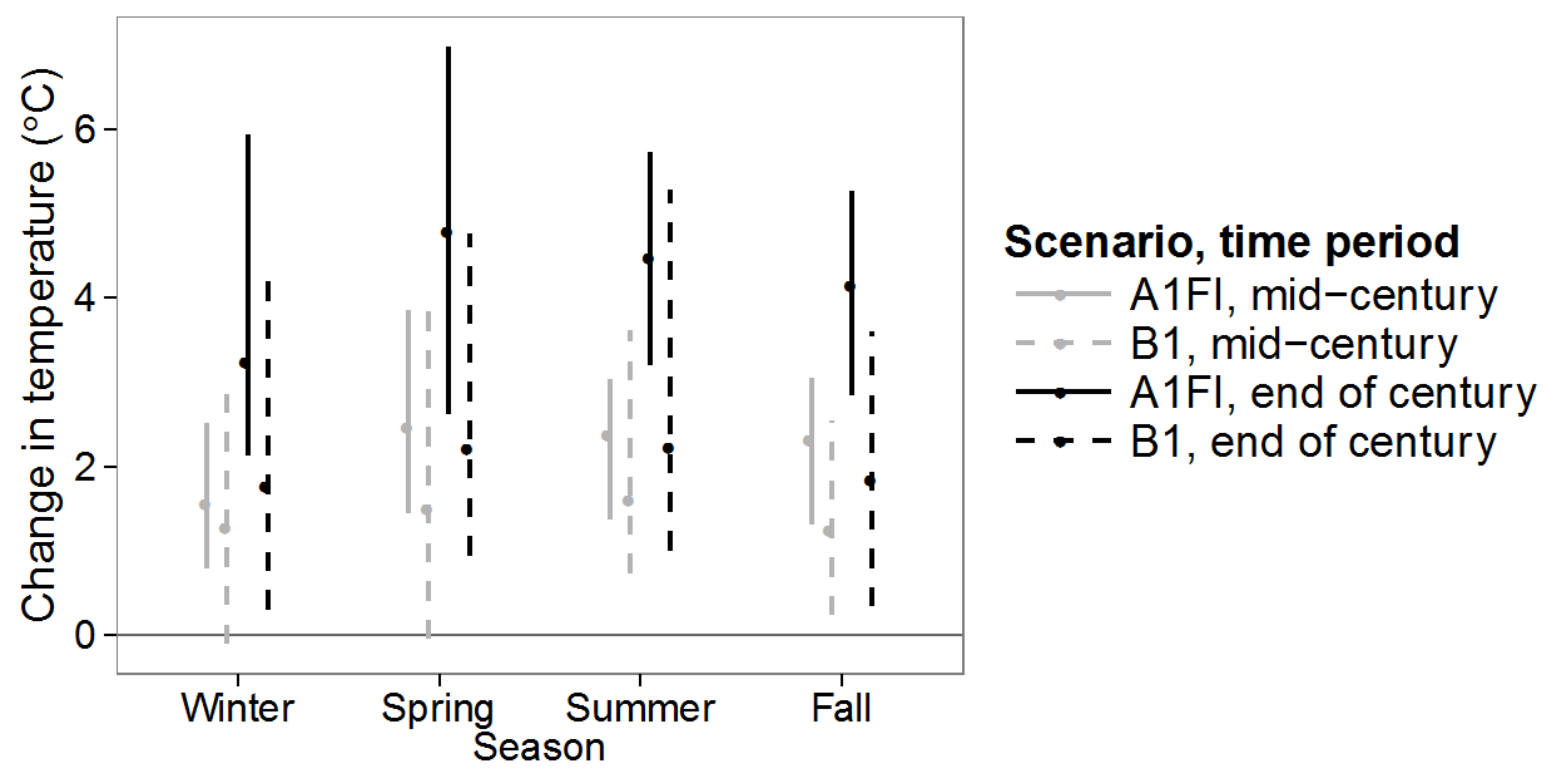

Figure 13.2. Projected change in seasonal maximum temperatures (in degrees Celsius $\left[{ }^{\circ} \mathrm{C}\right]$ ) for the middle $(2040$ 2060) and the end of the 21st century (2080-2100), compared with the recent time period (1981-2000), for two emissions scenarios for the Southern Coastal Plain Seepage Swamp and Baygall ecological system. Solid dots and error bars represent, respectively, the means and ranges of projections across climate models under each scenario.

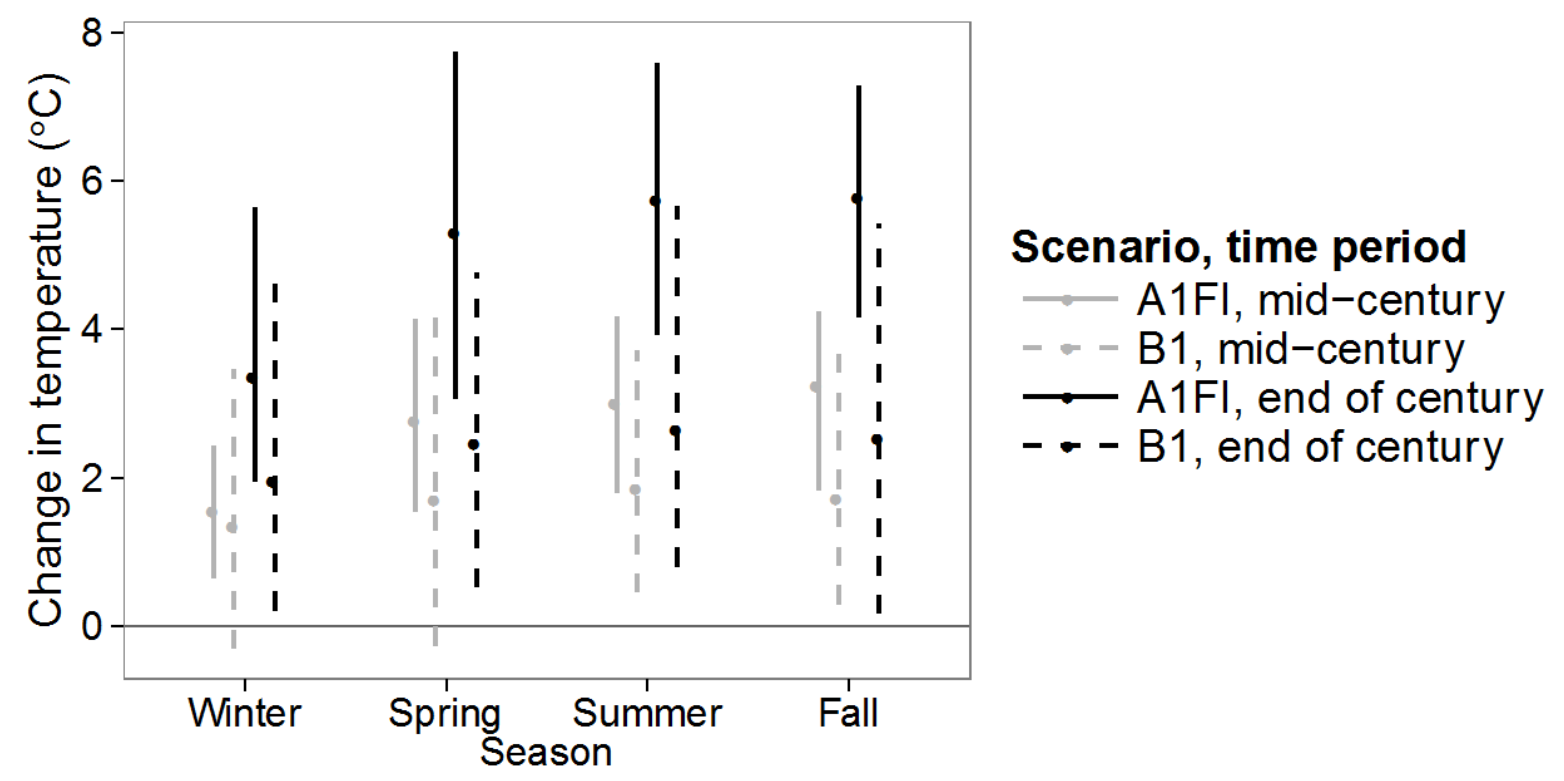

Figure 13.3. Projected change in seasonal minimum temperature (in degrees Celsius $\left.\left[{ }^{\circ} \mathrm{C}\right]\right)$ for the middle $(2040$ 2060) and the end of the 21st century (2080-2100), compared with the recent time period (1981-2000), for two emissions scenarios for the Southern Coastal Plain Seepage Swamp and Baygall ecological system. Solid dots and error bars represent, respectively, the means and ranges of projections across climate models under each scenario. 


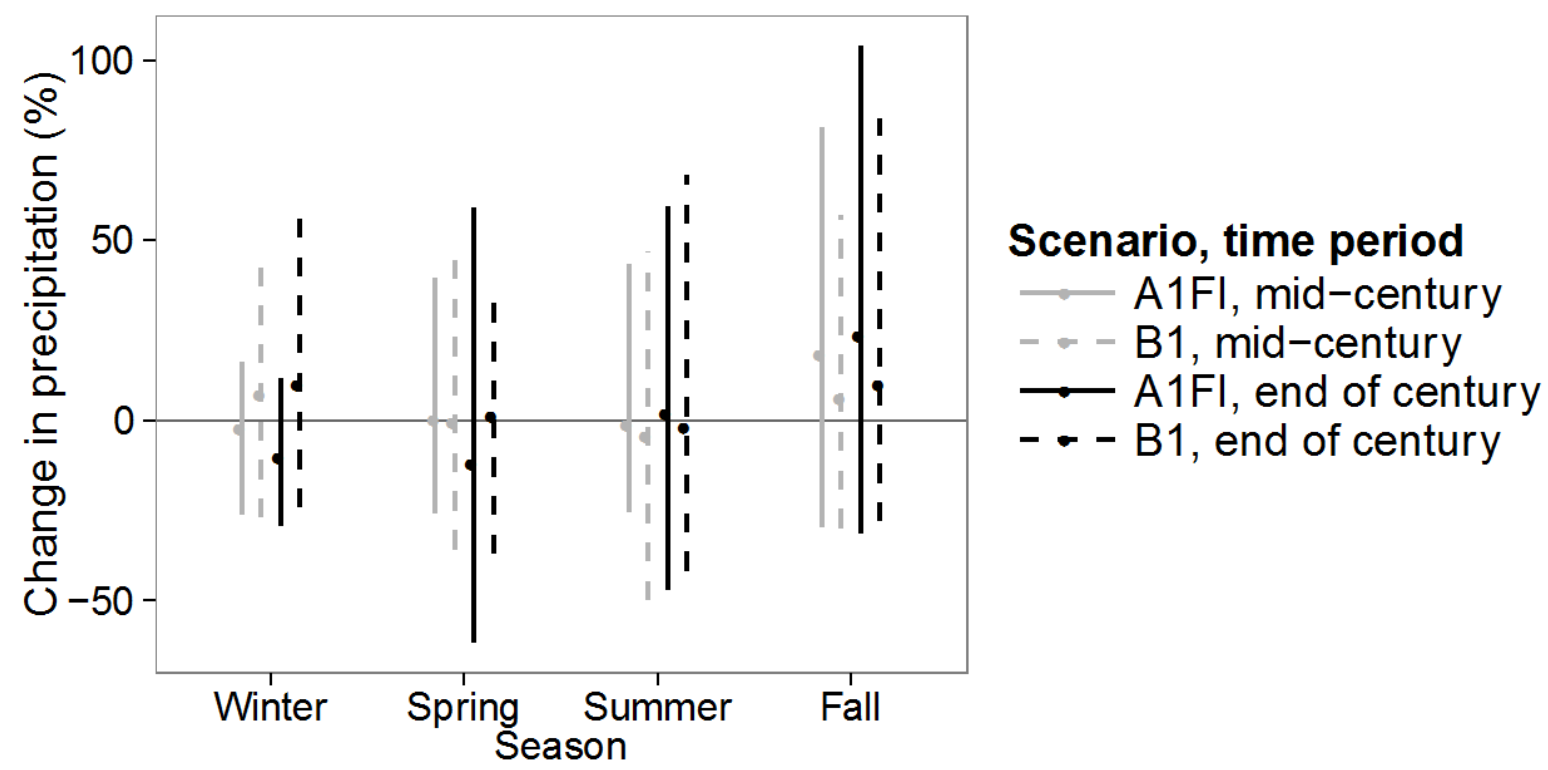

Figure 13.4. Projected percent change in seasonal average precipitation for the middle (2040-2060) and the end of the 21st century (2080-2100), compared with the recent time period (1981-2000), for two emissions scenarios for the Southern Coastal Plain Seepage Swamp and Baygall ecological system. Solid dots and error bars represent, respectively, the means and ranges of projections across climate models under each scenario. 
Adaptive Capacity.-The Southern Coastal Plain Seepage Swamp and Baygall ecological system historically existed as a fairly isolated system in wet areas protected from fire. The system also is limited in extent, occurring in small patches (average of 2,286 m², or $0.23 \mathrm{ha}$; Appendix A), and covering only $680 \mathrm{~km}^{2}$ over a small range of elevations ( -2 to $140 \mathrm{~m}$; Appendix A). A moderate percentage of its extent is protected for conservation (19 percent, fig. 13.5). On average, the system is relatively close to existing development (587 m; Appendix A), and has a moderate level of human modification (63 percent modified; Appendix A). Thus, management of the larger landscape to protect and restore natural hydrology surrounding baygalls is constrained. Additionally, this system faces a relatively low threat from future development compared with the Southeast as a whole, with almost 3 percent of its extent projected to be developed by 2050, and nearly 8 percent by 2100 (fig. 13.5).

A major non-climate threat to this system is artificial drainage, which can lead to high-severity peat fires, as well as succession to other communities as a result of peat fires, or independently of fire (Florida Natural Areas Inventory, 2010). When the soils are drained, this system transitions to a mixed hardwoods system. According to the Florida Natural Areas Inventory, one important management strategy for this ecological system should be a focus on maintaining high-quality adjacent natural uplands, in order to encourage landscape-level processes, especially hydrology (Florida Natural Areas Inventory, 2010).

Redbay, a dominant species in this system, is subject to laurel wilt disease, which is present in Florida and the Georgia coastal plain, where this ecological system occurs. Laurel wilt disease has caused high levels of death of redbay trees, and is still expanding (Koch and Smith, 2008; U.S. Forest Service, 2013). This potentially is a serious threat to the tree species. However, given the presence of many other tree species in this ecological system, the loss of redbay may have only a small effect on the structure and ecological function of this system.

Because this system occurs in relatively isolated places, maintaining and restoring connectivity between this ecological system and other systems nearby is important. However, following logging, the bay species that dominate this ecological system regenerate better than other species such as pond cypress (Casey and Ewel, 2006; Florida Natural Areas Inventory, 2010). As a result, this ecological system often replaces many other southeastern ecosystems after logging or fire suppression, and may thus be more common in the landscape in the future if fire suppression and logging continue. Additionally, the at-risk species that occur in this system are not endemic to the system. Some, such as the Eastern Indigo Snake, occur more frequently in longleaf pine savannas or flatwoods, and others, such as the Florida Panther, are relatively generalist species that can be found in various habitats. 


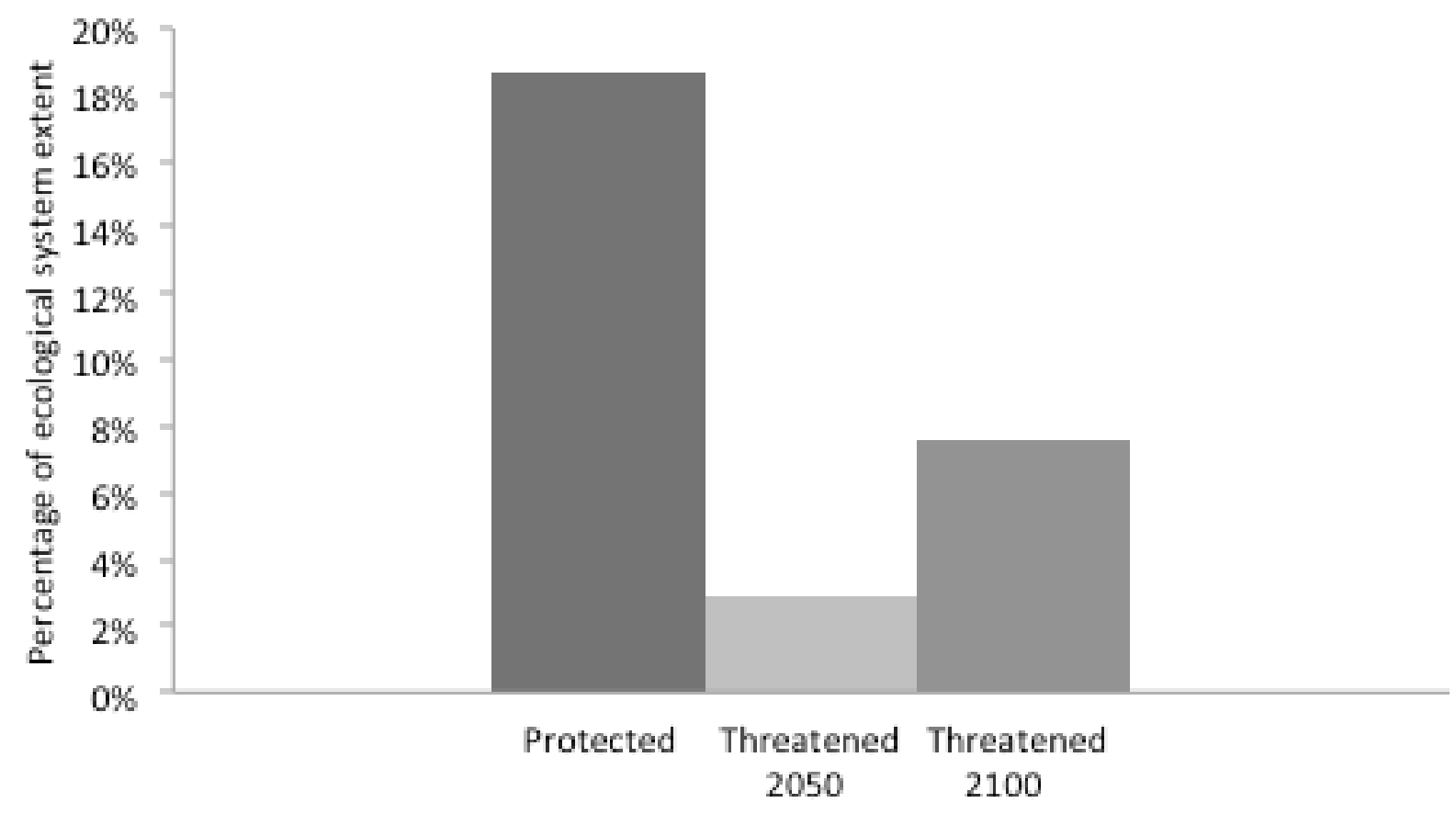

Figure 13.5. Percentage of the extent of the Southern Coastal Plain Seepage Swamp and Baygall ecological system that is protected for conservation, and the percentage threatened by future development in 2050 and 2100.

Summary. - The Southern Coastal Plain Seepage Swamp and Baygall ecological system is sensitive to soil hydrology and fire frequency. Specifically, it occurs where soils are usually moist but rarely flooded, and where fires are infrequent. Both minimum and maximum temperatures are projected to increase in the area where this ecological system occurs, with less change projected for winter temperatures than for temperatures during other seasons. There is much uncertainty about the direction and magnitude of projected changes in precipitation for every season. Changes in climate could lead to a decrease in wildfires, although projected effects of climate on wildfires have a high degree of uncertainty for this ecological system. This ecological system also will be exposed to sea level rise, because of its distribution along the coast, but our analysis shows that only a small amount may be inundated. There is much uncertainty about how fires and hydrology might change in the future, but if fires become less frequent, this system would become more common. Non-climate threats to this ecosystem that reduce its adaptive capacity include drainage, as well as existing and future urbanization. This system occurs in small patches that are relatively isolated, constraining possible conservation strategies in some cases. More research is needed on the potential impacts of climate change on the hydrology of seepage swamps and baygalls as well as surrounding ecological systems. 


\section{References Cited}

Beckage, B., Gross, L.J., Platt, W.J., Louis, J., and William, J., 2006, Modelling responses of pine savannas to climate change and large-scale disturbance: Applied Vegetation Science, v. 9, p. 75-82.

Burns, R.M., and Honkala, B.H., tech. coords., 1990, Silvics of North America-Volume 2, Hardwoods: U.S. Forest Service, Agriculture Handbook 654, accessed June 2013, at http://www.na.fs.fed.us/spfo/pubs/silvics_manual/table_of_contents.htm.

Casey, W.P., and Ewel, K.C., 2006, Patterns of succession in forested depressional wetlands in north Florida, USA: Wetlands, v. 26, p. 147-160.

Christensen, N.L., 2000, Vegetation of the southeastern coastal plain, in Barbour, M.G., and Billings, W.D., eds., North American terrestrial vegetation (2d ed.): Cambridge, United Kingdom, Cambridge University Press.

Cobb, K.M., Westphal, N., Sayani, H.R., Watson, J.T., Di Lorenzo, E., Cheng, H., Edwards, R.L., and Charles, C.D., 2013, Highly variable El Niño-Southern Oscillation throughout the Holocene: Science, v. 339, p. 67-70.

Costanza, J.K., Terando, A.J., McKerrow, A.J., and Collazo, J.A., 2015, Modeling climate change, urbanization, and fire effects on Pinus palustris ecosystems of the Southeastern U.S.: Journal of Environmental Management v. 151, p. 186-199.

Davenport, B., 2009, LANDFIRE biophysical setting model for Southern Coastal Plain Seepage Swamp and Baygall-LANDFIRE biophysical setting descriptions, Map zone 55: LANDFIRE program model, p. 132-136, accessed August 2013, at http://www.landfire.gov/national_veg_models_op2.php.

Florida Natural Areas Inventory, 2010, Guide to the natural communities of Florida-2010 edition:

Tallahassee, Florida Natural Areas Inventory, accessed May 2013, at

http://www.fnai.org/naturalcommguide.cfm.

Intergovernmental Panel on Climate Change, 2007a, Climate change 2007_Impacts, adaptation, and vulnerability-Contribution of Working Group II to the Fourth Assessment Report of the Intergovernmental Panel on Climate Change: Cambridge and New York, Cambridge University Press, $976 \mathrm{p}$.

Intergovernmental Panel on Climate Change, 2007b, Climate change 2007-The physical science basisContribution of Working Group I to the Fourth Assessment Report of the Intergovernmental Panel on Climate Change: Cambridge and New York, Cambridge University Press, 996 p.

Jurney, D., Evans, R., Ippolito, J., and Bergstrom, V., 2004, The role of wildland fire in portions of southeastern North America, in Engstrom, R.T., Galley, K.E.M., and de Groot, W.J., eds., Proceedings of the Tall Timbers Fire Ecology Conference, No. 22, Fire in temperate, boreal, and montane ecosystems, Tall Timbers Research Station, Tallahassee, Florida, p. 95-116 
Koch, F.H., and Smith, W.D., 2008, Spatio-temporal analysis of Xyleborus glabratus (Coleoptera: Curculionidae [corrected] Scolytinae) invasion in eastern U.S. forests: Environmental Entomology, v. 37, p. 442-452.

Monk, C.D., 1966, An ecological study of hardwood swamps in north-central Florida: Ecology, v. 47, p. 649-654.

Monk, C.D., 1968, Successional and environmental relationships of the forest vegetation of north central Florida: American Midland Naturalist, v. 79, p. 441-457.

National Oceanic and Atmospheric Administration, 2013, Sea levels online-Sea level variations of the United States derived from National Water Level Observation Network Stations: National Oceanic and Atmospheric Administration Ocean Service, Center for Operational Oceanographic Products and Services (CO-OPS), Silver Spring, Maryland, accessed October 2013, at http://tidesandcurrents.noaa.gov/sltrends.

NatureServe, 2013a, U.S. ecological systems National Map data: Arlington, Virginia, NatureServe database, accessed January 2013, at http://www.natureserve.org/getData/USecologyData.jsp.

NatureServe, 2013b, NatureServe explorer-An online encyclopedia of life, Version 7.1: Arlington, Virginia, NatureServe Web application, accessed May 2013, at http://www.natureserve.org/explorer.

Prasad, A.M., Iverson, L.R., Matthews, S., and Peters, M., 2007, A climate change atlas for 134 forest tree species of the Eastern United States: U.S. Forest Service database, Northern Research Station, Delaware, Ohio, accessed May 2013, at http://www.nrs.fs.fed.us/atlas/tree.

Seager, R., Tzanova, A., and Nakamura, J., 2009, Drought in the Southeastern United States-Causes, variability over the last millennium, and the potential for future hydroclimate change: Journal of Climate, v. 22, p. 5,021-5,045.

Stanturf, J.A., Goodrick, S.L., and Outcalt, K.W, 2007, Disturbance and coastal forests-A strategic approach to forest management in hurricane impact zones: Forest Ecology and Management, v. 250, p. 119-135.

Timmermann, A., Oberhuber, J., Bacher, A., Esch, M., Latif, M., and Roeckner, E., 1999, Increased El Niño frequency in a climate model forced by future greenhouse warming: Nature, v. 398, p. 694-697.

U.S. Forest Service, 2013, Laurel Wilt distribution map: U.S. Forest Service, accessed August 2013, at http://www.fs.fed.us/r8/foresthealth/laurelwilt/dist_map.shtml.

Webster, P.J., Holland, G.J., Curry, J.A., and Chang, H.-R., 2005, Changes in tropical cyclone number, duration, and intensity in a warming environment: Science, v. 309, p. 1,844-1,846. 


\section{Appendix A. Phase 1 Climate and Environmental Data Summaries}

Table A1. Summary of historical maximum temperature (in degrees Celsius) for each ecological system.

[Abbreviations: min, minimum; max, maximum]

\begin{tabular}{|c|c|c|c|c|c|c|c|c|c|c|c|c|}
\hline \multirow{2}{*}{ Ecological system } & \multicolumn{3}{|c|}{ Winter } & \multicolumn{3}{|c|}{ Spring } & \multicolumn{3}{|c|}{ Summer } & \multicolumn{3}{|c|}{ Fall } \\
\hline & Mean & Min & $\operatorname{Max}$ & Mean & Min & Max & Mean & Min & $\operatorname{Max}$ & Mean & Min & $\operatorname{Max}$ \\
\hline $\begin{array}{l}\text { Caribbean Mangrove Forest and Shrubland } \\
\text { - Puerto Rico }\end{array}$ & 29.1 & 27.8 & 31.0 & 30.2 & 28.9 & 31.8 & 31.6 & 30.3 & 33.0 & 31.2 & 30.1 & 32.5 \\
\hline $\begin{array}{l}\text { Caribbean Mangrove Forest and Shrubland } \\
\text { - U.S. Virgin Islands }\end{array}$ & 28.5 & 28.0 & 28.8 & 29.4 & 29.0 & 29.8 & 31.1 & 30.7 & 31.4 & 30.7 & 30.2 & 30.9 \\
\hline $\begin{array}{l}\text { Caribbean Mature Primary Elfin Woodland } \\
\text { - Puerto Rico }\end{array}$ & 22.8 & 20.5 & 24.9 & 24.3 & 22.0 & 26.3 & 25.9 & 23.6 & 27.9 & 25.2 & 23.0 & 27.2 \\
\hline $\begin{array}{l}\text { Central Atlantic Coastal Plain Wet } \\
\text { Longleaf Pine Savanna and Flatwoods }\end{array}$ & 13.3 & 10.3 & 15.6 & 22.9 & 20.4 & 25.0 & 31.2 & 29.6 & 32.9 & 23.8 & 22.1 & 25.3 \\
\hline $\begin{array}{l}\text { Central Florida Wet Prairie and Herbaceous } \\
\text { Seep }\end{array}$ & 15.7 & 13.4 & 18.2 & 25.3 & 23.8 & 27.5 & 33.9 & 32.1 & 35.5 & 25.9 & 24.0 & 27.6 \\
\hline $\begin{array}{l}\text { East Gulf Coastal Plain Near-Coast Pine } \\
\text { Flatwoods }\end{array}$ & 18.3 & 16.4 & 22.1 & 26.1 & 24.0 & 28.5 & 32.5 & 31.1 & 33.3 & 26.9 & 25.5 & 28.8 \\
\hline $\begin{array}{l}\text { East Gulf Coastal Plain Southern Loess } \\
\text { Bluff Forest }\end{array}$ & 15.8 & 14.7 & 16.7 & 25.0 & 24.3 & 25.7 & 32.7 & 32.1 & 33.6 & 25.8 & 25.1 & 26.6 \\
\hline Edwards Plateau Limestone Shrubland & 17.8 & 15.2 & 21.2 & 25.8 & 23.6 & 29.1 & 34.2 & 32.1 & 36.1 & 26.9 & 24.5 & 29.3 \\
\hline Edwards Plateau Mesic Canyon & 24.1 & 22.0 & 25.8 & 28.4 & 25.7 & 29.5 & 32.7 & 30.7 & 33.4 & 27.8 & 25.8 & 29.0 \\
\hline $\begin{array}{l}\text { Nashville Basin Limestone Glade and } \\
\text { Woodland }\end{array}$ & 9.7 & 8.5 & 10.3 & 21.1 & 20.0 & 21.6 & 31.1 & 29.8 & 31.5 & 22.1 & 21.0 & 22.5 \\
\hline South-Central Interior Mesophytic Forest & 6.6 & -1.5 & 14.1 & 18.8 & 10.5 & 24.3 & 29.3 & 20.7 & 32.9 & 19.9 & 12.4 & 24.8 \\
\hline $\begin{array}{l}\text { Southern Coastal Plain Nonriverine } \\
\text { Cypress Dome }\end{array}$ & 18.9 & 14.0 & 24.7 & 26.6 & 23.6 & 29.5 & 32.7 & 30.7 & 33.5 & 27.1 & 24.1 & 30.1 \\
\hline $\begin{array}{l}\text { Southern Coastal Plain Seepage Swamp } \\
\text { and Baygall }\end{array}$ & 20.4 & 14.8 & 24.7 & 27.3 & 24.1 & 29.5 & 32.7 & 30.7 & 33.5 & 27.7 & 24.7 & 30.1 \\
\hline
\end{tabular}




\begin{tabular}{|c|c|c|c|c|c|c|c|c|c|c|c|c|}
\hline \multirow{2}{*}{ Ecological system } & \multicolumn{3}{|c|}{ Winter } & \multicolumn{3}{|c|}{ Spring } & \multicolumn{3}{|c|}{ Summer } & \multicolumn{3}{|c|}{ Fall } \\
\hline & Mean & Min & $\operatorname{Max}$ & Mean & Min & $\operatorname{Max}$ & Mean & Min & $\operatorname{Max}$ & Mean & Min & Max \\
\hline Southeast & 12.3 & -4.1 & 25.7 & 22.7 & 7.2 & 33.0 & 31.6 & 18.8 & 38.7 & 23.5 & 9.6 & 31.7 \\
\hline $\begin{array}{l}\text { Caribbean Landscape Conservation } \\
\text { Cooperative }\end{array}$ & 27.9 & 20.5 & 31.0 & 29.1 & 22.0 & 31.8 & 30.5 & 23.6 & 33.0 & 30.0 & 23.0 & 32.5 \\
\hline
\end{tabular}


Table A2. Summary of historical minimum temperature (in degrees Celsius) for each ecological system.

[Abbreviations: min, minimum; max, maximum]

\begin{tabular}{|c|c|c|c|c|c|c|c|c|c|c|c|c|}
\hline \multirow{2}{*}{ Ecological system } & \multicolumn{3}{|c|}{ Winter } & \multicolumn{3}{|c|}{ Spring } & \multicolumn{3}{|c|}{ Summer } & \multicolumn{3}{|c|}{ Fall } \\
\hline & Mean & Min & $\operatorname{Max}$ & Mean & Min & Max & Mean & Min & $\operatorname{Max}$ & Mean & Min & Max \\
\hline $\begin{array}{l}\text { Caribbean Mangrove Forest and Shrubland - } \\
\text { Puerto Rico }\end{array}$ & 19.7 & 17.7 & 21.4 & 20.8 & 18.8 & 22.3 & 22.9 & 20.9 & 24.3 & 22.1 & 20.4 & 23.4 \\
\hline $\begin{array}{l}\text { Caribbean Mangrove Forest and Shrubland - } \\
\text { U.S. Virgin Islands }\end{array}$ & 21.6 & 21.2 & 21.9 & 22.5 & 22.0 & 22.8 & 24.4 & 24.0 & 24.7 & 23.6 & 23.3 & 23.9 \\
\hline $\begin{array}{l}\text { Caribbean Mature Primary Elfin Woodland - } \\
\text { Puerto Rico }\end{array}$ & 13.5 & 11.4 & 15.1 & 14.1 & 11.9 & 16.0 & 16.5 & 14.4 & 18.1 & 15.9 & 13.8 & 17.5 \\
\hline $\begin{array}{l}\text { Central Atlantic Coastal Plain Wet Longleaf } \\
\text { Pine Savanna and Flatwoods }\end{array}$ & 0.7 & -1.9 & 3.1 & 9.4 & 7.0 & 11.2 & 19.6 & 17.9 & 21.4 & 10.8 & 8.4 & 13.8 \\
\hline $\begin{array}{l}\text { Central Florida Wet Prairie and Herbaceous } \\
\text { Seep }\end{array}$ & 1.8 & -0.9 & 5.4 & 11.7 & 9.5 & 14.4 & 20.7 & 18.9 & 22.8 & 12.2 & 10.4 & 14.9 \\
\hline $\begin{array}{l}\text { East Gulf Coastal Plain Near-Coast Pine } \\
\text { Flatwoods }\end{array}$ & 5.6 & 4.0 & 10.0 & 13.2 & 11.9 & 15.9 & 21.4 & 20.1 & 23.2 & 14.3 & 12.3 & 18.0 \\
\hline $\begin{array}{l}\text { East Gulf Coastal Plain Southern Loess } \\
\text { Bluff Forest }\end{array}$ & 3.5 & 2.3 & 4.4 & 12.2 & 11.3 & 13.2 & 20.8 & 20.0 & 21.5 & 12.4 & 11.2 & 13.6 \\
\hline Edwards Plateau Limestone Shrubland & 3.6 & 0.3 & 7.7 & 11.7 & 9.0 & 15.4 & 20.8 & 18.8 & 23.6 & 10.2 & 7.3 & 14.3 \\
\hline Edwards Plateau Mesic Canyon & 10.2 & 7.1 & 13.6 & 15.4 & 13.3 & 17.9 & 21.8 & 20.8 & 23.2 & 18.0 & 15.4 & 20.5 \\
\hline $\begin{array}{l}\text { Nashville Basin Limestone Glade and } \\
\text { Woodland }\end{array}$ & -2.1 & -2.9 & -1.6 & 7.4 & 6.7 & 7.9 & 17.9 & 17.1 & 18.7 & 8.1 & 7.5 & 8.6 \\
\hline South-Central Interior Mesophytic Forest & -4.4 & -11.2 & 1.8 & 5.4 & -1.5 & 10.3 & 16.3 & 10.0 & 20.4 & 6.7 & 1.9 & 11.2 \\
\hline $\begin{array}{l}\text { Southern Coastal Plain Nonriverine Cypress } \\
\text { Dome }\end{array}$ & 5.9 & 0.5 & 13.5 & 12.9 & 9.2 & 17.8 & 21.0 & 19.1 & 23.6 & 14.6 & 10.1 & 20.5 \\
\hline $\begin{array}{l}\text { Southern Coastal Plain Seepage Swamp and } \\
\text { Baygall }\end{array}$ & 7.5 & 1.3 & 13.7 & 13.9 & 9.9 & 18.0 & 21.4 & 19.5 & 23.6 & 16.0 & 10.8 & 20.5 \\
\hline Southeast & 0.1 & -13.4 & 18.2 & 9.4 & -2.9 & 21.7 & 19.0 & 7.5 & 25.7 & 10.4 & 0.5 & 23.4 \\
\hline $\begin{array}{l}\text { Caribbean Landscape Conservation } \\
\text { Cooperative }\end{array}$ & 17.7 & 11.4 & 22.0 & 18.7 & 11.9 & 22.8 & 20.9 & 14.4 & 24.7 & 20.2 & 13.8 & 24.0 \\
\hline
\end{tabular}


Table A3. Summary of historical minimum temperature (in millimeters) for each ecological system.

[Abbreviations: min, minimum; max, maximum]

\begin{tabular}{|c|c|c|c|c|c|c|c|c|c|c|c|c|}
\hline \multirow{2}{*}{ Ecological system } & \multicolumn{3}{|c|}{ Winter } & \multicolumn{3}{|c|}{ Spring } & \multicolumn{3}{|c|}{ Summer } & \multicolumn{3}{|c|}{ Fall } \\
\hline & Mean & Min & Max & Mean & Min & $\operatorname{Max}$ & Mean & Min & Max & Mean & Min & Max \\
\hline $\begin{array}{l}\text { Caribbean Mangrove Forest and Shrubland - } \\
\text { Puerto Rico }\end{array}$ & 83.0 & 22.0 & 134.0 & 101.4 & 40.7 & 161.7 & 139.5 & 61.7 & 256.0 & 160.4 & 103.0 & 244.3 \\
\hline $\begin{array}{l}\text { Caribbean Mangrove Forest and Shrubland - } \\
\text { U.S. Virgin Islands }\end{array}$ & 67.3 & 56.3 & 74.3 & 73.5 & 61.7 & 90.3 & 82.0 & 69.7 & 96.0 & 136.2 & 105.7 & 156.3 \\
\hline $\begin{array}{l}\text { Caribbean Mature Primary Elfin Woodland - } \\
\text { Puerto Rico }\end{array}$ & 83.0 & 22.0 & 134.0 & 101.4 & 40.7 & 161.7 & 139.5 & 61.7 & 256.0 & 160.4 & 103.0 & 244.3 \\
\hline $\begin{array}{l}\text { Central Atlantic Coastal Plain Wet Longleaf } \\
\text { Pine Savanna and Flatwoods }\end{array}$ & 93.5 & 83.3 & 108.3 & 95.2 & 81.3 & 108.0 & 139.1 & 108.3 & 169.7 & 88.1 & 71.0 & 125.3 \\
\hline $\begin{array}{l}\text { Central Florida Wet Prairie and Herbaceous } \\
\text { Seep }\end{array}$ & 41.8 & 22.3 & 61.0 & 73.5 & 48.3 & 94.7 & 64.5 & 48.7 & 82.7 & 72.4 & 52.7 & 92.3 \\
\hline $\begin{array}{l}\text { East Gulf Coastal Plain Near-Coast Pine } \\
\text { Flatwoods }\end{array}$ & 114.7 & 50.0 & 158.7 & 108.6 & 35.3 & 152.0 & 166.4 & 71.3 & 207.0 & 100.2 & 31.7 & 143.0 \\
\hline $\begin{array}{l}\text { East Gulf Coastal Plain Southern Loess Bluff } \\
\text { Forest }\end{array}$ & 145.3 & 137.3 & 154.3 & 142.4 & 129.0 & 149.7 & 112.3 & 94.3 & 133.7 & 102.4 & 91.0 & 112.3 \\
\hline Edwards Plateau Limestone Shrubland & 34.8 & 12.7 & 64.3 & 64.2 & 30.7 & 98.3 & 60.7 & 27.0 & 84.3 & 67.1 & 37.0 & 97.3 \\
\hline Edwards Plateau Mesic Canyon & 61.2 & 44.3 & 86.0 & 78.8 & 55.0 & 117.3 & 186.1 & 126.7 & 237.3 & 100.5 & 74.7 & 160.0 \\
\hline $\begin{array}{l}\text { Nashville Basin Limestone Glade and } \\
\text { Woodland }\end{array}$ & 118.3 & 106.3 & 130.0 & 128.0 & 112.3 & 140.7 & 102.5 & 93.3 & 113.3 & 96.7 & 82.7 & 107.7 \\
\hline South-Central Interior Mesophytic Forest & 93.1 & 49.3 & 164.7 & 112.8 & 72.0 & 175.7 & 104.5 & 79.0 & 164.7 & 88.4 & 63.3 & 149.7 \\
\hline $\begin{array}{l}\text { Southern Coastal Plain Nonriverine Cypress } \\
\text { Dome }\end{array}$ & 92.6 & 40.7 & 143.3 & 94.1 & 35.3 & 142.7 & 156.4 & 71.3 & 238.0 & 86.8 & 31.7 & 162.0 \\
\hline $\begin{array}{l}\text { Southern Coastal Plain Seepage Swamp and } \\
\text { Baygall }\end{array}$ & 78.9 & 44.3 & 120.0 & 87.2 & 54.7 & 127.7 & 170.8 & 104.7 & 237.3 & 92.1 & 55.0 & 159.0 \\
\hline Southeast & 88.1 & 8.0 & 177.7 & 104.2 & 12.3 & 187.7 & 104.9 & 23.0 & 249.7 & 91.1 & 27.0 & 217.7 \\
\hline $\begin{array}{l}\text { Caribbean Landscape Conservation } \\
\text { Cooperative }\end{array}$ & 8.9 & 2.2 & 22.2 & 13.3 & 4.0 & 26.2 & 17.2 & 6.0 & 31.5 & 20.0 & 9.6 & 35.5 \\
\hline
\end{tabular}


Table A4. Projected change in mean maximum temperature (in degrees Celsius).

[Abbreviations: min, minimum; max, maximum; mid, mid-century; end, end of century]

\begin{tabular}{|c|c|c|c|c|c|c|c|c|c|c|c|c|c|}
\hline \multirow{2}{*}{ Ecological system } & \multirow{2}{*}{$\begin{array}{l}\text { Scenario, } \\
\text { time } \\
\text { period }\end{array}$} & \multicolumn{3}{|c|}{ Winter } & \multicolumn{3}{|c|}{ Spring } & \multicolumn{3}{|c|}{ Summer } & \multicolumn{3}{|c|}{ Fall } \\
\hline & & Mean & Min & $\operatorname{Max}$ & Mean & Min & $\operatorname{Max}$ & Mean & Min & $\operatorname{Max}$ & Mean & Min & $\operatorname{Max}$ \\
\hline $\begin{array}{l}\text { Caribbean Mangrove Forest and } \\
\text { Shrubland - Puerto Rico }\end{array}$ & B1, mid & 2.35 & 0.27 & 6.92 & 2.43 & 0.33 & 5.76 & 2.10 & 0.25 & 5.96 & 2.70 & 0.34 & 9.35 \\
\hline $\begin{array}{l}\text { Caribbean Mature Primary Elfin } \\
\text { Woodland - Puerto Rico }\end{array}$ & B1, mid & 2.38 & 0.43 & 4.21 & 2.22 & 0.52 & 3.85 & 1.93 & 0.38 & 3.24 & 2.46 & 0.46 & 4.12 \\
\hline $\begin{array}{l}\text { Central Atlantic Coastal Plain Wet } \\
\text { Longleaf Pine Savanna and } \\
\text { Flatwoods }\end{array}$ & B1, mid & 1.52 & -0.45 & 3.78 & 1.84 & -0.48 & 5.27 & 1.83 & 0.62 & 3.77 & 1.55 & -0.26 & 3.14 \\
\hline $\begin{array}{l}\text { Central Florida Wet Prairie and } \\
\text { Herbaceous Seep }\end{array}$ & B1, mid & 1.31 & -0.04 & 2.97 & 1.50 & 0.13 & 3.96 & 1.56 & 0.69 & 3.54 & 1.22 & 0.30 & 2.29 \\
\hline $\begin{array}{l}\text { East Gulf Coastal Plain Near-Coast } \\
\text { Pine Flatwoods }\end{array}$ & B1, mid & 1.42 & -0.13 & 3.63 & 1.49 & -0.09 & 3.65 & 1.61 & 0.70 & 3.81 & 1.34 & -0.26 & 3.09 \\
\hline $\begin{array}{l}\text { East Gulf Coastal Plain Southern } \\
\text { Loess Bluff Forest }\end{array}$ & B1, mid & 1.59 & -0.80 & 4.55 & 1.44 & -0.08 & 3.97 & 1.36 & 0.16 & 3.77 & 1.31 & -0.74 & 3.55 \\
\hline Edwards Plateau Limestone Shrubland & B1, mid & 1.55 & -0.76 & 5.14 & 1.65 & 0.23 & 4.26 & 1.35 & -0.18 & 4.19 & 1.34 & -0.83 & 4.28 \\
\hline Edwards Plateau Mesic Canyon & B1, mid & 1.56 & -0.82 & 5.06 & 1.59 & 0.26 & 4.13 & 1.35 & -0.11 & 4.14 & 1.33 & -0.74 & 4.17 \\
\hline $\begin{array}{l}\text { Nashville Basin Limestone Glade and } \\
\text { Woodland }\end{array}$ & B1, mid & 1.69 & -0.55 & 4.44 & 1.83 & -0.09 & 5.58 & 1.76 & 0.25 & 3.81 & 1.54 & -1.24 & 3.83 \\
\hline $\begin{array}{l}\text { South-Central Interior Mesophytic } \\
\text { Forest }\end{array}$ & B1, mid & 1.83 & -0.31 & 4.57 & 2.00 & -0.39 & 6.22 & 1.77 & 0.29 & 3.72 & 1.63 & -1.02 & 3.95 \\
\hline Southeast & B1, mid & 1.63 & -0.39 & 4.14 & 1.72 & -0.04 & 4.78 & 1.67 & 0.34 & 4.05 & 1.47 & -0.69 & 3.75 \\
\hline $\begin{array}{l}\text { Southern Coastal Plain Nonriverine } \\
\text { Cypress Dome }\end{array}$ & B1, mid & 1.28 & -0.27 & 3.16 & 1.49 & -0.14 & 4.03 & 1.63 & 0.74 & 3.59 & 1.27 & -0.04 & 2.74 \\
\hline $\begin{array}{l}\text { Southern Coastal Plain Seepage } \\
\text { Swamp and Baygall }\end{array}$ & B1, mid & 1.28 & -0.10 & 2.97 & 1.50 & -0.05 & 4.05 & 1.62 & 0.74 & 3.62 & 1.25 & 0.24 & 2.54 \\
\hline
\end{tabular}




\begin{tabular}{|c|c|c|c|c|c|c|c|c|c|c|c|c|c|}
\hline \multirow{2}{*}{ Ecological system } & \multirow{2}{*}{$\begin{array}{l}\text { Scenario, } \\
\text { time } \\
\text { period }\end{array}$} & \multicolumn{3}{|c|}{ Winter } & \multicolumn{3}{|c|}{ Spring } & \multicolumn{3}{|c|}{ Summer } & \multicolumn{3}{|c|}{ Fall } \\
\hline & & Mean & Min & Max & Mean & Min & Max & Mean & Min & Max & Mean & Min & Max \\
\hline $\begin{array}{l}\text { Caribbean Mangrove Forest and } \\
\text { Shrubland - Puerto Rico }\end{array}$ & B1, end & 3.81 & 0.31 & 10.77 & 3.87 & 0.61 & 9.11 & 3.52 & 0.29 & 9.83 & 4.30 & 0.64 & 11.26 \\
\hline $\begin{array}{l}\text { Caribbean Mature Primary Elfin } \\
\text { Woodland - Puerto Rico }\end{array}$ & B1, end & 3.81 & 0.48 & 6.57 & 3.52 & 0.94 & 6.34 & 3.19 & 0.43 & 4.91 & 3.85 & 0.82 & 5.78 \\
\hline $\begin{array}{l}\text { Central Atlantic Coastal Plain Wet } \\
\text { Longleaf Pine Savanna and } \\
\text { Flatwoods }\end{array}$ & B1, end & 2.18 & 0.51 & 4.67 & 2.60 & 1.18 & 5.68 & 2.52 & 0.87 & 5.53 & 2.26 & 0.33 & 4.33 \\
\hline $\begin{array}{l}\text { Central Florida Wet Prairie and } \\
\text { Herbaceous Seep }\end{array}$ & B1, end & 1.82 & 0.27 & 4.30 & 2.26 & 0.93 & 4.89 & 2.21 & 0.93 & 5.20 & 1.79 & 0.23 & 3.84 \\
\hline $\begin{array}{l}\text { East Gulf Coastal Plain Near-Coast } \\
\text { Pine Flatwoods }\end{array}$ & B1, end & 2.00 & 0.47 & 4.70 & 2.17 & 0.92 & 4.33 & 2.20 & 0.95 & 5.60 & 1.98 & 0.51 & 4.20 \\
\hline $\begin{array}{l}\text { East Gulf Coastal Plain Southern } \\
\text { Loess Bluff Forest }\end{array}$ & B1, end & 2.35 & 0.42 & 6.11 & 2.05 & 0.69 & 4.52 & 1.80 & 0.09 & 5.02 & 1.95 & 0.01 & 4.57 \\
\hline Edwards Plateau Limestone Shrubland & B1, end & 2.48 & 0.51 & 5.65 & 2.41 & 0.67 & 5.66 & 1.97 & 0.41 & 5.42 & 2.14 & -0.34 & 4.85 \\
\hline Edwards Plateau Mesic Canyon & B1, end & 2.47 & 0.49 & 5.59 & 2.33 & 0.68 & 5.56 & 1.93 & 0.43 & 5.36 & 2.10 & -0.20 & 4.72 \\
\hline $\begin{array}{l}\text { Nashville Basin Limestone Glade and } \\
\text { Woodland }\end{array}$ & B1, end & 2.52 & 0.56 & 6.01 & 2.45 & 0.66 & 5.92 & 2.32 & -0.09 & 5.30 & 2.23 & -0.16 & 4.97 \\
\hline $\begin{array}{l}\text { South-Central Interior Mesophytic } \\
\text { Forest }\end{array}$ & B1, end & 2.73 & 0.62 & 6.59 & 2.65 & 0.79 & 6.49 & 2.37 & 0.09 & 5.43 & 2.32 & -0.09 & 4.90 \\
\hline Southeast & B1, end & 2.45 & 0.74 & 5.49 & 2.40 & 0.89 & 5.15 & 2.27 & 0.41 & 5.69 & 2.18 & 0.26 & 4.62 \\
\hline $\begin{array}{l}\text { Southern Coastal Plain Nonriverine } \\
\text { Cypress Dome }\end{array}$ & B1, end & 1.79 & 0.37 & 4.28 & 2.18 & 0.96 & 4.63 & 2.22 & 1.01 & 5.29 & 1.88 & 0.45 & 3.79 \\
\hline $\begin{array}{l}\text { Southern Coastal Plain Seepage } \\
\text { Swamp and Baygall }\end{array}$ & B1, end & 1.78 & 0.31 & 4.24 & 2.22 & 0.95 & 4.76 & 2.23 & 1.01 & 5.28 & 1.85 & 0.34 & 3.61 \\
\hline $\begin{array}{l}\text { Caribbean Mangrove Forest and } \\
\text { Shrubland - Puerto Rico }\end{array}$ & A1FI, mid & 3.48 & 1.00 & 7.85 & 3.94 & 1.25 & 10.92 & 3.61 & 1.41 & 8.11 & 3.83 & 1.48 & 9.42 \\
\hline
\end{tabular}




\begin{tabular}{|c|c|c|c|c|c|c|c|c|c|c|c|c|c|}
\hline \multirow{2}{*}{ Ecological system } & \multirow{2}{*}{$\begin{array}{l}\text { Scenario, } \\
\text { time } \\
\text { period }\end{array}$} & \multicolumn{3}{|c|}{ Winter } & \multicolumn{3}{|c|}{ Spring } & \multicolumn{3}{|c|}{ Summer } & \multicolumn{3}{|c|}{ Fall } \\
\hline & & Mean & Min & $\operatorname{Max}$ & Mean & Min & Max & Mean & Min & Max & Mean & Min & $\operatorname{Max}$ \\
\hline $\begin{array}{l}\text { Caribbean Mature Primary Elfin } \\
\text { Woodland - Puerto Rico }\end{array}$ & A1FI, mid & 3.60 & 1.47 & 5.67 & 3.55 & 2.04 & 5.86 & 3.30 & 1.85 & 5.09 & 3.39 & 1.83 & 4.87 \\
\hline $\begin{array}{l}\text { Central Atlantic Coastal Plain Wet } \\
\text { Longleaf Pine Savanna and } \\
\text { Flatwoods }\end{array}$ & A1FI, mid & 1.47 & 0.14 & 2.48 & 2.36 & 1.09 & 3.77 & 2.11 & 1.15 & 3.32 & 2.21 & 0.83 & 3.29 \\
\hline $\begin{array}{l}\text { Central Florida Wet Prairie and } \\
\text { Herbaceous Seep }\end{array}$ & A1FI, mid & 1.70 & 0.97 & 2.89 & 2.61 & 1.43 & 4.25 & 2.61 & 1.33 & 3.42 & 2.44 & 1.44 & 3.19 \\
\hline $\begin{array}{l}\text { East Gulf Coastal Plain Near-Coast } \\
\text { Pine Flatwoods }\end{array}$ & A1FI, mid & 1.48 & 0.73 & 2.54 & 2.28 & 1.43 & 3.43 & 2.16 & 1.27 & 2.76 & 2.11 & 1.09 & 3.08 \\
\hline $\begin{array}{l}\text { East Gulf Coastal Plain Southern } \\
\text { Loess Bluff Forest }\end{array}$ & A1FI, mid & 1.53 & 0.44 & 2.87 & 2.18 & 1.48 & 2.97 & 1.84 & 1.02 & 2.60 & 1.71 & 0.50 & 2.62 \\
\hline Edwards Plateau Limestone Shrubland & A1FI, mid & 1.31 & -0.17 & 3.10 & 2.47 & 1.56 & 3.22 & 2.07 & 1.49 & 3.34 & 1.90 & -0.09 & 2.95 \\
\hline Edwards Plateau Mesic Canyon & A1FI, mid & 1.36 & -0.21 & 3.18 & 2.43 & 1.56 & 3.06 & 2.06 & 1.37 & 3.19 & 1.85 & -0.13 & 3.00 \\
\hline $\begin{array}{l}\text { Nashville Basin Limestone Glade and } \\
\text { Woodland }\end{array}$ & A1FI, mid & 1.69 & -0.12 & 2.71 & 2.37 & 1.02 & 3.74 & 2.21 & 0.90 & 3.84 & 1.92 & 0.19 & 3.67 \\
\hline $\begin{array}{l}\text { South-Central Interior Mesophytic } \\
\text { Forest }\end{array}$ & A1FI, mid & 1.81 & -0.12 & 2.73 & 2.39 & 0.71 & 4.33 & 2.23 & 0.81 & 4.06 & 1.96 & 0.06 & 3.49 \\
\hline Southeast & A1FI, mid & 1.61 & 0.26 & 2.71 & 2.36 & 1.28 & 3.46 & 2.24 & 1.15 & 3.15 & 1.97 & 0.32 & 2.93 \\
\hline $\begin{array}{l}\text { Southern Coastal Plain Nonriverine } \\
\text { Cypress Dome }\end{array}$ & A1FI, mid & 1.50 & 0.69 & 2.32 & 2.36 & 1.46 & 3.61 & 2.23 & 1.35 & 2.84 & 2.21 & 1.20 & 3.12 \\
\hline $\begin{array}{l}\text { Southern Coastal Plain Seepage } \\
\text { Swamp and Baygall }\end{array}$ & A1FI, mid & 1.57 & 0.79 & 2.51 & 2.47 & 1.45 & 3.86 & 2.39 & 1.37 & 3.04 & 2.32 & 1.31 & 3.05 \\
\hline $\begin{array}{l}\text { Caribbean Mangrove Forest and } \\
\text { Shrubland - Puerto Rico }\end{array}$ & A1FI, end & 7.43 & 2.12 & 16.19 & 7.81 & 2.20 & 16.39 & 7.09 & 2.67 & 14.32 & 7.62 & 2.99 & 13.30 \\
\hline $\begin{array}{l}\text { Caribbean Mature Primary Elfin } \\
\text { Woodland - Puerto Rico }\end{array}$ & A1FI, end & 7.66 & 3.29 & 11.65 & 7.12 & 3.69 & 11.30 & 6.69 & 3.77 & 10.73 & 6.89 & 4.30 & 9.85 \\
\hline
\end{tabular}




\begin{tabular}{|c|c|c|c|c|c|c|c|c|c|c|c|c|c|}
\hline \multirow{2}{*}{ Ecological system } & \multirow{2}{*}{$\begin{array}{l}\text { Scenario, } \\
\text { time } \\
\text { period }\end{array}$} & \multicolumn{3}{|c|}{ Winter } & \multicolumn{3}{|c|}{ Spring } & \multicolumn{3}{|c|}{ Summer } & \multicolumn{3}{|c|}{ Fall } \\
\hline & & Mean & Min & $\operatorname{Max}$ & Mean & Min & Max & Mean & Min & $\operatorname{Max}$ & Mean & Min & $\operatorname{Max}$ \\
\hline $\begin{array}{l}\text { Central Atlantic Coastal Plain Wet } \\
\text { Longleaf Pine Savanna and } \\
\text { Flatwoods }\end{array}$ & A1FI, end & 3.31 & 2.20 & 6.93 & 4.55 & 2.59 & 7.36 & 3.88 & 2.59 & 5.82 & 4.19 & 2.51 & 6.62 \\
\hline $\begin{array}{l}\text { Central Florida Wet Prairie and } \\
\text { Herbaceous Seep }\end{array}$ & A1FI, end & 3.44 & 2.18 & 6.46 & 5.21 & 2.81 & 8.08 & 5.05 & 3.17 & 6.74 & 4.34 & 2.92 & 6.15 \\
\hline $\begin{array}{l}\text { East Gulf Coastal Plain Near-Coast } \\
\text { Pine Flatwoods }\end{array}$ & A1FI, end & 3.13 & 2.32 & 4.61 & 4.19 & 2.47 & 5.72 & 4.01 & 3.13 & 5.01 & 3.81 & 2.60 & 5.34 \\
\hline $\begin{array}{l}\text { East Gulf Coastal Plain Southern } \\
\text { Loess Bluff Forest }\end{array}$ & A1FI, end & 3.51 & 1.98 & 5.06 & 3.55 & 2.38 & 5.11 & 3.41 & 1.93 & 4.66 & 3.28 & 2.01 & 4.75 \\
\hline Edwards Plateau Limestone Shrubland & A1FI, end & 3.63 & 1.47 & 6.04 & 4.05 & 2.14 & 5.53 & 4.22 & 2.12 & 6.02 & 3.72 & 1.12 & 4.87 \\
\hline Edwards Plateau Mesic Canyon & A1FI, end & 3.69 & 1.36 & 6.09 & 3.96 & 2.05 & 5.54 & 4.20 & 2.27 & 5.83 & 3.63 & 1.10 & 4.72 \\
\hline $\begin{array}{l}\text { Nashville Basin Limestone Glade and } \\
\text { Woodland }\end{array}$ & A1FI, end & 3.95 & 2.48 & 7.40 & 4.35 & 2.26 & 7.35 & 4.16 & 2.41 & 6.19 & 3.76 & 2.02 & 6.25 \\
\hline $\begin{array}{l}\text { South-Central Interior Mesophytic } \\
\text { Forest }\end{array}$ & A1FI, end & 4.09 & 2.47 & 8.05 & 4.46 & 2.27 & 8.19 & 4.21 & 2.74 & 6.73 & 3.82 & 1.84 & 6.28 \\
\hline Southeast & A1FI, end & 3.73 & 2.21 & 6.45 & 4.20 & 2.66 & 6.47 & 4.23 & 3.06 & 5.43 & 3.78 & 1.95 & 5.33 \\
\hline $\begin{array}{l}\text { Southern Coastal Plain Nonriverine } \\
\text { Cypress Dome }\end{array}$ & A1FI, end & 3.16 & 2.19 & 5.61 & 4.50 & 2.54 & 6.60 & 4.15 & 3.26 & 5.16 & 3.98 & 2.76 & 5.38 \\
\hline $\begin{array}{l}\text { Southern Coastal Plain Seepage } \\
\text { Swamp and Baygall }\end{array}$ & A1FI, end & 3.25 & 2.13 & 5.95 & 4.80 & 2.63 & 6.99 & 4.48 & 3.20 & 5.74 & 4.15 & 2.84 & 5.27 \\
\hline
\end{tabular}


Table A5. Projected change in mean minimum temperature (in degrees Celsius).

[Abbreviations: min, minimum; max, maximum; mid, mid-century; end, end of century]

\begin{tabular}{|c|c|c|c|c|c|c|c|c|c|c|c|c|c|}
\hline \multirow[b]{2}{*}{ Ecological system } & \multirow{2}{*}{$\begin{array}{l}\text { Scenario, } \\
\text { time } \\
\text { period }\end{array}$} & \multicolumn{3}{|c|}{ Winter } & \multicolumn{3}{|c|}{ Spring } & \multicolumn{3}{|c|}{ Summer } & \multicolumn{3}{|c|}{ Fall } \\
\hline & & Mean & Min & $\operatorname{Max}$ & Mean & Min & $\operatorname{Max}$ & Mean & Min & $\operatorname{Max}$ & Mean & Min & $\operatorname{Max}$ \\
\hline $\begin{array}{l}\text { Caribbean Mangrove Forest and } \\
\text { Shrubland - Puerto Rico }\end{array}$ & B1, mid & 2.48 & 0.35 & 8.56 & 2.71 & 0.35 & 6.80 & 2.63 & 0.27 & 8.83 & 3.34 & 0.86 & 14.30 \\
\hline $\begin{array}{l}\text { Caribbean Mature Primary Elfin } \\
\text { Woodland - Puerto Rico }\end{array}$ & B1, mid & 4.20 & 0.82 & 6.89 & 4.24 & 0.75 & 6.90 & 3.55 & 0.53 & 6.04 & 4.54 & 1.87 & 7.42 \\
\hline $\begin{array}{l}\text { Central Atlantic Coastal Plain Wet } \\
\text { Longleaf Pine Savanna and } \\
\text { Flatwoods }\end{array}$ & B1, mid & 1.19 & -0.32 & 3.23 & 1.71 & -0.44 & 4.78 & 1.95 & 0.80 & 3.94 & 1.74 & -0.14 & 4.53 \\
\hline $\begin{array}{l}\text { Central Florida Wet Prairie and } \\
\text { Herbaceous Seep }\end{array}$ & B1, mid & 1.57 & -0.43 & 3.75 & 1.79 & -0.08 & 4.45 & 1.88 & 0.44 & 3.67 & 1.73 & 0.40 & 3.34 \\
\hline $\begin{array}{l}\text { East Gulf Coastal Plain Near-Coast } \\
\text { Pine Flatwoods }\end{array}$ & B1, mid & 1.42 & -0.24 & 3.83 & 1.78 & -0.29 & 4.40 & 1.95 & 0.62 & 3.86 & 1.85 & -0.11 & 4.32 \\
\hline $\begin{array}{l}\text { East Gulf Coastal Plain Southern } \\
\text { Loess Bluff Forest }\end{array}$ & B1, mid & 1.29 & -0.70 & 3.23 & 1.63 & -0.17 & 4.71 & 1.81 & 0.71 & 3.62 & 1.65 & -0.52 & 4.03 \\
\hline $\begin{array}{l}\text { Edwards Plateau Limestone } \\
\text { Shrubland }\end{array}$ & B1, mid & 1.34 & -0.32 & 3.42 & 1.83 & 0.33 & 4.23 & 1.81 & 0.24 & 3.97 & 1.65 & -0.63 & 4.25 \\
\hline Edwards Plateau Mesic Canyon & B1, mid & 1.35 & -0.32 & 3.40 & 1.83 & 0.38 & 4.30 & 1.76 & 0.26 & 3.75 & 1.66 & -0.66 & 4.30 \\
\hline $\begin{array}{l}\text { Nashville Basin Limestone Glade and } \\
\text { Woodland }\end{array}$ & B1, mid & 1.47 & -0.25 & 3.30 & 1.73 & -0.18 & 4.92 & 1.92 & 0.77 & 4.14 & 1.58 & -0.98 & 4.12 \\
\hline $\begin{array}{l}\text { South-Central Interior Mesophytic } \\
\text { Forest }\end{array}$ & B1, mid & 1.67 & 0.05 & 3.88 & 1.76 & -0.22 & 4.78 & 1.94 & 0.69 & 4.14 & 1.56 & -0.95 & 4.16 \\
\hline Southeast & B1, mid & 1.42 & -0.18 & 3.18 & 1.72 & -0.05 & 4.44 & 1.88 & 0.83 & 3.88 & 1.63 & -0.44 & 4.14 \\
\hline $\begin{array}{l}\text { Southern Coastal Plain Nonriverine } \\
\text { Cypress Dome }\end{array}$ & B1, mid & 1.26 & -0.22 & 3.40 & 1.66 & -0.35 & 4.32 & 1.83 & 0.48 & 3.68 & 1.70 & 0.13 & 3.90 \\
\hline
\end{tabular}




\begin{tabular}{|c|c|c|c|c|c|c|c|c|c|c|c|c|c|}
\hline \multirow{2}{*}{ Ecological system } & \multirow{2}{*}{$\begin{array}{l}\text { Scenario, } \\
\text { time } \\
\text { period }\end{array}$} & \multicolumn{3}{|c|}{ Winter } & \multicolumn{3}{|c|}{ Spring } & \multicolumn{3}{|c|}{ Summer } & \multicolumn{3}{|c|}{ Fall } \\
\hline & & Mean & Min & Max & Mean & Min & Max & Mean & Min & Max & Mean & Min & Max \\
\hline $\begin{array}{l}\text { Southern Coastal Plain Seepage } \\
\text { Swamp and Baygall }\end{array}$ & B1, mid & 1.36 & -0.31 & 3.47 & 1.70 & -0.27 & 4.33 & 1.86 & 0.45 & 3.71 & 1.72 & 0.29 & 3.72 \\
\hline $\begin{array}{l}\text { Caribbean Mangrove Forest and } \\
\text { Shrubland - Puerto Rico }\end{array}$ & B1, end & 4.04 & 0.42 & 12.83 & 4.36 & 0.64 & 13.06 & 4.45 & 0.27 & 15.16 & 5.25 & 1.32 & 17.18 \\
\hline $\begin{array}{l}\text { Caribbean Mature Primary Elfin } \\
\text { Woodland - Puerto Rico }\end{array}$ & B1, end & 7.38 & 0.99 & 14.09 & 6.78 & 1.35 & 10.96 & 5.80 & 0.52 & 8.86 & 7.13 & 3.01 & 10.40 \\
\hline $\begin{array}{l}\text { Central Atlantic Coastal Plain Wet } \\
\text { Longleaf Pine Savanna and } \\
\text { Flatwoods }\end{array}$ & B1, end & 1.76 & 0.32 & 4.15 & 2.39 & 0.74 & 4.92 & 2.73 & 1.14 & 6.14 & 2.63 & 0.06 & 6.36 \\
\hline $\begin{array}{l}\text { Central Florida Wet Prairie and } \\
\text { Herbaceous Seep }\end{array}$ & B1, end & 2.27 & 0.19 & 5.28 & 2.64 & 0.56 & 5.24 & 2.75 & 0.72 & 5.46 & 2.55 & 0.29 & 4.86 \\
\hline $\begin{array}{l}\text { East Gulf Coastal Plain Near-Coast } \\
\text { Pine Flatwoods }\end{array}$ & B1, end & 2.03 & 0.19 & 4.82 & 2.57 & 0.45 & 5.20 & 2.75 & 1.04 & 5.87 & 2.72 & -0.05 & 6.33 \\
\hline $\begin{array}{l}\text { East Gulf Coastal Plain Southern } \\
\text { Loess Bluff Forest }\end{array}$ & B1, end & 1.90 & 0.22 & 4.20 & 2.39 & 0.53 & 5.64 & 2.45 & 1.28 & 5.25 & 2.49 & -0.13 & 5.83 \\
\hline $\begin{array}{l}\text { Edwards Plateau Limestone } \\
\text { Shrubland }\end{array}$ & B1, end & 2.16 & 0.38 & 4.61 & 2.73 & 0.99 & 5.46 & 2.53 & 1.17 & 5.39 & 2.53 & 0.11 & 5.61 \\
\hline Edwards Plateau Mesic Canyon & $\mathrm{B} 1$, end & 2.18 & 0.36 & 4.53 & 2.74 & 1.05 & 5.61 & 2.43 & 1.16 & 5.12 & 2.55 & 0.14 & 5.73 \\
\hline $\begin{array}{l}\text { Nashville Basin Limestone Glade and } \\
\text { Woodland }\end{array}$ & B1, end & 2.15 & 0.88 & 4.78 & 2.39 & 0.69 & 5.44 & 2.56 & 0.76 & 5.87 & 2.40 & 0.00 & 5.76 \\
\hline $\begin{array}{l}\text { South-Central Interior Mesophytic } \\
\text { Forest }\end{array}$ & B1, end & 2.44 & 0.94 & 5.16 & 2.40 & 0.65 & 5.32 & 2.64 & 0.84 & 6.13 & 2.35 & 0.27 & 5.54 \\
\hline Southeast & $\mathrm{B} 1$, end & 2.12 & 0.73 & 4.56 & 2.45 & 0.83 & 5.15 & 2.58 & 1.32 & 5.57 & 2.46 & 0.25 & 5.70 \\
\hline $\begin{array}{l}\text { Southern Coastal Plain Nonriverine } \\
\text { Cypress Dome }\end{array}$ & B1, end & 1.81 & 0.21 & 4.46 & 2.38 & 0.49 & 4.61 & 2.59 & 0.88 & 5.69 & 2.53 & 0.07 & 5.71 \\
\hline $\begin{array}{l}\text { Southern Coastal Plain Seepage } \\
\text { Swamp and Baygall }\end{array}$ & B1, end & 1.95 & 0.20 & 4.76 & 2.47 & 0.52 & 4.77 & 2.66 & 0.80 & 5.67 & 2.54 & 0.16 & 5.42 \\
\hline
\end{tabular}




\begin{tabular}{|c|c|c|c|c|c|c|c|c|c|c|c|c|c|}
\hline \multirow{2}{*}{ Ecological system } & \multirow{2}{*}{$\begin{array}{l}\text { Scenario, } \\
\text { time } \\
\text { period }\end{array}$} & \multicolumn{3}{|c|}{ Winter } & \multicolumn{3}{|c|}{ Spring } & \multicolumn{3}{|c|}{ Summer } & \multicolumn{3}{|c|}{ Fall } \\
\hline & & Mean & Min & Max & Mean & Min & Max & Mean & Min & Max & Mean & Min & Max \\
\hline $\begin{array}{l}\text { Caribbean Mangrove Forest and } \\
\text { Shrubland - Puerto Rico }\end{array}$ & A1FI, mid & 3.66 & 1.21 & 8.52 & 4.29 & 1.87 & 10.75 & 4.69 & 2.02 & 14.52 & 5.01 & 2.23 & 14.88 \\
\hline $\begin{array}{l}\text { Caribbean Mature Primary Elfin } \\
\text { Woodland - Puerto Rico }\end{array}$ & A1FI, mid & 6.71 & 3.19 & 9.79 & 6.85 & 4.46 & 10.63 & 6.39 & 4.21 & 9.68 & 6.95 & 5.58 & 9.66 \\
\hline $\begin{array}{l}\text { Central Atlantic Coastal Plain Wet } \\
\text { Longleaf Pine Savanna and } \\
\text { Flatwoods }\end{array}$ & A1FI, mid & 1.00 & -0.07 & 2.03 & 2.40 & 0.95 & 3.62 & 2.67 & 1.53 & 3.64 & 2.92 & 1.03 & 4.36 \\
\hline $\begin{array}{l}\text { Central Florida Wet Prairie and } \\
\text { Herbaceous Seep }\end{array}$ & A1FI, mid & 1.92 & 0.92 & 3.06 & 2.90 & 1.65 & 4.06 & 3.13 & 1.69 & 4.37 & 3.31 & 1.92 & 4.14 \\
\hline $\begin{array}{l}\text { East Gulf Coastal Plain Near-Coast } \\
\text { Pine Flatwoods }\end{array}$ & A1FI, mid & 1.44 & 0.31 & 2.86 & 2.77 & 1.61 & 4.16 & 3.07 & 2.08 & 4.55 & 3.15 & 1.81 & 4.46 \\
\hline $\begin{array}{l}\text { East Gulf Coastal Plain Southern } \\
\text { Loess Bluff Forest }\end{array}$ & A1FI, mid & 1.38 & 0.22 & 3.02 & 2.61 & 1.76 & 3.97 & 2.82 & 2.32 & 3.56 & 2.62 & 1.39 & 4.04 \\
\hline $\begin{array}{l}\text { Edwards Plateau Limestone } \\
\text { Shrubland }\end{array}$ & A1FI, mid & 1.58 & -0.10 & 3.34 & 2.98 & 1.65 & 4.40 & 2.83 & 2.22 & 4.08 & 2.73 & 1.37 & 4.37 \\
\hline Edwards Plateau Mesic Canyon & A1FI, mid & 1.59 & -0.10 & 3.42 & 3.01 & 1.72 & 4.52 & 2.73 & 2.07 & 3.85 & 2.74 & 1.36 & 4.39 \\
\hline $\begin{array}{l}\text { Nashville Basin Limestone Glade and } \\
\text { Woodland }\end{array}$ & A1FI, mid & 1.63 & -0.10 & 3.06 & 2.61 & 1.21 & 4.16 & 2.76 & 1.98 & 3.72 & 2.60 & 1.03 & 3.91 \\
\hline $\begin{array}{l}\text { South-Central Interior Mesophytic } \\
\text { Forest }\end{array}$ & A1FI, mid & 1.91 & 0.00 & 3.28 & 2.52 & 1.10 & 4.03 & 2.80 & 1.77 & 3.94 & 2.51 & 0.96 & 3.71 \\
\hline Southeast & A1FI, mid & 1.58 & 0.13 & 2.93 & 2.64 & 1.53 & 3.85 & 2.84 & 2.05 & 3.29 & 2.70 & 1.25 & 4.12 \\
\hline $\begin{array}{l}\text { Southern Coastal Plain Nonriverine } \\
\text { Cypress Dome }\end{array}$ & A1FI, mid & 1.39 & 0.47 & 2.40 & 2.68 & 1.49 & 4.05 & 2.90 & 1.84 & 3.95 & 3.15 & 1.72 & 4.26 \\
\hline $\begin{array}{l}\text { Southern Coastal Plain Seepage } \\
\text { Swamp and Baygall }\end{array}$ & A1FI, mid & 1.56 & 0.64 & 2.43 & 2.77 & 1.54 & 4.14 & 3.01 & 1.78 & 4.18 & 3.24 & 1.82 & 4.25 \\
\hline $\begin{array}{l}\text { Caribbean Mangrove Forest and } \\
\text { Shrubland - Puerto Rico }\end{array}$ & A1FI, end & 7.94 & 2.38 & 17.30 & 8.81 & 3.84 & 18.19 & 9.02 & 3.92 & 19.07 & 9.53 & 4.54 & 19.33 \\
\hline
\end{tabular}




\begin{tabular}{|c|c|c|c|c|c|c|c|c|c|c|c|c|c|}
\hline \multirow{2}{*}{ Ecological system } & \multirow{2}{*}{$\begin{array}{l}\text { Scenario, } \\
\text { time } \\
\text { period }\end{array}$} & \multicolumn{3}{|c|}{ Winter } & \multicolumn{3}{|c|}{ Spring } & \multicolumn{3}{|c|}{ Summer } & \multicolumn{3}{|c|}{ Fall } \\
\hline & & Mean & Min & Max & Mean & Min & Max & Mean & Min & Max & Mean & Min & Max \\
\hline $\begin{array}{l}\text { Caribbean Mature Primary Elfin } \\
\text { Woodland - Puerto Rico }\end{array}$ & A1FI, end & 14.61 & 7.89 & 21.31 & 13.31 & 8.89 & 17.75 & 12.46 & 8.49 & 18.76 & 14.14 & 12.10 & 18.80 \\
\hline $\begin{array}{l}\text { Central Atlantic Coastal Plain Wet } \\
\text { Longleaf Pine Savanna and } \\
\text { Flatwoods }\end{array}$ & A1FI, end & 2.56 & 1.34 & 4.33 & 4.68 & 2.54 & 7.17 & 4.84 & 3.97 & 6.40 & 5.54 & 2.57 & 7.44 \\
\hline $\begin{array}{l}\text { Central Florida Wet Prairie and } \\
\text { Herbaceous Seep }\end{array}$ & A1FI, end & 3.93 & 2.38 & 6.89 & 5.57 & 3.32 & 7.91 & 6.04 & 3.62 & 8.17 & 5.90 & 4.04 & 7.27 \\
\hline $\begin{array}{l}\text { East Gulf Coastal Plain Near-Coast } \\
\text { Pine Flatwoods }\end{array}$ & A1FI, end & 3.22 & 2.27 & 4.48 & 5.25 & 3.17 & 8.01 & 5.77 & 4.45 & 8.03 & 5.68 & 4.11 & 7.69 \\
\hline $\begin{array}{l}\text { East Gulf Coastal Plain Southern } \\
\text { Loess Bluff Forest }\end{array}$ & A1FI, end & 3.19 & 2.24 & 4.79 & 4.83 & 3.14 & 6.41 & 5.02 & 4.09 & 6.10 & 4.97 & 3.00 & 6.48 \\
\hline $\begin{array}{l}\text { Edwards Plateau Limestone } \\
\text { Shrubland }\end{array}$ & A1FI, end & 3.91 & 2.73 & 6.07 & 5.49 & 3.92 & 6.56 & 5.01 & 3.75 & 7.90 & 5.43 & 2.88 & 7.39 \\
\hline Edwards Plateau Mesic Canyon & A1FI, end & 3.94 & 2.64 & 6.00 & 5.51 & 3.97 & 6.78 & 4.77 & 3.66 & 7.38 & 5.38 & 2.91 & 7.30 \\
\hline $\begin{array}{l}\text { Nashville Basin Limestone Glade and } \\
\text { Woodland }\end{array}$ & A1FI, end & 3.63 & 2.54 & 5.61 & 4.88 & 2.58 & 7.01 & 4.93 & 4.21 & 5.96 & 5.11 & 2.35 & 7.38 \\
\hline $\begin{array}{l}\text { South-Central Interior Mesophytic } \\
\text { Forest }\end{array}$ & A1FI, end & 4.00 & 2.72 & 6.35 & 4.70 & 2.51 & 6.71 & 4.97 & 4.26 & 6.12 & 4.95 & 2.35 & 7.01 \\
\hline Southeast & A1FI, end & 3.56 & 2.62 & 5.61 & 4.93 & 3.03 & 6.71 & 5.10 & 4.25 & 6.11 & 5.21 & 2.83 & 6.76 \\
\hline $\begin{array}{l}\text { Southern Coastal Plain Nonriverine } \\
\text { Cypress Dome }\end{array}$ & A1FI, end & 3.09 & 1.77 & 5.11 & 5.15 & 2.93 & 7.76 & 5.52 & 4.10 & 7.33 & 5.66 & 3.93 & 7.29 \\
\hline $\begin{array}{l}\text { Southern Coastal Plain Seepage } \\
\text { Swamp and Baygall }\end{array}$ & A1FI, end & 3.36 & 1.95 & 5.64 & 5.30 & 3.07 & 7.75 & 5.75 & 3.92 & 7.59 & 5.77 & 4.15 & 7.29 \\
\hline
\end{tabular}


Table A6. Percentage projected change in mean precipitation for ecosystems in the Southeastern United States (excluding the Caribbean).

[Abbreviations: min, minimum; max, maximum; mid, mid-century; end, end of century]

\begin{tabular}{|c|c|c|c|c|c|c|c|c|c|c|c|c|c|}
\hline \multirow{2}{*}{ Ecological system } & \multirow{2}{*}{$\begin{array}{l}\text { Scenario, } \\
\text { time } \\
\text { period }\end{array}$} & \multicolumn{3}{|c|}{ Winter } & \multicolumn{3}{|c|}{ Spring } & \multicolumn{3}{|c|}{ Summer } & \multicolumn{3}{|c|}{ Fall } \\
\hline & & Mean & Min & Max & Mean & Min & Max & Mean & Winter & Spring & Mean & Min & Max \\
\hline $\begin{array}{l}\text { Central Atlantic Coastal Plain } \\
\text { Wet Longleaf Pine } \\
\text { Savanna and Flatwoods }\end{array}$ & B1, mid & 5.54 & -19.30 & 37.25 & 0.62 & -18.06 & 30.95 & 7.31 & -36.32 & 42.28 & 6.97 & -24.71 & 45.51 \\
\hline $\begin{array}{l}\text { Central Florida Wet Prairie } \\
\text { and Herbaceous Seep }\end{array}$ & B1, mid & 8.98 & -31.44 & 80.04 & -1.43 & -42.10 & 52.54 & -9.37 & -53.44 & 49.02 & 5.37 & -30.45 & 72.79 \\
\hline $\begin{array}{l}\text { East Gulf Coastal Plain Near- } \\
\text { Coast Pine Flatwoods }\end{array}$ & B1, mid & 5.19 & -36.15 & 46.64 & 2.65 & -34.33 & 53.13 & -1.78 & -50.66 & 42.68 & 8.06 & -31.11 & 46.82 \\
\hline $\begin{array}{l}\text { East Gulf Coastal Plain } \\
\text { Southern Loess Bluff } \\
\text { Forest }\end{array}$ & B1, mid & 1.01 & -44.55 & 47.05 & 1.95 & -30.06 & 64.59 & -1.00 & -41.27 & 70.38 & 7.28 & -31.76 & 86.48 \\
\hline $\begin{array}{l}\text { Edwards Plateau Limestone } \\
\text { Shrubland }\end{array}$ & B1, mid & 2.04 & -38.93 & 72.47 & -1.84 & -26.60 & 36.44 & 7.93 & -46.13 & 211.20 & 3.89 & -59.57 & 125.04 \\
\hline $\begin{array}{l}\text { Edwards Plateau Mesic } \\
\text { Canyon }\end{array}$ & B1, mid & 0.98 & -39.55 & 70.06 & -1.46 & -29.51 & 51.05 & 8.29 & -43.58 & 259.99 & 3.09 & -61.32 & 126.33 \\
\hline $\begin{array}{l}\text { Nashville Basin Limestone } \\
\text { Glade and Woodland }\end{array}$ & B1, mid & 1.72 & -28.44 & 33.28 & 5.74 & -25.41 & 61.32 & 0.52 & -34.51 & 41.63 & 2.80 & -34.06 & 42.76 \\
\hline $\begin{array}{l}\text { South-Central Interior } \\
\text { Mesophytic Forest }\end{array}$ & B1, mid & 3.46 & -26.85 & 37.64 & 5.29 & -21.13 & 52.83 & 3.56 & -20.80 & 42.59 & 3.02 & -26.52 & 50.77 \\
\hline Southeast & B1, mid & 2.98 & -28.14 & 30.86 & 1.69 & -20.72 & 36.46 & 1.23 & -32.20 & 27.93 & 3.72 & -25.97 & 35.26 \\
\hline $\begin{array}{l}\text { Southern Coastal Plain } \\
\text { Nonriverine Cypress Dome }\end{array}$ & B1, mid & 5.86 & -25.25 & 41.38 & 0.67 & -32.15 & 48.37 & -2.06 & -51.37 & 47.34 & 6.02 & -31.18 & 43.17 \\
\hline $\begin{array}{l}\text { Southern Coastal Plain } \\
\text { Seepage Swamp and } \\
\text { Baygall }\end{array}$ & B1, mid & 7.16 & -27.00 & 42.52 & -0.34 & -35.74 & 48.90 & -4.32 & -49.82 & 46.94 & 6.11 & -29.88 & 56.90 \\
\hline
\end{tabular}




\begin{tabular}{|c|c|c|c|c|c|c|c|c|c|c|c|c|c|}
\hline \multirow{2}{*}{ Ecological system } & \multirow{2}{*}{$\begin{array}{l}\text { Scenario, } \\
\text { time } \\
\text { period }\end{array}$} & \multicolumn{3}{|c|}{ Winter } & \multicolumn{3}{|c|}{ Spring } & \multicolumn{3}{|c|}{ Summer } & \multicolumn{3}{|c|}{ Fall } \\
\hline & & Mean & Min & Max & Mean & Min & Max & Mean & Winter & Spring & Mean & Min & $\operatorname{Max}$ \\
\hline $\begin{array}{l}\text { Central Atlantic Coastal Plain } \\
\text { Wet Longleaf Pine } \\
\text { Savanna and Flatwoods }\end{array}$ & B1, end & 8.24 & -21.91 & 35.04 & 6.40 & -27.70 & 38.62 & 9.93 & -42.50 & 57.48 & 12.70 & -18.77 & 79.81 \\
\hline $\begin{array}{l}\text { Central Florida Wet Prairie } \\
\text { and Herbaceous Seep }\end{array}$ & B1, end & 16.70 & -37.06 & 82.57 & -2.45 & -43.35 & 37.23 & -6.54 & -48.97 & 68.71 & 10.01 & -32.47 & 80.70 \\
\hline $\begin{array}{l}\text { East Gulf Coastal Plain Near- } \\
\text { Coast Pine Flatwoods }\end{array}$ & B1, end & 3.68 & -43.64 & 50.75 & 5.65 & -25.85 & 61.25 & 4.16 & -42.69 & 80.68 & 11.55 & -47.80 & 87.73 \\
\hline $\begin{array}{l}\text { East Gulf Coastal Plain } \\
\text { Southern Loess Bluff } \\
\text { Forest }\end{array}$ & B1, end & 0.35 & -51.94 & 26.18 & 7.32 & -22.64 & 66.88 & 4.26 & -39.58 & 72.95 & 11.68 & -51.33 & 109.25 \\
\hline $\begin{array}{l}\text { Edwards Plateau Limestone } \\
\text { Shrubland }\end{array}$ & B1, end & -0.36 & -48.26 & 73.15 & 1.99 & -42.65 & 41.06 & 11.40 & -55.96 & 169.03 & 5.06 & -64.18 & 103.58 \\
\hline $\begin{array}{l}\text { Edwards Plateau Mesic } \\
\text { Canyon }\end{array}$ & B1, end & -0.22 & -49.94 & 71.13 & 1.87 & -43.95 & 47.74 & 12.09 & -61.01 & 238.25 & 5.04 & -69.92 & 100.67 \\
\hline $\begin{array}{l}\text { Nashville Basin Limestone } \\
\text { Glade and Woodland }\end{array}$ & B1, end & 5.67 & -34.26 & 58.50 & 6.17 & -25.71 & 69.59 & 4.45 & -55.22 & 68.91 & 10.81 & -53.25 & 80.78 \\
\hline $\begin{array}{c}\text { South-Central Interior } \\
\text { Mesophytic Forest }\end{array}$ & B1, end & 5.84 & -29.95 & 33.65 & 8.40 & -26.69 & 46.72 & 6.21 & -46.76 & 35.34 & 9.42 & -23.26 & 59.19 \\
\hline Southeast & B1, end & 3.00 & -32.95 & 22.13 & 4.85 & -24.31 & 34.60 & 5.30 & -38.37 & 39.37 & 7.72 & -31.26 & 41.28 \\
\hline $\begin{array}{l}\text { Southern Coastal Plain } \\
\text { Nonriverine Cypress Dome }\end{array}$ & B1, end & 6.37 & -30.31 & 47.95 & 3.65 & -32.67 & 37.05 & 1.26 & -42.24 & 64.60 & 9.96 & -26.79 & 71.80 \\
\hline $\begin{array}{l}\text { Southern Coastal Plain } \\
\text { Seepage Swamp and } \\
\text { Baygall }\end{array}$ & B1, end & 9.95 & -24.19 & 59.45 & 1.26 & -37.02 & 35.08 & -1.94 & -41.70 & 68.36 & 10.14 & -27.99 & 83.86 \\
\hline $\begin{array}{l}\text { Central Atlantic Coastal Plain } \\
\text { Wet Longleaf Pine } \\
\text { Savanna and Flatwoods }\end{array}$ & A1FI, mid & 0.13 & -19.07 & 23.45 & 3.26 & -22.96 & 33.74 & 19.82 & -8.45 & 46.11 & 11.62 & -27.65 & 31.90 \\
\hline
\end{tabular}




\begin{tabular}{|c|c|c|c|c|c|c|c|c|c|c|c|c|c|}
\hline \multirow{2}{*}{ Ecological system } & \multirow{2}{*}{$\begin{array}{l}\text { Scenario, } \\
\text { time } \\
\text { period }\end{array}$} & \multicolumn{3}{|c|}{ Winter } & \multicolumn{3}{|c|}{ Spring } & \multicolumn{3}{|c|}{ Summer } & \multicolumn{3}{|c|}{ Fall } \\
\hline & & Mean & Min & $\operatorname{Max}$ & Mean & Min & Max & Mean & Winter & Spring & Mean & Min & Max \\
\hline $\begin{array}{l}\text { Central Florida Wet Prairie } \\
\text { and Herbaceous Seep }\end{array}$ & A1FI, mid & -2.58 & -29.03 & 31.24 & -4.30 & -31.00 & 36.39 & -15.06 & -37.31 & 21.45 & 20.46 & -11.78 & 118.17 \\
\hline $\begin{array}{l}\text { East Gulf Coastal Plain Near- } \\
\text { Coast Pine Flatwoods }\end{array}$ & A1FI, mid & 0.06 & -20.91 & 29.02 & 3.38 & -25.66 & 34.05 & 4.07 & -22.27 & 56.21 & 20.05 & -28.99 & 60.65 \\
\hline $\begin{array}{l}\text { East Gulf Coastal Plain } \\
\text { Southern Loess Bluff } \\
\text { Forest }\end{array}$ & A1FI, mid & 1.15 & -23.15 & 29.89 & 1.51 & -28.06 & 43.17 & -6.24 & -47.53 & 27.69 & 13.80 & -16.82 & 84.26 \\
\hline $\begin{array}{l}\text { Edwards Plateau Limestone } \\
\text { Shrubland }\end{array}$ & A1FI, mid & 13.32 & -4.05 & 44.56 & 0.83 & -38.85 & 59.60 & -8.05 & -52.88 & 49.79 & 14.35 & -17.18 & 106.59 \\
\hline $\begin{array}{l}\text { Edwards Plateau Mesic } \\
\text { Canyon }\end{array}$ & A1FI, mid & 11.26 & -5.54 & 42.92 & 2.35 & -37.23 & 61.91 & -12.00 & -59.74 & 38.81 & 12.67 & -21.64 & 111.74 \\
\hline $\begin{array}{l}\text { Nashville Basin Limestone } \\
\text { Glade and Woodland }\end{array}$ & A1FI, mid & 0.54 & -11.21 & 21.97 & 3.07 & -18.17 & 27.21 & 2.33 & -47.32 & 64.12 & 17.13 & -17.72 & 65.14 \\
\hline $\begin{array}{l}\text { South-Central Interior } \\
\text { Mesophytic Forest }\end{array}$ & A1FI, mid & 2.75 & -7.50 & 16.83 & 5.30 & -11.18 & 18.80 & 8.46 & -31.63 & 63.56 & 15.27 & -27.15 & 66.10 \\
\hline Southeast & A1FI, mid & 1.96 & -11.84 & 13.94 & 3.50 & -20.92 & 36.94 & 2.41 & -27.27 & 32.24 & 13.42 & -12.37 & 39.38 \\
\hline $\begin{array}{l}\text { Southern Coastal Plain } \\
\text { Nonriverine Cypress Dome }\end{array}$ & A1FI, mid & -2.78 & -24.70 & 13.81 & 1.73 & -21.31 & 34.00 & 4.39 & -24.27 & 52.94 & 16.98 & -31.58 & 61.91 \\
\hline $\begin{array}{l}\text { Southern Coastal Plain } \\
\text { Seepage Swamp and } \\
\text { Baygall }\end{array}$ & A1FI, mid & -2.14 & -26.04 & 16.47 & 0.43 & -25.76 & 39.73 & -1.13 & -25.36 & 43.35 & 18.57 & -29.55 & 81.58 \\
\hline $\begin{array}{l}\text { Central Atlantic Coastal Plain } \\
\text { Wet Longleaf Pine } \\
\text { Savanna and Flatwoods }\end{array}$ & A1FI, end & 4.26 & -8.37 & 25.90 & 16.19 & -18.80 & 73.46 & 38.95 & -14.46 & 91.30 & 10.58 & -48.25 & 60.44 \\
\hline $\begin{array}{l}\text { Central Florida Wet Prairie } \\
\text { and Herbaceous Seep }\end{array}$ & A1FI, end & -14.08 & -42.25 & 22.06 & -22.38 & -64.80 & 58.79 & -20.90 & -54.91 & 22.50 & 26.79 & -42.04 & 141.72 \\
\hline
\end{tabular}




\begin{tabular}{|c|c|c|c|c|c|c|c|c|c|c|c|c|c|}
\hline \multirow[b]{2}{*}{ Ecological system } & \multirow{2}{*}{$\begin{array}{l}\text { Scenario, } \\
\text { time } \\
\text { period }\end{array}$} & \multicolumn{3}{|c|}{ Winter } & \multicolumn{3}{|c|}{ Spring } & \multicolumn{3}{|c|}{ Summer } & \multicolumn{3}{|c|}{ Fall } \\
\hline & & Mean & Min & Max & Mean & Min & Max & Mean & Winter & Spring & Mean & Min & Max \\
\hline $\begin{array}{l}\text { East Gulf Coastal Plain Near- } \\
\text { Coast Pine Flatwoods }\end{array}$ & A1FI, end & -8.63 & -31.34 & 29.55 & -3.50 & -56.01 & 58.95 & 5.80 & -43.09 & 65.16 & 31.73 & -15.75 & 105.57 \\
\hline $\begin{array}{l}\text { East Gulf Coastal Plain } \\
\text { Southern Loess Bluff } \\
\text { Forest }\end{array}$ & A1FI, end & -4.49 & -28.24 & 43.20 & 3.86 & -47.67 & 66.79 & -29.97 & -69.02 & 15.68 & 27.35 & -41.02 & 127.80 \\
\hline $\begin{array}{l}\text { Edwards Plateau Limestone } \\
\text { Shrubland }\end{array}$ & A1FI, end & 8.24 & -35.15 & 50.42 & 17.22 & -65.20 & 83.13 & -24.22 & -72.75 & 64.63 & 16.81 & -49.47 & 94.83 \\
\hline $\begin{array}{l}\text { Edwards Plateau Mesic } \\
\text { Canyon }\end{array}$ & A1FI, end & 6.39 & -34.53 & 43.25 & 14.87 & -63.59 & 73.83 & -29.02 & -76.95 & 53.39 & 16.77 & -53.09 & 99.46 \\
\hline $\begin{array}{l}\text { Nashville Basin Limestone } \\
\text { Glade and Woodland }\end{array}$ & A1FI, end & 5.82 & -23.66 & 50.32 & 11.05 & -7.55 & 42.89 & -3.15 & -63.40 & 76.57 & 23.11 & -33.19 & 105.66 \\
\hline $\begin{array}{l}\text { South-Central Interior } \\
\text { Mesophytic Forest }\end{array}$ & A1FI, end & 8.85 & -15.64 & 33.55 & 16.40 & -6.73 & 50.78 & 6.33 & -53.77 & 71.87 & 20.52 & -40.07 & 87.31 \\
\hline Southeast & A1FI, end & 1.73 & -13.89 & 32.81 & 10.18 & -25.23 & 51.76 & -1.60 & -49.21 & 38.07 & 17.99 & -20.47 & 60.93 \\
\hline $\begin{array}{l}\text { Southern Coastal Plain } \\
\text { Nonriverine Cypress Dome }\end{array}$ & A1FI, end & -8.79 & -24.78 & 19.69 & -8.03 & -54.20 & 52.37 & 11.85 & -41.36 & 75.09 & 21.45 & -23.08 & 81.59 \\
\hline $\begin{array}{l}\text { Southern Coastal Plain } \\
\text { Seepage Swamp and } \\
\text { Baygall }\end{array}$ & A1FI, end & -10.00 & -29.30 & 11.83 & -11.91 & -61.74 & 59.25 & 1.89 & -47.11 & 59.50 & 23.62 & -31.37 & 104.20 \\
\hline
\end{tabular}


Table A7. Factor change in mean precipitation for ecosystems in Puerto Rico.

[Abbreviations: min, minimum; max, maximum; mid, mid-century; end, end of century]

\begin{tabular}{|c|c|c|c|c|c|c|c|c|c|c|c|c|c|}
\hline \multirow{2}{*}{ Ecological system } & \multirow{2}{*}{$\begin{array}{c}\text { Scenario, } \\
\text { time } \\
\text { period }\end{array}$} & \multicolumn{3}{|c|}{ Winter } & \multicolumn{3}{|c|}{ Spring } & \multicolumn{3}{|c|}{ Summer } & \multicolumn{3}{|c|}{ Fall } \\
\hline & & Mean & Min & $\operatorname{Max}$ & Mean & Min & $\operatorname{Max}$ & Mean & Min & Max & Mean & Min & Max \\
\hline $\begin{array}{l}\text { Caribbean Mangrove Forest and } \\
\text { Shrubland - Puerto Rico }\end{array}$ & RCP85, mid & 1.02 & 0.35 & 1.88 & 1.05 & 0.45 & 1.64 & 0.89 & 0.27 & 1.53 & 1.02 & 0.40 & 1.70 \\
\hline $\begin{array}{l}\text { Caribbean Mangrove Forest and } \\
\text { Shrubland - Puerto Rico }\end{array}$ & RCP85, end & 1.05 & 0.48 & 2.17 & 0.98 & 0.43 & 1.87 & 0.85 & 0.08 & 1.76 & 1.10 & 0.09 & 2.27 \\
\hline $\begin{array}{l}\text { Caribbean Mature Primary Elfin } \\
\text { Woodland - Puerto Rico }\end{array}$ & RCP85, mid & 0.92 & 0.23 & 3.19 & 0.87 & 0.19 & 1.81 & 0.73 & 0.21 & 1.46 & 0.94 & 0.43 & 1.68 \\
\hline $\begin{array}{l}\text { Caribbean Mature Primary Elfin } \\
\text { Woodland - Puerto Rico }\end{array}$ & RCP85, end & 0.71 & 0.15 & 2.29 & 0.72 & 0.13 & 2.46 & 0.56 & 0.05 & 5.32 & 0.81 & 0.20 & 1.71 \\
\hline Puerto Rico & RCP85, mid & 0.90 & 0.46 & 2.12 & 0.88 & 0.22 & 1.68 & 0.72 & 0.32 & 1.31 & 0.94 & 0.44 & 1.71 \\
\hline Puerto Rico & RCP85, end & 0.77 & 0.31 & 1.56 & 0.72 & 0.15 & 2.45 & 0.52 & 0.09 & 3.57 & 0.80 & 0.19 & 1.79 \\
\hline
\end{tabular}


Table A8. Projected change in standard deviation of mean maximum temperature.

[Abbreviations: min, minimum; max, maximum; mid, mid-century; end, end of century]

\begin{tabular}{|c|c|c|c|c|c|c|c|c|c|c|c|c|c|}
\hline \multirow[b]{2}{*}{ Ecological system } & \multirow{2}{*}{$\begin{array}{l}\text { Scenario, } \\
\text { time } \\
\text { period }\end{array}$} & \multicolumn{3}{|c|}{ Winter } & \multicolumn{3}{|c|}{ Spring } & \multicolumn{3}{|c|}{ Summer } & \multicolumn{3}{|c|}{ Fall } \\
\hline & & Mean & Min & Max & Mean & Min & Max & Mean & Min & Max & Mean & Min & $\operatorname{Max}$ \\
\hline $\begin{array}{l}\text { Caribbean Mangrove Forest and } \\
\text { Shrubland - Puerto Rico }\end{array}$ & B1, mid & 1.09 & 0.28 & 3.90 & 1.15 & 0.35 & 4.00 & 1.21 & 0.40 & 3.40 & 1.17 & 0.30 & 5.48 \\
\hline $\begin{array}{l}\text { Caribbean Mature Primary Elfin } \\
\text { Woodland - Puerto Rico }\end{array}$ & B1, mid & 0.91 & 0.47 & 2.01 & 1.01 & 0.56 & 2.06 & 1.04 & 0.57 & 1.79 & 0.97 & 0.54 & 1.51 \\
\hline $\begin{array}{l}\text { Central Atlantic Coastal Plain Wet } \\
\text { Longleaf Pine Savanna and } \\
\text { Flatwoods }\end{array}$ & B1, mid & 1.00 & 0.51 & 1.47 & 0.95 & 0.54 & 1.50 & 0.98 & 0.53 & 1.64 & 1.03 & 0.61 & 1.73 \\
\hline $\begin{array}{l}\text { Central Florida Wet Prairie and } \\
\text { Herbaceous Seep }\end{array}$ & B1, mid & 0.95 & 0.52 & 1.54 & 1.01 & 0.53 & 1.74 & 1.00 & 0.64 & 1.76 & 0.97 & 0.54 & 1.57 \\
\hline $\begin{array}{l}\text { East Gulf Coastal Plain Near-Coast } \\
\text { Pine Flatwoods }\end{array}$ & B1, mid & 0.96 & 0.57 & 1.43 & 0.99 & 0.54 & 1.66 & 1.05 & 0.53 & 1.93 & 0.99 & 0.61 & 1.45 \\
\hline $\begin{array}{l}\text { East Gulf Coastal Plain Southern Loess } \\
\text { Bluff Forest }\end{array}$ & B1, mid & 0.95 & 0.57 & 1.47 & 0.95 & 0.51 & 1.77 & 1.05 & 0.56 & 1.78 & 0.97 & 0.50 & 1.46 \\
\hline Edwards Plateau Limestone Shrubland & B1, mid & 1.00 & 0.54 & 1.80 & 1.04 & 0.66 & 1.69 & 1.01 & 0.49 & 1.79 & 1.02 & 0.65 & 1.86 \\
\hline Edwards Plateau Mesic Canyon & B1, mid & 1.00 & 0.53 & 1.83 & 1.04 & 0.63 & 1.71 & 1.01 & 0.49 & 1.75 & 1.01 & 0.63 & 1.76 \\
\hline $\begin{array}{l}\text { Nashville Basin Limestone Glade and } \\
\text { Woodland }\end{array}$ & B1, mid & 0.98 & 0.56 & 1.66 & 0.92 & 0.49 & 1.41 & 1.08 & 0.60 & 2.03 & 1.01 & 0.65 & 1.84 \\
\hline $\begin{array}{l}\text { South-Central Interior Mesophytic } \\
\text { Forest }\end{array}$ & B1, mid & 1.00 & 0.55 & 1.62 & 0.92 & 0.55 & 1.27 & 1.07 & 0.70 & 1.90 & 1.02 & 0.66 & 2.03 \\
\hline Southeast & B1, mid & 0.98 & 0.62 & 1.45 & 0.96 & 0.65 & 1.35 & 1.05 & 0.71 & 1.50 & 1.01 & 0.74 & 1.52 \\
\hline $\begin{array}{l}\text { Southern Coastal Plain Nonriverine } \\
\text { Cypress Dome }\end{array}$ & B1, mid & 0.97 & 0.62 & 1.46 & 0.99 & 0.54 & 1.53 & 1.01 & 0.68 & 1.76 & 0.99 & 0.63 & 1.52 \\
\hline $\begin{array}{l}\text { Southern Coastal Plain Seepage } \\
\text { Swamp and Baygall }\end{array}$ & B1, mid & 0.97 & 0.62 & 1.47 & 1.00 & 0.55 & 1.60 & 1.01 & 0.67 & 1.75 & 0.99 & 0.60 & 1.55 \\
\hline
\end{tabular}




\begin{tabular}{|c|c|c|c|c|c|c|c|c|c|c|c|c|c|}
\hline \multirow{2}{*}{ Ecological system } & \multirow{2}{*}{$\begin{array}{l}\text { Scenario, } \\
\text { time } \\
\text { period }\end{array}$} & \multicolumn{3}{|c|}{ Winter } & \multicolumn{3}{|c|}{ Spring } & \multicolumn{3}{|c|}{ Summer } & \multicolumn{3}{|c|}{ Fall } \\
\hline & & Mean & Min & Max & Mean & Min & Max & Mean & Min & Max & Mean & Min & $\operatorname{Max}$ \\
\hline $\begin{array}{l}\text { Caribbean Mangrove Forest and } \\
\text { Shrubland - Puerto Rico }\end{array}$ & B1, end & 1.00 & 0.29 & 4.18 & 1.06 & 0.36 & 3.15 & 1.16 & 0.46 & 2.60 & 1.01 & 0.06 & 5.13 \\
\hline $\begin{array}{l}\text { Caribbean Mature Primary Elfin } \\
\text { Woodland - Puerto Rico }\end{array}$ & B1, end & 0.84 & 0.36 & 1.32 & 0.95 & 0.54 & 1.72 & 1.02 & 0.58 & 1.87 & 0.85 & 0.45 & 1.39 \\
\hline $\begin{array}{l}\text { Central Atlantic Coastal Plain Wet } \\
\text { Longleaf Pine Savanna and } \\
\text { Flatwoods }\end{array}$ & B1, end & 0.98 & 0.51 & 1.50 & 0.94 & 0.51 & 1.62 & 0.92 & 0.59 & 1.41 & 1.04 & 0.40 & 1.73 \\
\hline $\begin{array}{l}\text { Central Florida Wet Prairie and } \\
\text { Herbaceous Seep }\end{array}$ & B1, end & 0.93 & 0.56 & 1.40 & 0.96 & 0.54 & 1.70 & 1.02 & 0.47 & 1.90 & 0.94 & 0.44 & 1.64 \\
\hline $\begin{array}{l}\text { East Gulf Coastal Plain Near-Coast } \\
\text { Pine Flatwoods }\end{array}$ & B1, end & 0.95 & 0.59 & 1.32 & 0.94 & 0.51 & 1.56 & 1.04 & 0.53 & 1.57 & 1.00 & 0.46 & 1.55 \\
\hline $\begin{array}{l}\text { East Gulf Coastal Plain Southern Loess } \\
\text { Bluff Forest }\end{array}$ & B1, end & 0.95 & 0.56 & 1.92 & 0.88 & 0.48 & 1.58 & 1.00 & 0.52 & 1.73 & 1.03 & 0.46 & 1.90 \\
\hline Edwards Plateau Limestone Shrubland & B1, end & 1.01 & 0.63 & 1.80 & 0.99 & 0.60 & 1.42 & 1.00 & 0.63 & 1.58 & 1.07 & 0.68 & 1.69 \\
\hline Edwards Plateau Mesic Canyon & B1, end & 1.01 & 0.64 & 1.86 & 0.99 & 0.60 & 1.41 & 0.99 & 0.61 & 1.57 & 1.06 & 0.64 & 1.67 \\
\hline $\begin{array}{l}\text { Nashville Basin Limestone Glade and } \\
\text { Woodland }\end{array}$ & B1, end & 0.98 & 0.52 & 1.84 & 0.88 & 0.50 & 1.56 & 1.02 & 0.45 & 1.72 & 1.06 & 0.56 & 1.73 \\
\hline $\begin{array}{l}\text { South-Central Interior Mesophytic } \\
\text { Forest }\end{array}$ & B1, end & 1.00 & 0.50 & 1.78 & 0.90 & 0.55 & 1.47 & 1.00 & 0.47 & 1.91 & 1.07 & 0.60 & 1.82 \\
\hline Southeast & B1, end & 0.99 & 0.66 & 1.71 & 0.93 & 0.60 & 1.38 & 1.01 & 0.60 & 1.47 & 1.05 & 0.62 & 1.49 \\
\hline $\begin{array}{l}\text { Southern Coastal Plain Nonriverine } \\
\text { Cypress Dome }\end{array}$ & B1, end & 0.96 & 0.59 & 1.30 & 0.94 & 0.50 & 1.52 & 1.00 & 0.47 & 1.48 & 0.99 & 0.51 & 1.68 \\
\hline $\begin{array}{l}\text { Southern Coastal Plain Seepage } \\
\text { Swamp and Baygall }\end{array}$ & B1, end & 0.95 & 0.57 & 1.34 & 0.95 & 0.51 & 1.55 & 1.00 & 0.47 & 1.55 & 0.97 & 0.49 & 1.68 \\
\hline $\begin{array}{l}\text { Caribbean Mangrove Forest and } \\
\text { Shrubland - Puerto Rico }\end{array}$ & $\begin{array}{l}\text { A1FI, } \\
\text { mid }\end{array}$ & 1.39 & 0.57 & 4.31 & 1.35 & 0.74 & 2.76 & 1.69 & 0.20 & 4.54 & 1.43 & 0.45 & 5.87 \\
\hline
\end{tabular}




\begin{tabular}{|c|c|c|c|c|c|c|c|c|c|c|c|c|c|}
\hline \multirow{2}{*}{ Ecological system } & \multirow{2}{*}{$\begin{array}{l}\text { Scenario, } \\
\text { time } \\
\text { period }\end{array}$} & \multicolumn{3}{|c|}{ Winter } & \multicolumn{3}{|c|}{ Spring } & \multicolumn{3}{|c|}{ Summer } & \multicolumn{3}{|c|}{ Fall } \\
\hline & & Mean & Min & Max & Mean & Min & Max & Mean & Min & $\operatorname{Max}$ & Mean & Min & $\operatorname{Max}$ \\
\hline $\begin{array}{l}\text { Caribbean Mature Primary Elfin } \\
\text { Woodland - Puerto Rico }\end{array}$ & $\begin{array}{l}\text { A1FI, } \\
\text { mid }\end{array}$ & 1.12 & 0.84 & 1.38 & 1.24 & 0.93 & 1.86 & 1.46 & 0.86 & 2.36 & 1.17 & 0.83 & 1.71 \\
\hline $\begin{array}{l}\text { Central Atlantic Coastal Plain Wet } \\
\text { Longleaf Pine Savanna and } \\
\text { Flatwoods }\end{array}$ & $\begin{array}{l}\text { A1FI, } \\
\text { mid }\end{array}$ & 1.02 & 0.72 & 1.43 & 1.14 & 0.75 & 1.62 & 0.87 & 0.52 & 1.56 & 0.98 & 0.62 & 1.63 \\
\hline $\begin{array}{l}\text { Central Florida Wet Prairie and } \\
\text { Herbaceous Seep }\end{array}$ & $\begin{array}{l}\text { A1FI, } \\
\text { mid }\end{array}$ & 1.02 & 0.68 & 1.34 & 1.29 & 0.82 & 2.73 & 1.05 & 0.79 & 1.52 & 0.91 & 0.60 & 1.22 \\
\hline $\begin{array}{l}\text { East Gulf Coastal Plain Near-Coast } \\
\text { Pine Flatwoods }\end{array}$ & $\begin{array}{l}\text { A1FI, } \\
\text { mid }\end{array}$ & 1.03 & 0.69 & 1.36 & 1.19 & 0.80 & 1.90 & 0.92 & 0.58 & 1.47 & 0.91 & 0.56 & 1.38 \\
\hline $\begin{array}{l}\text { East Gulf Coastal Plain Southern Loess } \\
\text { Bluff Forest }\end{array}$ & $\begin{array}{l}\text { A1FI, } \\
\text { mid }\end{array}$ & 0.97 & 0.59 & 1.31 & 1.05 & 0.61 & 1.60 & 1.00 & 0.57 & 1.61 & 1.00 & 0.60 & 1.44 \\
\hline Edwards Plateau Limestone Shrubland & $\begin{array}{l}\text { A1FI, } \\
\text { mid }\end{array}$ & 0.96 & 0.64 & 1.37 & 1.06 & 0.71 & 1.56 & 1.03 & 0.67 & 1.37 & 1.07 & 0.75 & 1.85 \\
\hline Edwards Plateau Mesic Canyon & $\begin{array}{l}\text { A1FI, } \\
\text { mid }\end{array}$ & 0.96 & 0.62 & 1.38 & 1.07 & 0.70 & 1.61 & 1.05 & 0.65 & 1.44 & 1.07 & 0.73 & 1.86 \\
\hline $\begin{array}{l}\text { Nashville Basin Limestone Glade and } \\
\text { Woodland }\end{array}$ & $\begin{array}{l}\text { A1FI, } \\
\text { mid }\end{array}$ & 1.00 & 0.71 & 1.40 & 1.05 & 0.92 & 1.23 & 0.97 & 0.72 & 1.61 & 0.98 & 0.60 & 1.49 \\
\hline $\begin{array}{l}\text { South-Central Interior Mesophytic } \\
\text { Forest }\end{array}$ & $\begin{array}{l}\text { A1FI, } \\
\text { mid }\end{array}$ & 1.00 & 0.75 & 1.39 & 1.06 & 0.95 & 1.21 & 0.94 & 0.74 & 1.51 & 1.00 & 0.66 & 1.40 \\
\hline Southeast & $\begin{array}{l}\text { A1FI, } \\
\text { mid }\end{array}$ & 0.99 & 0.70 & 1.32 & 1.09 & 0.92 & 1.35 & 0.98 & 0.72 & 1.38 & 1.02 & 0.69 & 1.44 \\
\hline $\begin{array}{l}\text { Southern Coastal Plain Nonriverine } \\
\text { Cypress Dome }\end{array}$ & $\begin{array}{l}\text { A1FI, } \\
\text { mid }\end{array}$ & 1.03 & 0.74 & 1.35 & 1.19 & 0.87 & 1.91 & 0.92 & 0.66 & 1.40 & 0.90 & 0.58 & 1.24 \\
\hline $\begin{array}{l}\text { Southern Coastal Plain Seepage } \\
\text { Swamp and Baygall }\end{array}$ & $\begin{array}{l}\text { A1FI, } \\
\text { mid }\end{array}$ & 1.03 & 0.72 & 1.31 & 1.23 & 0.85 & 2.18 & 0.95 & 0.68 & 1.44 & 0.90 & 0.57 & 1.25 \\
\hline $\begin{array}{l}\text { Caribbean Mangrove Forest and } \\
\text { Shrubland - Puerto Rico }\end{array}$ & A1FI, end & 1.33 & 0.31 & 5.42 & 1.24 & 0.18 & 3.28 & 1.46 & 0.40 & 4.36 & 1.27 & 0.07 & 4.36 \\
\hline
\end{tabular}




\begin{tabular}{|c|c|c|c|c|c|c|c|c|c|c|c|c|c|}
\hline \multirow{2}{*}{ Ecological system } & \multirow{2}{*}{$\begin{array}{l}\text { Scenario, } \\
\text { time } \\
\text { period }\end{array}$} & \multicolumn{3}{|c|}{ Winter } & \multicolumn{3}{|c|}{ Spring } & \multicolumn{3}{|c|}{ Summer } & \multicolumn{3}{|c|}{ Fall } \\
\hline & & Mean & Min & $\operatorname{Max}$ & Mean & Min & $\operatorname{Max}$ & Mean & Min & Max & Mean & Min & Max \\
\hline $\begin{array}{l}\text { Caribbean Mature Primary Elfin } \\
\text { Woodland - Puerto Rico }\end{array}$ & A1FI, end & 1.13 & 0.48 & 2.48 & 1.22 & 0.72 & 2.62 & 1.32 & 0.66 & 2.97 & 1.14 & 0.58 & 2.18 \\
\hline $\begin{array}{l}\text { Central Atlantic Coastal Plain Wet } \\
\text { Longleaf Pine Savanna and } \\
\text { Flatwoods }\end{array}$ & A1FI, end & 0.99 & 0.49 & 1.37 & 1.11 & 0.70 & 1.50 & 0.82 & 0.41 & 1.38 & 0.98 & 0.54 & 1.73 \\
\hline $\begin{array}{l}\text { Central Florida Wet Prairie and } \\
\text { Herbaceous Seep }\end{array}$ & A1FI, end & 0.93 & 0.56 & 1.38 & 1.29 & 0.69 & 2.62 & 0.88 & 0.54 & 1.17 & 0.88 & 0.52 & 1.43 \\
\hline $\begin{array}{l}\text { East Gulf Coastal Plain Near-Coast } \\
\text { Pine Flatwoods }\end{array}$ & A1FI, end & 0.96 & 0.37 & 1.35 & 1.18 & 0.67 & 1.87 & 0.91 & 0.70 & 1.35 & 0.89 & 0.53 & 1.44 \\
\hline $\begin{array}{l}\text { East Gulf Coastal Plain Southern Loess } \\
\text { Bluff Forest }\end{array}$ & A1FI, end & 0.90 & 0.22 & 1.46 & 0.91 & 0.47 & 1.64 & 0.91 & 0.42 & 1.36 & 0.92 & 0.57 & 1.42 \\
\hline Edwards Plateau Limestone Shrubland & A1FI, end & 0.96 & 0.31 & 1.63 & 0.94 & 0.46 & 1.57 & 1.12 & 0.52 & 1.71 & 0.86 & 0.48 & 1.21 \\
\hline Edwards Plateau Mesic Canyon & A1FI, end & 0.96 & 0.30 & 1.62 & 0.95 & 0.44 & 1.64 & 1.12 & 0.47 & 1.82 & 0.86 & 0.47 & 1.23 \\
\hline $\begin{array}{l}\text { Nashville Basin Limestone Glade and } \\
\text { Woodland }\end{array}$ & A1FI, end & 0.97 & 0.34 & 1.74 & 0.98 & 0.58 & 1.35 & 0.92 & 0.45 & 1.42 & 0.93 & 0.61 & 1.35 \\
\hline $\begin{array}{l}\text { South-Central Interior Mesophytic } \\
\text { Forest }\end{array}$ & A1FI, end & 1.00 & 0.42 & 1.62 & 1.00 & 0.65 & 1.28 & 0.94 & 0.57 & 1.56 & 0.93 & 0.65 & 1.30 \\
\hline Southeast & A1FI, end & 0.97 & 0.37 & 1.46 & 1.01 & 0.59 & 1.44 & 0.95 & 0.70 & 1.47 & 0.92 & 0.62 & 1.32 \\
\hline $\begin{array}{l}\text { Southern Coastal Plain Nonriverine } \\
\text { Cypress Dome }\end{array}$ & A1FI, end & 0.97 & 0.45 & 1.44 & 1.19 & 0.70 & 1.88 & 0.85 & 0.64 & 1.18 & 0.90 & 0.55 & 1.46 \\
\hline $\begin{array}{l}\text { Southern Coastal Plain Seepage } \\
\text { Swamp and Baygall }\end{array}$ & A1FI, end & 0.96 & 0.50 & 1.45 & 1.23 & 0.70 & 2.12 & 0.85 & 0.58 & 1.15 & 0.88 & 0.54 & 1.46 \\
\hline
\end{tabular}


Table A9. Projected change in standard deviation of mean minimum temperature.

[Abbreviations: min, minimum; max, maximum; mid, mid-century; end, end of century]

\begin{tabular}{|c|c|c|c|c|c|c|c|c|c|c|c|c|c|}
\hline \multirow[b]{2}{*}{ Ecological system } & \multirow{2}{*}{$\begin{array}{l}\text { Scenario, } \\
\text { time } \\
\text { period }\end{array}$} & \multicolumn{3}{|c|}{ Winter } & \multicolumn{3}{|c|}{ Spring } & \multicolumn{3}{|c|}{ Summer } & \multicolumn{3}{|c|}{ Fall } \\
\hline & & Mean & Min & Max & Mean & Min & Max & Mean & Min & $\operatorname{Max}$ & Mean & Min & Max \\
\hline $\begin{array}{l}\text { Caribbean Mangrove Forest and } \\
\text { Shrubland - Puerto Rico }\end{array}$ & B1, mid & 1.08 & 0.35 & 4.35 & 1.27 & 0.45 & 7.46 & 1.32 & 0.49 & 5.63 & 1.28 & 0.28 & 6.27 \\
\hline $\begin{array}{l}\text { Caribbean Mature Primary Elfin } \\
\text { Woodland - Puerto Rico }\end{array}$ & B1, mid & 1.26 & 0.53 & 2.42 & 1.30 & 0.70 & 2.49 & 1.21 & 0.67 & 2.00 & 1.19 & 0.56 & 1.76 \\
\hline $\begin{array}{l}\text { Central Atlantic Coastal Plain Wet } \\
\text { Longleaf Pine Savanna and } \\
\text { Flatwoods }\end{array}$ & B1, mid & 1.00 & 0.51 & 1.47 & 0.95 & 0.54 & 1.50 & 0.98 & 0.53 & 1.64 & 1.03 & 0.61 & 1.73 \\
\hline $\begin{array}{l}\text { Central Florida Wet Prairie and } \\
\text { Herbaceous Seep }\end{array}$ & B1, mid & 0.95 & 0.52 & 1.54 & 1.01 & 0.53 & 1.74 & 1.00 & 0.64 & 1.76 & 0.97 & 0.54 & 1.57 \\
\hline $\begin{array}{l}\text { East Gulf Coastal Plain Near-Coast } \\
\text { Pine Flatwoods }\end{array}$ & B1, mid & 0.96 & 0.57 & 1.43 & 0.99 & 0.54 & 1.66 & 1.05 & 0.53 & 1.93 & 0.99 & 0.61 & 1.45 \\
\hline $\begin{array}{l}\text { East Gulf Coastal Plain Southern Loess } \\
\text { Bluff Forest }\end{array}$ & B1, mid & 0.95 & 0.57 & 1.47 & 0.95 & 0.51 & 1.77 & 1.05 & 0.56 & 1.78 & 0.97 & 0.50 & 1.46 \\
\hline Edwards Plateau Limestone Shrubland & B1, mid & 1.00 & 0.54 & 1.80 & 1.04 & 0.66 & 1.69 & 1.01 & 0.49 & 1.79 & 1.02 & 0.65 & 1.86 \\
\hline Edwards Plateau Mesic Canyon & B1, mid & 1.00 & 0.53 & 1.83 & 1.04 & 0.63 & 1.71 & 1.01 & 0.49 & 1.75 & 1.01 & 0.63 & 1.76 \\
\hline $\begin{array}{l}\text { Nashville Basin Limestone Glade and } \\
\text { Woodland }\end{array}$ & B1, mid & 0.98 & 0.56 & 1.66 & 0.92 & 0.49 & 1.41 & 1.08 & 0.60 & 2.03 & 1.01 & 0.65 & 1.84 \\
\hline $\begin{array}{l}\text { South-Central Interior Mesophytic } \\
\text { Forest }\end{array}$ & B1, mid & 1.00 & 0.55 & 1.62 & 0.92 & 0.55 & 1.27 & 1.07 & 0.70 & 1.90 & 1.02 & 0.66 & 2.03 \\
\hline Southeast & B1, mid & 0.98 & 0.62 & 1.45 & 0.96 & 0.65 & 1.35 & 1.05 & 0.71 & 1.50 & 1.01 & 0.74 & 1.52 \\
\hline $\begin{array}{l}\text { Southern Coastal Plain Nonriverine } \\
\text { Cypress Dome }\end{array}$ & B1, mid & 0.97 & 0.62 & 1.46 & 0.99 & 0.54 & 1.53 & 1.01 & 0.68 & 1.76 & 0.99 & 0.63 & 1.52 \\
\hline $\begin{array}{l}\text { Southern Coastal Plain Seepage } \\
\text { Swamp and Baygall }\end{array}$ & B1, mid & 0.97 & 0.62 & 1.47 & 1.00 & 0.55 & 1.60 & 1.01 & 0.67 & 1.75 & 0.99 & 0.60 & 1.55 \\
\hline
\end{tabular}




\begin{tabular}{|c|c|c|c|c|c|c|c|c|c|c|c|c|c|}
\hline \multirow{2}{*}{ Ecological system } & \multirow{2}{*}{$\begin{array}{l}\text { Scenario, } \\
\text { time } \\
\text { period }\end{array}$} & \multicolumn{3}{|c|}{ Winter } & \multicolumn{3}{|c|}{ Spring } & \multicolumn{3}{|c|}{ Summer } & \multicolumn{3}{|c|}{ Fall } \\
\hline & & Mean & Min & Max & Mean & Min & Max & Mean & Min & Max & Mean & Min & Max \\
\hline $\begin{array}{l}\text { Caribbean Mangrove Forest and } \\
\text { Shrubland - Puerto Rico }\end{array}$ & B1, end & 1.04 & 0.33 & 5.72 & 1.19 & 0.42 & 4.85 & 1.26 & 0.28 & 4.64 & 1.16 & 0.04 & 4.28 \\
\hline $\begin{array}{l}\text { Caribbean Mature Primary Elfin } \\
\text { Woodland - Puerto Rico }\end{array}$ & B1, end & 1.45 & 0.58 & 3.32 & 1.19 & 0.68 & 2.12 & 1.13 & 0.71 & 2.03 & 1.09 & 0.64 & 1.77 \\
\hline $\begin{array}{l}\text { Central Atlantic Coastal Plain Wet } \\
\text { Longleaf Pine Savanna and } \\
\text { Flatwoods }\end{array}$ & B1, end & 0.98 & 0.51 & 1.50 & 0.94 & 0.51 & 1.62 & 0.92 & 0.59 & 1.41 & 1.04 & 0.40 & 1.73 \\
\hline $\begin{array}{l}\text { Central Florida Wet Prairie and } \\
\text { Herbaceous Seep }\end{array}$ & B1, end & 0.93 & 0.56 & 1.40 & 0.96 & 0.54 & 1.70 & 1.02 & 0.47 & 1.90 & 0.94 & 0.44 & 1.64 \\
\hline $\begin{array}{l}\text { East Gulf Coastal Plain Near-Coast } \\
\text { Pine Flatwoods }\end{array}$ & B1, end & 0.95 & 0.59 & 1.32 & 0.94 & 0.51 & 1.56 & 1.04 & 0.53 & 1.57 & 1.00 & 0.46 & 1.55 \\
\hline $\begin{array}{l}\text { East Gulf Coastal Plain Southern Loess } \\
\text { Bluff Forest }\end{array}$ & B1, end & 0.95 & 0.56 & 1.92 & 0.88 & 0.48 & 1.58 & 1.00 & 0.52 & 1.73 & 1.03 & 0.46 & 1.90 \\
\hline Edwards Plateau Limestone Shrubland & B1, end & 1.01 & 0.63 & 1.80 & 0.99 & 0.60 & 1.42 & 1.00 & 0.63 & 1.58 & 1.07 & 0.68 & 1.69 \\
\hline Edwards Plateau Mesic Canyon & B1, end & 1.01 & 0.64 & 1.86 & 0.99 & 0.60 & 1.41 & 0.99 & 0.61 & 1.57 & 1.06 & 0.64 & 1.67 \\
\hline $\begin{array}{l}\text { Nashville Basin Limestone Glade and } \\
\text { Woodland }\end{array}$ & B1, end & 0.98 & 0.52 & 1.84 & 0.88 & 0.50 & 1.56 & 1.02 & 0.45 & 1.72 & 1.06 & 0.56 & 1.73 \\
\hline $\begin{array}{l}\text { South-Central Interior Mesophytic } \\
\text { Forest }\end{array}$ & $\mathrm{B} 1$, end & 1.00 & 0.50 & 1.78 & 0.90 & 0.55 & 1.47 & 1.00 & 0.47 & 1.91 & 1.07 & 0.60 & 1.82 \\
\hline Southeast & B1, end & 0.99 & 0.66 & 1.71 & 0.93 & 0.60 & 1.38 & 1.01 & 0.60 & 1.47 & 1.05 & 0.62 & 1.49 \\
\hline $\begin{array}{l}\text { Southern Coastal Plain Nonriverine } \\
\text { Cypress Dome }\end{array}$ & B1, end & 0.96 & 0.59 & 1.30 & 0.94 & 0.50 & 1.52 & 1.00 & 0.47 & 1.48 & 0.99 & 0.51 & 1.68 \\
\hline $\begin{array}{l}\text { Southern Coastal Plain Seepage } \\
\text { Swamp and Baygall }\end{array}$ & B1, end & 0.95 & 0.57 & 1.34 & 0.95 & 0.51 & 1.55 & 1.00 & 0.47 & 1.55 & 0.97 & 0.49 & 1.68 \\
\hline $\begin{array}{l}\text { Caribbean Mangrove Forest and } \\
\text { Shrubland - Puerto Rico }\end{array}$ & $\begin{array}{l}\text { A1FI, } \\
\text { mid }\end{array}$ & 1.45 & 0.52 & 6.03 & 1.58 & 0.52 & 6.39 & 1.93 & 0.08 & 6.75 & 1.56 & 0.13 & 5.40 \\
\hline
\end{tabular}




\begin{tabular}{|c|c|c|c|c|c|c|c|c|c|c|c|c|c|}
\hline \multirow[b]{2}{*}{ Ecological system } & \multirow{2}{*}{$\begin{array}{l}\text { Scenario, } \\
\text { time } \\
\text { period }\end{array}$} & \multicolumn{3}{|c|}{ Winter } & \multicolumn{3}{|c|}{ Spring } & \multicolumn{3}{|c|}{ Summer } & \multicolumn{3}{|c|}{ Fall } \\
\hline & & Mean & Min & $\operatorname{Max}$ & Mean & Min & $\operatorname{Max}$ & Mean & Min & Max & Mean & Min & Max \\
\hline $\begin{array}{l}\text { Caribbean Mature Primary Elfin } \\
\text { Woodland - Puerto Rico }\end{array}$ & $\begin{array}{l}\text { A1FI, } \\
\text { mid }\end{array}$ & 1.79 & 1.13 & 3.77 & 1.61 & 0.87 & 2.49 & 1.70 & 1.19 & 2.42 & 1.46 & 1.03 & 1.83 \\
\hline $\begin{array}{l}\text { Central Atlantic Coastal Plain Wet } \\
\text { Longleaf Pine Savanna and } \\
\text { Flatwoods }\end{array}$ & $\begin{array}{l}\text { A1FI, } \\
\text { mid }\end{array}$ & 1.02 & 0.72 & 1.43 & 1.14 & 0.75 & 1.62 & 0.87 & 0.52 & 1.56 & 0.98 & 0.62 & 1.63 \\
\hline $\begin{array}{l}\text { Central Florida Wet Prairie and } \\
\text { Herbaceous Seep }\end{array}$ & $\begin{array}{l}\text { A1FI, } \\
\text { mid }\end{array}$ & 1.02 & 0.68 & 1.34 & 1.29 & 0.82 & 2.73 & 1.05 & 0.79 & 1.52 & 0.91 & 0.60 & 1.22 \\
\hline $\begin{array}{l}\text { East Gulf Coastal Plain Near-Coast } \\
\text { Pine Flatwoods }\end{array}$ & $\begin{array}{l}\text { A1FI, } \\
\text { mid }\end{array}$ & 1.03 & 0.69 & 1.36 & 1.19 & 0.80 & 1.90 & 0.92 & 0.58 & 1.47 & 0.91 & 0.56 & 1.38 \\
\hline $\begin{array}{l}\text { East Gulf Coastal Plain Southern Loess } \\
\text { Bluff Forest }\end{array}$ & $\begin{array}{l}\text { A1FI, } \\
\text { mid }\end{array}$ & 0.97 & 0.59 & 1.31 & 1.05 & 0.61 & 1.60 & 1.00 & 0.57 & 1.61 & 1.00 & 0.60 & 1.44 \\
\hline Edwards Plateau Limestone Shrubland & $\begin{array}{l}\text { A1FI, } \\
\text { mid }\end{array}$ & 0.96 & 0.64 & 1.37 & 1.06 & 0.71 & 1.56 & 1.03 & 0.67 & 1.37 & 1.07 & 0.75 & 1.85 \\
\hline Edwards Plateau Mesic Canyon & $\begin{array}{l}\text { A1FI, } \\
\text { mid }\end{array}$ & 0.96 & 0.62 & 1.38 & 1.07 & 0.70 & 1.61 & 1.05 & 0.65 & 1.44 & 1.07 & 0.73 & 1.86 \\
\hline $\begin{array}{l}\text { Nashville Basin Limestone Glade and } \\
\text { Woodland }\end{array}$ & $\begin{array}{l}\text { A1FI, } \\
\text { mid }\end{array}$ & 1.00 & 0.71 & 1.40 & 1.05 & 0.92 & 1.23 & 0.97 & 0.72 & 1.61 & 0.98 & 0.60 & 1.49 \\
\hline $\begin{array}{l}\text { South-Central Interior Mesophytic } \\
\text { Forest }\end{array}$ & $\begin{array}{l}\text { A1FI, } \\
\text { mid }\end{array}$ & 1.00 & 0.75 & 1.39 & 1.06 & 0.95 & 1.21 & 0.94 & 0.74 & 1.51 & 1.00 & 0.66 & 1.40 \\
\hline Southeast & $\begin{array}{l}\text { A1FI, } \\
\text { mid }\end{array}$ & 0.99 & 0.70 & 1.32 & 1.09 & 0.92 & 1.35 & 0.98 & 0.72 & 1.38 & 1.02 & 0.69 & 1.44 \\
\hline $\begin{array}{l}\text { Southern Coastal Plain Nonriverine } \\
\text { Cypress Dome }\end{array}$ & $\begin{array}{l}\text { A1FI, } \\
\text { mid }\end{array}$ & 1.03 & 0.74 & 1.35 & 1.19 & 0.87 & 1.91 & 0.92 & 0.66 & 1.40 & 0.90 & 0.58 & 1.24 \\
\hline $\begin{array}{l}\text { Southern Coastal Plain Seepage } \\
\text { Swamp and Baygall }\end{array}$ & $\begin{array}{l}\text { A1FI, } \\
\text { mid }\end{array}$ & 1.03 & 0.72 & 1.31 & 1.23 & 0.85 & 2.18 & 0.95 & 0.68 & 1.44 & 0.90 & 0.57 & 1.25 \\
\hline $\begin{array}{l}\text { Caribbean Mangrove Forest and } \\
\text { Shrubland - Puerto Rico }\end{array}$ & $\begin{array}{l}\text { A1FI, } \\
\text { end }\end{array}$ & 1.26 & 0.36 & 4.71 & 1.43 & 0.39 & 4.34 & 1.59 & 0.22 & 4.64 & 1.30 & 0.07 & 3.73 \\
\hline
\end{tabular}




\begin{tabular}{|c|c|c|c|c|c|c|c|c|c|c|c|c|c|}
\hline \multirow[b]{2}{*}{ Ecological system } & \multirow{2}{*}{$\begin{array}{l}\text { Scenario, } \\
\text { time } \\
\text { period }\end{array}$} & \multicolumn{3}{|c|}{ Winter } & \multicolumn{3}{|c|}{ Spring } & \multicolumn{3}{|c|}{ Summer } & \multicolumn{3}{|c|}{ Fall } \\
\hline & & Mean & Min & $\operatorname{Max}$ & Mean & Min & $\operatorname{Max}$ & Mean & Min & Max & Mean & Min & Max \\
\hline $\begin{array}{l}\text { Caribbean Mature Primary Elfin } \\
\text { Woodland - Puerto Rico }\end{array}$ & $\begin{array}{l}\text { A1FI, } \\
\text { end }\end{array}$ & 1.23 & 0.53 & 2.66 & 1.26 & 0.46 & 2.70 & 1.46 & 0.65 & 2.71 & 1.26 & 0.38 & 2.40 \\
\hline $\begin{array}{l}\text { Central Atlantic Coastal Plain Wet } \\
\text { Longleaf Pine Savanna and } \\
\text { Flatwoods }\end{array}$ & $\begin{array}{l}\text { A1FI, } \\
\text { end }\end{array}$ & 0.99 & 0.49 & 1.37 & 1.11 & 0.70 & 1.50 & 0.82 & 0.41 & 1.38 & 0.98 & 0.54 & 1.73 \\
\hline $\begin{array}{l}\text { Central Florida Wet Prairie and } \\
\text { Herbaceous Seep }\end{array}$ & $\begin{array}{l}\text { A1FI, } \\
\text { end }\end{array}$ & 0.93 & 0.56 & 1.38 & 1.29 & 0.69 & 2.62 & 0.88 & 0.54 & 1.17 & 0.88 & 0.52 & 1.43 \\
\hline $\begin{array}{l}\text { East Gulf Coastal Plain Near-Coast } \\
\text { Pine Flatwoods }\end{array}$ & $\begin{array}{l}\text { A1FI, } \\
\text { end }\end{array}$ & 0.96 & 0.37 & 1.35 & 1.18 & 0.67 & 1.87 & 0.91 & 0.70 & 1.35 & 0.89 & 0.53 & 1.44 \\
\hline $\begin{array}{l}\text { East Gulf Coastal Plain Southern Loess } \\
\text { Bluff Forest }\end{array}$ & $\begin{array}{l}\text { A1FI, } \\
\text { end }\end{array}$ & 0.90 & 0.22 & 1.46 & 0.91 & 0.47 & 1.64 & 0.91 & 0.42 & 1.36 & 0.92 & 0.57 & 1.42 \\
\hline Edwards Plateau Limestone Shrubland & $\begin{array}{l}\text { A1FI, } \\
\text { end }\end{array}$ & 0.96 & 0.31 & 1.63 & 0.94 & 0.46 & 1.57 & 1.12 & 0.52 & 1.71 & 0.86 & 0.48 & 1.21 \\
\hline Edwards Plateau Mesic Canyon & $\begin{array}{l}\text { A1FI, } \\
\text { end }\end{array}$ & 0.96 & 0.30 & 1.62 & 0.95 & 0.44 & 1.64 & 1.12 & 0.47 & 1.82 & 0.86 & 0.47 & 1.23 \\
\hline $\begin{array}{l}\text { Nashville Basin Limestone Glade and } \\
\text { Woodland }\end{array}$ & $\begin{array}{l}\text { A1FI, } \\
\text { end }\end{array}$ & 0.97 & 0.34 & 1.74 & 0.98 & 0.58 & 1.35 & 0.92 & 0.45 & 1.42 & 0.93 & 0.61 & 1.35 \\
\hline $\begin{array}{l}\text { South-Central Interior Mesophytic } \\
\text { Forest }\end{array}$ & $\begin{array}{l}\text { A1FI, } \\
\text { end }\end{array}$ & 1.00 & 0.42 & 1.62 & 1.00 & 0.65 & 1.28 & 0.94 & 0.57 & 1.56 & 0.93 & 0.65 & 1.30 \\
\hline Southeast & $\begin{array}{l}\text { A1FI, } \\
\text { end }\end{array}$ & 0.97 & 0.37 & 1.46 & 1.01 & 0.59 & 1.44 & 0.95 & 0.70 & 1.47 & 0.92 & 0.62 & 1.32 \\
\hline $\begin{array}{l}\text { Southern Coastal Plain Nonriverine } \\
\text { Cypress Dome }\end{array}$ & $\begin{array}{l}\text { A1FI, } \\
\text { end }\end{array}$ & 0.97 & 0.45 & 1.44 & 1.19 & 0.70 & 1.88 & 0.85 & 0.64 & 1.18 & 0.90 & 0.55 & 1.46 \\
\hline $\begin{array}{l}\text { Southern Coastal Plain Seepage } \\
\text { Swamp and Baygall }\end{array}$ & $\begin{array}{l}\text { A1FI, } \\
\text { end }\end{array}$ & 0.96 & 0.50 & 1.45 & 1.23 & 0.70 & 2.12 & 0.85 & 0.58 & 1.15 & 0.88 & 0.54 & 1.46 \\
\hline
\end{tabular}


Table A10. Projected change in standard deviation of mean precipitation.

[Abbreviations: min, minimum; max, maximum; mid, mid-century; end, end of century]

\begin{tabular}{|c|c|c|c|c|c|c|c|c|c|c|c|c|c|}
\hline \multirow{2}{*}{ Ecological system } & \multirow{2}{*}{$\begin{array}{l}\text { Scenario, } \\
\text { time period }\end{array}$} & \multicolumn{3}{|c|}{ Winter } & \multicolumn{3}{|c|}{ Spring } & \multicolumn{3}{|c|}{ Summer } & \multicolumn{3}{|c|}{ Fall } \\
\hline & & Mean & Min & $\operatorname{Max}$ & Mean & Min & $\operatorname{Max}$ & Mean & Min & $\operatorname{Max}$ & Mean & Min & Max \\
\hline $\begin{array}{l}\text { Caribbean Mangrove Forest and } \\
\text { Shrubland - Puerto Rico }\end{array}$ & $\begin{array}{l}\text { RCP85, } \\
\text { mid }\end{array}$ & 1.15 & 0.28 & 3.04 & 1.16 & 0.51 & 2.52 & 0.95 & 0.33 & 2.39 & 1.10 & 0.39 & 1.90 \\
\hline $\begin{array}{l}\text { Caribbean Mature Primary Elfin } \\
\text { Woodland - Puerto Rico }\end{array}$ & $\begin{array}{l}\text { RCP85, } \\
\text { mid }\end{array}$ & 1.06 & 0.10 & 3.72 & 0.96 & 0.23 & 2.78 & 0.96 & 0.17 & 3.49 & 1.02 & 0.35 & 2.12 \\
\hline Puerto Rico & $\begin{array}{l}\text { RCP85, } \\
\text { mid }\end{array}$ & 0.99 & 0.27 & 2.35 & 0.98 & 0.24 & 2.69 & 0.86 & 0.28 & 2.06 & 1.06 & 0.38 & 3.25 \\
\hline $\begin{array}{l}\text { Caribbean Mangrove Forest and } \\
\text { Shrubland - Puerto Rico }\end{array}$ & $\begin{array}{l}\text { RCP85, } \\
\text { end }\end{array}$ & 1.22 & 0.38 & 2.49 & 1.10 & 0.40 & 2.21 & 0.95 & 0.09 & 1.78 & 1.37 & 0.09 & 4.61 \\
\hline $\begin{array}{l}\text { Caribbean Mature Primary Elfin } \\
\text { Woodland - Puerto Rico }\end{array}$ & $\begin{array}{l}\text { RCP85, } \\
\text { end }\end{array}$ & 0.83 & 0.14 & 3.01 & 0.79 & 0.19 & 3.16 & 0.83 & 0.09 & 7.35 & 0.92 & 0.16 & 2.37 \\
\hline Puerto Rico & $\begin{array}{l}\text { RCP85, } \\
\text { end }\end{array}$ & 0.82 & 0.23 & 2.38 & 0.78 & 0.16 & 3.56 & 0.74 & 0.12 & 4.85 & 0.92 & 0.14 & 2.52 \\
\hline $\begin{array}{l}\text { Central Atlantic Coastal Plain Wet } \\
\text { Longleaf Pine Savanna and } \\
\text { Flatwoods }\end{array}$ & B1, mid & 2.75 & 1.79 & 3.98 & 2.59 & 1.90 & 4.24 & 1.61 & 0.99 & 2.85 & 2.27 & 1.12 & 3.38 \\
\hline $\begin{array}{l}\text { Central Florida Wet Prairie and } \\
\text { Herbaceous Seep }\end{array}$ & B1, mid & 2.66 & 1.72 & 3.55 & 1.98 & 1.15 & 3.29 & 1.23 & 0.69 & 2.09 & 1.85 & 0.79 & 4.20 \\
\hline $\begin{array}{l}\text { East Gulf Coastal Plain Near-Coast } \\
\text { Pine Flatwoods }\end{array}$ & B1, mid & 1.82 & 1.09 & 2.49 & 1.74 & 1.25 & 2.40 & 1.20 & 0.90 & 1.55 & 1.66 & 0.82 & 2.78 \\
\hline $\begin{array}{l}\text { East Gulf Coastal Plain Southern Loess } \\
\text { Bluff Forest }\end{array}$ & B1, mid & 1.58 & 0.82 & 2.22 & 1.58 & 1.06 & 2.96 & 1.53 & 0.69 & 2.45 & 1.63 & 0.76 & 3.12 \\
\hline Edwards Plateau Limestone Shrubland & B1, mid & 3.72 & 2.26 & 5.18 & 2.67 & 1.16 & 4.98 & 2.07 & 0.99 & 3.67 & 2.27 & 1.38 & 3.89 \\
\hline Edwards Plateau Mesic Canyon & B1, mid & 3.17 & 1.94 & 4.67 & 2.41 & 1.16 & 4.37 & 1.97 & 0.77 & 3.51 & 2.10 & 1.32 & 3.42 \\
\hline $\begin{array}{l}\text { Nashville Basin Limestone Glade and } \\
\text { Woodland }\end{array}$ & B1, mid & 1.97 & 1.22 & 2.96 & 2.03 & 1.56 & 2.80 & 1.84 & 1.25 & 2.77 & 2.09 & 1.39 & 2.83 \\
\hline
\end{tabular}




\begin{tabular}{|c|c|c|c|c|c|c|c|c|c|c|c|c|c|}
\hline \multirow{2}{*}{ Ecological system } & \multirow{2}{*}{$\begin{array}{l}\text { Scenario, } \\
\text { time period }\end{array}$} & \multicolumn{3}{|c|}{ Winter } & \multicolumn{3}{|c|}{ Spring } & \multicolumn{3}{|c|}{ Summer } & \multicolumn{3}{|c|}{ Fall } \\
\hline & & Mean & Min & $\operatorname{Max}$ & Mean & Min & $\operatorname{Max}$ & Mean & Min & $\operatorname{Max}$ & Mean & Min & $\operatorname{Max}$ \\
\hline $\begin{array}{l}\text { South-Central Interior Mesophytic } \\
\text { Forest }\end{array}$ & B1, mid & 2.42 & 1.77 & 3.35 & 2.33 & 1.86 & 3.19 & 2.01 & 1.40 & 2.71 & 2.44 & 1.67 & 3.20 \\
\hline Southeast & B1, mid & 2.32 & 1.74 & 3.09 & 2.12 & 1.56 & 2.80 & 1.72 & 1.23 & 2.19 & 1.98 & 1.31 & 2.73 \\
\hline $\begin{array}{l}\text { Southern Coastal Plain Nonriverine } \\
\text { Cypress Dome }\end{array}$ & B1, mid & 2.15 & 1.37 & 2.68 & 2.01 & 1.42 & 2.83 & 1.37 & 0.80 & 1.85 & 1.98 & 1.03 & 3.38 \\
\hline $\begin{array}{l}\text { Southern Coastal Plain Seepage } \\
\text { Swamp and Baygall }\end{array}$ & B1, mid & 2.34 & 1.49 & 3.10 & 2.01 & 1.37 & 2.91 & 1.31 & 0.72 & 1.88 & 1.94 & 0.90 & 3.65 \\
\hline $\begin{array}{l}\text { Central Atlantic Coastal Plain Wet } \\
\text { Longleaf Pine Savanna and } \\
\text { Flatwoods }\end{array}$ & $\mathrm{B} 1$, end & 2.74 & 1.82 & 4.02 & 2.59 & 1.90 & 4.24 & 1.61 & 1.01 & 2.83 & 2.27 & 1.12 & 3.39 \\
\hline $\begin{array}{l}\text { Central Florida Wet Prairie and } \\
\text { Herbaceous Seep }\end{array}$ & $\mathrm{B} 1$, end & 2.67 & 1.71 & 3.52 & 1.98 & 1.17 & 3.33 & 1.23 & 0.69 & 2.10 & 1.85 & 0.75 & 4.02 \\
\hline $\begin{array}{l}\text { East Gulf Coastal Plain Near-Coast } \\
\text { Pine Flatwoods }\end{array}$ & B1, end & 1.83 & 1.10 & 2.49 & 1.74 & 1.24 & 2.51 & 1.19 & 0.90 & 1.54 & 1.66 & 0.80 & 2.70 \\
\hline $\begin{array}{l}\text { East Gulf Coastal Plain Southern Loess } \\
\text { Bluff Forest }\end{array}$ & B1, end & 1.58 & 0.82 & 2.22 & 1.58 & 1.06 & 2.97 & 1.53 & 0.69 & 2.46 & 1.63 & 0.76 & 3.13 \\
\hline Edwards Plateau Limestone Shrubland & B1, end & 3.67 & 2.24 & 5.15 & 2.66 & 1.14 & 5.20 & 2.10 & 1.00 & 3.78 & 2.25 & 1.37 & 3.62 \\
\hline Edwards Plateau Mesic Canyon & B1, end & 3.16 & 1.91 & 4.73 & 2.40 & 1.16 & 4.36 & 1.98 & 0.77 & 3.57 & 2.09 & 1.29 & 3.28 \\
\hline $\begin{array}{l}\text { Nashville Basin Limestone Glade and } \\
\text { Woodland }\end{array}$ & B1, end & 1.97 & 1.22 & 2.97 & 2.03 & 1.52 & 2.81 & 1.84 & 1.25 & 2.77 & 2.09 & 1.38 & 2.81 \\
\hline $\begin{array}{l}\text { South-Central Interior Mesophytic } \\
\text { Forest }\end{array}$ & B1, end & 2.43 & 1.76 & 3.58 & 2.32 & 1.82 & 3.20 & 2.01 & 1.39 & 2.70 & 2.44 & 1.67 & 3.26 \\
\hline Southeast & B1, end & 2.34 & 1.74 & 3.08 & 2.12 & 1.58 & 2.88 & 1.72 & 1.28 & 2.21 & 1.98 & 1.30 & 2.66 \\
\hline $\begin{array}{l}\text { Southern Coastal Plain Nonriverine } \\
\text { Cypress Dome }\end{array}$ & B1, end & 2.17 & 1.42 & 2.64 & 2.02 & 1.44 & 2.84 & 1.36 & 0.79 & 1.88 & 1.99 & 0.95 & 3.33 \\
\hline $\begin{array}{l}\text { Southern Coastal Plain Seepage } \\
\text { Swamp and Baygall }\end{array}$ & B1, end & 2.35 & 1.53 & 3.06 & 2.01 & 1.40 & 2.92 & 1.30 & 0.72 & 1.91 & 1.94 & 0.83 & 3.57 \\
\hline
\end{tabular}




\begin{tabular}{|c|c|c|c|c|c|c|c|c|c|c|c|c|c|}
\hline \multirow[b]{2}{*}{ Ecological system } & \multirow{2}{*}{$\begin{array}{l}\text { Scenario, } \\
\text { time period }\end{array}$} & \multicolumn{3}{|c|}{ Winter } & \multicolumn{3}{|c|}{ Spring } & \multicolumn{3}{|c|}{ Summer } & \multicolumn{3}{|c|}{ Fall } \\
\hline & & Mean & Min & Max & Mean & Min & Max & Mean & Min & Max & Mean & Min & Max \\
\hline $\begin{array}{l}\text { Central Atlantic Coastal Plain Wet } \\
\text { Longleaf Pine Savanna and } \\
\text { Flatwoods }\end{array}$ & A1FI, mid & 3.01 & 2.29 & 3.65 & 2.56 & 2.22 & 2.93 & 1.43 & 1.13 & 1.81 & 2.23 & 1.06 & 3.15 \\
\hline $\begin{array}{l}\text { Central Florida Wet Prairie and } \\
\text { Herbaceous Seep }\end{array}$ & A1FI, mid & 2.52 & 1.82 & 3.29 & 1.93 & 1.36 & 2.97 & 1.21 & 0.78 & 1.55 & 1.86 & 1.03 & 3.17 \\
\hline $\begin{array}{l}\text { East Gulf Coastal Plain Near-Coast } \\
\text { Pine Flatwoods }\end{array}$ & A1FI, mid & 1.91 & 1.45 & 2.49 & 1.74 & 1.35 & 2.37 & 1.13 & 0.94 & 1.40 & 1.74 & 0.97 & 2.57 \\
\hline $\begin{array}{l}\text { East Gulf Coastal Plain Southern Loess } \\
\text { Bluff Forest }\end{array}$ & A1FI, mid & 1.77 & 1.29 & 2.40 & 1.40 & 1.04 & 2.09 & 1.24 & 0.69 & 2.05 & 1.49 & 1.15 & 1.80 \\
\hline Edwards Plateau Limestone Shrubland & A1FI, mid & 3.96 & 2.98 & 5.20 & 2.70 & 1.60 & 4.17 & 2.05 & 1.11 & 2.92 & 2.18 & 1.19 & 3.79 \\
\hline Edwards Plateau Mesic Canyon & A1FI, mid & 3.27 & 2.59 & 4.50 & 2.41 & 1.49 & 3.80 & 1.86 & 0.94 & 2.93 & 2.01 & 1.13 & 3.32 \\
\hline $\begin{array}{l}\text { Nashville Basin Limestone Glade and } \\
\text { Woodland }\end{array}$ & A1FI, mid & 2.09 & 1.59 & 2.96 & 1.87 & 1.06 & 2.35 & 1.47 & 1.17 & 1.82 & 2.06 & 1.38 & 2.65 \\
\hline $\begin{array}{l}\text { South-Central Interior Mesophytic } \\
\text { Forest }\end{array}$ & A1FI, mid & 2.54 & 2.07 & 3.33 & 2.21 & 1.59 & 2.57 & 1.79 & 1.50 & 2.03 & 2.47 & 1.86 & 3.32 \\
\hline Southeast & A1FI, mid & 2.52 & 2.20 & 3.07 & 2.04 & 1.55 & 2.44 & 1.52 & 1.24 & 1.88 & 1.97 & 1.45 & 2.64 \\
\hline $\begin{array}{l}\text { Southern Coastal Plain Nonriverine } \\
\text { Cypress Dome }\end{array}$ & A1FI, mid & 2.24 & 1.74 & 2.64 & 1.97 & 1.61 & 2.83 & 1.30 & 0.92 & 1.54 & 2.03 & 1.25 & 3.26 \\
\hline $\begin{array}{l}\text { Southern Coastal Plain Seepage } \\
\text { Swamp and Baygall }\end{array}$ & A1FI, mid & 2.35 & 1.80 & 2.84 & 1.98 & 1.57 & 2.92 & 1.24 & 0.84 & 1.52 & 1.99 & 1.17 & 3.32 \\
\hline $\begin{array}{l}\text { Central Atlantic Coastal Plain Wet } \\
\text { Longleaf Pine Savanna and } \\
\text { Flatwoods }\end{array}$ & A1FI, end & 3.02 & 2.30 & 3.66 & 2.57 & 2.21 & 2.95 & 1.44 & 1.14 & 1.80 & 2.24 & 1.05 & 3.15 \\
\hline $\begin{array}{l}\text { Central Florida Wet Prairie and } \\
\text { Herbaceous Seep }\end{array}$ & A1FI, end & 2.52 & 1.86 & 3.36 & 1.93 & 1.37 & 2.98 & 1.20 & 0.78 & 1.53 & 1.88 & 1.03 & 3.20 \\
\hline $\begin{array}{l}\text { East Gulf Coastal Plain Near-Coast } \\
\text { Pine Flatwoods }\end{array}$ & A1FI, end & 1.90 & 1.45 & 2.49 & 1.72 & 1.37 & 2.21 & 1.13 & 0.93 & 1.41 & 1.73 & 0.94 & 2.66 \\
\hline
\end{tabular}




\begin{tabular}{|c|c|c|c|c|c|c|c|c|c|c|c|c|c|}
\hline \multirow[b]{2}{*}{ Ecological system } & \multirow{2}{*}{$\begin{array}{l}\text { Scenario, } \\
\text { time period }\end{array}$} & \multicolumn{3}{|c|}{ Winter } & \multicolumn{3}{|c|}{ Spring } & \multicolumn{3}{|c|}{ Summer } & \multicolumn{3}{|c|}{ Fall } \\
\hline & & Mean & Min & $\operatorname{Max}$ & Mean & Min & $\operatorname{Max}$ & Mean & Min & $\operatorname{Max}$ & Mean & Min & $\operatorname{Max}$ \\
\hline $\begin{array}{l}\text { East Gulf Coastal Plain Southern Loess } \\
\text { Bluff Forest }\end{array}$ & A1FI, end & 1.78 & 1.29 & 2.40 & 1.41 & 1.05 & 2.08 & 1.25 & 0.69 & 2.09 & 1.48 & 1.14 & 1.80 \\
\hline Edwards Plateau Limestone Shrubland & A1FI, end & 3.96 & 2.94 & 5.15 & 2.72 & 1.62 & 3.94 & 2.08 & 1.14 & 2.93 & 2.23 & 1.16 & 4.34 \\
\hline Edwards Plateau Mesic Canyon & A1FI, end & 3.28 & 2.56 & 4.48 & 2.40 & 1.49 & 3.62 & 1.87 & 0.94 & 2.95 & 2.04 & 1.11 & 3.75 \\
\hline $\begin{array}{l}\text { Nashville Basin Limestone Glade and } \\
\text { Woodland }\end{array}$ & A1FI, end & 2.10 & 1.57 & 2.96 & 1.88 & 1.06 & 2.36 & 1.47 & 1.19 & 1.83 & 2.06 & 1.38 & 2.63 \\
\hline $\begin{array}{l}\text { South-Central Interior Mesophytic } \\
\text { Forest }\end{array}$ & A1FI, end & 2.53 & 2.07 & 3.30 & 2.23 & 1.68 & 2.59 & 1.80 & 1.52 & 2.02 & 2.50 & 1.87 & 3.37 \\
\hline Southeast & A1FI, end & 2.50 & 2.18 & 3.04 & 2.06 & 1.61 & 2.46 & 1.52 & 1.25 & 1.90 & 1.99 & 1.36 & 2.72 \\
\hline $\begin{array}{l}\text { Southern Coastal Plain Nonriverine } \\
\text { Cypress Dome }\end{array}$ & A1FI, end & 2.24 & 1.72 & 2.64 & 1.99 & 1.62 & 2.80 & 1.29 & 0.92 & 1.54 & 2.03 & 1.21 & 3.25 \\
\hline $\begin{array}{l}\text { Southern Coastal Plain Seepage } \\
\text { Swamp and Baygall }\end{array}$ & A1FI, end & 2.35 & 1.78 & 2.91 & 2.01 & 1.58 & 2.92 & 1.23 & 0.84 & 1.52 & 1.99 & 1.12 & 3.32 \\
\hline
\end{tabular}


Table A11. Proportion of ecosystem extent projected to be inundated under two sea level rise scenarios. NA indicates the metric was not calculated.

\begin{tabular}{|c|c|c|c|}
\hline Ecological system & $\begin{array}{l}\text { Portion of extent } \\
\text { covered by projections } \\
\text { (percent) }\end{array}$ & $\begin{array}{l}1 \text { foot - } \\
\text { proportion } \\
\text { (percent) }\end{array}$ & $\begin{array}{l}6 \text { feet- } \\
\text { proportion } \\
\text { (percent) }\end{array}$ \\
\hline Caribbean Mangrove Forest and Shrubland - Puerto Rico & 100 & 37.3 & 90.2 \\
\hline $\begin{array}{l}\text { Caribbean Mangrove Forest and Shrubland - U.S. Virgin } \\
\text { Islands }\end{array}$ & 100 & 10.6 & 62.6 \\
\hline Caribbean Mature Primary Elfin Woodland - Puerto Rico & NA & NA & NA \\
\hline $\begin{array}{l}\text { Central Atlantic Coastal Plain Wet Longleaf Pine Savanna } \\
\text { and Flatwoods }\end{array}$ & 71.6 & 3.6 & 13.9 \\
\hline Central Florida Wet Prairie and Herbaceous Seep & 97.7 & 0.1 & 0.8 \\
\hline East Gulf Coastal Plain Near-Coast Pine Flatwoods & 85.2 & 0.7 & 7.9 \\
\hline East Gulf Coastal Plain Southern Loess Bluff Forest & NA & NA & NA \\
\hline Edwards Plateau Limestone Shrubland & NA & NA & NA \\
\hline Edwards Plateau Mesic Canyon & NA & NA & NA \\
\hline Nashville Basin Limestone Glade and Woodland & NA & NA & NA \\
\hline South-Central Interior Mesophytic Forest & NA & NA & NA \\
\hline Southern Coastal Plain Nonriverine Cypress Dome & 99.0 & 1.3 & 5.7 \\
\hline Southern Coastal Plain Seepage Swamp and Baygall & 98.1 & 1.1 & 4.9 \\
\hline Southeast & NA & NA & NA \\
\hline Caribbean Landscape Conservation Cooperative & NA & NA & NA \\
\hline
\end{tabular}


Table A12. Proportion of each ecosystem projected to change ecosystem type under two emissions scenarios. NA indicates the metric was not calculated.

\begin{tabular}{|c|c|c|c|c|c|}
\hline \multirow{2}{*}{ Ecological system } & \multirow{2}{*}{$\begin{array}{l}\text { Portion of coastal extent } \\
\text { covered by projections } \\
\text { (percent) }\end{array}$} & \multicolumn{2}{|c|}{$\begin{array}{c}2050 \\
\text { (percent) }\end{array}$} & \multicolumn{2}{|c|}{$\begin{array}{c}2100 \\
\text { (percent) }\end{array}$} \\
\hline & & B1 & A1FI & B1 & A1FI \\
\hline $\begin{array}{l}\text { Caribbean Mangrove Forest and Shrubland - Puerto } \\
\text { Rico/U.S. Virgin Islands }\end{array}$ & NA & NA & NA & NA & NA \\
\hline Caribbean Mature Primary Elfin Woodland - Puerto Rico & NA & NA & NA & NA & NA \\
\hline $\begin{array}{l}\text { Central Atlantic Coastal Plain Wet Longleaf Pine Savanna } \\
\text { and Flatwoods }\end{array}$ & 100.0 & 15.2 & 17.2 & 24.2 & 24.6 \\
\hline Central Florida Wet Prairie and Herbaceous Seep & NA & NA & NA & NA & NA \\
\hline East Gulf Coastal Plain Near-Coast Pine Flatwoods & 44.0 & 1.7 & 2.0 & 3. & 3.1 \\
\hline East Gulf Coastal Plain Southern Loess Bluff Forest & NA & NA & NA & NA & NA \\
\hline Edwards Plateau Limestone Shrubland & NA & NA & NA & NA & NA \\
\hline Edwards Plateau Mesic Canyon & NA & NA & NA & NA & NA \\
\hline Nashville Basin Limestone Glade and Woodland & NA & NA & NA & NA & NA \\
\hline South-Central Interior Mesophytic Forest & NA & NA & NA & NA & NA \\
\hline Southern Coastal Plain Nonriverine Cypress Dome & 24.0 & 1.9 & 2.2 & 3.9 & 3.9 \\
\hline Southern Coastal Plain Seepage Swamp and Baygall & 21.1 & 6.3 & 7.5 & 11.1 & 12.2 \\
\hline Southeast & NA & NA & NA & NA & NA \\
\hline Caribbean Landscape Conservation Cooperative & NA & NA & $\mathrm{NA}$ & $\mathrm{NA}$ & NA \\
\hline
\end{tabular}


Table A13. Mapped extent of each ecological system.

[Abbreviations: km², square kilometer; ha, hectare; NA, metric not calculated]

\begin{tabular}{|c|c|c|c|c|c|}
\hline Ecological system & $\begin{array}{l}\text { Range } \\
\left(\mathrm{km}^{2}\right)\end{array}$ & $\begin{array}{l}\text { Range } \\
\text { (ha) }\end{array}$ & $\begin{array}{c}\text { Extent } \\
\left(\mathrm{km}^{2}\right)\end{array}$ & $\begin{array}{l}\text { Extent } \\
\text { (ha) }\end{array}$ & $\begin{array}{c}\text { Proportion- } \\
\text { Extent/range } \\
\text { (percent) }\end{array}$ \\
\hline Caribbean Mature Primary Elfin Woodland - Puerto Rico & 160.90 & $16,089.87$ & 15.37 & $1,537.02$ & 9.55 \\
\hline $\begin{array}{l}\text { Caribbean Mangrove Forest and Shrubland - Puerto Rico/ } \\
\text { U.S. Virgin Islands }\end{array}$ & 2,059.18 & $205,918.33$ & 90.40 & $9,039.83$ & 4.39 \\
\hline Central Florida Wet Prairie and Herbaceous Seep & $56,085.88$ & $5,608,587.73$ & 190.75 & $19,074.87$ & 0.34 \\
\hline Nashville Basin Limestone Glade and Woodland & $5,399.51$ & $539,951.23$ & 638.58 & $63,858.24$ & 11.83 \\
\hline Southern Coastal Plain Seepage Swamp and Baygall & $123,572.69$ & $12,357,269.41$ & 679.14 & $67,914.36$ & 0.55 \\
\hline Edwards Plateau Mesic Canyon & $61,263.32$ & $6,126,332.14$ & 943.64 & $94,364.19$ & 1.54 \\
\hline $\begin{array}{l}\text { Central Atlantic Coastal Plain Wet Longleaf Pine Savanna } \\
\text { and Flatwoods }\end{array}$ & $78,358.92$ & $7,835,892.02$ & $1,416.36$ & $141,635.88$ & 1.81 \\
\hline East Gulf Coastal Plain Southern Loess Bluff Forest & 4,389.85 & $438,985.04$ & $1,975.04$ & $197,504.01$ & 44.99 \\
\hline Southern Coastal Plain Nonriverine Cypress Dome & $221,163.49$ & $22,116,348.87$ & $5,154.69$ & $515,468.61$ & 2.33 \\
\hline East Gulf Coastal Plain Near-Coast Pine Flatwoods & $47,047.56$ & $4,704,756.29$ & $6,624.37$ & $662,437.44$ & 14.08 \\
\hline Edwards Plateau Limestone Shrubland & $125,623.57$ & $12,562,357.11$ & $17,100.15$ & $1,710,014.76$ & 13.61 \\
\hline South-Central Interior Mesophytic Forest & $488,969.08$ & $48,896,907.97$ & $67,004.80$ & $6,700,479.84$ & 13.70 \\
\hline Southeast & NA & NA & $2,265,185.23$ & $226,518,523.00$ & NA \\
\hline Caribbean Landscape Conservation Cooperative & NA & NA & $11,532.92$ & $1,153,292.00$ & NA \\
\hline
\end{tabular}


Table A14. Summary of patch sizes.

[Abbreviations: $\mathrm{m}^{2}$, square meter; min, minimum; max, maximum; std dev, standard deviation]

\begin{tabular}{|c|c|c|c|c|c|}
\hline Ecological system & $\begin{array}{l}\text { Number of } \\
\text { patches }\end{array}$ & $\begin{array}{l}\text { Mean size } \\
\quad\left(m^{2}\right)\end{array}$ & $\begin{array}{l}\text { Min size } \\
\left(m^{2}\right)\end{array}$ & $\begin{array}{l}\text { Max size } \\
\left(\mathrm{m}^{2}\right)\end{array}$ & $\begin{array}{l}\text { Std dev } \\
\left(\mathrm{m}^{2}\right)\end{array}$ \\
\hline Central Florida Wet Prairie and Herbaceous Seep & 94,300 & $2,022.79$ & 900 & 484,200 & $4,220.81$ \\
\hline $\begin{array}{l}\text { Caribbean Mangrove Forest and Shrubland - U.S. } \\
\text { Virgin Islands }\end{array}$ & 1,609 & 2,114.92 & 100 & 273,600 & $12,788.00$ \\
\hline $\begin{array}{l}\text { Southern Coastal Plain Seepage Swamp and } \\
\text { Baygall }\end{array}$ & 297,026 & $2,286.48$ & 900 & $4,985,100$ & $13,419.50$ \\
\hline $\begin{array}{l}\text { Central Atlantic Coastal Plain Wet Longleaf Pine } \\
\text { Savanna and Flatwoods }\end{array}$ & 497,524 & $2,846.08$ & 900 & $3,621,600$ & $13,683.62$ \\
\hline Edwards Plateau Mesic Canyon & 263,978 & $3,574.70$ & 900 & $12,096,000$ & $37,287.81$ \\
\hline $\begin{array}{l}\text { Southern Coastal Plain Nonriverine Cypress } \\
\text { Dome }\end{array}$ & 896,919 & $5,747.10$ & 900 & $25,287,300$ & $65,440.55$ \\
\hline Edwards Plateau Limestone Shrubland & $2,310,279$ & $7,401.77$ & 900 & 295,344,900 & $423,411.90$ \\
\hline $\begin{array}{l}\text { East Gulf Coastal Plain Near-Coast Pine } \\
\text { Flatwoods }\end{array}$ & 738,035 & $8,971.10$ & 900 & $40,095,000$ & $138,401.06$ \\
\hline South-Central Interior Mesophytic Forest & $7,428,529$ & $9,019.93$ & 900 & $139,242,600$ & $129,264.48$ \\
\hline $\begin{array}{l}\text { Caribbean Mangrove Forest and Shrubland - } \\
\text { Puerto Rico }\end{array}$ & 3,931 & $22,130.59$ & 225 & $15,154,650$ & $278,596.47$ \\
\hline Nashville Basin Limestone Glade and Woodland & 21,421 & 29,811.05 & 900 & $6,107,400$ & $134,339.60$ \\
\hline $\begin{array}{l}\text { Caribbean Mature Primary Elfin Woodland - } \\
\text { Puerto Rico }\end{array}$ & 322 & $47,733.54$ & 225 & $1,786,725$ & $144,991.61$ \\
\hline $\begin{array}{l}\text { East Gulf Coastal Plain Southern Loess Bluff } \\
\text { Forest }\end{array}$ & 10,021 & $197,090.12$ & 900 & $550,110,600$ & $6,516,043.51$ \\
\hline Southeast & NA & NA & NA & NA & NA \\
\hline Caribbean Landscape Conservation Cooperative & NA & NA & NA & NA & NA \\
\hline
\end{tabular}


Table A15. Summary of area and percentage of each ecological system in protected areas.

[Abbreviation: km² , square kilometer]

\begin{tabular}{|l|c|c|}
\hline \multicolumn{1}{|c|}{ Ecological system } & $\begin{array}{c}\text { Area } \\
\left(\mathbf{k m}^{\mathbf{2}}\right.\end{array}$ & $\begin{array}{c}\text { Portion of extent } \\
\text { (percent) }\end{array}$ \\
\hline Caribbean Mangrove Forest and Shrubland - Puerto Rico & 28.42 & 31.4 \\
\hline Caribbean Mangrove Forest and Shrubland - U.S. Virgin Islands & 1.32 & 0.8 \\
\hline Caribbean Mature Primary Elfin Woodland - Puerto Rico & 2.17 & 14.1 \\
\hline Central Atlantic Coastal Plain Wet Longleaf Pine Savanna and Flatwoods & 78.19 & 5.5 \\
\hline Central Florida Wet Prairie and Herbaceous Seep & 370.40 & 39.3 \\
\hline East Gulf Coastal Plain Near-Coast Pine Flatwoods & $3,409.80$ & 51.5 \\
\hline East Gulf Coastal Plain Southern Loess Bluff Forest & 56.08 & 2.8 \\
\hline Edwards Plateau Limestone Shrubland & 202.66 & 1.2 \\
\hline Edwards Plateau Mesic Canyon & 13.34 & 7.0 \\
\hline Nashville Basin Limestone Glade and Woodland & 33.91 & 5.3 \\
\hline South-Central Interior Mesophytic Forest & $6,064.06$ & 9.1 \\
\hline Southern Coastal Plain Nonriverine Cypress Dome & $1,645.89$ & 31.9 \\
\hline Southern Coastal Plain Seepage Swamp and Baygall & 126.92 & 18.7 \\
\hline Southeast & $243,235.35$ & 10.7 \\
\hline Caribbean Landscape Conservation Cooperative & 778.63 & 6.8 \\
\hline
\end{tabular}


Table A16. Summary of distance from development for each ecological system. NA indicates the metric was not calculated.

\begin{tabular}{|c|c|c|c|c|}
\hline Ecological system & $\begin{array}{c}\text { Mean } \\
\text { (meters) }\end{array}$ & $\begin{array}{l}\text { Minimum } \\
\text { (meters) }\end{array}$ & $\begin{array}{l}\text { Maximum } \\
\text { (meters) }\end{array}$ & $\begin{array}{l}\text { Standard } \\
\text { deviation } \\
\text { (meters) }\end{array}$ \\
\hline Caribbean Mangrove Forest and Shrubland - U.S. Virgin Islands & 166.57 & 10 & $3,779.02$ & 217.32 \\
\hline Nashville Basin Limestone Glade and Woodland & 342.30 & 0 & $1,784.43$ & 252.35 \\
\hline Central Atlantic Coastal Plain Wet Longleaf Pine Savanna and Flatwoods & 424.84 & 0 & $6,331.14$ & 477.82 \\
\hline East Gulf Coastal Plain Near Coast Pine Flatwoods & 429.98 & 0 & $6,180.00$ & 517.30 \\
\hline East Gulf Coastal Plain Southern Loess Bluff Forest & 479.77 & 0 & $5,531.73$ & 406.02 \\
\hline Southern Coastal Plain Nonriverine Cypress Dome & 585.59 & 0 & $9,888.58$ & 745.09 \\
\hline Southern Coastal Plain Seepage Swamp and Baygall & 586.85 & 0 & $9,765.91$ & 848.76 \\
\hline South-Central Interior Mesophytic Forest & 791.21 & 0 & $83,286.70$ & $3,292.59$ \\
\hline Caribbean Mature Primary Elfin Woodland - Puerto Rico & 939.52 & 15 & $3,278.66$ & 619.93 \\
\hline Caribbean Mangrove Forest and Shrubland - Puerto Rico & 966.20 & 15 & $5,710.19$ & 974.69 \\
\hline Edwards Plateau Mesic Canyon & $1,167.31$ & 0 & $95,305.20$ & $2,284.11$ \\
\hline Central Florida Wet Prairie and Herbaceous Seep & $1,707.11$ & 0 & $9,919.53$ & $1,735.45$ \\
\hline Edwards Plateau Limestone Shrubland & $16,637.10$ & 0 & $133,683.00$ & $25,233.70$ \\
\hline Southeast & NA & NA & NA & NA \\
\hline Caribbean Landscape Conservation Cooperative & NA & NA & NA & NA \\
\hline
\end{tabular}


Table A17. Summary of projected development or percentage of impervious surface for ecological systems.

[Abbreviations: km², square kilometer; NA, metric not calculated]

\begin{tabular}{|c|c|c|c|c|c|c|c|}
\hline Ecological system & $\begin{array}{l}2050 \text { area } \\
\left(\mathrm{km}^{2}\right)\end{array}$ & $\begin{array}{c}2050 \\
\text { proportion } \\
\text { (percent) }\end{array}$ & $\begin{array}{l}2100 \text { area } \\
\left(\mathrm{km}^{2}\right)\end{array}$ & $\begin{array}{c}2100 \\
\text { proportion } \\
\text { (percent) }\end{array}$ & $\begin{array}{c}2010 \text { mean } \\
\text { percent } \\
\text { impervious }\end{array}$ & $\begin{array}{l}2050 \text { mean } \\
\text { percent } \\
\text { impervious }\end{array}$ & $\begin{array}{c}2100 \text { mean } \\
\text { percent } \\
\text { impervious }\end{array}$ \\
\hline $\begin{array}{l}\text { Caribbean Mangrove Forest and } \\
\text { Shrubland - Puerto Rico }\end{array}$ & NA & NA & NA & NA & NA & NA & NA \\
\hline $\begin{array}{l}\text { Caribbean Mangrove Forest and } \\
\text { Shrubland - U.S. Virgin Islands }\end{array}$ & NA & NA & NA & NA & NA & NA & NA \\
\hline $\begin{array}{l}\text { Caribbean Mature Primary Elfin } \\
\text { Woodland - Puerto Rico }\end{array}$ & NA & NA & NA & NA & NA & NA & NA \\
\hline $\begin{array}{l}\text { Central Atlantic Coastal Plain Wet } \\
\text { Longleaf Pine Savanna and Flatwoods }\end{array}$ & 12.85 & 0.9 & 33.60 & 2.4 & NA & NA & NA \\
\hline $\begin{array}{l}\text { Central Florida Wet Prairie and } \\
\text { Herbaceous Seep }\end{array}$ & 7.56 & 0.8 & 65.66 & 7.0 & NA & NA & NA \\
\hline $\begin{array}{l}\text { East Gulf Coastal Plain Near Coast Pine } \\
\text { Flatwoods }\end{array}$ & 399.28 & 6.0 & 817.51 & 12.3 & NA & NA & NA \\
\hline $\begin{array}{l}\text { East Gulf Coastal Plain Southern Loess } \\
\text { Bluff Forest }\end{array}$ & 15.60 & 0.8 & 48.25 & 2.4 & NA & NA & NA \\
\hline Edwards Plateau Limestone Shrubland & NA & NA & NA & NA & 0.5 & 0.9 & 1.1 \\
\hline Edwards Plateau Mesic Canyon & NA & NA & NA & NA & 1.5 & 2.7 & 3.4 \\
\hline $\begin{array}{l}\text { Nashville Basin Limestone Glade and } \\
\text { Woodland }\end{array}$ & 105.29 & 16.5 & 247.08 & 38.7 & NA & NA & NA \\
\hline South-Central Interior Mesophytic Forest & 164.51 & 0.3 & 4600.02 & 9.7 & NA & NA & NA \\
\hline $\begin{array}{l}\text { Southern Coastal Plain Nonriverine } \\
\text { Cypress Dome }\end{array}$ & 35.26 & 0.7 & 124.53 & 2.4 & NA & NA & NA \\
\hline $\begin{array}{l}\text { Southern Coastal Plain Seepage Swamp } \\
\text { and Baygall }\end{array}$ & 19.42 & 2.9 & 51.60 & 7.6 & NA & NA & NA \\
\hline Southeast & $78,968.10$ & 6.2 & $184,208.05$ & 14.5 & NA & NA & NA \\
\hline $\begin{array}{l}\text { Caribbean Landscape Conservation } \\
\text { Cooperative }\end{array}$ & NA & NA & NA & NA & NA & NA & NA \\
\hline
\end{tabular}


Table A18. Summary of elevation for each ecological system. Vertical datum used was North American Vertical Datum of 1988.

\begin{tabular}{|c|c|c|c|c|c|}
\hline Ecological system & $\begin{array}{c}\text { Mean } \\
\text { (meters) }\end{array}$ & $\begin{array}{l}\text { Minimum } \\
\text { (meters) }\end{array}$ & $\begin{array}{l}\text { Maximum } \\
\text { (meters) }\end{array}$ & $\begin{array}{l}\text { Range } \\
\text { (meters) }\end{array}$ & $\begin{array}{l}\text { Standard } \\
\text { deviation } \\
\text { (meters) }\end{array}$ \\
\hline Central Florida Wet Prairie and Herbaceous Seep & 4.4 & 3 & 7 & 4 & 0.6 \\
\hline East Gulf Coastal Plain Near-Coast Pine Flatwoods & 12.2 & -7 & 80 & 87 & 12.6 \\
\hline East Gulf Coastal Plain Southern Loess Bluff Forest & 48.7 & 2 & 142 & 140 & 28.7 \\
\hline Southern Coastal Plain Seepage Swamp and Baygall & 24.2 & -2 & 140 & 142 & 20.7 \\
\hline $\begin{array}{l}\text { Central Atlantic Coastal Plain Wet Longleaf Pine } \\
\text { Savanna and Flatwoods }\end{array}$ & 27.3 & -41 & 166 & 207 & 25.6 \\
\hline Southern Coastal Plain Nonriverine Cypress Dome & 60.6 & -1 & 245 & 246 & 43.6 \\
\hline $\begin{array}{l}\text { Caribbean Mangrove Forest and Shrubland - Puerto } \\
\text { Rico }\end{array}$ & 178.8 & 5 & 253 & 248 & 14.3 \\
\hline $\begin{array}{l}\text { Caribbean Mangrove Forest and Shrubland - U.S. Virgin } \\
\text { Islands }\end{array}$ & 173.3 & 0 & 253 & 253 & 25.1 \\
\hline $\begin{array}{l}\text { Caribbean Mature Primary Elfin Woodland - Puerto } \\
\text { Rico }\end{array}$ & 168.9 & 0 & 254 & 254 & 47.7 \\
\hline Nashville Basin Limestone Glade and Woodland & 213.8 & 116 & 417 & 301 & 37.1 \\
\hline Edwards Plateau Mesic Canyon & 488.5 & 116 & 698 & 582 & 105.4 \\
\hline Edwards Plateau Limestone Shrubland & 456.2 & 102 & 848 & 746 & 180.0 \\
\hline South-Central Interior Mesophytic Forest & 297.1 & 28 & 2004 & 1976 & 161.4 \\
\hline Southeast & 839.5 & -41 & 2038 & 2079 & 124.1 \\
\hline Caribbean Landscape Conservation Cooperative & 172.9 & 0 & 254 & 254 & 34.9 \\
\hline
\end{tabular}


Table A19. Summary of human modification values for ecological systems. NA indicates the metric was not calculated.

\begin{tabular}{|c|c|c|c|}
\hline Ecological system & $\begin{array}{c}\text { Mean } \\
\text { (percent) }\end{array}$ & $\begin{array}{l}\text { Minimum } \\
\text { (percent) }\end{array}$ & $\begin{array}{r}\text { Maximum } \\
\text { (percent) }\end{array}$ \\
\hline East Gulf Coastal Plain Southern Loess Bluff Forest & 44 & 21 & 78 \\
\hline Edwards Plateau Limestone Shrubland & 52 & 0 & 97 \\
\hline Edwards Plateau Mesic Canyon & 54 & 30 & 97 \\
\hline East Gulf Coastal Plain Near-Coast Pine Flatwoods & 57 & 0 & 98 \\
\hline Southern Coastal Plain Seepage Swamp and Baygall & 63 & 0 & 100 \\
\hline Central Florida Wet Prairie and Herbaceous Seep & 64 & 25 & 87 \\
\hline Southern Coastal Plain Nonriverine Cypress Dome & 71 & 0 & 100 \\
\hline South-Central Interior Mesophytic Forest & 71 & 30 & 100 \\
\hline Nashville Basin Limestone Glade and Woodland & 81 & 35 & 98 \\
\hline $\begin{array}{l}\text { Central Atlantic Coastal Plain Wet Longleaf Pine } \\
\text { Savanna and Flatwoods }\end{array}$ & 81 & 0 & 100 \\
\hline $\begin{array}{l}\text { Caribbean Mangrove Forest and Shrubland - } \\
\text { Puerto Rico }\end{array}$ & NA & NA & NA \\
\hline $\begin{array}{l}\text { Caribbean Mangrove Forest and Shrubland - } \\
\text { U.S. Virgin Islands }\end{array}$ & NA & NA & NA \\
\hline $\begin{array}{l}\text { Caribbean Mature Primary Elfin Woodland - } \\
\text { Puerto Rico }\end{array}$ & NA & NA & NA \\
\hline Southeast & 65 & 0 & 100 \\
\hline Caribbean Landscape Conservation Cooperative & NA & NA & NA \\
\hline
\end{tabular}




\section{Appendix B. Climate Sensitivity Graphs}

Mean and range of seasonal maximum temperature, minimum temperature, and precipitation for 19501999.

\section{Southeastern United States}

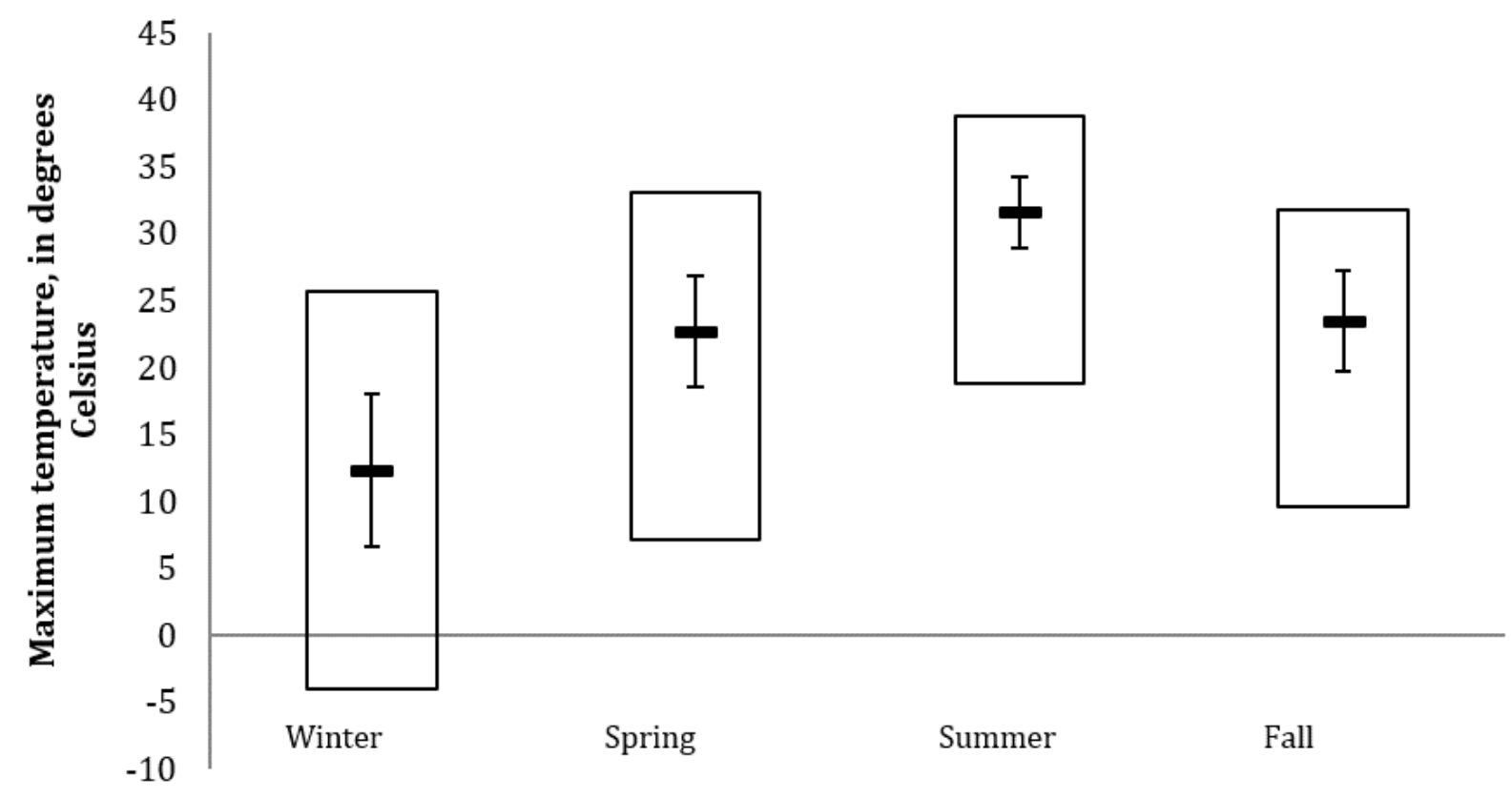

Figure B1. Range of historical (1950-1999) seasonal maximum temperatures for all Landscape Conservation Cooperatives in the Southeast. 


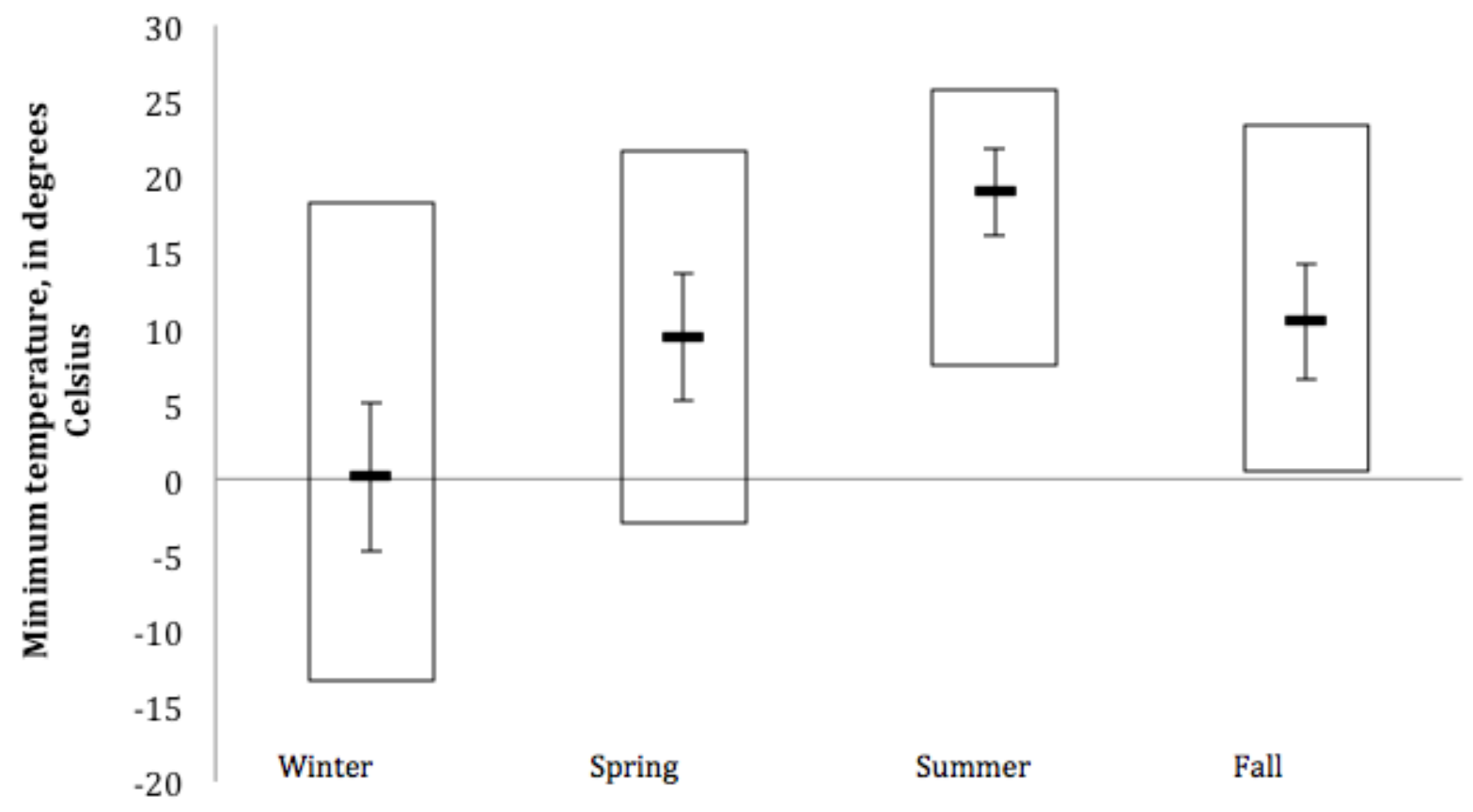

Figure B2. Range of historical (1950-1999) seasonal minimum temperatures for all Landscape Conservation Cooperatives in the Southeast.

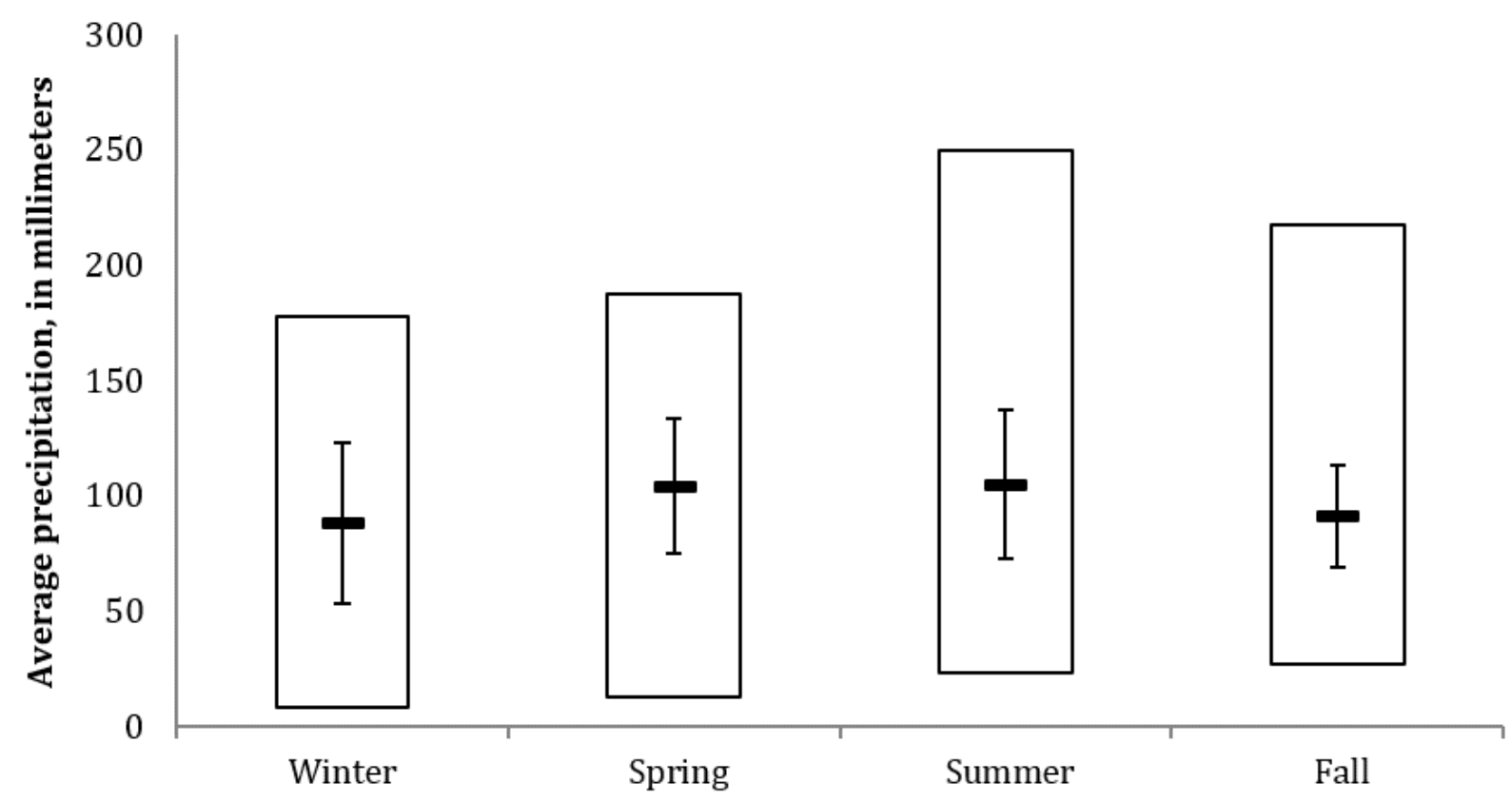

Figure B3. Range of historical (1950-1999) seasonal precipitation for all Landscape Conservation Cooperatives in the Southeast. 


\section{Caribbean Landscape Conservation Cooperative}

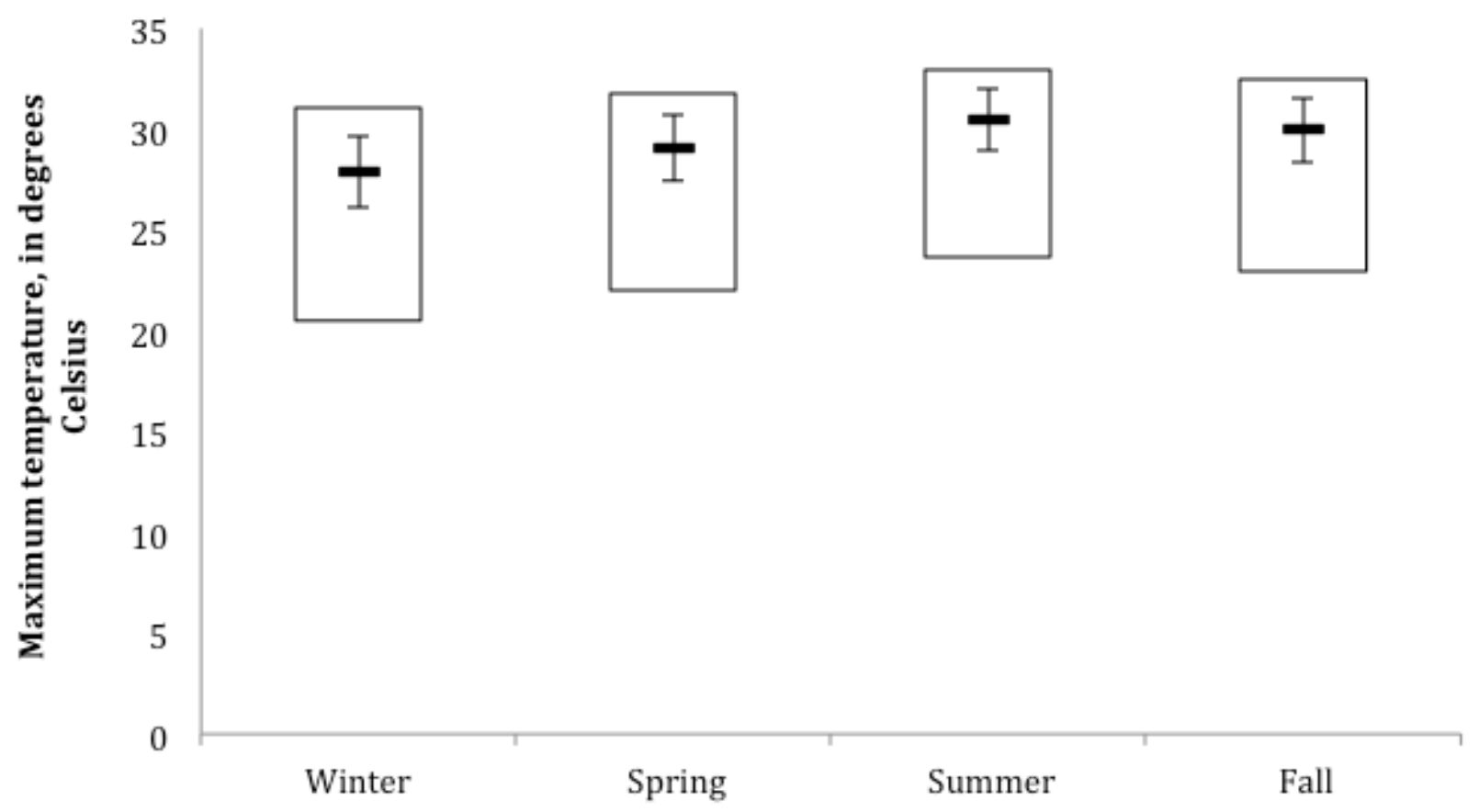

Figure B4. Range of historical (1950-1999) seasonal maximum temperatures for the Caribbean Landscape Conservation Cooperative.

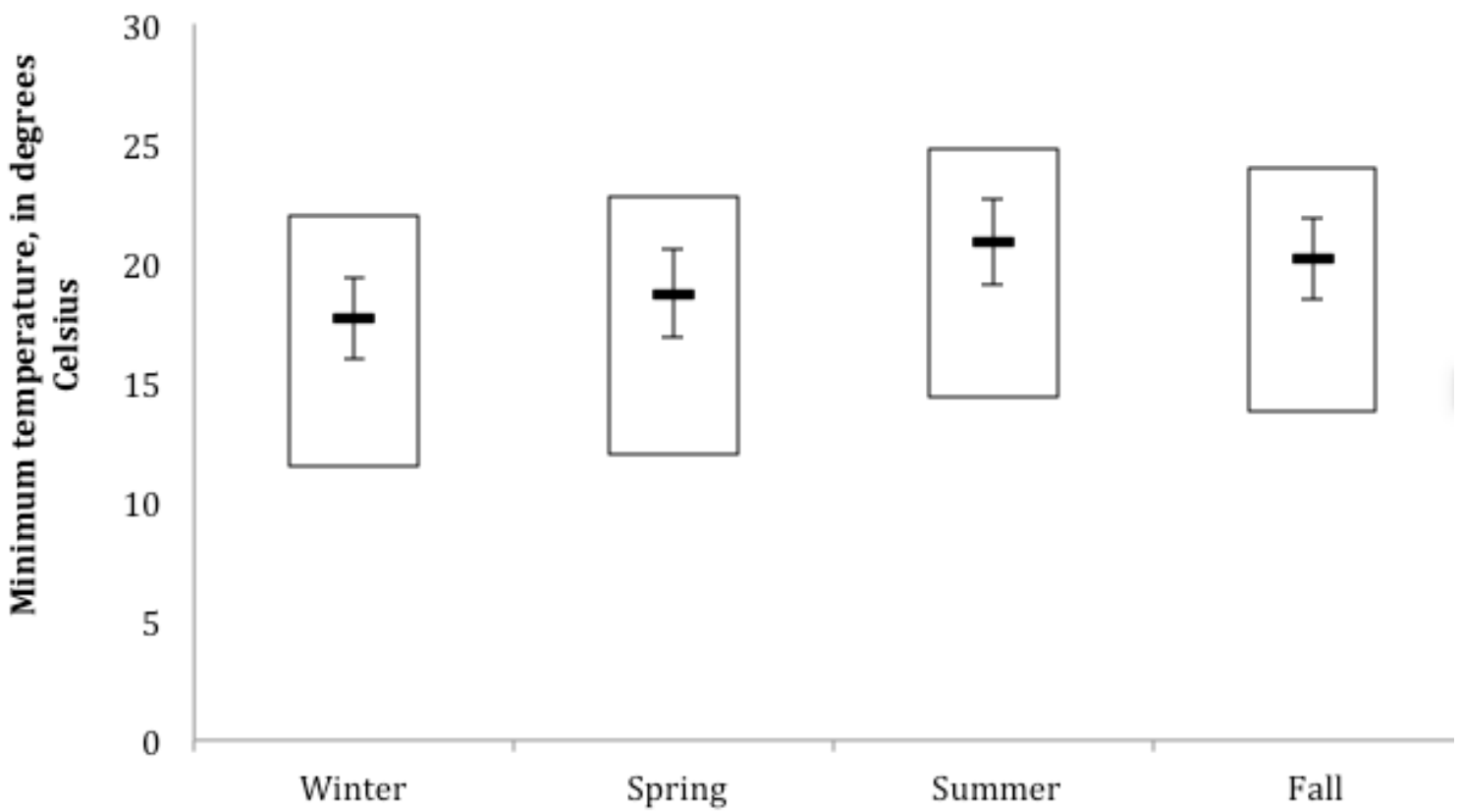

Figure B5. Range of historical (1950-1999) seasonal minimum temperatures for the Caribbean Landscape Conservation Cooperative. 


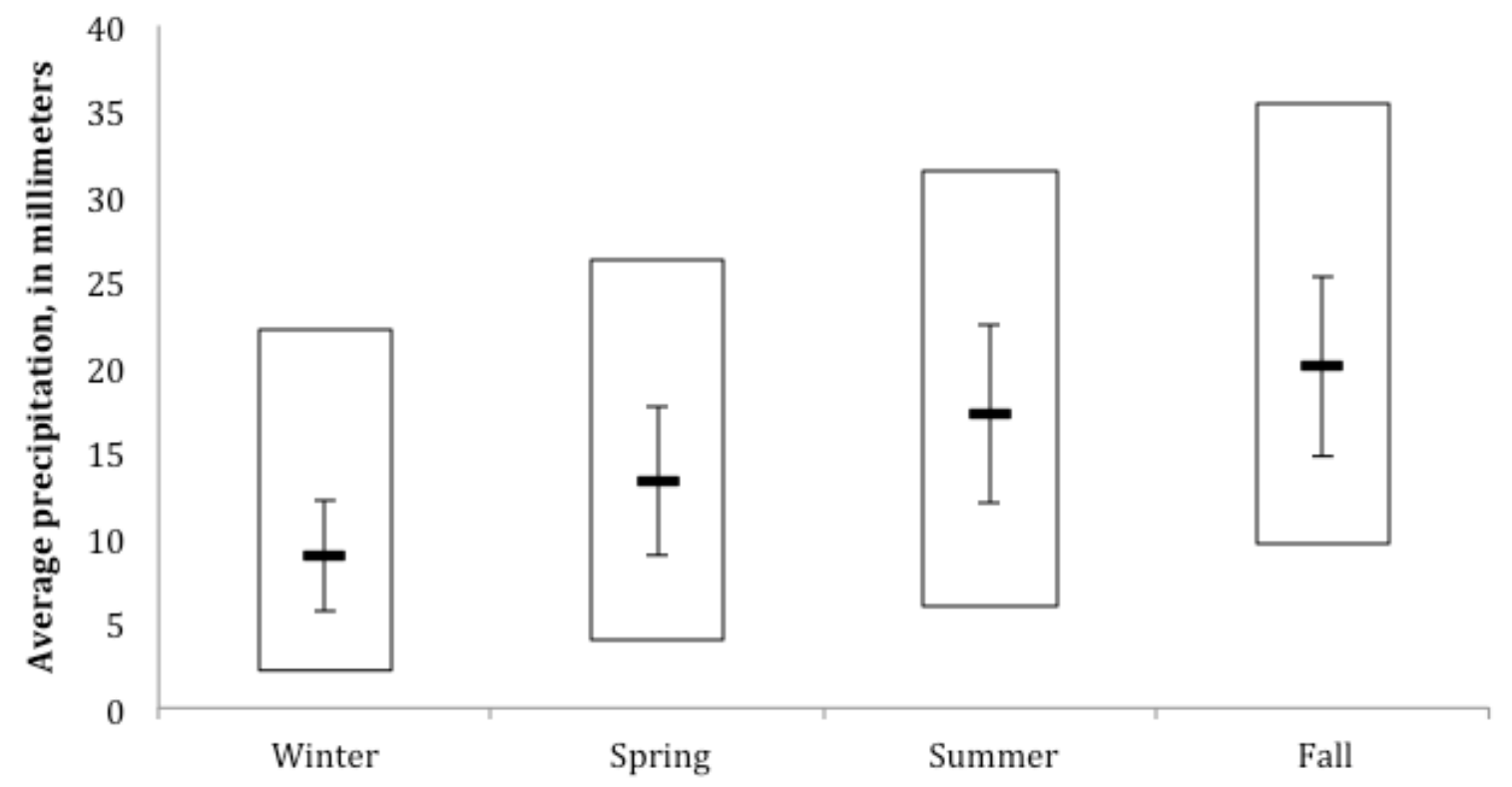

Figure B6. Range of historical (1950-1999) seasonal precipitation for the Caribbean Landscape Conservation Cooperative. 


\section{Caribbean Coastal Mangrove}

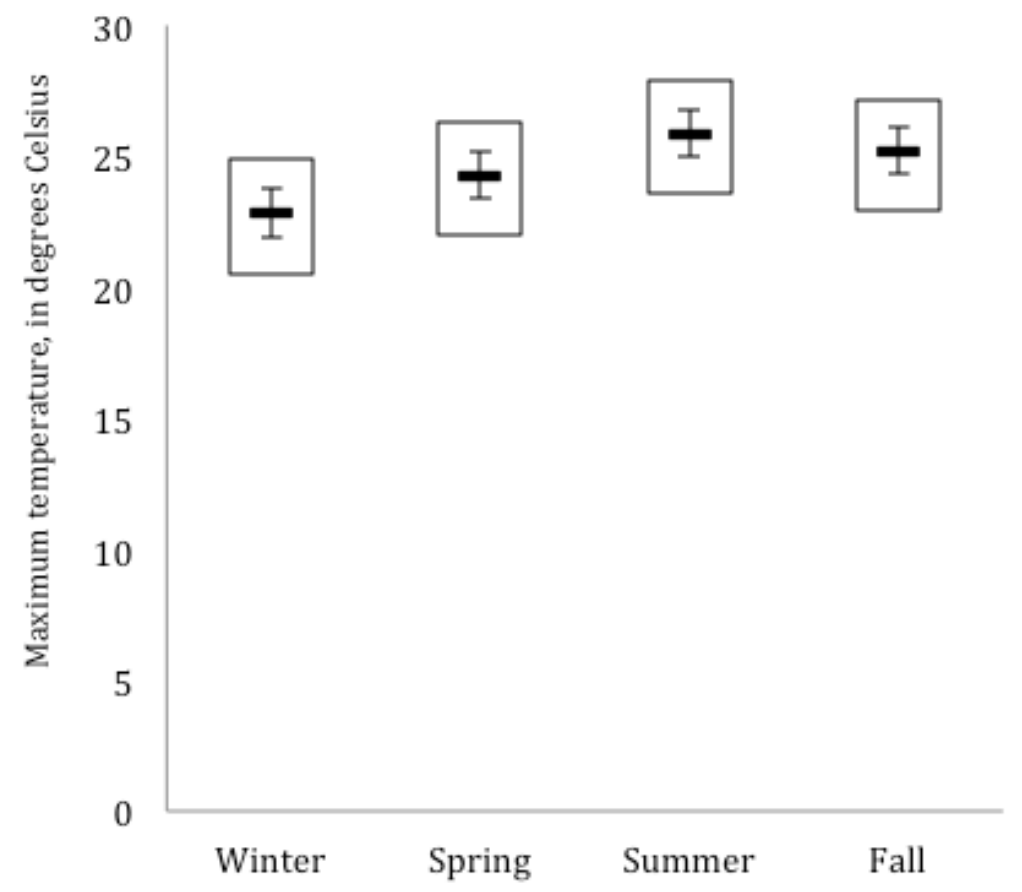

Figure B7. Range of historical (1950-1999) seasonal maximum temperatures for mangroves in Puerto Rico and the U.S. Virgin Islands.

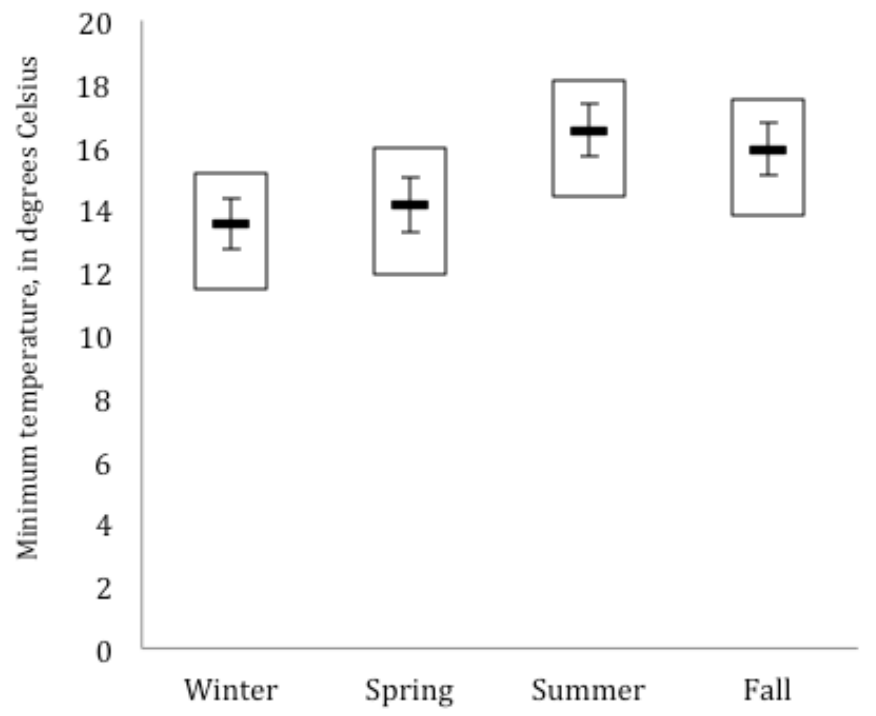

Figure B8. Range of historical (1950-1999) seasonal minimum temperatures for mangroves in Puerto Rico and the U.S. Virgin Islands. 


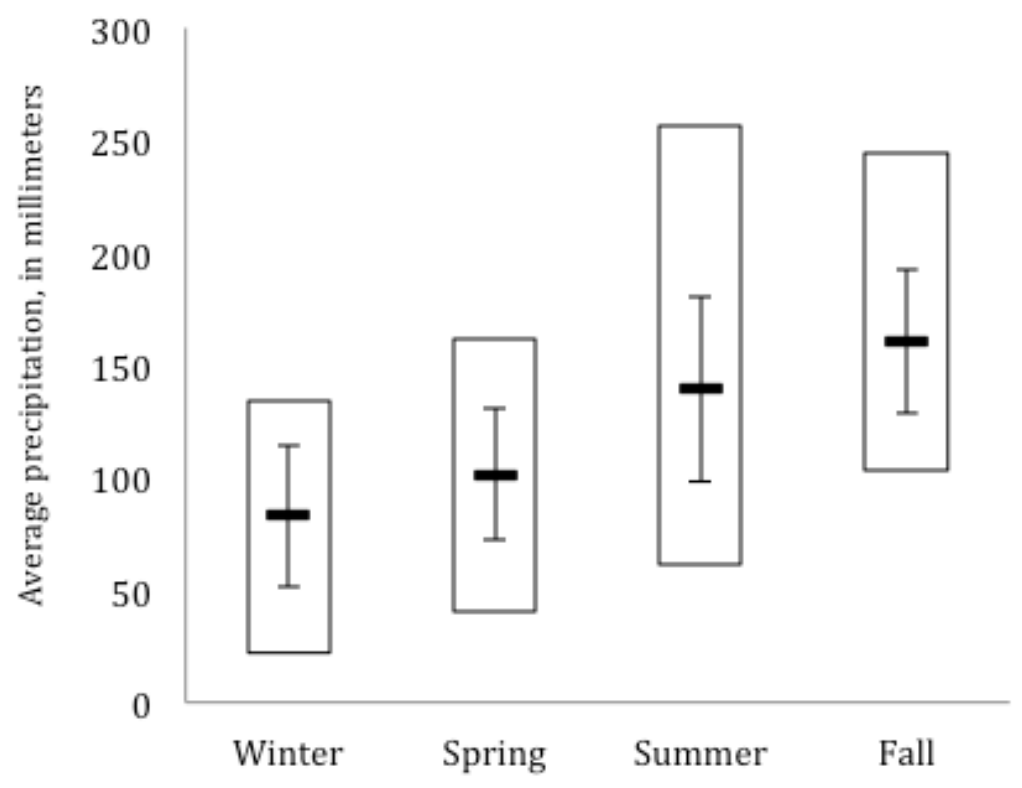

Figure B9. Range of historical (1950-1999) seasonal precipitation for mangroves in Puerto Rico and the U.S. Virgin Islands. 


\section{Caribbean Montane Wet Elfin Forest}

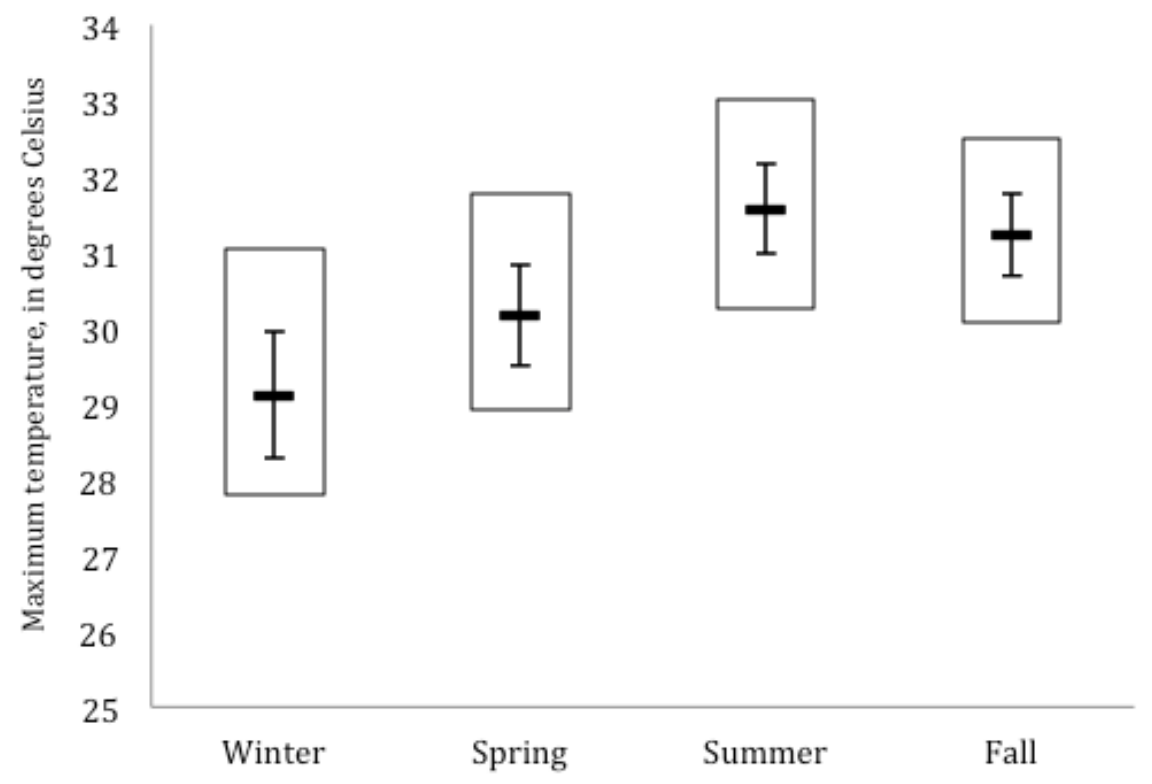

Figure B10. Range of historical (1950-1999) seasonal maximum temperatures for the Caribbean Montane Wet Elfin Forest ecological system.

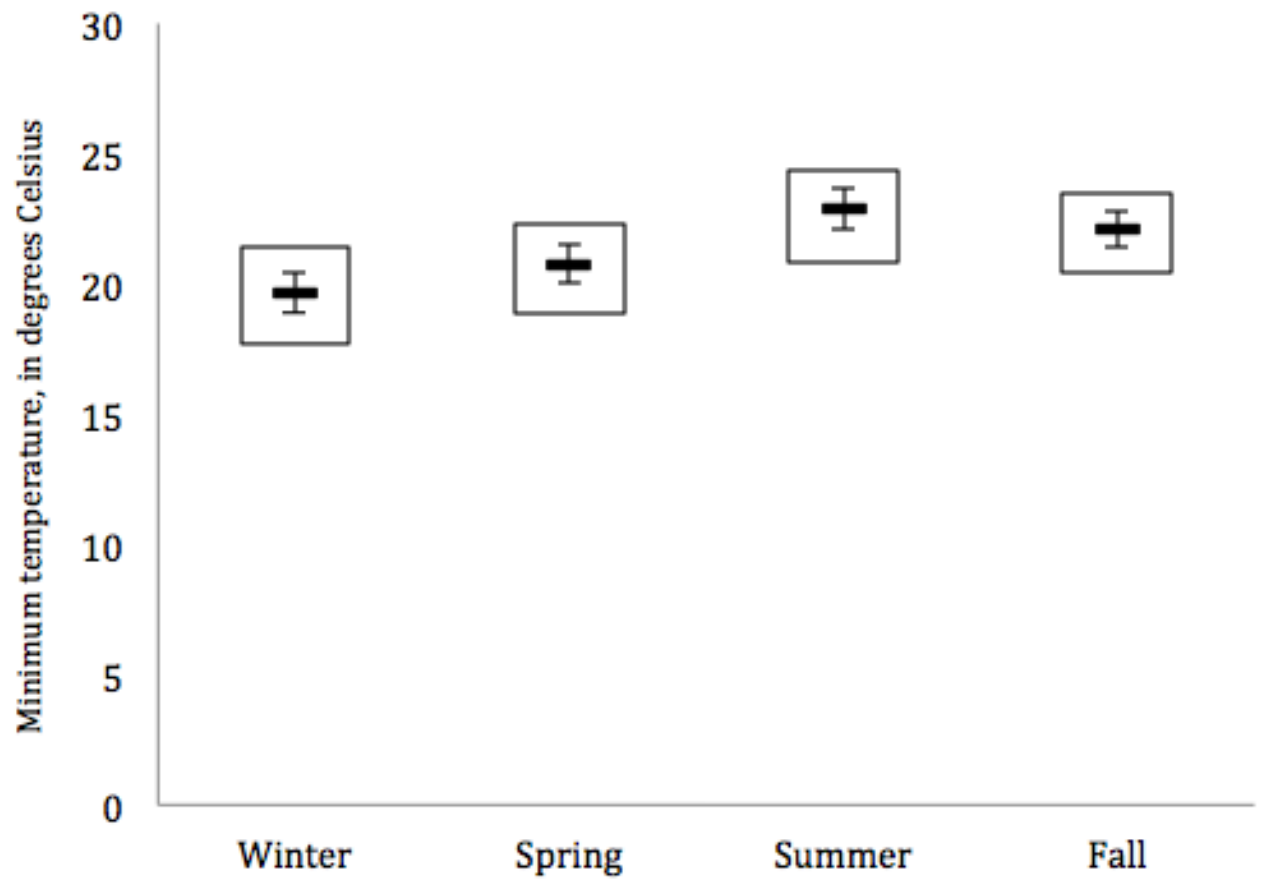

Figure B11. Range of historical (1950-1999) seasonal minimum temperatures for the Caribbean Montane Wet Elfin Forest ecological system. 


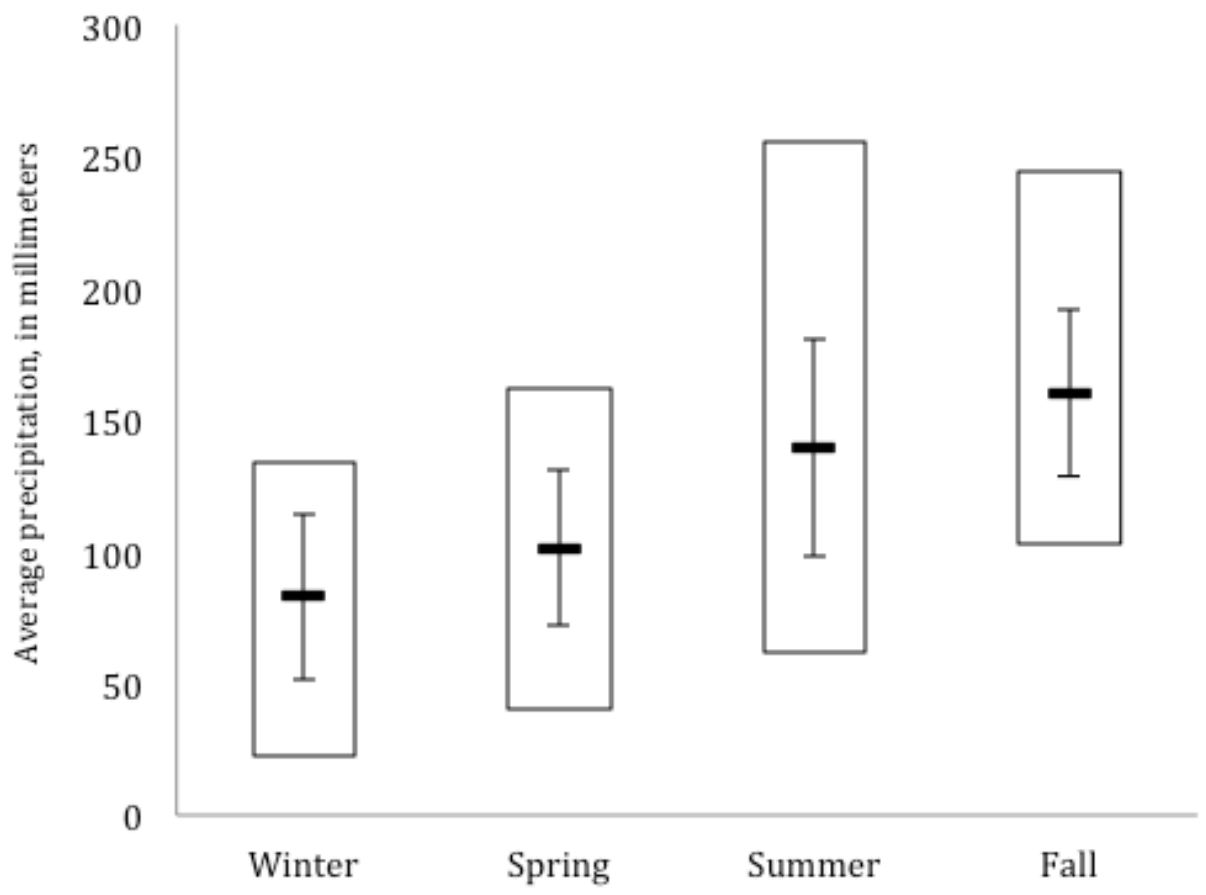

Figure B12. Range of historical (1950-1999) seasonal precipitation for the Caribbean Montane Wet Elfin Forest ecological system. 


\section{Central Atlantic Coastal Plain Wet Longleaf Pine Savanna and Flatwoods}

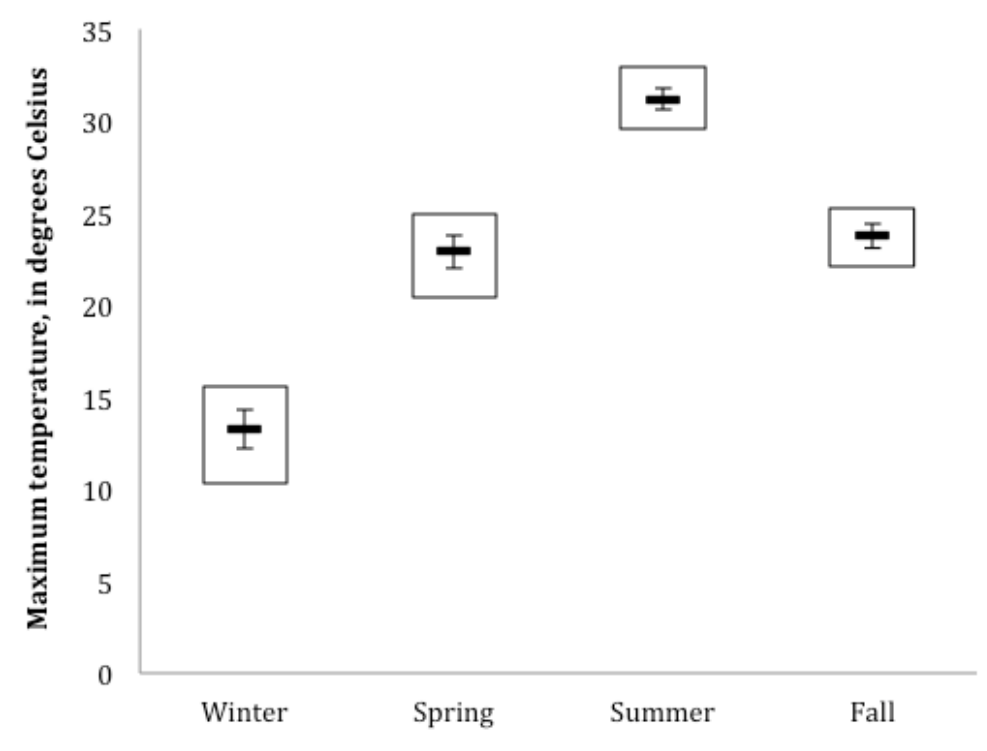

Figure B13. Range of historical (1950-1999) seasonal maximum temperatures for the Central Atlantic Coastal Plain Wet Longleaf Pine Savanna and Flatwoods system.

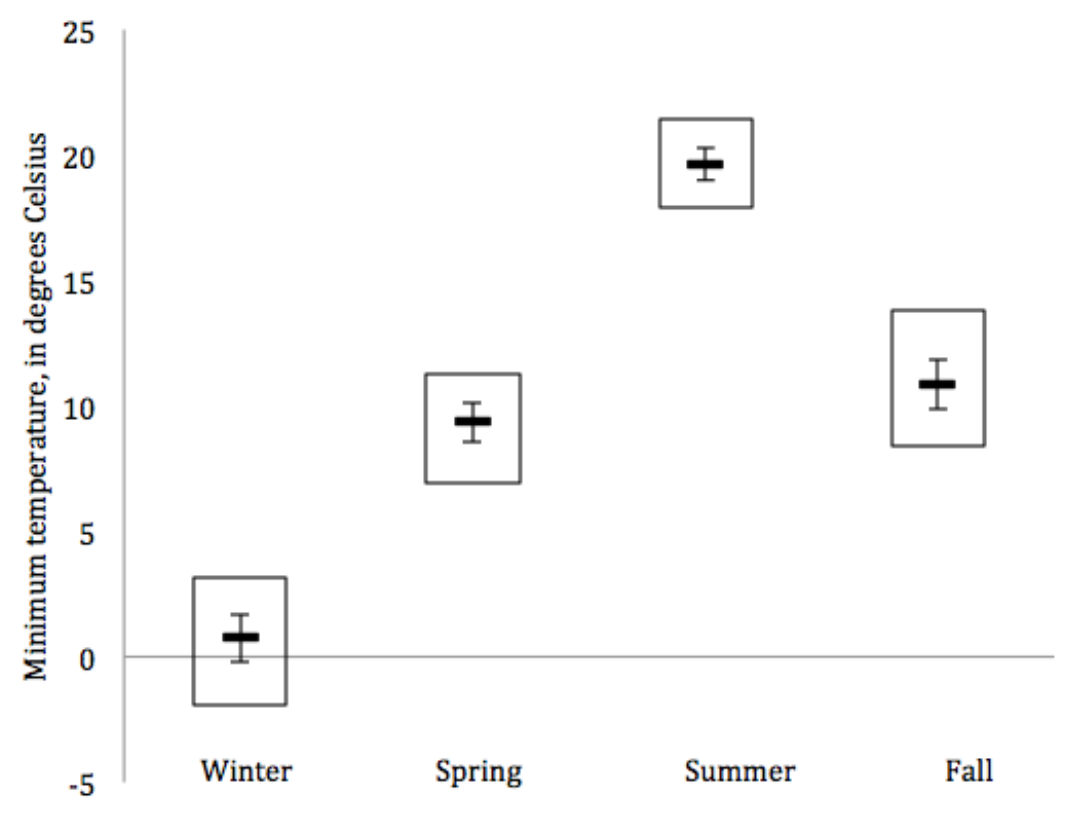

Figure B14. Range of historical (1950-1999) seasonal minimum temperatures for the Central Atlantic Coastal Plain Wet Longleaf Pine Savanna and Flatwoods ecological system. 


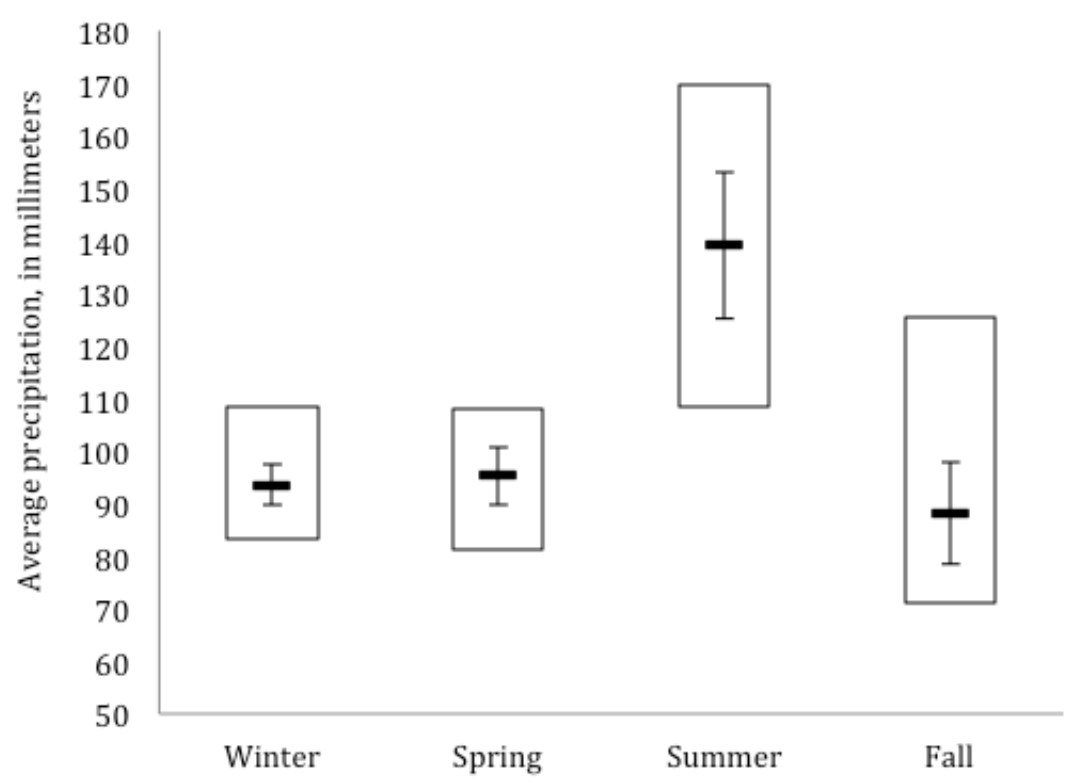

Figure B15. Range of historical (1950-1999) seasonal precipitation for the Central Atlantic Coastal Plain Wet Longleaf Pine Savanna and Flatwoods ecological system. 


\section{Central Florida Wet Prairie and Herbaceous Seep}

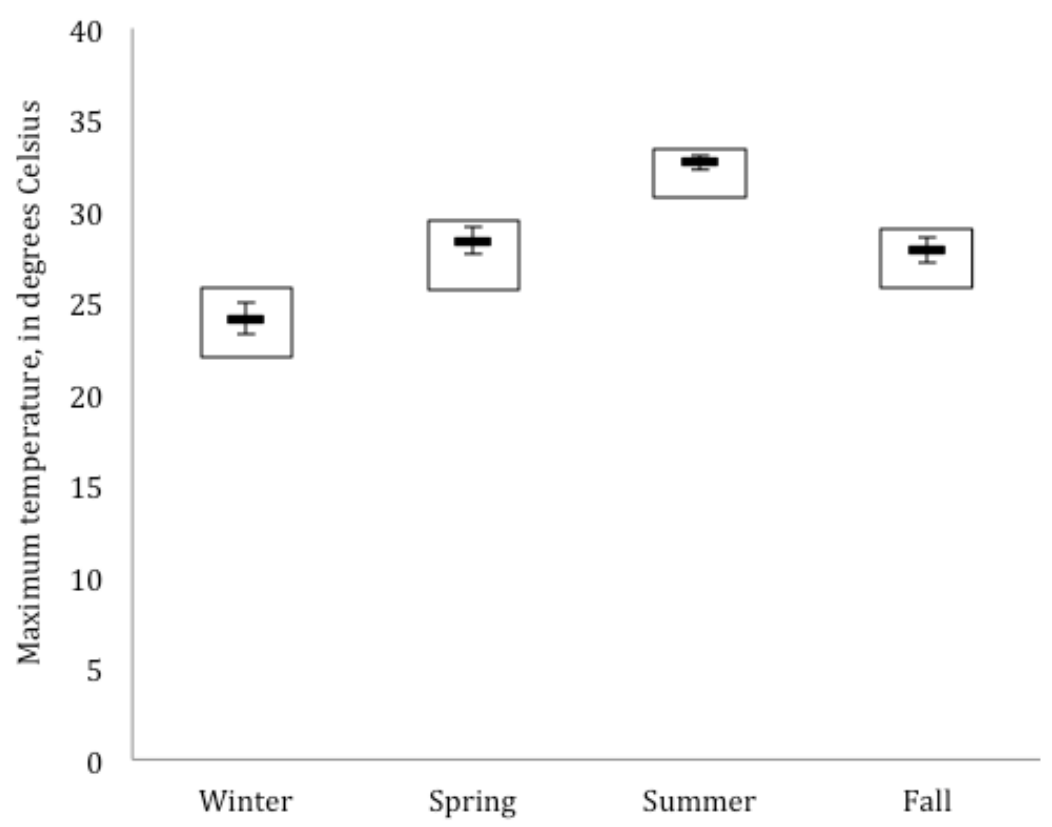

Figure B16. Range of historical (1950-1999) seasonal maximum temperatures for the Central Florida Wet Prairie and Herbaceous Seep ecological system.

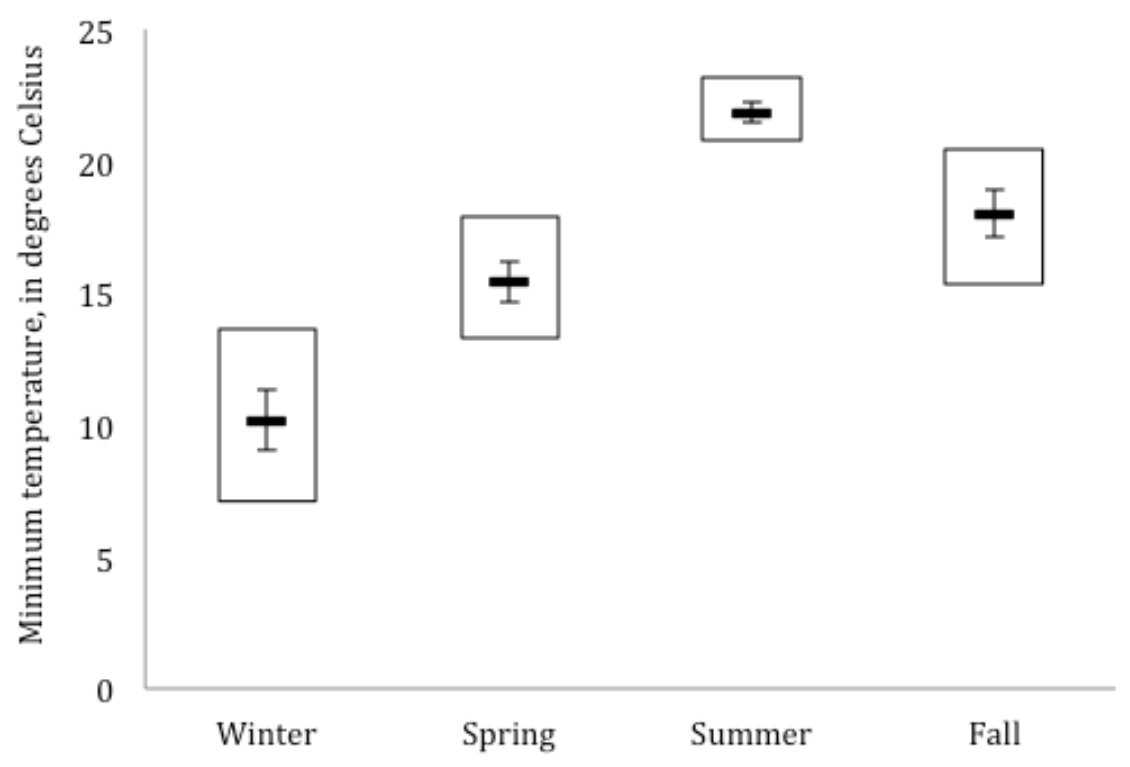

Figure B17. Range of historical (1950-1999) seasonal minimum temperatures for the Central Florida Wet Prairie and Herbaceous Seep ecological system. 


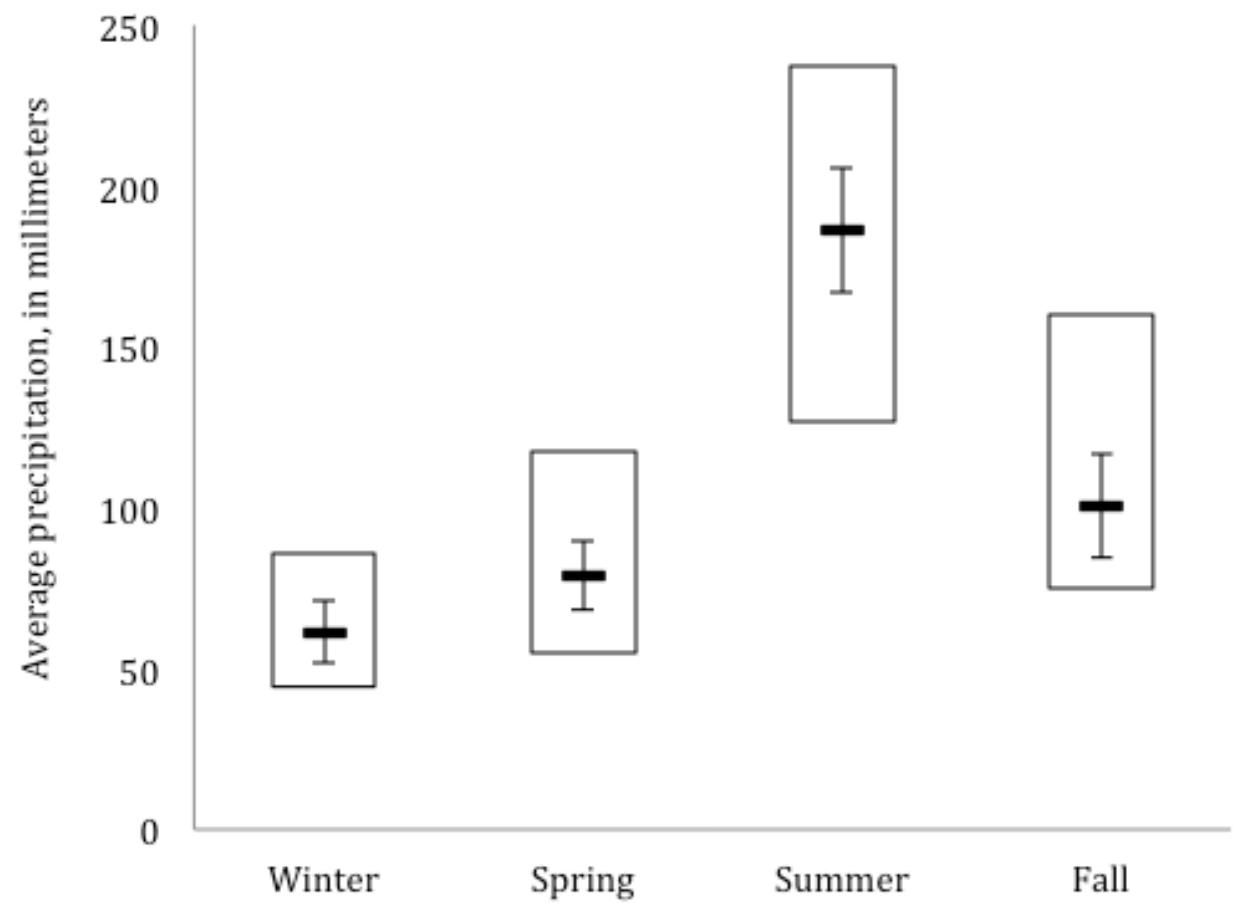

Figure B18. Range of historical (1950-1999) seasonal precipitation for the Central Florida Wet Prairie and Herbaceous Seep ecological system. 


\section{East Gulf Coastal Plain Near-Coast Pine Flatwoods}

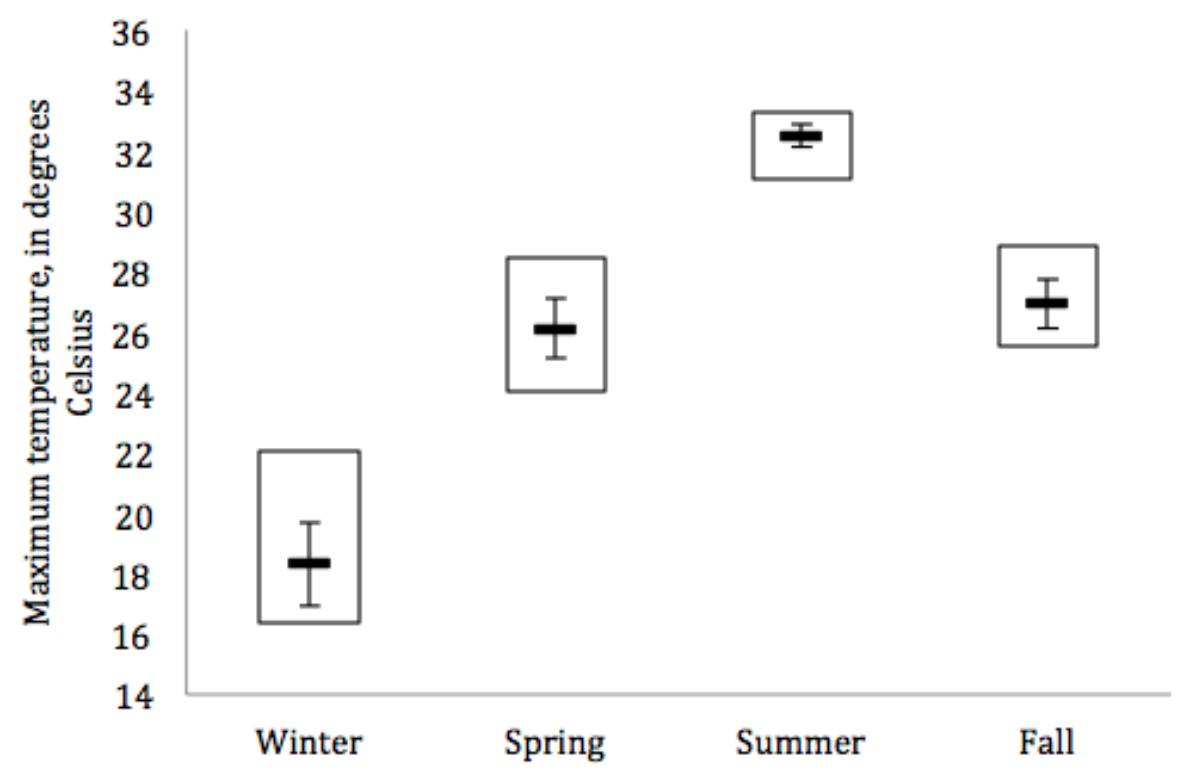

Figure B19. Range of historical (1950-1999) seasonal maximum temperatures for the East Gulf Coastal Plain NearCoast Pine Flatwoods ecological system.

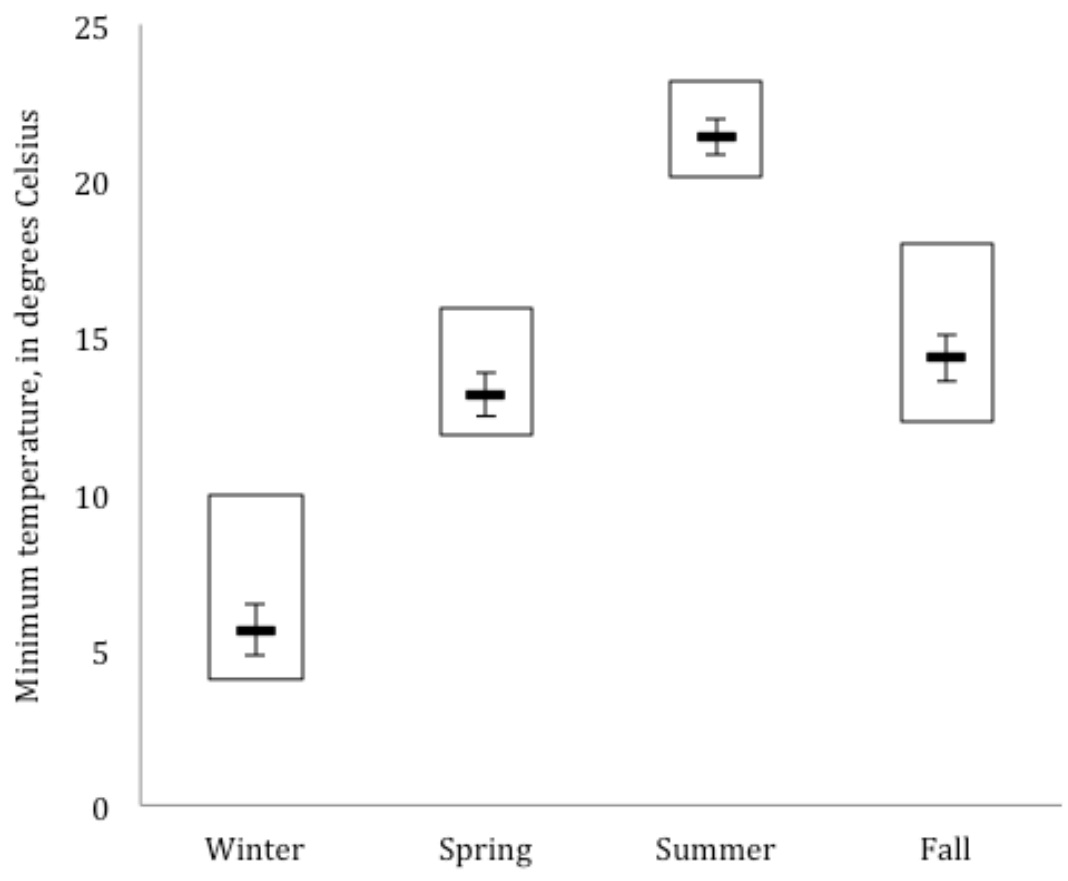

Figure B20. Range of historical (1950-1999) seasonal minimum temperatures for the East Gulf Coastal Plain NearCoast Pine Flatwoods ecological system. 


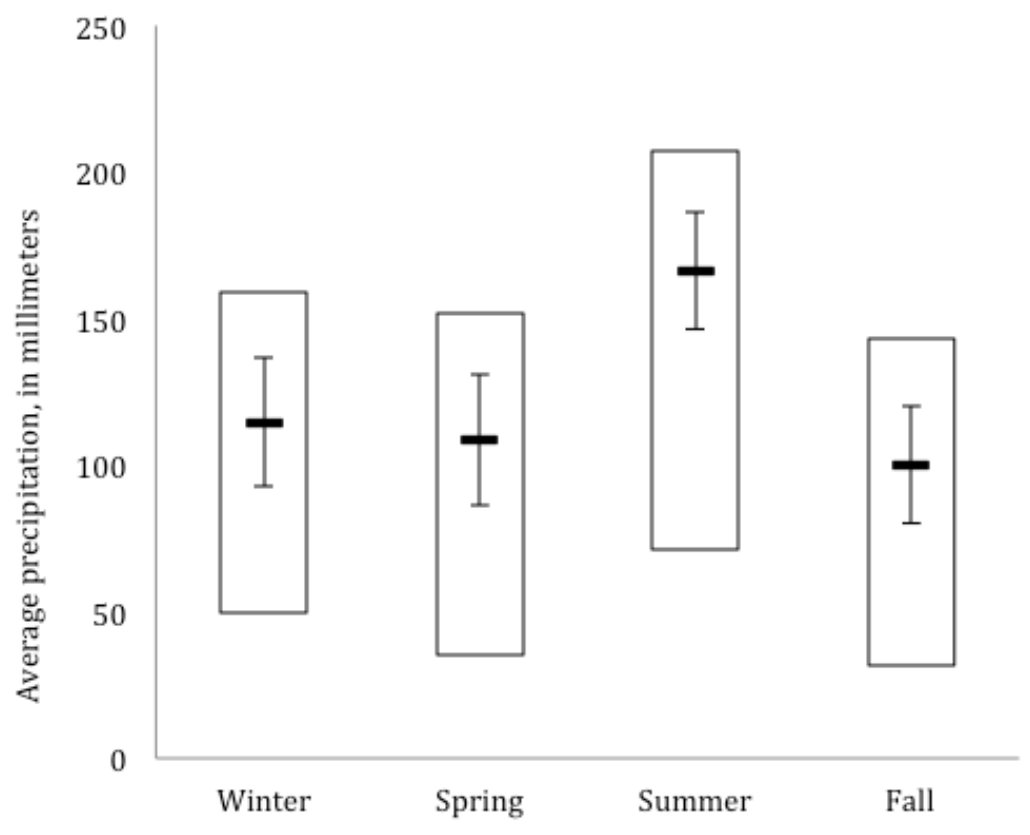

Figure B21. Range of historical (1950-1999) seasonal precipitation for the East Gulf Coastal Plain Near-Coast Pine Flatwoods ecological system. 


\section{East Gulf Coastal Plain Southern Loess Bluff Forest}

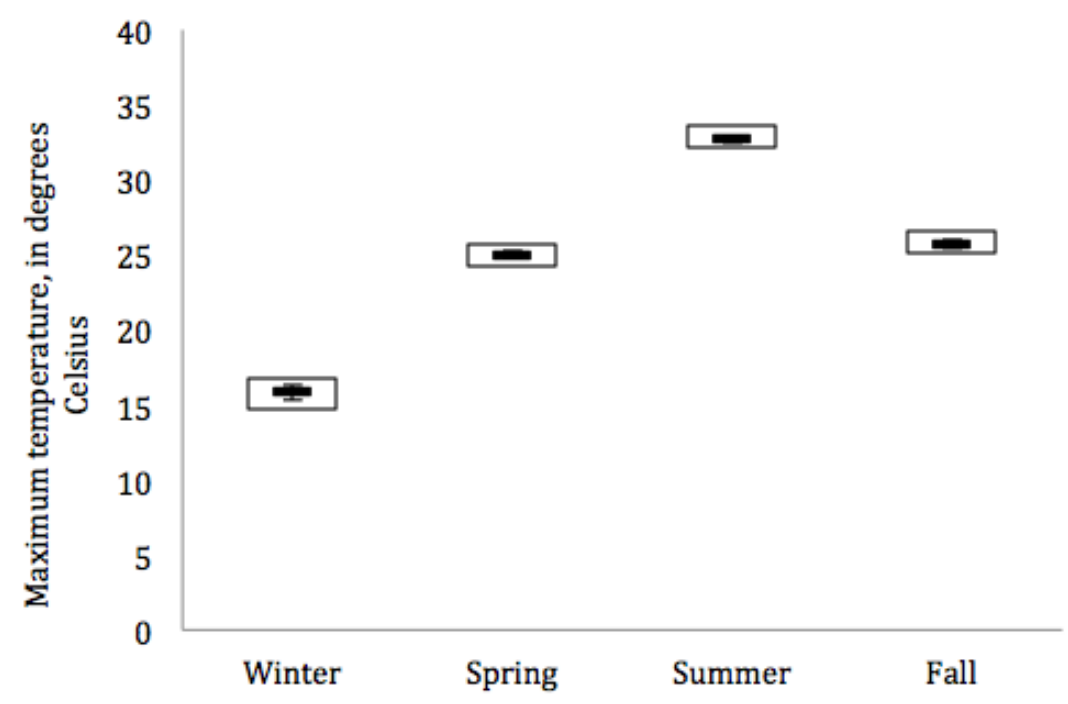

Figure B22. Range of historical (1950-1999) seasonal maximum temperatures for the East Gulf Coastal Plain Southern Loess Bluff Forest ecological system.

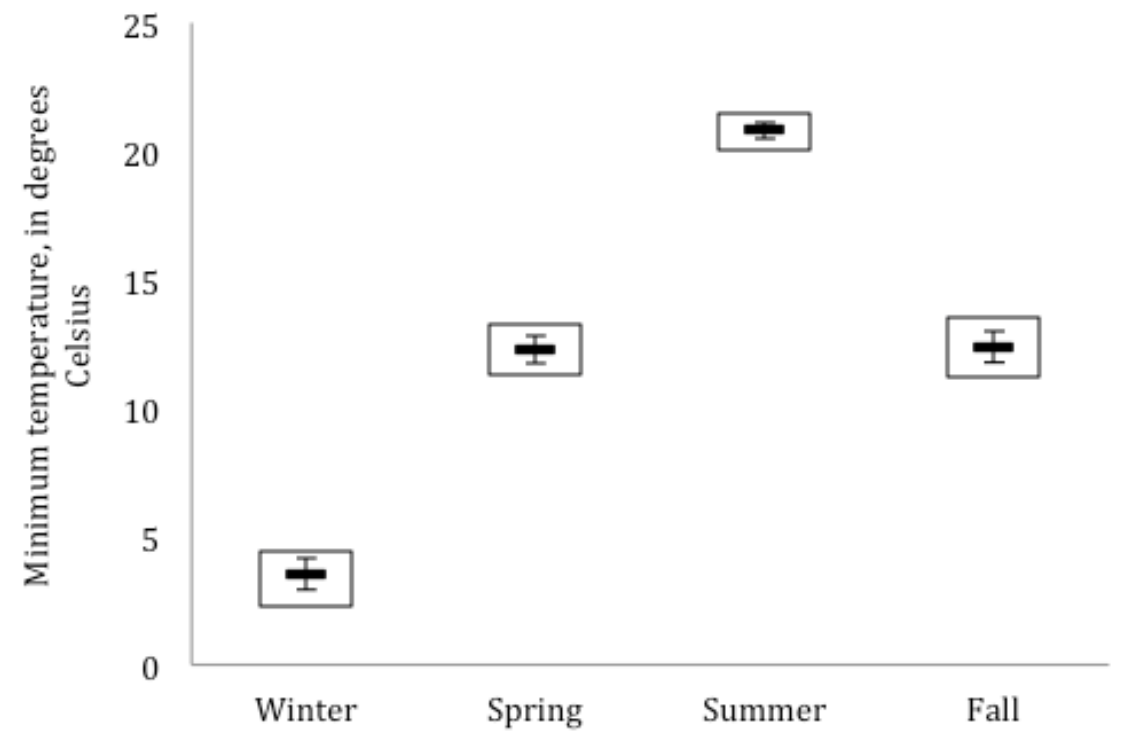

Figure B23. Range of historical (1950-1999) seasonal minimum temperatures for the East Gulf Coastal Plain Southern Loess Bluff Forest ecological system. 


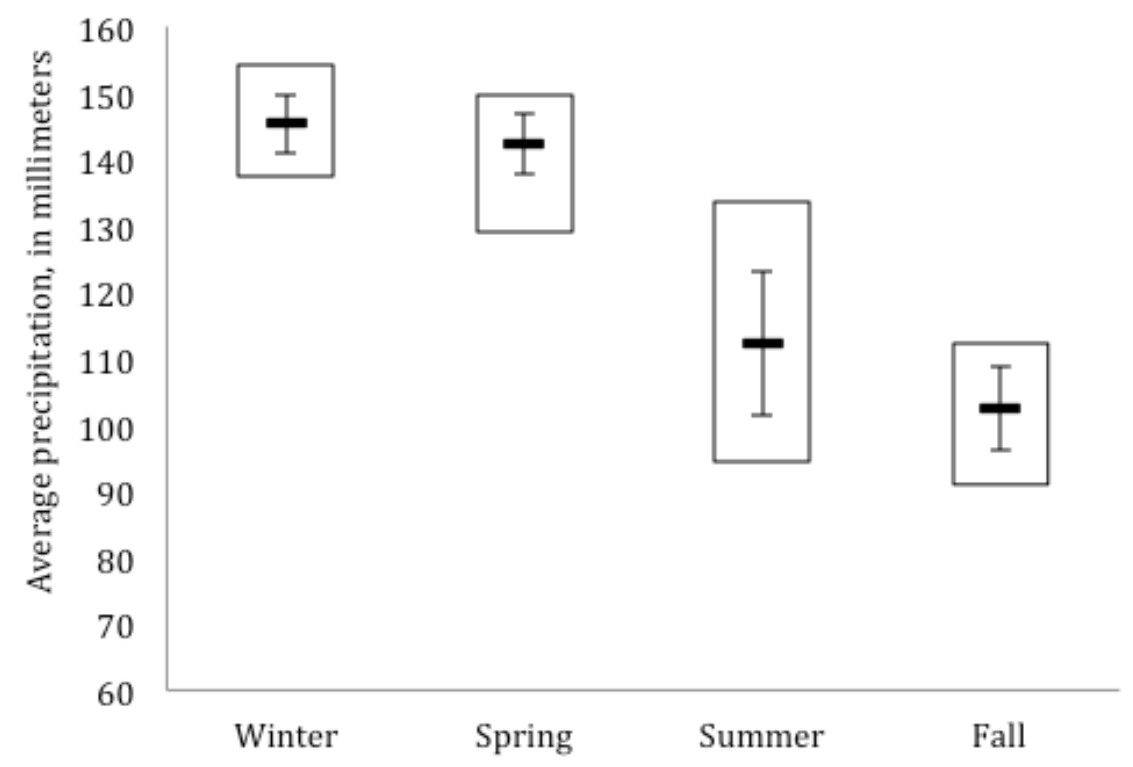

Figure B24. Range of historical (1950-1999) seasonal precipitation for the East Gulf Coastal Plain Southern Loess Bluff Forest ecological system. 
Edwards Plateau Limestone Shrubland

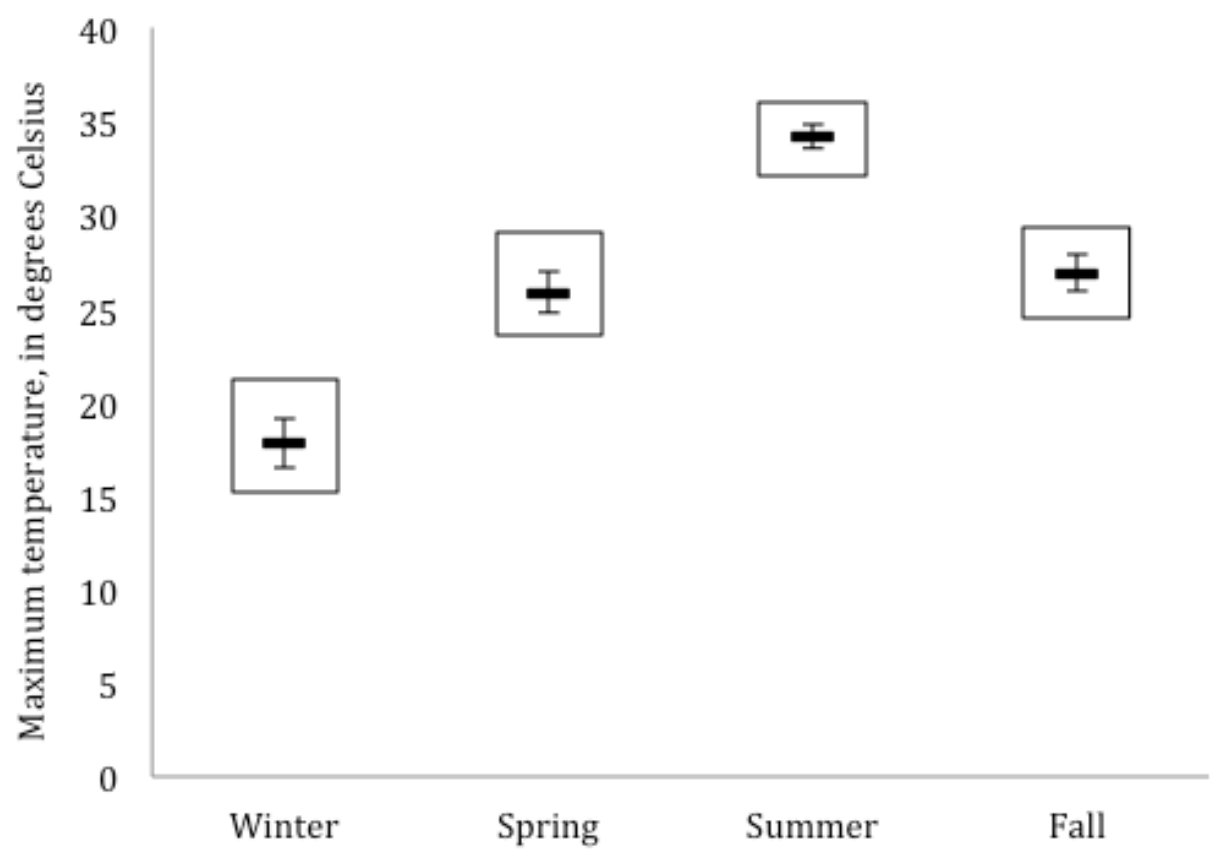

Figure B25. Range of historical (1950-1999) seasonal maximum temperatures for the Edwards Plateau Limestone Shrubland ecological system.

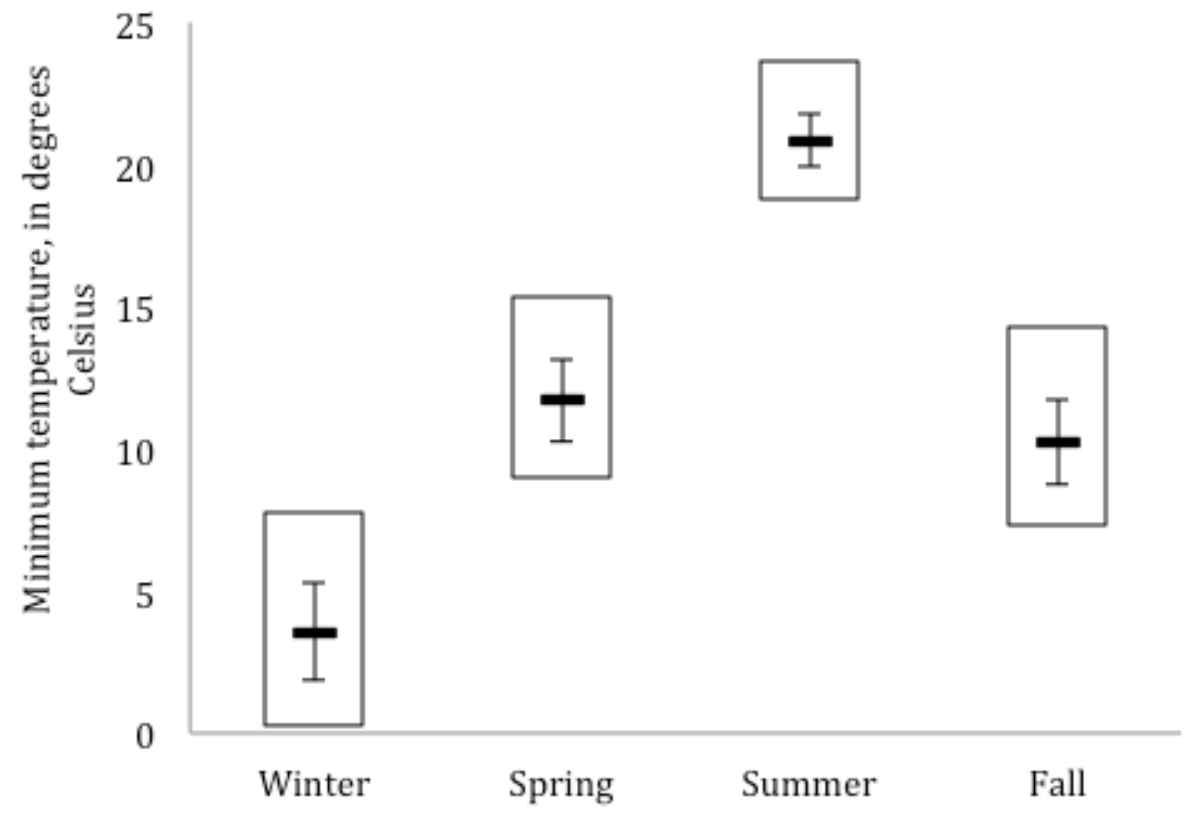

Figure B26. Range of historical (1950-1999) seasonal minimum temperatures for the Edwards Plateau Limestone Shrubland ecological system. 


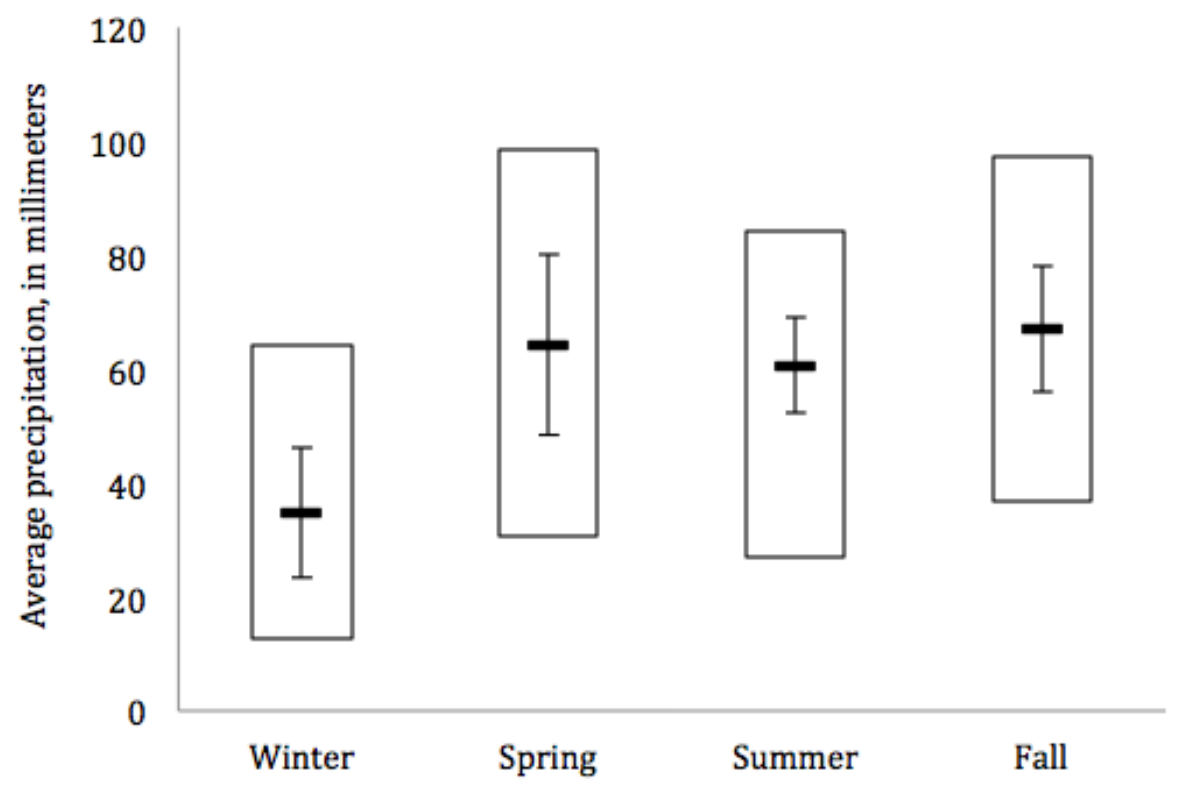

Figure B27. Range of historical (1950-1999) seasonal precipitation for the Edwards Plateau Limestone Shrubland ecological system. 
Edwards Plateau Mesic Canyon

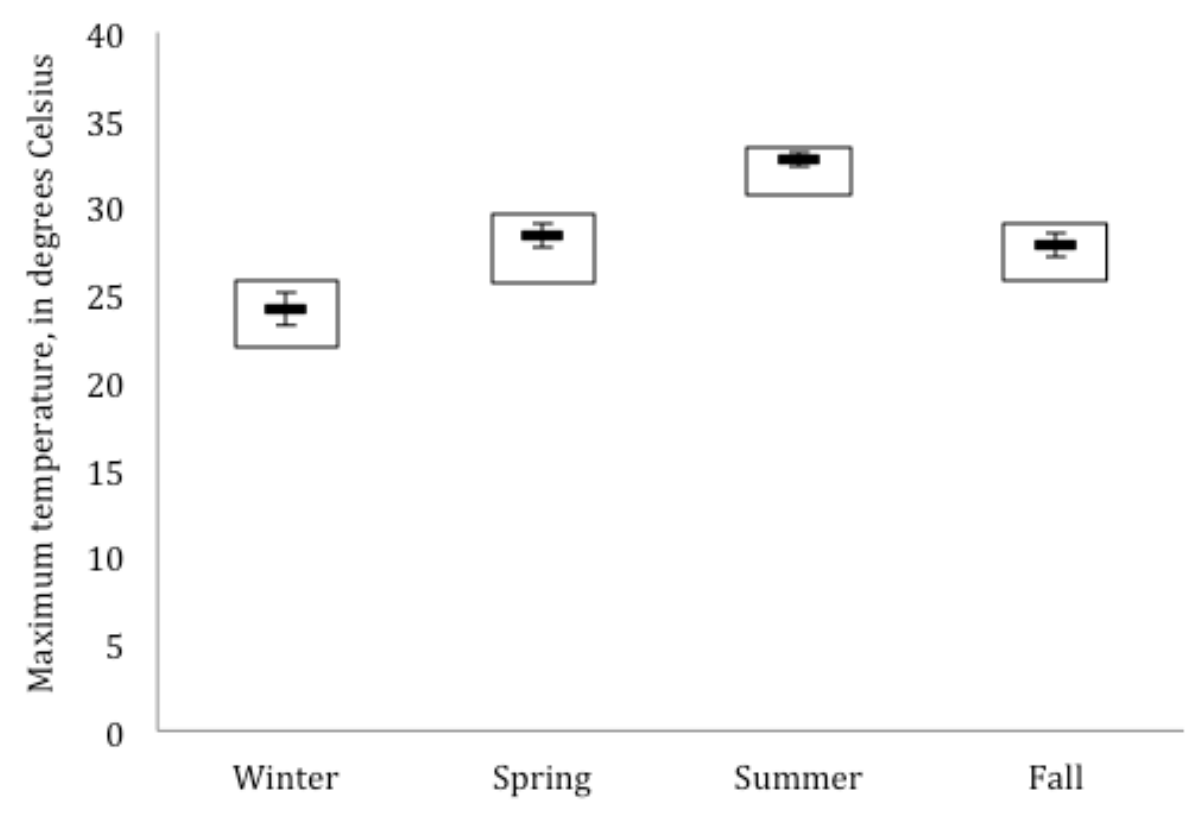

Figure B28. Range of historical (1950-1999) seasonal maximum temperatures for the Edwards Plateau Mesic Canyon ecological system.

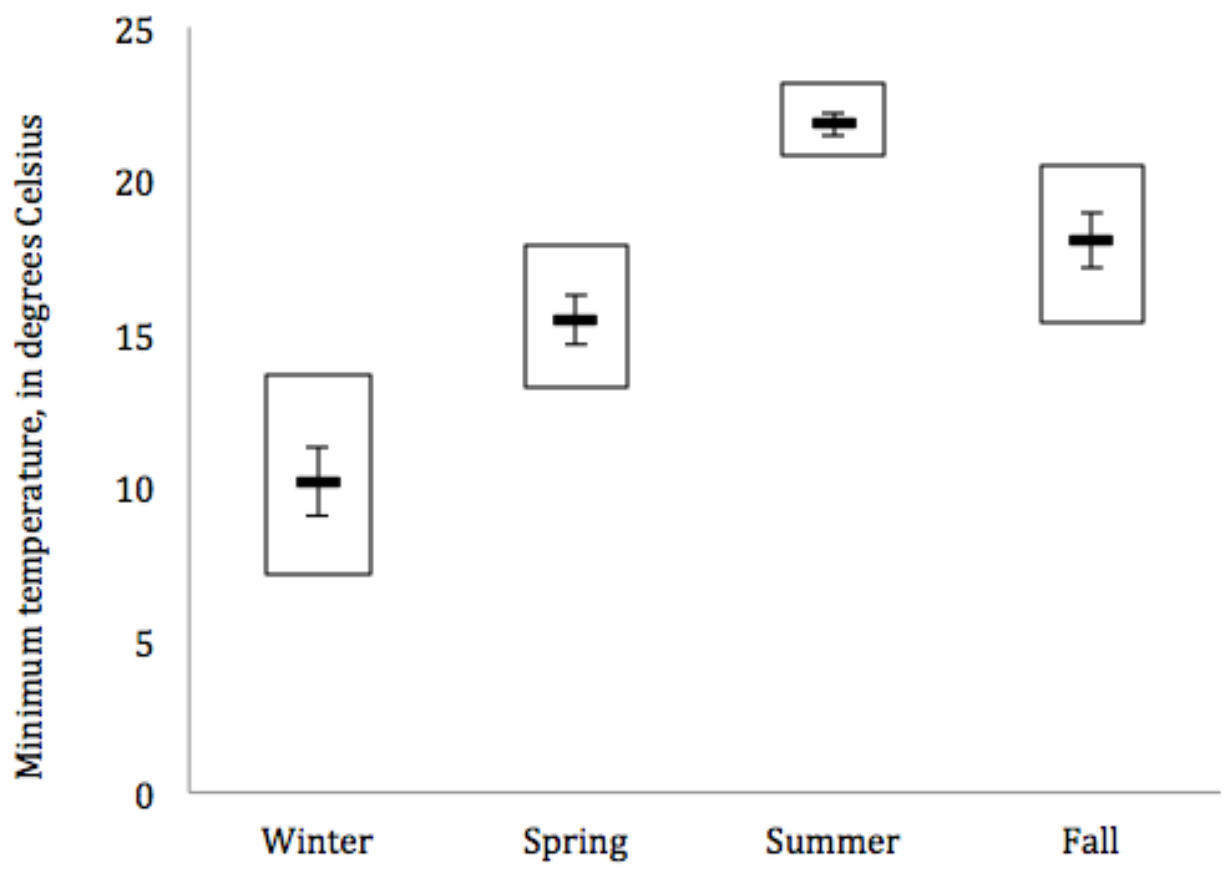

Figure B29. Range of historical (1950-1999) seasonal minimum temperatures for the Edwards Plateau Mesic Canyon ecological system. 


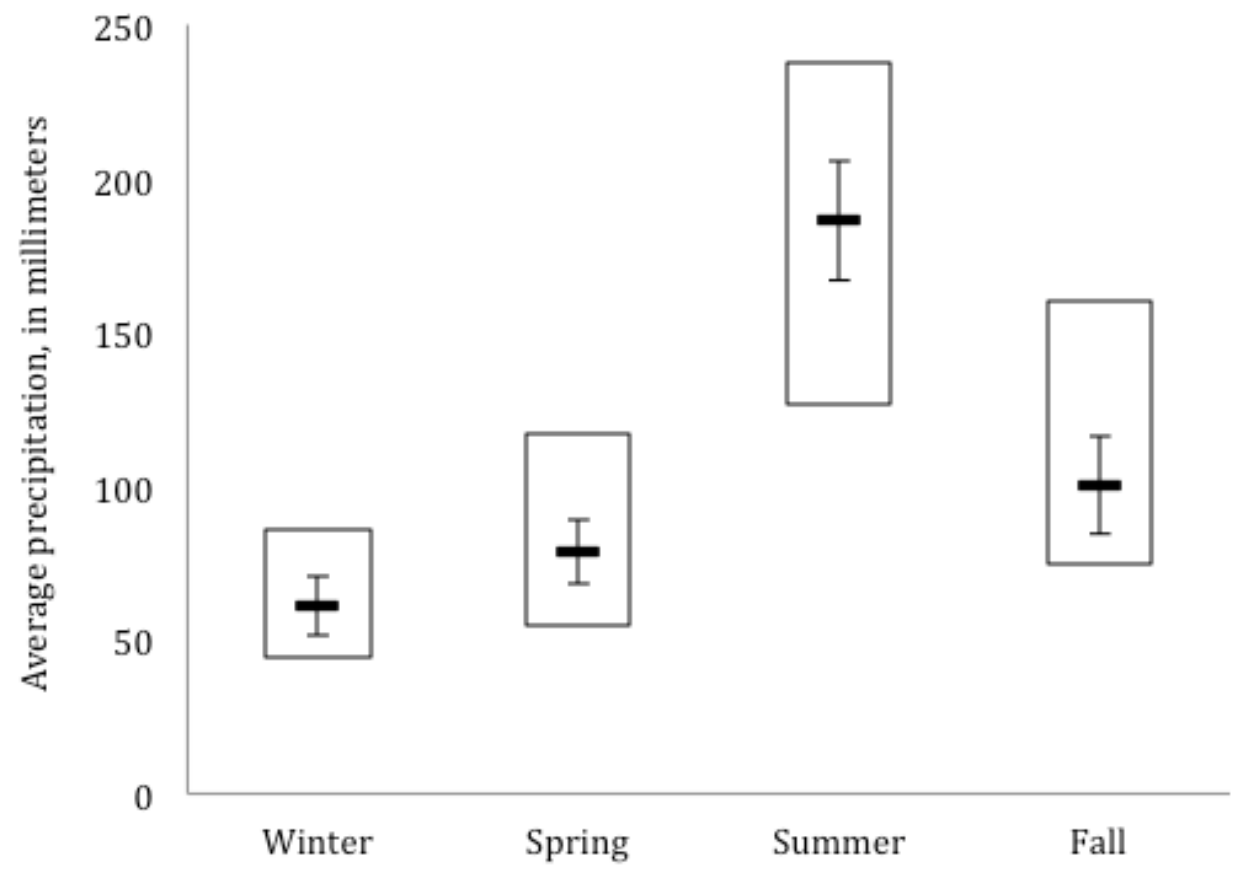

Figure B30. Range of historical (1950-1999) seasonal precipitation for the Edwards Plateau Mesic Canyon ecological system. 


\section{Nashville Basin Limestone Glade and Woodland}

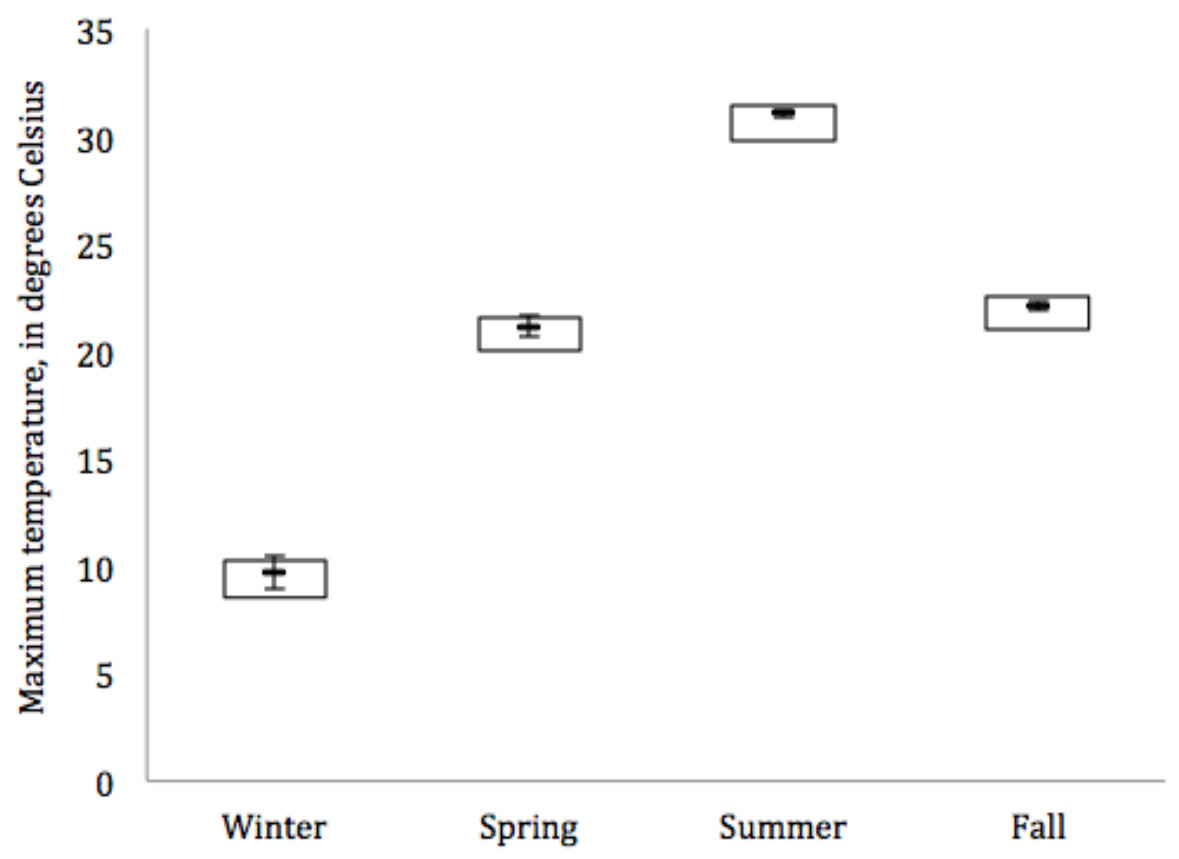

Figure B31. Range of historical (1950-1999) seasonal maximum temperatures for the Nashville Basin Limestone Glade and Woodland ecological system.

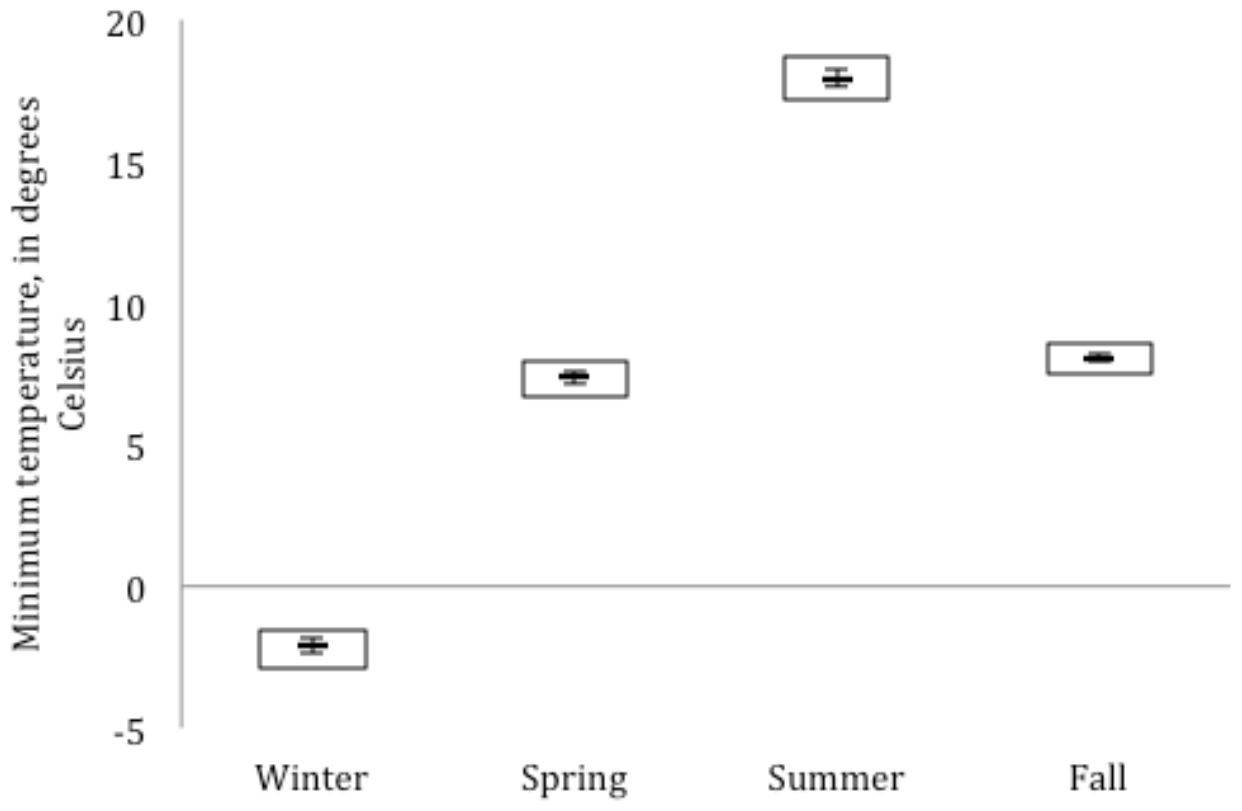

Figure B32. Range of historical (1950-1999) seasonal minimum temperatures for the Nashville Basin Limestone Glade and Woodland ecological system. 


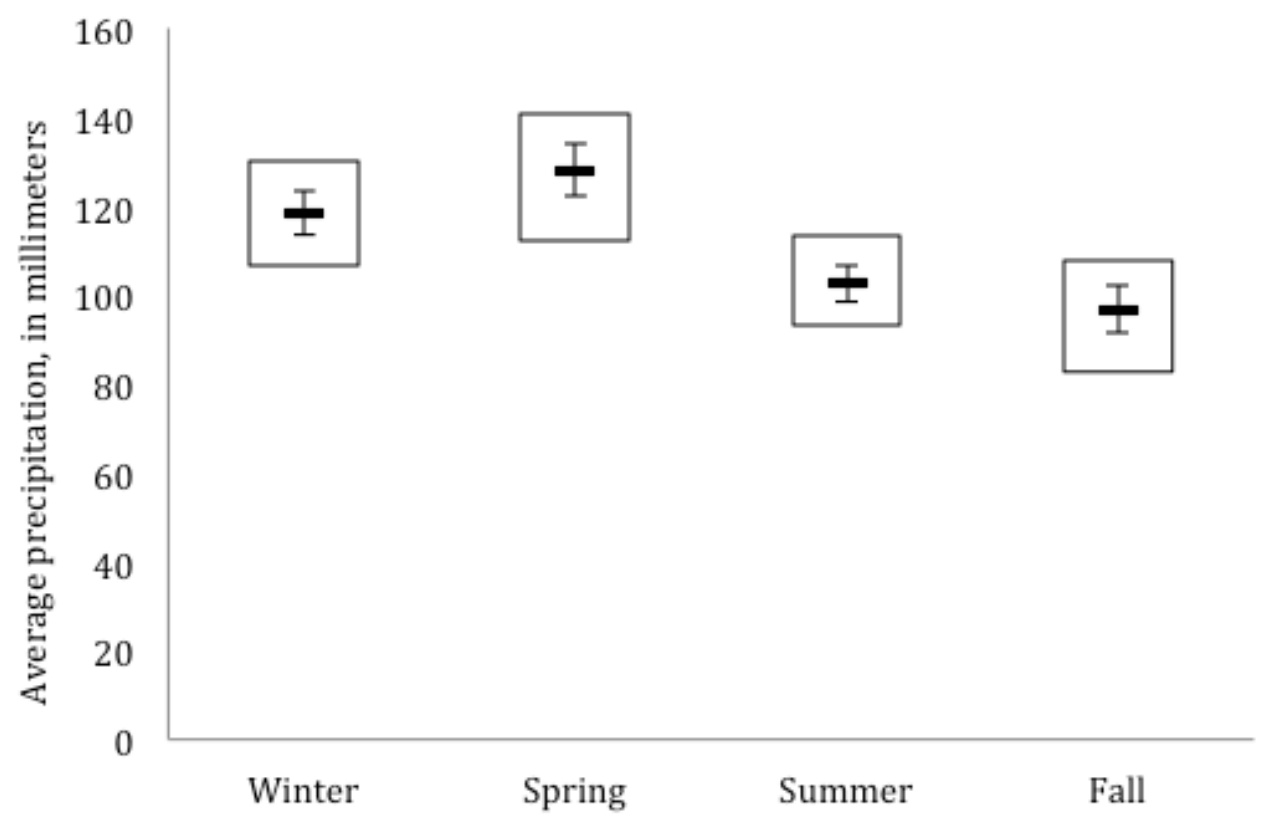

Figure B33. Range of historical (1950-1999) seasonal precipitation for the Nashville Basin Limestone Glade and Woodland ecological system. 


\section{South-Central Interior Forest}

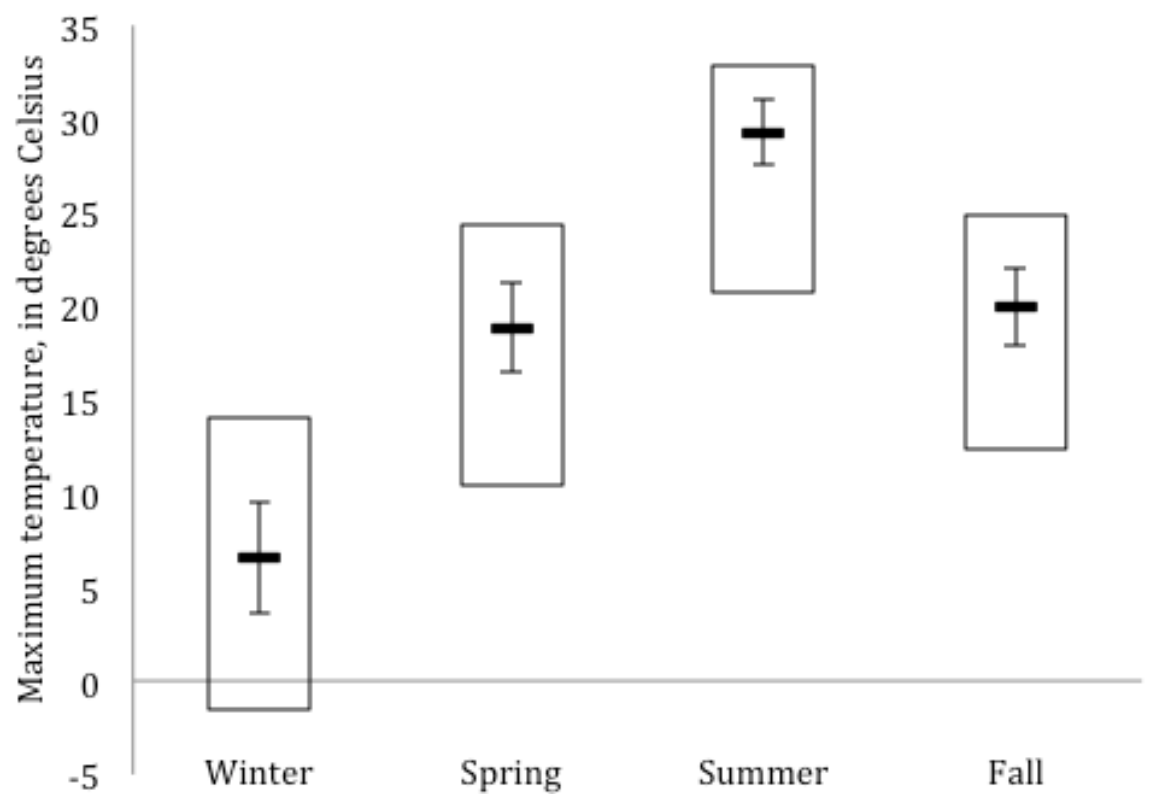

Figure B34. Range of historical (1950-1999) seasonal maximum temperatures for the South-Central Interior Mesophytic Forest ecological system.

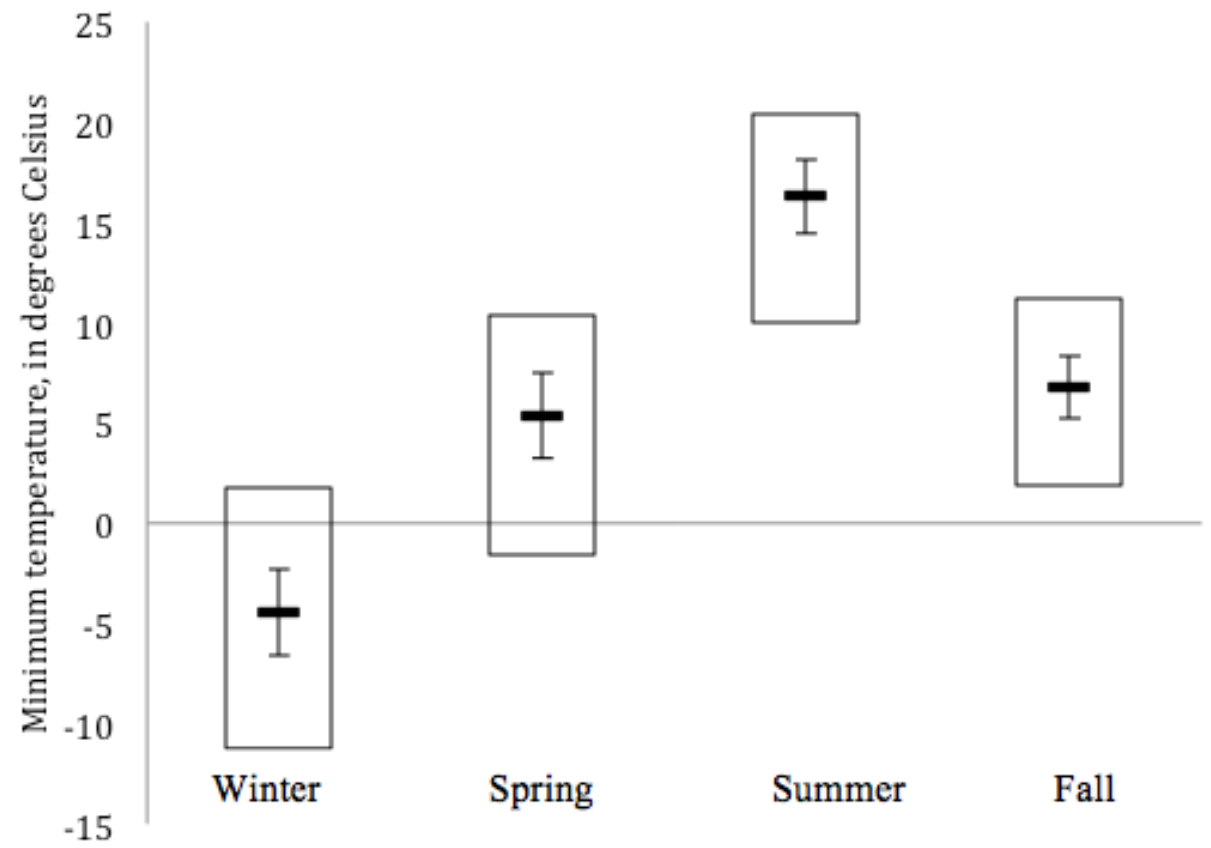

Figure B35. Range of historical (1950-1999) seasonal minimum temperatures for the South-Central Interior Mesophytic Forest ecological system. 


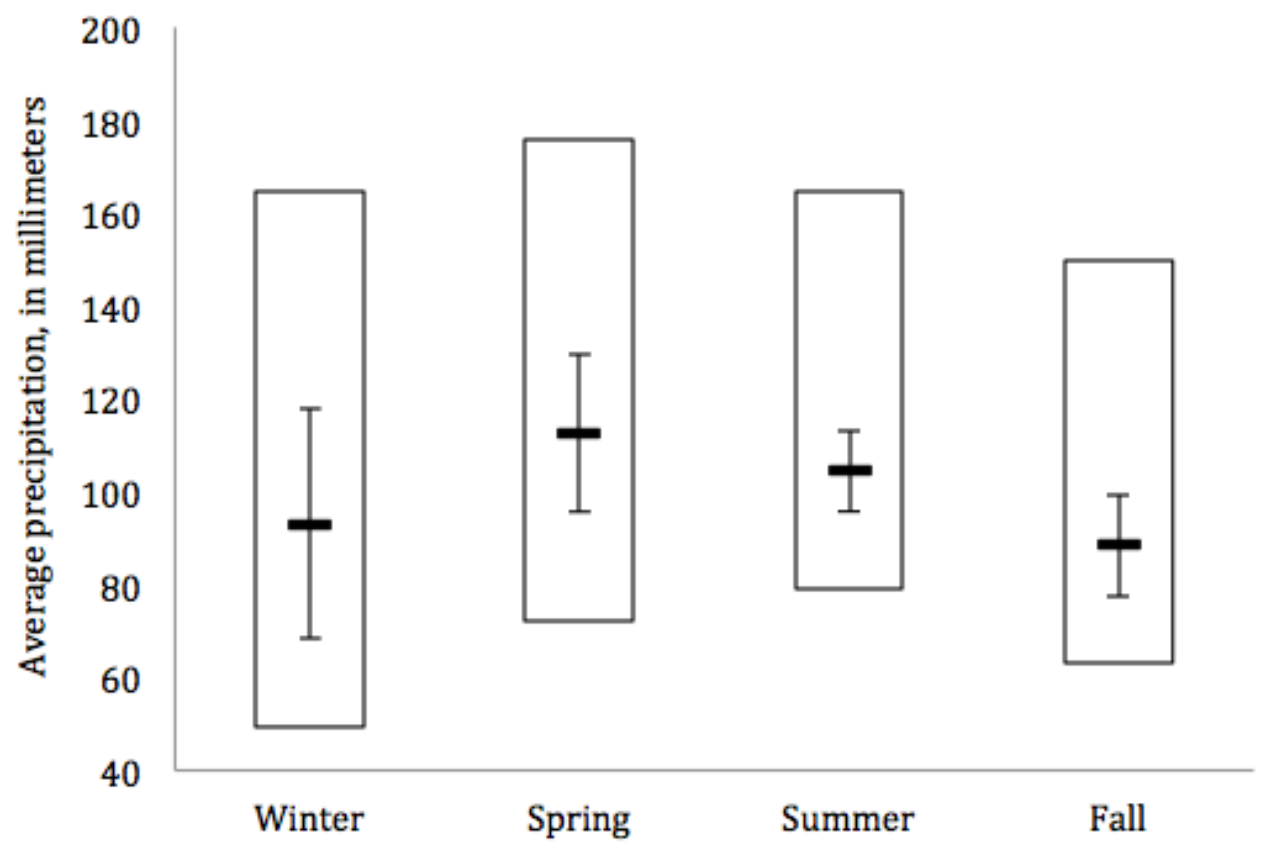

Figure B36. Range of historical (1950-1999) seasonal precipitation for the South-Central Interior Mesophytic Forest ecological system. 


\section{Southern Coastal Plain Nonriverine Cypress Dome}

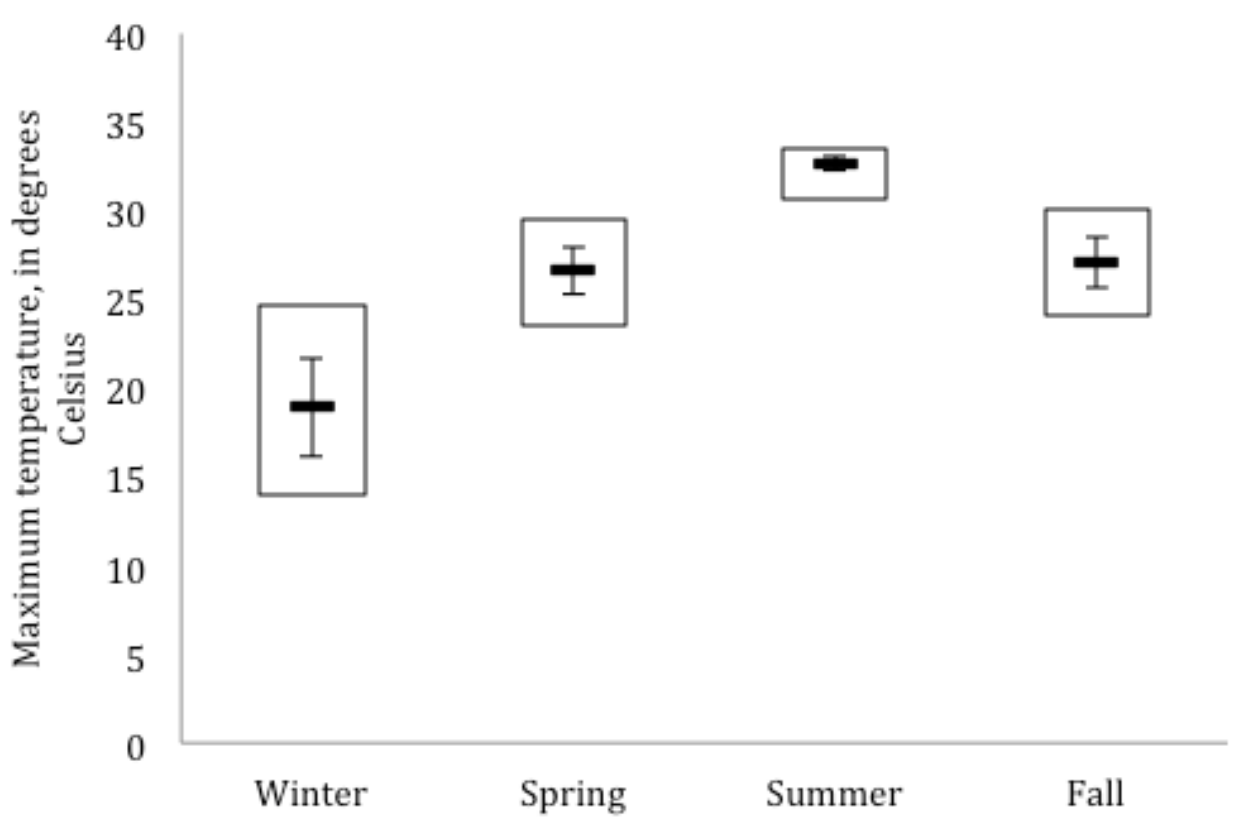

Figure B37. Range of historical (1950-1999) seasonal maximum temperatures for the Southern Coastal Plain Nonriverine Cypress Dome ecological system.

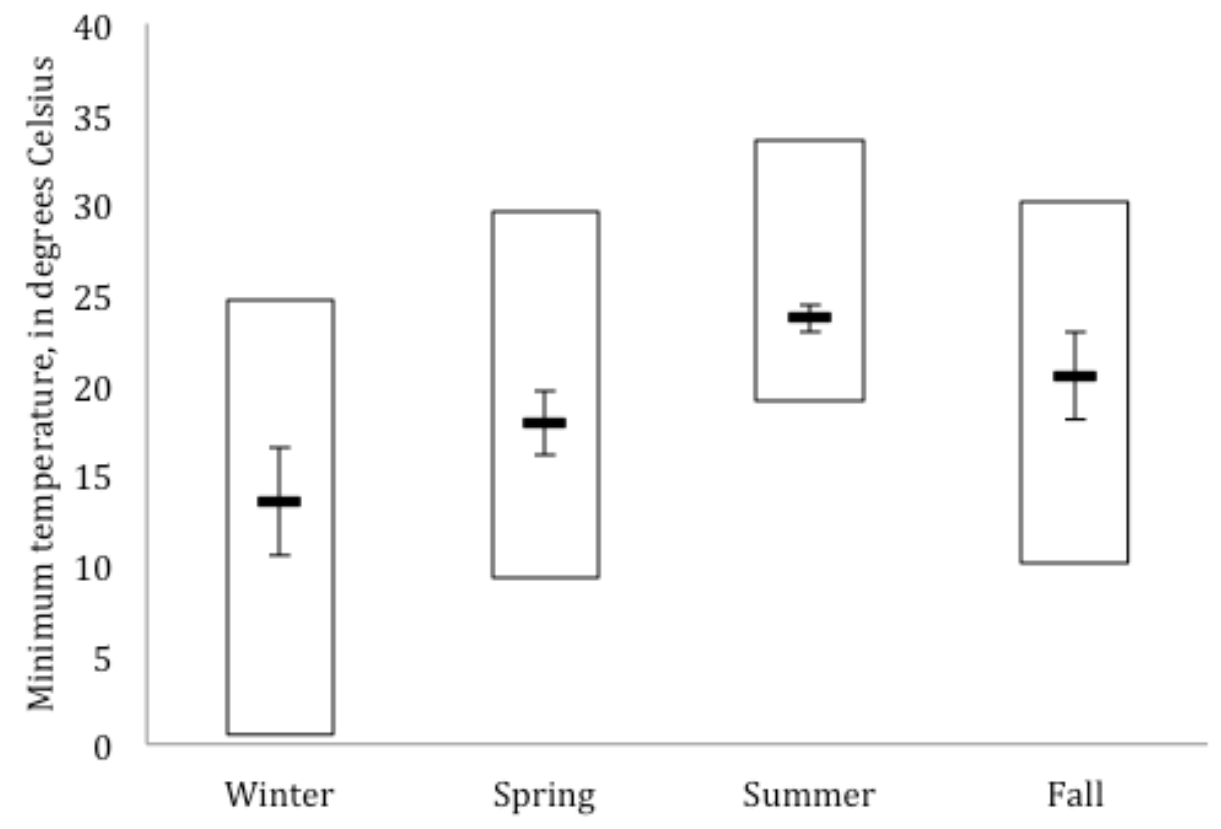

Figure B38. Range of historical (1950-1999) seasonal minimum temperatures for the Southern Coastal Plain Nonriverine Cypress Dome ecological system. 


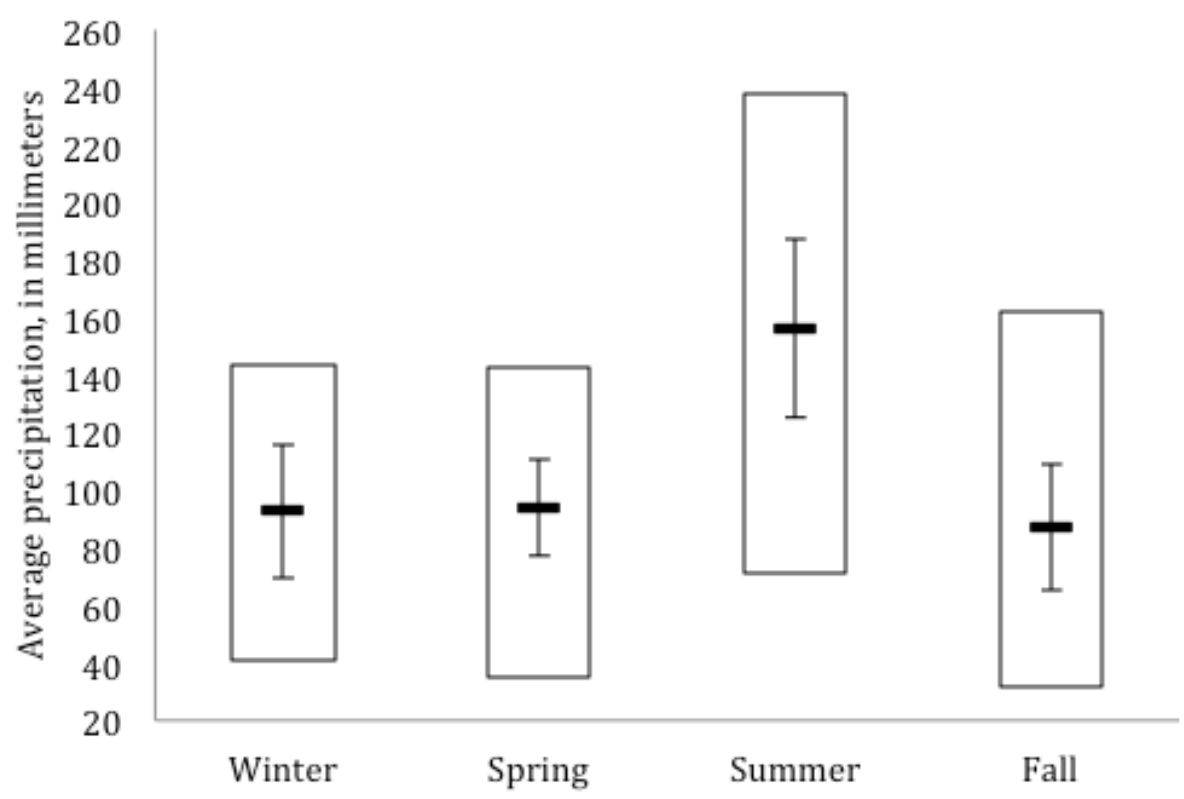

Figure B39. Range of historical (1950-1999) seasonal precipitation for the Southern Coastal Plain Nonriverine Cypress Dome ecological system. 


\section{Southern Coastal Plain Seepage Swamp and Baygall}

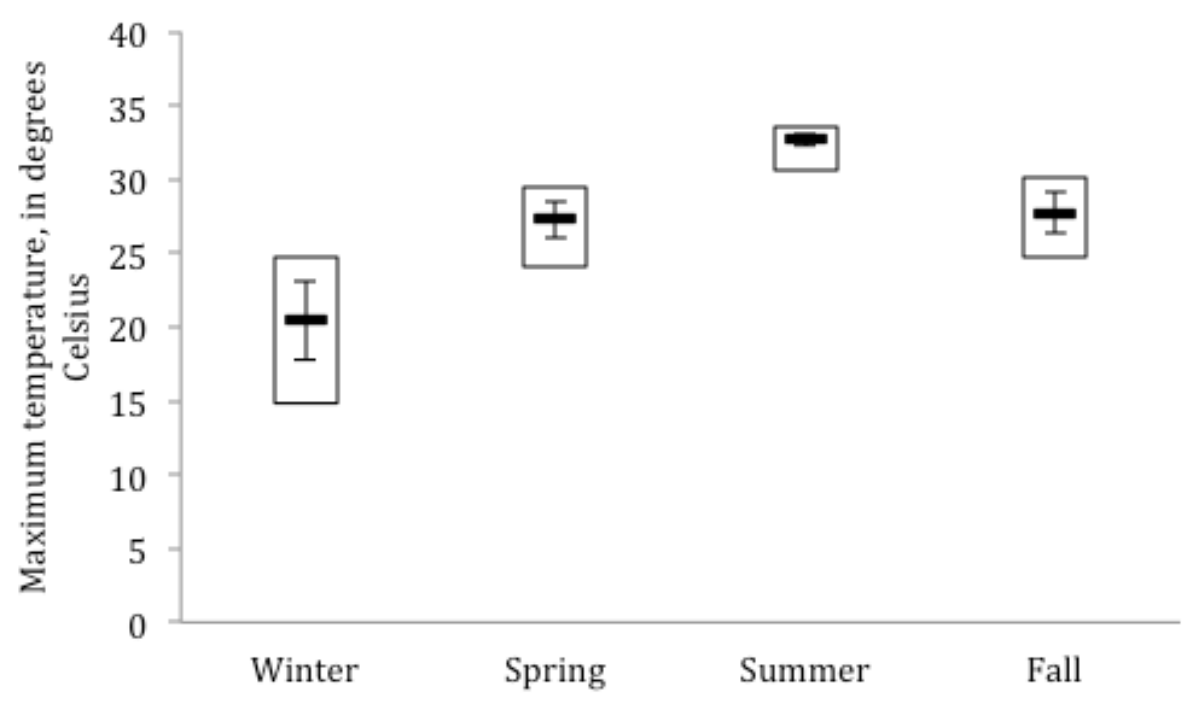

Figure B40. Range of historical (1950-1999) seasonal maximum temperatures for the Southern Coastal Plain Seepage Swamp and Baygall ecological system.

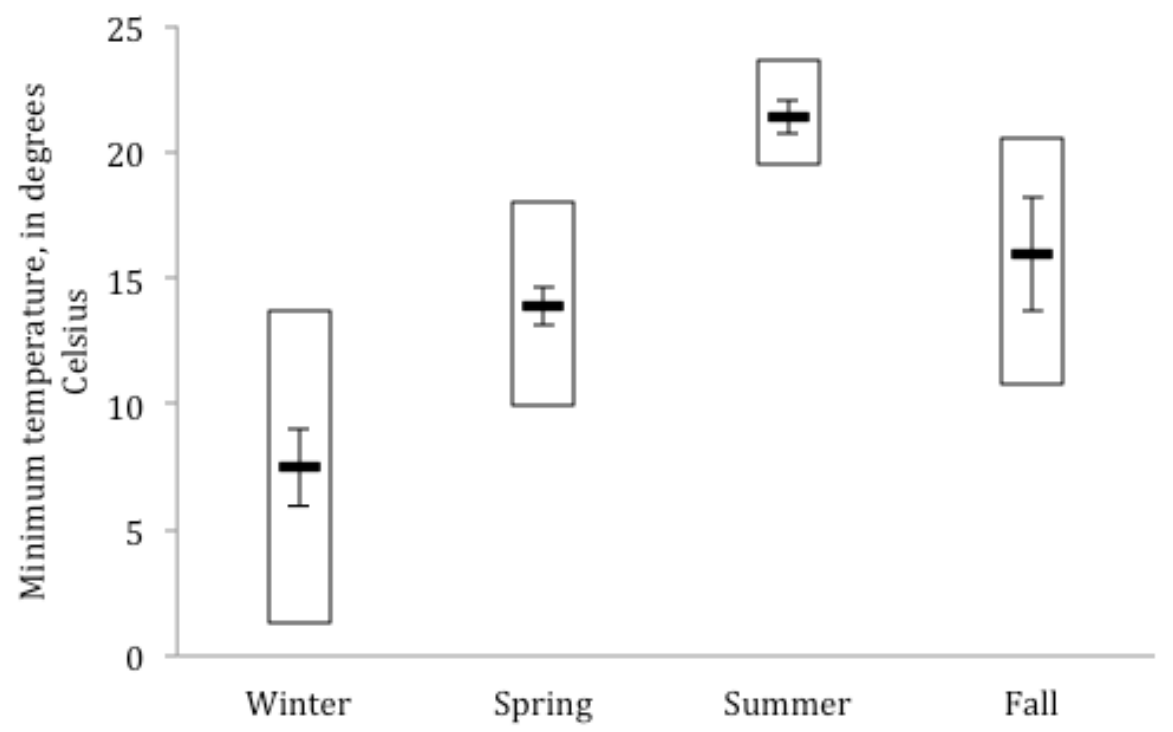

Figure B41. Range of historical (1950-1999) seasonal minimum temperatures for the Southern Coastal Plain Seepage Swamp and Baygall ecological system. 


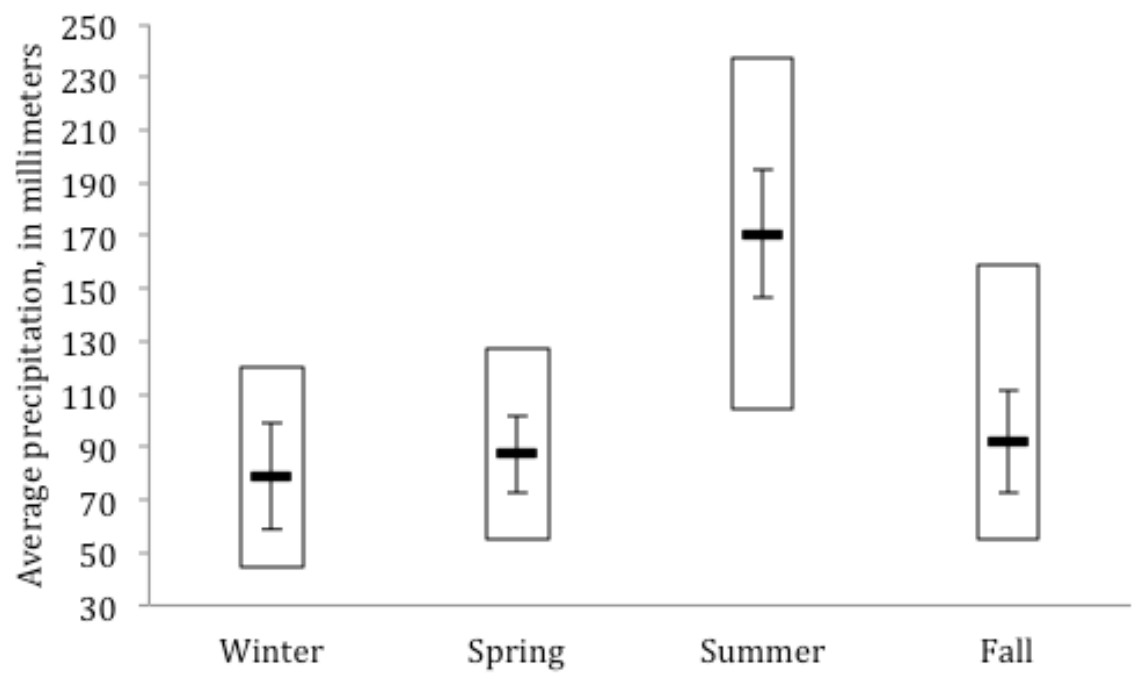

Figure B42. Range of historical (1950-1999) seasonal precipitation for the Southern Coastal Plain Seepage Swamp and Baygall ecological system. 


\section{Appendix C. Projected Change in Standard Deviation of Climate Variables}

Changes in the standard deviation of maximum temperature, minimum temperature, and precipitation for mid-century (2040-2060) and late century (2080-2100), as compared with recent (1981-2000) climate.

\section{Southeastern United States}

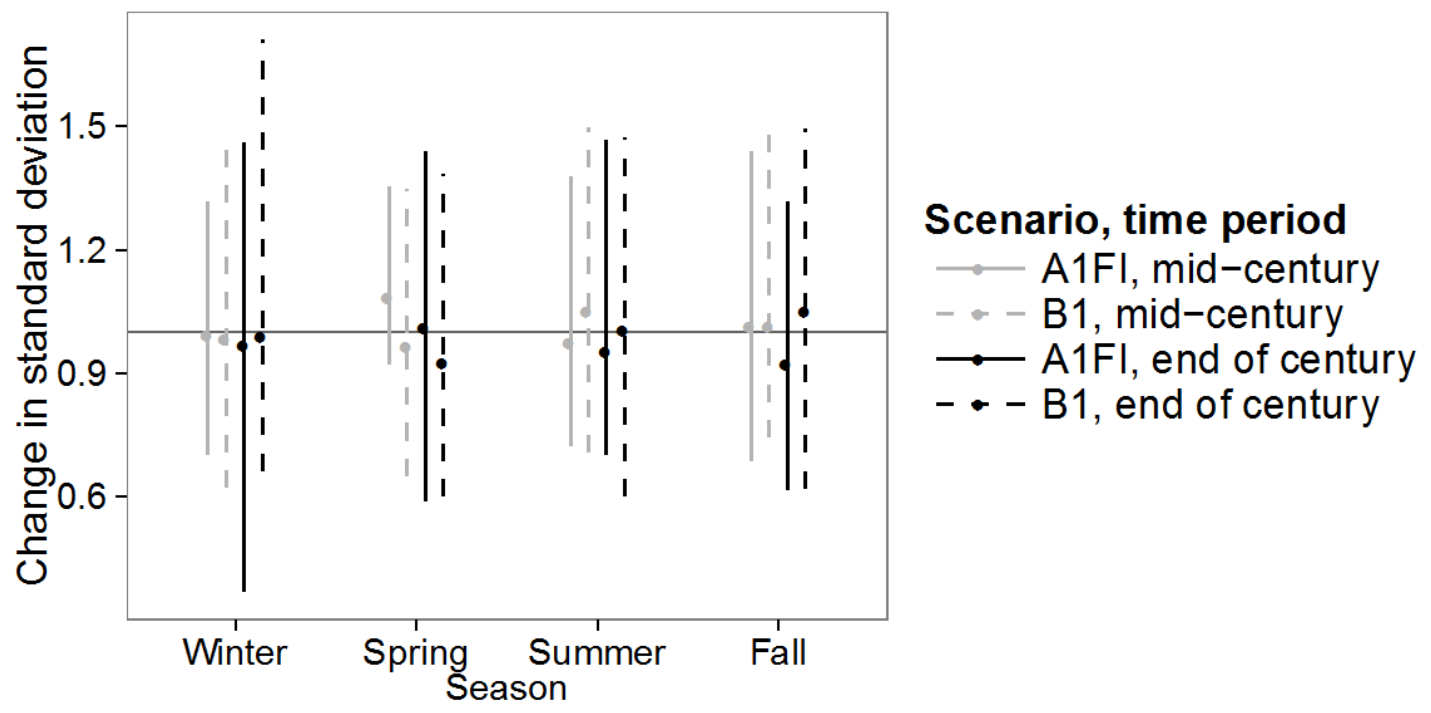

Figure C1. Projected change in standard deviation of seasonal maximum temperatures (in degrees Celsius) for the middle (2040-2060) and the end of the 21st century (2080-2100), compared with the recent time period (1981-2000), for two emissions scenarios for all Landscape Conservation Cooperatives in the Southeast. Solid dots and error bars represent, respectively, the means and ranges of projections across climate models under each scenario. 


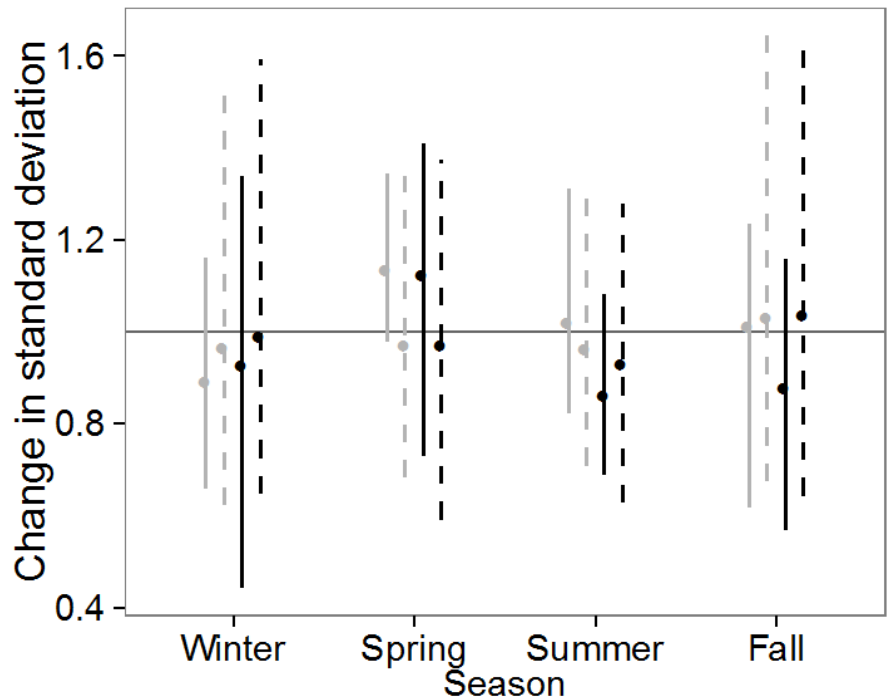

Scenario, time period

$\ldots \mathrm{A} 1 \mathrm{FI}$, mid-century

- B1, mid-century

$\rightarrow \mathrm{A} 1 \mathrm{Fl}$, end of century

- - B1, end of century

Figure C2. Projected change in standard deviation of seasonal minimum temperatures (in degrees Celsius) for the middle (2040-2060) and the end of the 21st century (2080-2100), compared with the recent time period (1981-2000), for two emissions scenarios for all Landscape Conservation Cooperatives in the Southeast. Solid dots and error bars represent, respectively, the means and ranges of projections across climate models under each scenario.

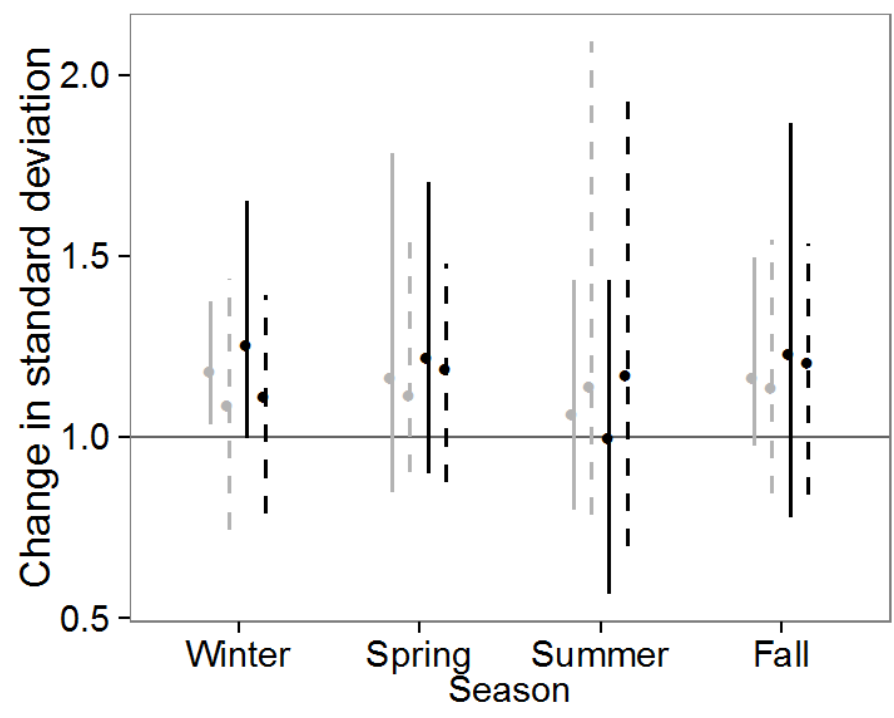

Scenario, time period

- A1FI, mid-century

- B1, mid-century

$\rightarrow \mathrm{A} 1 \mathrm{FI}$, end of century

- - B1, end of century

Figure C3. Projected change in standard deviation of seasonal average precipitation for the middle (2040 2060) and the end of the 21st century (2080-2100), compared with the recent time period (1981-2000), for two emissions scenarios for all Landscape Conservation Cooperatives in the Southeast. Solid dots and error bars represent, respectively, the means and ranges of projections across climate models under each scenario. 


\section{Puerto Rico}

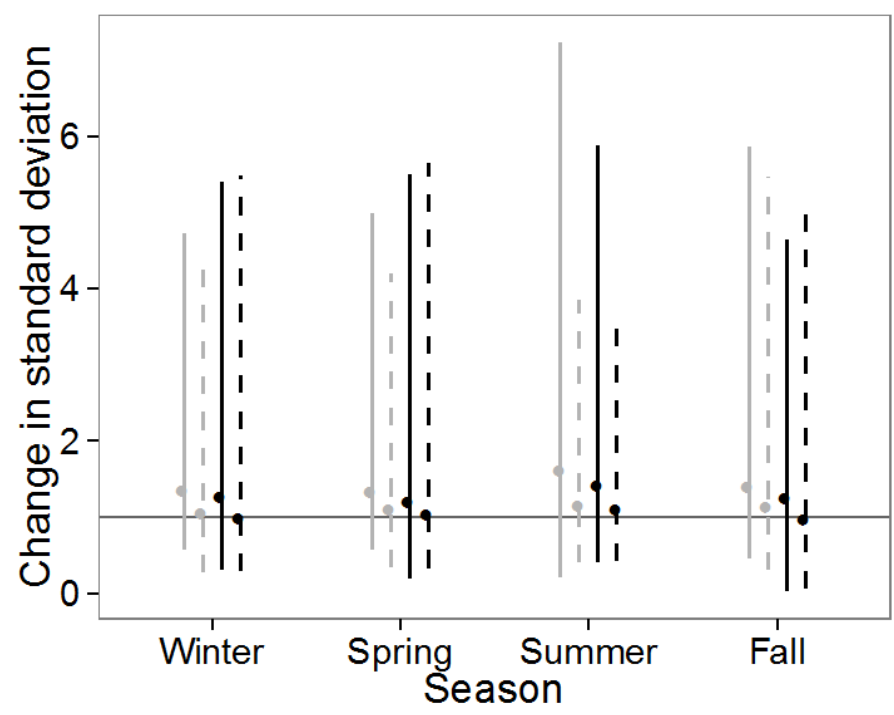

Scenario, time period

$\because \mathrm{A} 1 \mathrm{FI}$, mid-century

- B1, mid-century

$\rightarrow \mathrm{A} 1 \mathrm{Fl}$, end of century

- - B1, end of century

Figure C4. Projected change in standard deviation of seasonal maximum temperatures (in degrees Celsius) for the middle (2040-2060) and the end of the 21st century (2080-2100), compared with the recent time period (1981-2000), for two emissions scenarios for all climate stations in Puerto Rico. Solid dots and error bars represent, respectively, the means and ranges of projections across climate models under each scenario.

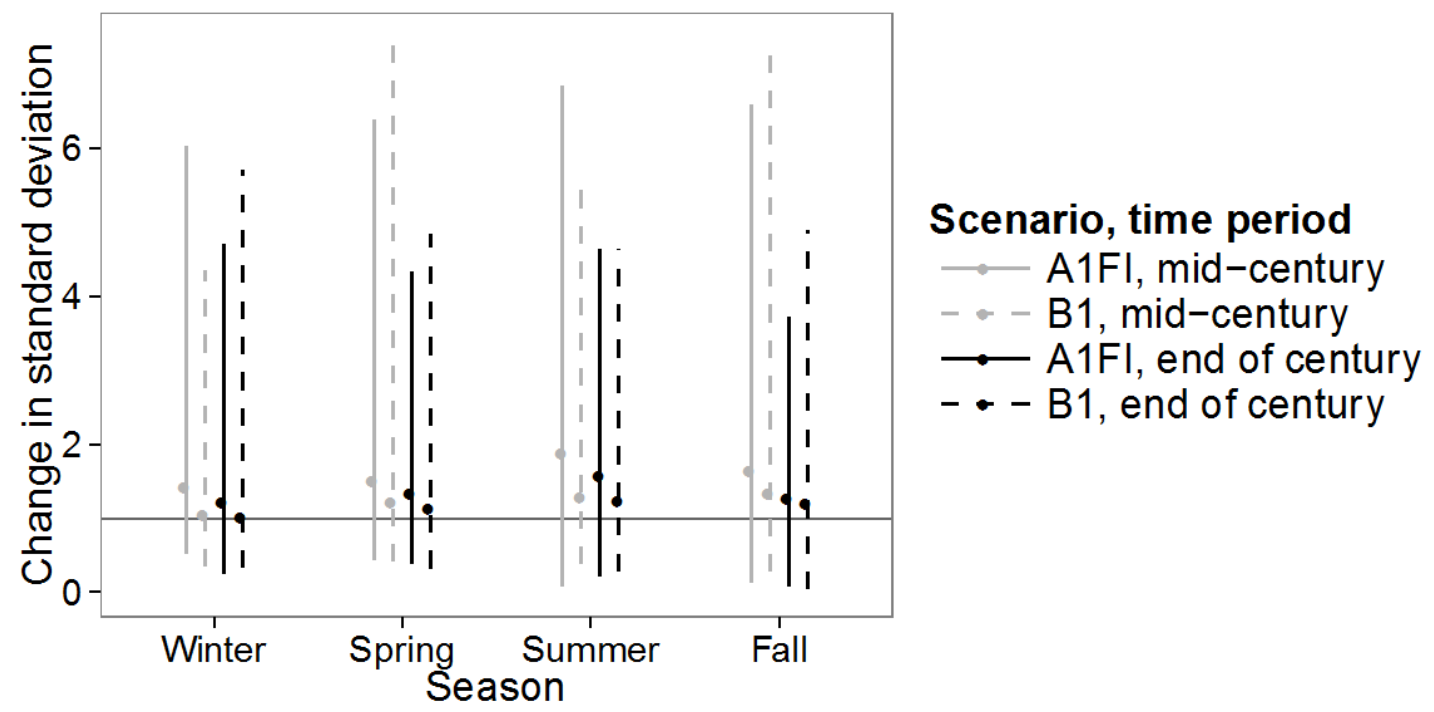

Figure C5. Projected change in standard deviation of seasonal minimum temperatures (in degrees Celsius) for the middle (2040-2060) and the end of the 21st century (2080-2100), compared with the recent time period (1981-2000), for two emissions scenarios for all climate stations in Puerto Rico. Solid dots and error bars represent, respectively, the means and ranges of projections across climate models under the scenario. 


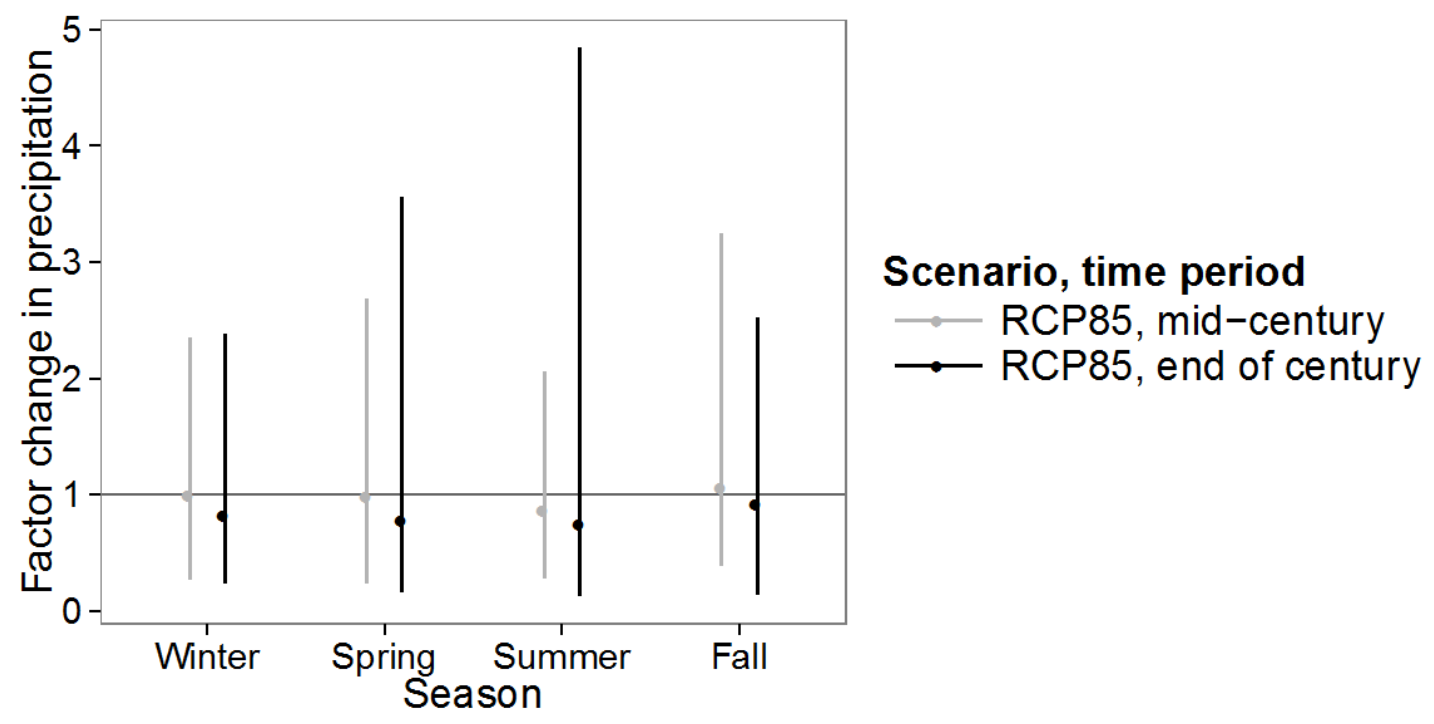

Figure C6. Projected change in standard deviation of seasonal average precipitation for the middle (20402060) and the end of the 21st century (2080-2100), compared with the recent time period (1981-2000), for a high-emissions scenario for all climate stations in Puerto Rico. Solid dots and error bars represent, respectively, the means and ranges of projections across climate models under the scenario. 


\section{Caribbean Coastal Mangrove in Puerto Rico}

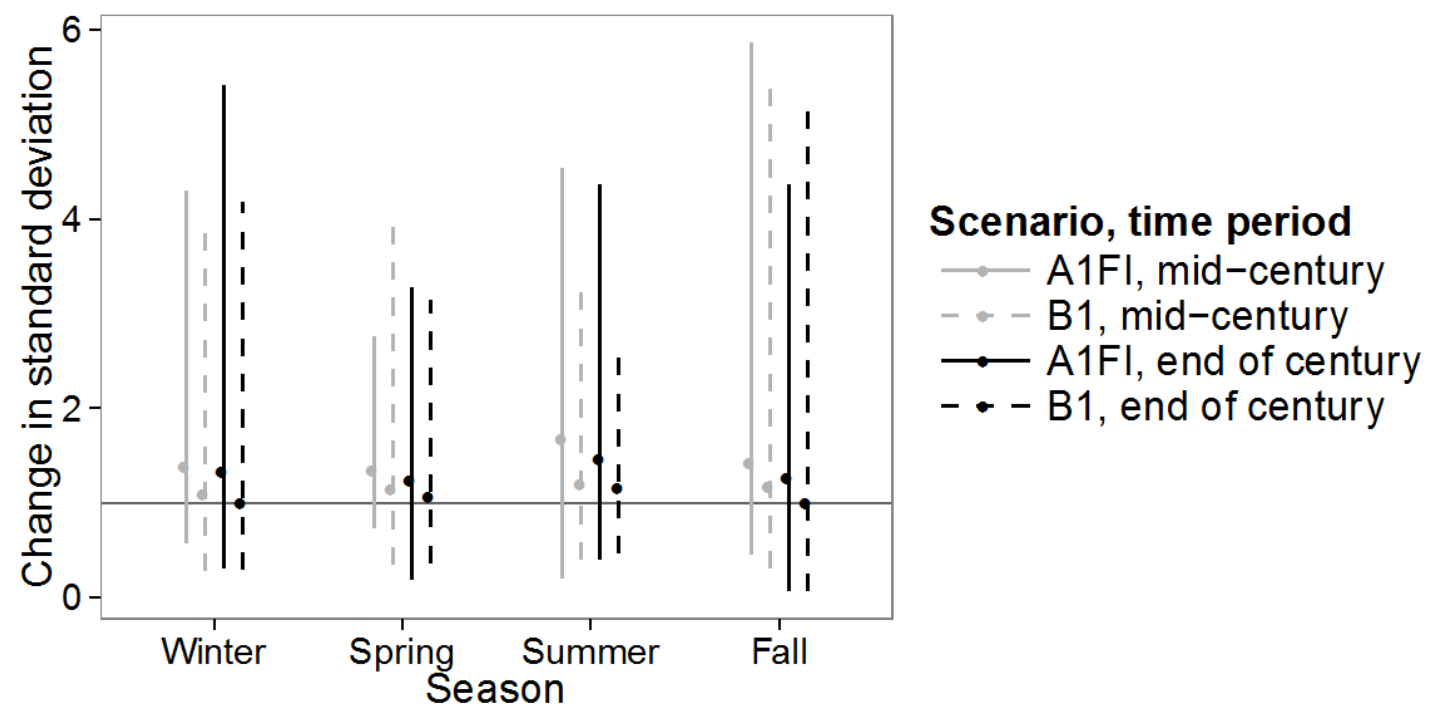

Figure C7. Projected change in standard deviation of seasonal maximum temperatures (in degrees Celsius) for the middle (2040-2060) and the end of the 21st century (2080-2100,) compared with the recent time period (1981-2000), for two emissions scenarios for mangroves in Puerto Rico. Solid dots and error bars represent, respectively, the means and ranges of projections across climate models under each scenario.

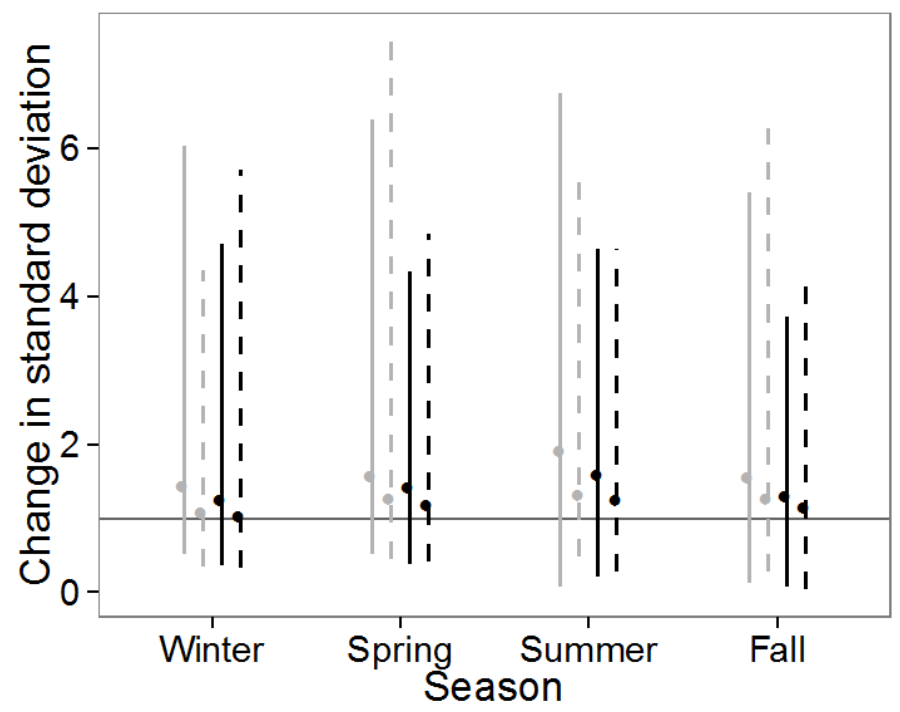

Scenario, time period A1FI, mid-century

$-\cdots$ B1, mid-century

$\longrightarrow \mathrm{A} 1 \mathrm{FI}$, end of century

- B1, end of century

Figure C8. Projected change in standard deviation of seasonal minimum temperatures (in degrees Celsius) for the middle (2040-2060) and the end of the 21st century (2080-2100), compared with the recent time period (1981-2000), for two emissions scenarios for mangroves in Puerto Rico. Solid dots and error bars represent, respectively, the means and ranges of projections across climate models under each scenario. 


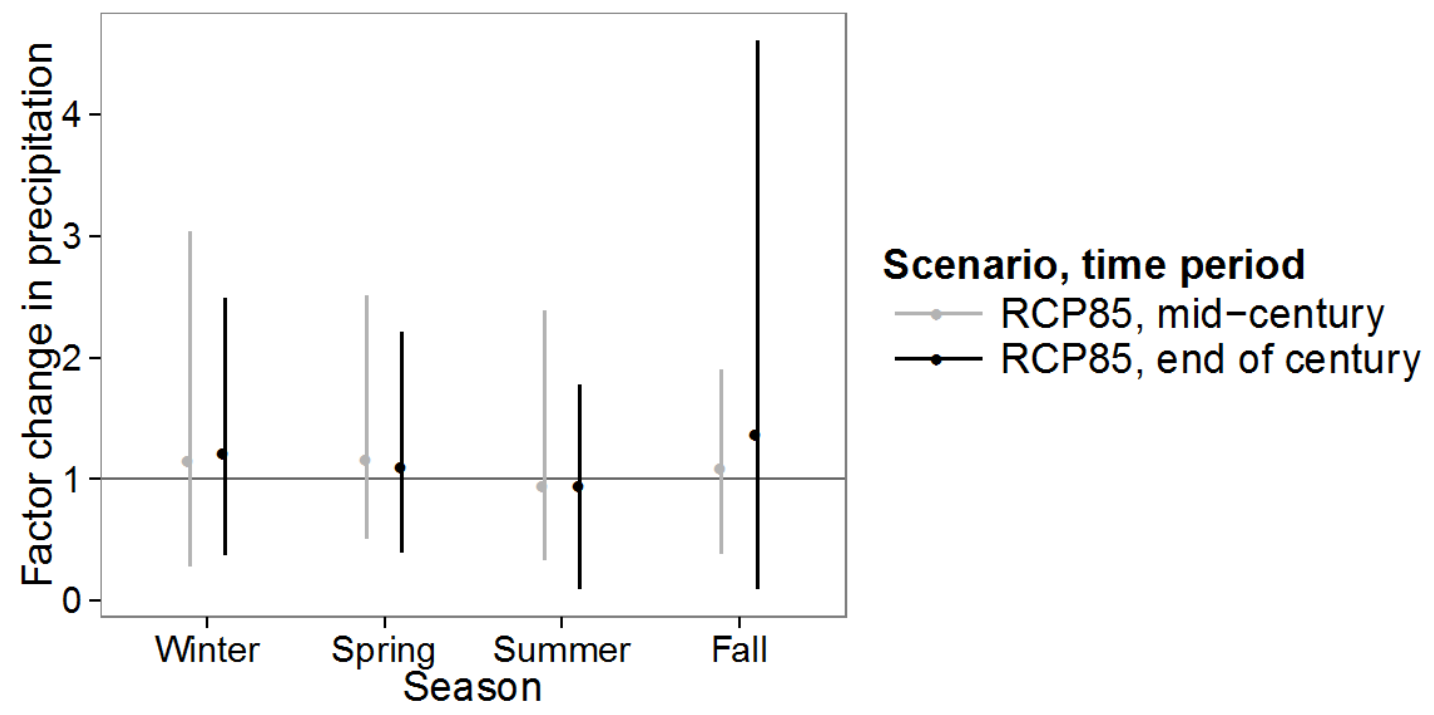

Figure C9. Projected change in standard deviation of seasonal average precipitation for the middle (2040-2060) and the end of the 21st century (2080-2100), compared with the recent time period (19812000), for a high-emissions scenario for mangroves in Puerto Rico. Solid dots and error bars, respectively, represent the means and ranges of projections across climate models under the scenario. 


\section{Caribbean Montane Wet Elfin Forest in Puerto Rico}

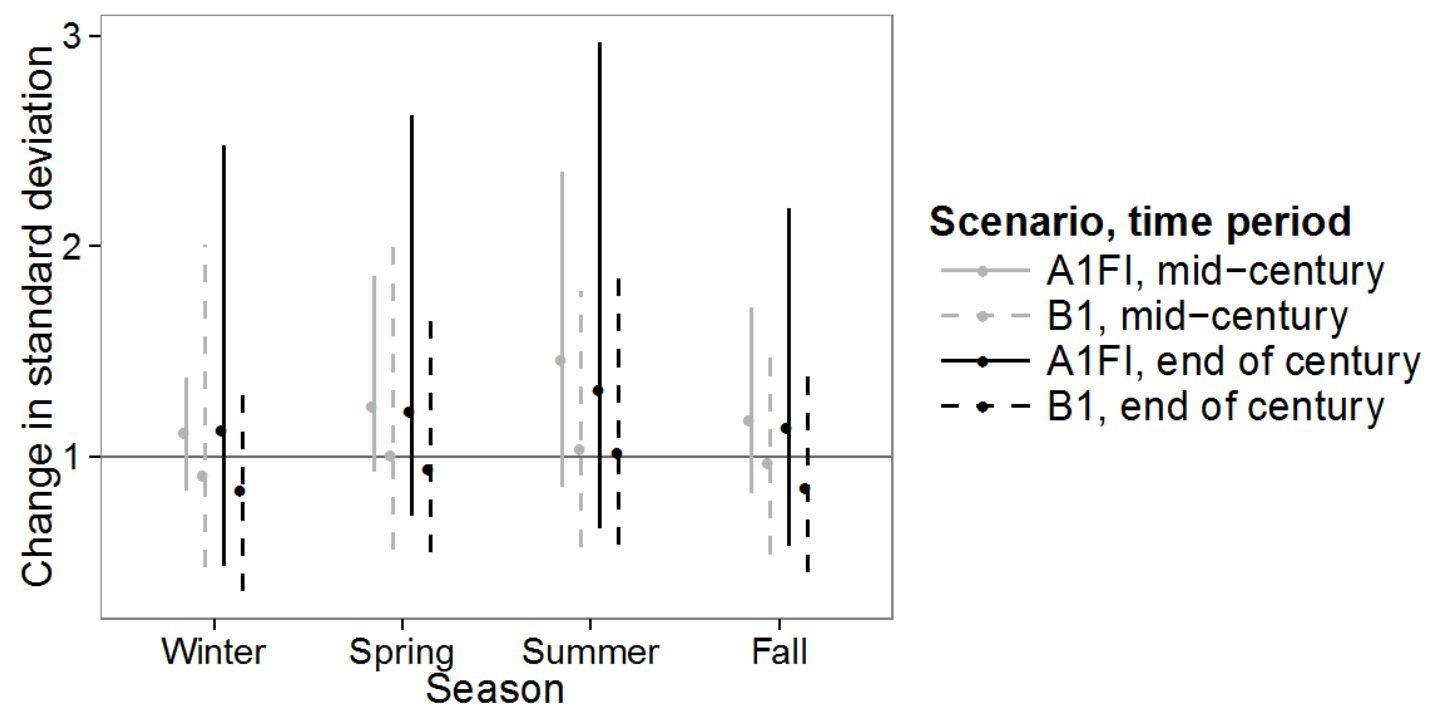

Figure C10. Projected change in standard deviation of seasonal maximum temperatures (in degrees Celsius) for the middle (2040-2060) and the end of the 21st century (2080-2100), compared with the recent time period (1981-2000), for two emissions scenarios for the Caribbean Montane Wet Elfin Forest ecological system. Solid dots and error bars, respectively, represent the means and ranges of projections across climate models under each scenario.

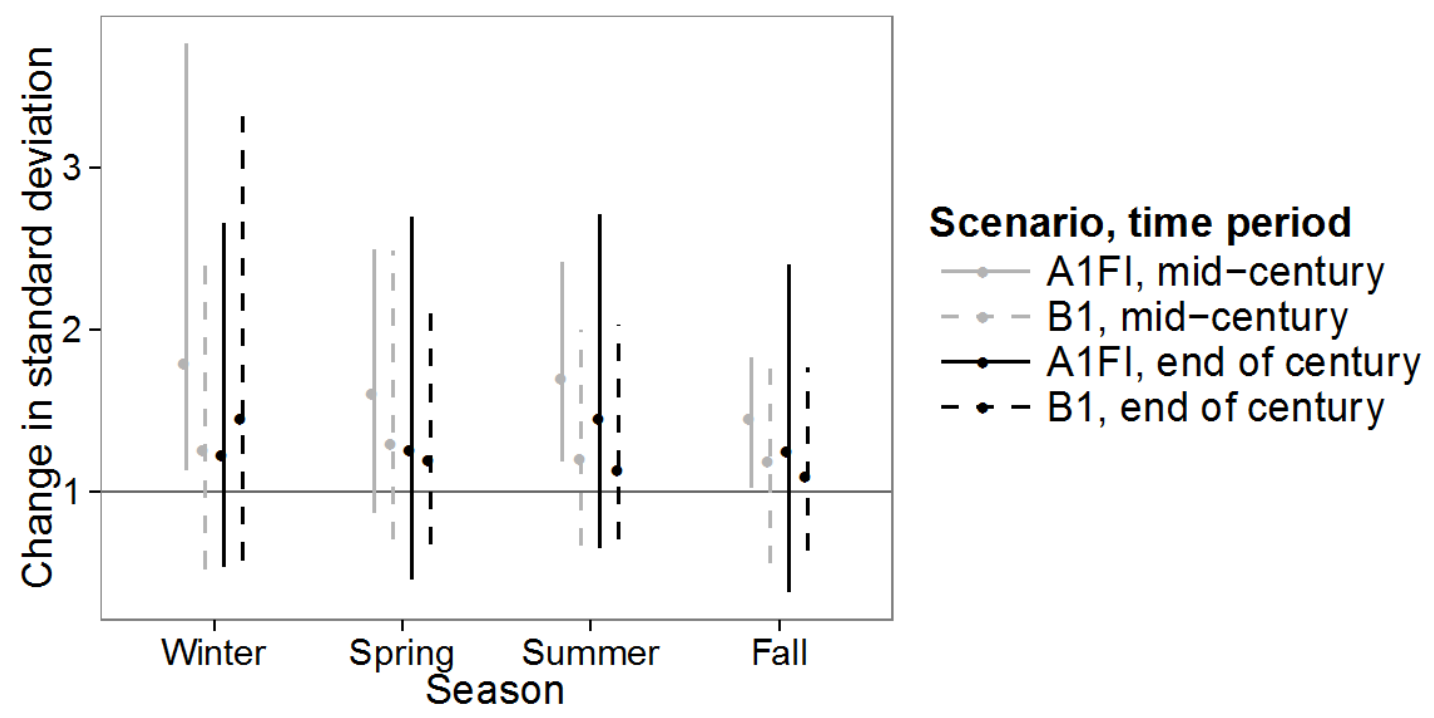

Figure C11. Projected change in standard deviation of seasonal minimum temperatures (in degrees Celsius) for the middle (2040-2060) and the end of the 21st century (2080-2100), compared with the recent time period (1981-2000), for two emissions scenarios for the Caribbean Montane Wet Elfin Forest ecological system. Solid dots and error bars, respectively, represent the means and ranges of projections across climate models under each scenario. 


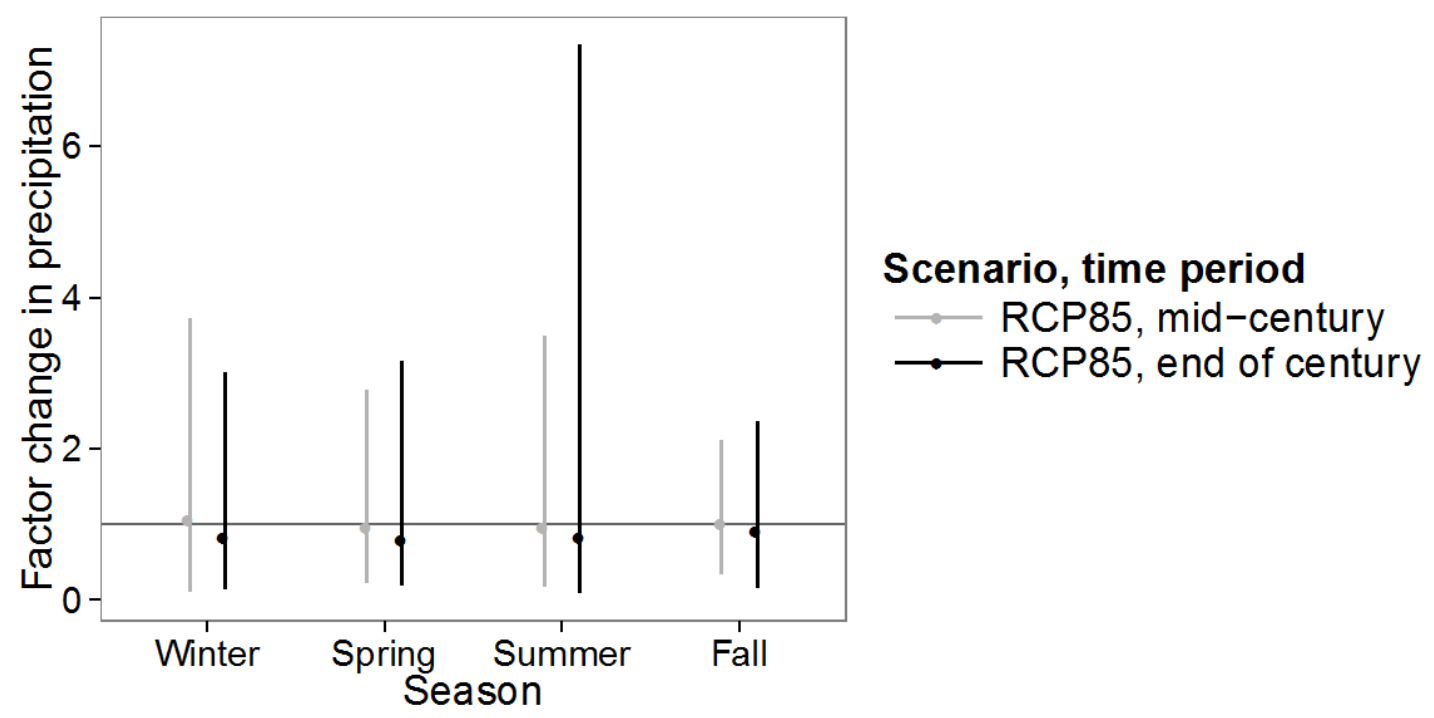

Figure C12. Projected change in standard deviation of seasonal average precipitation for the middle (2040-2060) and the end of the 21st century (2080-2100), compared with the recent time period (19812000), for a high-emissions scenario for the Caribbean Montane Wet Elfin Forest ecological system. Solid dots and error bars represent, respectively, the means and ranges of projections across climate models under the scenario. 


\section{Central Atlantic Coastal Plain Wet Longleaf Pine Savanna and Flatwoods}

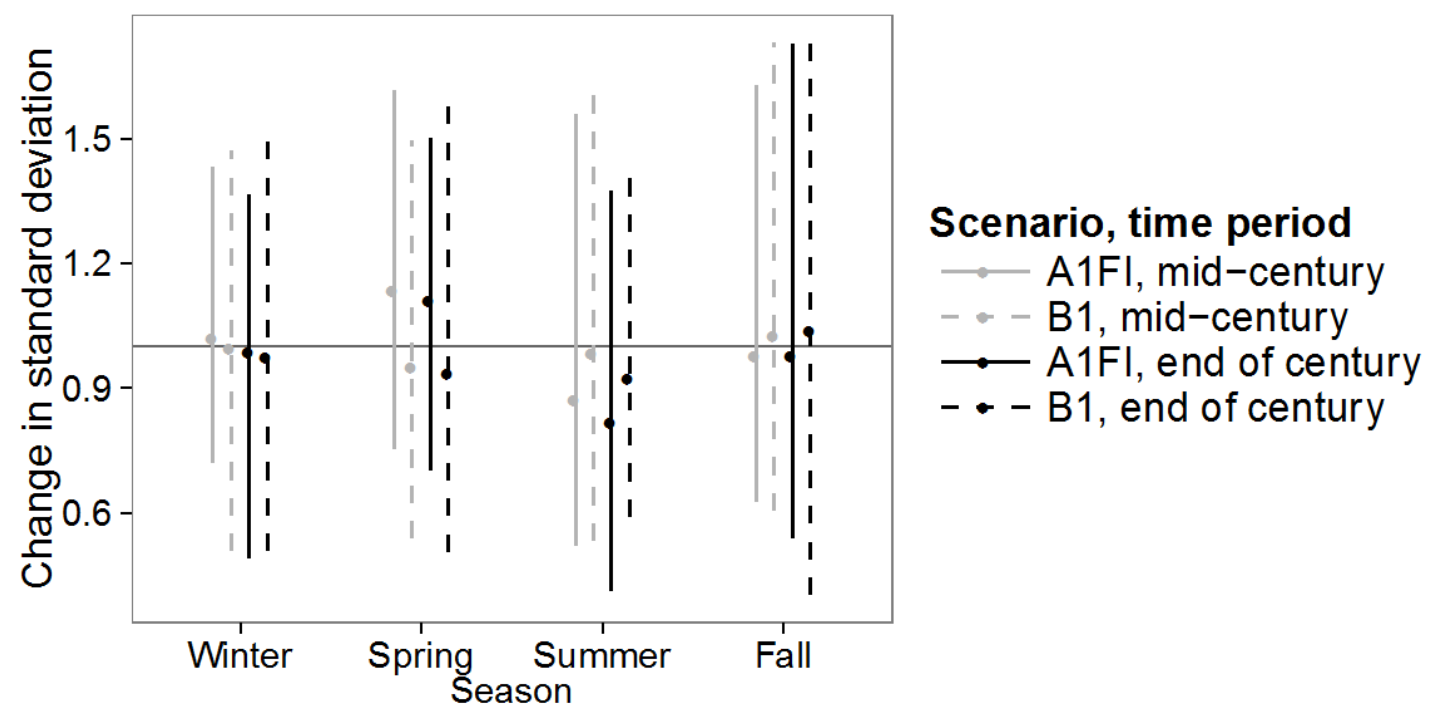

Figure C13. Projected change in standard deviation of seasonal maximum temperatures (in degrees Celsius) for the middle (2040-2060) and the end of the 21st century (2080-2100), compared with the recent time period (1981-2000), for two emissions scenarios for the Central Atlantic Coastal Plain Wet Longleaf Pine Savanna and Flatwoods system. Solid dots and error bars represent, respectively, the means and ranges of projections across climate models under each scenario.

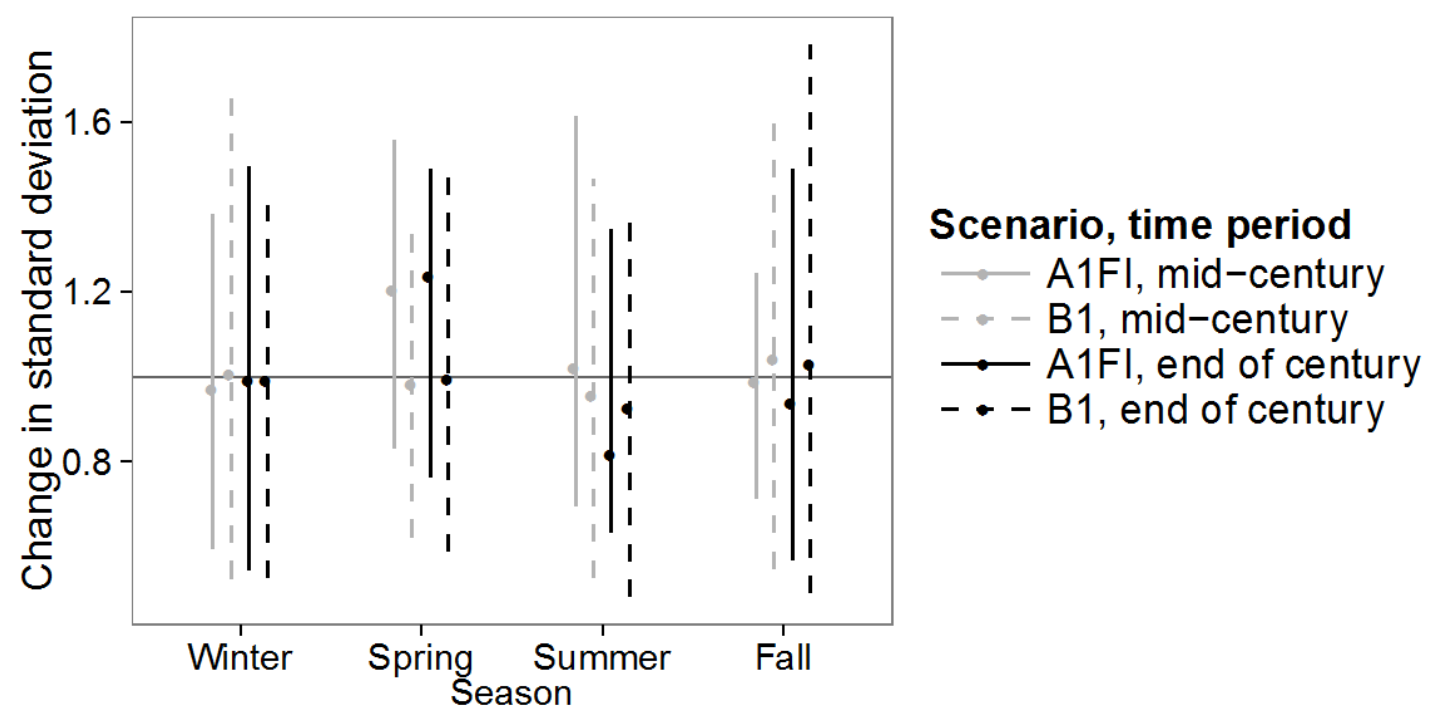

Figure C14. Projected change in standard deviation of seasonal minimum temperatures (in degrees Celsius) for the middle (2040-2060) and the end of the 21st century (2080-2100), compared with the recent time period (1981-2000), for two emissions scenarios for the Central Atlantic Coastal Plain Wet Longleaf Pine Savanna and Flatwoods system. Solid dots and error bars represent, respectively, the means and ranges of projections across climate models under each scenario. 


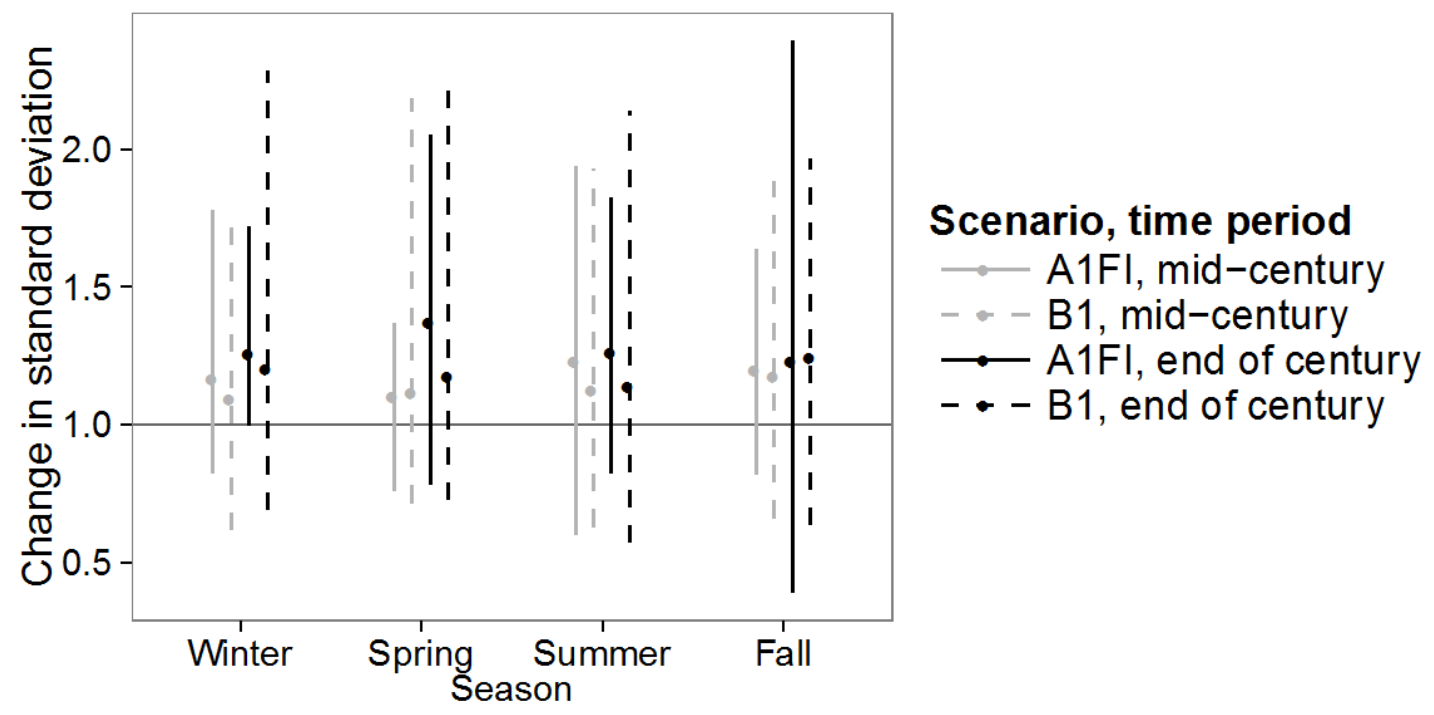

Figure C15. Projected change in standard deviation of seasonal average precipitation for the middle (2040-2060) and the end of the 21st century (2080-2100), compared with the recent time period (19812000), for two emissions scenarios for the Central Atlantic Coastal Plain Wet Longleaf Pine Savanna and Flatwoods system. Solid dots and error bars represent, respectively, the means and ranges of projections across climate models under each scenario. 


\section{Central Florida Wet Prairie and Herbaceous Seep}

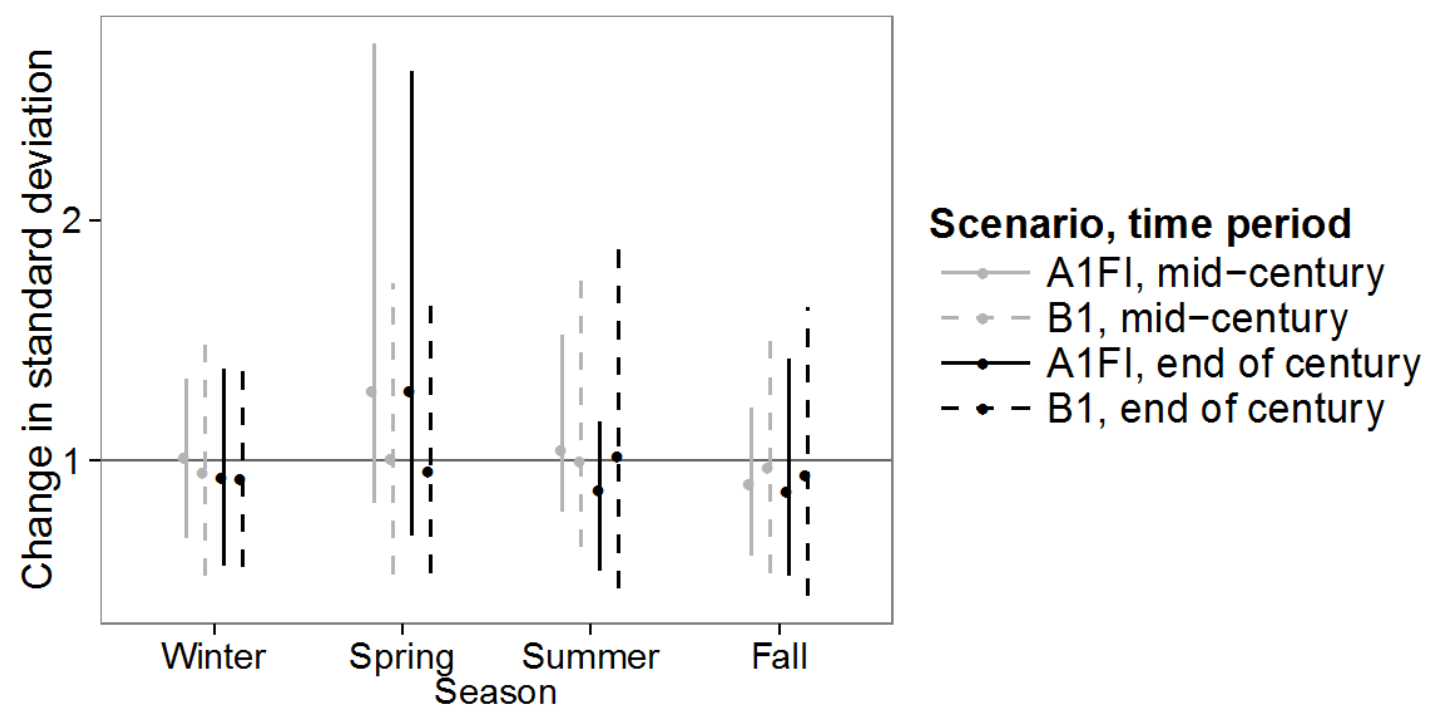

Figure C16. Projected change in standard deviation of seasonal maximum temperatures (in degrees Celsius) for the middle (2040-2060) and the end of the 21st century (2080-2100), compared with the recent time period (1981-2000), for two emissions scenarios for the Central Florida Wet Prairie and Herbaceous Seep ecological system. Solid dots and error bars represent, respectively, the means and ranges of projections across climate models under each scenario.

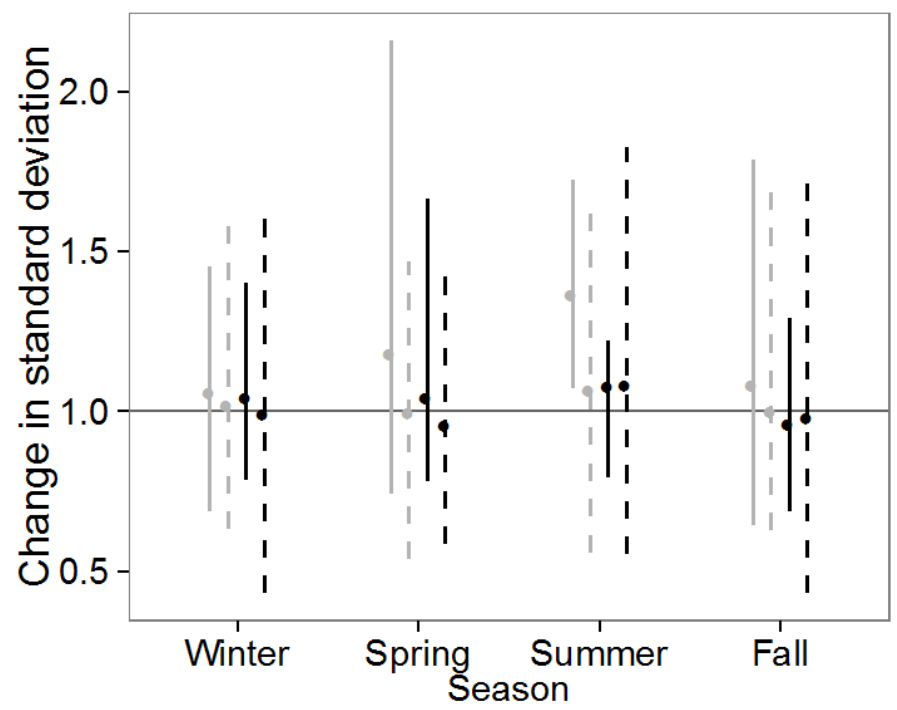

Scenario, time period A1FI, mid-century

- B1, mid-century

$\rightarrow \mathrm{A} 1 \mathrm{FI}$, end of century

- - B1, end of century

Figure C17. Projected change in standard deviation of seasonal minimum temperatures (in degrees Celsius) for the middle (2040-2060) and the end of the 21st century (2080-2100), compared with the recent time period (1981-2000), for two emissions scenarios for the Central Florida Wet Prairie and Herbaceous Seep ecological system. Solid dots and error bars represent, respectively, the means and ranges of projections across climate models under each scenario. 


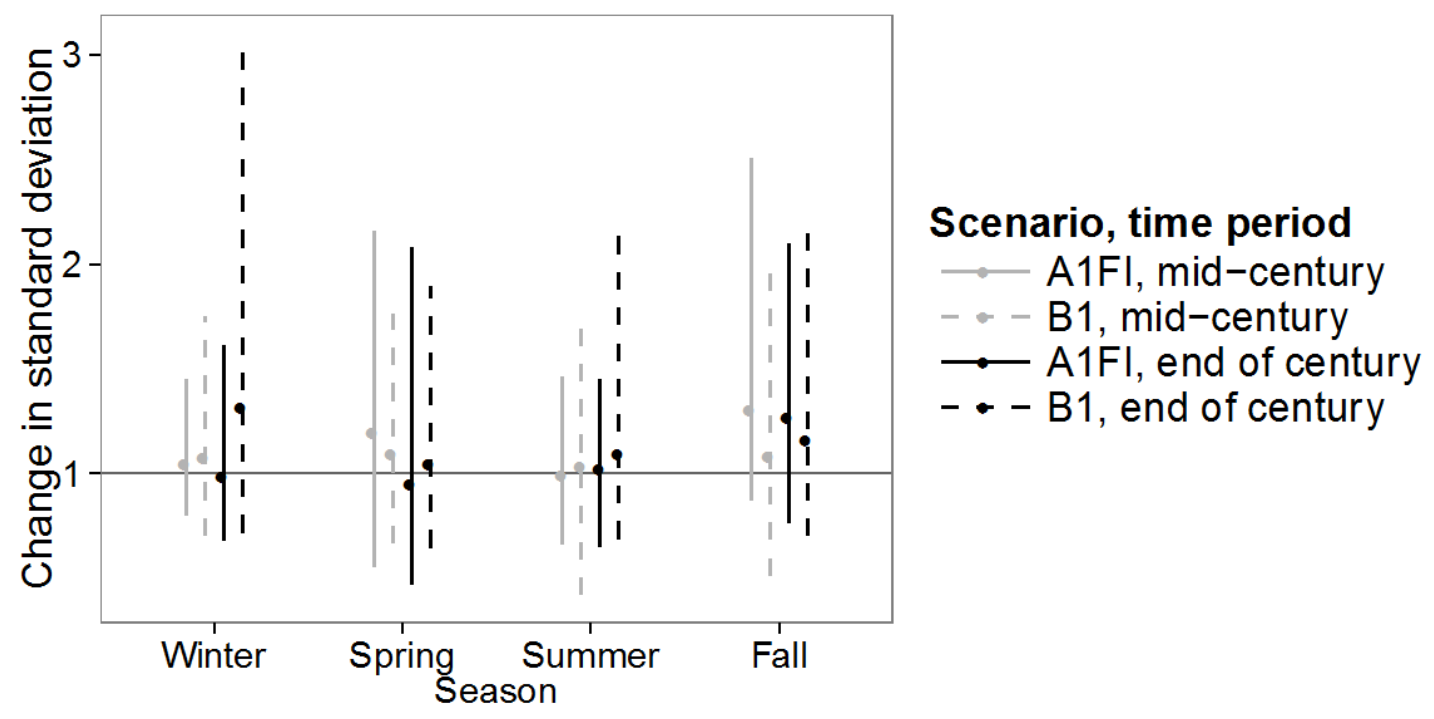

Figure C18. Projected change in standard deviation of seasonal average precipitation for the middle (2040-2060) and the end of the 21st century (2080-2100), compared with the recent time period (19812000), for two emissions scenarios for the Central Florida Wet Prairie and Herbaceous Seep ecological system. Solid dots and error bars represent, respectively, the means and ranges of projections across climate models under each scenario. 


\section{East Gulf Coastal Plain Near-Coast Pine Flatwoods}

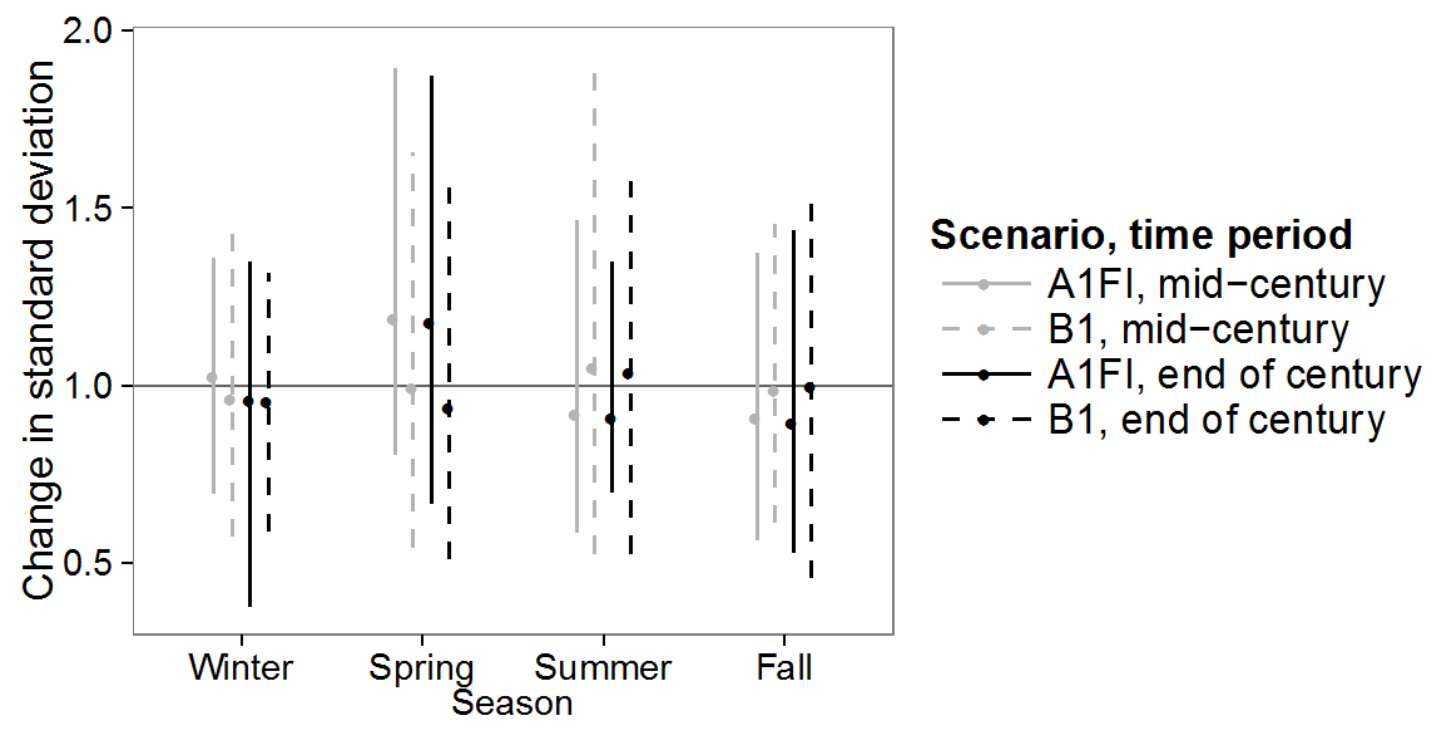

Figure C19. Projected change in standard deviation of seasonal maximum temperatures (in degrees Celsius) for the middle (2040-2060) and the end of the 21st century (2080-2100), compared with the recent time period (1981-2000), for two emissions scenarios for the East Gulf Coastal Plain Near-Coast Pine Flatwoods ecological system. Solid dots and error bars represent, respectively, the means and ranges of projections across climate models under each scenario.

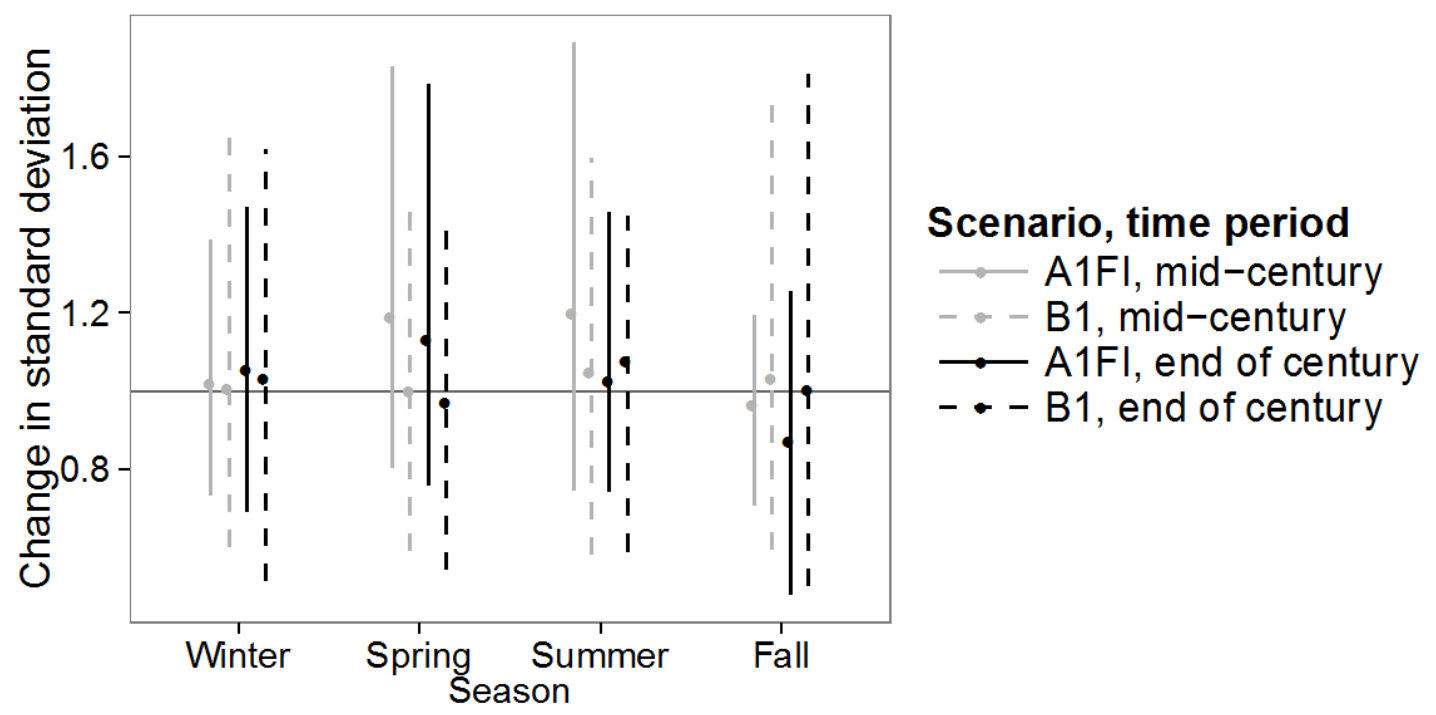

Figure C20. Projected change in standard deviation of seasonal minimum temperatures (in degrees Celsius) for the middle (2040-2060) and the end of the 21st century (2080-2100), compared with the recent time period (1981-2000), for two emissions scenarios for the East Gulf Coastal Plain Near-Coast Pine Flatwoods ecological system. Solid dots and error bars represent, respectively, the means and ranges of projections across climate models under each scenario. 


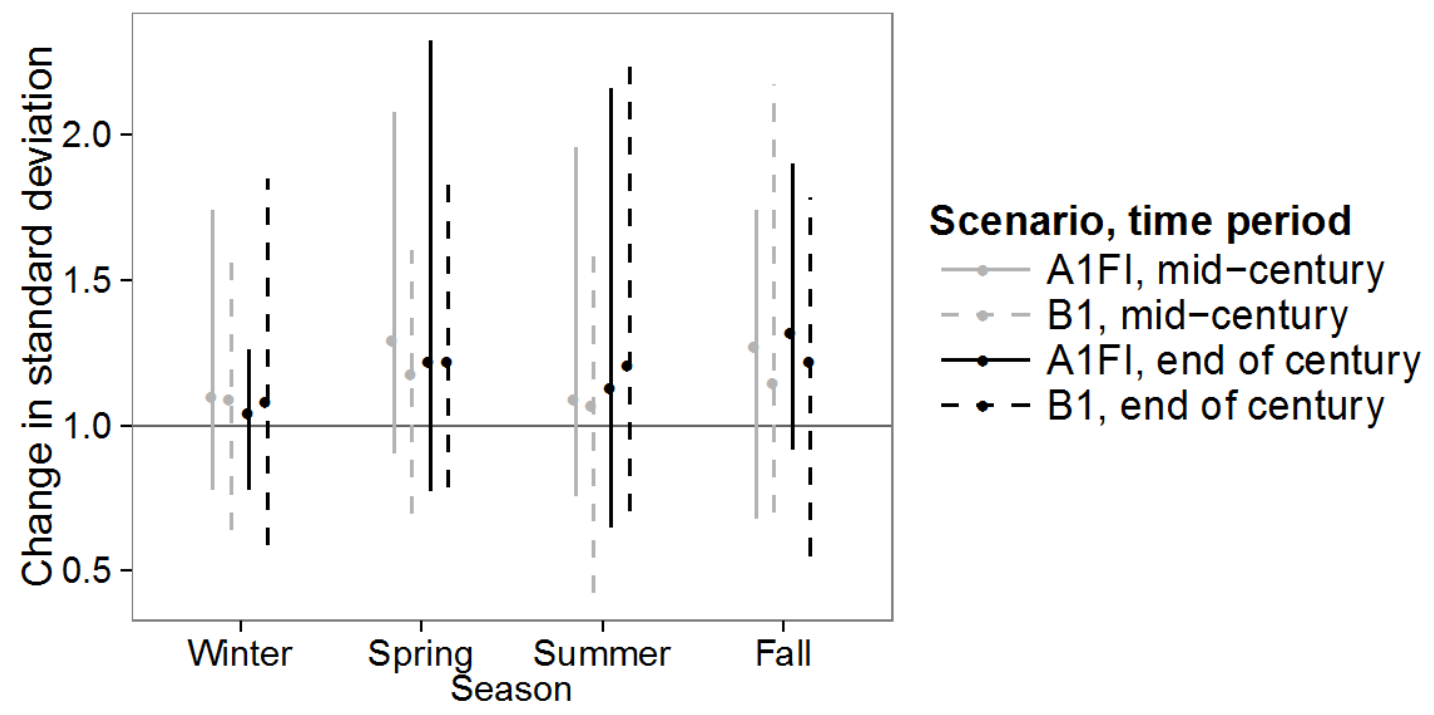

Figure C21. Projected change in standard deviation of seasonal average precipitation for the middle (2040-2060) and the end of the 21st century (2080-2100), compared with the recent time period (19812000), for two emissions scenarios for the East Gulf Coastal Plain Near-Coast Pine Flatwoods ecological system. Solid dots and error bars represent, respectively, the means and ranges of projections across climate models under each scenario. 


\section{East Gulf Coastal Plain Southern Loess Bluff Forest}

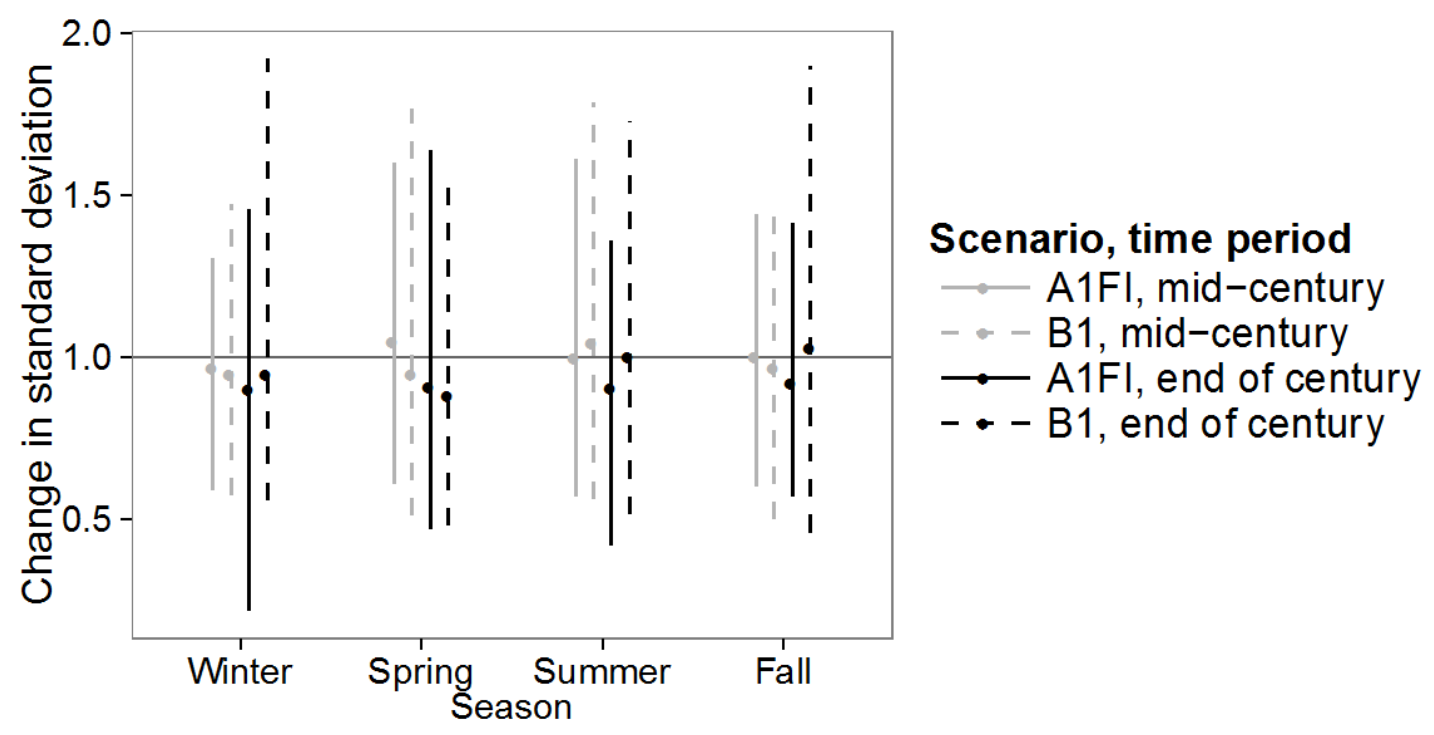

Figure C22. Projected change in standard deviation of seasonal maximum temperatures (in degrees Celsius) for the middle (2040-2060) and the end of the 21st century (2080-2100), compared with the recent time period (1981-2000), for two emissions scenarios for the East Gulf Coastal Plain Southern Loess Bluff Forest ecological system. Solid dots and error bars represent, respectively, the means and ranges of projections across climate models under each scenario.

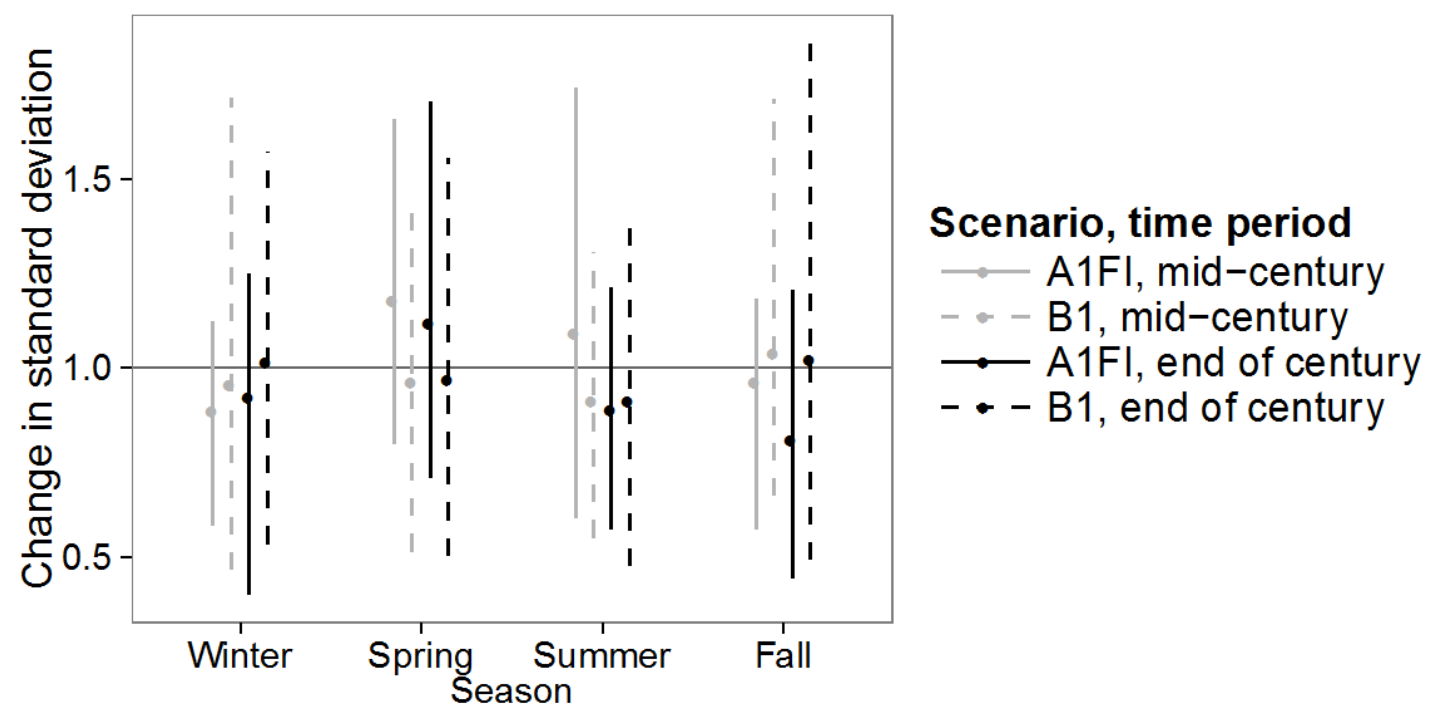

Figure C23. Projected change in standard deviation of seasonal minimum temperatures (in degrees Celsius) for the middle (2040-2060) and the end of the 21st century (2080-2100), compared with the recent time period (1981-2000), for two emissions scenarios for the East Gulf Coastal Plain Southern Loess Bluff Forest ecological system. Solid dots and error bars represent, respectively, the means and ranges of projections across climate models under each scenario. 


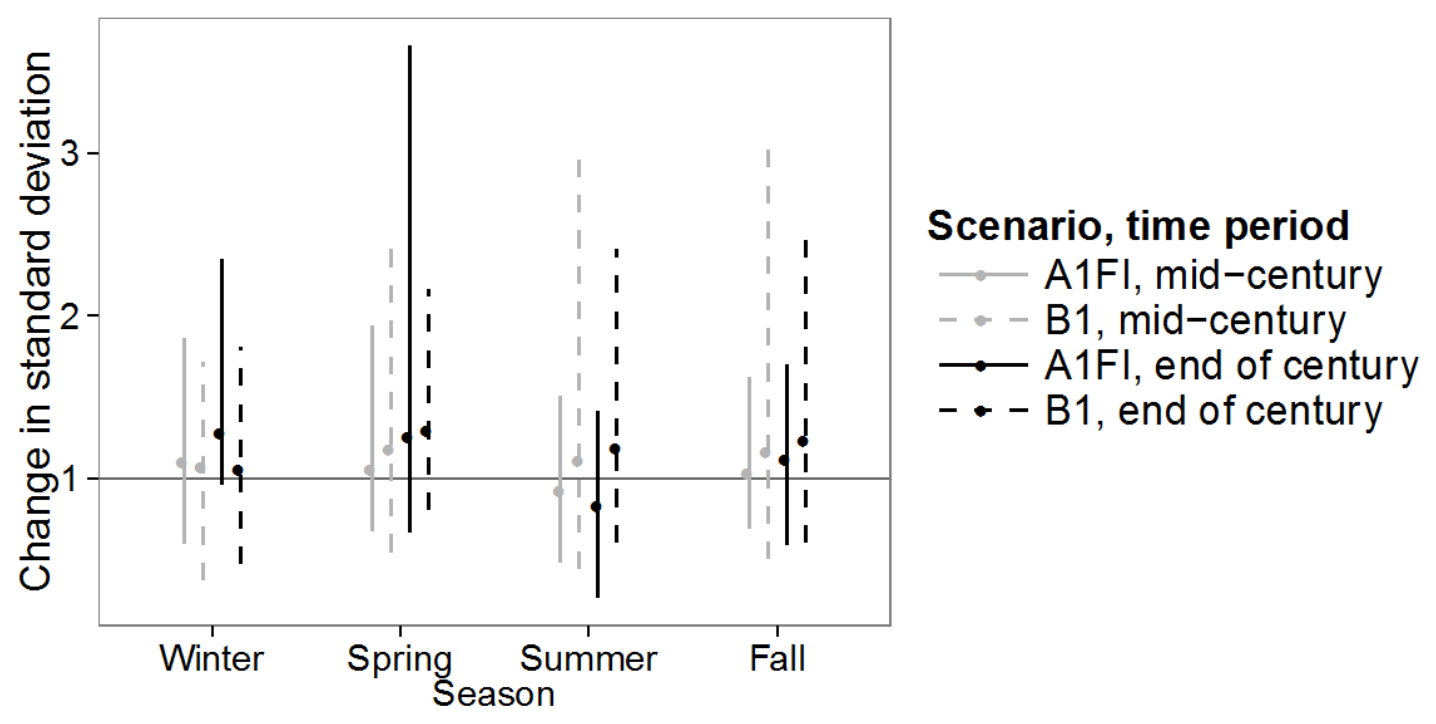

Figure C24. Projected change in standard deviation of seasonal average precipitation for the middle (2040-2060) and the end of the 21st century (2080-2100), compared with the recent time period (19812000), for two emissions scenarios for the East Gulf Coastal Plain Southern Loess Bluff Forest ecological system. Solid dots and error bars represent, respectively, the means and ranges of projections across climate models under each scenario. 


\section{Edwards Plateau Limestone Shrubland}

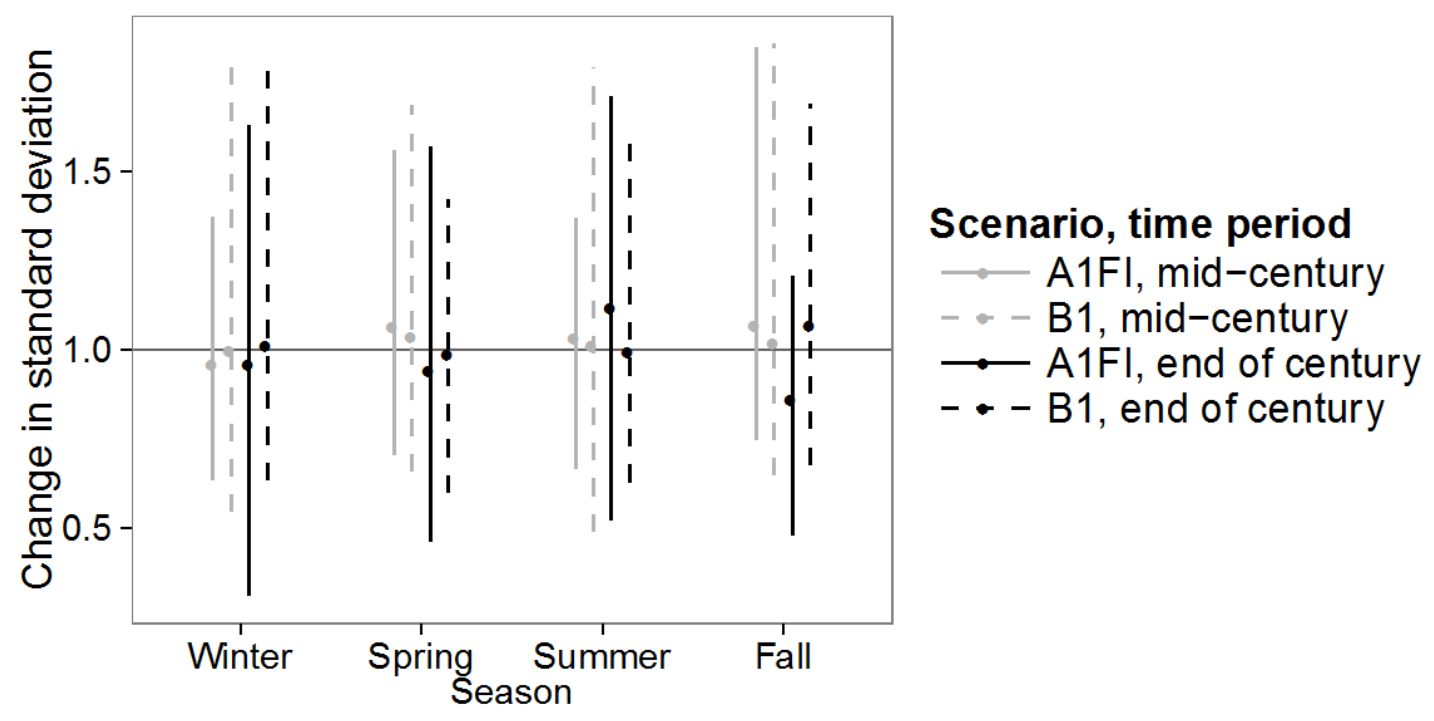

Figure C25. Projected change in standard deviation of seasonal maximum temperatures (in degrees Celsius) for the middle (2040-2060) and the end of the 21st century (2080-2100), compared with the recent time period (1981-2000), for two emissions scenarios for the Edwards Plateau Limestone Shrubland ecological system. Solid dots and error bars represent, respectively, the means and ranges of projections across climate models under each scenario.

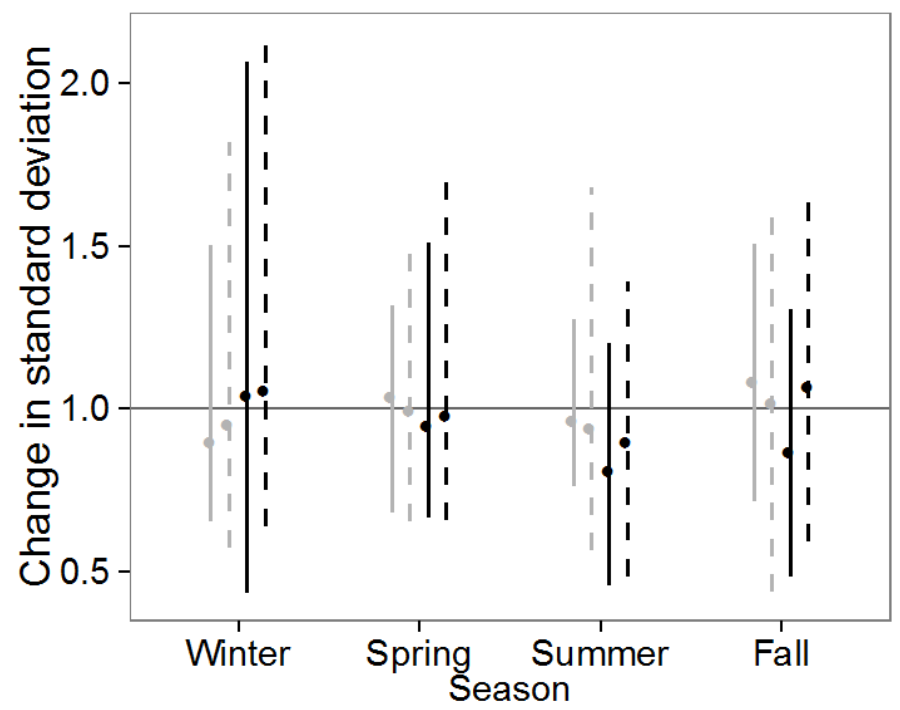

Scenario, time period A1FI, mid-century

- B1, mid-century

$\rightarrow \mathrm{A} 1 \mathrm{FI}$, end of century

- - B1, end of century

Figure C26. Projected change in standard deviation of seasonal minimum temperatures (in degrees Celsius) for the middle (2040-2060) and the end of the 21st century (2080-2100), compared with the recent time period (1981-2000), for two emissions scenarios for the Edwards Plateau Limestone Shrubland ecological system. Solid dots and error bars represent, respectively, the means and ranges of projections across climate models under each scenario. 


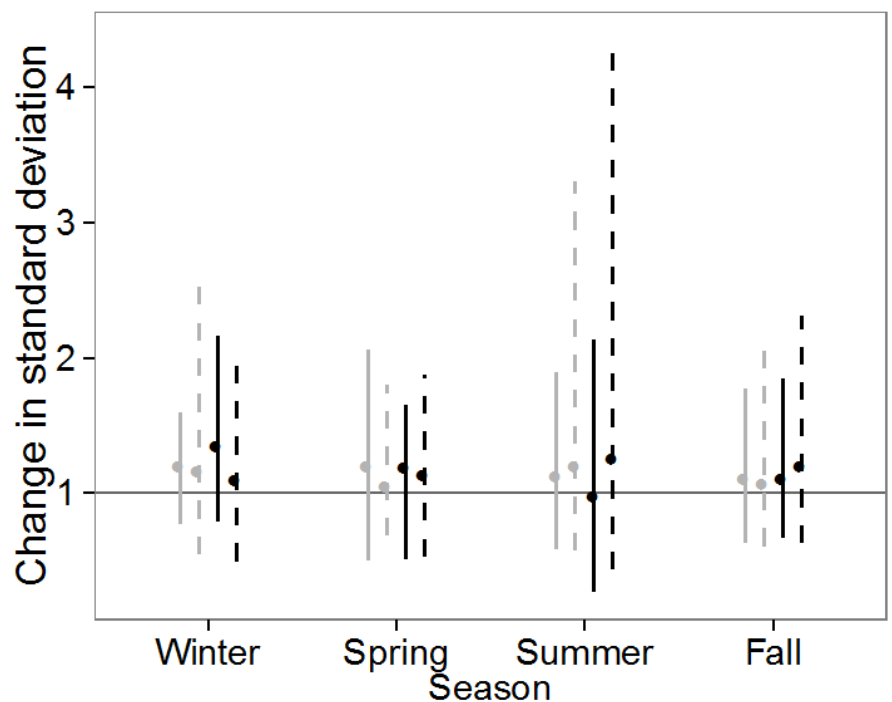

\section{Scenario, time period}

$\because \mathrm{A} 1 \mathrm{FI}$, mid-century

- B1, mid-century

$\rightarrow \mathrm{A} 1 \mathrm{FI}$, end of century

- - B1, end of century

Figure C27. Projected change in standard deviation of seasonal average precipitation for the middle (2040-2060) and the end of the 21st century (2080-2100), compared with the recent time period (19812000), for two emissions scenarios for the Edwards Plateau Limestone Shrubland ecological system. Solid dots and error bars represent, respectively, the means and ranges of projections across climate models under each scenario. 


\section{Edwards Plateau Mesic Canyon}

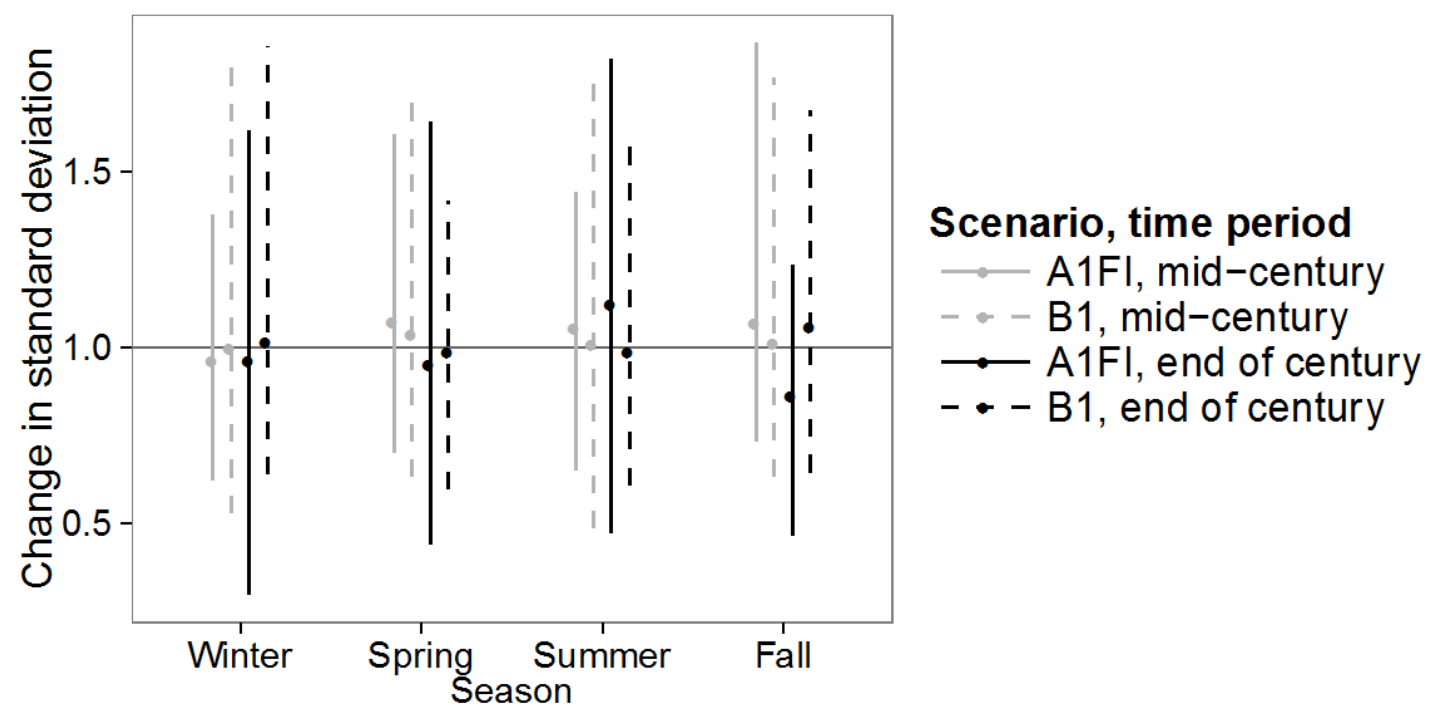

Figure C28. Projected change in standard deviation of seasonal maximum temperatures (in degrees Celsius) for the middle (2040-2060) and the end of the 21st century (2080-2100), compared with the recent time period (1981-2000) for two emissions scenarios for the Edwards Plateau Mesic Canyon ecological system. Solid dots and error bars represent, respectively, the means and ranges of projections across climate models under each scenario.

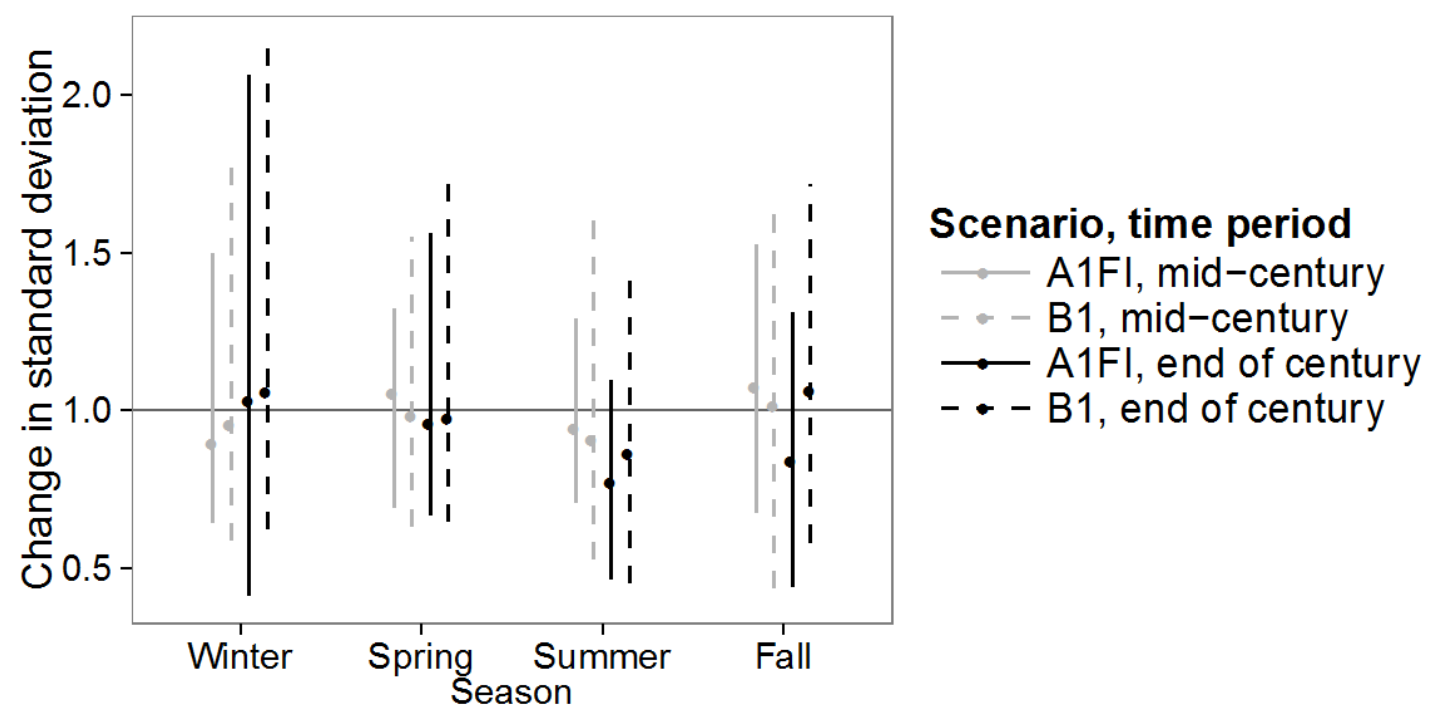

Figure C29. Projected change in standard deviation of seasonal minimum temperatures (in degrees Celsius) for the middle (2040-2060) and the end of the 21st century (2080-2100), compared with the recent time period (1981-2000), for two emissions scenarios for the Edwards Plateau Mesic Canyon ecological system. Solid dots and error bars represent, respectively, the means and ranges of projections across climate models under each scenario. 


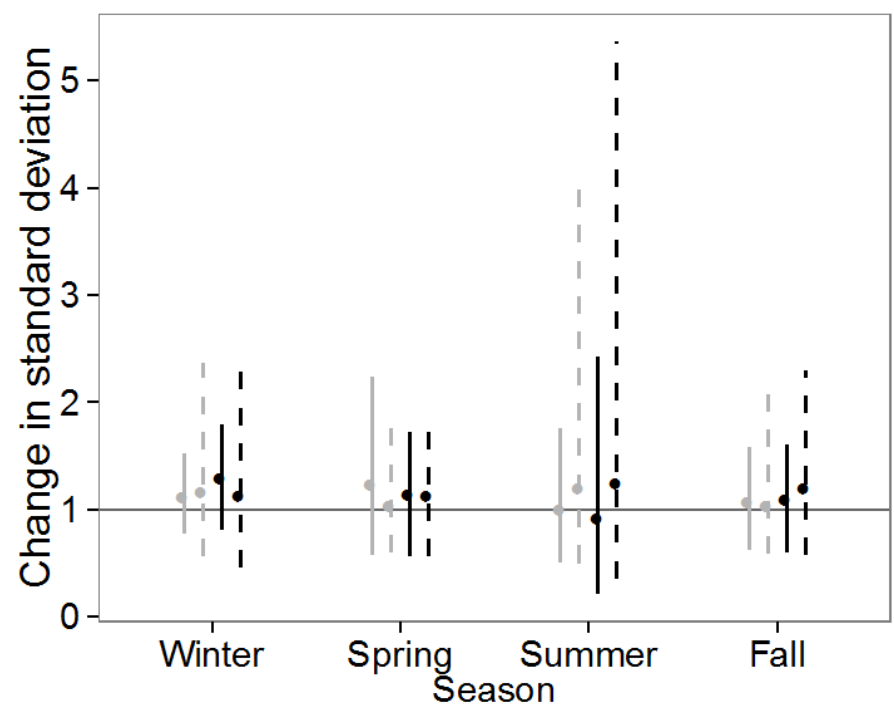

Scenario, time period

$\because \mathrm{A} 1 \mathrm{FI}$, mid-century

- B1, mid-century

$\rightarrow \mathrm{A} 1 \mathrm{FI}$, end of century

- - B1, end of century

Figure C30. Projected change in standard deviation of seasonal average precipitation for the middle (2040-2060) and the end of the 21st century (2080-2100), compared with the recent time period (19812000,) for two emissions scenarios for the Edwards Plateau Mesic Canyon ecological system. Solid dots and error bars represent, respectively, the means and ranges of projections across climate models under each scenario. 


\section{Nashville Basin Limestone Glade and Woodland}

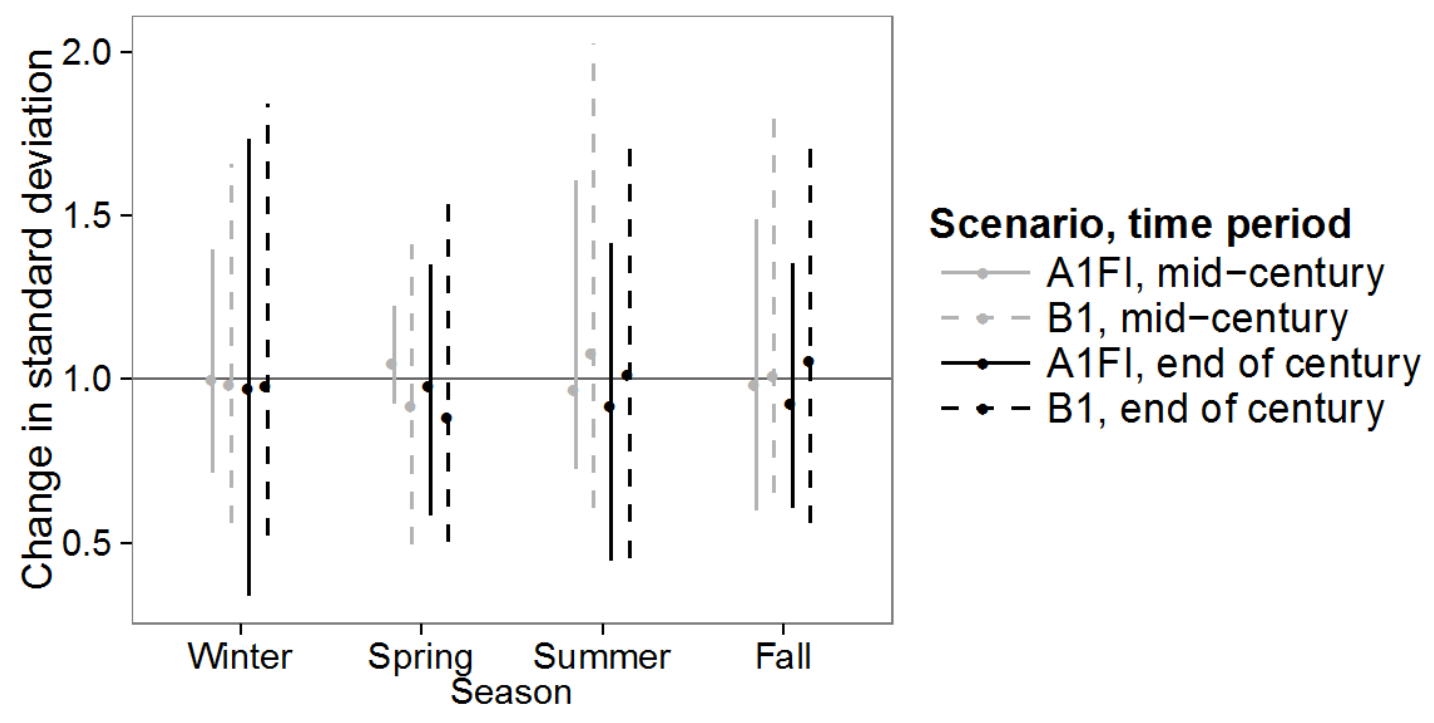

Figure C31. Projected change in standard deviation of seasonal maximum temperatures (in degrees Celsius) for the middle (2040-2060) and the end of the 21st century (2080-2100), compared with the recent time period (1981-2000), for two emissions scenarios for the Nashville Basin Limestone Glade and Woodland ecological system. Solid dots and error bars represent, respectively, the means and ranges of projections across climate models under each scenario.

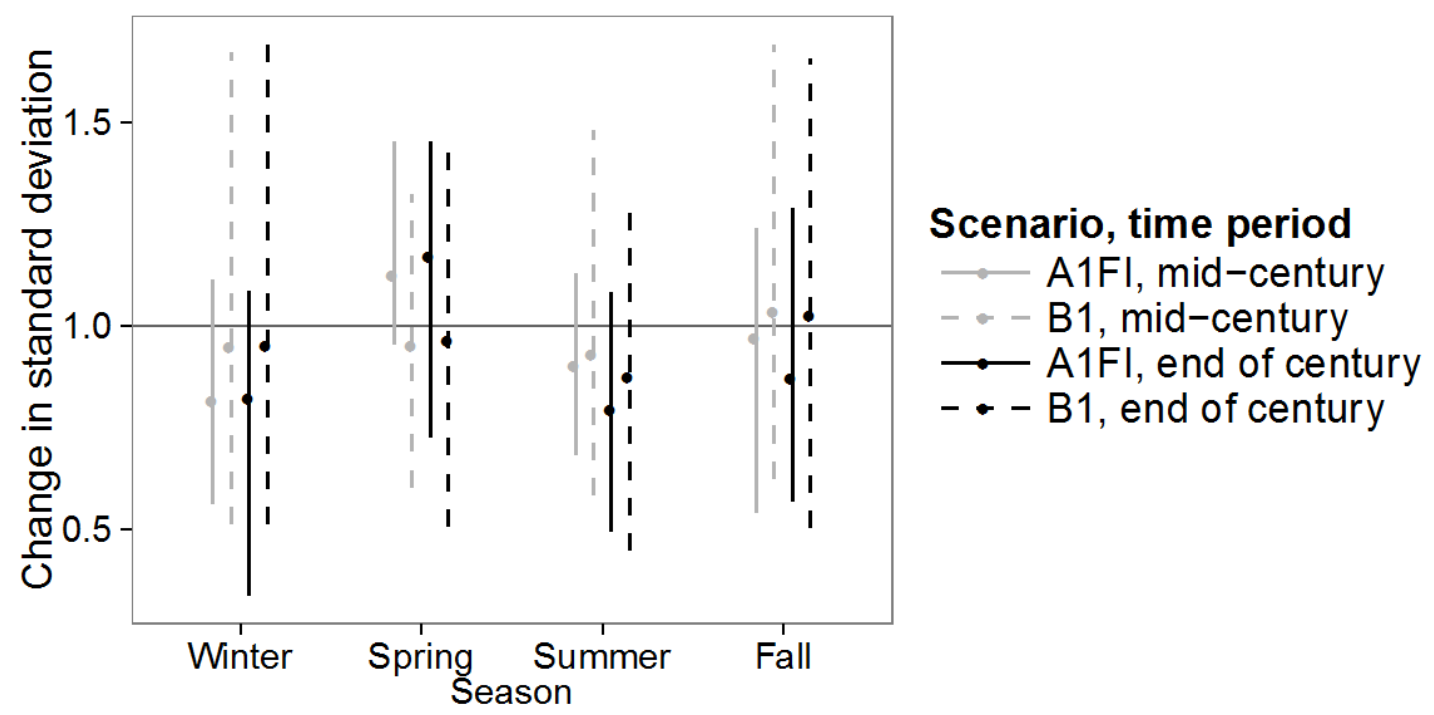

Figure C32. Projected change in standard deviation of seasonal minimum temperatures (in degrees Celsius) for the middle (2040-2060) and the end of the 21st century (2080-2100), compared with the recent time period (1981-2000), for two emissions scenarios for the Nashville Basin Limestone Glade and Woodland ecological system. Solid dots and error bars represent, respectively, the means and ranges of projections across climate models under each scenario. 


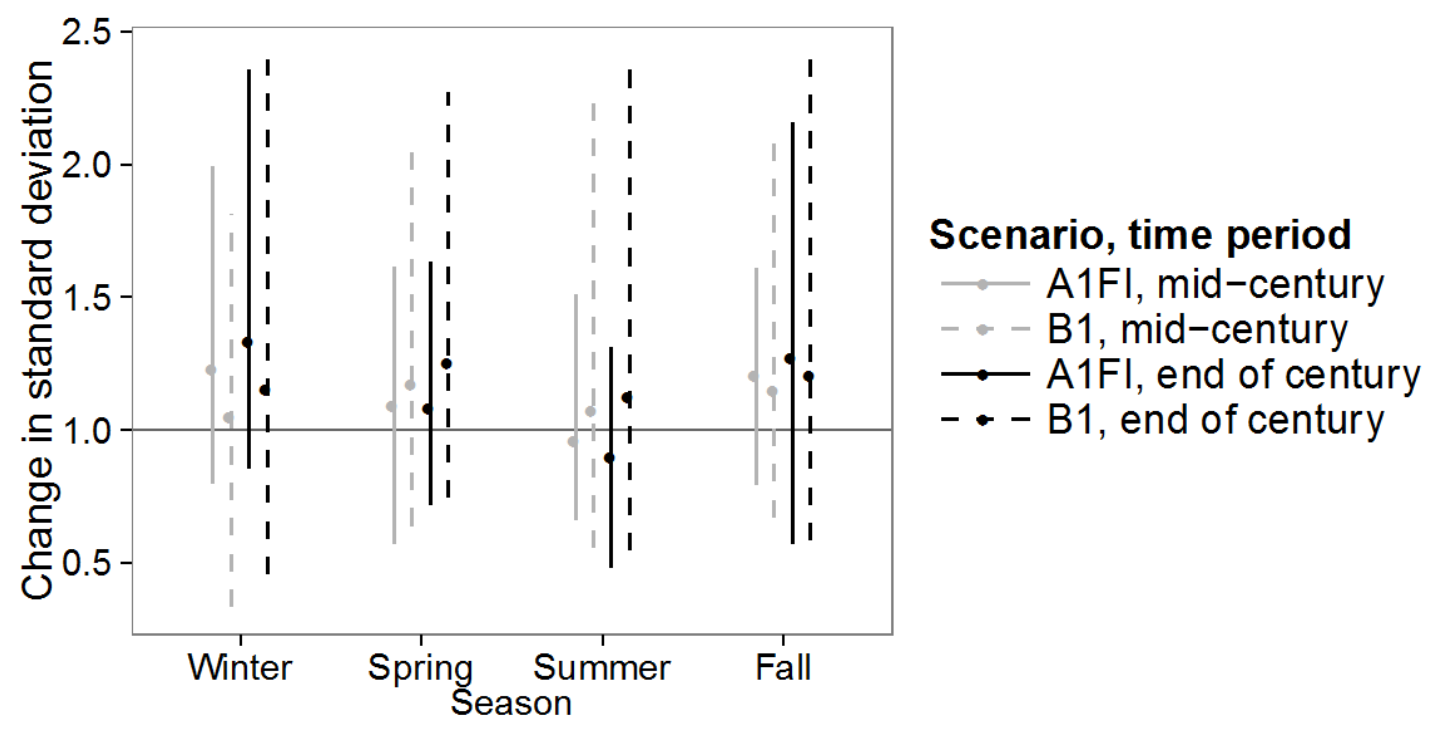

Figure C33. Projected change in standard deviation of seasonal average precipitation for the middle (2040-2060) and the end of the 21st century (2080-2100), compared with the recent time period (19812000), for two emissions scenarios for the Nashville Basin Limestone Glade and Woodland ecological system. Solid dots and error bars represent, respectively, the means and ranges of projections across climate models under each scenario. 


\section{South-Central Interior Mesophytic Forest}

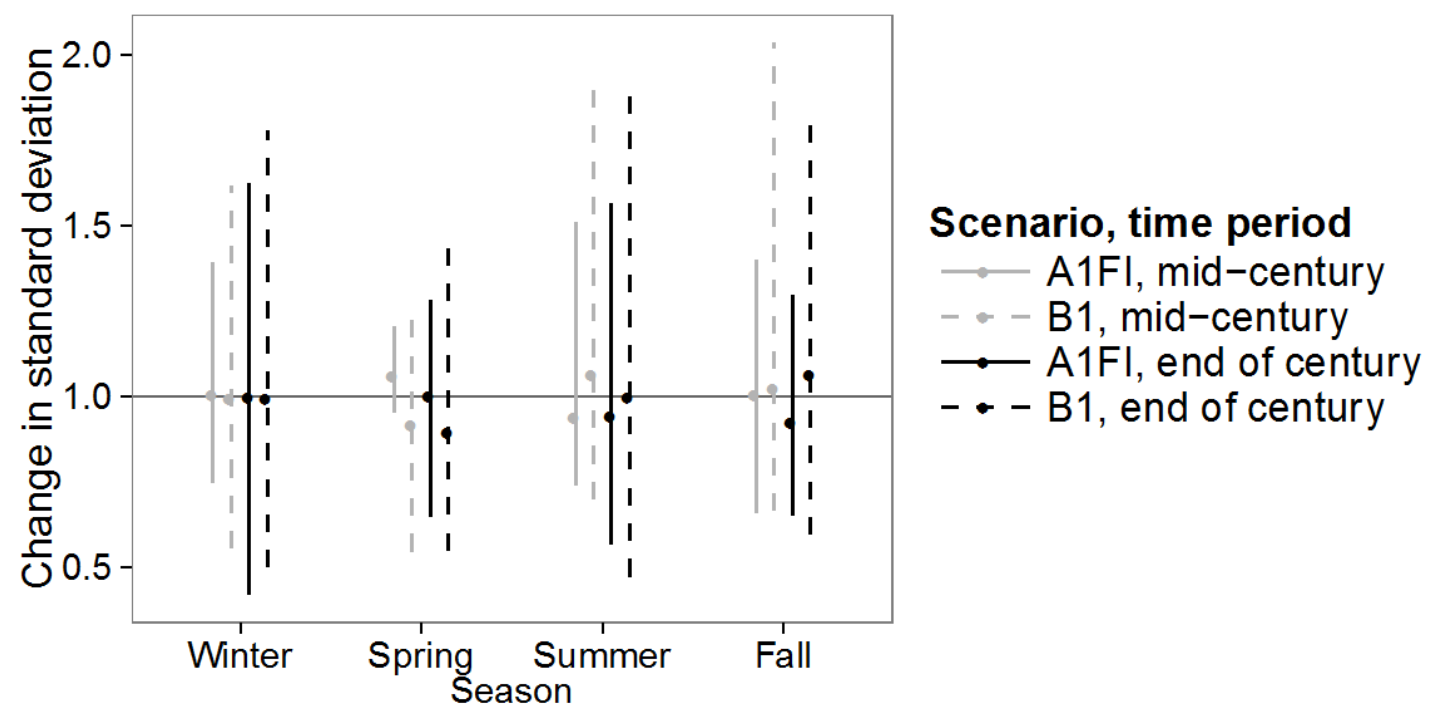

Figure C34. Projected change in standard deviation of seasonal maximum temperatures (in degrees Celsius) for the middle (2040-2060) and the end of the 21st century (2080-2100), compared with the recent time period (1981-2000), for two emissions scenarios for the South-Central Interior Mesophytic Forest ecological system. Solid dots and error bars represent, respectively, the means and ranges of projections across climate models under each scenario.

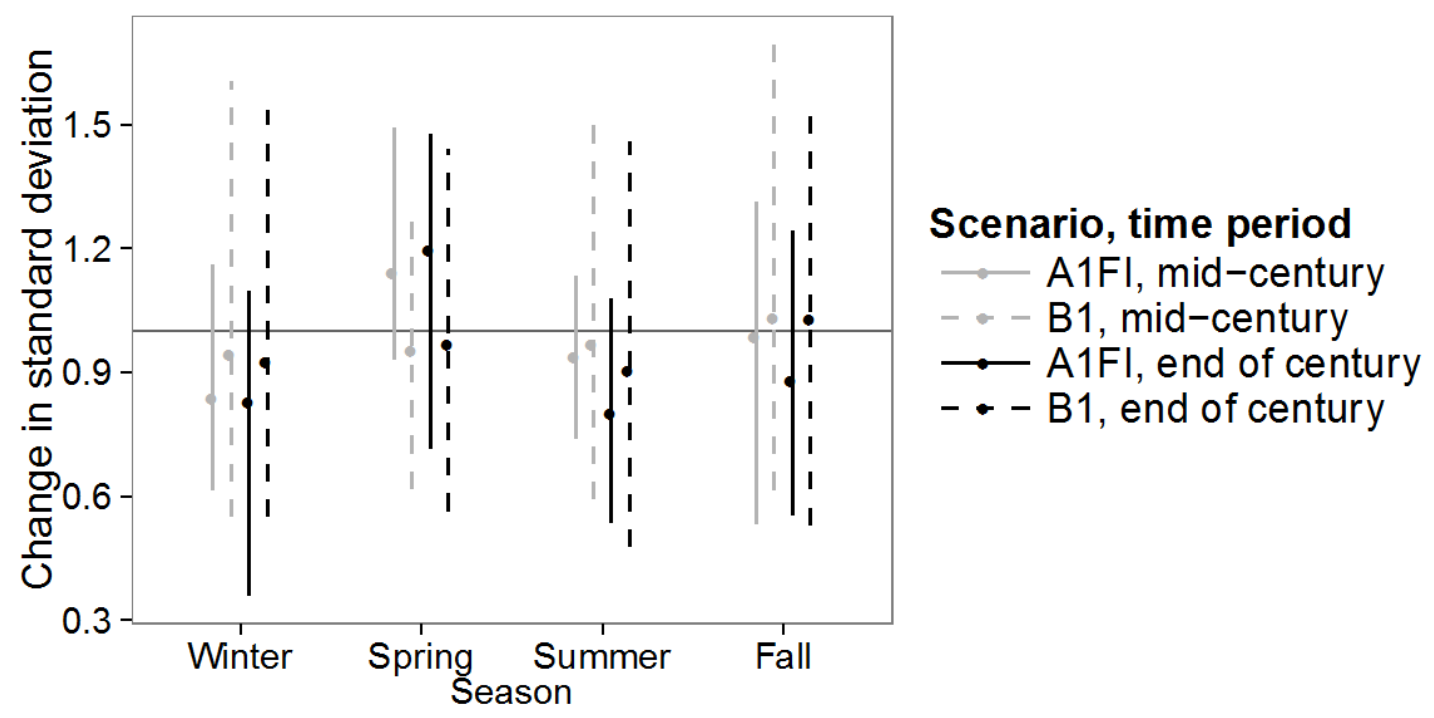

Figure C35. Projected change in standard deviation of seasonal minimum temperatures (in degrees Celsius) for the middle (2040-2060) and the end of the 21st century (2080-2100), compared with the recent time period (1981-2000), for two emissions scenarios for the South-Central Interior Mesophytic Forest ecological system. Solid dots and error bars represent, respectively, the means and ranges of projections across climate models under each scenario. 


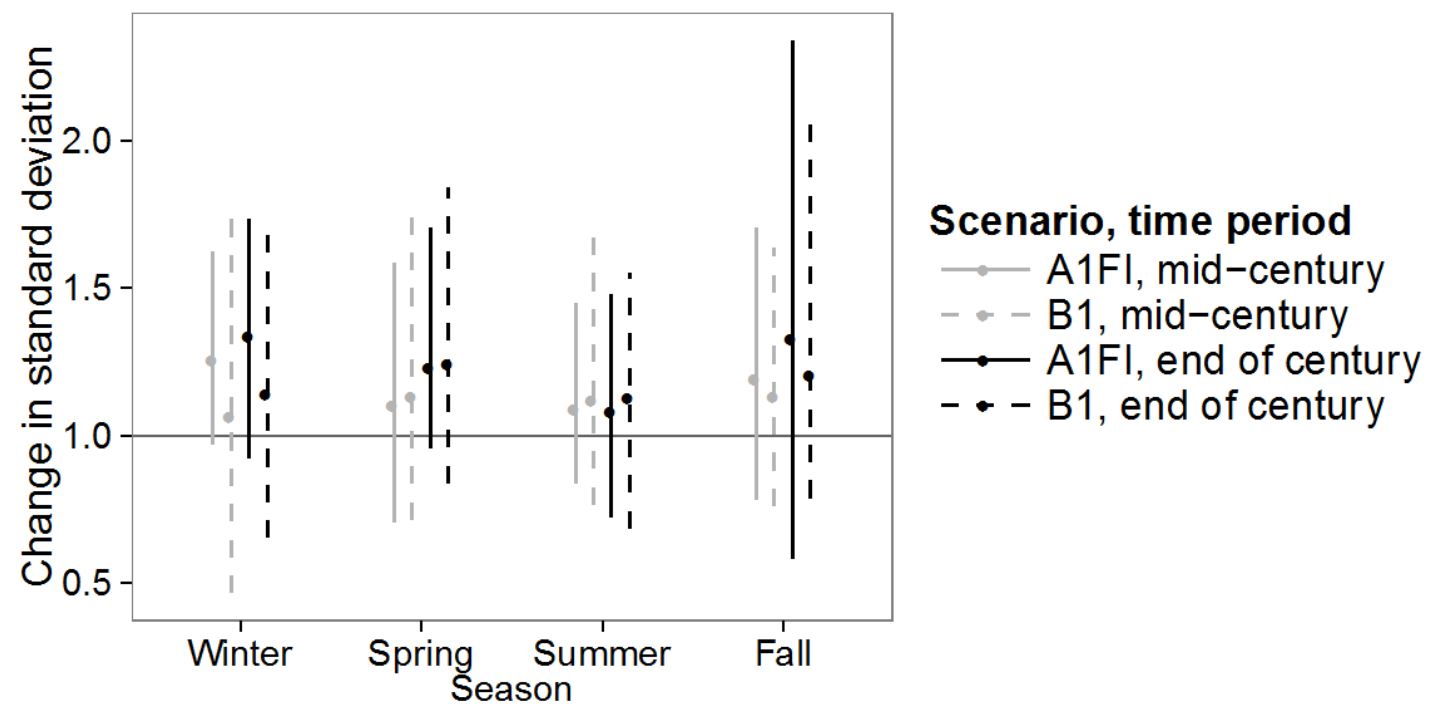

Figure C36. Projected change in standard deviation of seasonal average precipitation for the middle (2040-2060) and the end of the 21st century (2080-2100), compared with the recent time period (19812000), for two emissions scenarios for the South-Central Interior Mesophytic Forest ecological system. Solid dots and error bars represent, respectively, the means and ranges of projections across climate models under each scenario. 


\section{Southern Coastal Plain Nonriverine Cypress Dome}

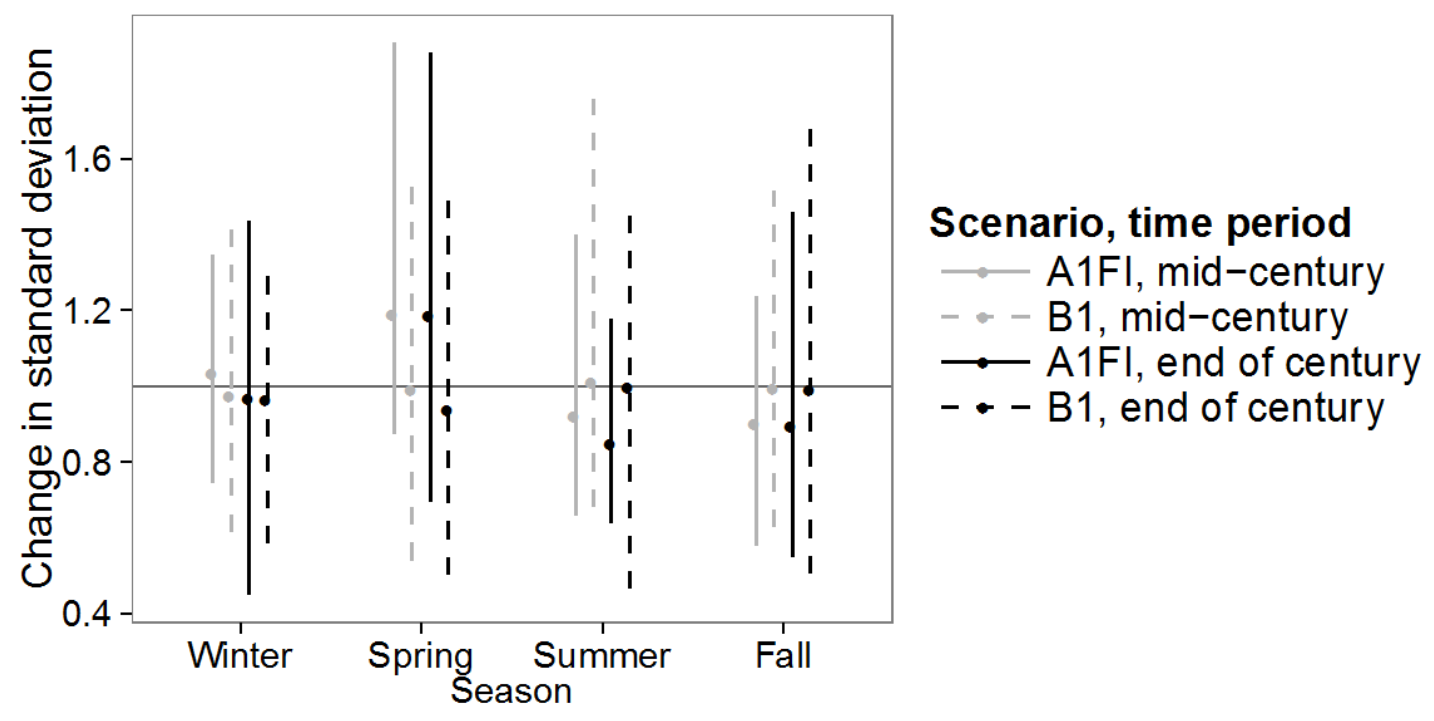

Figure C37. Projected change in standard deviation of seasonal maximum temperatures (in degrees Celsius) for the middle (2040-2060) and the end of the 21st century (2080-2100), compared with the recent time period (1981-2000), for two emissions scenarios for the Southern Coastal Plain Nonriverine Cypress Dome ecological system. Solid dots and error bars represent, respectively, the means and ranges of projections across climate models under each scenario.

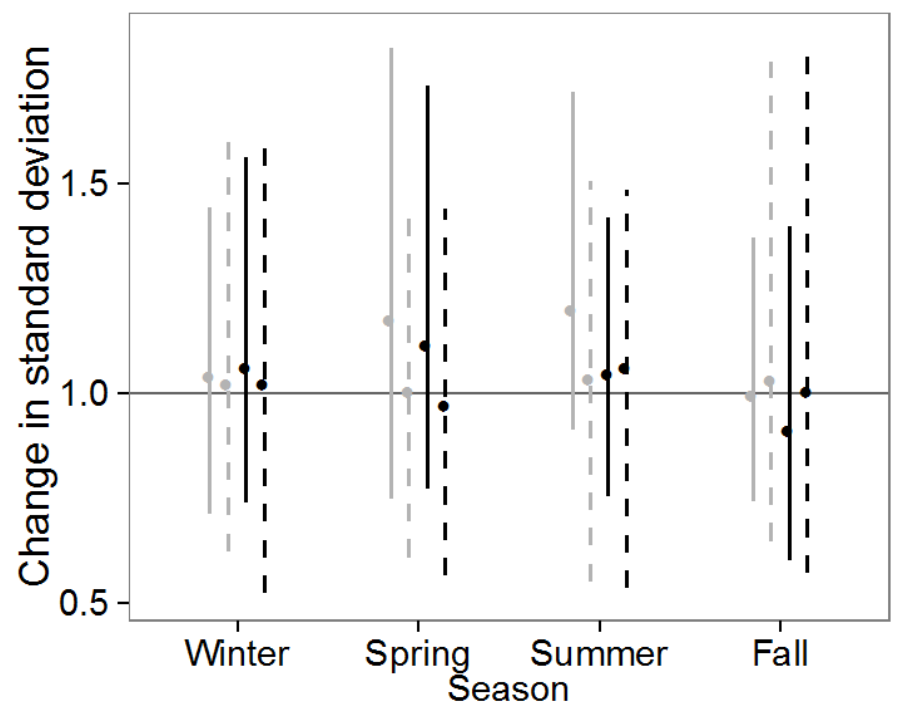

Scenario, time period A1FI, mid-century

- B1, mid-century A1FI, end of century

- - B1, end of century

Figure C38. Projected change in standard deviation of seasonal minimum temperatures (in degrees Celsius) for the middle (2040-2060) and the end of the 21st century (2080-2100), compared with the recent time period (1981-2000), for two emissions scenarios for the Southern Coastal Plain Nonriverine Cypress Dome ecological system. Solid dots and error bars represent, respectively, the means and ranges of projections across climate models under each scenario. 


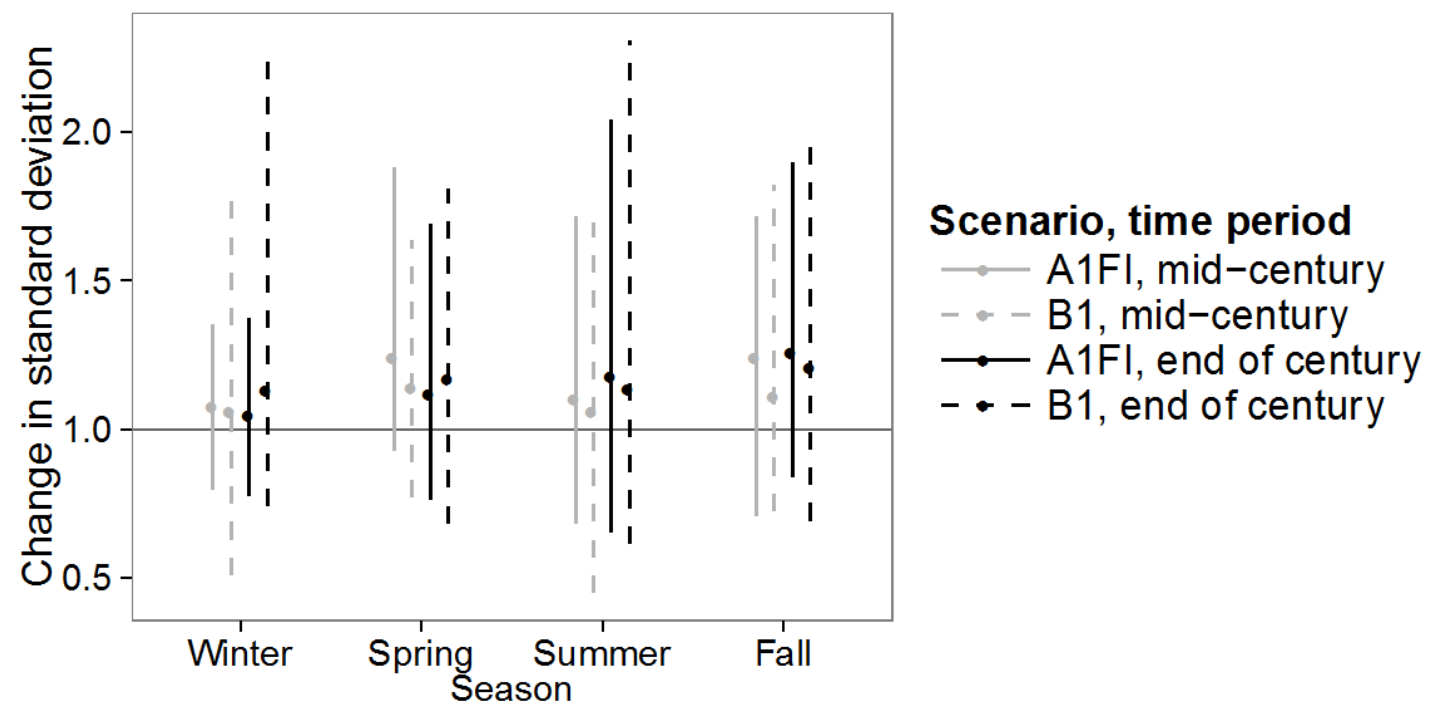

Figure C39. Projected change in standard deviation of seasonal average precipitation for the middle (20402060) and the end of the 21st century (2080-2100), compared with the recent time period (1981-2000), for two emissions scenarios for the Southern Coastal Plain Nonriverine Cypress Dome ecological system. Solid dots and error bars represent, respectively, the means and ranges of projections across climate models under each scenario. 


\section{Southern Coastal Plain Seepage Swamp and Baygall}

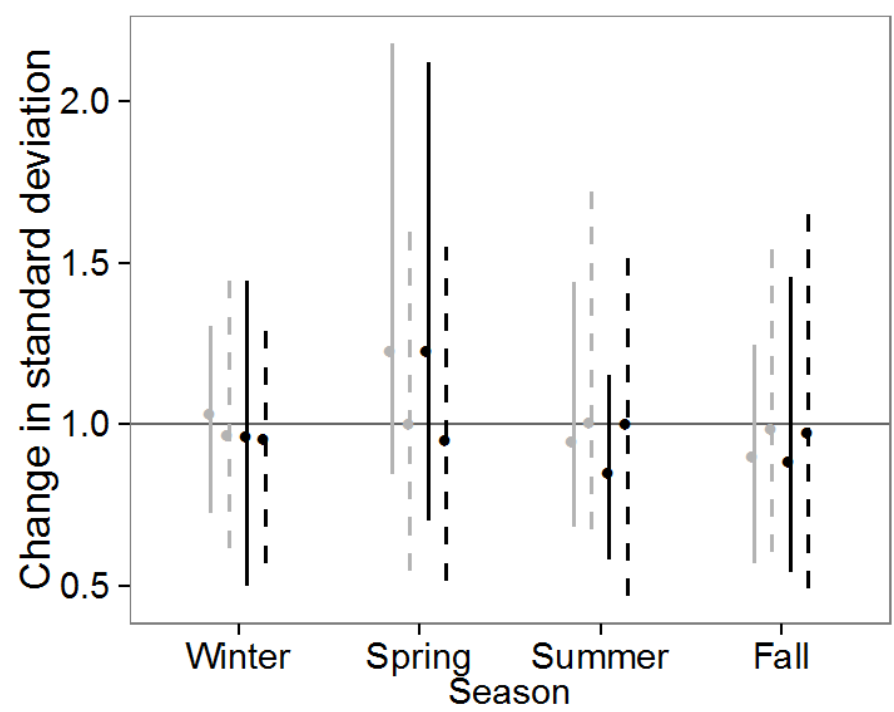

Scenario, time period A1FI, mid-century B1, mid-century $\mathrm{A} 1 \mathrm{FI}$, end of century - - B1, end of century

Figure C40. Projected change in standard deviation of seasonal maximum temperatures (in degrees Celsius) for the middle (2040-2060) and the end of the 21st century (2080-2100), compared with the recent time period (1981-2000), for two emissions scenarios for the Southern Coastal Plain Seepage Swamp and Baygall ecological system. Solid dots and error bars represent, respectively, the means and ranges of projections across climate models under each scenario.

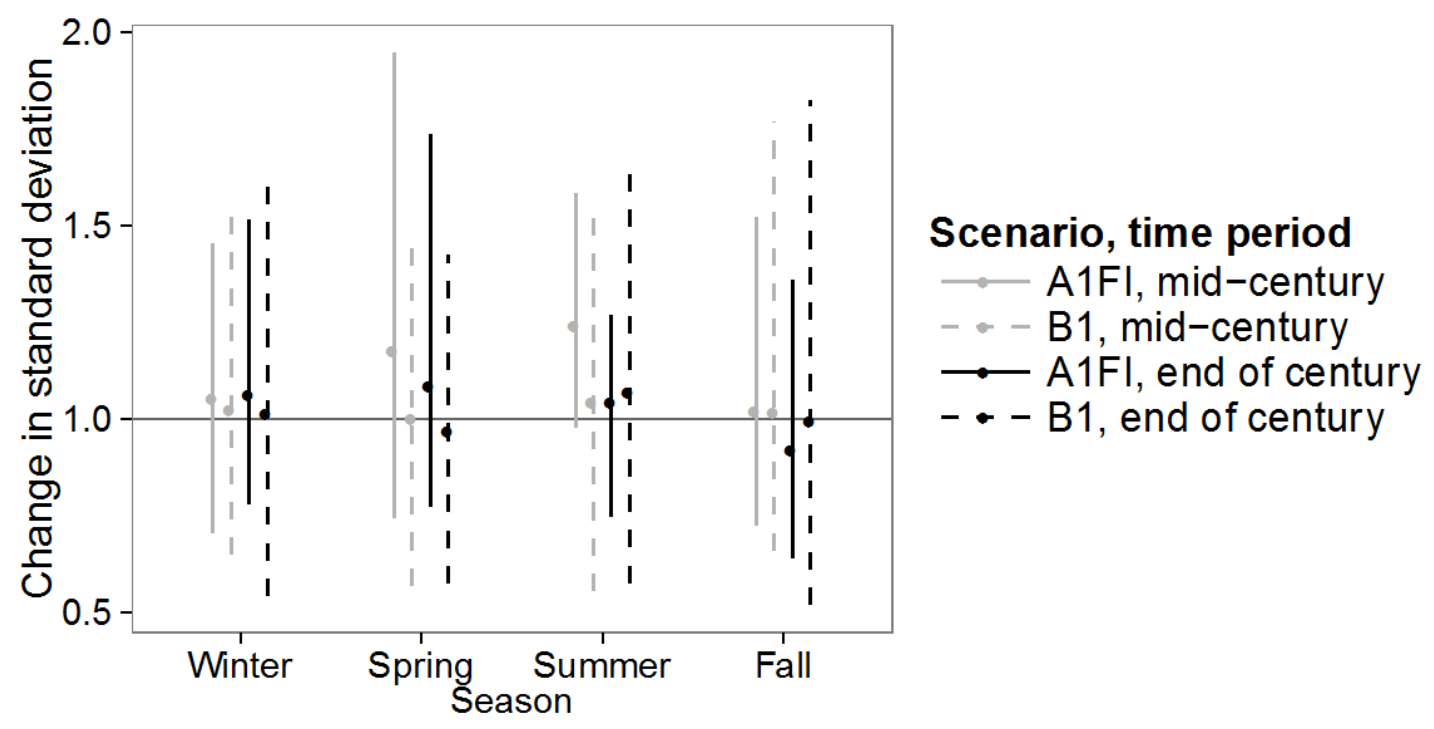

Figure C41. Projected change in standard deviation of seasonal minimum temperatures (in degrees Celsius) for the middle (2040-2060) and the end of the 21st century (2080-2100), compared with the recent time period (1981-2000), for two emissions scenarios for the Southern Coastal Plain Seepage Swamp and Baygall ecological system. Solid dots and error bars represent, respectively, the means and ranges of projections across climate models under each scenario. 


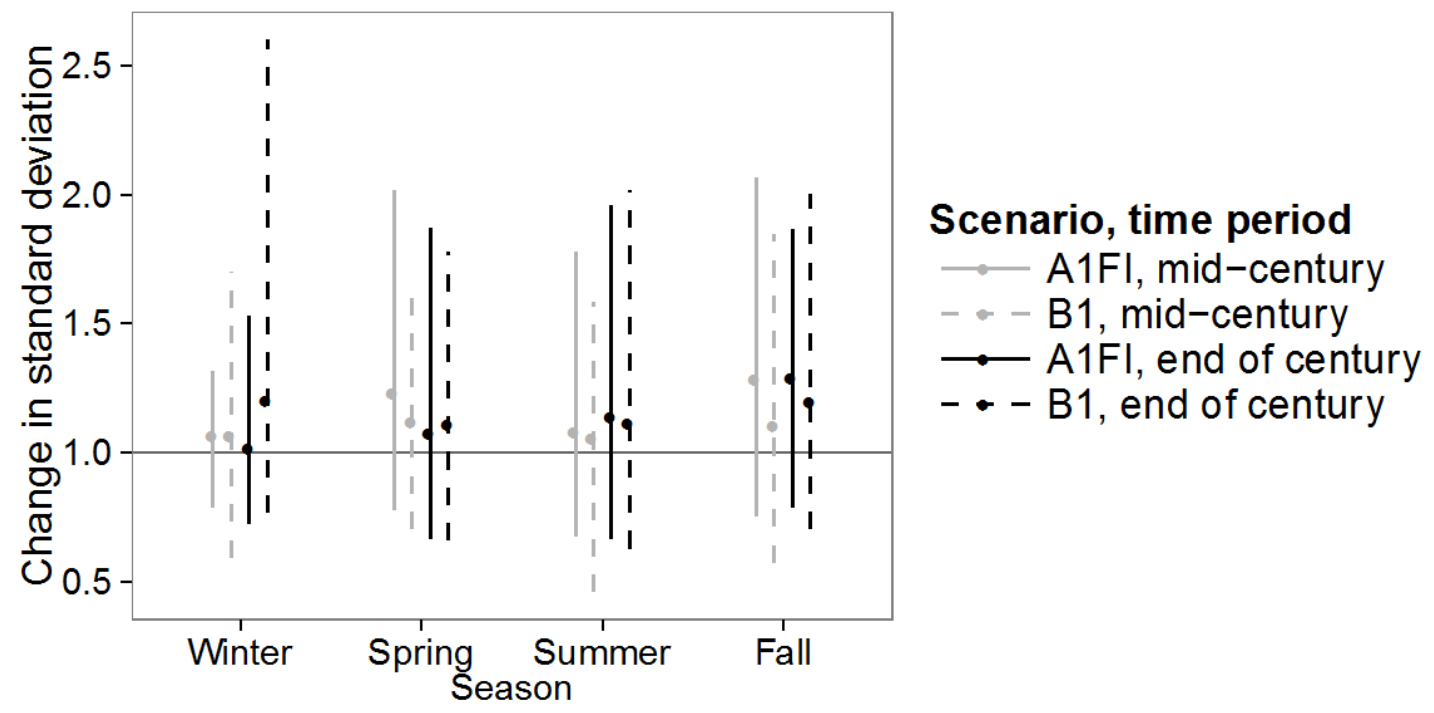

Figure C42. Projected change in standard deviation of seasonal average precipitation for the middle (20402060) and the end of the 21st century (2080-2100), compared with the recent time period (1981-2000), for two emissions scenarios for the Southern Coastal Plain Seepage Swamp and Baygall ecological system. Solid dots and error bars represent, respectively, the means and ranges of projections across climate models under each scenario. 


\section{Appendix D. MaxEnt ${ }^{\mathrm{TM}}$-Data Preparation and Processing for the East Gulf Coastal Plain Near-Coast Pine Flatwoods Ecological System}

\section{Introduction}

The maximum entropy modeling algorithm software developed by Phillips and others (2006) was used to assess the distribution of future climate envelopes for a southeast endemic ecological system - the East Gulf Coastal Plain Near-Coast Pine Flatwoods system (fig. D1). This system of open forests or woodlands occupies broad, sandy flatlands in a relatively narrow band along the northern Gulf of Mexico coast east of the Mississippi River from eastern Louisiana to the Big Bend region of Florida. Data for three climate variables (mean minimum monthly temperature, mean maximum monthly temperature, and mean monthly precipitation) were projected for two time periods (mid-century [to 2050] and end-of-century [2050-2100]) under three emissions scenarios (A1FI, A2, and B1). A total of 36 observed variables (3 climate variables for each of 12 months) were used to generate a maximum entropy distribution for the mapped range of East Gulf Coastal Plain Near-Coast Pine Flatwoods system. This "climate envelope” was then projected to the entire Southeastern United States, extending from west of the Mississippi River, north to northern Kentucky and Virginia, east to the Outer Banks of North Carolina, and south to central Florida.

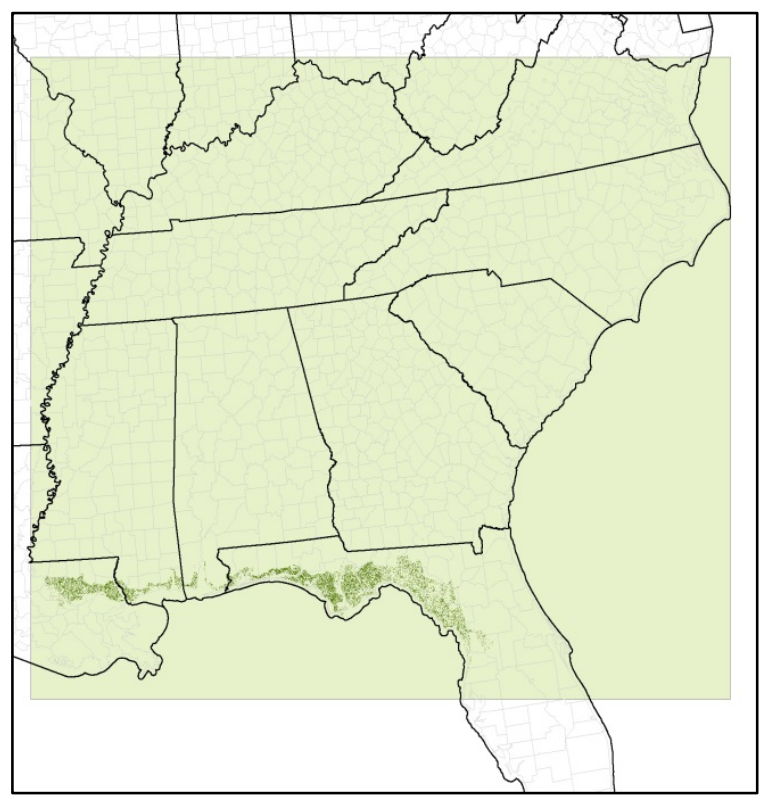

Figure D1. East Gulf Coastal Plain Near-Coast Pine Flatwoods ecological system distribution in the Southeastern United States. 


\section{Input Data}

Downscaled climate data were generated for $7.5^{\prime} \times 15^{\prime}$ tiles $\left(1 / 8^{\circ} \times 1 / 8^{\circ}\right)$ of geographic coordinates in decimal degrees (World Geodetic System 1984). Data within the bounding rectangle (fig. D2) $\{$ ULxy $=-91.6875,39.5625$ LRxy $=-74.8125,27.1875\}$ were assembled in a table where each row $(10,827$ rows total) is a coordinate location and each column is a climate variable. Coordinate locations encompassing open ocean were assigned a NoData value equal to 9999. These data were split into seven separate tables_one for observed values and six for future/projected values ( 3 climate scenarios $\times 2$ time periods). Each table has 39 columns (table D1) and serves as input to the MaxEnt ${ }^{\mathrm{TM}}$ software.

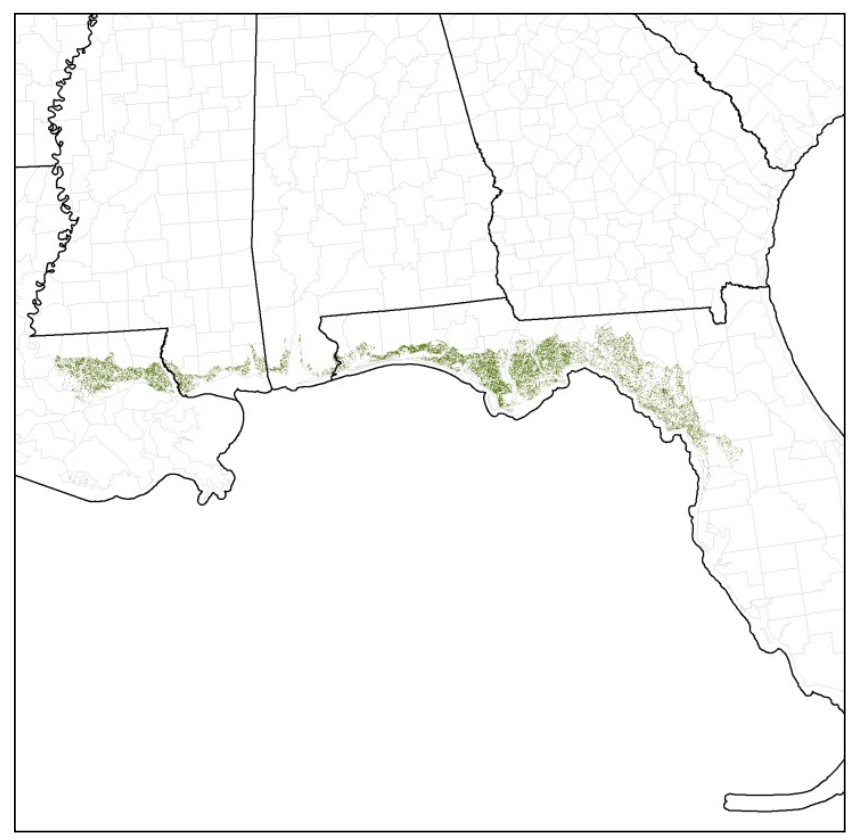

Figure D2. Southeast analysis extent for climate envelope modeling of the East Gulf Coastal Plain NearCoast Pine Flatwoods ecological system. 
Table D1. Column names and descriptions for climate data inputs for MaxEnt ${ }^{\mathrm{TM}}$ software.

\begin{tabular}{ll}
\hline \multicolumn{1}{c}{ Column name } & \\
\hline $\begin{array}{l}\text { ECOSYS or } \\
\text { BACKGROUND or } \\
\text { PROJECTED }\end{array}$ & Text field used to identify modeling “target” by MaxEnt ${ }^{\mathrm{TM}}$ \\
\hline X-COORD & X coordinate = Longitude in decimal degrees \\
\hline Y-COORD & Y coordinate = Latitude in decimal degrees \\
\hline MX_MON_1 & Maximum monthly temperature (mean in degrees Celsius) for January \\
\hline MN_MON_1 & Minimum monthly temperature (mean in degrees Celsius) for January \\
\hline PR_MON_1 & Monthly precipitation (mean in millimeters) for January \\
\hline MX_MON_2 & Maximum monthly temperature (mean in degrees Celsius) for February \\
\hline MN_MON_2 & Minimum monthly temperature (mean in degrees Celsius) for February \\
\hline PR_MON_2 & Monthly precipitation (mean in millimeters) for February \\
\hline ...and so forth & Maximum and minimum temperatures and precipitation for each month \\
\hline
\end{tabular}

After some testing, we determined that collapsing the 36 variables into a total of 12 seasonal variables (3 variables [minimum temperature, maximum temperature, average precipitation] $\times 4$ seasons [winter, spring, summer, fall]) was desirable to reduce model overfitting and to increase model interpretability. Therefore, we used these seasonal variables as inputs to MaxEnt ${ }^{\mathrm{TM}}$.

Data representing the distribution of Near-Coast Pine Flatwoods (NCPF) in the Southeast were generated from the U.S. Geological Survey Gap Analysis Program (GAP) land cover as a 30-m $\times 30-\mathrm{m}$ raster of 1 's and NoData. In order to match the approximate size of the climate data tiles $\left(1 / 8^{\circ} \times 1 / 8^{\circ}\right)$, it was necessary to reproject the NCPF data (originally Alber's projection in North American Data of 1983 meters) to a geographic coordinate system (World Geodetic System 1984) and aggregate 30-m cells by summing. The ESRI ArcGIS ${ }^{\mathrm{TM}}$ Spatial Analyst function Aggregate was used with the sum technique and a cell factor of 367. A cell factor of 367 produces an output where cells are 367 times larger than input cell size-the approximate difference between climate data tile size and 30-m raster cells. Summing adds all 30-m cell values within the larger aggregated cell outputs. In this case, because input cell values are 1 , the output is the total number of 30-m cells that are contained in a cell of the larger aggregated output. A threshold of 50 cells was established to identify the cells in which the aggregated raster the NCPF would be considered present. Three hundred seventeen of the 335 total number of cells in the aggregated raster were considered present based on the 50-cell sum threshold, leaving 18 cells (summed value $<50$ ) out of the analysis.

\section{Samples}

MaxEnt ${ }^{\mathrm{TM}}$ takes either two or three inputs. When "projecting” suitability estimates onto either a new area of interest (AOI) or the same AOI with future conditions, such as with climate 
change, three inputs are required. The first input is a table (CSVfile) with $\mathrm{x}$ and y coordinates indicating locations where the modeling target is known to occur-referred to as "samples". "Samples" dataset or point locations must be in a comma-separated value text (*.csv) file with the following format:

$\begin{array}{lll}\text { ECOSYS } & \text { X_COORD } & \text { Y_COORD } \\ \text { NCPF } & -82.6875 & 29.0625 \\ \text { NCPF } & -82.5625 & 29.0625\end{array}$

The leftmost column indicates the model target to run (this could be an individual species name or, in this case, the ecosystem of interest-NCPF), and the $\mathrm{X}$ and $\mathrm{Y}$ values are $\mathrm{X}$ and $\mathrm{Y}$ coordinates for each presence location. This file and its location are indicated in the Samples box on the left side of the MaxEnt ${ }^{\mathrm{TM}}$ interface (fig. D3).

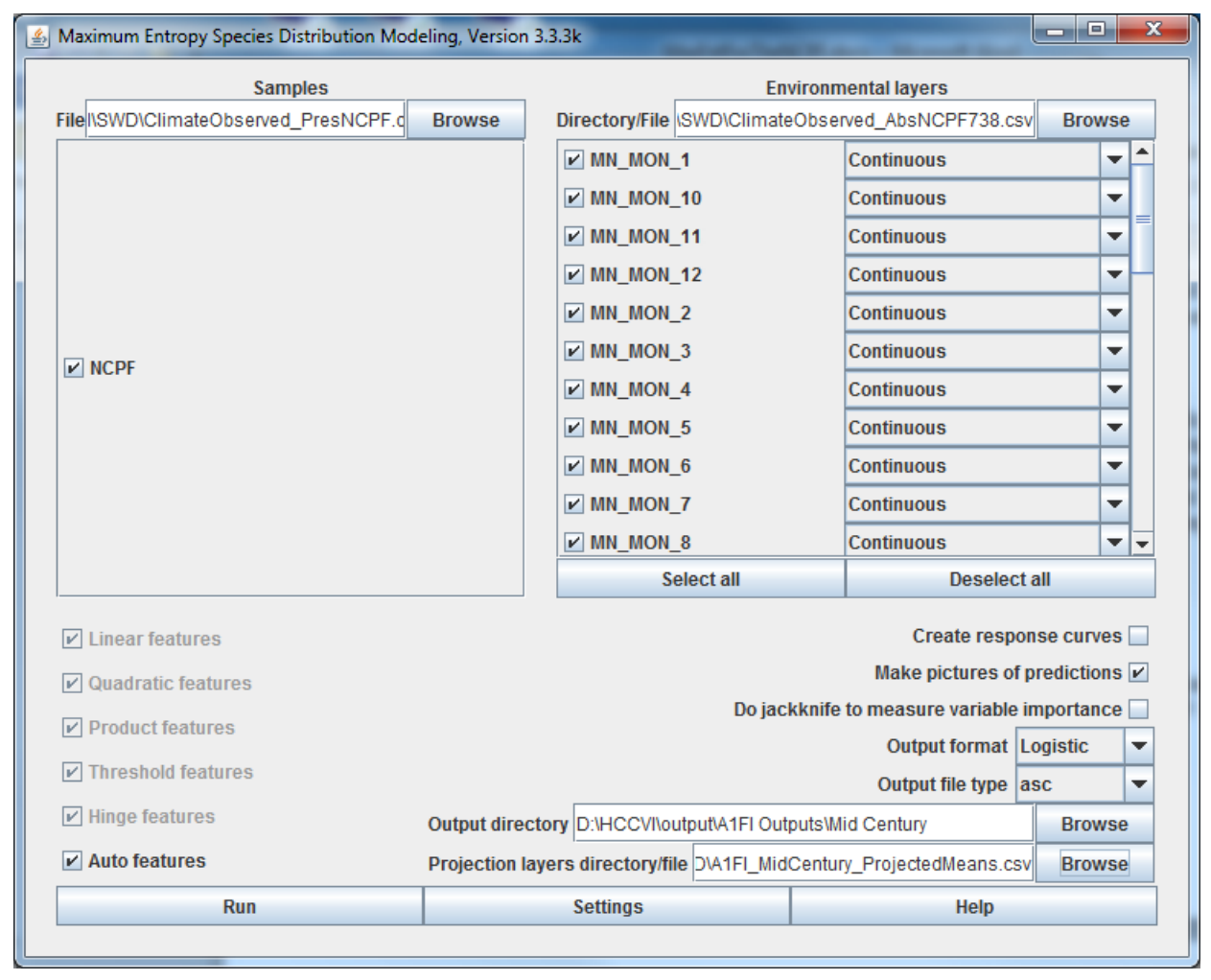

Figure D3. MaxEnt ${ }^{\text {Tw }}$ software input form showing samples, environmental layers, output directory, and projection file selections for 36 climate variable envelope modeling on the Near-Coast Pine Flatwoods in the Southeast. 


\section{Using "Samples with Data" (SWD) / CSV Files as Inputs}

Because climate data were generated as a text file, it was necessary either to create ASCII rasters for each climate variable and use these as inputs - the "Environmental layers" directory box in the right portion of the MaxEnt ${ }^{\mathrm{TM}}$ interface—or to create a text file containing both presence location AND environmental variable values (fig. D3). In MaxEnt ${ }^{\mathrm{TM}}$ documentation, this is referred to as SWD — "samples with data". The file contains environmental data at each presence sample location. It has the following format:

$\begin{array}{lllllll}\text { ECOSYS } & \text { X_COORD } & \text { Y_COORD } & \text { MX_MON_1 } & \text { MN_MON_1 } & \text { PR_MON_1 } & \text { MX_MON_2 } \\ \text { NCPF } & -82.6875 & 29.0625 & 20.9 & 7.0285 & 2.953 & 22.61 \\ \text { NCPF } & -82.5625 & 29.0625 & 20.933 & 7.0195 & 2.9352 & 22.613 \\ \text { NCPF } & -82.8125 & 29.1875 & 20.201 & 6.193 & 3.1692 & 21.994\end{array}$

In order to generate this file, it was necessary to combine the "presence" locations with the observed climate data. First, climate data were converted to a point shapefile using the latitude and longitude coordinates. Next, the Spatial Analyst function "Extract Values to Points" was used to add information for the aggregated raster's table to the observed climate point shapefile's table. The aggregated raster of NCPF distribution contains two fields: (1) VALUE = the number of NCPF 30-m cells from the summing aggregation, and (2) COUNT = the number of cells with that value. When "Extract Values to Points" is run, the resulting table has a field RASTERVALU that represents the cell values (in this case, sums) of the aggregated NCPF raster. It is then possible to select all points with RASTERVALU $\geq 50$ (the established "presence" threshold) and to export those selections to a new text file. This file is then edited to match the format shown above this paragraph for use as the input SWD.

\section{Environmental Layers}

ASCII rasters of climate variables can be used as input environmental layers. When this is the case, MaxEnt ${ }^{\mathrm{TM}}$ will randomly generate 10,000 locations throughout the climate variable raster landscape and use data values at these locations, along with values from presence locations to fit the maximum entropy distribution model. These 10,000 random locations are referred to as "Background" or pseudo-absences. However, based on the range of the NCPF ecosystem, it is reasonable to assume that any area outside the geographic extent depicted by GAP land cover is a known absence for this ecosystem and can be provided as direct input. MaxEnt ${ }^{\mathrm{TM}}$ will use data in SWD data format (similar to the samples CSV file) as input for background locations instead of ASCII rasters. This file is then used directly by MaxEnt ${ }^{\mathrm{TM}}$ and can be selected in the Directory/File box at the top of the MaxEnt ${ }^{\mathrm{TM}}$ graphical user interface input form (fig. D3). It has the following format:

$\begin{array}{lllllll}\text { BACKGROUND } & \text { X_COORD } & \text { Y_COORD } & \text { MX_MON_1 } & \text { MN_MON_1 } & \text { PR_MON_1 } & \text { MX_MON_2 } \\ \text { Background } & -80.4375 & 27.4375 & 23.472 & 10.816 & 2.3768 & 24.406 \\ \text { Background } & -80.3125 & 27.4375 & 23.607 & 10.732 & 2.4273 & 24.545 \\ \text { Background } & -81.1875 & 27.5625 & 23.299 & 9.3985 & 1.9884 & 24.673\end{array}$


The first column (BACKGROUND) lets MaxEnt ${ }^{\mathrm{TM}}$ know that these data are used for developing model distributions. Note that both SWD CSV files have climate variables (environmental layers) as the last columns in the table and that these column heading names match. Once the file input is selected and provided column headings between samples and backgrounds match, MaxEnt ${ }^{\mathrm{TM}}$ will complete the variable names in the box below the environmental layers selection. Note for the 36 climate variables, all data are continuous.

In order to generate this file, 1,000 random points were created throughout the study extent and saved in a separate shapefile using the "Create Random Points" tool in ArcGIS ". This point shapefile was spatially joined to the observed climate points file and manually edited to remove points in open ocean (738 total points after editing) (fig. D4). This table was then exported and formatted to create the background SWD input file. 


\section{Projection Layers}

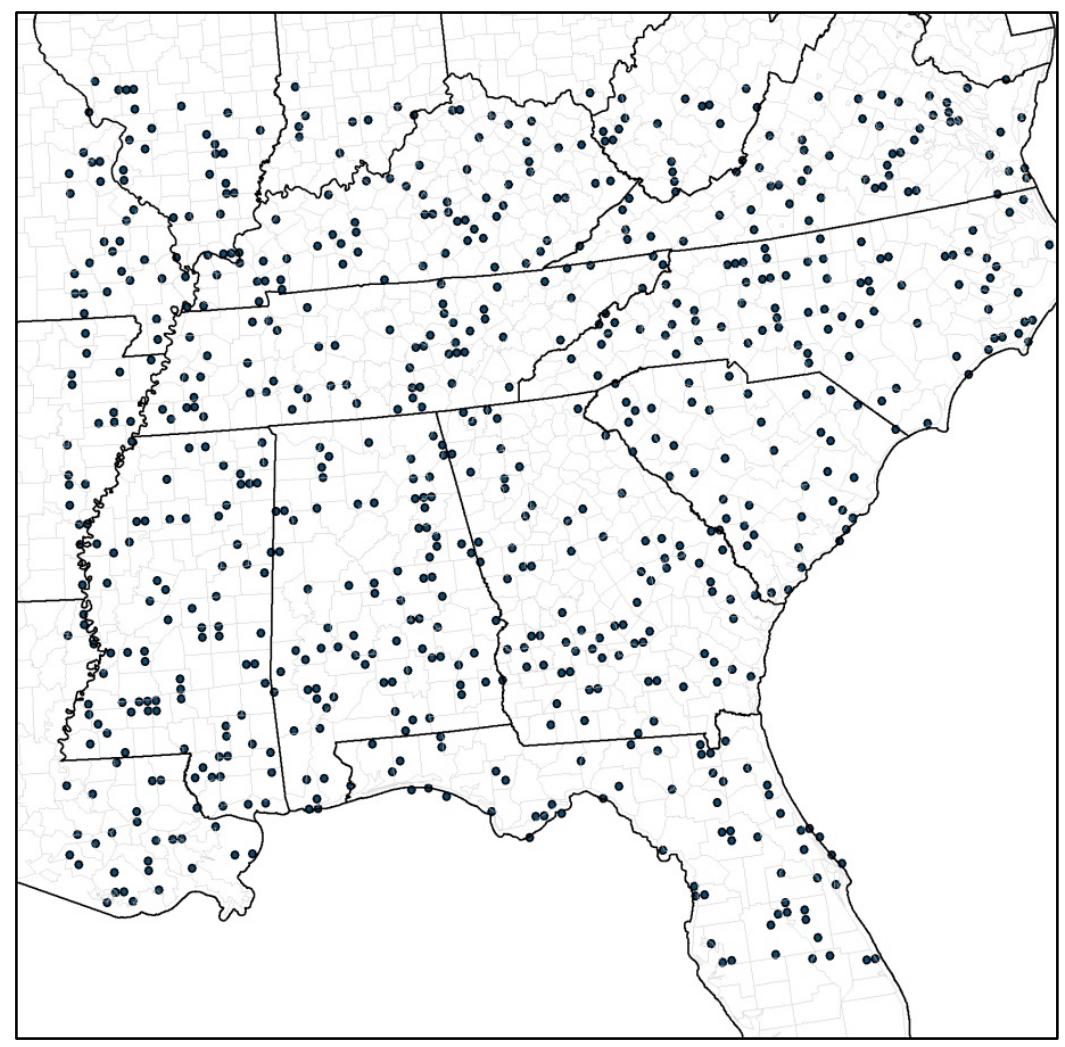

Figure D4. The 738 randomly generated points used as "background" for climate variables in MaxEnt ${ }^{\text {TM }}$ modeling for Near-Coast Pine Flatwoods in the Southeast.

Projection layers are the environmental data onto which the model will be "projected", that is, predicted. This produces the final map or maps of predicted probabilities for each point within the AOI. This can either be a directory where ASCII raster data layers are stored, or a SWD/CSV file prepared as described in the "Samples" section. For this analysis, "projections" are one of six future climate variable data values in table format. They represent three climate emission scenarios (A1FI, A2, and B1) and two time periods (mid-century and end-century). These are edited in SWD format and selected as the input projection layers directory file at the bottom of the MaxEnt ${ }^{\mathrm{TM}}$ form (fig. D3). One model run is made for each of the six emission scenario/time period combinations.

\section{Settings}

Clicking on the Settings button opens a window for altering MaxEnt ${ }^{\mathrm{TM}}$ modeling parameters (Fig. D5). These parameters allow the user to change some of the defaults such as iteration numbers, random test percentages, use of duplicates, and so on. The default values seem to be appropriate for most modeling situations. The only four options that may need to be altered are the random test percentages, the regularization multiplier, the default prevalence, and the threshold rule settings. 


\section{Basic Tab}

Random Test Percentage.-MaxEnt ${ }^{\mathrm{TM}}$ can use a portion of the input sample locations to train the model and to set aside a portion to test the model. Use the Random test percentage box to specify the percentage of data points to use for testing. For this analysis, all random test percentages were set to 25 percent.

Regularization multiplier.-Regularization affects model fit. According to the MaxEnt ${ }^{\mathrm{TM}}$ documentation:

The "regularization multiplier" parameter on the settings panel affects how focused or closely-fitted the output distribution is-a smaller value than the default of 1.0 will result in a more localized output distribution that is a closer fit to the given presence records, but can result in over-fitting (fitting so close to the training data that the model does not generalize well to independent test data). A larger regularization multiplier will give a more spread out, less localized prediction.

Models were run with the default 1.0 setting for regularization, but this could be adjusted depending on model outputs.

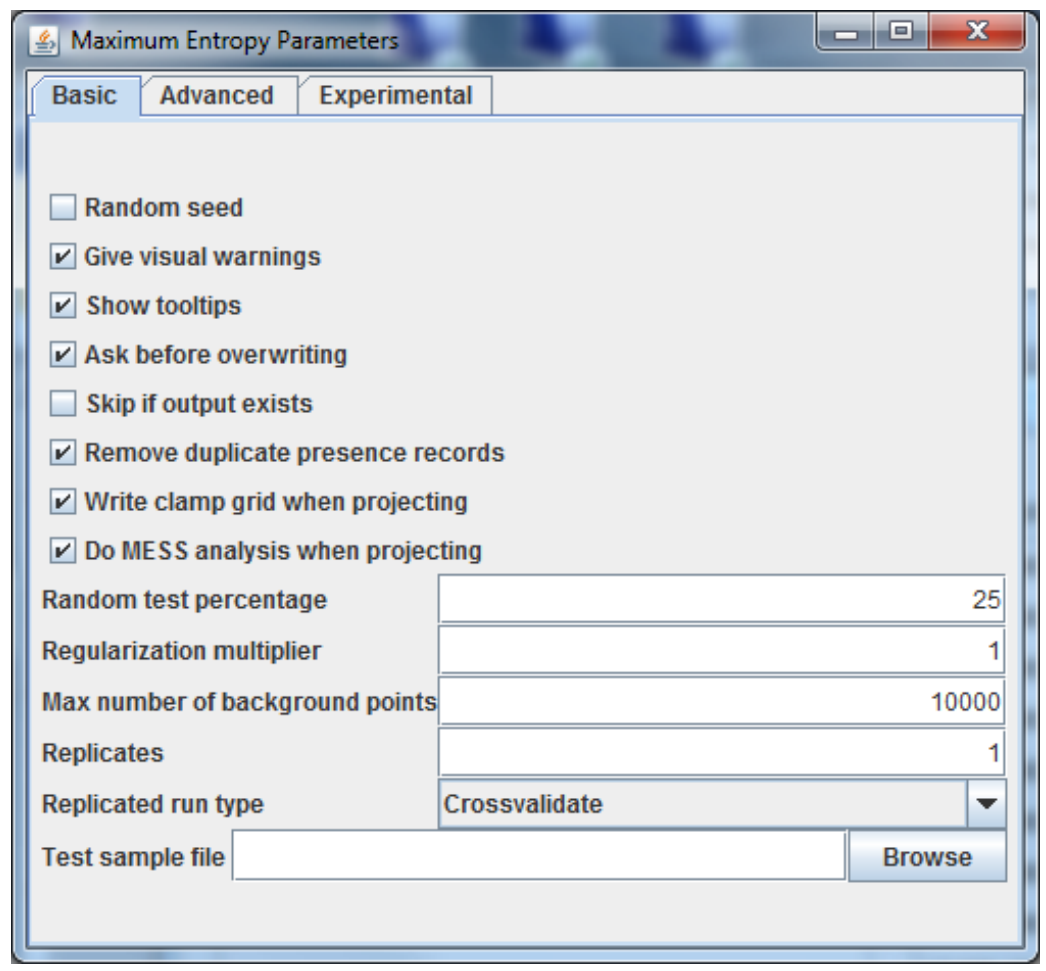

Figure D5. Additional settings [Basic tab] to adjust MaxEnt ${ }^{\text {TM }}$ model parameters and outputs. 


\section{Advanced Tab}

Default prevalence.- - Under the Advanced tab (Fig. D6), a setting can be adjusted based on "probability of presence" for the given model target. According to MaxEnt documentation:

Note that probability of presence depends on details of the sampling design, such as the plot size and (for vagile organisms) observation time; logistic output estimates probability of presence assuming that the sampling design is such that typical presence localities have probability of presence of about 0.5 . This value of 0.5 is fairly arbitrary, and can be adjusted (using the "default prevalence" parameter) if information is available on the probability of presence at typical presence localities.

For the NCPF, because the mapped extent accuracy was assessed by the agency (LANDFIRE) that created the data, it is possible to use this accuracy as a probability of presence. Overall accuracy reported by LANDFIRE was 0.699 (user's accuracy $=0.685$, producer's accuracy $=0.625$; see LANDFIRE accuracy contingency tables). Default prevalence, therefore, was set to 0.7 for all model runs.

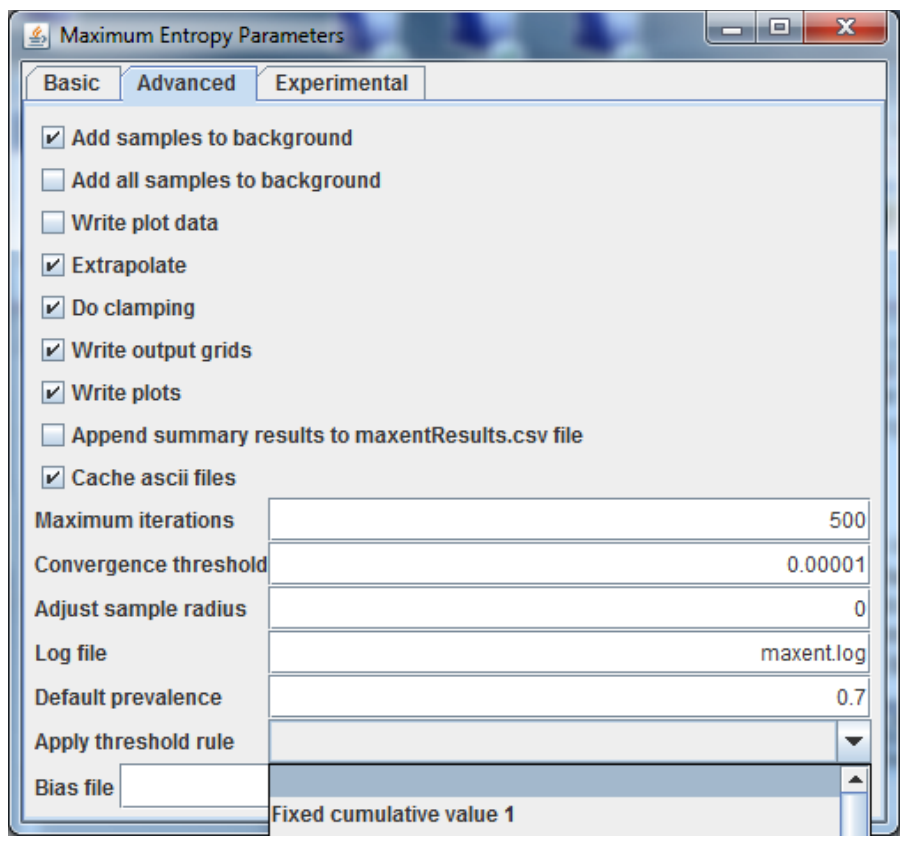

Figure D6. Additional settings [Advanced tab] to adjust MaxEnt ${ }^{\text {TM }}$ modeling parameters and outputs.

Apply Threshold Rule.-When the threshold rule is implemented, MaxEnt ${ }^{\mathrm{TM}}$ will generate a separate binary output of predicted suitability/presence. This output could then be used to draw distinctions on the landscape for planning, prioritization, and so on. However, the binary raster is only produced when inputs are ASCII rasters. When inputs are SWD CSV files, a threshold still can be applied but that threshold must be manually created from outputs (either cumulative or logistic) based on numbers supplied in the output table report generated at the end of a model run. The threshold rule of "equal training sensitivity and specificity” was used for all models (fig. D7). 


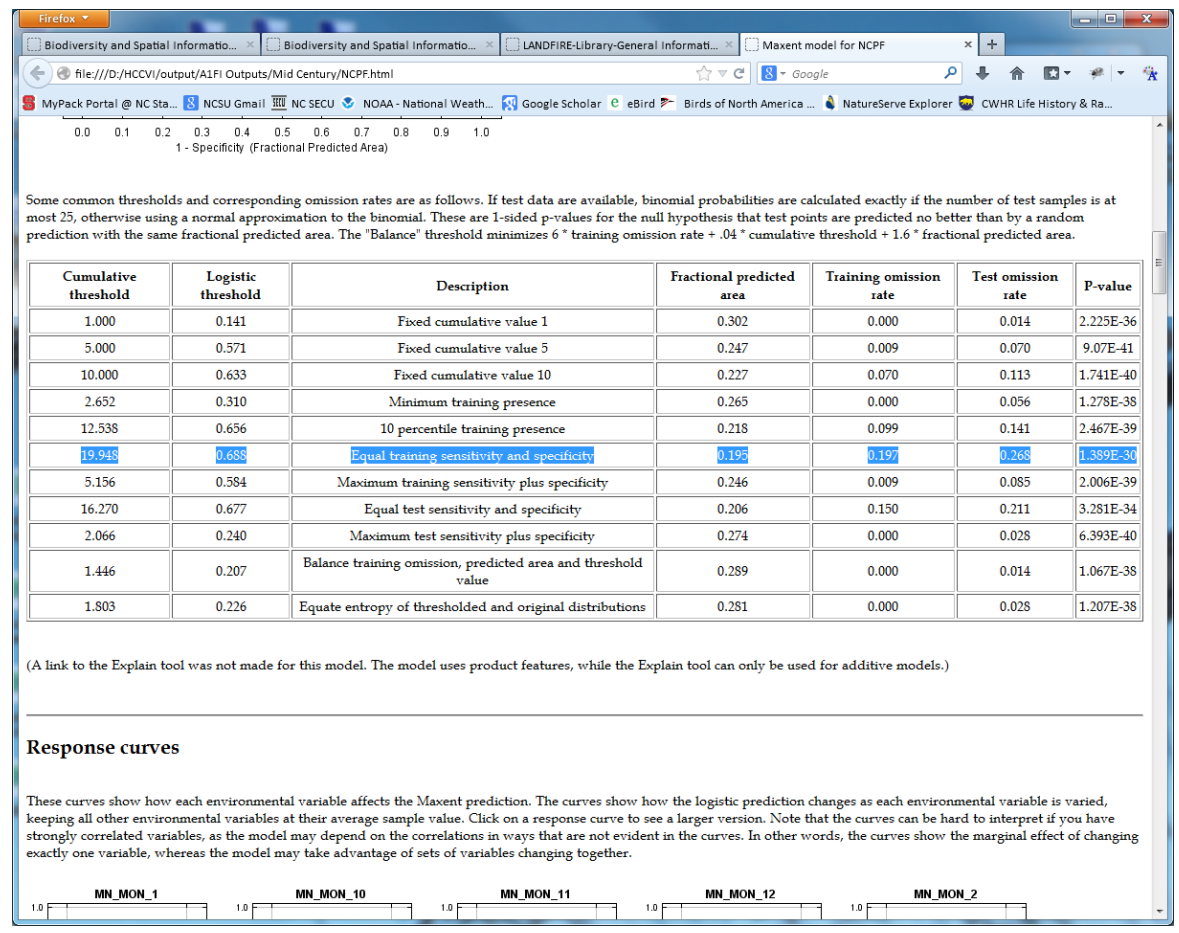

Figure D7. Threshold table generated from a MaxEnt ${ }^{\text {TM }}$ model run.

\section{Outputs}

Output Format.-The user can select an output format of logistic, cumulative, or raw. Logistic will produce maps of predicted habitat suitability with values between 0 and 1 . These values are easily interpreted as a probability. The other two formats, Cumulative and Raw, are not as easily interpretable and produce ranges of very small values and very large values.

Output File Type.-When ASCII rasters are chosen as the input environmental layers and (or) projection layers, MaxEnt ${ }^{\mathrm{TM}}$ writes the final "projected" suitability map to a single raster output file. This output file can be one of four types—*.bil, *.asc, *.mxe, or *.grd—and can be used in geographic information system (GIS) for further spatial analysis. However, when inputs are SWD files,

no raster outputs are generated. Regardless of input type, MaxEnt ${ }^{\mathrm{TM}}$ will generate a CSV file with predictions at X-Y coordinates. This file can be converted to a point shapefile for geographic representation in GIS (fig. D8). 


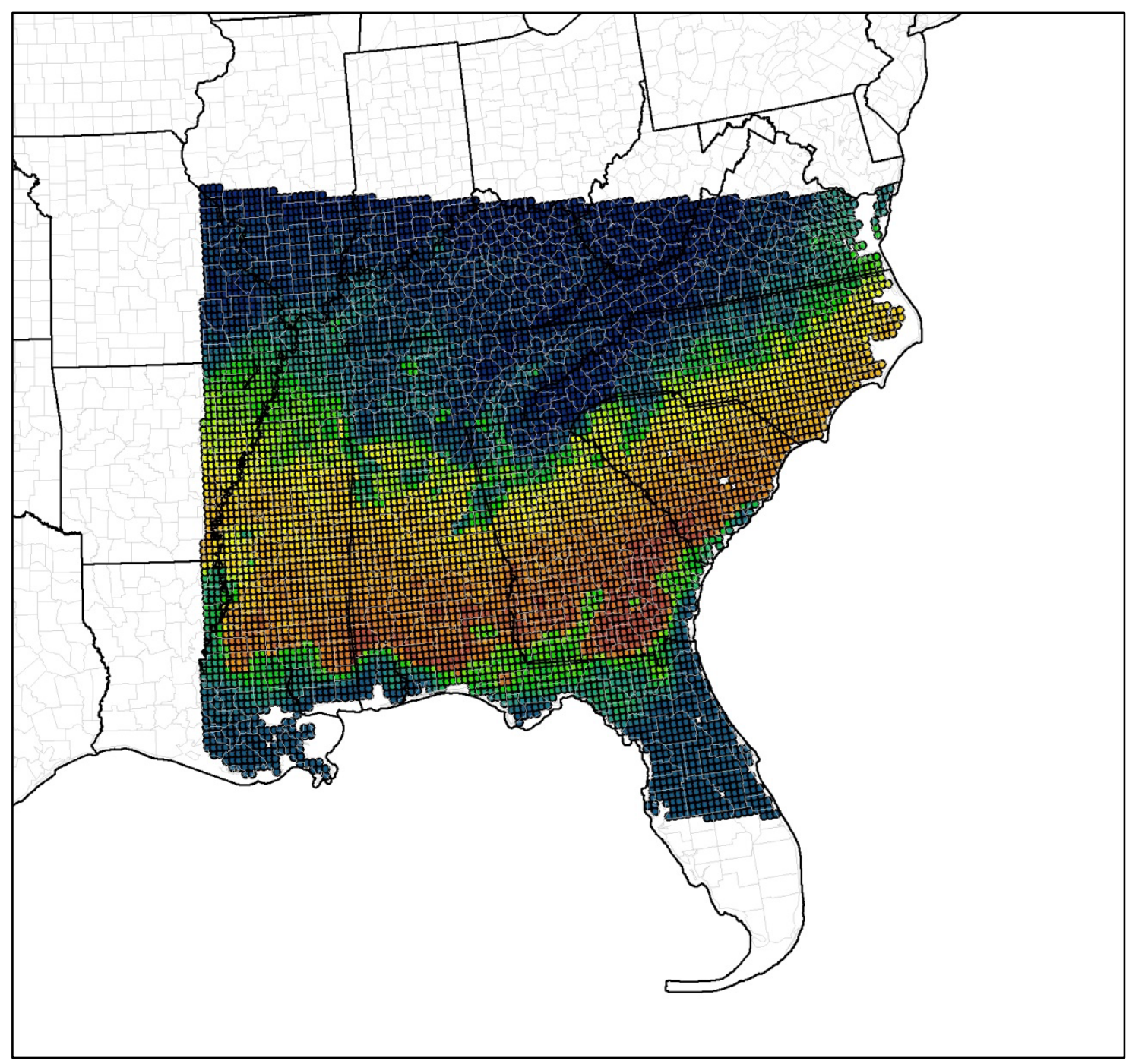

Figure D8. MaxEnt ${ }^{\text {TM }}$ predicted logistic output converted from CSV file format to a point shapefile and classified by graduated quantity at equal intervals.

\section{Reference Cited}

Phillips, S.J., Anderson, R.P., and Schapire, R.E., 2006, Maximum entropy modeling of species geographic distributions: Ecological Modelling, v. 190, p. 231-259. 